Universidad Politécnica de Madrid

Escuela Técnica Superior de Ingenieros en Topografía, Geodesia y Cartografía

\title{
Desarrollo de mapas a través del diseño de experiencias de usuario
}

Tesis Doctoral

\section{María Teresa Manrique Sancho}

Ingeniera en Geodesia y Cartografía 



\title{
POLITÉCNICA
}

Departamento en Ingeniería Topográfica y Cartografía

Escuela Técnica Superior de Ingenieros en Topografía, Geodesia y Cartografía

\section{Desarrollo de mapas a través del diseño de experiencias de usuario}

\author{
Tesis Doctoral
}

Autora

\section{María Teresa Manrique Sancho}

Ingeniera en Geodesia y Cartografía

\author{
Directores: \\ Dra. Monica Wachowicz \\ Doctora en Geografía \\ Dr. Miguel Ángel Manso Callejo \\ Doctor en Ingeniería Geográfica
}



Tribunal de la Tesis Doctoral, nombrado por el Magnífico y Excelentísimo Sr. Rector de la Universidad Politécnica de Madrid, el día

Integrado por:

Presidente:

Secretario:

Vocal 10:

Vocal 2ㅇ:

Vocal 3:

realizado el acto de defensa y lectura de tesis el día

Decide otorgar a la tesis doctoral presentada la calificación de:

EL PRESIDENTE

EL SECRETARIO

EL VOCAL 1음

EL VOCAL 2음

EL VOCAL 3응 

A mi familia y en especial a mis padres,

a Javi y a Rodrigo,

a Isaac y a Antonio. 



\section{Agradecimientos}

A lo largo de la ejecución de esta tesis son muchos los organismos y las personas que han contribuido de una $u$ otra forma en el presente trabajo y que, en su momento, aportaron aquello que hizo falta para poder llevarlo a buen fin:

- El Instituto Geográfico Nacional y más concretamente Sebastián Mas Mayoral, cuyo apoyo a la colaboración con la UPM ha dado soporte a mi trabajo en esta Universidad, a lo largo de los últimos 10 años.

- El Consorcio Regional de Transportes y especialmente Miguel Ángel Delgado.

- Turismo de la CAM y especialmente Francisco Bravo, Vanesa Carro, Macarena Machado y Alicia Bajo.

- Turismo del Ayuntamiento de Madrid y más concretamente Mónica Mena e Iván González.

- La empresa Pangea (Chus Blázquez) y la editorial Dumont (Manuel Blázquez).

Quiero hacer una mención especial a mis tutores Mónica Wachowicz y Miguel Ángel Manso, que confiaron en mí y que han sabido guiarme y darme el apoyo necesario, desde el inicio de esta investigación hasta su finalización.

También agradezco la ayuda del psicólogo Héctor Rodrigo Núñez, los cartógrafos Xiomara Gonzalo, Teresa Iturrioz, Dolores Arteaga y Miguel Ángel Bernabé, el geógrafo Antonio Vázquez y los diseñadores Alberto Jiménez y David Sherriff. Algunos de los cuales ya eran amigos antes de comenzar esta tesis y otros cuya amistad ha sido un regalo recibido a lo largo de esta experiencia.

Esta investigación no habría sido posible sin la participación de los turistas de Madrid y en espacial de los que colaboraron en la técnica de los diarios: Adriana Navarro, Ángeles Sofía Subarroca, Cristian Damián Martínez, Kristian Clemmensen, Pankaj Sodhi y Vivi Clemmensen.

Finalmente, quiero agradecer al personal de la Biblioteca del Campus Sur y a José Javier Querol de la UPM su eficiente y atento servicio.

Muchas gracias a todos de corazón.

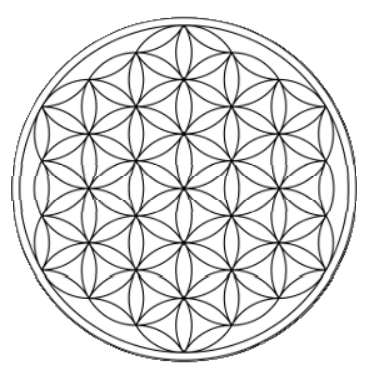




\section{Resumen}

Las posibilidades de acceso a la información geográfica se han multiplicado en las últimas décadas. La diversidad de situaciones y tipologías de usuarios que consultan mapas hace que su representación sea un problema complejo. Existen numerosas investigaciones que abordan el desarrollo de los mapas siguiendo procesos de diseño centrados en el usuario, con el fin de garantizar su usabilidad. El objetivo de esta investigación trasciende la mejora del rendimiento en la interacción con los mapas y propone considerar la experiencia del usuario como una nueva forma de conceptualizar la tarea objeto de la visualización de la información geográfica.

Esta investigación se centra en la componente cognitiva de la experiencia de los usuarios y la hipótesis a corroborar es que: los mapas se pueden considerar instrumentos activos en los procesos cognitivos de los usuarios, que inciden en su comportamiento y en sus experiencias del espacio. Con tal fin, se plantea la pregunta de investigación ¿Cómo desarrollar mapas que den soporte a la experiencia cognitiva del usuario, asociada a un determinado espacio urbano?

En el presente trabajo, los mapas se conciben como interfaces entre el usuario y el espacio geográfico y se propone un proceso para desarrollarlos, que tiene en cuenta la forma en la que el usuario afronta la experiencia del espacio a representar y la manera en la que conceptualiza dicho espacio. El proceso propuesto consta de cuatro fases que abordan: 1) la concepción del contexto asociado a la experiencia, 2) la exploración de la experiencia de los usuarios, 3) la síntesis de dicha experiencia (identificación de patrones en las interacciones entre los usuarios, los ambientes o entornos del espacio urbano y los mapas que utilizan) y 4) el diseño de prototipos de los mapas. En cada una de ellas se ejecutan una serie de tareas en las que se aplican varias técnicas de diseño. De este modo, el cartógrafo asimila el conocimiento que precisa a cerca de la experiencia de los usuarios para diseñar los mapas, estableciendo correspondencias entre estos y sus mapas cognitivos.

El proceso de diseño de experiencias propuesto integra conocimientos de varias áreas: psicología cognitiva (usuarios y mapas mentales), análisis geográfico (contextos), diseño cartográfico (visualización de datos) y nuevas tecnologías (mapas personalizados al vuelo en dispositivos móviles). Para su validación, el proceso se ha aplicado al turismo en Madrid, como caso de estudio. Como resultado, se han diseñado varios mapas adaptados a turistas que afrontan su experiencia en Madrid de diferentes maneras (exploradora, guiada y condicionada) y en distintos ambientes (durante la planificación y ejecución de la visita), con el fin de dar soporte a su experiencia cognitiva de la ciudad.

Esta investigación propone una nueva metodología que ofrece un marco general para el desarrollo de mapas que asistan a los usuarios en sus experiencias, dentro de un contexto multidisciplinario y multifacético más complejo. Este contexto se caracteriza por espacios geográficos como las denominadas ciudades inteligentes, donde dispositivos innovadores basados en nuevas tecnologías (nanotecnologías, loT, wearables,...) son capaces de identificar, reconocer y proponer a cada usuario mapas, de forma activa y en tiempo real. 


\section{Abstract}

The possibilities to access geographic information have multiplied in recent decades. The diversity of situations and user types consulting maps makes its representation a complex issue. There is much research about developing maps following user-centered design processes in order to ensure their usability. This work aims to go beyond improving the performance of the user interaction with maps by proposing to consider the user experience as a new way of conceptualizing the geographic information visualization task.

This thesis focuses on the cognitive component of the user experience and the research hypothesis is that: maps can be viewed as active instruments in the users' cognitive processes, affecting how they behave and how they experience space. The research question that arises is: how to develop maps that support the user cognitive experience in relation to a particular urban space?.

In this work, maps are conceived of as interfaces between the user and geographic space. To develop these maps we propose a process that takes into account the experience of the user vis-à-vis the space represented and that establishes a connection between the user's cognitive map and the map to be designed. This process consists of four phases which address: 1 ) the association between context and experience, 2) an exploration of the user experience, 3) a synthesis of this experience (identifying interaction patterns between users, locations or environments in urban space, and the maps being used) and 4) the design of map prototypes. In each of these phases, a series of tasks involving different design techniques are executed. These design techniques enable the cartographer to assimilate the knowledge about the user experience into the design of the maps.

The process put forth to design experiences incorporates knowledge from different disciplines: cognitive psychology (user and mental maps), geographical analysis (contexts), cartographic design (data visualization), and new technologies (custom maps on mobile devices on the fly), and has been validated by applying it to the case study of tourism in Madrid. As a result, several maps have been designed for tourists, tailored to the different experiences of Madrid they could have (exploratory, guided, or conditioned) and to the different environments they will find themselves into while planning and during the visit, in order to support their cognitive experience of the city.

This research proposes a new methodology that provides a general framework for the development of maps that assist users in their experiences within a more complex multidisciplinary and multifaceted context. This context is characterized by geographical areas, such as "smart cities", and innovative devices based on new technologies (nanotechnology, loT, wearables, etc.) that are able to identify, recognize and propose actively and in real time maps to each user. 


\section{Tabla de contenidos}

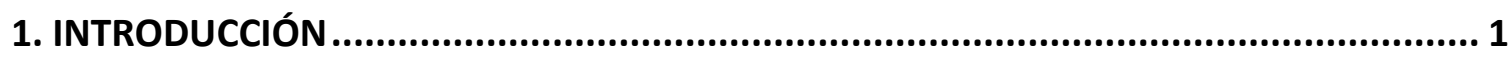

1.1 Motivación de la investigación y contexto …………………………………..... 1

1.2 Descripción del proyecto de investigación ………………………………….... 3

1.3 Cuestiones que se pretenden resolver en esta investigación .............................. 4

\section{FUNDAMENTOS TEÓRICOS Y SU INTEGRACIÓN EN EL DESARROLLO DE} MAPAS A TRAVÉS DEL DISEÑO DE EXPERIENCIAS DE USUARIO …............................... 5

2.1. Objeto de diseño: Mapas ................................................................................ 5

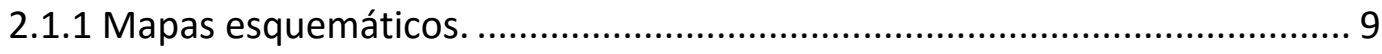

2.1.2 Mapas personalizados ............................................................................ 11

2.2 Acción de diseñar: Aspectos cognitivos involucrados en el diseño cartográfico ...................................................................................................... 14

2.3 Proceso de diseño centrado en el usuario en el ámbito cartográfico.................... 21

2.4 Diseño de experiencias de usuario ...................................................................... 25

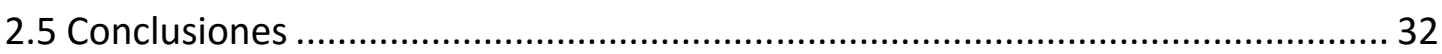

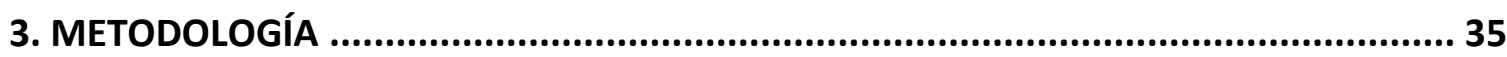

3.1 Fase 1: Concepción del contexto de la experiencia de los usuarios....................... 36

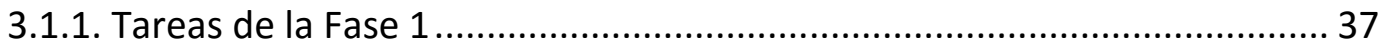

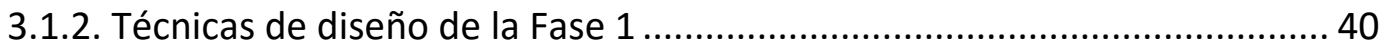

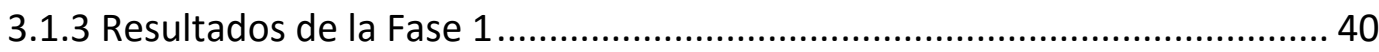

3.2 Fase 2: Exploración de la experiencia de los usuarios........................................... 41

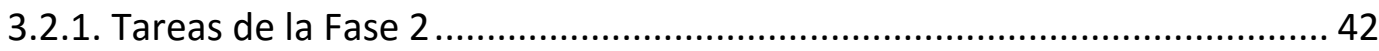

3.2.2. Técnicas de diseño de la Fase 2 ………………………………………..... 45

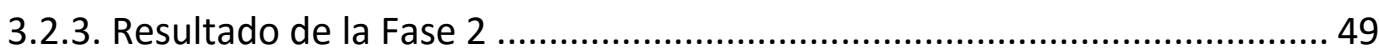


3.3 Fase 3: Síntesis de la experiencia de los usuarios

3.3.1 Tareas de la Fase 3

3.3.2 Técnicas de la Fase 3

3.3.3. Resultado de la Fase 3

3.4 Fase 4: Diseño de los prototipos de los mapas como interfaz 59

3.4.1 Técnicas de la Fase 4 60

3.5 Resumen 62

4. CASO DE ESTUDIO: EL TURÍSMO URBANO EN MADRID 64

4.1 Fase 1: Concepción del turismo en Madrid 64

4.1.1 Tareas de la Fase 1 65

4.1.2. Resultado de la concepción del turismo en Madrid 71

4.2. Fase 2: Exploración de la experiencia turística 73

4.2.1 Tareas de la Fase 2 73

4.2.2. Resultado de la exploración de la experiencia turística 97

4.3. Fase 3: Síntesis de la experiencia de los turistas 98

4.3.1 Tareas de la Fase 3 99

4.3.2. Resultados de síntesis de la experiencia turística 112

4.4. Fase 4: Diseño de los prototipos de los mapas para los turistas 126

5. CONCLUSIONES 161

5.1 Revisión de las preguntas de investigación 162

5.1.1 Proceso para el desarrollo de mapas, en base al diseño de experiencias del usuario 163

5.1.2 Factores y criterios a tener en cuenta para desarrollar mapas, a través de la experiencia cognitiva del usuario. 163

5.2 Futuras líneas de investigación. 166 
ANEXOS.

Anexo 1. Atributos de los turistas de Madrid, en base a fuentes documentales consultadas.

Anexo 2. Factores humanos y temporales que condicionan las actividades de los turistas de Madrid, en base a fuentes documentales consultadas. 190

Anexo 3. Productos y servicios cartográficos utilizados por los turistas. 195

Anexo 4. Zonas turísticas de Madrid según la relevancia y la tipología de los atractivos turísticos

Anexo 5. Ventas de billetes turísticos de transporte.

Anexo 6. Infraestructura hotelera y localización del alojamiento de los turistas internacionales de Madrid

Anexo 7. Guion de las entrevistas realizadas en la Fase 2 Tarea 2.1: Indagar sobre los grupos de interés asociados a la experiencia turística de Madrid.

Anexo 8. Cuestionario utilizado para encuestar al personal del CRTM 207

Anexo 9. Iniciativas para el desarrollo y suministro de productos turísticocartográficos de Madrid.

Anexo 10. Cuestionario utilizado para encuestar a los turistas al inicio de su primera visita a Madrid.

Anexo 11. Cuestionario realizado a turistas al finalizar su primera visita a Madrid

Anexo 12. Recursos y pautas utilizadas en la técnica de los diarios.

Anexo 13. Tablas elaboradas con la información recogida en la encuesta a los turistas

Anexo 14. Atributos de los turistas encuestados

Anexo 15. Factores que condicionan las actividades de los turistas en el previaje

Anexo 16. Mapas mentales de los turistas encuestados al inicio de su visita 237 
Anexo 17. Factores que condicionan las actividades de los turistas durante su visita

Anexo 18. Mapas mentales de los turistas encuestados al final de su visita.

Anexo 19. Productos cartográficos que utilizan los turistas encuestados

Anexo 20. Peculiaridades encontradas en los cuestionarios al realizar la síntesis de la interacción entre el turista y el ambiente en el que se desarrolla su experiencia (Tarea 3.1)......

Anexo 21. Detalles de la síntesis de la interacción entre el turista y los mapas que dan soporte a su experiencia de Madrid (Tarea 3.2)

Anexo 22. Inspiraciones para los diseños de los mapas

Anexo 23. Prototipos de los mapas en papel 


\section{Lista de tablas}

Tabla 2.1: Tipos de interacciones usuario-producto. Fuente: adaptación de Forlizzi y Battarbee (2004)

Tabla 2.2: Tipos de experiencias. Fuente: adaptación de Forlizzi y Battarbee (2004)

Tabla 3.1: Técnicas de diseño utilizadas en la Fase 1

Tabla 3.2: Técnicas de diseño utilizadas para recopilar información en la Fase 2

Tabla 3.3: Técnicas de diseño para organizar la información recopilada en la Fase 2

Tabla 3.4: Técnicas de diseño utilizadas en la Fase 3

Tabla 3.5: Técnicas para la Fase 4

Tabla 4.1: Técnicas de diseño llevadas a cabo para realizar la indagación de los grupos de interés asociados al turismo en Madrid

Tabla 4.2: Características de los turistas que participaron en la técnica de los diarios y de sus experiencias

Tabla 4.3: Atractivos turísticos puntuales que los turistas tienen previsto visitar en Madrid al inicio de su estancia y que se han mencionado en los cuestionarios iniciales en más de 2 ocasiones

Tabla 4.4: Atractivos turísticos puntuales de Madrid con más de 5 repeticiones (entre mapas y textos)

Tabla 4.5: Atractivos turísticos lineales de Madrid con más de 3 repeticiones (entre mapas y textos)

Tabla 4.6: Zonas turísticas de Madrid con más de 2 repeticiones (entre mapas y textos)

Tabla 4.7: $\quad$ Lugares de interés turístico alrededor de Madrid conocidos por los turistas encuestados al final de su visita (localidades con más de 2 repeticiones)

Tabla 4.8: Estaciones de metro con más de 3 repeticiones en los mapas mentales de los cuestionarios finales

Tabla 4.9: Enfoques de la experiencia turística de Madrid: motivación o aspecto determinante de la experiencia y características de los factores condicionantes de las actividades que realizan los turistas, incluida una caracterización general de sus mapas mentales, una vez finalizada la visita

Tabla 4.10: Mapas finales característicos de los turistas según la forma que tienen de abordar la experiencia (elementos, sistemas de referencia, cobertura y focos de los mismos) 
Tabla 4.11: Experiencias deseadas, nivel de personalización, oportunidades de influencia y dispositivos afines a cada turista según su enfoque

Tabla 4.12: Descripción del Explorador-Escenario 1: Durante el viajeDesplazamiento en metro

Tabla 4.13: Descripción del Explorador-Escenario 2: Planeando que hacer al día siguiente

Tabla 4.14: Descripción del Guiado-Escenario 1: Planeando el viaje

Tabla 4.15: Descripción del Guiado-Escenario 2: Consultando información sobre el viaje, durante la visita

Tabla 4.16: Descripción del Condicionado-Escenario 1: Visitando Madrid en el bus turístico

Tabla A1: Tipos de preguntas formuladas a los Servicios de Atención e Información Turística del Ayuntamiento de Madrid. Fuente: Empresa Municipal Madrid Destino

Tabla A2: Lugares que los turistas tienen previsto visitar en Madrid al inicio de su estancia y número de veces que se han mencionado en los cuestionarios iniciales

Tabla A3: Atractivos turísticos puntuales de Madrid registrados en los mapas mentales y en las listas de libre recuerdo de los cuestionarios finales

Tabla A4: Porcentajes por rangos de repeticiones de atractivos turísticos puntuales registrados en los mapas mentales y en las listas de libre recuerdo de los cuestionarios finales

Tabla A5: Ejes de Madrid incluidos en los mapas mentales y en las listas de libre recuerdo de los cuestionarios finales

Tabla A6: Zonas turísticas de Madrid incluidos en los mapas mentales y en las listas de libre recuerdo de los cuestionarios finales

Tabla A7: Lugares de interés turístico alrededor de Madrid mencionados por los turistas al final de su visita

Tabla A8: Estaciones de metro incluidas en los mapas mentales de los cuestionarios finales

Tabla A9: Líneas de metro incluidas en los mapas mentales de los cuestionarios finales 


\section{Lista de figuras}

Figura 2.1: Plano de la Ciudad de Catal Hüyül de entorno al 6.000 AC, descubierto por el arqueólogo James Mellaart en Ankara 6

Figura 2.2: Tabla de Peutinger del siglo IV, que representa caminos del Imperio Romano

Figura 2.3: Plano de Londres con información sobre personas muertas por cólera (1854)

Figura 2.4: Gráfico de la caída de las tropas de Napoleón en la campaña de Rusia realizado por Charles Minard (1861).

Figura 2.5: Mapa de metro de Londres de Henry Beck 1931. 8

Figura 2.6: Interacciones que tienen lugar cuando se resuelve una tarea en base al uso de mapas. Fuente: adaptación de Freksa (1999) 10

Figura 2.7: Aproximaciones al desarrollo de los mapas esquemáticos: una basada en datos (de abajo a arriba) y otra en el enfoque cognitivo (de arriba abajo) Fuente: adaptación de Klippel, Lee, et al. (2005).

Figura 2.8: Aspectos del mapa que pueden adaptarse y factores de adaptación. Fuente: adaptación de Reichenbacher (2003) y Nivala \& Sarjakoski (2003).

Figura 2.9: Codificación de la información espacial que el usuario adquiere a través de sus experiencias mediante el contacto directo con el espacio geográfico (fuentes primarias) y a través de mapas u otros medios de comunicación (fuentes segundarias). Fuente: adaptación de Lloyd (1993).

Figura 2.10: Proceso cognitivo asociado a la lectura e interacción con los mapas. Fuente: adaptación de imagen extraida de http://www.worddive.com/.

Figura 2.11: Mapas cognitivos con sistema de referencia egocéntrico (superior izquierda); diferenciado y parcialmente coordinado, variedad de rutas (superior derecha); diferenciado y parcialmente coordinado, variedad punto-radial (inferior izquierda) y abstractamente coordinado e integrado jerárquicamente (inferior derecha). Fuente: Moore (1973) 
Figura 2.12: Grado de adecuación de cada propiedad perceptiva al ser aplicada a cada una de las variables planteadas por Bertin (1967). Los cuadros oscuros identifican las que son adecuadas y los blancos las que no lo son. Dentro de las adecuadas las más propicias se han identificado con una exclamación. Las menos adecuadas se han marcado con una interrogación. La posición se ha separado con una línea del resto de las variables para indicar que en cartografía no es adecuado utilizarla como variable visual. Fuente: adaptación de Bertin (1967)

Figura 2.13: Diseño Centrado en el Usuario. Fuente: adaptación de Van Elzakker y Wealands (2007).

Figura 2.14: Modelo de comunicación cartográfico centrado en el usuario. Fuente Schobesberger (2012).

Figura 2.15: Clasificación de técnicas de diseño utilizadas en el Diseño Centrado en el Usuario de sitios web cartográficos. Fuente: Schobesberger (2012)

Figura 2.16: Experiencia y experiencia de usuario. Fuente: Law et al. (2009) 26

Figura 2.17: Modelo conceptual de experiencia de usuario teniendo en cuenta el tiempo. Fuente: Kankainen (2002).

Figura 2.18: Modelo de diseño de experiencias de Hassenzahl (2014)

Figura 2.19: Experiencia de usuario desde a) la perspectiva del diseñador y b) la perspectiva del usuario. Fuente: adaptación de Hassenzahl (2003).

Figura 2.20: Profesionales que suelen intervenir en el diseño de experiencias.

Fuente: Fuente: http://asinthecity.com/2011/11/10/the-difference-between-aux-designer-and-ui-developer/.....

Figura 2.21:a) Formas de aprender acerca de las experiencias de los usuarios y

b) niveles de necesidades. Fuente: Sanders (2002). 30

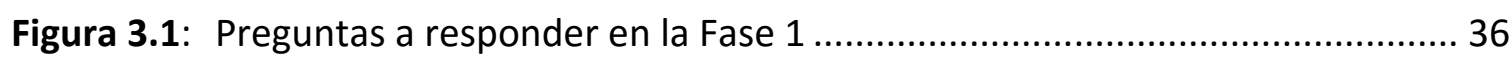

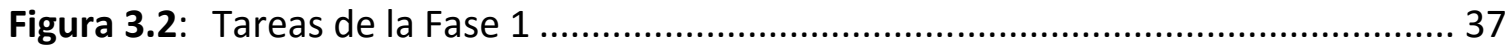

Figura 3.3: Preguntas a responder en la Fase 2 .......................................................... 42

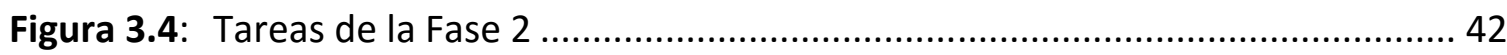

Figura 3.5: Preguntas a responder en la Fase 3 ..................................................... 50

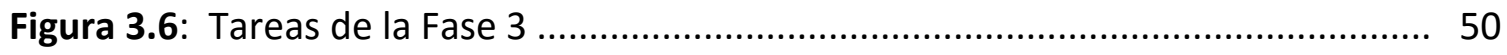

Figura 3.7: Interacción entre el usuario y el ambiente en el que se desarrolla su

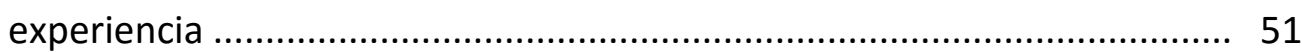

Figura 3.8: Interacción entre el usuario y los mapas que dan soporte a su experiencia

Figura 3.9: Interacción entre los mapas y el ambiente en el que se desarrolla la experiencia del usuario 
Figura 3.10: Ejemplo de la descripción de una "persona"

60

Figura 3.11:Ejemplo de la descripción de un escenario. Fuente: http://unify.eightshapes.com/.

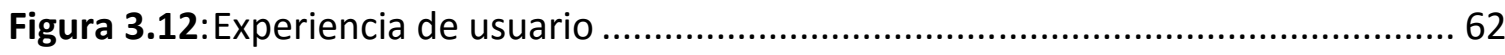

Figura 3.13: Proceso de Diseño de Experiencia de Usuario ............................................... 63

Figura 4.1: Canales de información utilizados por los turistas internacionales para preparar su viaje Madrid. Fuente: Madrid Visitors \& Convention Bureau (2012). 68

Figura 4.2: Diferentes modos de uso de la tecnología Morph de Nokia. Fuente: Rajesh, Sulthana, Majeed, \& Student (2013)................................ 70

Figura 4.3: Técnicas de diseño aplicadas en la Fase 2 para recopilar información.......... 74

Figura 4.4: Material utilizado para llevar a cabo la técnica de diagramas de afinidad, con el fin de organizar la información recopilada de los grupos de interés

Figura 4.5: Plano esquemático de metro con la parada "Vodafone-Sol" en su centro

Figura 4.6: Mapa suministrado por el Consorcio Regional de Transportes de Madrid junto al Billete de Transporte Turístico.

Figura 4.7: Mapa mental con: a) atractivos puntuales de interés: Plaza Mayor, b) eje: Gran vía y c) zonas: Barrio de Chamberí.

Figura 4.8: Mapa mental donde la Estación de Atocha aparece como atractivo turístico (color azul) y como estación (color rojo).

Figura 4.9: Mapas mentales que ilustran la presencia del eje del Paseo del Prado.

Figura 4.10: Mapa mental que ilustra la presencia del eje del Paseo del Prado y un gran número de atractivos puntuales en su entorno 89

Figura 4.11: Mapas mentales que incluyen diferentes concepciones de la Gran Vía. 89

Figura 4.12: Mapas mentales con escasa presencia de ejes y atractivos puntuales sueltos.

Figura 4.13: Atractivos turísticos puntuales y ejes de Madrid más conocidos por los turistas tras su visita

Figura 4.14: Mapa mental que incluye zonas de la ciudad caracterizadas por las actividades turística realizadas en ellas.

Figura 4.15: Mapa mental que incluye una infraestructura de transporte ("Start: Callao") como elemento clave en su experiencia cognitivoespacial de Madrid. 
Figura 4.16: Mapas mentales cuyos ejes son líneas de metro: a) varias líneas de metro coordinadas y b) varios tramos de líneas que parecen formar parte de un mismo recorrido

Figura 4.17: Medios de transporte que han utilizado los turistas encuestados durante su visita. Gráfica obtenida a partir de datos sobre los tres medios de transporte más utilizados por cada turista, ponderados por su intensidad de uso (peso 1 al menos utilizado y peso 3 al más utilizado por cada turista).

Figura 4.18: Mapas mentales de dos turistas con enfoque de experiencia de tipo explorador: a) al inicio de la visita y b) al finalizar la visita. 100

Figura 4.19: Mapas mentales de dos turistas con enfoques de experiencia de tipo guiado: a) al inicio de la visita y b) al finalizar la visita.

Figura 4.20: Mapas mentales de dos turistas con enfoques de experiencia de tipo condicionado: a) al inicio de la visita y b) al finalizar la visita.

Figura 4.21: Mapas mentales dibujados por los turistas encuestados con sistemas de referencia: a) Egocéntrico, b) Diferenciado y c) Coordinado. 106

Figura 4.22: Mapas mentales de los turistas encuestados con sistemas de referencia adicionales a los establecidos por Moore $(1973,1974)$ : a) Puntual tipo imagen, b) Puntual tipo cartográfico, c) Multi-puntual tipo imagen y c) Multi-puntual tipo cartográfico.

Figura 4.23: Mapas mentales caracterizados según sus marcos de referencia: Recorrido/s que integran puntos de interés turístico; b) Puntos de interés de los que parten ejes sueltos o que conectan con otros puntos de interés; c) Puntos de interés sin conexiones; d) Zonas o barrios (ver líneas discontinuas) y referencias naturales (Río Manzanares en la parte inferior izquierda).

Figura 4.24: Mapas mentales caracterizados según sus focos de referencia: a) Lugar de alojamiento; b) Atractivo de interés turístico y c) Sin foco de referencia destacado.

Figura 4.25: Evolución de los mapas mentales del turista de Dinamarca que participó en la técnica de los diarios (Fase 2, Tarea 2.2) y cuyo enfoque de experiencia fue explorador 
Figura 4.26: Evolución de los mapas mentales de la turista de Dinamarca que participó en la técnica de los diarios (Fase 2, Tarea 2.2) y cuyo enfoque de experiencia fue guiado. Estos mapas son un ejemplo especialmente particular por un lado, por el contraste con respecto a los del esposo (Figura 4.25) y por su cobertura global zonal, siendo el único caso con este tipo de cobertura entre los mapas finales de este enfoque

Figura 4.27: Evolución de los mapas mentales del turista de UK que participó en la técnica de los diarios (Fase 2, Tarea 2.2) y cuyo enfoque de experiencia fue condicionado. Su visita duró 6 días, pero durante los últimos 3 asistió a un curso y no tuvo tiempo de hacer turismo, por lo que su mapa final fue el del día 3.

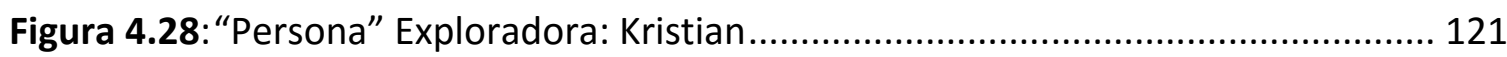

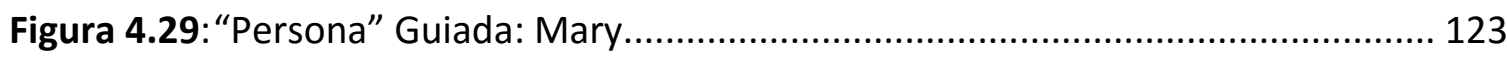

Figura 4.30: "Persona” Condicionada: Adriana............................................................ 125

Figura 4.31:Storyboard Explorador-Escenario 1: Durante el viajeDesplazamiento en metro.....

Figura 4.32: Kristian y su mujer se encuentran en el andén del metro de Conde de Casal y tienen previsto ir al Parque del Capricho. El mapa muestra a Kristian 3 sugerencias de lugares que les pueden resultar de interés camino a su destino.

Figura 4.33: Kristian selecciona uno de los lugares sugeridos (Breakfast in Los Timbales) y el mapa muestra las modificaciones en el recorrido en caso de que decidiera ir a ese lugar, camino a su destino final. Kristian decide hacer una parada en el lugar sugerido (selecciona "Go").

Figura 4.34: El sistema actualiza el recorrido al incorporar la nueva visita camino al Parque del Capricho (Los Timbales), segundos antes de de que llegue el metro.

Figura 4.35: Kristian y su mujer ya están en el vagón camino a Los Timbales. El sistema muestra fotografías de lugares de interés por los que van pasando y en el mapa se puede ver el lugar del recorrido donde se encuentran en cada momento. 
Figura 4.36: Kristian y su mujer están a punto de llegar a la parada de metro donde tienen que salir para ir a "Los Timbales". El sistema muestra el tiempo restante para llegar, la salida que tienen que tomar y la dirección que tienen que ir al salir del vagón, así como información geográfica de interés de la superficie como la ubicación de "Los Timbales" y de otro atractivo turístico próximo (la plaza de toros de las Ventas).

Figura 4.37:Storyboard Explorador-Escenario 2: Planeando que hacer al día siguiente

Figura 4.38: Kristian visualiza el mapa esquemático de "Su Madrid". Este mapa no presenta foco e incluye los puntos de interés turístico, ejes destacados y zonas visitadas, así como las líneas de transporte utilizadas. Iconos personalizados de atractivos clave sobre círculos cuyo tamaño está determinado por el peso que cada uno de ellos tiene en el mapa mental agregado de los turistas de Madrid (Figura 4.13) y servicios que Kristian ha valorado de forma destacada (restaurantes, lugares de compras y espectáculos). Kristian puede visualizar el mismo mapa en su versión geográfica y consultar sugerencias.

Figura 4.39: Cuando Kristian selecciona el botón "Region" el sistema mantiene el modo de visualización esquemático y muestra una selección de lugares afines a sus intereses a menos de 2 horas de Madrid y tres sugerencias (una ruta panorámica en Toledo, un recorrido para ver cigüeñas en Alcalá de Henares y un tour de tapas por Segovia). Los círculos que representan los lugares tienen un tamaño acorde como el peso que éstos tienen en el mapa cognitivo agregado de los turistas de Madrid. Los lugares se ubican en su dirección geográfica y a una distancia equivalente al tiempo de acceso más rápido en transporte público desde Madrid.

Figura 4.40: Kristian decide ver más detalles del plan sugerido en Toledo. El sistema muestra a Kristian información de detalle de la ruta panorámica: valoración de otros turistas exploradores, medios de transporte disponibles y precios. Kristian puede expandir la información de detalle para ver horarios, ubicación de estaciones, ... Tras consultar a su esposa, Kristian indica al sistema que irán a Toledo. 
Figura 4.41: Kristian ha decidido que al día siguiente irán a Toledo y el sistema muestra el mapa esquemático de los alrededores de Madrid con el nuevo destino incorporado. Kristian decide entonces echar un vistazo a la ubicación geográfica de Toledo.

Figura 4.42: Representación geográfica de lugares de interés alrededor de Madrid, el destino seleccionado para ir al día siguiente (Toledo) y dos sugerencias.

Figura 4.43: Storyboard Guiado-Escenario1: Planeando el viaje.

Figura 4.44: El sistema muestra un mapa con foco en el lugar de alojamiento y los atractivos que visitarán el primer día, así como fotografías capturadas del video y principales calles de referencia según la exploración realizada de los mapas mentales de los turistas (Figura 4.13). Mary puede seleccionar los atractivos que desee para obtener más información y consultar por otro día de la estancia.

Figura 4.45: El sistema muestra los atractivos que visitarán el segundo día. Los iconos de los mapas están personalizados siguiendo las pautas de varios mapas mentales recogidos de los turistas (Figura 4.8, 4.11b, 4.14 y $4.22 \mathrm{c}$ ).

Figura 4.46: El sistema muestra los atractivos que visitarán el tercer día. El sistema resalta en el mapa y en la lista de texto el atractivo correspondiente a la imagen mostrada, para facilitar la asimilación de conocimiento.

Figura 4.47: El sistema muestra los atractivos que visitarán el cuarto día. El mapa está focalizado en el lugar de alojamiento y como este día visitarán varios lugares próximos andando, se incluye una referencia geográfico-temporal (anillo de 10 minutos andando desde el alojamiento).

Figura 4.48: El sistema muestra los atractivos que Mary y Kate visitarán a lo largo de su estancia. Mary, como turista guiado, es posible que tenga dificultades para integrar geográficamente la ubicación los atractivos visitados a lo largo de su estancia. Por esta razón, se ha propuesto una visualización individualizada por días y una integrada, que de soporte a Mary en sus procesos cognitivos asociados a la asimilación de conocimiento espacial de Madrid.

Figura 4.49:Storyboard Guiado-Escenario2: Consultando información sobre el viaje durante la visita. 
Figura 4.50: El sistema muestra los atractivos que Mary y Kate visitaron el primer día de su estancia en Madrid, en el que recorrieron la ciudad en bus turírico. El menú de botones de los días de la estancia indica con contornos en rojo actividades por realizar. El último botón permite a Mary acceder a una visualización que integra todos los atractivos y recorridos realizados y por realizar durante el viaje.

Figura 4.51:El sistema muestra los atractivos que Mary y Kate visitaron el segundo día de su estancia en Madrid. Por la mañana fueron andando al Rastro donde hicieron unas compras y por la tarde tomaron un taxi para ir al Prado. La fotografias tomadas por Mary ilustran sus experiencias de ese día.

Figura 4.52: El sistema muestra donde se encuentran Mary y Kate en ese momento (en el Parque del Retiro), los atractivos que aun les quedan por disfrutar durante el resto del día (compras por Serrano) y los recorridos realizados (taxi desde el alojamiento al parque y paseo dentro de él).

Figura 4.53: Mary selecciona el botón del día 15 de abril y el sistema muestra los atractivos que visitarán al día siguiente (el Mercado de San Miguel y la Plaza Mayor). A diferencia de las pantallas anteriores, en ésta las fotografías son las capturadas del vídeo del plan de viaje, aunque serán sustituidas por las realizadas por Mary en cuanto visite estos atractivos.

Figura 4.54:Mary selecciona "My Madrid" y el sistema muestra todo el contenido del viaje: atractivos visitados, recorridos realizados y lugares por descubrir. Esta vista da soporte al desarrollo del mapa cognitivo de Mary ayudándola a integrar todos los espacios de la ciudad asociados a su experiencia turística.

Figura 4.55: Storyboard Condicionado-Escenario1: Visitando Madrid en el bus turístico.

Figura 4.56: El sistema muestra a Adriana donde se encuentra espacial y temporalmente a lo largo del recorrido, así como fotografías de los atractivos que puede ver en ese momento y sus nombres.

Figura 4.57: El sistema sugiere a Adriana que puede ser una buena idea bajarse en la siguiente parada y muestra un mapa que ilustra las calles próximas donde puede hacer compras y comer 
Figura A1: Viajeros nacionales e internacionales en la CM entre el 2009 y el 2013:

a) Número de viajeros, b) Incremento interanual de porcentajes de viajeros. Fuente: Instituto de Estadística de la CM (n.d.) .

Figura A2: Evolución del número de turistas extranjeros en diferentes Comunidades Autónomas de España entre el 2010 y el 2014. Fuente: Expectativas 2015. Fuente: Deloitte (2015)

Figura A3: Edad de los turistas internacionales que visitan Madrid. Fuente: Madrid Visitors \& Convention Bureau (2012)

Figura A4: Distribución de gasto total del turismo receptor de España (anillo exterior) y el de la CM (anillo interior). Fuente: Instituto de Turismo de

España (2013)

Figura A5: Grupos de viaje de turistas internacionales de Madrid. Fuente: Madrid Visitors \& Convention Bureau (2012) .

Figura A6: Percepción de la ciudad de los visitantes internacionales de Madrid Fuente: Madrid Visitors \& Convention Bureau (2012).....

Figura A7: Valoración de la experiencia turística en Madrid por parte de los turistas internacionales

Fuente: Madrid Visitors \& Convention Bureau (2012).

Figura A8: Evolución de la estancia media de los viajeros (nacionales e internacionales) en la ciudad de Madrid. Fuente: Ayuntamiento de Madrid (n.d.)

Figura A9: Duración de la estancia de viajeros extranjeros que usaron móvil en Barcelona y Madrid, en el mes de octubre del 2012, por rangos de días. Fuente: RocaSalvatella \& Telefónica (2014).

Figura A10: Estancia media de viajeros extranjeros que usaron móvil en Barcelona y Madrid durante el mes de octubre del 2012. Fuente: RocaSalvatella \& Telefónica (2014)

Figura A11: Evolución de pernoctaciones de viajeros (nacionales e internacionales) en la ciudad de Madrid. Fuente: Ayuntamiento de Madrid (n.d.).

Figura A12: Mapa turístico del centro de la ciudad elaborado por el Ayuntamiento de Madrid.

Figura A13: Mapa turístico del centro de la ciudad del Consorcio de Transportes de Madrid.

Figura A14: Mapa turístico de metro de Madrid. 196 
Figura A15: Mapa turístico de Madrid de la empresa El Corte Inglés. 196

Figura A16: Geoportal de "Madrid card" http://geoportal.madridcard.com/ . 198

Figura A17: Aplicación cartográfica de la web turística de la Comunidad de Madrid http://turismomadrid.es/es/organizate/mapas.html.

Figura A18: Visualizador cartográfico de la web turística de TripAdvisor-Madrid http://www.tripadvisor.es/Tourism-g187514-MadridVacations.htmI\#MAPVIEW 198

Figura A19: App "Guía Oficial de Madrid", de la empresa municipal Madrid Destino Cultura, Turismo y Negocio.

Figura A20: App "Madrid card" asociada a la tarjeta turística oficial del Ayuntamiento de Madrid.

Figura A21: App "Metro de Madrid Oficial": Pantalla principal, Mapa de metro y Mapa turístico. 200

Figura A22: App "Madrid city guide" de TripAdvisor. 200

Figura A23: Zonas turísticas de Madrid según la relevancia y la tipología de los atractivos turísticos: Tradicional (azul), Complementarios (naranja) y de Renovación (amarillo). Fuente: Madrid Visitors \& Convention Bureau (2012).

Figura A24: Zonas de los billetes turísticos de transporte del CRTM 202

Figura A25: Ventas de los billetes turísticos de transporte del CRTM durante el 2013

Figura A26: Porcentaje de pernoctaciones en los distritos de Madrid de turistas internacionales, en base a pagos con tarjetas extranjeras, durante Octubre del 2012.Fuente: RocaSalvatella \& Telefónica (2014)

Figura A27: Mapa de calor de las 297.444 transacciones realizadas por visitantes españoles de fuera de Madrid durante 2012 y que han sumado compras en el barrio de Salamanca por valor de 24.914.120€.

Figura A28: Ritmo de compra de turistas internacionales. Número de horas entre compras en las 8 zonas más comerciales y turísticas de Madrid según nacionalidad. Fuente: BBVA y Ayuntamiento de Madrid (2013)

Figura A29: App "The Traveler" para Android utilizada en la técnica de los diarios

Fuente:https://play.google.com/store/apps/details?id=edu.bsu.and roid.apps.traveler.....

Figura A30: Tabla de Excel con las respuestas de los cuestionarios finales relativas al conocimiento del espacio de Madrid.

Figura A31: Tabla de Excel con los atributos de los turistas encuestados al final de su visita y el resto de información sobre los factores condicionantes de sus actividades. 
Figura A32: Características de los turistas encuestados: a) Edad, b) Género, c) Nivel de estudios, d) Procedencia, e) Experiencia visitando grandes ciudades, f) Experiencia en el uso de IG y g) Percepción de los desplazamientos

Figura A33: Principal motivo de la visita de los turistas encuestados (iniciales y finales)

Figura A34: Grupo de viaje de los turistas encuestados (iniciales y finales).

Figura A35: Intereses manifestados por los turistas encuestados (iniciales y finales).

Gráfica obtenida a partir de información sobre los cinco intereses principales de cada turista, ponderados según la importancia y promediados.

Figura A36: Nivel de planificación del viaje de los turistas recién llegados (iniciales).

Figura A37: Porcentajes de encuestados antes de inicar la visita que identifican fotografías de lugares de interés de Madrid.

Figura A38: Porcentaje de encuestados antes de iniciar su visita que identifican fotografías de lugares de interés y los localizan en un mapa de Madrid.

Figura A39: Medios de transporte que los turistas tienen previsto utilizar en Madrid, antes de comenzar su vista (iniciales). Gráfica obtenida a partir de datos sobre los tres medios de transporte que el turista tiene intención de utilizar, ponderados por su estimación de frecuencia de uso.

Figura A40: Duración de la estancia de los turistas encuestados al finalizar su visita, por rangos de días

Figura A41: Zona de Sol en a) imagen de satélite de Google Maps, b) mapa de Google Maps, c) y d) mapas mentales de dos turistas de Madrid cuyos ejes entorno a Sol se representan de forma muy similar a como lo hace Google Maps y e) Zona de Sol en el mapa en papel suministrado con el billete turístico de transporte del CRTM, cuya representación difiere significativamente de las anteriores.

Figura A42: Adjetivos utilizados por los turistas para describir Madrid una vez finalizada su visita.

Figura A43: Grado en el que Madrid ha cubierto las expectativas de los turistas encuestados al finalizar su visita.

Figura A44: Productos turístico-cartográficos consultados durante el pre-viaje. 314

Figura A45: Soporte o fuente de información turística consultada durante el previaje. 
Figura A46: Información consultada durante el pre-viaje por los turistas encuestados.

Figura A47: Productos turistico-cartográficos consultados durante el viaje.

Figura A48: Soporte o fuente de información turística consultada durante el viaje.

Figura A49: Información consultada durante el viaje por los turistas encuestados al finalizar su visita.

Figura A50: Mapas mentales de dos turistas al finalizar su visita, con un enfoque de experiencia a) condicionado y b) explorador.

Figura A51: Mapas mentales iniciales de turistas que abordan su experiencia desde un enfoque explorador: a) Diferenciado; b) y c) Multi-puntual cartográfico; d) y e) Coordinado.

Figura A52: Mapas mentales finales de turistas que abordan su experiencia desde un enfoque explorador: a) Multi-puntual cartográfico; b), c) y d) Diferenciado y d), e), f) g) y h) Coordinado.

Figura A53: Mapas mentales iniciales de turistas que abordan su experiencia desde un enfoque guiado: a) Puntual tipo imagen, b) Puntual tipo cartográfico y c) Egocéntrico.

Figura A54: Mapas mentales de turistas que abordan su experiencia desde el enfoque guiado: a) Puntual, b) Multi-puntual de tipo cartográfico, c) Egocéntrico y d) Diferenciado.

Figura A55: Mapas mentales iniciales de turistas que abordan su experiencia desde un enfoque condicionado: a) Puntual tipo cartográfico, b) Egocéntrico y c) Coordinado.

Figura A56: Mapas mentales finales de turistas que abordan su experiencia desde un enfoque condicionado: a), b) y c) Egocéntrico; d) Multipuntual cartográfico; y e) Diferenciado y f) Coordinado.

Figura A57: Inspiraciones para los diseños de los mapas: a) Estructuras de navegación y contenidos cartográficos, b) Atractivos puntuales, c) Atractivos entorno a una localización, d) Caminando, e) Visualización de recorridos y f) Visualización de zonas

Figura A58: a-e) Prototipos de los mapas en papel del Explorador-Escenario 1: Durante el viaje. Desplazamiento en metro 341 


\section{INTRODUCCIÓN}

\subsection{Motivación de la investigación y contexto}

El volumen de información, la capacidad de su almacenamiento y la velocidad de transmisión se han incrementado exponencialmente y cualquier persona está sometida a miles y miles de estímulos a lo largo del día. Las posibilidades de acceso a la información se han multiplicado en los últimos años, pero nuestros recursos como seres humanos (tiempo, conocimiento, capacidades cognitivas,...) siguen siendo limitados. Por esta razón, la cantidad de información disponible se ha convertido en muchos casos en una sobrecarga que refuerza nuestra incapacidad de acción, debido al desbordamiento de posibilidades generado. La facilidad de acceso a la información no tiene una utilidad real, si ésta no se adapta a nuestra necesidad en un momento dado. Deseamos acceder a la información de forma rápida y dedicar el menor tiempo posible a procesarla.

Neisser (1981) define la cognición como "la actividad de conocer: la adquisición, organización y uso del conocimiento", es decir, cómo la mente humana procesa los estímulos, desde el momento en que entran a través de los sentidos, hasta el momento que son utilizados para realizar cualquier conducta en base al estímulo en cuestión. Todo lo que sabemos de la realidad está condicionado por nuestra percepción. Ésta se interpone entre el mundo real y nuestro comportamiento, de manera que nuestras respuestas a una situación no se generan en base al entorno físico real, sino en función de la imagen o mapa cognitivo que tenemos de él (Downs R. M. \&. Stea, 1973). El mundo real es demasiado grande y complejo para conocerlo complemente y las personas afrontan esta complejidad generando mapas cognitivos del espacio con el que interactúan. Estos mapas están compuestos por información extraída de manera subjetiva, con un propósito que refleja las necesidades y los valores de cada persona (Walmsley \& Jenkins, 1992).

Los avances tecnológicos están cambiando lo que es posible producir a nivel cartográfico y los cartógrafos tienen que enfrentar desafíos cada vez más complejos, como la creciente demanda de modos cognitivamente más adecuados de interactuar con los mapas (Van Elzakker \& Griffin 2013). La comunidad cartográfica internacional ha dedicado notables esfuerzos en aplicar enfoques de diseño en los que los usuarios son la referencia fundamental. Durante décadas los cartógrafos han investigado como desarrollar productos cartográficos a través de procesos de diseño centrado en el usuario (DCU), con el fin de proporcionar interacciones cartográficas de una forma eficiente, efectiva y satisfactoria (Slocum et al., 2001; Reichenbacher, 2004; Lloyd, 2009; Schobesberger, 2012). Sin embargo, el diseño de experiencias supone un cambio en "el fin a lograr", donde el objetivo, no se limita únicamente a mejorar el rendimiento del usuario en la interacción con los mapas, sino que se tiene en cuenta la experiencia asociada a su uso. Los cartógrafos deben realizar un esfuerzo en la integración de los principios teóricos y prácticos del ámbito del diseño de experiencias (Roth 2013 y 2015) y la presente investigación aborda este reto. La primera premisa en esta tesis es que los dispositivos basados en las nuevas tecnologías (nanotecnologías, loT, wearables,...) son capaces de 
identificar, reconocer y proponer a cada usuario, de forma activa y en tiempo real, mapas que le asistan en sus experiencias.

Del mismo modo que los aspectos cognitivos influyen en como los usuarios interpretan el espacio que les rodea y los mapas (esquemáticos, topográficos,...), el uso de los mismos también afecta su percepción del espacio (Elzakker \& Griffin 2013) y con ello su comportamiento y experiencias. Tanto las geo-tecnologías como sus posibilidades de uso son susceptibles de asistir a las personas, dando soporte a sus experiencias $y$, por tanto, juegan un papel relevante en la adquisición de conocimiento geográfico, en el comportamiento espacial y en la realización de actividades que requieren de la interacción persona-espacio geográfico (Tussyadiah \& Zach, 2012). La experiencia que un usuario tiene de un determinado espacio está relacionada con la adquisición de conocimiento del mismo, a través de las interacciones complejas con y en él. Las interacciones con un espacio geográfico se pueden llevar a cabo a través de mapas que actúan como interfaces (experiencias de usuario) y, las interacciones en el espacio se producen cuando el usuario está inmerso en él. Teniendo esto en cuenta, la segunda premisa de esta tesis es que las interacciones del usuario con los mapas inciden en su adquisición de conocimiento del espacio representado y, por lo tanto, en su experiencia cognitiva del mismo.

En esta tesis se analiza la interacción cartográfica enfatizando la distinción entre el diseño de experiencias de usuario y el diseño de los propios mapas. La experiencia de usuario se contempla como una nueva forma de conceptualizar la tarea objeto de la visualización de la información geográfica, para cuyo soporte se suministra al usuario la interacción con mapas. El diseño de los mapas se aborda a través de la presentación de la información de forma gráfica (diseño cartográfico).

El foco de esta investigación es estudiar cómo dar soporte a la experiencia cognitiva del usuario, asistiéndole en la ejecución de actividades a través del uso de mapas. Se busca que estos actúen como interfaces evocadoras entre el usuario y el ambiente urbano, propiciando el establecimiento de asociaciones entre los elementos del espacio que faciliten su recuerdo. Los mapas a diseñar desempeñarán la función de componentes externos de los sistemas cognitivos de los usuarios (Peterson, 1996; MacEachren, 2013), con el objeto de facilitarles la información y la asimilación de conocimiento que necesitan (como apoyo a la ejecución de las actividades que pretenden realizar). Por esta razón, en el proceso para el desarrollo de mapas que se propone en esta tesis, el estudio de los mapas cognitivos de los usuarios desempeñará un papel fundamental, dado que estos (al igual que los mapas que pretendemos diseñar) dan soporte a su experiencia cognitiva y, su análisis, ayuda a comprenderla.

El proceso propuesto para el desarrollo de estos mapas, a través del diseño de experiencias de usuario, se probará y validará mediante el caso de estudio del turismo urbano en Madrid. La experiencia turística es un proceso subjetivo condicionado por el turista (motivación, preferencias, intereses,...), las características del destino turístico, los servicios y productos con los que interactúa a la hora de llevar a cabo sus actividades y el ambiente en el que éstas se desarrollan. La naturaleza espacio-temporal del turismo hace de él un caso de estudio idóneo para el diseño de experiencias cognitivas del usuario. El turista vive 
experiencias en las que utiliza mapas, que le asisten en el descubrimiento y la comprensión de características únicas del destino. Sin embargo, no existen investigaciones conocidas que aborden el diseño de mapas focalizados en propiciar experiencias significativas al turista, teniendo en cuenta cómo percibe y asimila conocimiento del espacio visitado.

\subsection{Descripción del proyecto de investigación}

El principal objetivo de este trabajo es proponer un proceso de diseño de mapas que asistan al usuario en su experiencia cognitiva de un espacio urbano. Se busca que los mapas diseñados sirvan como soporte al mapa cognitivo que el usuario tenga de dicho espacio.

En esta investigación se considera que las interacciones con los mapas no solo impactan en la ejecución de tareas por parte de los usuarios, sino que también lo hacen en el aprendizaje del espacio y del ambiente que les rodea (experiencias cognitivas del usuario).

En base a la revisión bibliográfica, la hipótesis de esta tesis es que:

Los mapas (esquemáticos, personalizados, cognitivos,...) se pueden considerar instrumentos activos en los procesos cognitivos de los usuarios (procesos en los que intervienen la memoria sensorial, de trabajo y a largo plazo), que inciden en su comportamiento y en sus experiencias cognitivas del espacio geográfico urbano.

La innovación de esta investigación reside en la definición de un proceso de diseño de mapas que, teniendo en cuenta el comportamiento del usuario en el espacio y sus mapas cognitivos, de soporte a su experiencia cognitiva de dicho espacio.

Las contribuciones al ámbito cartográfico de esta investigación radican en:

- Establecer un procedimiento en el que el desarrollo de los mapas se fundamente en una conceptualización de la actividad a la que el mapa da soporte, en base a una compresión de la forma en la que el usuario aborda su experiencia en el espacio urbano.

- Realizar el diseño de mapas, considerando la forma en la que el usuario aborda la experiencia del espacio urbano y la incidencia que esta tiene en su mapa cognitivo. 


\subsection{Cuestiones que se pretenden resolver en esta investigación}

Esta tesis aborda la integración de los principios teóricos y prácticos del ámbito del diseño de experiencias con el fin de dar soporte a la experiencia cognitiva de los usuarios en relación a un espacio geográfico urbano.

La principal pregunta de investigación de esta tesis es:

¿Cómo desarrollar mapas que den soporte a la experiencia cognitiva de un usuario, asociada a un espacio urbano?

Para abordar esta interrogante se plantean las siguientes cuestiones complementarias:

¿Bajo qué factores asociados a las actividades que realiza un usuario (comportamiento, mapas que utiliza, conocimiento del espacio geográfico,...) se pueden desarrollar mapas que den soporte a su experiencia cognitiva de un espacio urbano?

¿Bajo qué criterios de contenido (elementos, representaciones,...) se pueden desarrollar mapas teniendo en cuenta la experiencia cognitiva de un usuario?

¿Bajo qué criterios de contexto (actividad, entorno físico...) se pueden desarrollar mapas teniendo en cuenta la experiencia cognitiva de un usuario?

Para finalizar esta introducción, se describe la estructura de la presente tesis. Tras estas primeras líneas introductorias se aborda el estado del arte sobre los mapas, los aspectos cognitivos involucrados en el diseño cartográfico y el proceso de DCU aplicado a su desarrollo; para introducir a continuación el conocimiento en torno al diseño de experiencias de usuario (Capítulo 2). A continuación, dando respuesta a la pregunta de investigación, se expone la metodología para el desarrollo de mapas en base al diseño de experiencias de usuario, haciendo un espacial hincapié en la experiencia cognitiva del mismo (Capítulo 3). Seguidamente se prueba y valida el proceso de diseño de experiencias de usuario aplicándolo al desarrollo de mapas turísticos de Madrid (Capítulo 4). Finalmente, la tesis concluye con la respuesta a las preguntas de investigación y la propuesta de trabajos futuros (Capítulo 5) 


\section{FUNDAMENTOS TEÓRICOS Y SU INTEGRACIÓN EN EL DESARROLLO DE MAPAS A TRAVÉS DEL DISEÑO DE EXPERIENCIAS DE USUARIO}

El término diseño se utiliza en la literatura con tres acepciones (Heskett, 2005): 1) diseño como una propuesta única, un resultado final en forma por ejemplo, de producto u objeto (un mapa); 2) diseño como una actividad o acción (diseño cartográfico); y 3) diseño como una intención, enfoque, plan o proceso para la creación de ese nuevo objeto. Esta tesis está enfocada en este último sentido, la del diseño como proceso. Esto implica la ejecución de un plan para desarrollar un determinado producto, de tal manera que se establece una distinción entre el diseño y el producto. Así el diseño se convierte en el proceso precursor de su creación.

El producto a diseñar en esta investigación son mapas que desempeñen el papel de interfaces, conectando al usuario con un espacio geográfico, teniendo en cuenta su experiencia.

A continuación se revisan los antecedentes del diseño en el ámbito cartográfico, considerando las tres acepciones del término diseño, mencionadas previamente, haciendo un especial hincapié en sus aspectos cognitivos. Seguidamente, se introduce el proceso de diseño de experiencias de usuario, que será el enfoque seguido para desarrollar los mapas. Finalmente se exponen las conclusiones de este capítulo.

\subsection{Objeto de diseño: Mapas}

La Asociación Internacional de Cartografía define el mapa como "una imagen simbólica de la realidad geográfica que representa una serie de elementos y características seleccionadas, resultado del esfuerzo creativo del autor, diseñada para ser usada cuando las relaciones espaciales tienen una relevancia primordial" (Rystedt et al., 2003).

Tradicionalmente, el término "mapa" se ha reservado para aquellos gráficos que utilizan un sistema de coordenadas para ubicar localizaciones geográficas específicas de forma "realista" y representar sus atributos. Sin embargo, los seres humanos no experimentamos los lugares que nos rodean como un mero conjunto de coordenadas, sino como espacios a los que atribuimos una gran variedad de significados y percepciones subjetivas (Agnew, 2011).

El término mapa ha ido evolucionando y actualmente se utiliza para referirse a cualquier representación espacial (como los cartogramas o cualquier otro tipo de diagrama espacial), que permite capturar diferentes formas de conocer el mundo (Gomez \& Jones III, 2010).

Desde la perspectiva del diseño, la representación esquemática utiliza un lenguaje visual que busca comunicar con claridad y lograr compresión universal, a través de representaciones simplificadas de la realidad (Pontis, 2008). Las representaciones esquemáticas se han caracterizado por una continua evolución y 
adaptación a nuevas funciones, propiciadas por cambios en las necesidades o debidos a influencias socioculturales, nuevos conocimientos teóricos y desarrollos tecnológicos (Villafañe Gallego, 1981).

Todos los mapas son fruto, en mayor o menor medida, de una simplificación o generalización del espacio que nos rodea (Campbell, 1998; Tversky, 2000; Klippel, Richter, Barkowsky, \& Freksa, 2005) y, por lo tanto, son representaciones esquemáticas, cuya evolución a lo largo de la historia se puede estructurar en tres grandes etapas (Pontis, 2008):

- Hasta finales del siglo XIV, la mayoría de las representaciones se derivaron del conocimiento que el hombre tenía del mundo, sin basarse en implicaciones científicas o teóricas. Se trataban de meras reproducciones estéticas, que no seguían reglas ni parámetros establecidos. Dentro de esta etapa se incluyen, entre otros, el plano de la ciudad de Catal Hüyük, el más antiguo descubierto hasta la fecha, datado en torno al 6.000 a.C. (Figura 2.1). También encontramos la tabla de Peutinger, copia medieval de un mapa de rutas del imperio romano, que se estima del siglo IV (Figura 2.2).

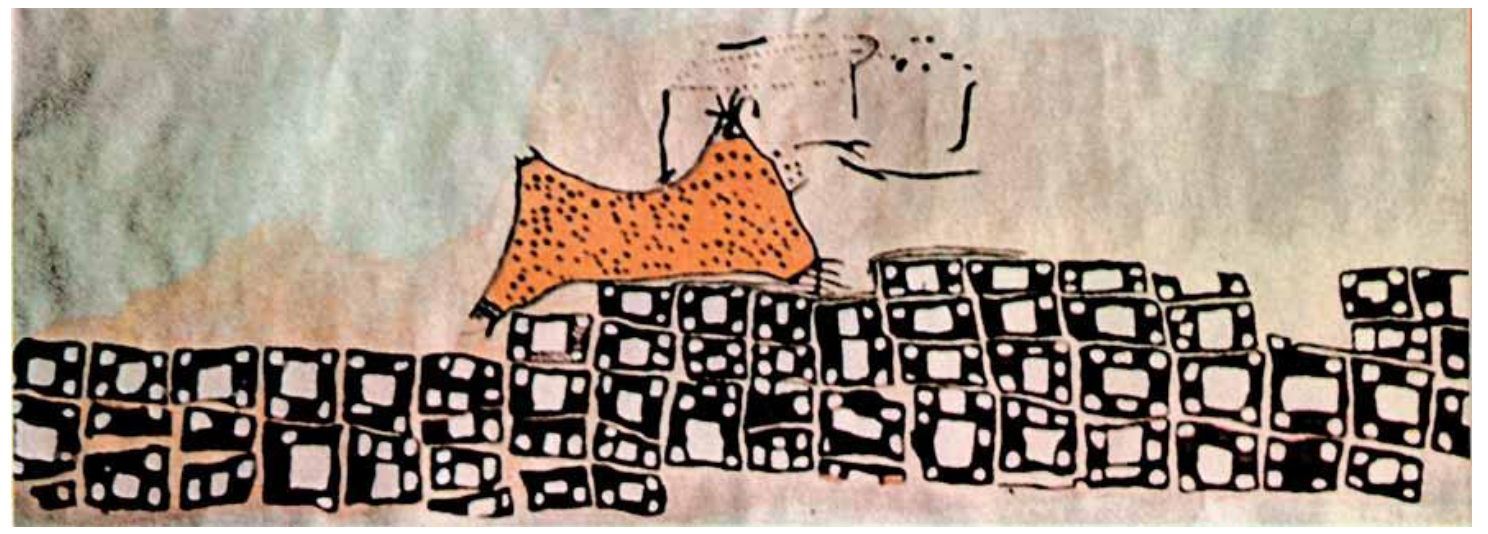

Figura 2.1: Plano de la Ciudad de Catal Hüyül de entorno al 6.000 AC, descubierto por el arqueólogo James Mellaart en Ankara.

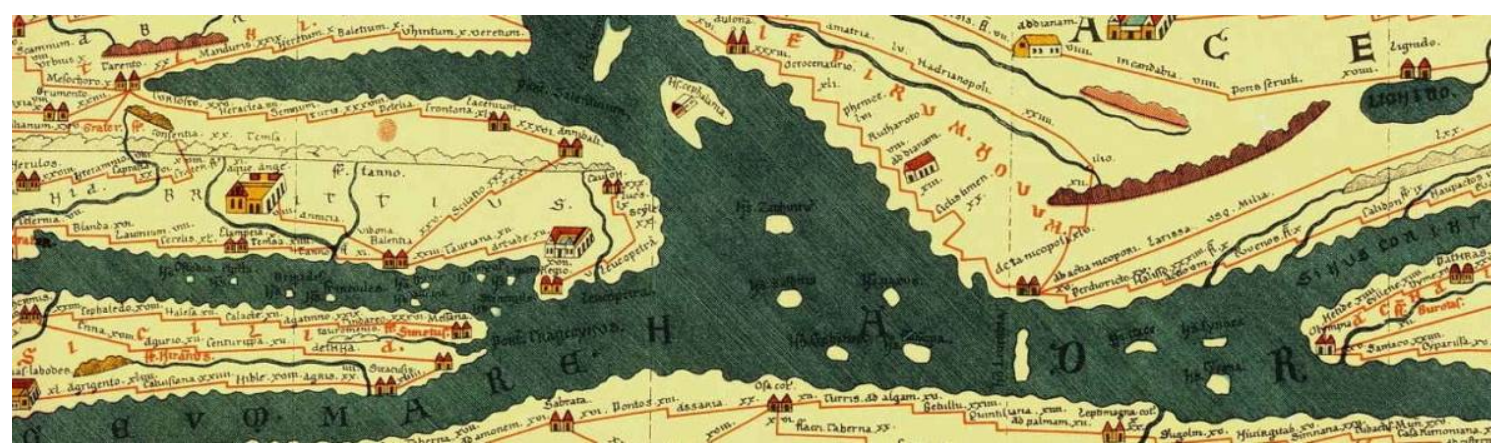

Figura 2.2: Tabla de Peutinger del siglo IV que representa caminos del Imperio Romano.

- A partir del siglo XV, los avances tecnológicos (herramientas de dibujo y de reproducción: como el papel, la imprenta, o el grabado en madera y en cobre) y de conocimiento teórico (concepto de escala, geometría analítica, teoría de errores y medidas, geometría descriptiva, superficies de referencia, proyecciones,...) hacen que la cartografía se transforme. En el siglo XVII, Edmund Halley diseña el que se 
considera el primer mapa temático donde se visualizan datos sobre previsiones meteorológicas. A lo largo de siglo XVIII y XIX los tipos de mapas se diversificaron, aparecieron cartogramas, mapas geológicos, mapas de puntos, y se comenzaron a utilizar codificaciones cromáticas para representar información relacionada con aspectos sociales y de interés para el hombre. Se pone de manifiesto que las representaciones espaciales de datos facilitan su compresión y de esta época destacan entre otros: el plano de Londres del Dr. John Snow (1854) que permitió descubrir la causa de una epidemia de cólera (Figura 2.3) y una de las primeras construcciones multivariables realizada por Charles Minard en 1861, que representa la caída de las tropas de Napoleón en la campaña de Rusia (Figura 2.4).

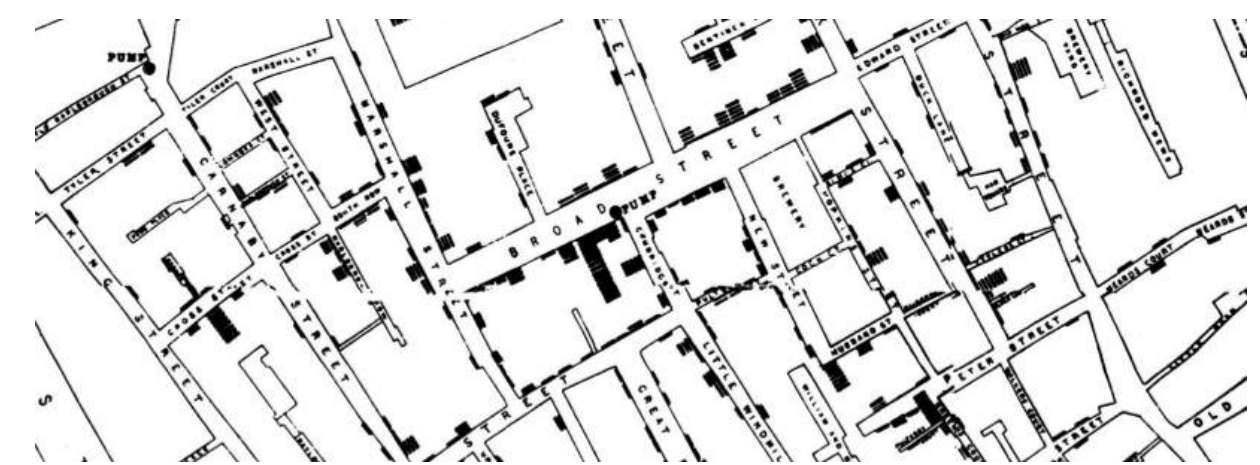

Figura 2.3: Plano de Londres con información sobre personas muertas por cólera (1854).

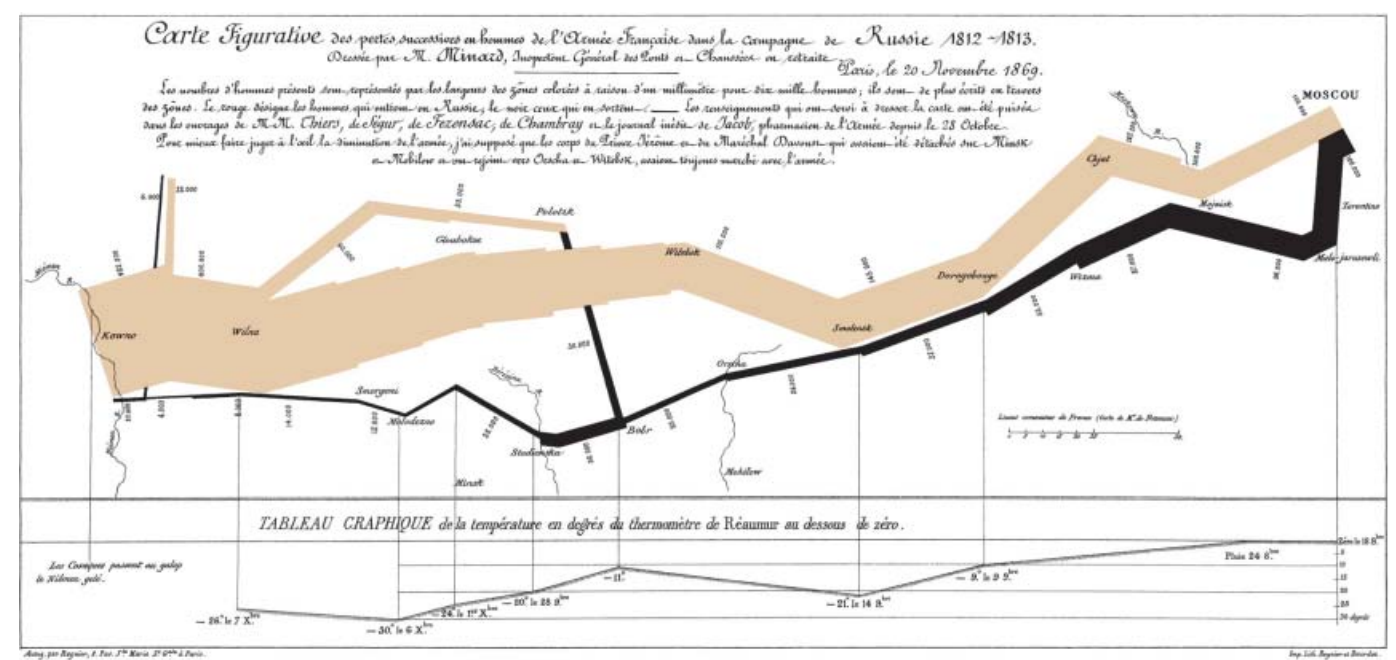

Figura 2.4: Gráfico de la caída de las tropas de Napoleón en la campaña de Rusia realizado por Charles Minard (1861).

- A partir del siglo XIX aparecen nuevas tecnologías, instituciones oficiales permanentes y sociedades geográficas en diferentes países. Se pone en marcha una nueva cartografía basada en el establecimiento de redes geodésicas, con el fin de suministrar la información necesaria de su territorio. La producción cartográfica de todos los países fue experimentando una convergencia en sus métodos y propósitos. Los organismos internacionales fueron adoptando resoluciones acerca 
del meridiano origen y las unidades de medida, entre otras. Es también en este siglo cuando comienzan a elaborarse los mapas topográficos a nivel nacional.

En cuanto a las nuevas formas de representación cartográfica, cabe destacar el mapa esquemático del metro de Londres de Harry Beck del 1931, el cual incorporó nuevos conceptos como la abstracción de las características geográficas (Figura 2.5). Por otro lado, la publicación de Jacques Bertin (1967) "Semiología gráfica", incluye un análisis de las reglas gramaticales de los elementos que componen el lenguaje gráfico.

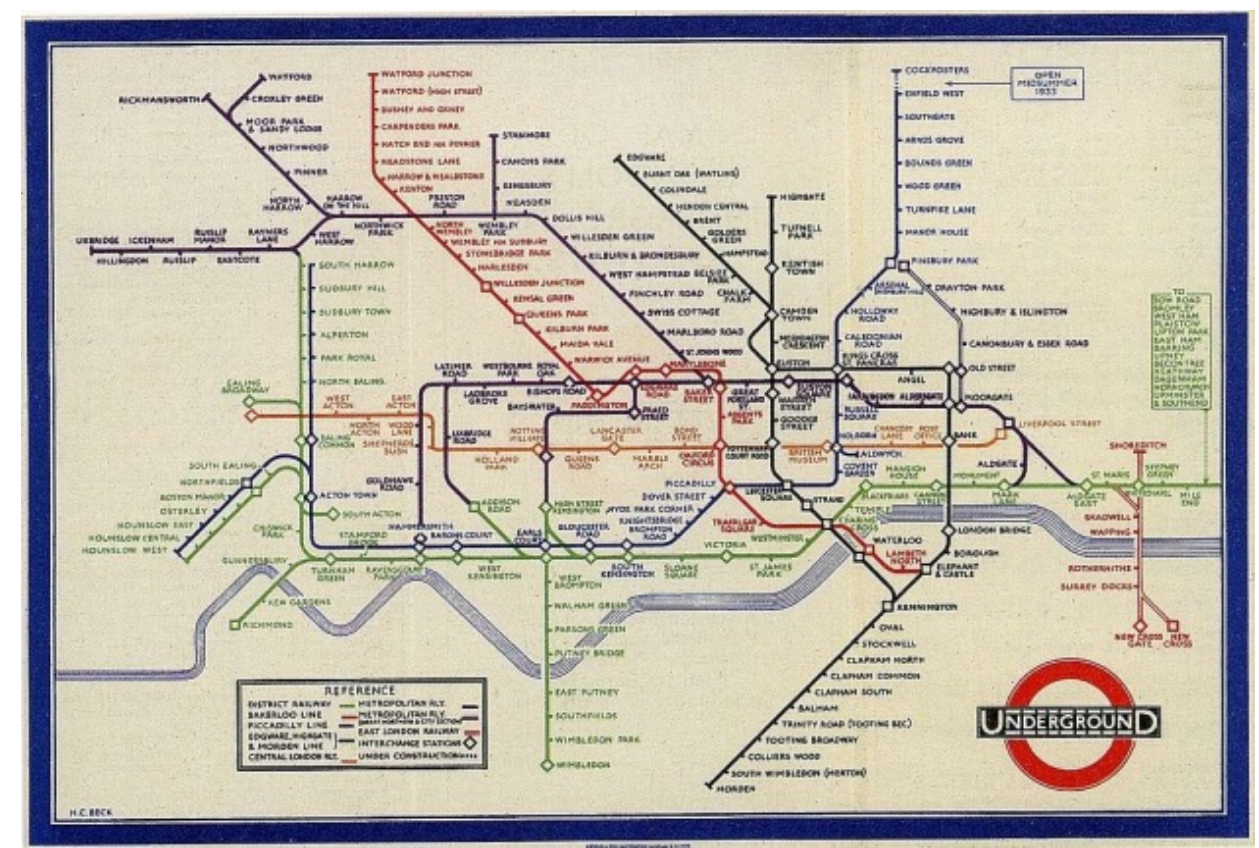

Figura 2.5: Mapa de metro de Londres de Henry Beck 1931.

A finales del siglo XX e inicios del XXI las tecnologías de la información y las telecomunicaciones comienzan a ocupar un lugar creciente en la vida diaria a través de sus redes, (telefonía móvil, ADSL, Wi-Fi, GPS,...). Los terminales (teléfonos móviles, tablet, ordenadores personales, consolas) y servicios (búsquedas en internet, servicios basados en localización,...) facilitaron y expandieron el acceso y uso de los mapas "en red" (MapQuest.com en 1996, Google Maps en el 2005,...) y a través de aplicaciones móviles. En esta época se publican varios libros que abordan las posibilidades de estos "nuevos mapas": "Interactive and Animated Cartography" (Peterson, 1995), "Web Cartography" (Kraak \& Brown, 2001), "Maps and the Internet" (Peterson, 2003) y "Multimedia Cartography" (Cartwright \& Peterson, 2007), entre otros. Respecto a la cartografía en dispositivos móviles, Bollmann (1996) fue el primero en comprender el mapa como una secuencia de representaciones en el contexto de las actividades del usuario, atribuyendo al mapa el papel de sistema dinámico. Hirtle y Raubal (2013) definen los mapas, a través de dispositivos móviles, como representaciones espaciales geográficamente sensibles y desplegadas en pequeños dispositivos personales conectadas a múltiples fuentes de información y sensores. 
Tal y como se ha descrito, los avances tecnológicos están cambiado lo que es factible producir a nivel cartográfico. Los desafíos actuales de los cartógrafos (como la creciente demanda de los usuarios de modos cognitivamente más adecuados de interactuar con los mapas) son cada vez más complejos. Esta investigación parte de la premisa de que los dispositivos basados en las nuevas tecnologías (nanotecnologías, IoT, wearables...) son capaces de identificar, reconocer y proponer a cada usuario, de forma activa y en tiempo real, mapas que le asistan en sus experiencias. Esta tesis se focaliza en analizar cómo elaborar mapas adecuados a las experiencias específicas (motivaciones, actividades, contextos y heterogeneidad de soportes) de cada usuario.

\subsubsection{Mapas esquemáticos}

Tal y como se ha expuesto, todos los mapas son, en mayor o menor medida, esquemáticos, aunque esto no quiere decir que todos los mapas sean mapas esquemáticos (Klippel, Richter, et al., 2005). Los mapas esquemáticos proporcionan un medio adecuado para la representación de las entidades significativas del mundo representado, así como sus relaciones espaciales (relaciones topológicas). Por otra parte, vinculan información espacial concreta y detallada del entorno físico, con la información abstracta y conceptual almacenada en nuestro cerebro (Freksa, 1991 y Casakin et al., 2000).

La definición de los mapas esquemáticos puede abordarse en base a su contraposición a los mapas topográficos. Estos muestran las principales características geográficas de un entorno, con la mayor precisión posible, a una determinada resolución/escala. Cumplen criterios cuantificables sobre la exactitud de la información espacial y la integridad de los datos. El proceso de diseño de los mapas topográficos está estandarizado, desde su comienzo con la recopilación de datos, hasta la aplicación de algoritmos de generalización con el fin de controlar la representación óptima a diferentes escalas (Shekhar \& Xiong, 2008). Esta derivación controlada de la representación óptima de un fenómeno geográfico, es como se suele abordar la esquematización en el ámbito cartográfico: como un proceso de generalización en el que se simplifican ejes mediante la reducción de quiebros y curvaturas; se establecen categorías; se destaca información relevante,... (Meilinger et al., 2007). La esquematización en cartografía se asocia, por tanto, con un aspecto del proceso de la generalización cartográfica, a través del cual la representación espacial de líneas y superficies se simplifica para adaptarse a un suporte y garantizar su legibilidad (escala).

Los mapas esquemáticos, en contraposición a los topográficos, se obtienen mediante la relajación de restricciones, entre otras, las espaciales (Barkowsky \& Freksa, 1997), ya que se pueden distorsionar intencionalmente con diferentes propósitos (Avelar, 2008). Por ejemplo, Freksa (1999) propone unos mapas esquemáticos (focus maps) para guiar a los usuarios en la lectura de la información relevante para la ejecución de una tarea determinada, teniendo en cuenta el entorno en el que se ejecuta la tarea, el usuario y el propio mapa (Figura 2.6). 


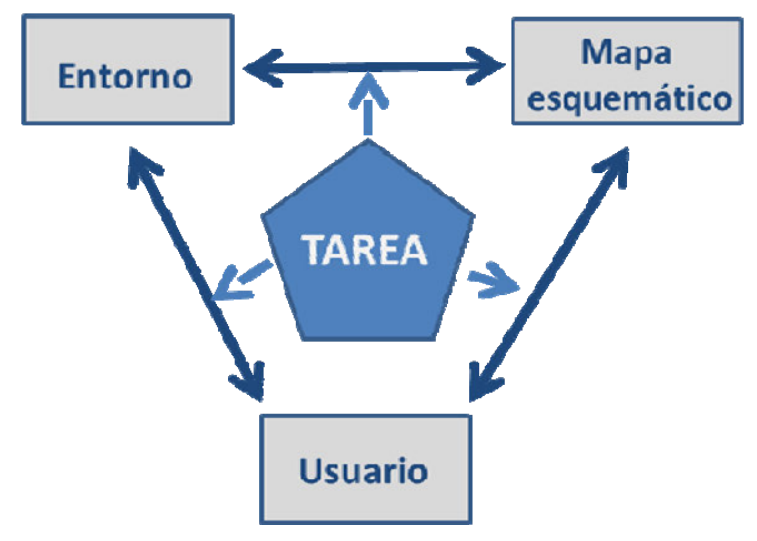

Figura 2.6: Interacciones que tienen lugar cuando se resuelve una tarea en base al uso de mapas Fuente: adaptación de Freksa (1999).

En la misma línea que Freksa, aunque desde el punto de vista de la ciencia cognitiva, Berendt et al. (1998) proponen un enfoque de los mapas esquemáticos (aspect maps) que representan el conocimiento necesario para ejecutar una tarea específica. Planteando para ello que, la elaboración de estos mapas requiere determinar: el conocimiento espacial que necesita ser representado de forma inalterada, el que puede ser distorsionado o modificado pero que necesita ser representado y el que puede ser obviado.

Por otro lado, también desde una perspectiva cognitiva, Klippel, Lee, et al., (2005) proponen una aproximación cognitivo-conceptual a los mapas esquemáticos (Figura 2.7). Estos autores establecen una distinción clara entre un mapa esquemático basado en datos de un determinado espacio y otro fundamentado en la conceptualización de dicho espacio. El primero se trata de un mapa diseñado a partir de datos del espacio que son adaptados gradualmente a través de la generalización y la simplificación (aproximación fundamentada en datos). El segundo surge como resultado de un proceso que parte de la conceptualización del espacio (mapa cognitivo) y continúa con su análisis a través de externalizaciones, que pueden llevarse a cabo mediante su registro gráfico o mapa mental (aproximación cognitivo-conceptual). Klippel y sus colaboradores se focalizaron en esta última aproximación a los mapas, proponiendo una representación esquemática de diseño flexible, focalizada en aspectos espacialmente relevantes y cognitivamente adecuada. 


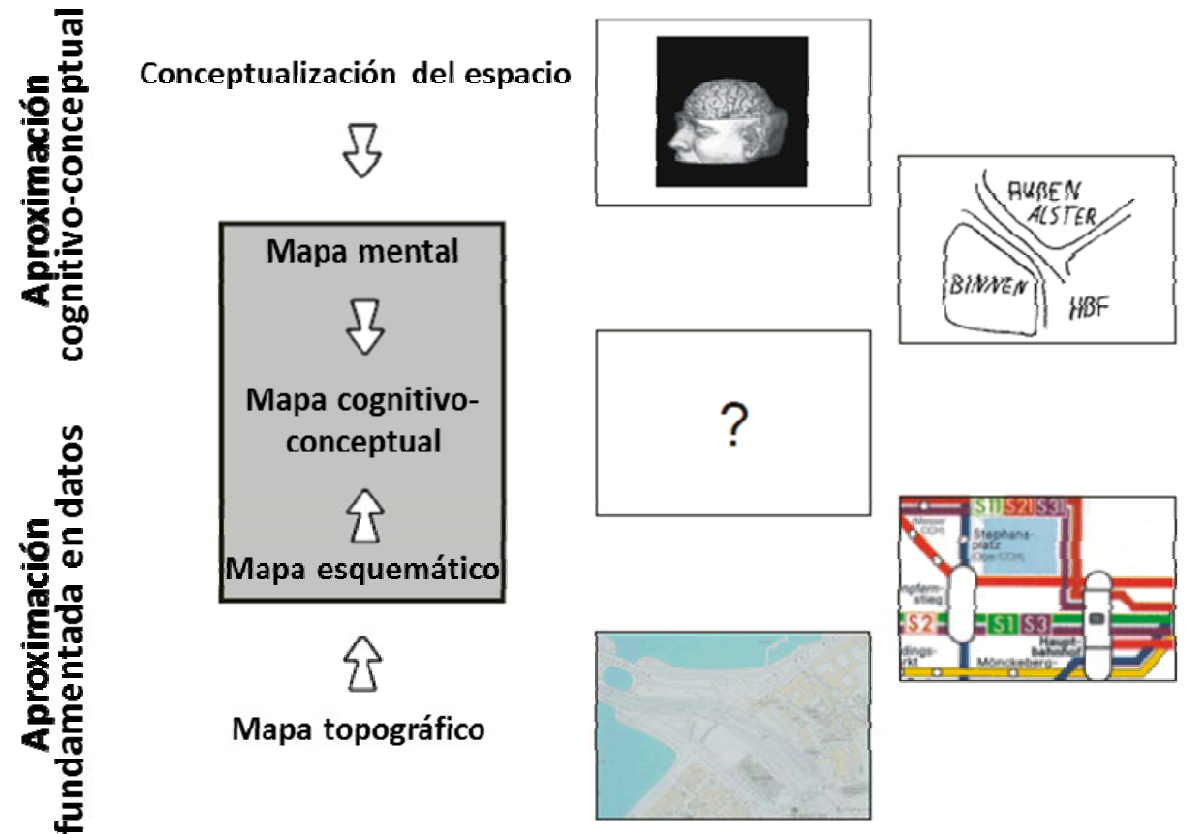

Figura 2.7: Aproximaciones al desarrollo de los mapas esquemáticos: una basada en datos (de abajo a arriba) y otra en el enfoque cognitivo (de arriba abajo). Fuente: adaptación de Klippel, Lee, et al.,

(2005).

Esta tesis se apoya en la propuesta de investigadores como Klippel, Lee, et al.,(2005) de abordar el diseño de mapas teniendo en cuenta una correspondencia entre éstos y la representación conceptual del espacio en la mente de los usuarios, favoreciendo así los procesos cognitivos. A diferencia de la mayoría de los mapas esquemáticos que están normalmente orientados a usuarios genéricos, en esta investigación se tienen en cuenta características y necesidades individuales, en contextos específicos.

\subsubsection{Mapas personalizados}

Internet y los dispotivos móviles permiten el acceso a información en cualquier momento y lugar. Sin embargo, si dos usuarios con diferentes intereses, necesidades, experiencia y conocimiento previo de un espacio, consultan información acerca de dicha zona geográfica -a través por ejemplo, de un sitio weblo más normal es que visualicen el mismo mapa. Los mapas personalizados tienen por objeto reducir el suministro de información espacial irrelevante, haciendo que el contenido del mapa sea más efectivo, según el usuario y los apectos relevantes en la ejecución de su tarea (Wilson et al. 2010).

En el ámbito de la personalización cartográfica se distinguen dos líneas de investigación (Aissi \& Gouider, 2012): recomendación y adaptación.

Los trabajos orientados a la recomendación se focalizan en suministrar sugerencias al usuario de acuerdo a sus preferencias y necesidades. La recomendación se puede materializar en el mapa en forma de objetos espaciales concretos (museos, monumentos,...), capas de información (comunicaciones y 
atractivos turísticos) y trayectorias (ruta más rápida para ir a un determinado lugar). Por ejemplo, a la hora de recomendar puntos de interés se pueden tener en cuenta criterios como: la localización, la distancia, el precio, el tiempo, la meteorología, el transporte, experiencias e intereses u objetivos (Kabassi, 2010). Mientras que para la recomendación de recorridos se puede considerar además de la ubicación del usuario, limitaciones físicas de éste, restricciones ambientales (si dispone de vehículo en propiedad, si existe transporte público, meteorología, seguridad) y condicionantes asociados al comportamiento (comer, trabajar, hábitos de conducción) (Gervais et al., 2007; Niaraki et al., 2009).

Por otro lado, las investigaciones sobre adaptación están orientadas a ofrecer mapas considerando factores como el contexto de uso, el perfil del usuario o la tarea, con el objetivo de proporcionar la información y herramientas más relevantes, de la forma más apropiada. Reichenbacher (2003) expone los aspectos del mapa que son adaptables según tres categorías: información geográfica (contenido), interfaz de usuario (funcionalidades e interacción) y visualización (Figura 2.8).

Se denomina mapa adaptado (adaptive map) aquel capaz de cambiar sus propias características automáticamente de acuerdo a las necesidades y los intereses del usuario (idioma, edad, nivel de habilidades de usuario, tiempo de uso, ubicación, dispositivo utilizado, tarea para la que el usuario necesita el mapa,...) (Shekhar \& Xiong, 2008).

También se pueden considerar mapas adaptados los mapas sensibles al contexto (contexts-aware maps) (Nivala \& Sarjakoski, 2003 y Chalmers et al., 2004). El contexto se refiere a una serie de parámetros que describen el propósito de uso del mapa, el ambiente en el que se utiliza (tecnología, localización, momento,...) y las características y necesidades del usuario (prefererencias, conocimiento,...) (Figura 2.8).

Por otro lado, Hirtle y Raubal (2013), al analizar el uso de los mapas en dispositivos personales (PDAs, SmartPhones, Tablets), señalan que diferentes usuarios perciben su entorno de manera distinta y, que esto, debe reflejarse en los mapas. En esta misma línea, Caquard (2014) concluye que ya que nuestros modelos mentales del espacio no son "como el mapa" y que los mapas no son "como el mundo", el uso de mapas (como intermediarios entre los modelos mentales y el mundo), es en el mejor de los casos inexacto (y en el peor irrelevante); y que, en cualquier caso, tiene que ser reconsiderado. 


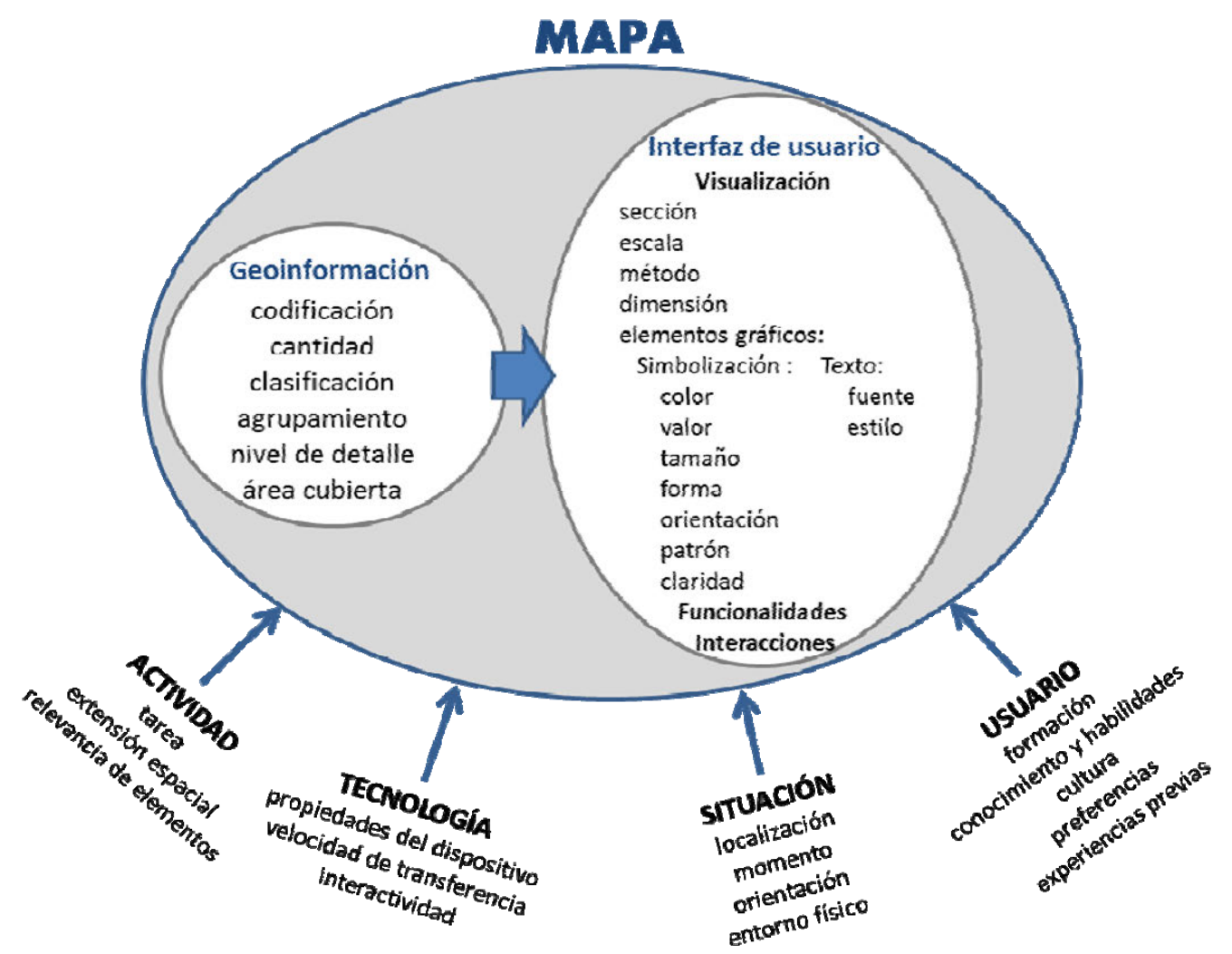

Figura 2.8: Aspectos del mapa que pueden adaptarse y factores de adaptación. Fuente: adaptación de Reichenbacher (2003) y Nivala \& Sarjakoski (2003).

Siguiendo este planteamiento, cabe destacar el trabajo de un grupo de cartógrafos y psicólogos cuya investigación se centra en desarrollar mapas adaptados teniendo en cuenta "estilos cognitivos" (Konečný, 2008; Stanek \& Friedmannová, 2010; Konečný \& Staněk, 2010). El estilo cognitivo se definió por primera vez por Witkin et al (1975) como la manera individual en la que una persona percibe, piensa, aprende, resuelve problemas y se relaciona con otros. Posteriormente, otros autores como Messick (1984) definieron los estilos cognitivos como diferencias individuales consistentes en la forma de organizar y procesar la información y la experiencia; mientras que Cools et al., (2006) lo definen como la forma en que las personas perciben los estímulos ambientales, y cómo organizan y utilizan esta información para guiar sus acciones. Konečný (2011) señala que el concepto de estilo cognitivo no está definido de forma inequívoca y que hay muchos enfoques que exploran este problema desde diferentes puntos de vista. Por ejemplo, Sternberg y Grigorenko (1997) argumentan que los estilos cognitivos son el enlace entre la personalidad y la cognición.

Konečný (2011) expone que la utilidad del concepto "estilo cognitivo", en el ámbito cartográfico, reside en la posibilidad de adaptar la visualización del mapa a grupos de usuarios con estilos cognitivos definidos y conocidos. Además, este autor plantea la hipótesis de que si el método para la visualización del mapa se corresponde con el estilo cognitivo de un usuario específico, él o ella podrá lograr mejores resultados en la ejecución de las tareas. Sin embargo, no se han encontrado 
estudios que aborden el desarrollo de mapas en base a estilos cognitivos, aunque Konečný (2011) expone que para ello haría falta observar cómo utilizan los mapas los usuarios y estudiar las diferencias entre individuos en la forma de manejarlos, lo que podría estar asociado a diferentes personalidades o estilos cognitivos.

Finalmente, el modelado de usuarios proporciona un marco para la personalización a la hora de hacer frente a las necesidades y preferencias de los individuos (Wilson et al., 2010). En la definición de los tipos de usuarios intervienen tres dimensiones (Rich, 1983):

1. Usuario individual versus grupos de usuarios o estereotipos: El modelado de grupos tiene la ventaja de proporcionar recomendaciones personalizadas desde la primera interacción del usuario con el sistema. Sin embargo, los usuarios pueden ser similares en algunas características y diferenciarse en otras que, además, pueden cambiar con el tiempo. Así, por ejemplo, Kabassi (2010) realiza una recopilación de sistemas de recomendación turísticos que utilizan una de las dos opciones, o ambas, para el modelado de usuarios.

2. Usuarios determinados explícitamente (ya sea por el diseñador o por los propios usuarios) versus usuarios inferidos por el sistema en base a su comportamiento: El principal problema que plantea el enfoque explícito es que los usuarios pueden tener que responder a muchas preguntas y que quizás no son capaces de describirse a sí mismos y sus preferencias con precisión. En este sentido, el modelado de usuario implícito es menos intrusivo y puede ser más fiable, siempre que se fundamente en hipótesis acertadas. Sin embargo, esta opción requiere que el usuario interactúe con el sistema el tiempo suficiente como para poder realizar un "diagnóstico" del mismo. Dadas las ventajas e inconvenientes de ambas opciones, existen sistemas que utilizan una combinación de ambos (Wilson et al., 2010).

3. Usuarios determinados en base a características recopiladas durante un largo plazo versus usuarios en base a características a corto plazo (como las relacionadas con el problema que el usuario está tratando de resolver en un momento dado): En el ámbito turístico, por ejemplo, casi todos los sistemas de recomendación utilizan modelos de usuario a largo plazo, ya que se consideran más eficaces (Kabassi, 2010).

Esta investigación se centra en desarrollar mapas esquemáticos personalizados, a través de un modelado de usuarios que tenga en cuenta sus "estilos cognitivos": Mapas únicos (mi mapa aquí y ahora), que muestren contenidos de relevancia, fruto de la consideración de aspectos que van más allá de la posición, como la actividad o tarea desempeñada, las preferencias, las necesidades individuales y la forma en la que el usuario utiliza los mapas y se relaciona con un determinado espacio.

\subsection{Acción de diseñar: Aspectos cognitivos involucrados en el diseño cartográfico}

El diseño cartográfico es una actividad intelectualmente compleja y visual, que requiere tener en cuenta aspectos cognitivos involucrados en el diseño y en el 
uso de los mapas (Medyckyj-Scott, Scott, \& Board, 1991; MacEachren \& Kraak, 2001; Slocum et al., 2001; Ooms, 2012).

El usuario tiene contacto con el espacio geográfico de forma directa (fuente primaria) o a través de mapas (fuente secundaria). Estas fuentes de información ponen en marcha una serie de procesos cognitivos en el usuario, asociados a sus vivencias (experiencias) (Goodey, 1971; R Lloyd, 1993; McDonald \& Pellegrino, 1993) (Figura 2.9).

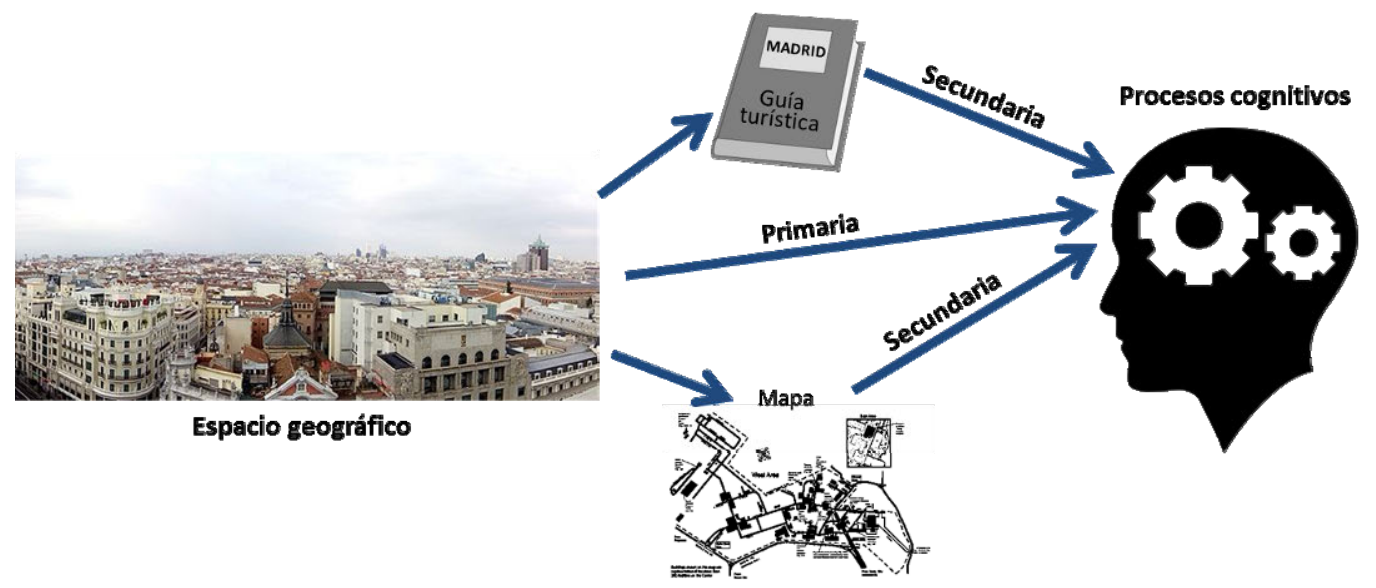

Figura 2.9: Codificación de la información espacial que el usuario adquiere a través de sus experiencias mediante el contacto directo con el espacio geográfico (fuentes primarias) y a través de mapas u otros medios de comunicación (fuentes segundarias). Fuente: adaptación de Lloyd (1993).

En los procesos cognitivos involucrados en el uso de los mapas, intervienen tres tipos de memoria: sensorial, de trabajo y a largo plazo (Figura 2.10). La memoria sensorial es la memoria que recibe la información percibida por los sentidos al visualizar el mapa (símbolos, textos) y que retiene esa información durante menos de un segundo. La memoria de trabajo (o memoria a corto plazo), controla la información que llega de los sentidos, la codifica y la procesa convirtiéndola en una representación interna, almacenándola en parte en la memoria a largo plazo. La memoria de trabajo solo puede retener información alrededor de 20 segundos y su capacidad es limitada (entre 7 y 9 elementos a la vez). Por esta razón, las expectativas del usuario al visualizar el mapa deben de dirigir los objetivos de diseño, de forma que los elementos del mapa atraigan su atención. La memoria de trabajo utiliza el conocimiento almacenado previamente en la memoria a largo plazo para codificar la información del mapa. La memoria a largo plazo retiene todo el conocimiento que el usuario posee del espacio representado en el mapa (mapa cognitivo) y todo el conocimiento acumulado en base a su experiencia en lectura de mapas (significado que suele tener un determinado símbolo, aspectos del mapa que se pueden interpretar literalmente y cuáles no,...). La memoria a largo plazo, tiene capacidad ilimitada y los elementos incluidos en ella se recuerdan durante mucho tiempo (Hegarty, 2011; Ooms, 2012). Además, si el mapa es interactivo o se adapta a diferentes aspectos del contexto, la información visualizada irá cambiando, en cuyo caso durante el proceso de 
comprensión, no solo cambiará constantemente la representación interna (mapa cognitivo) sino que también lo hará la externa (el mapa).

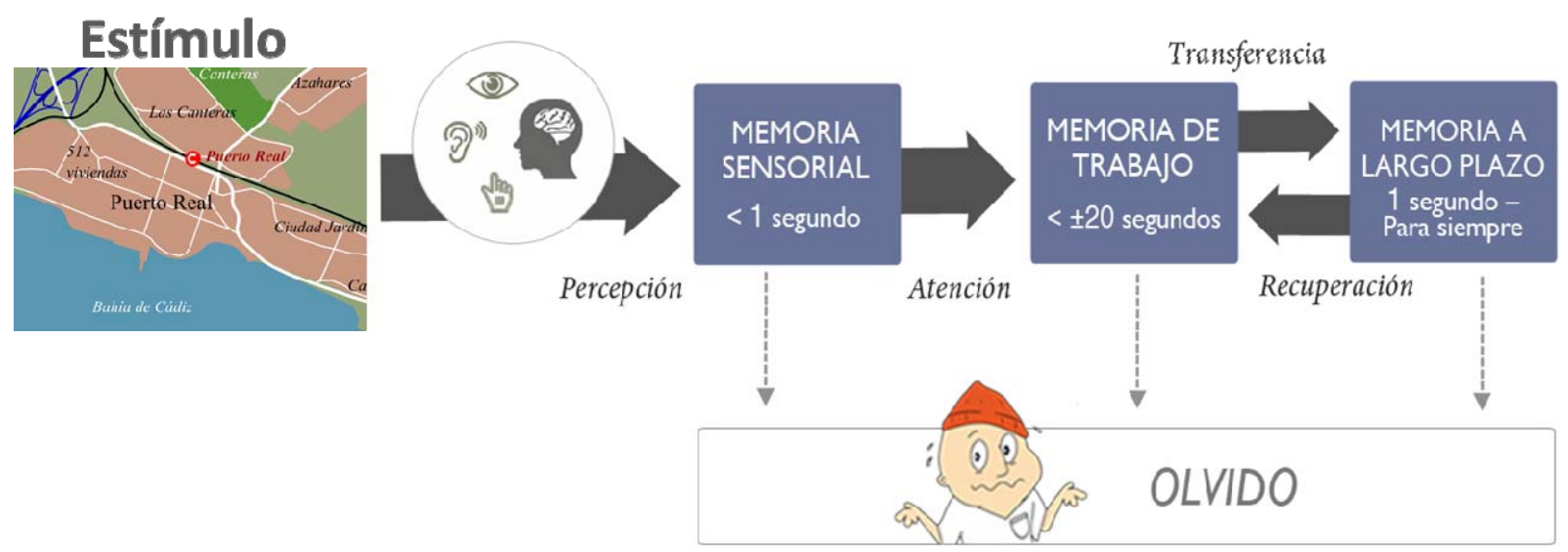

Figura 2.10: Proceso cognitivo asociado a la lectura e interacción con los mapas. Fuente: adaptación de imagen extraida de http://www.worddive.com/.

Los mapas cognitivos son abstracciones internas de un conjunto de ubicaciones geográficas que se han aprendido (Lloyd, 2000). Los mapas cognitivos, al igual que los cartográficos, son herramientas que estructuran y almacenan conocimiento (Tuan, 1975). Ambos son fruto de un proceso de abstracción orientado a simplificar y dar sentido a la complejidad del mundo real. Por lo tanto, los mapas cartográficos pueden concebirse como interfaces del mundo real ( Peterson, 1995; MacEachren, 2013), como representaciones externas que liberan recursos en la memoria de trabajo para que estén disponibles para otras tareas mentales ( Scaife \& Rogers, 1996; Card et al., 1999).

Boulding (1956) señala que el mapa cognitivo es el eslabón que media entre el mundo real y el comportamiento del hombre y que, por tanto, no puede comprenderse, ni su comportamiento, ni la relación espacio-hombre, sin entender los mapas cognitivos. En la misma línea, Downs y Stea (1973) señalan que el mapa cognitivo es la base para la ejecución de cualquier estrategia de comportamiento espacial. Estos autores exponen que el mapa cognitivo cambia a medida que el hombre interactúa con el espacio y que conocer el mapa cognitivo de un individuo es "dar un corte transversal en un punto del tiempo", que permite saber cómo es ese espacio en ese punto para la persona. El mapa cognitivo permite conocer (Downs \&. Stea, 1973; Kaplan, 1973; Tuan, 1975; Siegel et al., 1978; Neisser, 1981 y Caballero Garcia, 2002):

- dónde se encuentra uno y reconocer los objetos del espacio (reconocimiento de un marco de referencia espacial), ya que es un recurso nemotécnico para estructurar y almacenar el conocimiento del espacio,

- lo que puede suceder (predicción). Ensayar el comportamiento espacial en la mente, de manera que al pasar a la realidad del entorno, podemos actuar con un grado de seguridad,

- si las cosas son buenas o malas, siendo posible anticipar si las acciones alternativas tienen consecución probable (evaluación) y 
- qué hacer, pudiendo valorar diferentes opciones antes de tomar una decisión (acción).

En este sentido, Garling y Golledge (2000) postulan que la información almacenada en nuestro mapa cognitivo impacta en nuestras elecciones a la hora de viajar, ya que solo podemos ir a lugares que conocemos. El conocimiento que tenemos de los posibles lugares a los que ir, influye en nuestra elección, así como, en la forma de trasladarnos hasta ellos.

En cuanto a los mapas cognitivos de espacios urbanos, una referencia fundamental es Kevin Lynch y su libro "The image of the city" (1960). Lynch se interesó en la forma en la que las personas, perciben, entienden y estructuran su mapa cognitivo, para así poder diseñar intervenciones urbanísticas de acuerdo con las maneras que tenemos de percibir y entender la ciudad. Éste investigador identificó 5 elementos distintos en los mapas cognitivos de espacios urbanos: nodo (donde confluyen varias trayectorias); hito (o punto de referencia); senda (o eje de desplazamiento); borde (o límite no transitable de áreas) y barrio (o región de la ciudad). Por otro lado, Milgram (1977) describe el mapa cognitivo urbano como "un dibujo de la ciudad que una persona retiene en su mente: las calles, barrios, plazas, que son importantes para él, de algún modo enlazadas y con una carga emocional vinculada a cada elemento".

Sin embargo, las personas parecen ser diferentes, no solo en términos de lo que saben y de cuanto saben acerca de un espacio urbano, sino también en la forma en la que organizan lo que saben (Moore, 1979). El análisis de los mapas cognitivos, desde el punto de vista del sistema de referencia, considera los mapas como conjuntos de elementos (no como elementos aislados) y permite un análisis cualitativo del proceso de construcción de la representación espacial, a través del cual se obtiene una visión sintética y dinámica de los mismos (Caballero Garcia, 2002). Moore $(1973,1974)$ propone tres tipos de sistemas de referencia para caracterizar diferencias consistentes en la representación gráfica de espacios urbanos (Figura 2.11):

- egocéntrico e indiferenciado (el mapa cognitivo está regido por las propias acciones y experiencias sobre el entorno, y no hay posibilidad de distanciarse de él),

- diferenciado y parcialmente coordinado (existe ya un distanciamiento del entorno pero los distintos elementos o grupos de elementos que configuran el mapa no están coordinados entre sí, y la representación espacial se organiza en torno a elementos fijos y concretos), $y$

- abstractamente coordinado e integrado jerárquicamente (la representación espacial se hace al margen de la experiencia concreta, coordina y secuencia distintos elementos, y es fruto de la abstracción). 

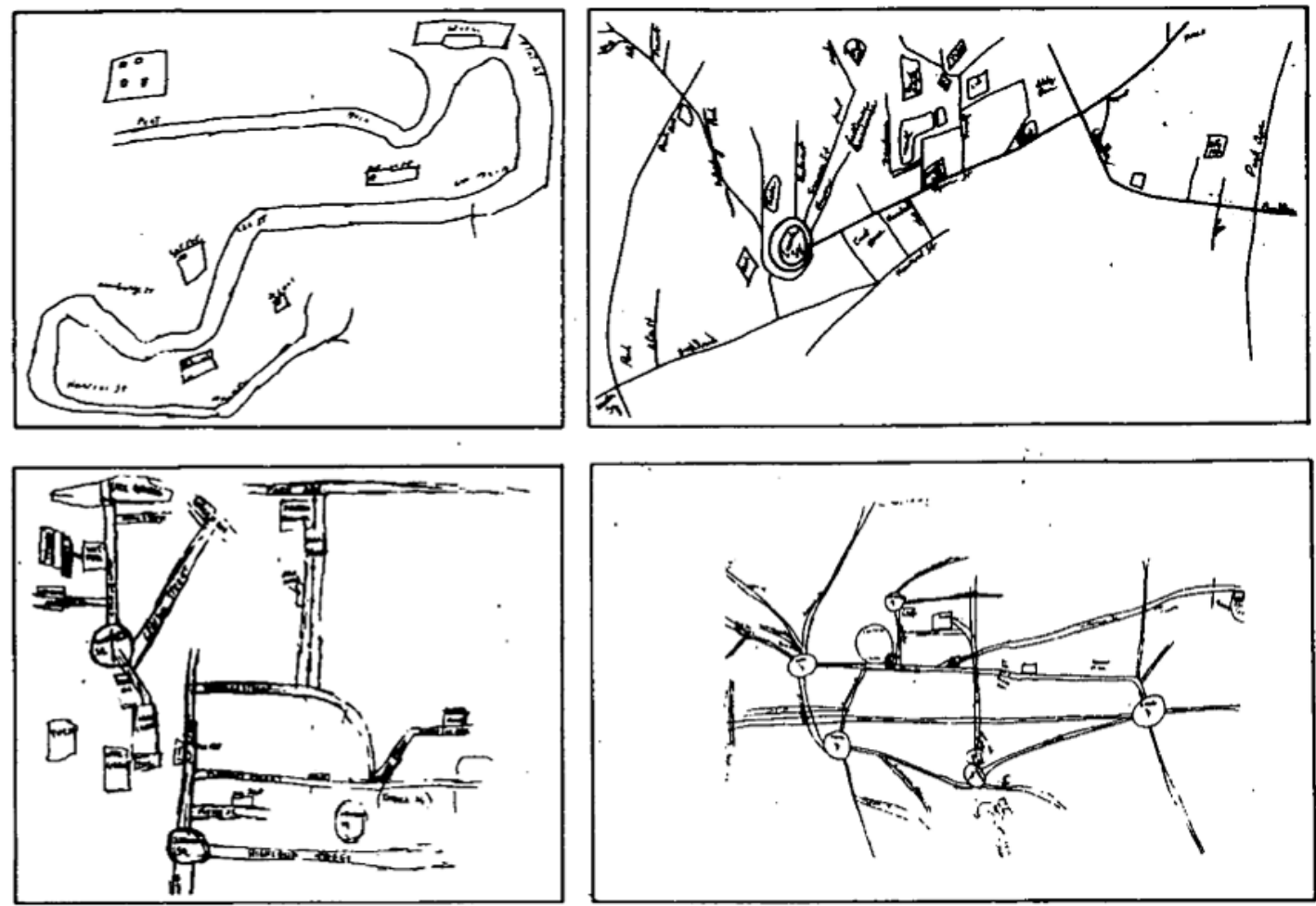

Figura 2.11: Mapas cognitivos con sistema de referencia egocéntrico (superior izquierda); diferenciado y parcialmente coordinado, variedad de rutas (superior derecha); diferenciado y parcialmente coordinado, variedad punto-radial (inferior izquierda) y abstractamente coordinado e integrado jerárquicamente (inferior derecha). Fuente: Moore (1973).

En relación al orden en el que se aprenden los elementos del mapa cognitivo, la mayoría de las investigaciones coinciden en que primero se incorporan los nodos, seguidamente las sendas y, finalmente, los barrios (Hart y Moore, 1973; Siegel y White, 1975; Golledge y Spector, 1978; Evans, 1980). Además, existen ciertos nodos que pueden considerarse focos o puntos de anclaje de la representación, ya que, en torno a ellos, se organiza el conocimiento del espacio. Estos puntos suelen ser lugares familiares para la persona, como puede ser, su propia casa, el lugar de trabajo o el hotel, en el caso de los turistas durante su estancia (Lynch, 1960; Milgram et al., 1972; Couclelis et al., 1987). Otro aspecto que también incide en la formación de los mapas cognitivos urbanos es la percepción del centro de la ciudad (De Jonge, 1962; Klein, 1967; Siervets, 1967; Goodey et al., 1971; Ross, 1974; Lee, 1976; Bailly, 1979 y Shimizu, 1979).

Finalmente, merece la pena señalar el carácter tanto individual como colectivo, de los mapas cognitivos. Aunque la construcción y uso de mapas cognitivos difieren de una persona a otra, dependiendo de muchas características como la edad, el género, la experiencia, la personalidad o el conocimiento (Lynch, 1960; Beatty, 2002), existen elementos significativos dentro de ellos que son similares entre los grupos de personas (Lynch, 1960; Appleyard, 1970; Pockock, 1972; Gould \& White, 1974 Gould, 1975; Lloyd, 1976; Milgram, 1977; Moore, 1979; Wood \& Beck, 1990; Look \& Shrobe, 2007). En este sentido, por ejemplo, Holahan \& Dobrowolny, (1978) analizan la formación del mapa cognitivo de un campus, por 
parte de sus universitarios, utilizando una combinación de métodos (dibujos de mapas, un pequeño cuestionario y observación de ciertos lugares del campus). Estos autores concluyeron que los universitarios forman sus mapas cognitivos en función de dos variables: "las conductas individuales" y "las conductas colectivas" que realizan en el campus.

Esta tesis propone un proceso de diseño de mapas urbanos personalizados, teniendo en cuenta "estilos cognitivos" de grupos de usuarios, que se caracterizarán en base a los elementos de sus mapas cognitivos (Lynch, 1963) y a sus sistemas de referencia (Moore 1973, 1974).

Los mapas pueden considerarse herramientas cognitivas: "componentes externos de un sistema cognitivo con el que los componentes internos interactúan en un proceso dinámico y orientado a la ejecución de tareas" (Peterson, 1996). El cartógrafo, por tanto, debe tener en cuenta los procesos cognitivos a la hora de tomar las decisiones necesarias para abordar el diseño cartográfico (MacEachren \& Kraak, 2001; Slocum et al., 2001). En este ámbito, la ciencia cognitiva ha generado, en base a validaciones empíricas, un conjunto de principios básicos para generar representaciones visuales efectivas, que pueden aplicarse al diseño de mapas, como los siguientes propuestos por Hegarty (2011):

- Principios relacionados con la expresividad de las visualizaciones:

- El Principio de Relevancia: las visualizaciones no deben presentar ni más ni menos información que la que necesita el usuario. Por ejemplo, los mapas utilizados en situaciones de riesgo deben facilitar la selección de símbolos, la memorización de información importante y la selección de rutas óptimas. Existen estudios que sugieren que la utilización de una base cartográfica frente a ortofotos facilita este tipo de tareas (Konečný, 2011), probablemente porque la ortofoto incluye mucha información superflua y sin jerarquía visual.

- El principio de las limitaciones de capacidad: las visualizaciones deben diseñarse teniendo en cuenta las limitaciones de la memoria de trabajo y de atención del usuario (Kosslyn, 2006).

- Principios relacionados con la percepción de las visualizaciones:

- El principio de la compresión: para ser efectivas, las variables visuales de las visualizaciones deben elegirse en base a sus propiedades perceptivas (Cleveland \& McGill, 1984; Hollands \& Wickens, 1999). Las variables visuales "básicas", establecidas por Bertin (1967) tienen una serie de propiedades perceptivas: asociativa, selectiva, ordenada y cuantitativa. La figura 2.12 ilustra el grado de adecuación de cada propiedad perceptiva con cada variable. 


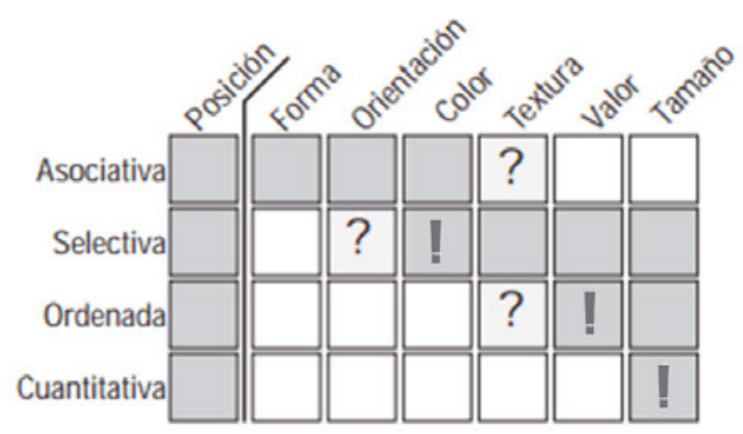

Figura 2.12: Grado de adecuación de cada propiedad perceptiva al ser aplicada a cada una de las variables planteadas por Bertin (1967). Los cuadros oscuros identifican las que son adecuadas y los blancos las que no lo son. Dentro de las adecuadas las más propicias se han identificado con una exclamación. Las menos adecuadas se han marcado con una interrogación. La posición se ha separado con una línea del resto de las variables para indicar que en cartografía no es adecuado utilizarla como variable visual. Fuente: adaptación de Bertin (1967).

- El principio de discriminalidad: las formas gráficas que indican una diferencia entre dos variables deben diferir en una cantidad suficientemente grande como para ser percibidas como diferentes (Kosslyn, 2006).

- El principio de organización perceptiva: Las agrupaciones basadas en los principios Gestalt que describen, por ejemplo, como los usuarios diferencian la percepción de grupos en lugar de objetos individuales o son capaces de distinguir entre figura y fondo. En este caso, las características emergentes de forma más general (figura), deben ser compatibles con las tareas que se llevan a cabo (Vicente, 2002; Kosslyn, 2006). Por ejemplo, Meng (2005) muestra diferentes representaciones egocéntricas de un mismo espacio para un usuario que conduce por el día y por la noche, resaltando en ambas diferentes elementos del espacio.

- Principios relacionados con la semántica de las visualizaciones:

- El principio de compatibilidad: Una representación gráfica es más fácil de entender si su forma es compatible con su significado (Kosslyn, 2006). Por ejemplo, si un elemento individual, como un edificio singular que tiene características únicas, se representa mediante un símbolo personalizado se facilita que el usuario lo reconozca.

- El enfoque representacional epistémico: codificar los elementos de la visualización en base a la estructura conceptual fundamental del dominio (Cheng, 2002; Cheng \& Barone, 2007). En este sentido, por ejemplo, Look y Shrobe (2007) estudian aspectos comunes en mapas cognitivos de la ciudad de Boston, con el fin de integrar en el diseño cartográfico este modelo mental y facilitar así al usuario la conceptualización y ubicación de nuevos lugares, en función de los que ya conoce.

- Principios relacionados con la faceta pragmática de las visualizaciones:

- El principio de la prominencia: visualizaciones que destaquen la información temática más importante ( Bertin, 1983; Dent, 1999; Kosslyn, 2006). 
- El principio de los cambios informativos: evitar grandes cambios en las visualizaciones que no aporten información (Kosslyn, 2006).

- Principios relacionados con la usabilidad de las visualizaciones:

- El principio de conocimiento apropiado: asegurarse de que el usuario tiene el conocimiento necesario para extraer e interpretar la información de la visualización (Kosslyn, 2006).

- El principio de momento visual: codificar diferentes visualizaciones de forma consistente entre sí, de manera que los usuarios pueden establecer conexiones a través de elementos de referencia entre diferentes pantallas, evitando la desorientación (Woods, 1984; Hollands \& Wickens, 1999). Por ejemplo, al hacer un zoom o en el transcurso de una animación.

Esta investigación aborda el diseño cartográfico de los mapas teniendo en cuenta aspectos comunes en los mapas cognitivos de sus usuarios (principio epistémico), incluyendo la información necesaria en cada situación (principio de relevancia), representándola teniendo en cuenta las propiedades perceptivas de las variables visuales (principio de la compresión) y de tal manera que el usuario podrá establecer conexiones entre los diferentes mapas a los que tiene acceso, mediante elementos de referencia presentes en todos ellos (principio de momento visual).

En esta tesis el diseño cartográfico de los mapas se focalizará, por lo tanto, en la expresividad de las características gráficas de sus elementos, pero no solo teniendo en cuenta los procesos cognitivos que intervienen en su visualización, sino también los estilos cognitivos de sus usuarios. De tal manera, que los mapas esquemáticos a diseñar harán de componentes externos del sistema cognitivo de los usuarios, facilitándoles la información que necesitan para apoyarles en la ejecución de las actividades en el espacio y, al mismo tiempo, la asimilación del conocimiento del mismo.

\subsection{Proceso de diseño centrado en el usuario en el ámbito cartográfico}

Los avances tecnológicos de los años 90 (ordenadores, internet y los dispositivos móviles) dieron lugar a la proliferación y diversificación de la forma de uso de los mapas (Morrison, 1994; Peterson, 1995; Cartwright, 1997). Los mapas comenzaron a considerarse como interfaces de usuario interactivas condicionadas por el tamaño de la pantalla, diversidad de tipologías de usuario y de tareas a ejecutar. Estos cambios hicieron que las técnicas de captura de requisitos de usuario y de diseño tradicionales, ya no resultaban adecuadas (Nivala et al., 2007). Es por ello que, desde los inicios de este siglo, se promueve la asimilación de enfoques de DCU (Haklay \& Tobón, 2003), así como la consideración de aspectos cognitivos y de 
usabilidad en el diseño de los productos cartográficos y sus mapas (Cartwright et al., 2001; MacEachren \& Kraak, 2001; Slocum et al., 2001; Montello, 2002;).

EI DCU es un enfoque de diseño cuyo proceso está dirigido por información sobre las personas que van a usar el producto. Como filosofía de diseño, el DCU engloba un conjunto heterogéneo de metodologías que comparten un objetivo común: conocer y comprender las necesidades, limitaciones, comportamiento y características del usuario con el fin de desarrollar productos usables en un contexto de uso determinado por usuarios, tareas y ambiente. La norma ISO 9241-210 (ISO, 2010) proporciona un marco para el DCU. No asume un proceso de diseño en particular, ni especifica técnicas concretas. Plantea, eso sí, una serie de fases, que se pueden integrar en diferentes procesos de diseño: 1) planificar el proceso de DCU, 2) comprender y especificar el contexto de uso, 3) definir los requisitos de usuario, 4) producir propuestas de diseño para satisfacer los requisitos y (5) evaluar. Si la evaluación no es satisfactoria, las fases necesarias deben repetirse.

La Figura 2.13 muestra el modelo de DCU propuesta por van Elzakker et al., (2007) para el diseño de productos cartográficos: la fase de análisis de requisitos incluye aspectos organizacionales y puntos de vista de diferentes grupos de interés, además de los vinculados a las características, preferencias, contexto de uso y tareas de los usuarios. La segunda fase comienza con un diseño conceptual del producto, seguido de una serie de prototipos que son evaluados y refinados iterativamente hasta que cumplen con los requisitos previamente especificados.

Desde la perspectiva del DCU, se trata de diseñar productos teniendo en cuenta al usuario, ya que si se hiciera para lograr un objetivo según la visión del cartógrafo, del interés del promotor, de los datos o de las tecnologías disponibles, el producto podría quedar desvinculado de su contexto de uso. El factor humano presente en el proceso de DCU, busca que el diseño resultante aglutine todo lo necesario con el fin de conseguir un producto útil y fácil de usar, esto es: eficiente, efectivo y cuya experiencia de uso resulte satisfactoria para los usuarios. Estos atributos objetivos (eficiencia y efectividad) y subjetivos (satisfacción) permiten evaluar la usabilidad de un producto (ISO 9241-11, 1988). 


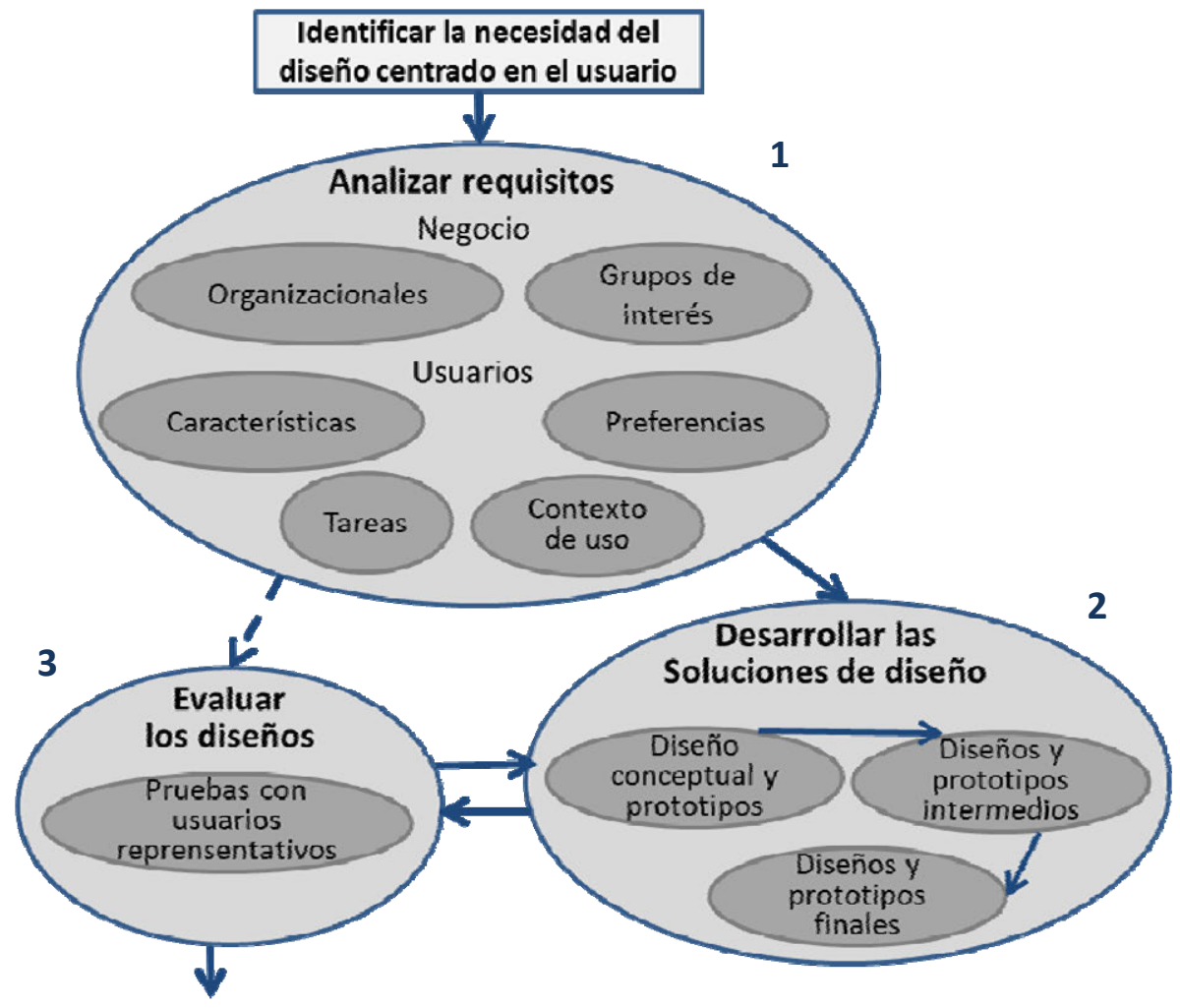

El diseño satisface los requisitos

Figura 2.13: Diseño Centrado en el Usuario.

Fuente: adaptación de Van Elzakker y Wealands (2007).

La tesis de Nivala (Nivala, 2007) pionera en la aplicación del DCU y la consideración de la usabilidad en el diseño de productos cartográficos interactivos, estableció una serie de circunstancias en las que el DCU es especialmente adecuado. Éste lo es cuándo: 1) las necesidades de los usuarios son especialmente exigentes, 2) el producto se va a utilizar en situaciones difíciles, 3) las tareas de los usuarios son desconocidas, 4) las situaciones en las que se va a utilizar el producto no son familiares, o si 5) el producto está orientado a un gran número de usuarios. Sin embargo, en el ámbito de la cartografía, son pocos los estudios que han abordado todas las fases del proceso de DCU (Flink et al., 2011), salvo algunas excepciones documentadas como es el caso de van Elzakker \& Wealands (2007) y Kramers (2008). Kramers aplica el DCU al rediseño del Atlas Web de Canadá y destaca los siguientes beneficios de este enfoque de diseño: la toma de decisiones está fundamentada y se reduce el impacto de suposiciones incorrectas; se establece un equilibrio entre requisitos de negocio y de usuario; los desarrolladores no tienen que evaluar su propio diseño; se incrementa la satisfacción del usuario y la efectividad del producto; y se obtiene el producto adecuado, por las razones correctas, para los usuarios deseados.

A pesar de que hace ya más de una década que el DCU se aplica al desarrollo de productos cartográficos, siguen identificándose nuevos retos que han sido objeto de tesis recientes. Es el caso de la de Ooms (2012), que incluye un aporte 
metodológico para evaluar productos cartográficos digitales en base a como sus usuarios leen, interpretan, almacenan y recuperan información visual de mapas en pantalla, mediante técnicas de DCU. Schobesberger (2012) plantea un proceso integrado de DCU para asegurar y aumentar la utilidad y usabilidad de aplicaciones cartográficas en la web. En su trabajo, Schobesberger incluye una actualización del modelo de comunicación cartográfico, en el que destaca la intervención del usuario durante el proceso de diseño (Figura 2.14). Con la integración del enfoque del DCU, el rol del cartógrafo ha pasado, de restringirse al modelo de comunicación cerrado "creador $\rightarrow$ usuario" planteado previamente por Kolácný (1969) y Peterson (1995), a otro donde los papeles del cartógrafo como investigador, guía en el desarrollo del producto y diseñador, se diluyen (van Elzakker, 2004). En el modelo de comunicación cartográfico centrado en el usuario de Schobesberger (Figura 2.14), se plasma la necesaria retroalimentación constante del usuario en todas las fases de desarrollo del producto cartográfico, que ya no suministra una sola visión y representación de la realidad, preconcebida y basada únicamente en la experiencia del cartógrafo. El cartógrafo hace de mediador, pero no condiciona en exceso a los usuarios seleccionando los datos y las interfaces por ellos, sino que facilita la consecución de los objetivos y requisitos establecidos por los propios usuarios. Para ello, el cartógrafo debe partir de la observación de los usuarios, asimilar en primera persona sus necesidades e incluso invitarles a participar facilitándoles los mecanismos de expresión necesarios. Luego deberá analizar e interpretar la información recopilada como fuente de inspiración para el diseño y la innovación de nuevos productos cartográficos.

Finalmente, merece la pena destacar que uno de los retos del DCU es la selección de las técnicas de diseño para llevar a cabo las tareas necesarias en cada fase del proceso. Existe una gran variedad de técnicas y su combinación permite recopilar información complementaria, que ayuda a completar la visión de las necesidades de los usuarios. La Figura 2.15 muestra algunas de las técnicas de diseño utilizadas para el desarrollo de sitios web cartográficos siguiendo el DCU. 


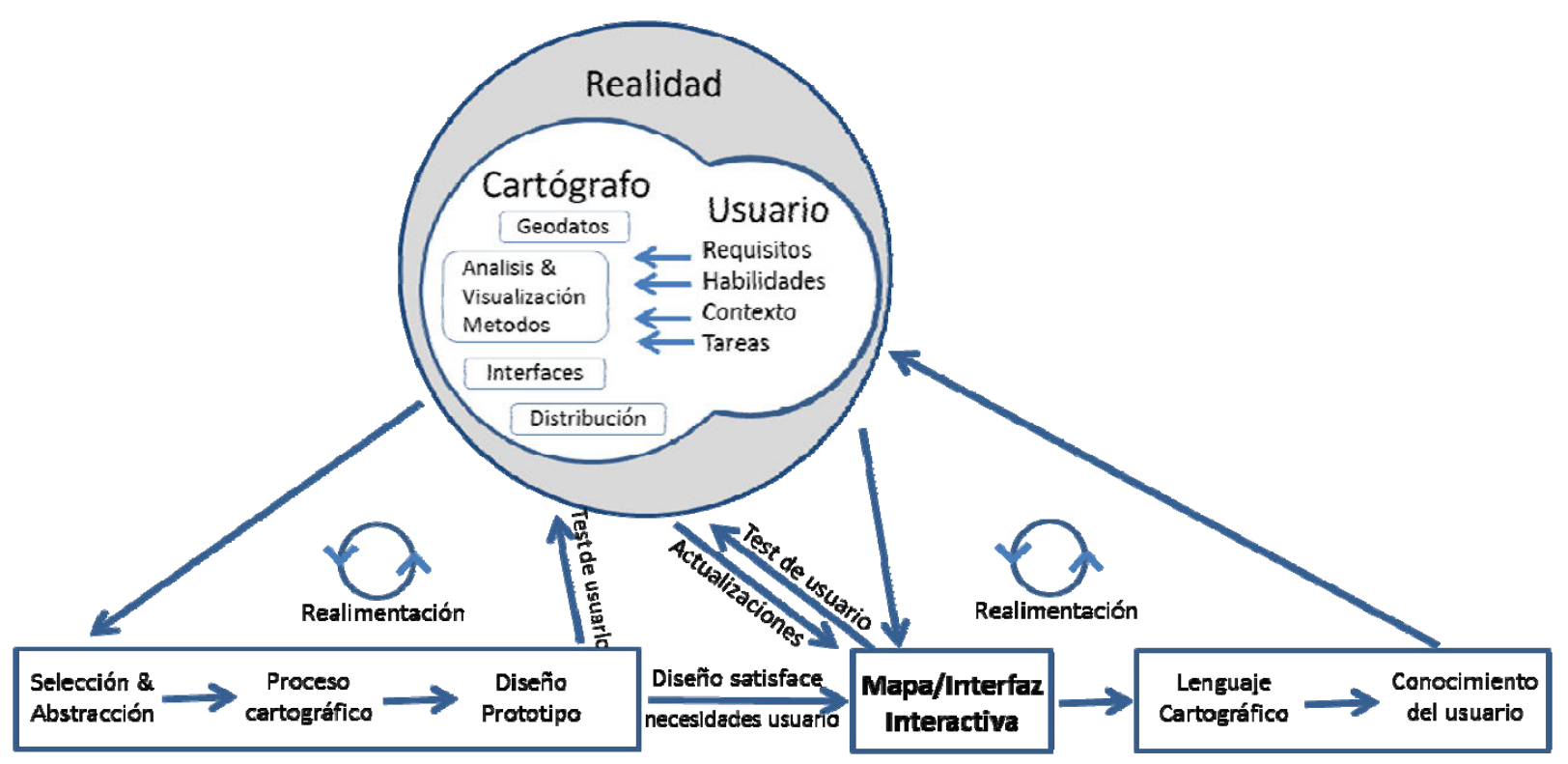

Figura 2.14: Modelo de comunicación cartográfico centrado en el usuario.

Fuente: Schobesberger (2012).

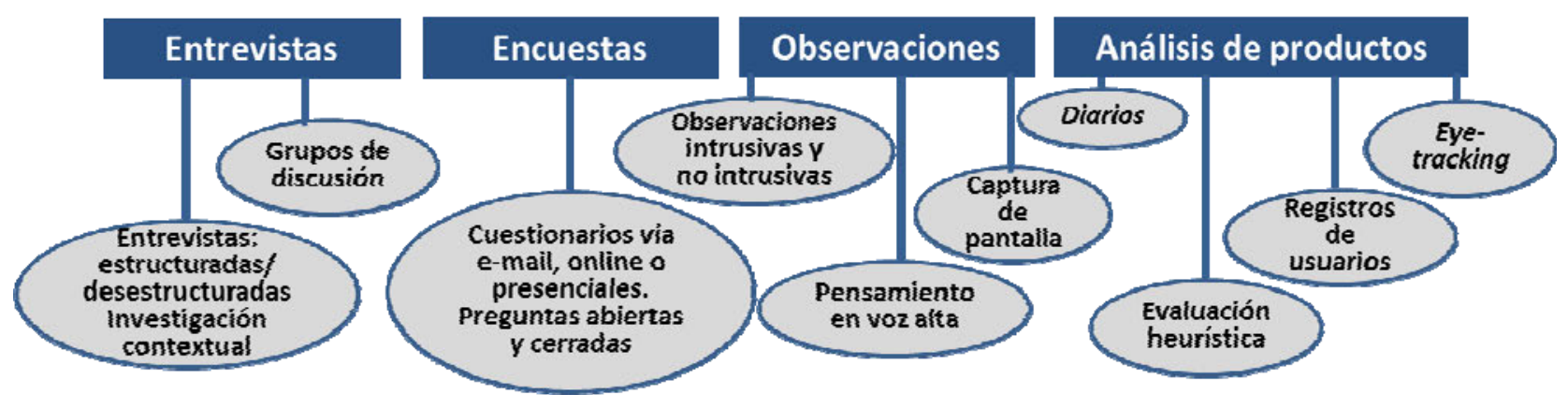

Figura 2.15: Clasificación de técnicas de diseño utilizadas en el Diseño Centrado en el Usuario de sitios web cartográficos. Fuente: Schobesberger (2012).

Como se ha expuesto, durante la última década, los cartógrafos han investigado como desarrollar productos cartográficos a través del DCU con el fin de proporcionar interacciones cartográficas de una forma eficiente, efectiva y satisfactoria (Slocum et al., 2001; Reichenbacher, 2004; Lloyd, 2009; Schobesberger, 2012). Sin embargo, este enfoque resulta muy restringido, ya que se limita a mejorar el rendimiento del usuario en la interacción con los mapas, es por ello que en esta tesis se propone el desarrollo de mapas teniendo en cuenta la experiencia de los usuarios, asociada a su uso.

\subsection{Diseño de experiencias de usuario}

El diseño de experiencias implica la consideración de los factores que influyen en la experiencia del usuario como base del diseño, poniendo en práctica 
para ello un enfoque humano y teniendo en cuenta disciplinas como la psicología y la etnografía, para poder comprender el comportamiento de los usuarios (Tussyadiah, 2013). Pero, ¿qué es la experiencia?. La experiencia es la totalidad irreductible de actos, pensamientos, sentimientos, significados, percepciones y sensaciones que las personas tienen de sus propias acciones (Dewey, 1958). Desde el punto de vista de la psicología, la experiencia se trata de un episodio, un lapso de tiempo en el que imágenes, sonidos, sentimientos, pensamientos, motivaciones y acciones, se entretejen estrechamente, se almacenan en la memoria, se etiquetan, se reviven y se comunican a los demás (Hassenzahl, et al 2010). Law et al., (2009) analizan lo que puede experimentar el ser humano y diferencian la experiencia de usuario, que implica la interacción a través de una interfaz con un producto, servicio, sistema u objeto, del resto de experiencias en las que no interviene una interfaz, como por ejemplo: la experiencia de un espacio, de un acontecimiento o de una obra de arte (Figura 2.16).

La experiencia de usuario aglutina, según la ISO 9241-210 (ISO, 2010), "Ias percepciones de una persona y las respuestas que resultan de la utilización o utilización prevista de un producto, sistema o servicio". La experiencia de usuario es una consecuencia del estado interno del usuario (personalidad, motivación, experiencias previas...), las características del producto diseñado (el propósito, apariencia, funcionalidad...) y el ambiente en el que se produce la interacción (momento, ubicación, temperatura, disponibilidad de tiempo...) (Arhippainen \& Tähti, 2003).

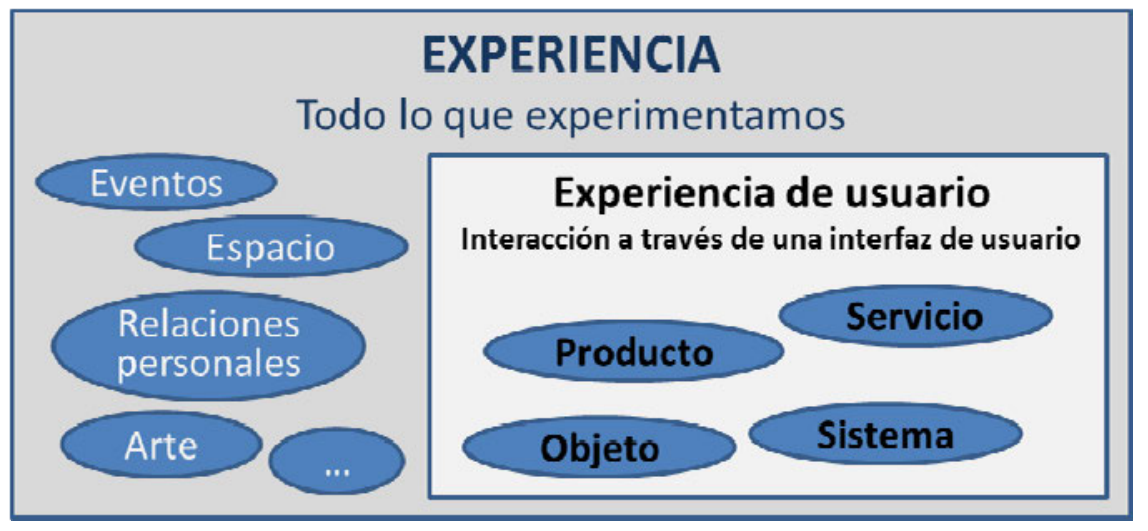

Figura 2.16: Experiencia y experiencia de usuario. Fuente: Law et al. (2009).

La tecnología está tan profundamente arraigada en nuestra experiencia cotidiana, que puede decirse que más que utilizarla, convivimos con ella. Al abordar el análisis de la experiencia de usuario asociada al uso de tecnologías, McCarthy y Wright (2004) identifican cuatro facetas que contribuyen a las acciones y a la creación de significado:

1) Compositiva: Las experiencias son eventos singulares que se desarrollan en relación a otras experiencias, de tal forma que una pequeña experiencia se interpreta y contribuye a una experiencia mayor. Cuando interactuamos con un producto (un mapa), la relación entre nosotros y el artefacto podría considerarse 
una estructura narrativa en la que intervienen las posibilidades de acción, las acciones en sí mismas y las consecuencias.

2) Sensorial: Las experiencias conllevan un vínculo sensorial entre artefacto y usuario. Cuando este vínculo es estrecho, esta faceta sumerge al usuario en la actividad que está realizando. Es el caso de, por ejemplo, un niño atento, absorto y concentrado en su videojuego, que dirige de forma concreta, palpable y visceral la experiencia.

3) Emocional: la ira, alegría, decepción, frustración,... afectan a la intención que ponemos al utilizar un producto, a la forma en que lo usamos, así como a las percepciones y a los resultados que rodean esa interacción. Además, la emoción sirve de recurso para comprender y comunicar lo que experimentamos.

4) Espacio-temporal: Las acciones y los acontecimientos se desarrollan en un tiempo y lugar determinado. Podemos por ejemplo, distinguir entre espacio público y privado, reconocer lugares en los que nos sentimos cómodos y los límites entre nuestra persona y el otro, o entre el presente y el futuro. Dichas construcciones afectan a los resultados de la experiencia, tales como la voluntad de permanecer o volver a visitar lugares.

En relación a la componente temporal de la experiencia de usuario, Kankainen (2002) define la experiencia vivida en el momento presente como el resultado de una acción motivada en un contexto determinado en la que inciden expectativas y experiencias previas y que repercute en las expectativas y futuras experiencias del usario (Figura 2.17).

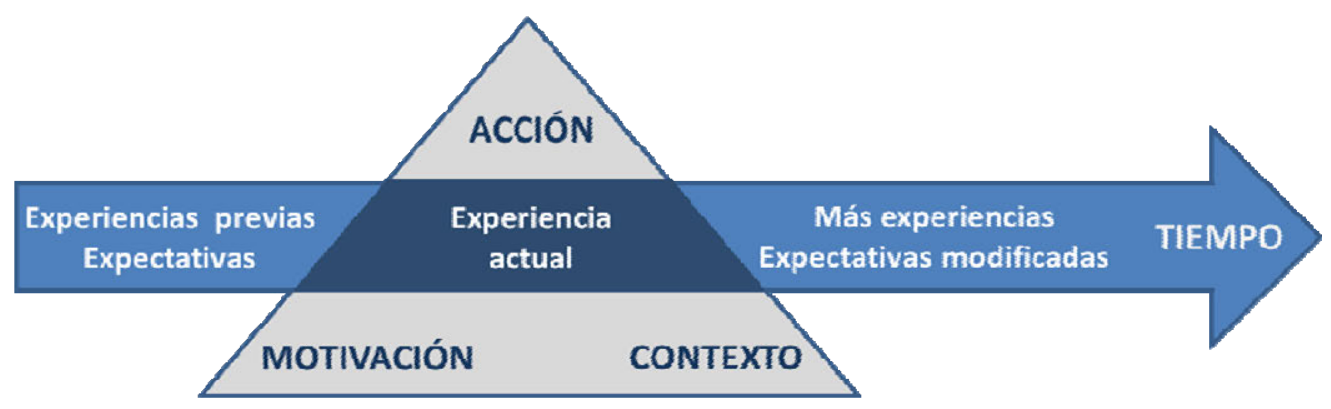

Figura 2.17: Modelo conceptual de experiencia de usuario teniendo en cuenta el tiempo Fuente: Kankainen (2002).

Ahora bien, ¿cómo se pueden diseñar experiencias?. Varios autores coinciden en que las experiencias pueden ser soportadas o apoyadas pero no diseñadas, ya que no se pueden diseñar ni al usuario, ni al contexto de uso del producto. En este sentido, lo que se puede diseñar es un producto que facilite al usuario un tipo de experiencias, un producto que influencie en ellas. Todo ello teniendo en cuenta que, en última instancia, son las personas las que utilizarán el producto en una determinada situación y las que tendrán la experiencia (Sanders, 2002; Wright et al., 2005; Hassenzahl, 2014).

Una experiencia es una historia que emerge del diálogo entre la persona y su mundo, a través de la acción (Hassenzahl et al., 2010). El diseño de experiencias 
consiste en contar historias significativas a través del producto: su apariencia, el contenido, las funcionalidades y la interacción; y colocar esas historias en el centro del proceso de diseño (Knobel \& Hassenzahl, 2013). Aunque las experiencias son únicas, es posible agrupar un número de ellas e identificar su esencia asociada a un "patrón de experiencia" subyacente. Así, mientras los relatos de las experiencias particulares pueden ser diferentes, la esencia de las experiencias pertenecientes a un mismo grupo de personas es común (Hassenzahl, 2010) y se convierte en el input del proceso de diseño de experiencias.

Hassenzahl (2014) hace hincapié en que diseñar productos bajo este enfoque supone basar el proceso de diseño en la experiencia que se desea propiciar y no en el producto. En base a ello, propone una metodología de diseño de experiencias de usuario, que abarca tres etapas secuenciales:

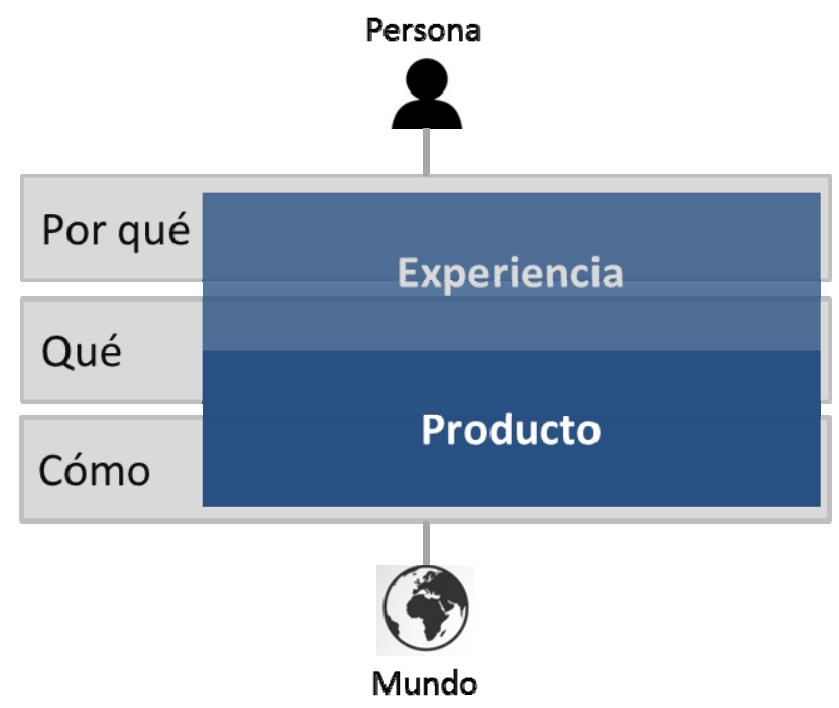

Figura 2.18: Modelo de diseño de experiencias de Hassenzahl (2014).

1. ¿Por qué?: en esta etapa se estudian las necesidades y emociones involucradas en una actividad, el significado y las experiencias que se desean para el usuario.

2. ¿Qué?: en este nivel se determina lo que los usuarios pueden hacer a través del producto interactivo, la funcionalidad que es capaz de proporcionar soporte a la experiencia y que con frecuencia está asociada a una tecnología o tipología de productos, y

3. ¿Cómo?: que aborda la forma en la que los usuarios interactuarán con el producto a nivel sensorial. Esta es la etapa asociada con el producto real a diseñar y con su contexto de uso.

Hassenzahl (2003) analiza la experiencia de usuario desde la perspectiva del diseñador y del usuario (Figura 2.19). El producto tiene una serie de características (contenido, apariencia, funcionalidades y modos de interacción) elegidas por el diseñador. Cuando el usuario entra en contacto con el producto se desencadena un proceso. En primer lugar, el usuario percibe las características del producto y en base a ello establece su punto de vista del mismo. Esta visión del producto, está 
compuesta por una serie de atributos pragmáticos, relacionados con la forma en la que el producto da soporte al usuario en el cumplimiento de sus tareas (contenidos, funcionalidades y formas de acceder a ellas) y hedónicos, que repercuten en el bienestar psicológico del usuario. Los atributos hedónicos del producto proporcionan estimulación, comunican la identidad y provocan recuerdos: 1. Estimulación: Las personas pueden buscar su desarrollo personal (incrementar sus conocimientos, desarrollar habilidades,...) para lo cual, el producto tiene que ser estimulante, ofrecer nuevas impresiones, oportunidades y perspectivas; 2. Identificación: Las personas expresan su identidad a través de objetos y para ello pueden preferir productos que les permitan comunicar una identidad favorable a los demás; y 3. Evocación: el producto puede dar soporte a los recuerdos representando por ejemplo eventos pasados y propiciando las relaciones o asociaciones que son importantes para el individuo en el presente. Finalmente, la visión del producto desencadena en el usuario consecuencias en forma de juicio acerca del producto (el producto es bueno o malo), emocionales (placer o satisfacción) y a nivel de comportamiento (incremento del uso del producto, decisión de ir a un lugar o a otro...).

a) Perspectiva del diseñador

\begin{tabular}{|c|c|c|}
\hline Características & Carácter del producto pretendido por el diseñador & Consecuencias \\
\hline del producto & \multirow{2}{*}{$\begin{array}{c}\text { Atributos pragmáticos } \\
\text { Manipulación }\end{array}$} & \\
\hline Contenido & & Juicios \\
\hline Apariencia & \multirow{2}{*}{$\begin{array}{c}\text { Atributos hedónicos } \\
\text { Estimulación } \\
\text { Identificación } \\
\text { Evocación }\end{array}$} & Emociones \\
\hline Funcionalidad & & \multirow[t]{2}{*}{ Comportamientos } \\
\hline Interacción & Visión del producto por parte del usuario & \\
\hline
\end{tabular}

b) Perspectiva del usuario

Figura 2.19: Experiencia de usuario desde a) la perspectiva del diseñador y b) la perspectiva del usuario. Fuente: adaptación de Hassenzahl (2003).

El diseño de experiencias de usuario es un proceso que se enclava entre un entorno humano (los usuarios) y otro tecnológico (las herramientas que darán soporte a la implementación del producto y su puesta en el mercado). Trasladar los aportes procedentes de los usuarios a un producto, para dar soporte a la experiencia del usuario, involucra una serie de tareas tales como: la investigación de los usuarios, el diseño de información, el diseño visual y el diseño de interacción. Para su ejecución, suelen intervenir una serie de profesionales: diseñador de experiencias; diseñador gráfico; desarrollador de la interfaz de usuario y desarrollador del producto o aplicación (Figura 2.20). 


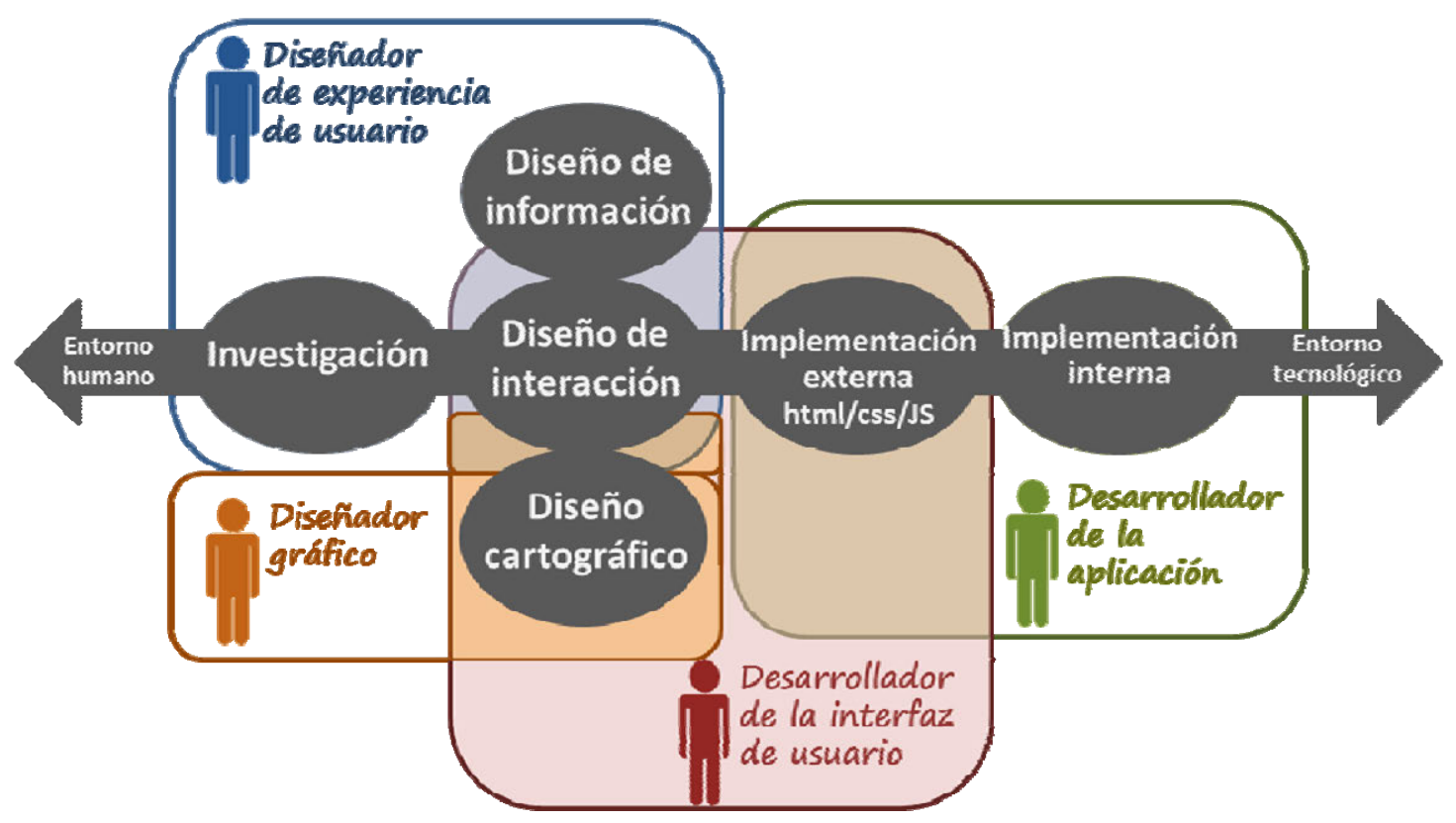

Figura: 2.20: Profesionales que suelen intervenir en el diseño de experiencias.

Fuente: http://asinthecity.com/2011/11/10/the-difference-between-a-ux-designer-and-uideveloper/

El diseñador de experiencias necesita tener acceso a las experiencias de los usuarios y hacer de ellas la fuente de inspiración del diseño (investigación). Sanders (2002) expone que hay muchas formas de investigar y aprender acerca de lo que los usuarios recuerdan, de sus actuales experiencias y de sus experiencias ideales, y que cada ruta de acceso a la experiencia revela una fotografía o historia diferente (Figura 2.21). Escuchar lo que la gente dice permite al diseñador saber lo que están dispuestos a expresar en palabras (conocimiento explícito). Contemplar lo que lo que la gente hace y lo que utiliza, suministra información observable. Descubrir lo que las personas piensan y conocen, suministra al diseñador sus percepciones de la experiencia $y$, comprender lo que lo que sienten, le permite empatizar con ellos. Estas vías proporcionan conocimiento tácito, que raramente se expresa en palabras. Por último, identificar lo que la gente sueña, lo que le gustaría, ofrece información sobre necesidades latentes.
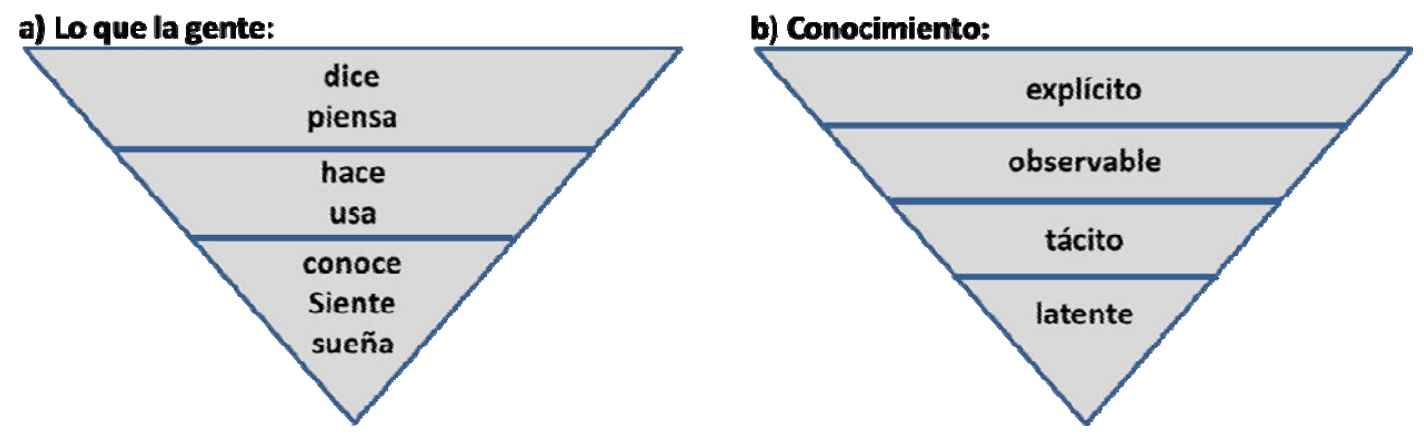

Figura 2.21: a) Formas de aprender acerca de las experiencias de los usuarios y b) niveles de necesidades. Fuente: Sanders (2002). 
Shedroff y Officer (1994) exponen que del mismo modo que los datos se pueden transformar en información útil, la información se transforma en conocimiento a través de un diseño de la interacción que propicia experiencias significativas. Estos autores afirman que para ello es necesario estructurar adecuadamente los datos y la información que el diseñador ha recabado en la investigación, para dar soporte a esas experiencias (diseño de información, Figura 2.20). Exponen que con cada experiencia se adquiere conocimiento y que el conocimiento se comunica mediante la construcción de interacciones adecuadas con los productos (diseño de interacción, Figura 2.20), de tal manera que los significados de la información representada (diseño visual, diseño cartográfico en el caso de los mapas) y percibida a través de nuestros sentidos, puedan ser aprendidos (Figura 2.10 y 2.20 ).

En cuanto a los tipos de interacción entre el usuario y el producto, estas pueden ser (Forlizzi \& Battarbee, 2004): fluidas, cognitivas y expresivas (Tabla 2.1); dando como resultado: "experiencia", "una experiencia" o "co-experiencia"(Tabla 2.2).

\begin{tabular}{|c|l|l|}
\hline $\begin{array}{c}\text { Tipos de } \\
\text { interacción } \\
\text { usuario- } \\
\text { producto }\end{array}$ & \multicolumn{1}{|c|}{ Descripción } & \multicolumn{1}{|c|}{ Ejemplo } \\
\hline Fluidas & $\begin{array}{l}\text { Interacciones automáticas y habituales que no } \\
\text { demandan atención y nos permiten centrarnos } \\
\text { en las consecuencias de nuestra actividad o en } \\
\text { otros asuntos. }\end{array}$ & $\begin{array}{l}\text { Hacer café por la mañana. } \\
\text { Montar en bicicleta. }\end{array}$ \\
\hline Cognitivas & $\begin{array}{l}\text { Interacciones que tienen lugar con el producto } \\
\text { en la mano y que desembocan en una } \\
\text { adquisición de conocimiento o en confusión o } \\
\text { error, si el usuario no logra utilizar el producto } \\
\text { de forma satisfactoria. Las experiencias } \\
\text { cognitivas causan un cambio en el usuario (tal } \\
\text { como adquirir una habilidad o encontrar una } \\
\text { solución) y a menudo en el contexto de uso. }\end{array}$ & $\begin{array}{l}\text { Consultar un mapa en } \\
\text { ciudad que no se conoce para } \\
\text { decidir hacia dónde ir. } \\
\text { Utilizar un tutorial en línea sobre } \\
\text { problema de matemáticas. }\end{array}$ \\
\hline Expresivas & $\begin{array}{l}\text { Interacciones que permiten al usuario cambiar, } \\
\text { modificar o personalizar el producto de forma } \\
\text { que se ajuste mejor a sus necesidades o justos. }\end{array}$ & $\begin{array}{l}\text { Cambiar la simbología de un } \\
\text { mapa. } \\
\text { Modificar la imagen de fondo del } \\
\text { móvil. }\end{array}$ \\
\hline
\end{tabular}

Tabla 2.1: Tipos de interacciones usuario-producto. Fuente: adaptación de Forlizzi y Battarbee (2004). 


\begin{tabular}{|c|l|l|}
\hline $\begin{array}{c}\text { Tipos de } \\
\text { experiencias }\end{array}$ & \multicolumn{1}{|c|}{ Descripción } & \multicolumn{1}{|c|}{ Ejemplo } \\
\hline Experiencia & $\begin{array}{l}\text { Es el constante "diálogo interno" que ocurre } \\
\text { mientras interactuamos con un producto. La } \\
\text { experiencia es la forma en la que evaluamos } \\
\text { constantemente nuestros objetivos en } \\
\text { relación con las personas, productos y } \\
\text { entornos que nos rodean en un momento } \\
\text { dado. }\end{array}$ & $\begin{array}{l}\text { Hacer las tareas del hogar. } \\
\text { Unstantáneo. un sistema de mensajes }\end{array}$ \\
\hline $\begin{array}{c}\text { Una } \\
\text { experiencia }\end{array}$ & $\begin{array}{l}\text { Puede ser expresada o denominada: tienen } \\
\text { un comienzo y un fin e inspira cambios de } \\
\text { comportamiento o emocionales. }\end{array}$ & $\begin{array}{l}\text { Utilizar un mapa. } \\
\text { Ver una película. }\end{array}$ \\
\hline experiencia & $\begin{array}{l}\text { Tiene lugar cuando las experiencias se crean } \\
\text { de forma compartida con otros, de tal } \\
\text { manera que las interpretaciones, } \\
\text { significados y emociones derivadas del uso } \\
\text { del producto son fruto de la intervención } \\
\text { conjunta. }\end{array}$ & $\begin{array}{l}\text { Utilizar una aplicación cartográfica } \\
\text { que permite recabar sugerencias } \\
\text { de amigos que han visitado un } \\
\text { lugar al que iremos. } \\
\text { Participar en una obra de teatro } \\
\text { que involucra al público. }\end{array}$ \\
\hline
\end{tabular}

Tabla 2.2: Tipos de experiencias. Fuente: adaptación de Forlizzi y Battarbee (2004).

Teniendo en cuenta todo lo expuesto, la segunda premisa de esta tesis es que las interacciones del usuario con los mapas inciden en su adquisición de conocimiento del espacio representado y por lo tanto, en su experiencia cognitiva del mismo.

\subsection{Conclusiones}

La diversidad de situaciones en las que los usuarios consultan mapas a través de distintos dispositivos hace que su representación sea un problema complejo, que como ya se ha comentado, ha sido y es objeto de investigación en esta tesis. Cuando un usuario se pregunta por ejemplo "¿dónde estoy?", éste recurre a varias fuentes de información: la realidad que le rodea, la representación cartográfica y su propio mapa cognitivo buscando dar respuesta a su pregunta a través de una serie de interacciones mentales. En esta tesis, se plantea la hipótesis de que los mapas se pueden considerar instrumentos activos en los procesos cognitivos de los usuarios, que inciden en su comportamiento y en sus experiencias cognitivas del espacio urbano y que, para ello, se ha de mejorar la vinculación de las diferentes fuentes de información que maneja el usuario para llevar a cabo sus actividades.

Ante esta hipótesis surge la pregunta de investigación ¿cómo desarrollar mapas que den soporte a la experiencia cognitiva del usuario?. En esta tesis se aborda el análisis de la interacción cartográfica haciendo énfasis en la distinción del diseño de experiencias de usuario, en relación a la experiencia como nueva forma de conceptualizar la tarea objeto de la visualización de la información y para cuyo soporte se suministra al usuario la interacción con la interfaz; y el diseño de la propia interfaz de usuario (mapa), en relación a la presentación de la información de 
forma gráfica (diseño cartográfico). Esta tesis resalta el cambio experimentado en el foco de la interacción cartográfica que ha pasado del diseño de interfaces al diseño de experiencias y la consecuente necesidad de investigar en esta línea dentro del ámbito cartográfico. Teniendo en cuenta, para ello, la comunicación bidireccional entre el usuario y la visualización.

Con tal fin, esta investigación aborda la propuesta de una metodología de diseño que, fundamentándose en las investigaciones expuestas en este capítulo, permita abordar el desarrollo de mapas que den soporte a las experiencias cognitivas del usuario.

Los mapas esquemáticos encajan en el enfoque con el que se quiere llevar a cabo el proceso de diseño de experiencias de usuario, ya que son lo suficientemente flexibles como para: dar soporte a actividades específicas; suministrar el conocimiento necesario; combinar información espacial concreta y detallada del entorno físico con información abstracta y conceptual almacenada en nuestro cerebro (mapa cognitivo) y dar cabida a personalizaciones y adaptaciones basadas en los estilos cognitivos de los usuarios.

Los mapas esquemáticos a diseñar actuarán como interfaz. Sus visualizaciones, funcionalidades e interacciones, permitirán la comunicación necesaria entre el usuario y el espacio geográfico, teniendo en cuenta su experiencia cognitiva de dicho espacio.

Para lograr este objetivo, se propone un proceso de desarrollo de mapas esquemáticos desde un enfoque centrado en el usuario, en el que el objetivo no se limite a mejorar el rendimiento del usuario en la interacción con los mapas (usabilidad), sino que también tenga en cuenta la experiencia asociada a su uso. Estos mapas darán soporte a las experiencias cognitivas de los usuarios, de tal manera que éstas serán el foco durante el proceso de diseño y los mapas se convertirán el medio suministrado para lograr dicho objetivo. Para ello, a lo largo del proceso, se llevarán a cabo técnicas de diseño que faciliten la asimilación de conocimiento acerca de las experiencias de los usuarios. En base a este conocimiento, los mapas esquemáticos tendrán, unos atributos pragmáticos, relacionados con la forma en la que darán soporte a las tareas de los usuarios y otros evocadores orientados a dar soporte al recuerdo de lugares del espacio asociados a sus experiencias, así como el aprendizaje de nuevos lugares a través de relaciones relevantes para el individuo. 


\section{METODOLOGÍA}

Las experiencias de usuario objeto de estudio de esta tesis son las asociadas a interacciones complejas entre el usuario y los mapas de un determinado espacio geográfico, al realizar una serie de actividades. El usuario tiene contacto directo con el espacio o a través de mapas, experimentando una serie de vivencias (experiencias). Por ejemplo, un turista puede tener una experiencia cuando, al planificar el viaje, interactúa con los mapas en un sitio web de la ciudad de destino, o cuando, durante su visita, consulta un servicio basado en localización al salir de un museo.

Tal y como se ha descrito en el capítulo 2, las interacciones entre un usuario y un producto pueden ser: fluidas, cognitivas y expresivas (apartado 2.5). Por ejemplo, un turista durante unas vacaciones urbanas podría consultar mapas que, a través de mecanismos de adaptación y personalización, le asistieran en la asimilación de conocimiento espacial del entorno geográfico (interacción cognitiva). Ese mismo turista podría modificar también la simbología de los mapas que consulta (interacción expresiva).

El diseño de experiencias de usuario (DEU) propuesto en esta tesis, se concentra en las experiencias cognitivas del usuario, asociadas a las interacciones cognitivas de éste con los mapas.

EI DEU se aborda a través de un proceso que tiene dos dimensiones: una dimensión vertical, que integra cuatro fases, y una horizontal, correspondiente con las tareas de diseño, que dan respuesta a una serie de preguntas planteadas en cada fase de la dimensión vertical. Cada fase tiene una función distinta debido a las diferentes necesidades que se tienen que abordar a lo largo del proceso, desde la definición de la visión de los mapas, hasta la elaboración de los prototipos. Los resultados de una fase, dan respuesta a las preguntas planteadas y se utilizan en otras, creando un proceso de retroalimentación. Las tareas de diseño dan soporte a cada fase y requieren de cierta investigación que se lleva a cabo a través de diferentes técnicas de diseño. La selección de las técnicas dependerá de las cuestiones a resolver y de los recursos necesarios para su aplicación: participantes, tiempo, materiales... Entre las posibles técnicas de diseño se incluyen: cuestionarios, entrevistas, grupos de discusión, diarios, observaciones de campo, escenarios,...

A continuación se introducen las fases del proceso propuesto de DEU y los objetivos a abordar en cada una de ellas. Seguidamente se describen en detalle.

\section{Fase 1: Concepción del contexto asociado a la experiencia de los usuarios}

En esta fase se lleva a cabo una aproximación teórica al contexto asociado a la experiencia de los usuarios, abordando tres preguntas: 1) ¿Cuál es el contexto del diseño?, 2) ¿Quiénes son los usuarios? y 3) ¿Qué mapas utilizan y cuales podrían usar?. Las tareas a ejecutar para dar respuesta a estas preguntas deben permitir conformar una idea de contexto de diseño de los mapas a desarrollar, así como comenzar a perfilar la visión de los mismos. 


\section{Fase 2: Exploración de la experiencia de los usuarios}

Durante esta fase, se recopila información de los grupos de interés y de los usuarios a los que van destinados los mapas a diseñar, con el fin de obtener un conocimiento realista de su experiencia. Las preguntas a abordar son: 1) ¿Cuál es el contexto de las actividades que realizan los usuarios?, 2) ¿Cómo son los usuarios? y

3) ¿Cómo son los mapas que utilizan y cómo es su experiencia?.

\section{Fase 3: Síntesis de la experiencia de los usuarios}

El diseñador lleva a cabo en esta fase una labor de abstracción, en la que modela las interacciones entre el usuario, el ambiente y el mapa. En esta etapa del proceso de diseño se afrontan las preguntas: 1) ¿Cuáles serán los ambientes en los que los usuarios utilizarán los mapas?, 2) ¿Cómo serán las experiencias de los usuarios a las que los mapas darán soporte? y 3) ¿Cómo serán los mapas a diseñar?. Como resultado de esta fase, se obtiene una concepción de los mapas y se definen unos enfoques de experiencia, perfiles de usuario y escenarios, en base a los cuales el diseñador puede ilustrar cómo se utilizan.

Fase 4. Diseño de prototipos de los mapas

En esta fase, el diseñador elabora el diseño de los prototipos de los mapas y como resultado se obtienen ejemplos de los mapas como interfaz.

\subsection{Fase 1: Concepción del contexto de la experiencia de los usuarios}

En esta fase se abordan tres cuestiones: 1) ¿Cuál es el contexto del diseño?, 2) ¿Quiénes son los usuarios? y 3) ¿Qué mapas utilizan y cuales podrían usar?.

\section{Fase 1: Concepción del contexto de la experiencia de los usuarios}

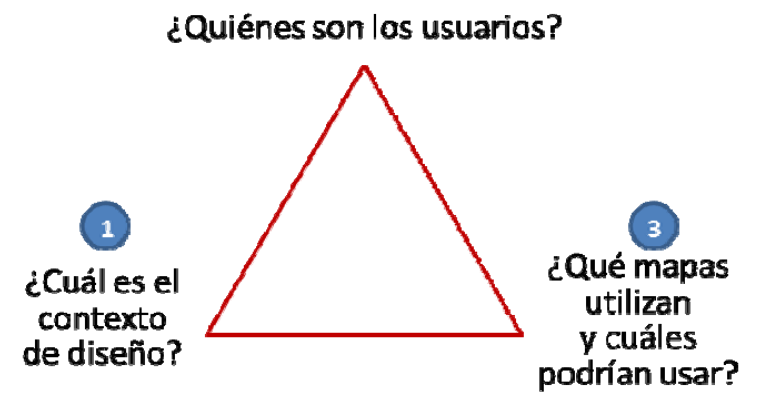

Figura 3.1: Preguntas a responder en la Fase 1.

Para poder dar respuesta a estas preguntas, se plantea la ejecución de cuatro tareas, a través de la revisión de documentación y de la consulta a expertos. Las tareas de esta fase consisten en identificar: los grupos de interés, los usuarios y sus atributos, las actividades que realizan y los factores que condicionan su ejecución; 
los productos cartográficos, así como de los factores que caracterizan su uso; y el espacio geográfico vinculado a la experiencia del usuario (Figura 3.2).

Concepción del contexto de la experiencia de los usuarios

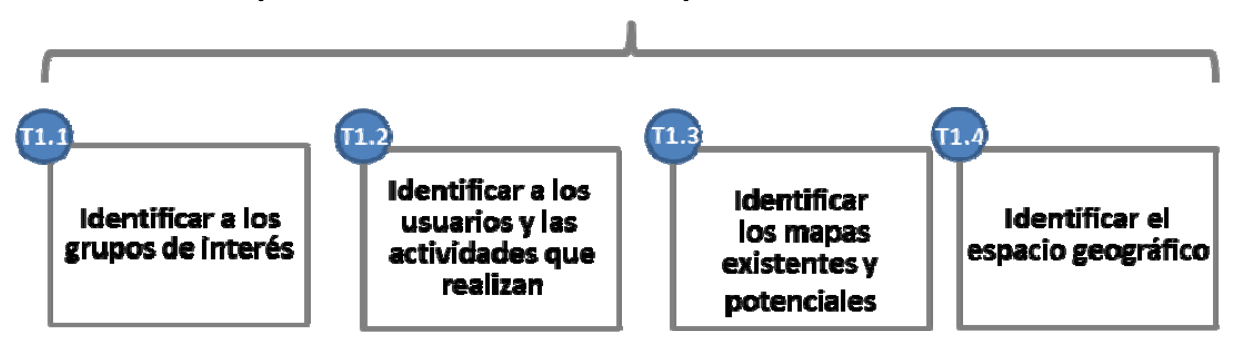

Figura 3.2: Tareas de la Fase 1.

A continuación, se describen con más detalle las tareas ejecutadas en esta fase, las técnicas de diseño que se pueden aplicar para llevarlas a cabo y los resultados obtenidos.

\subsubsection{Tareas de la Fase 1}

\section{T 1.1 Identificar a los grupos de interés}

Los grupos de interés son los colectivos de personas, organismos y empresas relacionados con el ámbito en el que se utilizarán los mapas a diseñar, que pueden influir en las experiencias del usuario y ayudar a comprenderlas.

Tanto si la iniciativa del diseño de los mapas surge del cartógrafo (en cuyo caso le interesa saber que entidades podrían comercializarlos o suministrarlos a los usuarios) como si el proyecto se ha puesto en marcha a raíz de una iniciativa externa (individual o conjunta), conviene saber desde el inicio quieres son los grupos de interés y determinar su papel en el proceso de diseño.

\section{T 1.2 Identificar a los usuarios y sus atributos, las actividades que realizan y los factores que condicionan su ejecución}

Los usuarios son una pieza clave en el DEU. De ahí la necesidad de identificarlos desde un principio. Además, puesto que los mapas a diseñar están orientados a dar soporte a las experiencias cognitivas de los usuarios, resulta fundamental determinar cuáles de sus atributos son susceptibles de condicionar estas experiencias.

Por ejemplo, en el contexto turístico urbano, los atributos del turista a tener en cuenta, identificados en base a investigaciones previas, son: 
1. País de procedencia (Moore,1979; Bramwell 1998; Slocum et al., 2001; Shoval \& Raveh, 2004; Edsall, 2007; Castaño et al. 2006).

2. Experiencia en grandes ciudades (Beck \& Wood, 1976; Dziekan,2008; Guo, 2011; Kinsella \& Caulfield,2011).

3. Edad (Beck, \& Wood, 1976; Moore,1979; Bramwell ,1998; Slocum et al., 2001; Gibson,2002; Shoval, \& Raveh, 2004; Lew \& McKercher,2006; Hannes et al. ,2006; Guo, 2011; Dziekan,2008; Caulfield \& Kinsella,2011).

4. Género (Beck, \& Wood, 1976; Slocum et al., 2001; Gibson,2002; Shoval \& Raveh, 2004; Castaño et al. 2006; Hannes et al. ,2006; Hannes et al.,2006; Dziekan,2008; Kinsella \& Caulfield,2011).

5. Nivel económico (Francescato \& Mebane, 1973; Gibson ,2002).

6. Nivel de estudios (Gibson ,2002; Shoval \& Raveh, 2004; Hannes et al. ,2006).

7. Capacidad cognitivo-espacial (Beck \& Wood , 1976, Moore,1979; Slocum et al., 2001; Hannes et al.,2006; Savage, 2006).

8. Experiencia en el uso de la información geográfica (Beck \& Wood, 1976, Slocum et al., 2001; Savage, 2006).

Por otro lado, el usuario se relaciona con el espacio a través de una serie de actividades. Por ejemplo, el turista (usuario) planifica el viaje, se desplaza del aeropuerto al hotel, selecciona los lugares a visitar... y, a su vez, estas actividades están condicionadas por una serie de factores, cuya identificación resulta de interés para dar soporte a las experiencias del usuario. Siguiendo con el ejemplo, a continuación se incluyen los factores que inciden en las actividades que realizan los turistas urbanos y los estudios que los avalan:

\section{Factores humanos:}

1. Motivo de la visita (Shoval \& Raveh, 2004; Lew \& McKercher ,2006; Castaño et al., 2006).

2. Intereses relacionados con la visita (Lew \& McKercher, 2006; Savage, 2006).

3. Grupo de viaje (Lew \& McKercher, 2006).

4. Conocimiento turístico-espacial del destino turístico urbano (Appleyard, 1970; Lew, \& McKercher, 2006).

5. Conocimiento de infraestructuras de transporte (Lew \& McKercher, 2006; Dziekan, 2008).

6. Percepción de los desplazamientos/Forma de moverse (Beck \& Wood, 1976; Lew \& McKercher, 2006).

7. Percepción de la ciudad como destino turístico (Castaño et al., 2006).

8. Valoración de la experiencia (Castaño et al., 2006; Dziekan, 2008).

\section{Factores físicos:}

9. Productos cartográficos utilizados.

10. Configuración espacial del destino turístico.

11. Atractivos turísticos del destino turístico (Lew \& McKercher, 2006).

12. Infraestructuras de transporte del destino turístico.

13. Infraestructuras de transporte utilizadas (Beck \& Wood, 1976; Moore, 1979; Castaño et al., 2006).

14. Ubicación del alojamiento (Beck \& Wood, 1976; Bramwell, 1998; Lew \& McKercher, 2006; Dziekan, 2008). 
Factores temporales (Beck \& Wood, 1976; Moore, 1979; Pearce, 1988; Bramwell, 1998; Shoval \& Raveh, 2004; Lew \& McKercher, 2006; Castaño et al., 2006):

15. Duración de la estancia.

16. Época del año.

T 1.3 Identificar los mapas utilizados por los usuarios, así como los factores que caracterizan su uso

Sea cual sea el ámbito de las experiencias del usuario (turístico, urbanístico, de emergencias,...), se considera que deben existir mapas a su disposición. El objetivo de esta tarea es identificar estos mapas y los factores que caracterizan su uso y que condicionan las experiencias del usuario. Estos factores, en el caso del ámbito turístico, son:

1. Etapa del viaje en la que se utilizan los mapas (Pre-viaje/Realización de la visita/Post-viaje).

2. Actividad/necesidad asociada a su uso (Vertesi, 2008).

3. Producto a través del cual se accede a los mapas (tipo de dispositivo y aplicación) (Lew \& McKercher, 2006; Dziekan, 2008).

4. Información suministrada por los mapas (Kinsella \& Caulfield, 2011; Guo, 2011).

\section{T 1.4 Identificar el espacio geográfico asociado a las experiencias del usuario y sus principales características}

El usuario percibe el territorio asociado a su experiencia urbana como una superficie subjetiva, que en muchos casos no obedece a demarcaciones administrativas. En el capítulo 2 se expone que el diseño de los mapas se abordará teniendo en cuenta una correspondencia entre éstos y la representación conceptual del espacio en la mente de los usuarios. Teniendo esto en cuenta, para dar soporte a las experiencias del usuario, el espacio geográfico asociado debe determinarse en base a la conceptualización que los usuarios tienen de él (mapa cognitivo). En esta primera fase se recurre a fuentes documentales para poder establecer una primera aproximación teórica del espacio geográfico a considerar en el proceso de diseño. En la Fase 2, gracias a la información que recopilada acerca de los mapas cognitivos de los usuarios, se confirma o rectifica el espacio geográfico definido en esta fase.

En cuanto a las características del espacio geográfico, se identifican aquellas que tienen una mayor relevancia en las actividades que realizan los usuarios. Por ejemplo, si el ámbito de la experiencia del usuario fuera el de la gestión de emergencias y los usuarios fueran personal de protección civil, podría resultar de interés documentarse acerca de las infraestructuras de hospitales, carreteras,... 


\subsubsection{Técnicas de diseño de la Fase 1}

La siguiente tabla ilustra las técnicas de diseño de esta fase:

\begin{tabular}{|c|c|c|c|c|c|}
\hline \multicolumn{6}{|c|}{ Fase 1: Concepción del contexto } \\
\hline \multirow[b]{2}{*}{$\begin{array}{l}\text { Técnica de } \\
\text { diseño }\end{array}$} & \multirow[b]{2}{*}{ Descripción } & \multicolumn{4}{|c|}{ Tareas de identificación de } \\
\hline & & $\begin{array}{c}1.1 \\
\text { grupos } \\
\text { interés }\end{array}$ & $\begin{array}{c}1.2 \\
\text { usuarios }\end{array}$ & $\begin{array}{l}\mathrm{T} 1.3 \\
\text { mapas }\end{array}$ & $\begin{array}{c}\text { T } 1.4 \\
\text { espacio } \\
\text { geográfico }\end{array}$ \\
\hline $\begin{array}{l}\text { Diseño } \\
\text { basado en } \\
\text { evidencias }\end{array}$ & $\begin{array}{l}\text { Esta técnica utiliza métodos } \\
\text { tradicionales de investigación y } \\
\text { evidencias existentes para influir en } \\
\text { las decisiones de diseño. Estos } \\
\text { métodos abarcan, entre otros, la } \\
\text { revisión bibliográfica, los análisis } \\
\text { comparativos y los casos de estudio. }\end{array}$ & $X$ & $X$ & $X$ & $X$ \\
\hline Entrevistas & $\begin{array}{l}\text { Conversación, basada en preguntas, } \\
\text { sobre las que la persona } \\
\text { entrevistada da su respuesta u } \\
\text { opinión. El entrevistador tiene la } \\
\text { oportunidad de recoger información } \\
\text { de primera mano del entrevistado. } \\
\text { Las entrevistas pueden ser } \\
\text { estructuradas, si en ellas se abordan } \\
\text { una serie de preguntas previamente } \\
\text { definidas, o no estructuradas si se } \\
\text { plantean en forma de conversación } \\
\text { acerca de una serie de temas. En } \\
\text { cuanto a las preguntas, estas } \\
\text { pueden ser cerradas si tienen un } \\
\text { formato de respuesta } \\
\text { predeterminado (Si/No, una } \\
\text { determinada escala u opciones } \\
\text { concretas) o abiertas. }\end{array}$ & $X$ & $X$ & $X$ & $X$ \\
\hline $\begin{array}{l}\text { Análisis de la } \\
\text { competencia }\end{array}$ & $\begin{array}{l}\text { Se trata de saber cuáles son los } \\
\text { mapas disponibles actualmente y } \\
\text { sus características, con el fin de } \\
\text { tener una visión de ellos. }\end{array}$ & & & $X$ & \\
\hline $\begin{array}{l}\text { Lluvia de } \\
\text { ideas }\end{array}$ & $\begin{array}{l}\text { Reunión de un grupo de personas } \\
\text { con la finalidad de estimular su } \\
\text { participación, creatividad y generar } \\
\text { ideas con respecto a un desafío } \\
\text { específico. }\end{array}$ & & & $X$ & \\
\hline
\end{tabular}

Tabla 3.1: Técnicas de diseño utilizadas en la Fase 1.

\subsubsection{Resultados de la Fase 1}

La ejecución de las tareas de esta fase, permite dar respuesta a las siguientes preguntas:

1) ¿Cuál es el contexto de diseño?

El contexto de diseño está definido por el ámbito de las experiencias del usuario (turístico, urbanístico, emergencias...) y comprende a los usuarios, las 
actividades que realizan en un determinado espacio geográfico y los grupos de interés y productos cartográficos asociados.

La descripción del contexto de diseño debe abarcar las debilidades y fortalezas del contexto de la experiencia del usuario a la que los mapas van a dar soporte (relaciones entre los grupos de interés, necesidades de conocimiento del espacio detectadas, repercusiones de esas necesidades, recursos disponibles, aspectos en los que el uso de los mapas puede incidir...).

2) ¿Quiénes son los usuarios?

Los usuarios son el elemento clave del proceso de DEU. En esta fase se determinan quiénes son, cuáles son sus atributos y qué factores condicionan la ejecución de sus actividades.

3) ¿Qué mapas utilizan y cuales podría usar?

La identificación de los mapas que se encuentran a disposición de los usuarios y la documentación consultada sobre las posibles deficiencias en el suministro de información geográfica, permitirán describir, en una primera aproximación, hasta qué punto los mapas existentes están cubriendo las necesidades de los usuarios. En base a ello, se plantean que mapas podrían dar soporte a su experiencia cognitiva.

\subsection{Fase 2: Exploración de la experiencia de los usuarios}

En esta fase, se recopila información de los grupos de interés y de los usuarios, con el fin de obtener una perspectiva más cercana de la experiencia de éstos últimos, en relación al espacio urbano. Para ello, las preguntas que se abordan son: 1) ¿Cuál es el contexto de las actividades que realizan los usuarios?, 2) ¿Cómo son los usuarios a los que van destinados los mapas a diseñar? y 3) ¿Cómo son los mapas que utilizan y cómo es su experiencia en el espacio urbano? (Figura 3.3).

Para abordar la exploración de las experiencias de los usuarios se han definido cuatro tareas. Éstas permiten dar respuesta a las preguntas planteadas, a través de la indagación acerca de: los grupos de interés; las características de los usuarios; las actividades que realizan y los factores que condicionan su ejecución; los productos cartográficos que utilizan, los que podrían utilizar y el espacio geográfico asociado (Figura 3.4). La información obtenida en esta fase permite asimilar un conocimiento realista sobre los aspectos que repercuten en las experiencias de los usuarios. Esta información complementa la información obtenida en la Fase 1. 
Fase 2: Exploración de la experiencia de los usuarios

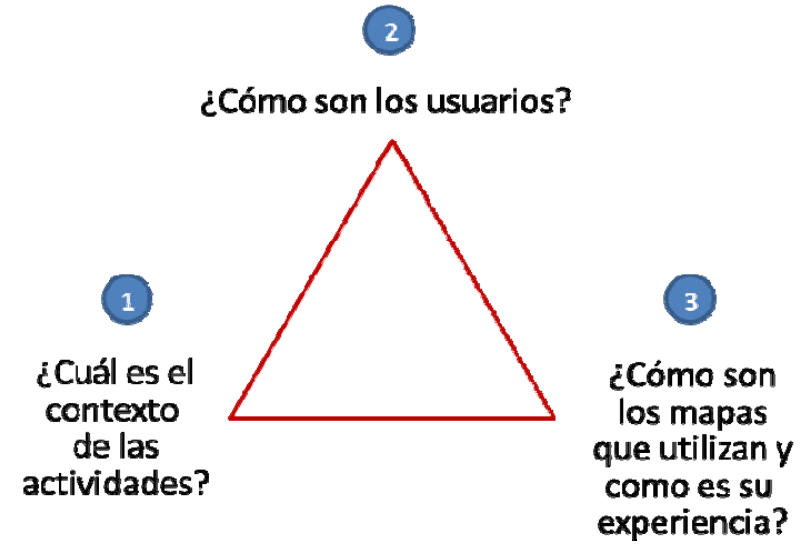

Figura 3.3: Preguntas a responder en la Fase 2.

Exploración de la experiencia de los usuarios

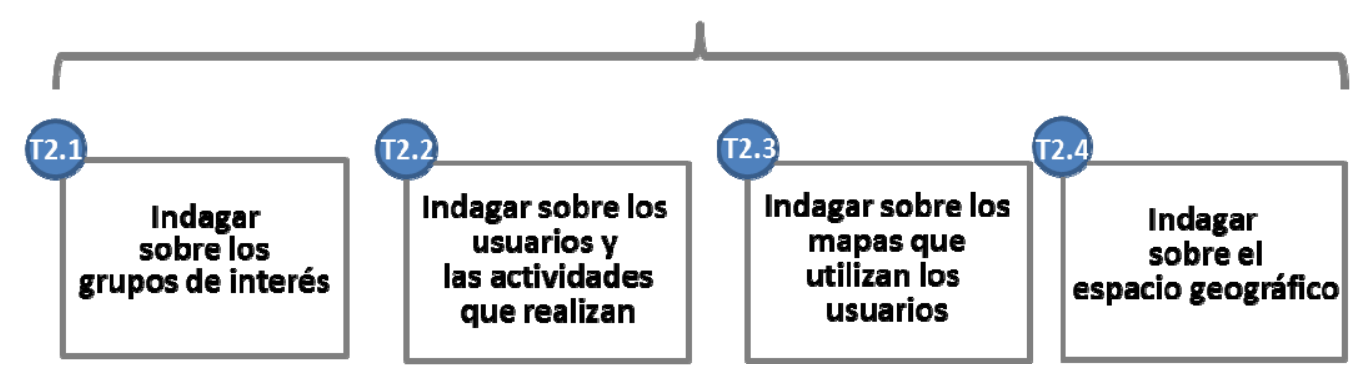

Figura 3.4: Tareas de la Fase 2.

A continuación, se describe con más detalle cada una de las tareas de esta fase, las técnicas de diseño y los resultados obtenidos una vez ejecutadas.

\subsubsection{Tareas de la Fase 2}

\section{T 2.1 Indagar sobre los grupos de interés}

En esta tarea se obtiene información de los grupos de interés que permite adquirir un conocimiento acerca de los aspectos que inciden en la experiencia de los usuarios, tales como:

- Los roles y relaciones entre los grupos de interés.

- Posibles estrategias en el contexto asociado a la experiencia de los usuarios.

- Los productos cartográficos suministrados a los usuarios. 
- Existencia de algún tipo de criterio de segmentación de los usuarios a la hora de suministrar información geográfica a través de los productos cartográficos existentes.

- Posibles proyectos de desarrollo de nuevos productos cartográficos o de mejora de los actuales.

- Los procesos y las técnicas de diseño utilizadas para el desarrollo de los productos cartográficos existentes.

- Necesidades o deficiencias detectadas en relación a los actuales productos cartográficos y posibles repercusiones en el comportamiento y en la experiencia de los usuarios.

- Su punto de vista sobre el comportamiento de los usuarios.

- Su opinión sobre el impacto potencial de los productos cartográficos en la experiencia de los usuarios.

- Datos sobre los usuarios de los mapas a diseñar.

- Aspectos que, en base a, su experiencia, a estudios, y/o a normativas vigentes dentro del ámbito, deberían tenerse en cuenta a la hora de afrontar el diseño de los mapas.

En el resto de tareas de esta fase se recaba información de los usuarios.

\section{T 2.2 Indagar sobre las características del usuario, las actividades que realizan y los factores que condicionan su ejecución}

En esta tarea se obtiene información sobre los atributos de los usuarios, actividades y factores que condicionan su ejecución, identificados en la Tarea 1.2. A continuación se incluyen algunos ejemplos considerando el ámbito de las emergencias:

a) atributos del usuario:

- Edad, Sexo, Puesto, Nivel de estudios.

- Capacidad cognitivo-espacial.

- Experiencia en espacios geográficos similares a los del contexto de diseño y

- Experiencia en el uso de información geográfica.

b) actividades que realizan:

- Localizar lugares.

- Identificar rutas.

- Reconocer emplazamientos.

- Estimar tiempos de recorrido.

- Delimitar zonas.

- Estimar cantidades.

- Detectar situaciones. 
- Identificar procesos.

- Cuantificar daños.

- Identificar cambios.

c) factores que condicionan la ejecución de dichas actividades, como por ejemplo:

- Comportamientos de los usuarios.

- Productos cartográficos que utilizan.

- Situaciones en las que utilizan los productos cartográficos (lugar, momento y tarea).

- Dificultades encontradas al realizar las actividades.

- Conocimiento y conceptualización del espacio asociado a la experiencia.

- Motivaciones de los usuarios.

- Intereses de los usuarios.

- Personas con las que el usuario comparte la experiencia.

- Duración de la actividad.

- Percepción de la experiencia y

- Valoración de la experiencia.

T 2.3 Indagar sobre los mapas que utilizan los usuarios, los que podrían usar y los factores que caracterizan su uso

En esta tarea se obtiene información sobre los productos cartográficos y los mapas que utilizan los usuarios para ejecutar las actividades que configuran su experiencia, como por ejemplo:

- Etapa de la experiencia en la que se utilizan. Siguiendo con el ejemplo de las emergencias, estas etapas podrían ser: detección de la emergencia, planificación de la actuación, ejecución de la actuación, seguimiento y cierre de la actuación.

- Actividad o necesidad que motiva su uso.

- Productos a través de los cuales acceden a los mapas: sistemas de información geográfica en ordenador de sobremesa, aplicación móvil...

- Información consultada en los mapas (localización de lugares, rutas...) y

- Valoración que tienen de los productos cartográficos y sus mapas.

Por otro lado, en esta tarea también se averigua acerca de nuevas tecnologías hardware y software, que podrían utilizarse para suministrar a los usuarios mapas que den soporte a su experiencia cognitiva.

\section{T 2.4 Indagar sobre el espacio geográfico asociado a la experiencia del usuario}

En esta tarea se obtiene información sobre factores físicos del espacio geográfico que inciden las actividades que realizan los usuarios y, por consiguiente, 
en su experiencia. Estos factores podrían ser, en el ámbito de las emergencias: la localización de las distintas instalaciones (sanitarias, bomberos, policía,...), la ubicación de equipamientos móviles, la localización y características de las infraestructuras de transporte...

\subsubsection{Técnicas de diseño de la Fase 2}

Para poder llevar a cabo la recopilación de la información en esta fase, existen numerosas técnicas, pudiéndose seleccionar aquellas que mejor se adapten a las circunstancias de acceso a los participantes de los grupos de interés y al colectivo de usuarios. Otros aspectos a tener en cuenta a la hora de elegir y utilizar las técnicas son, por ejemplo:

- El objetivo a lograr.

- Identificación de los participantes.

- Relación con los participantes (consentimiento informado, incentivos...).

- Combinación de varias técnicas para obtener información complementaria desde varias perspectivas (triangulación).

- Realización pruebas piloto.

- Selección del método de análisis de los datos una vez recogidos.

La Tabla 3.2 ilustra las técnicas de diseño para recopilar la información necesaria en esta fase. Una vez ejecutadas estas técnicas, el volumen y la heterogeneidad de la información obtenida suele ser elevado (grabaciones de audio y video, fotografías, registros GPS de los desplazamientos, notas tomadas a mano, dibujos, cuestionarios...) y requiere de un proceso de transcripción, armonización y destilación, que facilite su posterior análisis. La Tabla 3.3 incluye algunas de las técnicas que se pueden llevar a cabo para organizar la información recopilada.

Finalmente, el análisis y la posterior interpretación de la información recogida pueden dar resultados:

- Cuantitativos: Valores numéricos como porcentajes, promedios, medias, desviaciones estándar...

- Cualitativos: Patrones y/o aspectos recurrentes, categorías que pueden establecerse a partir de los datos o que pueden estar establecidas previamente, análisis de los incidentes críticos, como eventos claves en la experiencia de los usuarios...

Las herramientas que se pueden utilizar para analizar los datos son: hojas de cálculo; programas estadísticos como SPSS ${ }^{1}$; software para el análisis de datos cualitativos, como los utilizados para categorizar o realizar análisis en base a temas (como QDA Miner ${ }^{2}$ ) o programas de análisis cuantitativo basados en texto (como los paquetes Quanted $a^{3}$ y Topicmodels ${ }^{4}$, desarrollados en R).

\footnotetext{
${ }_{1}^{1}$ Statistical Package for the Social Sciences: http://www-01.ibm.com/software/es/analytics/spss/

2 QDA Miner: https://en.wikipedia.org/wiki/QDA Miner

${ }^{3}$ Quanteda: https://github.com/kbenoit/quanteda

${ }^{4}$ Topicmodels: https:/ran.r-project.org/web/packages/topicmodels/index.html
} 
Fase 2: Exploración de la experiencia de los usuarios

\begin{tabular}{|c|c|c|c|c|c|}
\hline \multicolumn{6}{|c|}{ Fase 2: Exploración de la experiencia de los usuarios } \\
\hline \multirow[b]{2}{*}{ Técnica de diseño } & \multirow{2}{*}{ 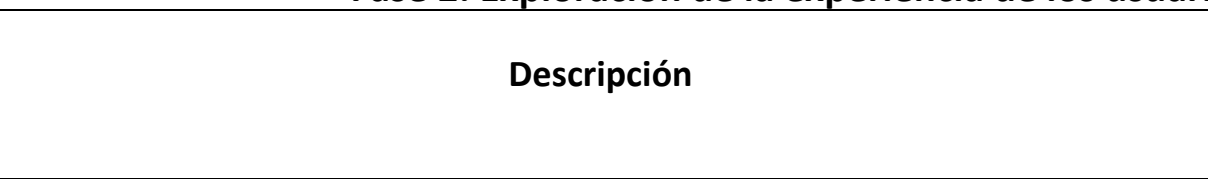 } & \multicolumn{4}{|c|}{ Tareas de indagación sobre } \\
\hline & & $\begin{array}{c}2.1 \\
\text { grupos } \\
\text { interés }\end{array}$ & $\begin{array}{c}2.2 \\
\text { usuarios }\end{array}$ & $\begin{array}{c}2.3 \\
\text { mapas }\end{array}$ & $\begin{array}{c}2.4 \\
\text { espacio } \\
\text { geográfico }\end{array}$ \\
\hline Grupos de discusión & $\begin{array}{l}\text { Especie de entrevista a un grupo de personas, de tal manera que cada } \\
\text { participante expresa su punto de vista, lo que permite obtener una visión de las } \\
\text { distintas opiniones y que surjan ideas a partir de la interacción entre ellos. El } \\
\text { moderador prepara un guion de la discusión con los temas a tratar, a modo de } \\
\text { entrevista no estructurada. La sesión comienza con una pequeña introducción. }\end{array}$ & $\mathrm{X}$ & & & \\
\hline Diarios & $\begin{array}{l}\text { Observación indirecta de los usuarios con el fin de hacer un seguimiento de su } \\
\text { experiencia a través del tiempo. Para ello los usuarios van registrando sus } \\
\text { desplazamientos, las actividades en las que utilizan mapas, cómo los utilizan, } \\
\text { qué mapas usan, qué problemas tienen, etc. Los diarios también pueden } \\
\text { incorporar fotografías que ilustren la experiencia de los usuarios y } \\
\text { complementarse con otras técnicas, como las entrevistas y los cuestionarios. }\end{array}$ & & $\mathrm{X}$ & $\mathrm{X}$ & $\mathrm{X}$ \\
\hline Entrevistas & Ver Tabla 3.1 & $\mathrm{X}$ & $\mathrm{X}$ & $\mathrm{X}$ & $\mathrm{X}$ \\
\hline Encuestas & $\begin{array}{l}\text { En las encuestas se recopila información a través de cuestionarios, que } \\
\text { permiten llegar a un mayor número de personas que las entrevistas y que se } \\
\text { pueden analizar de forma automatizada. Las encuestas pueden dirigirse a } \\
\text { representantes de los grupos de interés o a los usuarios. En este último caso } \\
\text { suelen incluir preguntas sobre aspectos demográficos (cómo son), tecnológicos } \\
\text { (cómo acceden a los mapas), sobre comportamientos y hábitos (cómo, para qué } \\
\text { y qué mapas usan), preferencias (qué les gusta y qué no) y deseos (qué echan } \\
\text { en falta), entre otras. }\end{array}$ & $\mathrm{X}$ & $\mathrm{X}$ & $\mathrm{X}$ & $\mathrm{X}$ \\
\hline $\begin{array}{l}\text { Observación de } \\
\text { campo }\end{array}$ & $\begin{array}{l}\text { Observación de los usuarios realizando las actividades que caracterizan su } \\
\text { experiencia y que permite averiguar qué información consultan, qué recursos } \\
\text { utilizan, cuáles son sus objetivos, qué similitudes y diferencias hay entre } \\
\text { usuarios, qué factores condicionan el uso de los mapas... }\end{array}$ & $\mathrm{X}$ & $\mathrm{X}$ & $\mathrm{X}$ & $\mathrm{X}$ \\
\hline
\end{tabular}




\begin{tabular}{|c|c|c|c|}
\hline $\begin{array}{l}\text { Investigación de los } \\
\text { mapas cognitivos }\end{array}$ & $\begin{array}{l}\text { La investigación de los mapas cognitivos es una manera de averiguar las } \\
\text { estrategias que utilizan los usuarios para desenvolverse en un espacio } \\
\text { geográfico. Acceder al mapa cognitivo de los usuarios no resulta sencillo y } \\
\text { normalmente se realiza solicitándoles "representaciones externas", que reflejan } \\
\text { sus puntos de vista personales (lo que saben y su interpretación) acerca de un } \\
\text { lugar específico. Las representaciones pueden ser en forma de dibujo (mapa } \\
\text { mental); mediante listas de libre recuerdo, de manera que el usuario escribe o } \\
\text { verbaliza los lugares que tiene en su memoria y también a través de imágenes, } \\
\text { como fotografías que el usuario tiene que identificar y ubicar en un mapa. La } \\
\text { solicitud de esta información puede integrarse en cuestionarios. Otro enfoque } \\
\text { para investigar los mapas cognitivos es indagar acerca de los errores cometidos } \\
\text { por los usuarios en el transcurso de sus experiencias. }\end{array}$ & $X$ & $X$ \\
\hline
\end{tabular}

Tabla 3.2: Técnicas de diseño utilizadas para recopilar información en la Fase 2. 


\begin{tabular}{|c|c|c|c|c|c|}
\hline \multicolumn{6}{|c|}{ Fase 2: Exploración de la experiencia de los usuarios } \\
\hline \multirow{2}{*}{$\begin{array}{l}\text { Técnica de } \\
\text { diseño }\end{array}$} & \multirow[b]{2}{*}{ Descripción } & \multicolumn{4}{|c|}{ Tareas de indagación sobre } \\
\hline & & $\begin{array}{c}2.1 \\
\text { grupos } \\
\text { interés }\end{array}$ & $\begin{array}{c}2.2 \\
\text { usuarios }\end{array}$ & $\begin{array}{c}2.3 \\
\text { mapas }\end{array}$ & $\begin{array}{c}2.4 \\
\text { espacio } \\
\text { geográfico }\end{array}$ \\
\hline $\begin{array}{l}\text { Diagramas } \\
\text { de afinidad }\end{array}$ & $\begin{array}{l}\text { Una vez recopilada la información a través de las diversas técnicas, puede resultar difícil } \\
\text { sintetizar lo que se ha aprendido. Los diagramas de afinidad ayudan a capturar ideas, } \\
\text { inquietudes, observaciones... respaldadas por la investigación previa, a través de notas } \\
\text { adhesivas individuales, de tal manera que cada una de ellas puede ser considerada y } \\
\text { repercutir en el proceso de diseño. Una vez elaboradas las notas, éstas se agrupan en base a } \\
\text { afinidad, configurando los temas fundamentales de la investigación. }\end{array}$ & $X$ & & & \\
\hline $\begin{array}{l}\text { Análisis de } \\
\text { contenido }\end{array}$ & $\begin{array}{l}\text { Esta técnica consiste en la descripción sistemática de la forma y el contenido escrito, } \\
\text { hablado o expresado de forma visual o gráfica, de temas, patrones, ocurrencias de palabras, } \\
\text { frases imágenes o conceptos. Esta técnica permite abordar la extracción de significado a } \\
\text { partir de datos cualitativos que pueden haber sido obtenidos, por ejemplo, a través de } \\
\text { entrevistas, cuestionarios o mediante métodos más creativos como el dibujo (mapas } \\
\text { mentales). El análisis de contenidos se puede abordar desde un enfoque inductivo o } \\
\text { deductivo. En el enfoque inductivo, las categorías o códigos que se utilizan para organizar la } \\
\text { información se obtienen de analizar los datos disponibles. Al analizar una serie de } \\
\text { entrevistas, es posible que aparezcan frases o términos comunes de forma recurrente que } \\
\text { permitan caracterizar un tema de interés. En el enfoque deductivo, sin embargo, los códigos } \\
\text { o categorías están establecidos antes de analizar los datos y normalmente están extraídos } \\
\text { de un marco teórico (por ejemplo los elementos que componen los mapas mentales de las } \\
\text { ciudades en base a la investigación de Lynch). Los resultados de los análisis de contenido } \\
\text { pueden ser cuantitativos (número de palabras, imágenes, conceptos, frases...) y también } \\
\text { posibilitan la identificación de formas o estructuras de comunicación o conocimiento (por } \\
\text { ejemplo, los sistemas de referencia a través de los cuales se relacionan los elementos de los } \\
\text { mapas mentales). }\end{array}$ & $X$ & $X$ & $X$ & $X$ \\
\hline
\end{tabular}

Tabla 3.3: Técnicas de diseño para organizar la información recopilada en la Fase 2. 


\subsubsection{Resultado de la Fase 2}

La información recopilada a través de la ejecución de las tareas de esta fase permite dar respuesta a las siguientes preguntas:

1) ¿Cuál es el contexto de las actividades que realizan los usuarios?

El contexto de las actividades que realizan los usuarios puede ser muy distinto, según el ámbito de sus experiencias. Aspectos como: la motivación que lleva a los usuarios a vivir la experiencia, los intereses, las personas con las que interactúa, la repercusión de unas actividades en otras o la situación espaciotemporal; acerca de los que se ha obtenido información, permiten describir el contexto de las actividades que configuran la experiencia del usuario.

2) ¿Cómo son los usuarios a los que van destinados los mapas a diseñar?

Para poder describir a los usuarios se recurre a la información recopilada sobre sus atributos, de tal manera que aspectos como su procedencia, edad, nivel de estudios, género o experiencia, permiten adquirir el conocimiento necesario sobre ellos.

3) ¿Cómo son los mapas que utilizan los usuarios y cómo es su experiencia?

La ejecución de las tareas de esta fase permite identificar, por un lado, cuáles son los productos cartográficos, los soportes y los tipos de mapas que utilizan los usuarios y la información que consultan en ellos. Por otro lado, también se identifican los comportamientos de los usuarios a lo largo de su experiencia, el conocimiento adquirido del espacio urbano y las dificultades y las necesidades que han experimentado, entre otros aspectos de interés.

Toda esta información complementa la recopilada en la Fase 1 y sirve de fundamento para la ejecución de la Fase 3.

\subsection{Fase 3: Síntesis de la experiencia de los usuarios}

En esta fase se lleva a cabo una labor de abstracción, en la que se modelan las interacciones entre los usuarios, los ambientes del espacio urbano y de los mapas que utilizan, para lo cual se analizan los datos recopilados y a las respuestas obtenidas a las preguntas de las Fases 1 y 2 . Esta abstracción tiene el fin de proyectar cuáles serán las experiencias de usuario a las que los mapas a diseñar darán soporte. En esta fase del proceso se abordan las preguntas: 1) ¿Cuáles serán los ambientes en los que los usuarios utilizarán los mapas?, 2) ¿Cómo serán las experiencias de los usuarios a las que los mapas darán soporte? y 3) ¿Cómo serán los mapas a diseñar? (Figura 3.5). 


\section{Fase 3: Síntesis de la experiencia de los usuarios}

\section{2.}

¿Cómo serán las experiencias de los usuarios a las que los mapas darán soporte?

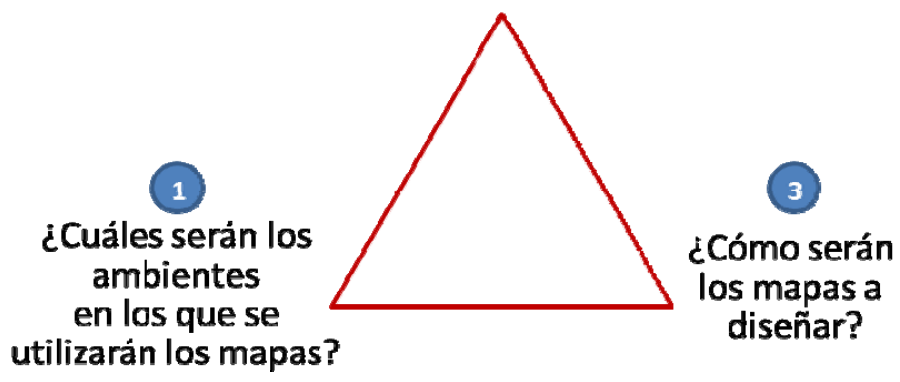

Figura 3.5: Preguntas a responder en la Fase 3.

Para responder a estas preguntas se plantean tres tareas de síntesis de la experiencia de los usuarios que, a través de la identificación de patrones en las diferentes interacciones, permiten obtener el conocimiento necesario para concretar el diseño de los mapas (Figura 3.6):

Síntesis de la experiencia de los usuarios

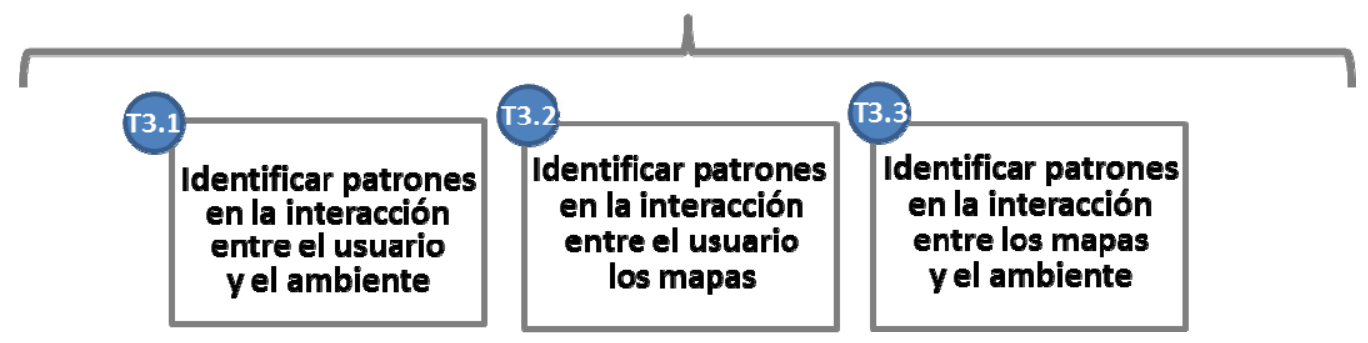

Figura 3.6: Tareas de la Fase 3.

A continuación se describen con más detalle las tareas ejecutadas en esta fase, las técnicas de diseño que se pueden aplicar y los resultados obtenidos. 


\subsubsection{Tareas de la Fase 3}

\section{T 3.1 Identificar patrones en la interacción entre el usuario y el ambiente}

En esta tarea se da respuesta a la pregunta ¿Cómo abordan los usuarios sus experiencias?. La conceptualización de un determinado espacio geográfico se lleva a cabo a medida que el usuario va integrando elementos de dicho espacio, a través de la ejecución de actividades en un determinado ambiente.

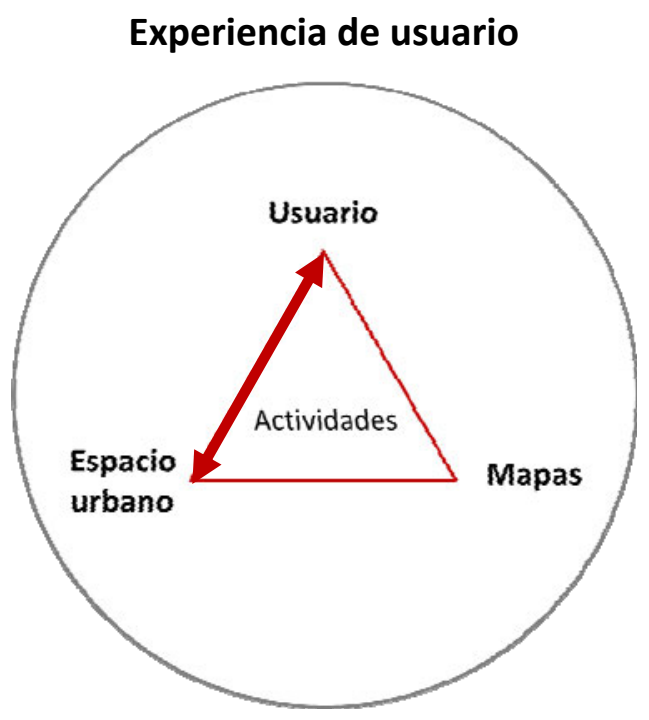

Figura 3.7: Interacción entre el usuario y el ambiente en el que se desarrolla su experiencia.

Sin embargo, la forma con la que los usuarios abordan la ejecución de las actividades puede ser muy diferente y este hecho repercute en su experiencia cognitiva. Por ejemplo, si un turista visita un museo con un grupo guiado, probablemente su mapa cognitivo al final del recorrido será diferente de si hubiera realizado la visita por su cuenta.

En esta tarea, se analizan y detectan relaciones entre aquellos factores condicionantes de las actividades, que realizan los usuarios, que más incidencia tienen en su experiencia. Para ello se analizan de forma cualitativa los datos de dichos factores, recopilados en la Fase 2 (Tarea 2.2). En el caso del ejemplo del ámbito turístico, estos factores podrían ser: la motivación que ha llevado a los turistas a viajar a la ciudad, los medios de transporte que utilizan, sus intereses, la duración de la visita y el mapa mental que tienen de la ciudad. Como resultado se determinan enfoques de las experiencias del espacio, que aglutinan comportamientos y conceptualizaciones del espacio comunes a grupos de usuarios, a los que los mapas darán soporte. Siguiendo con el ejemplo turístico, se podrían definir, entre otros, dos enfoques de la experiencia: explorador y guiado. Los turistas con un enfoque explorador visitan la ciudad con un énfasis en conocer su "verdadera esencia". Su comportamiento se caracteriza por evitar las rutas turísticas y por tomar decisiones de forma espontánea. Sus mapas mentales del espacio urbano tienen un gran número de elementos y un alto nivel de abstracción. Por otro lado, los turistas 
con enfoque guiado desean visitar la ciudad minimizando la toma de decisiones, para lo cual recurren a apoyos (acompañantes, guía, recorridos en bus turístico,...). Sus mapas mentales se caracterizan por un reducido número de elementos y un bajo nivel de abstracción.

La identificación del enfoque de la experiencia permite suministrar distintos mapas a grupos de usuarios, dándoles así un soporte adecuado. Siguiendo con el ámbito turístico, se podrían diseñar diferentes mapas para dar soporte, por ejemplo, a la experiencia de viajar en metro. De tal forma que un turista con enfoque explorador podría recibir información que le conecte con escenas reales de la ciudad de las zonas por las que vaya pasando en metro, en cada momento. Mientras que otro que aborda su experiencia desde un enfoque guiado, al montar en metro, sería asistido con el suministro de la información necesaria para que se encuentre "acompañado" en todo momento y no tenga ningún inconveniente a la hora de realizar el recorrido.

El enfoque con el que un usuario aborda su experiencia permanece relativamente estable en el tiempo ya que depende, fundamentalmente, de aspectos psicológicos y de personalidad (motivaciones, intereses, preferencias...). Sin embargo, circunstancias concretas pueden incidir puntualmente en el usuario, haciendo que varíe temporalmente el enfoque con el que aborda la ejecución de alguna de sus actividades.

\section{T 3.2 Identificar patrones en la interacción entre el usuario y los mapas}

En esta tarea se lleva a cabo la identificación de patrones en los mapas mentales de los usuarios, según los diferentes enfoques con los que éstos abordan la experiencia (Figura 3.8). El objetivo de este proceso de diseño, es dar soporte a la experiencia cognitiva del usuario a través de mapas (representación externa) cuyo diseño (contenido y forma de representación) se fundamente en una correspondencia con la conceptualización del espacio por parte del usuario (mapa cognitivo o representación interna). Con tal fin, en esta tarea se da respuesta a dos preguntas: 1) ¿Qué elementos constituyen los mapas cognitivos de los usuarios, según los diferentes enfoques de su experiencia? y 2) ¿Cómo se estructuran los elementos en los mapas cognitivos de cada enfoque?. Para ello se analizan los mapas mentales de los usuarios en base a las investigaciones de Lynch (1960) y Moore $(1973,1974)$ (apartado 2.3.1).

Para dar respuesta a la pregunta ¿qué elementos constituyen los mapas cognitivos urbanos de los usuarios, según los diferentes enfoques de su experiencia?, se realiza un análisis cualitativo y cuantitativo de los 5 tipos de elementos que pueden identificarse en los mapas mentales (Lynch, 1960): nodos, donde confluyen varias trayectorias; hitos o puntos de referencia; sendas o ejes de desplazamiento; bordes o límites no transitables de áreas y barrios o regiones de la ciudad. 


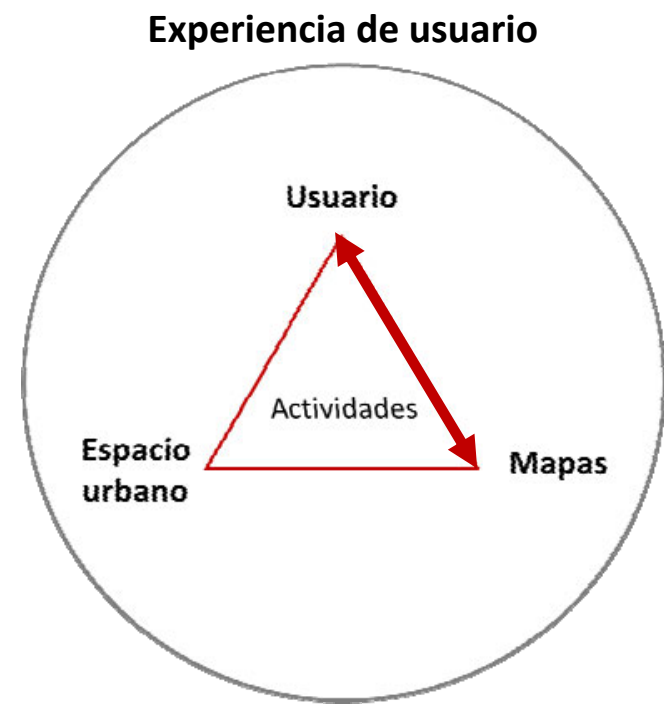

Figura 3.8: Interacción entre el usuario y los mapas que dan soporte a su experiencia.

Para dar respuesta a la pregunta ¿cómo se estructuran los elementos en los mapas cognitivos de cada enfoque?, se tienen en cuenta la forma en la que se relacionan y configuran los elementos de los mapas mentales de los usuarios, identificando: a) sistemas de referencia, b) marcos de referencia y c) focos.

a) Los sistemas de referencia reflejan cómo los usuarios organizan lo que saben del espacio asociado a la experiencia. El análisis de los mapas mentales, desde el punto de vista del sistema de referencia, considera los mapas como conjuntos de elementos (no como elementos aislados) y permite un análisis cualitativo de las representaciones espaciales internas según diferentes estadios de diferenciación e integración, pudiendo ser estos, de tipo (Moore, 1973, 1974): (1) Egocéntrico e indiferenciado; (2) Diferenciado y parcialmente coordinado; (3) Abstractamente coordinado y jerárquicamente integrado (apartado 2.2).

b) Los marcos de referencia reflejan patrones de tipo topológico entre los elementos que configuran los mapas mentales urbanos pudiendo ser de tipo: (1) ejes o sendas de desplazamiento que integran nodos y puntos de referencia; (2) puntos de referencia asociados a ejes y (3) nodos o puntos de referencia aislados.

c) Los focos reflejan casuísticas en las que un mojón (o nodo) del mapa mental toma un significado destacado, ya que la conceptualización del espacio se organiza en torno a él. Estos puntos suelen ser lugares familiares para el usuario como su casa, lugar de trabajo...

\section{T 3.3 Identificar patrones en la interacción entre los mapas y el ambiente urbano}

Esta metodología busca el desarrollo de mapas que actúen como interfaces entre el usuario y el ambiente en el que los utilice, con el fin de dar soporte a la experiencia cognitiva del usuario. Las tareas previas de esta fase permiten identificar, por un lado, los diferentes enfoques con los que los usuarios abordan la experiencia $y$, por otro, como estos enfoques inciden en la experiencia cognitiva de los grupos de usuarios (lo que se refleja en sus mapas mentales). Pero hay un tercer factor que 
interviene en la experiencia de los usuarios: los diferentes ambientes en los que desarrollan sus actividades (Figura 3.9).

En esta tarea se da respuesta a la pregunta ¿Cuál es el ambiente asociado a la experiencia del usuario?. Para ello, se analizan datos relativos a los aspectos del ambiente que condicionan las actividades de los usuarios, identificando aquellos cuya consideración debe tenerse en cuenta en el diseño de los mapas, así como las tecnologías necesarias para ello. Se trata, por lo tanto, de caracterizar el ambiente en base a diferentes dimensiones o contextos a los que se adaptarán los mapas, para dar un adecuado soporte a la experiencia cognitiva del usuario. A continuación se describen los contextos del ambiente que condicionan la experiencia del usuario, así como las tecnologías que podrían dar soporte a los mapas.

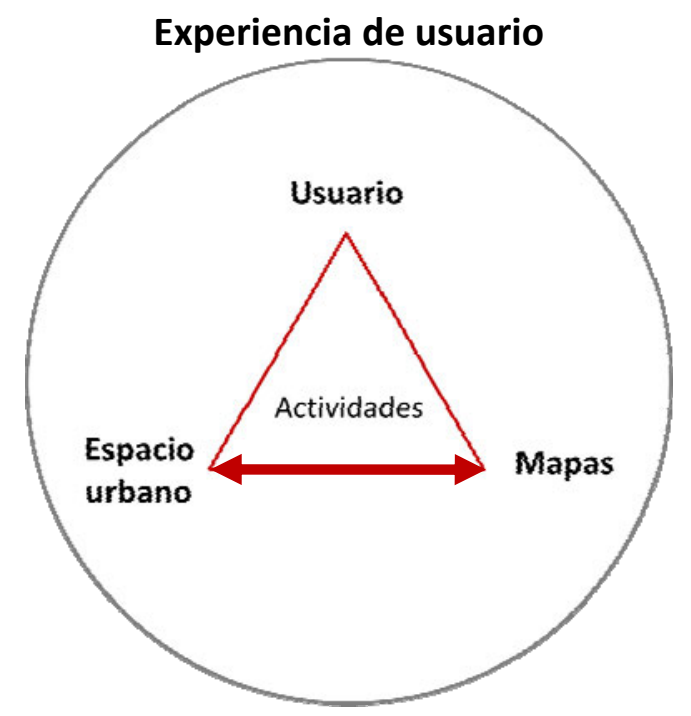

Figura 3.9: Interacción entre los mapas y el ambiente en el que se desarrolla la experiencia del usuario.

- Contexto del usuario: Muchos de los aspectos considerados en este contexto son atributos del usuario, como la edad, el género o la nacionalidad, que pueden ser suministrados directamente por el usuario u obtenidos utilizando información disponible en sus cuentas de redes sociales. Sin embargo, hay otros aspectos adicionales del usuario que hay que tener en cuenta, como la actividad que realiza en cada momento, que puede especificarse manualmente por él, obtenerse del calendario del usuario o inferirse del contexto histórico-evolutivo (ver más adelante en este apartado). También hay que prestar atención a los aspectos asociados a características espaciales como la ubicación del usuario (que puede calcularse utilizando sistemas de posicionamiento global o inferirse con el uso de otros sensores integrados en el dispositivo móvil o ubicados en el espacio geográfico donde se encuentre); información de orientación (que se puede obtener de la brújula y el giróscopo digital del dispositivo móvil del usuario) y la velocidad y la aceleración (adquiridos a partir de los cambios de ubicación o con un acelerómetro). 
- Contexto físico: Este contexto está compuesto por aspectos como la localización, las condiciones de iluminación y los niveles de ruido (que se podrían obtener usando un sensor de luz y un micrófono en el dispositivo en el que se visualicen los mapas); la meteorología (que se podría determinar a través de sensores en el dispositivo como un barómetro, termómetro o, en su defecto, a través de la recepción de información meteorológica en línea); y las condiciones del tráfico (que también podrían ser suministradas en línea).

- Contexto temporal: El contexto temporal se puede definir a distintos niveles, por ejemplo: hora, día de la semana, fecha, estación del año y a través de información específica del día actual (si se trata de un día festivo o que coincide con algún evento destacado). Los aspectos que condicionan este contexto se pueden gestionar a través de la información del reloj y del calendario interno del dispositivo.

- Contexto histórico-evolutivo: El contexto histórico-evolutivo consiste en un registro de las experiencias espaciales del usuario ya ocurridas, que pueden obtenerse a través del uso de los registros grabados. Estos registros pueden consistir, por ejemplo, en una lista de lugares que el usuario ha visitado anteriormente o en consultas espaciales previas y las decisiones derivadas de ellas. En este sentido, se pueden registrar tiempos de visita a lugares, valoraciones... y utilizar estas informaciones para adaptar los mapas a suministrar, para dar soporte a futuras experiencias del usuario.

- Contexto tecnológico: Este contexto del ambiente se relaciona con las especificaciones técnicas del dispositivo en el que se visualizan los mapas, de sus conexiones inalámbricas de datos y de recursos periféricos como impresoras, computadoras, sensores o dispositivos móviles que pueden ser conectados al dispositivo. Estas especificaciones pueden incluir: el tipo y la capacidad de procesamiento, memoria y capacidad de almacenamiento del dispositivo, aspectos gráficos, tales como la densidad de tamaño de la pantalla, la resolución y tamaño del pixel y los tipos disponibles de periféricos de interacción. La información sobre las conexiones de datos se debe obtener en tiempo real para las especificaciones que son dinámicas, como el tráfico o la meteorología. Por último, la presencia de dispositivos en el entorno del usuario podría obtenerse a través de protocolos inalámbricos como, Bluetooth, Wi-Fi o Universal Plug and Play, entre otros.

\subsubsection{Técnicas de la Fase 3}

La técnica utilizada para ejecutar las tareas de esta fase consiste en un análisis cualitativo de la información de los usuarios y los grupos de interés, recopilada en la Fase 2 (Tabla 3.4). 


\begin{tabular}{|c|c|c|c|c|c|}
\hline \multicolumn{6}{|c|}{ Fase 3: Síntesis de la experiencia de los usuarios } \\
\hline \multirow[t]{2}{*}{$\begin{array}{l}\text { Técnica de } \\
\text { diseño }\end{array}$} & \multirow{2}{*}{ Descripción } & \multicolumn{3}{|c|}{$\begin{array}{l}\text { Tareas de identificación de los } \\
\text { patrones en la interacción entre: }\end{array}$} & \multirow[t]{2}{*}{ Resultados } \\
\hline & & $\begin{array}{l}\text { T } 3.1 \\
\text { usuario/ } \\
\text { ambiente }\end{array}$ & $\begin{array}{l}\text { T } 3.2 \\
\text { usuario/ } \\
\text { mapas }\end{array}$ & $\begin{array}{l}\mathrm{T} 3.3 \\
\text { mapas/ } \\
\text { ambiente }\end{array}$ & \\
\hline $\begin{array}{l}\text { Análisis } \\
\text { cualitativo }\end{array}$ & $\begin{array}{l}\text { Técnica, a través de la cual, se analizan los factores condicionantes de las actividades } \\
\text { que realizan los usuarios, que más incidencia tienen en su experiencia cognitiva. Esta } \\
\text { técnica se utiliza para: 1) determinar los diferentes enfoques con los que los usuarios } \\
\text { abordan la experiencia (T3.1); } 2 \text { ) identificar (T3.2): los tipos de elementos de los } \\
\text { mapas mentales de los usuarios establecidos según Lynch (1960), los sistemas de } \\
\text { referencia de los mapas en base a los tipos definidos por Moore }(1973,1974) \text {, los } \\
\text { marcos de referencia y los focos; y 3) caracterizar los contextos del ambiente que } \\
\text { condicionan la experiencia del usuario (T3.3). }\end{array}$ & $X$ & $\mathrm{X}$ & $X$ & \\
\hline Personas & $\begin{array}{l}\text { Técnica, a través de la cual, se consolidan descripciones arquetípicas de los patrones } \\
\text { de comportamiento de los usuarios a través de perfiles representativos, con el fin de } \\
\text { humanizar el proceso de diseño. Las descripciones humanas de las "personas" } \\
\text { facilitan la empatía y la comunicación, mientras que las diferencias entre ellas } \\
\text { permiten describir objetivos diferenciados y significativos de diseño. Las "personas" } \\
\text { (de entidades ficticias) se suelen describir a través de una ficha que incluye, el nombre } \\
\text { de la persona, una fotografía, características personales relevantes (como el mapa } \\
\text { mental), aspectos de su situación, objetivos y comportamientos relevantes para el } \\
\text { diseño (Figura 3.10). Las "personas" proporcionan una referencia para la técnica de } \\
\text { los escenarios. }\end{array}$ & & & & $\mathrm{X}$ \\
\hline Escenarios & $\begin{array}{l}\text { Los escenarios son narraciones que describen la experiencia del usuario al utilizar los } \\
\text { mapas. Los escenarios se describen con una historia que comienza con un evento y } \\
\text { termina con la ejecución de una o varias tareas, a través de los mapas que asisten a la } \\
\text { "persona". Los escenarios pueden caracterizarse desde múltiples perspectivas: } \\
\text { interacciones, experiencia de usuario, contenidos y funcionalidades de los mapas... } \\
\text { (Figura 3.11) }\end{array}$ & & & & $X$ \\
\hline
\end{tabular}

Tabla 3.4: Técnicas de diseño utilizadas en la Fase 3. 


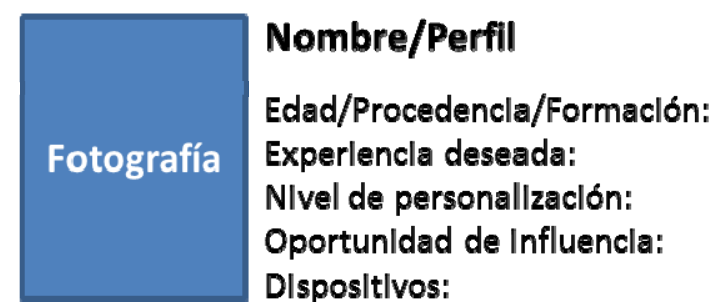

Aspecto que condiciona la experiencia Aspecto que condiciona la experiencia Aspecto que condiciona la experiencia Aspecto que condiciona la experiencia Dinámica de la experiencia:

Día 1:

Día 2:

Día 3:

\section{Conocimiento del espacio:}

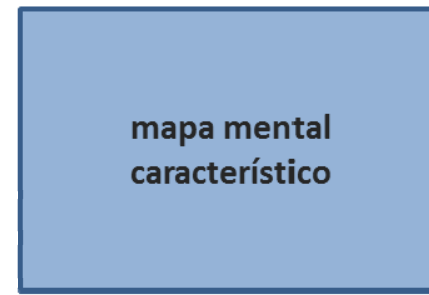

Sistema de referencia Marcos de referencia Elementos puntuales

Zonas

Cobertura y foco
Característica de la persona

Característica de la experiencia

Característica de la experiencia

Característica de la persona

Intereses: Interés 1

Interés 2

Interés 3

Interés 4

Interés 5

Interés 6

Interés 7

\section{Escenario 1:}

Descripción del ambiente

Necesidad de la persona

Objetivo del mapa

\section{Escenario 2:}

Descripción del ambiente

Necesidad de la persona

ObJetlvo del mapa

Figura 3.10: Ejemplo de la descripción de una "persona". 


\subsubsection{Resultado de la Fase 3}

La ejecución de las tareas de esta fase, permite dar respuesta a las siguientes preguntas:

1) ¿Cómo serán las experiencias a las que los mapas darán soporte?

Los mapas a diseñar darán soporte a los usuarios teniendo en cuenta los enfoques con los que abordan la experiencia (por ejemplo, en el ámbito turístico el enfoque podría ser "explorador" o "guiado"). Estos enfoques son un marco que permite caracterizar las experiencias concretas del usuario para las que se diseñarán los mapas (siguiendo con el ejemplo turístico, la experiencia podría ser viajar en metro). La descripción de los enfoques puede incluir: la motivación o aspecto determinante de la experiencia (restricciones, intereses concretos...), las expectativas de cada grupo de usuarios en relación a la experiencia (por ejemplo, que la toma de decisiones espaciales se realice de forma espontánea y flexible o por el contrario, minimizar la toma de decisiones) y las características diferenciadoras, entre enfoques, de los factores que inciden en la ejecución de las actividades (comportamientos de los usuarios, productos cartográficos que utilizan, conocimiento del espacio geográfico, personas con las que comparten la experiencia...).

2) ¿Cómo serán los mapas a diseñar?

El mapa como interfaz se plantea como una herramienta de conexión entre el espacio geográfico y el usuario, con el fin de dar soporte a su experiencia cognitiva.

El usuario percibe elementos del espacio geográfico y establece relaciones entre ellos dando forma a su conceptualización del mismo a modo de "entidad vida", que utiliza y se retroalimenta a través de sus experiencias.

Los mapas como interfaz se conciben con un enfoque de uso personalizado a través de representaciones espaciales cognitivamente adecuadas, que crecen y evolucionan a medida que lo hace la conceptualización del usuario a lo largo de su experiencia. Estos mapas acompañan y asisten al usuario, dando soporte a sus necesidades en cada momento, facilitándole la asimilación de conocimiento y el recuerdo del espacio urbano, a través del establecimiento de relaciones entre los elementos que ya forman parte de su mapa cognitivo y otros nuevos asociados con la actividad que esté realizando en ese momento.

De nuevo, la forma en la que el usuario lleva a cabo una determinada actividad, depende de la manera con la que aborda la experiencia. Aspectos asociados a la manera con la que el usuario aborda la experiencia, como el tipo de vivencias y los niveles de personalización deseados, las oportunidades de influencia y los dispositivos adecuados para los turistas de cada enfoque, condicionarán el diseño de sus mapas. 
3) ¿Cuáles serán los ambientes en los que se utilizarán los mapas?

Tal y como se ha expuesto, el ambiente en el que tiene lugar la experiencia del usuario está compuesto por diferentes contextos (de usuario, físico, temporal, histórico-evolutivo y tecnológico). El componente más importante del ambiente de la experiencia cognitiva es el propio usuario y, por ello, con el fin de poder abordar el diseño de prototipos concretos de los mapas, se definen unos perfiles de usuario y unos escenarios.

Los perfiles de usuario ayudan al diseñador a entender para quién y para qué tipo de enfoque de experiencia está diseñando.

Los escenarios sirven para que el diseñador pueda ilustrar cómo los usuarios utilizarán los mapas como interfaz, describiendo las interacciones entre los usuarios y el espacio urbano, a través de los mapas. Los escenarios se eligen teniendo en cuenta las dificultades y necesidades de los usuarios, que están repercutiendo en sus experiencias (Fase 2). En esta fase, se define cada escenario a través de una descripción literal especificando, el perfil de usuario, la actividad llevada a cabo por él y el objetivo concreto de los mapas en ese escenario.

Como resultado de las tareas de síntesis llevadas a cabo en esta fase se conciben los mapas, en coherencia con su objetivo de propiciar el recuerdo y la asociación entre elementos del espacio vinculados a la experiencia del usuario, y se definen los perfiles de usuarios y los escenarios a considerar en la Fase 4.

\subsection{Fase 4: Diseño de los prototipos de los mapas como interfaz}

En esta fase se aborda el diseño de los prototipos de los mapas, para cada uno de los escenarios y perfiles de usuario establecidos en la Fase 3. Para ello, se analiza detalladamente cada escenario, prestando una especial atención a cómo el usuario lleva a cabo la actividad, con la asistencia del sistema que da soporte a los mapas. Cada escenario se describe incluyendo: imágenes que ilustran las interacciones entre el usuario, los mapas como interfaz y el ambiente. También se incluyen textos descriptivos de dichas interacciones, de la experiencia del usuario a lo largo de ellas y del contenido y las funcionalidades de los mapas como interfaz. La Figura 3.11 ilustra una plantilla para la descripción de un escenario.

Como resultado de esta fase se obtienen prototipos de los diseños de los mapas como interfaz que asisten al usuario en su experiencia cognitiva, a la hora de ejecutar la actividad planteada en el escenario correspondiente.

A continuación se describen las técnicas de diseño para aplicar en esta fase. 


\subsubsection{Técnicas de la Fase 4}

\begin{tabular}{|c|c|}
\hline \multicolumn{2}{|c|}{ Fase 4: Diseño de los prototipos de los mapas como interfaz } \\
\hline $\begin{array}{l}\text { Técnica de } \\
\text { diseño }\end{array}$ & Descripción \\
\hline Storyboards & $\begin{array}{l}\text { Esta técnica permite ilustrar de forma gráfica los escenarios. Un storyboard } \\
\text { se compone de una serie de dibujos ordenados secuencialmente a modo de } \\
\text { viñetas de comic, que ilustran como se utilizaran los mapas a diseñar de } \\
\text { una forma realista y significativa. El storyboard describe cómo la "persona" } \\
\text { ejecuta una actividad con el soporte de los mapas, sin entrar en detalles } \\
\text { sobre su aspecto visual. El storyboard incluye texto con el fin de } \\
\text { complementar las imágenes para ayudar a describir un concepto o idea y } \\
\text { de alguna manera ilustra el paso del tiempo a lo largo de la ejecución de la } \\
\text { actividad. }\end{array}$ \\
\hline Escenarios & Ver tabla 3.3 y Figura 3.11 \\
\hline Prototipos & $\begin{array}{l}\text { Los prototipos son creaciones tangibles de los mapas a diferentes niveles } \\
\text { de detalle, con el fin de desarrollar y ensayar ideas de diseño. Los } \\
\text { prototipos suponen la materialización física de los mapas como interfaces, } \\
\text { representando estos la transformación creativa y visible de los resultados } \\
\text { de la investigación llevada a cabo previamente. Estos prototipos pueden ser } \\
\text { de bajo nivel de fidelidad con relación a la apariencia final de los mapas } \\
\text { (croquis en papel) o de alta fidelidad, cuando su apariencia es muy similar a } \\
\text { la de los mapas que utilizarán los usuarios en la realidad. }\end{array}$ \\
\hline
\end{tabular}

Tabla 3.5: Técnicas para la Fase 4. 


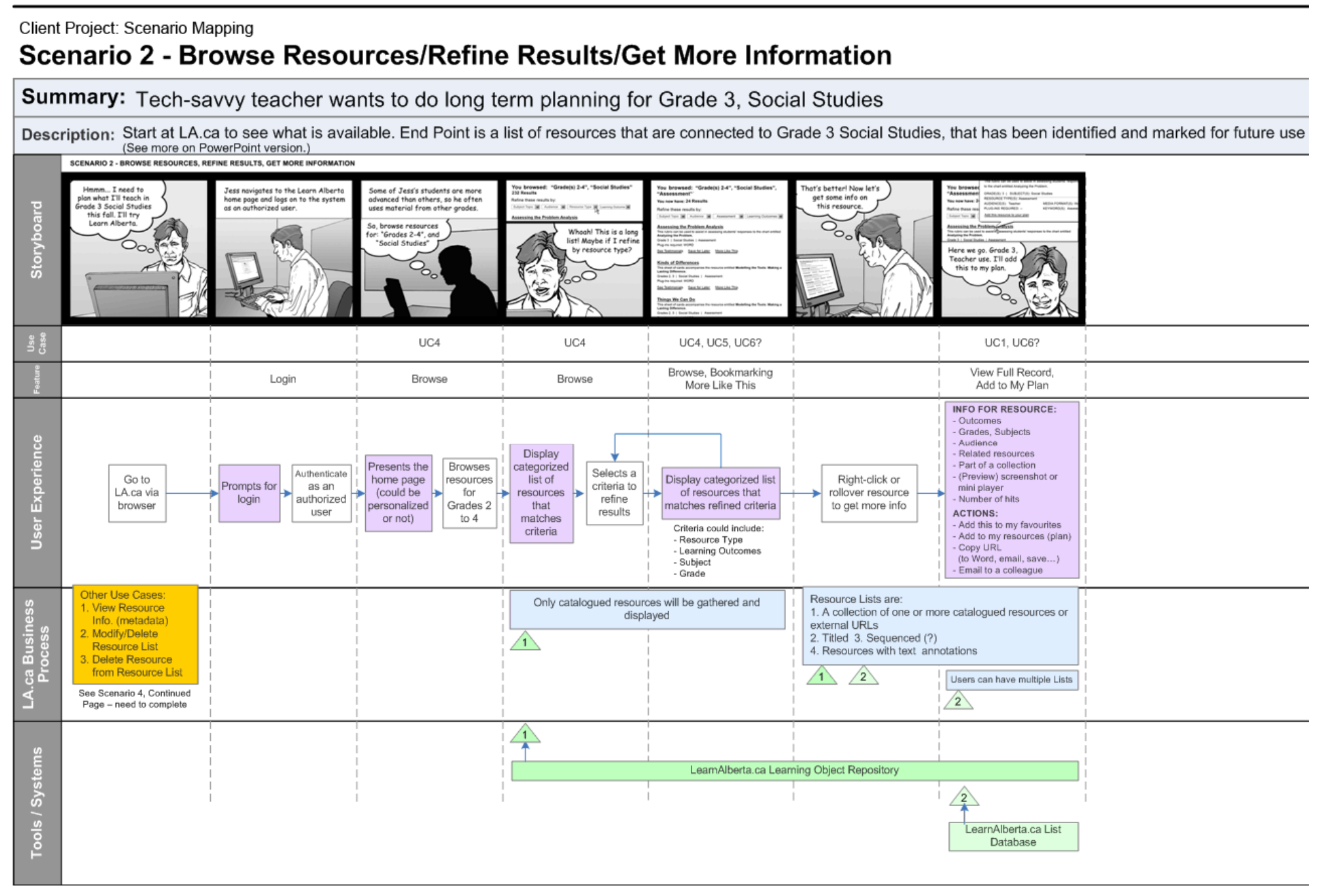

Figura 3.11: Ejemplo de la descripción de un escenario. Fuente: http://unify.eightshapes.com/. 


\subsection{Resumen}

Este trabajo se focaliza en la experiencia de usuario, derivada de la interacción con mapas de espacios urbanos.

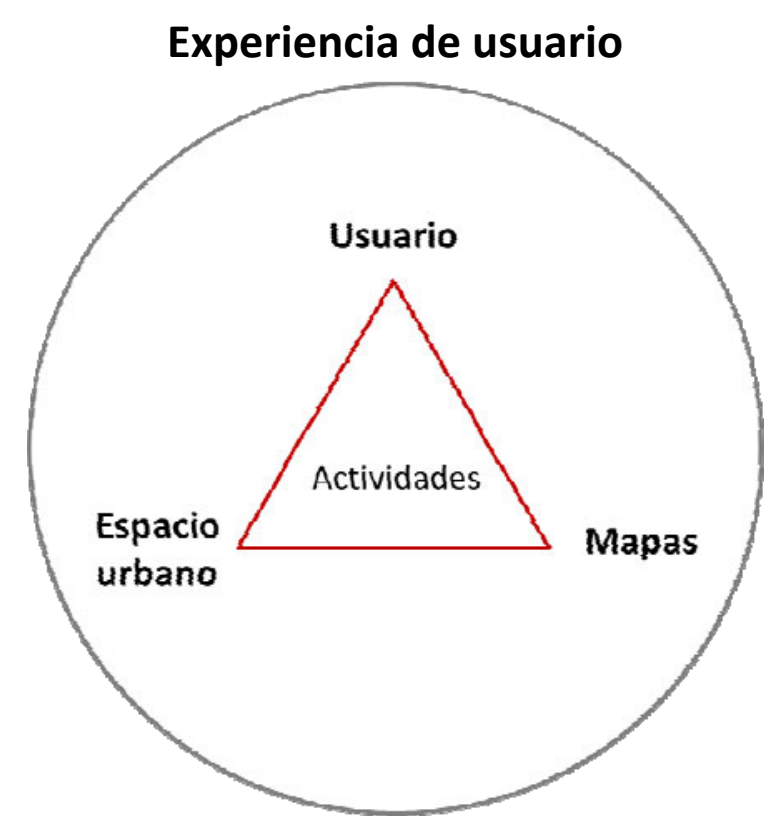

Figura 3.12: Experiencia de usuario.

En este capítulo se ha expuesto el proceso propuesto para desarrollar mapas urbanos que den soporte a las experiencias cognitivas de sus usuarios (Figura 3.13). 
Fase 1: Concepción del contexto de la experiencia de los usuarios

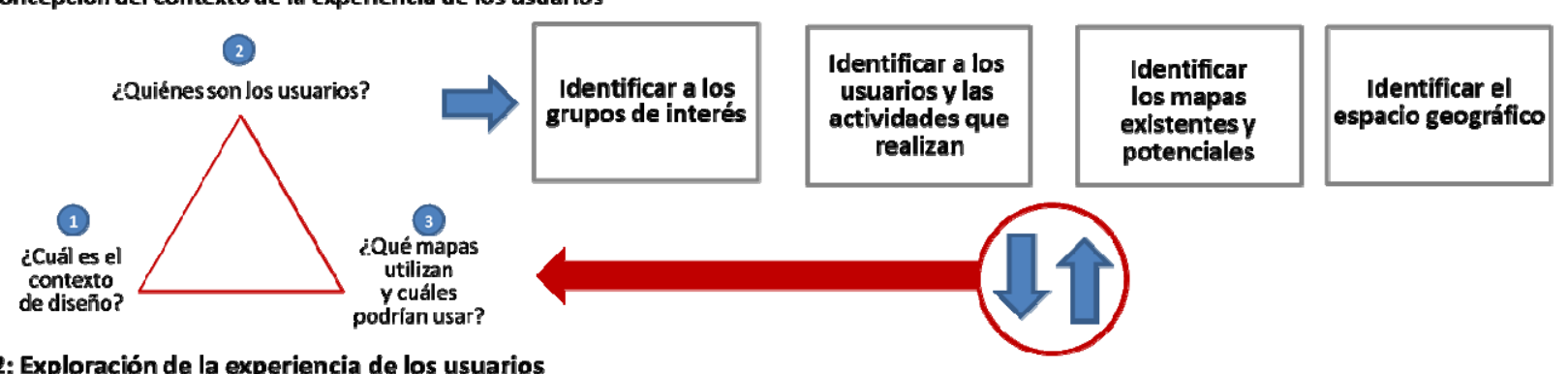

Fase 2: Exploración de la experiencia de los usuarios

(2)

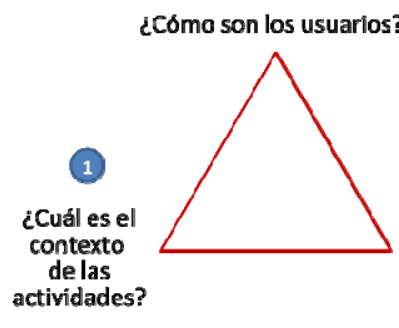

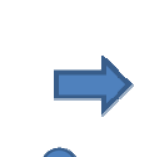

(3)

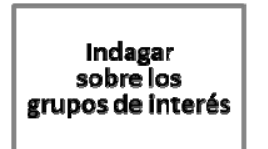

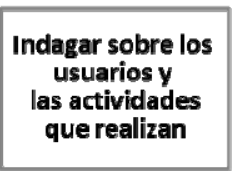

¿Cómo son los mapas que utilizany como es su experiencia?

Fase 3: Síntesis de la experiencia de los usuarios

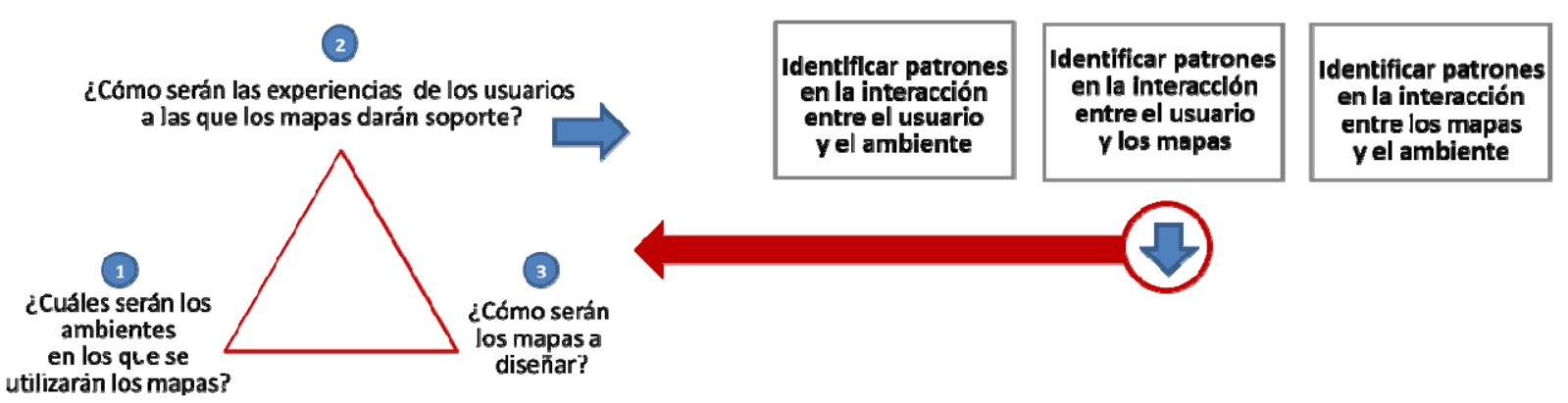
utilizaran los mapas?

Fase 4: Diseño de los prototipos de los mapas

Figura 3.13: Proceso de Diseño de Experiencia de Usuario. 


\section{CASO DE ESTUDIO: EL TURÍSMO URBANO EN MADRID}

Para probar y validar la metodología propuesta en ésta tesis se ha seleccionado como caso de estudio el turístico urbano de Madrid. Con tal propósito, se han ejecutado las siguientes fases, que seguidamente se exponen en detalle:

Fase 1. Concepción del turismo.

Fase 2. Exploración de la experiencia turística.

Fase 3. Síntesis de la experiencia de los turistas.

Fase 4. Diseño de los prototipos de los mapas para los turistas de Madrid.

\subsection{Fase 1: Concepción del turismo en Madrid}

Esta fase se llevó a cabo entre finales del 2013 y mediados del 2014 y consistió en realizar una aproximación teórica al turismo en Madrid para responder a tres preguntas: 1) ¿Cuál es el contexto de diseño?, 2) ¿Quiénes son los turistas de Madrid? y 3) ¿Qué mapas utilizan y cuales podrían usar? (Figura 3.1).

Con este propósito, se ejecutaron cuatro tareas (T1.1-T1.4), en las que se revisó documentación y se consultó a expertos. Estas tareas permitieron identificar: 1) los grupos de interés; 2 ) los turistas, sus atributos, las actividades que realizan y los factores que las condicionan; 3) los mapas actuales y potenciales y 4) el espacio geográfico asociado al turismo en Madrid.

Para realizar estas tareas se aplicaron las siguientes técnicas de diseño (Tabla 3.1):

- Investigación basada en evidencias, en la que se abarcó: 1) la revisión de artículos de investigación relacionados con: la conceptualización de espacios urbanos, el comportamiento de los turistas y las diferentes tecnologías aplicadas al desarrollo de productos turístico-cartográficos; 2) la identificación de productos turísticocartográficos de Madrid y 3) la revisión de documentos turístico-técnicos del destino, como: el Plan estratégico de turismo 2012-2015 del Ayuntamiento de Madrid (Madrid Visitors \& Convention Bureau,2012); el Informe Anual 2012 del Instituto de Turismo de España basado en las encuestas de movimientos turísticos en fronteras (FRONTUR) y de gasto turístico (EGATUR) (Instituto de Turismo de España, 2013) y datos del Instituto de Estadística de la Comunidad de Madrid $^{1}$ y del área de turismo y eventos del Ayuntamiento de Madrid ${ }^{6}$, entre otros.

\footnotetext{
${ }^{1}$ Instituto de estadística de la CM. Comercio, turismo y otros servicios. Fuente: http://www.madrid.org/iestadis/fijas/estructu/general/anuario/ianucap13.htm

2 Área de turismo y eventos del Ayuntamiento de Madrid: http://www.madrid.es/portales/munimadrid/es/Estadistica/Areas-de-Informacion-Estadistica/Turismo-yeventos?vgnextfmt=detNavegacion\&vgnextchannel=6930c7edcd025210VgnVCM2000000c205a0aRCRD
} 
- Entrevistas: a un experto en psicología social aplicada al turismo, estudioso del turismo en Madrid y profesor titular de universidad y al responsable del suministro de cartografía del Consorcio Regional de Transportes de Madrid (CRTM). Estas entrevistas permitieron recabar información de la realidad turística del destino, tanto a nivel de los aspectos psicológicos involucrados, como en lo que se refiere al espacio geográfico, a sus infraestructuras y a los mecanismos de provisión de información para facilitar la movilidad.

- Lluvia de ideas: con expertos cartógrafos e informáticos, en el contexto del "schematic maps workshop", celebrado en abril del 2014 en la ciudad de Essex. Allí se intercambiaron distintos puntos de vista de los modos de integrar información relativa a la conceptualización de los espacios urbanos, comportamiento y motivación de los turistas en el desarrollo de los mapas.

Los resultados de estas tareas, complementados con datos recabados en la Fase 2, permitieron dar respuesta a las preguntas planteadas. A continuación se describen con más detalle las tareas realizadas (Figura 3.2).

\subsubsection{Tareas de la Fase 1}

\section{T 1.1 Identificar los grupos de interés asociados al turismo en Madrid}

En el turismo, como en otros sectores económicos e industriales de las sociedades contemporáneas, existen colectivos interesados en su promoción. Estos grupos de interés participan en la definición e impulso de Madrid como destino turístico, realizando estudios y planes estratégicos, definiendo normativas y suministrando productos y servicios. Su rol en el proceso de diseño, ha sido el de suministrar información que ayude a entender la experiencia del usuario turista. Para identificar los grupos de interés, tanto públicos como privados, se utilizó el Plan estratégico de turismo 2012-2015 del Ayuntamiento de Madrid.

Las entidades públicas abarcan a nivel estatal, la Secretaría de estado perteneciente al Ministerio de Industria, Energía y Turismo, cuyos órganos de gestión son: Turespaña (Instituto de turismo de España, que se encarga de la promoción del país en el exterior) y Segittur (Sociedad estatal para la gestión de la innovación y las tecnologías turísticas); la autonómica Dirección General de Turismo de la Comunidad de Madrid (en adelante CM) y la asociación público-privada Plataforma Turística de Madrid, que aglutina representantes de todos los subsectores del ámbito turístico de la CM; la Oficina municipal de Turismo de Madrid Visitors \& Convention Bureau, cuyo objetivo es coordinar la acción pública y privada en materia de Turismo de Madrid; y otros actores públicos como la empresa municipal Madrid Destino Cultura, Turismo y Negocio; el Consorcio Regional de Transportes de Madrid (CRTM) y Madrid Espacios y Congresos.

Entre las entidades privadas se incluyen la Asociación Empresarial Hotelera de Madrid, la de Agencias de Viaje de Madrid y la Profesional de Guías de Turismo; y empresas como las aerolíneas, las cadenas hoteleras y las agencias de viajes. 
Finalmente, también hay universidades públicas y privadas que forman parte de los grupos de interés.

\section{T 1.2 Identificar a los usuarios y las actividades que realizan}

Los usuarios seleccionados para aplicar la metodología fueron turistas internacionales de entre 15 y 60 años, que visitaron Madrid por primera vez y que no tenían ningún tipo de discapacidad. Se seleccionó este colectivo por dos razones: la consolidación de la región como un destino turístico con mayor potencial internacional que nacional y por la progresión, inferior en la región que en otras comunidades españolas, de turistas extranjeros (Anexo 1).

Para caracterizar a los turistas en base a atributos susceptibles de condicionar sus experiencias cognitivas, se recurrió a investigaciones en el ámbito turístico, cognitivo y cartográfico (capítulo 3, Tarea 1.2). Los atributos identificados fueron: país de procedencia, experiencia en grandes ciudades, edad, género, nivel económico, nivel de estudios, capacidad cognitivo-espacial y experiencia en el uso de información geográfica.

A continuación se incluye información referida a datos del periodo 2011-2013, que constituyen un breve resumen de los contenidos a los que se ha tenido acceso a través de fuentes documentales. La información ampliada se puede consultar en el Anexo 1.

Los turistas internacionales que llegan a Madrid son relativamente jóvenes, ya que alrededor del 75\% es menor de 40 años. La distribución entre hombres y mujeres que llegan a Madrid es homogénea (Madrid Visitors \& Convention Bureau, 2012). La mayoría de los turistas internacionales de Madrid tienen una renta media o media alta (el $96 \%$ en el 2012). Y su gasto medio diario y su nivel de estudios son los más elevados de España (159 € y el 82 \% tiene estudios superiores según el Instituto de Turismo de España, 2013).

\section{-Actividades realizadas por los turistas}

La experiencia del turista puede dividirse en tres etapas secuenciales: 1) previaje, 2) realización de la visita y 3) post-viaje. Cada etapa aglutina una serie de actividades, en las que la toma de decisiones ocupa un lugar central:

1) Pre-viaje: El turista vive con anticipación el viaje (futuro). Inicia su experiencia a través de las fuentes de información que consulta. El turista se enfrenta a la decisión de a dónde ir (reconocimiento del problema), explora información de diferentes destinos turísticos, evalúa varias opciones, selecciona el destino, busca información sobre el transporte, el alojamiento y realiza compras y reservas.

2) Visita: El turista realiza el grueso de las actividades que configuran su experiencia: desplazarse por la ciudad, visitar lugares e ir de compras, entre otras. El turista vive lo que está ocurriendo en cada momento (presente) y estas vivencias van conformando el pasado cercano del viaje (recuerdo). También anticipa los comportamientos y las actividades que aún le quedan por hacer (futuro inmediato). 
Estas últimas actividades pueden clasificarse como: planificadas antes del viaje o espontáneas.

3) Post-viaje: Finalizado el viaje queda en la voluntad del turista volver algún día al mismo destino, en cuyo caso añadirá recuerdos al viaje anterior, ampliando la experiencia previa. Los recuerdos positivos asociados a la experiencia turística serán un factor importante, para decidir si volver a la ciudad y para recomendarla.

\section{Factores que condicionan las actividades de los turistas}

De acuerdo con la documentación consultada (ver capítulo 3, Tarea 1.2) y tras su contraste con un experto en psicología social aplicada al turismo, se concluyó que hay tres tipos de factores que pueden condicionar las actividades del turista: humanos, físicos y temporales.

A continuación se incluye un resumen de la información encontrada sobre los factores humanos y temporales de los turistas de Madrid, de la que puede consultarse más detalles en el Anexo 2. Mientras que los factores físicos se describen en las Tareas 1.3 y 1.4 .

Factores humanos que condicionan las actividades de los turistas internacionales

- Motivo de la visita: la mayoría de los turistas internacionales visitan Madrid por vacaciones y ocio. Por otro lado, la ciudad se está consolidando como uno de los destinos mundiales en turismo de congresos y negocios (International Congress and Convention Association, 2014). Además, un número considerable de turistas llega por razones de trabajo ( 20\%) y estudios (4 \%) (Instituto de Turismo de España, 2013).

- Intereses relacionados con la visita: entre los turistas internacionales destaca el interés cultural (patrimonio, monumentos y museos), seguido del gastronómico (Instituto de Turismo de España, 2013).

- Grupo de viaje: Los turistas visitan Madrid solos (48\%), seguidos de los que lo hacen en pareja, con amigos o en familia; siendo el caso menos común el de los grupos organizados (14\%) (Instituto de Turismo de España, 2013).

- Conocimiento turístico-espacial de Madrid: Existe un gran desconocimiento de la amplia oferta que ofrece la ciudad y de su potencial como destino turístico. La oferta turística no se percibe de una forma clara ni ordenada y hay zonas de interés que los turistas desconocen (Madrid Visitors \& Convention Bureau, 2012). Este factor se analiza en profundidad en la Fase 2 (Tarea 2.2).

- Percepción de la ciudad y valoración de la experiencia: A los visitantes internacionales les llama positivamente la atención el patrimonio y la agenda cultural, los medios de transporte, la gastronomía, la seguridad y la limpieza de la ciudad. Sin embargo, esperaban poder comunicarse más fácilmente en inglés durante su estancia (Madrid Visitors \& Convention Bureau, 2012). 


\section{Factores temporales que condicionan las actividades turísticas}

- Duración de la estancia: Muchos viajeros perciben Madrid como una simple escala a otros destinos y en consecuencia permanecen en la ciudad menos de un día. Además, la frecuencia de repetición es baja. La estancia media de los visitantes que llegan a Madrid es de 1,9 días (Madrid Visitors \& Convention Bureau, 2012), mientras que la de los turistas (visitantes que pernoctan en la $\mathrm{CM}$ ) es de 7,3 noches (Instituto de Turismo de España, 2013).

- Época del año: Aunque hay meses de mayor (abril, mayo, junio, septiembre y octubre) y menor ocupación (enero, febrero, agosto y diciembre), la media trimestral del número de turistas a lo largo del año es homogénea (Ayuntamiento de Madrid, n.d.).

\section{T 1.3 Identificar los mapas utilizados por los turistas, los que podrían usar, así como los factores que caracterizan su uso}

Para llevar a cabo esta tarea se visitaron varias oficinas de turismo del Ayuntamiento y de la CM. Se exploraron las web turísticas de ambas instituciones y de entidades privadas del sector. También se examinaron aplicaciones para móviles (Apps) que suministran información turístico-cartográfica de la ciudad. Además, se llevó a cabo una investigación basada en evidencias fundamentada en la revisión de documentos (Tabla 3.1).

\section{-Mapas utilizados por los turistas}

Los turistas internacionales preparan su viaje buscando información en internet, en guías de viaje y a través de las recomendaciones de familiares y amigos (Figura 4.1).

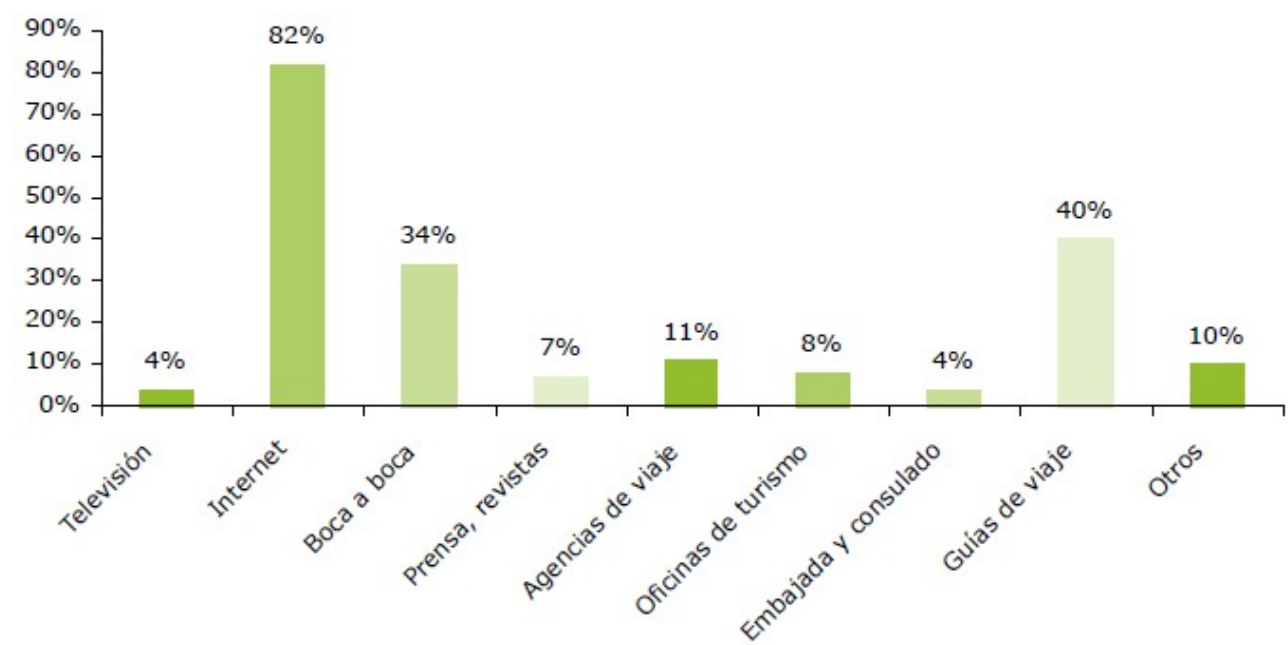

Figura 4.1: Canales de información utilizados por los turistas internacionales para preparar su viaje a Madrid. Fuente: Madrid Visitors \& Convention Bureau (2012). 
En cuanto a los tipos de mapas turísticos, a continuación se incluye una breve descripción de ellos. En el Anexo 3 se puede consultar información más detallada.

- Mapas suministrados en papel: como los elaborados por el Ayuntamiento, la CM, el CRTM y por empresas como Metro de Madrid o el Corte Inglés, entre otras. Cabe destacar, que la consulta más frecuente realizada por los turistas internacionales en las oficinas de información del Ayuntamiento es la solicitud de mapas de la ciudad (Departamento de Atención Acogida e Información Turística, 2014).

- Mapas en la web: Existen numerosos sitios web turísticos que contienen mapas de Madrid, tanto oficiales (Ayuntamiento ${ }^{7} \mathrm{y} \mathrm{CM}^{8}$ ), como de origen privado (Tripadvisor ${ }^{9}$ ).

- Mapas en aplicaciones móviles: Existe una gran variedad de aplicaciones con información turístico-geográfica de Madrid: como la "Guía Oficial de Madrid" de la empresa municipal Madrid Destino Cultura o "Madrid city guide" de TripAdvisor.

Estos mapas están destinados a usuarios genéricos (turistas y en algunos casos también a residentes). En el caso de las aplicaciones móviles, los mapas apenas contemplan mecanismos de personalización y su adaptación tiene en cuenta fundamentalmente la posición.

Por otro lado, cabe destacar que, según el Plan Estratégico de Turismo del Ayuntamiento, la oferta turística de Madrid no se comunica bien y en general la transmisión de información es mejorable, por incompleta, insuficiente y en algunos casos errónea (Madrid Visitors \& Convention Bureau, 2012).

\section{- Factores que caracterizan el uso de los mapas utilizados por los turistas}

Los aspectos que caracterizan el uso de los mapas y que inciden en la experiencia del turista se han mencionado previamente en el capítulo 3, Tarea 1.3, y se analizan en detalle en la Fase 2 (Tarea 2.3) de este capítulo.

\section{-Nuevas tecnologías que podrán utilizar los turistas}

Predeciblemente, la forma en la que los turistas interactuarán con los mapas será a corto plazo muy diferente. En cuanto a hardware existen, por ejemplo, tecnologías disruptivas como las wearables (en forma de, entre otras, gafas o relojes) o las nanotecnologías, en base a las cuales se están desarrollando nuevos soportes extensibles, flexibles y transparentes, para adaptarse a las necesidades de cada momento. Este es el caso, de la tecnología Morph de Nokia que se puede llevar puesta en forma de reloj o auricular y utilizar como móvil o tablet (Figura 4.2).

\footnotetext{
${ }^{7}$ Web turística del Ayuntamiento de Madrid: www.esmadrid.com

${ }^{8}$ Web turística de la Comunidad de Madrid: www.madrid.org

${ }^{9}$ Web turística de Tripadvisor: www.tripadvisor.es
} 
Respecto al software, cabe destacar las tecnologías sensibles al contexto (context-aware) dado que las grandes ciudades son cada vez más digitales y conectadas, de manera que ya no solo son físicas, sino también virtuales. Cada vez están más cerca las ciudades inteligentes, que integren dispositivos que asistan a los turistas en la realización de actividades y tareas con naturalidad, utilizando la información y la inteligencia que se esconde en la red y que conecte dichos dispositivos (Internet de las Cosas, loT). En estos ambientes inteligentes, los mapas podrían desempeñar el rol de artefactos cognitivos externos que, a modo de interfaz, conectaran el razonamiento del usuario con los mecanismos tecnológicos del entorno.

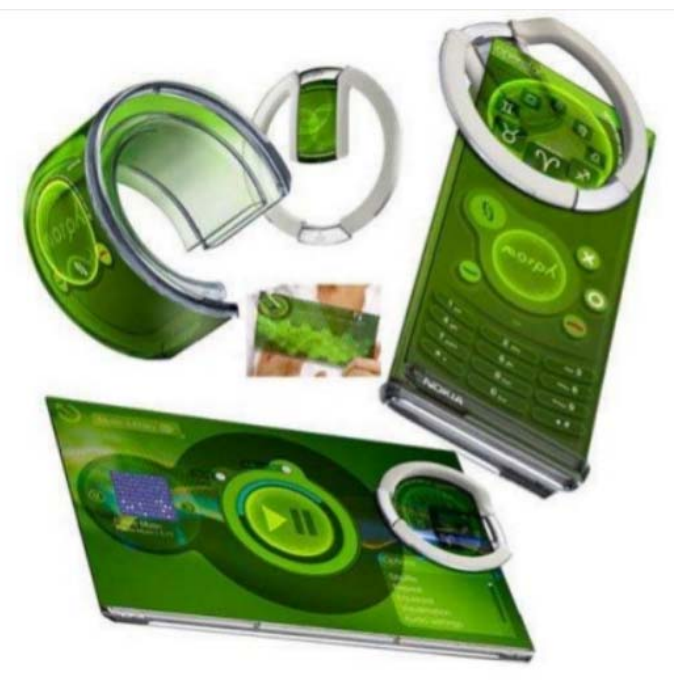

Figura 4.2: Diferentes modos de uso de la tecnología Morph de Nokia. Fuente: Rajesh, Sulthana, Majeed, \& Student (2013).

\section{T 1.4 Identificar el espacio geográfico asociado al turismo, sus principales atractivos e infraestructuras de transporte}

Dentro de la ciudad se pueden identificar dos tipos de estructuras: "la topográfica", que se refiere al aspecto geográfico (la configuración espacial de la ciudad) y la "funcional", que hace referencia al tipo de actividades que se realizan en ella (atractivos, infraestructuras de transporte y de alojamiento). Para llevar a cabo esta tarea se tomó como referencia principal el contenido del Plan Estratégico de Turismo 2012-2015 de la ciudad de Madrid.

\section{- Espacio geográfico como destino turístico}

Desde el punto de vista de los recursos de un destino turístico, el territorio supera los límites administrativos, ya que existen relaciones e interdependencias con otros destinos próximos. Teniendo esto en cuenta, se consideraron dentro del espacio geográfico del destino turístico de Madrid, todos aquellos lugares de interés, accesibles en menos de 2 horas, desde su núcleo urbano. 


\section{- Atractivos turísticos}

Los atractivos turísticos de Madrid son muy variados: arte y cultura, gastronomía, compras, naturaleza, parques y jardines, ocio, eventos... Sin embargo, Madrid carece de una imagen bien definida y diferenciada de otros destinos turísticos. Además, solo una reducida zona de la ciudad se percibe como de interés turístico, y es en ella donde los turistas realizan prácticamente todas sus actividades (ver la "zona turística tradicional" en el mapa del Anexo 4). Sin embargo, Madrid cuenta con muchos recursos de interés en otras zonas, que los turistas desconocen (Anexo 4). En cuanto a los lugares situados a menos de 2 horas de Madrid y que deberían asociarse al destino turístico, entre otros, se incluyen: El Escorial, Aranjuez, Alcalá de Henares, Ávila, Córdoba, Toledo y Segovia.

\section{- Infraestructuras de transporte}

Uno de los grandes activos con los que cuenta Madrid es su excelente red de transportes. Madrid tiene un aeropuerto internacional, líneas ferroviarias de alta velocidad, una red de metro, otra de trenes de cercanías, así como un extenso entramado de autobuses urbanos e interurbanos. Los intercambiadores son nodos esenciales para la movilidad en la ciudad (Aeropuerto, Atocha Renfe, Chamartín, Plaza Elíptica...). Por otro lado, existe un billete de transporte turístico con varias modalidades (extensiones geográficas y días de duración), de cuyas ventas se incluye información de detalle en el Anexo 5.

\section{- Ubicación de los alojamientos}

La mayoría de los turistas se alojan en el distrito Centro, mientras que el número de turistas que lo hacen en otros distritos es significativamente menor. En el Anexo 6 puede consultarse más información.

\subsubsection{Resultado de la concepción del turismo en Madrid}

\section{1) ¿Cuál es el contexto de diseño?}

El impacto económico que el turismo tiene en Madrid, hace que sea un sector atractivo tanto para entidades públicas como privadas. Sin embargo, la crisis ha afectado al turismo y existe la necesidad de una mayor coordinación institucional, del impulso de la colaboración público-privada y de la transferencia de información y conocimiento entre sus grupos de interés, con el fin de transmitir a los turistas una imagen más clara y coherente del destino turístico.

La ciudad cuenta con atractivos turísticos muy variados, buena relación calidad/precio, seguridad, clima y estilo de vida agradables; y es un destino que no presenta estacionalidad. Sin embargo, carece de una imagen bien definida y diferenciada de otros destinos turísticos y de un icono turístico representativo. Se percibe por muchos viajeros como una simple escala para visitar otros lugares. Madrid se asocia sobre todo a sus museos y el desconocimiento del resto de sus facetas puede suponer una desventaja respecto a otros destinos competidores. 
Además, los turistas perciben como área turística de interés una pequeña superficie de la ciudad, la mayoría se aloja en el centro y solo un reducido número de turistas utiliza el transporte público fuera del núcleo urbano. Lo que pone en evidencia una mejorable distribución geográfica de la actividad turística.

\section{2) ¿Quiénes son los turistas de Madrid?}

Los turistas internacionales permanecen en Madrid menos que en otras comunidades autónomas ( 7 noches de media) y su frecuencia de repetición es baja. Este colectivo viene principalmente de vacaciones, pero también por otros motivos (trabajo y educación) y se interesa sobre todo por los monumentos, los museos y las actividades culturales. Los turistas vienen con frecuencia solos y casi nunca en grupos organizados. El conocimiento que tienen de la ciudad es bajo y perciben su oferta de forma poco clara y desordenada. Sin embargo, tras la visita, los turistas internacionales suelen valorar positivamente la experiencia, aunque echan en falta poder comunicarse más fácilmente en inglés.

3) ¿Qué mapas utilizan actualmente y cuales podrían utilizar?

Las fuentes de información que más utilizan los turistas para preparar el viaje son internet, guías de viaje y las recomendaciones de familiares y amigos. Existen mapas turísticos en soporte papel, múltiples sitios web y aplicaciones móviles públicas y privadas que los integran. Los mapas están destinados a usuarios genéricos, no contemplan prácticamente mecanismos de personalización y su adaptación se limita fundamentalmente la posición.

La oferta turística no se comunica bien y en general la transmisión de información es mejorable, por incompleta, insuficiente y en algunos casos, errónea. Además, la implantación de nuevas tecnologías es escasa.

Teniendo en cuenta todo lo expuesto y la información recopilada en la siguiente fase, la visión de los mapas a diseñar fue la de representaciones espaciales que actúen como interfaces entre el turista y el espacio de Madrid, asistiéndole en su experiencia, facilitándole la comprensión y el recuerdo de las características espaciales del destino turístico. Para ello se propuso un diseño de estos mapas teniendo en cuenta una aproximación cognitivo-espacial a través del análisis de comportamientos, motivaciones, expectativas y formas de asimilar el conocimiento del espacio visitado, comunes a los turistas.

La visión de estos mapas fue que integraran la información (contenido y forma) y funcionalidades adecuadas para poder transmitir la información espacial que necesita cada turista a la hora de realizar sus actividades. En este sentido, los mapas se plantearon con un enfoque de uso personalizado (el mapa tendrá en cuenta lugares donde ya ha estado el turistas), cognitivamente adecuado (el contenido y la representación del mapa tendrá en consideración la forma en la que los turistas conceptualizan el espacio visitado) e integrado en el ambiente en el que se va a utilizar (se adaptará a la actividad realizada en un momento y lugar dado). El planteamiento de diseño de los mapas se realizó en base a tres pautas:

- Alto nivel de abstracción: representaciones flexibles en las que la información espacial que puede ser distorsionada (mapas esquemáticos). 
- Adecuación cognitiva: teniendo en cuenta, por un lado, el carácter único (personal) y colectivo de los mapas cognitivos (al incluir componentes comunes al grupo al que pertenece el individuo) y, por otro, un enfoque de correspondencia entre las abstracciones internas (los mapas mentales) y las abstracciones externas (los mapas a diseñar), al que el carácter cualitativo de los mapas esquemáticos permite dar soporte.

- Soporte cognitivo a la ejecución de actividades: durante las etapas del pre-viaje y la realización de la visita a Madrid. Asistiendo al turista en el descubrimiento de los atractivos turísticos de la ciudad y en sus desplazamientos.

En cuanto al alcance del desarrollo de estos mapas, éste se fijó a nivel de prototipos gráficos (sin incluir su implementación, Figura 2.20). En relación a su extensión geográfica, se especificó que podrían incluir todos aquellos lugares de interés accesibles desde el núcleo urbano de Madrid en menos de 2 horas.

\subsection{Fase 2: Exploración de la experiencia turística}

En esta fase se recopiló información de los grupos de interés y de los turistas con el fin de conocer con más detalle su experiencia.

Las preguntas que se abordaron en esta fase fueron: 1) ¿Cuál es el contexto de las actividades que realizan los turistas?; 2) ¿Cómo son los turistas a los que van destinados los mapas a diseñar? y 3) ¿Cómo son los mapas que utilizan y cómo es su experiencia? (Figura 3.5).

\subsubsection{Tareas de la Fase 2}

Para dar respuesta a estas preguntas se realizaron tres tareas de indagación sobre: 1) los grupos de interés asociados al turismo en Madrid; 2) los turistas, las actividades que realizan y los factores que condicionan su ejecución; 3) los productos cartográficos que utilizan y los factores que caracterizan su uso y 4) el espacio geográfico asociado a su experiencia turística.

En estas tareas se utilizaron un conjunto de técnicas de diseño entre septiembre de 2013 y mayo de 2014. Las técnicas se pueden agrupar en dos grupos: en las que participaron representantes de los grupos de interés y las realizadas con turistas de Madrid (Figura 4.3).

Los datos recopilados de las 98 personas que colaboraron en la ejecución de las tareas de esta fase, se utilizaron como complemento a la información obtenida en la Fase 1, para dar respuesta a las preguntas aquí planteadas y para suministrar información a la Fase 3.

A continuación se describen las tareas realizadas: 


Grupos de interés (24 personas)
Responsable del Centro
de Inteligencia Turística

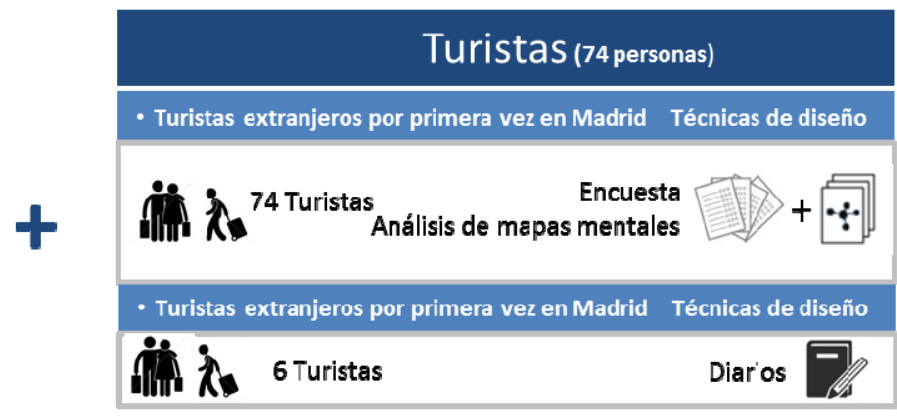

Figura 4.3: Técnicas de diseño aplicadas en la Fase 2 para recopilar información.

\section{T 2.1 Indagar sobre los grupos de interés asociados al turismo en Madrid}

Para llevar a cabo esta tarea, se contactó con un total de 24 personas, representantes de las siguientes entidades públicas y privadas de los grupos de interés: oficina de Turismo de Madrid Visitors \& Convention Bureau y el Centro de Inteligentica Turística del Ayuntamiento de Madrid, Dirección General de Turismo de la CM y CRTM; dos empresas de servicios turísticos de Madrid y una editorial de viajes (que publica una guía turística de Madrid). La tabla 4.1 muestra las técnicas de diseño, los participantes, como se ejecutaron y la información complementaria disponible en los anexos.

Una vez recopilada la información de los representantes de los grupos de interés, se procedió a organizarla a través de la técnica de diagramas de afinidad (Tabla 3.3). La Figura 4.4 ilustra parte del material utilizado para llevar a cabo esta técnica. Como resultado, la información recopilada se agrupó en cuatro apartados, considerados como los más relevantes en la experiencia cognitiva de los turistas: 1) Iniciativas para el desarrollo de productos turístico-cartográficos; 2) Necesidades y deficiencias detectadas en cuanto al suministro de mapas a los turistas; 3 ) Punto de vista sobre el comportamiento de los turistas y 4) Sugerencias de cara al diseño de los mapas. A continuación se incluye un resumen de ellos: 


\begin{tabular}{|c|c|c|c|}
\hline $\begin{array}{c}\text { Técnicas } \\
\text { de diseño }\end{array}$ & Participantes & Ejecución & $\begin{array}{c}\text { Información } \\
\text { complementaria }\end{array}$ \\
\hline Entrevistas & $\begin{array}{l}\text { Cinco personas: } \\
\text { - El Director del centro de inteligencia } \\
\text { turística del Ayuntamiento. } \\
\text { - El responsable de las oficinas turísticas de } \\
\text { la CM. } \\
\text { - Una informadora turística de la CM. } \\
\text { - El gerente de una empresa que ofrece } \\
\text { servicios a turistas durante su visita. } \\
\text { - El redactor de una guía turística de } \\
\text { Madrid. }\end{array}$ & $\begin{array}{l}45 \text { minutos. } \\
20 \text { preguntas. } \\
\text { Entrevistas } \\
\text { semiestructuradas } \\
\text { con preguntas } \\
\text { abiertas en base a } \\
\text { un guion. }\end{array}$ & $\begin{array}{l}\text { Guion de las } \\
\text { entrevistas } \\
\text { en Anexo } 7 .\end{array}$ \\
\hline $\begin{array}{l}\text { Grupos de } \\
\text { discusión }\end{array}$ & $\begin{array}{l}\text { Diez personas: } \\
\text { - Tres informadoras turísticas del } \\
\text { ayuntamiento y } \\
\text { - Siete miembros del CRTM vinculados a } \\
\text { las áreas: comercial, de estudios y } \\
\text { planificación, de información del servicio y } \\
\text { señalización y de sistemas y SIG. }\end{array}$ & $\begin{array}{l}60 \text { minutos. } \\
\text { Discusión dando } \\
\text { cabida al debate y } \\
\text { al intercambio de } \\
\text { puntos de vista. }\end{array}$ & \\
\hline Encuestas & $\begin{array}{l}\text { Cuatro representantes del CRTM de las } \\
\text { áreas de: } \\
\text { - calidad y atención al ciudadano, } \\
\text { - estudios y planificación, } \\
\text { - servicio de información y señalización y } \\
\text { - sistemas y SIG. }\end{array}$ & $\begin{array}{l}\text { El cuestionario se } \\
\text { distribuyó y } \\
\text { recopilo en } \\
\text { formato Word a } \\
\text { través de e-mails. }\end{array}$ & $\begin{array}{l}\text { Cuestionario } \\
\text { en el Anexo } \\
8 .\end{array}$ \\
\hline $\begin{array}{l}\text { Observación } \\
\text { de campo }\end{array}$ & $\begin{array}{l}\text { Cuatro miembros del personal de las } \\
\text { oficinas turísticas de la CM situadas en la } \\
\text { Estación de Atocha y en el Aeropuerto } \\
\text { Adolfo Suárez Madrid-Barajas y turistas que } \\
\text { solicitaron sus servicios. } \\
\text { Turistas viajando en el bus turístico de la } \\
\text { ciudad (Madrid city tour) y guía turística } \\
\text { asistiéndoles durante el recorrido. }\end{array}$ & $\begin{array}{l}\text { Observación y } \\
\text { recopilación de } \\
\text { información sobre } \\
\text { los turistas y los } \\
\text { suministradores } \\
\text { de información. }\end{array}$ & \\
\hline
\end{tabular}

Tabla 4.1: Técnicas de diseño llevadas a cabo para realizar la indagación de los grupos de interés asociados al turismo en Madrid.

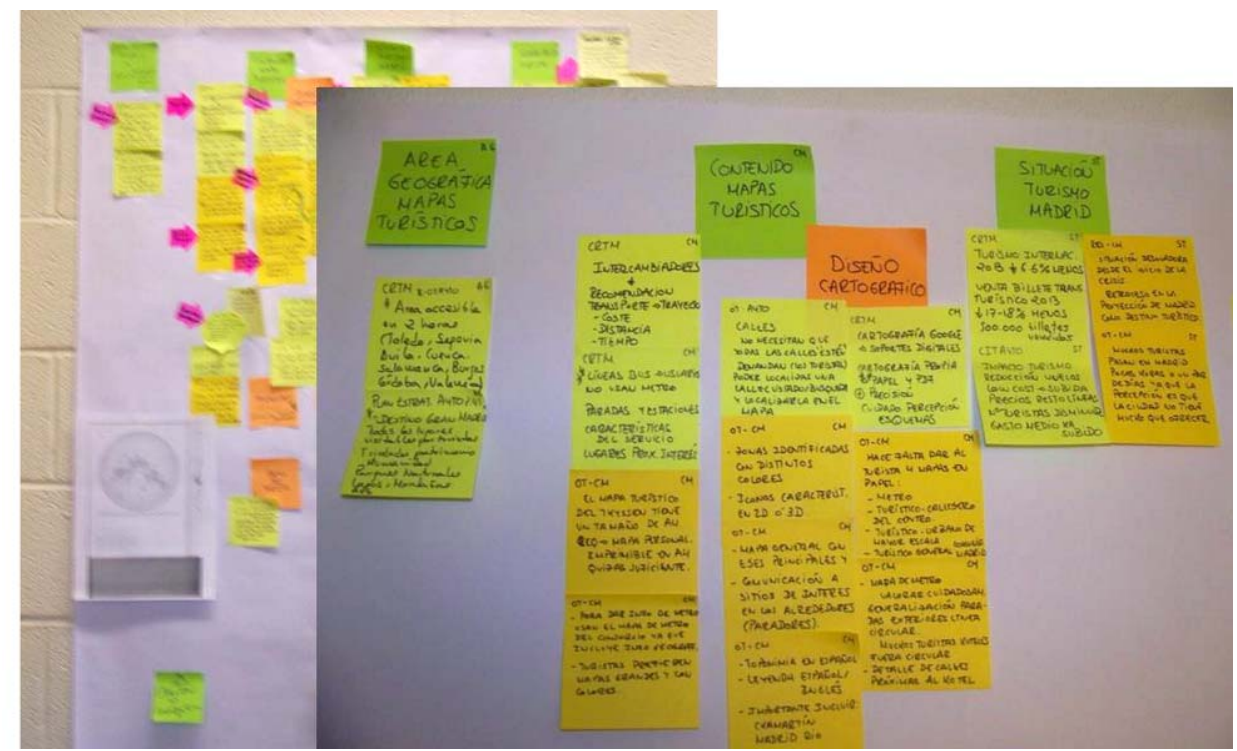

Figura 4.4: Material utilizado para llevar a cabo la técnica de diagramas de afinidad, con el fin de organizar la información recopilada de los grupos de interés. 


\section{1) Iniciativas para el desarrollo y el suministro de productos turístico-cartográficos}

Los productos cartográficos oficiales se llevan a cabo a través de iniciativas individuales, a partir de las decisiones de un reducido número de personas y están dirigidos a usuarios genéricos. En su desarrollo no participan los turistas $y$, en la mayoría de los casos, no se tienen en cuenta recursos disponibles como el conocimiento del personal de las oficinas de turismo o los datos sobre el comportamiento de los turistas de estudios previos existentes.

Por otro lado, los responsables de pequeñas empresas del sector sienten incertidumbre debido, por un lado, a la falta de una puesta en práctica clara del Plan Estratégico de Turismo de la ciudad y, por otro, a la crisis económica. Lo que está repercutiendo negativamente en la creación de nuevos productos cartográficos.

En cuanto al suministro de mapas oficiales en formato papel, ni las oficinas de turismo de la $\mathrm{CM}$, ni las del Ayuntamiento, proporcionan mapas del otro organismo, aunque en todas ellas se distribuyen mapas del CRTM y de empresas privadas. Cabe resaltar que los sitios web turísticos de la $\mathrm{CM}$ y del Ayuntamiento solo difunden sus propios mapas en formato pdf y que ambos disponen de aplicaciones cartográficas interactivas basadas en la cartografía de Google Maps.

La información recopilada, sobre la cual se puede consultar más detalles en el Anexo 9, refleja una situación deficiente en cuanto al desarrollo y al suministro de productos cartográficos. Este hecho refuerza la conveniencia del enfoque adoptado en esta investigación, en cuanto a la intención de utilizar recursos de diversas fuentes para el desarrollo de los mapas (conocimiento de expertos, datos de los turistas y de personas que están en contacto con ellos,...) y en lo que se refiere al diseño de mapas personalizados.

\section{2) Necesidades y deficiencias detectadas en cuanto al suministro de mapas a los turistas}

La mayoría de las personas consultadas coincidieron en la necesidad de hacer un esfuerzo coordinado a nivel público y privado para que los mapas suministrados al turista transmitan una imagen clara y coherente de Madrid. En opinión, por ejemplo, del director del Centro de Inteligencia Turística del Ayuntamiento de Madrid, la información proporcionada en el entorno digital es heterogénea y mejorable, ostentando su hegemonía la base cartográfica de Google Maps; y respecto a los mapas en soporte papel, en general es bastante deficiente ya que, entidades privadas sufragan en parte su impresión, a cambio de la inclusión de publicidad en su contenido. En este sentido cabe destacar, por ejemplo, el cambio de denominación de la parada de metro de Sol por Vodafone-Sol debido a una campaña publicitaria (a raíz de la cual algunos turistas consultados asociaron el centro de la ciudad al lugar "Vodafone-Sol") (Figura 4.5).

A continuación se incluyen detalles sobre el punto de vista de los grupos de interés acerca de las necesidades y deficiencias de la información suministrada a los turistas, durante el pre-viaje y la realización de la visita. 


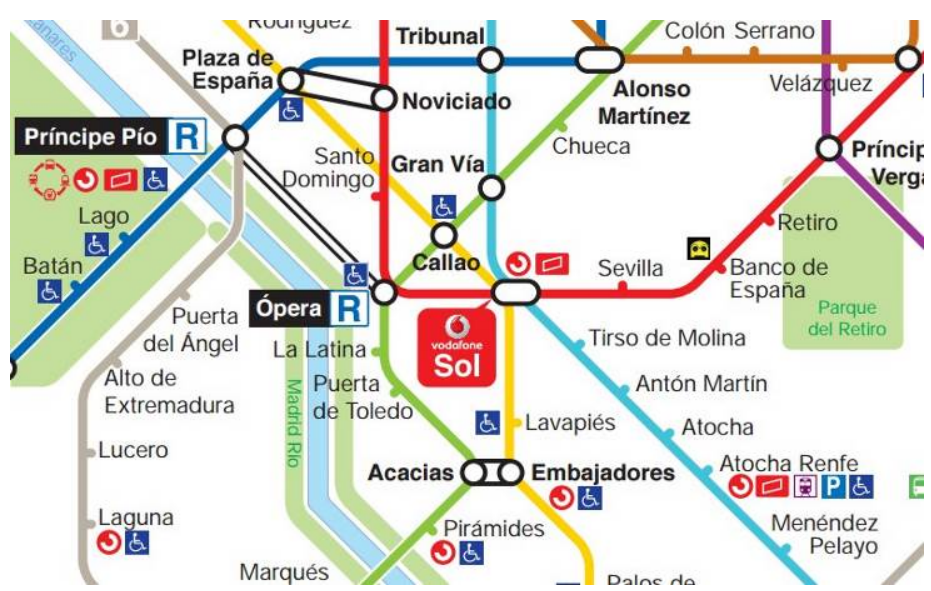

Figura 4.5: Plano esquemático de metro con la parada "Vodafone-Sol" en su centro.

\section{- Pre-viaje}

Los turistas en esta etapa utilizan sobre todo internet, aunque algunos se ponen en contacto vía e-mail con los servicios de las oficinas turísticas solicitando recomendaciones de los lugares a visitar, en función de los días de estancia y mapas en papel. Este hecho puede deberse a que hay turistas que tienen dificultades para acceder a la información que necesitan a través de internet y/o a preferir mapas en papel para planificar el viaje.

\section{- Realización de la visita}

Nada más llegar, el turista busca con frecuencia mapas para poder orientarse, así como información de transporte. Para suministrar al turista los mapas más adecuados, el personal de las oficinas de turismo pregunta cuál es su lugar de alojamiento y la duración de su estancia. Los turistas en ocasiones llegan a recibir hasta 4 mapas (metro, turístico del centro de Madrid con información de detalle de calles, turístico urbano de menor escala y otro de toda la Comunidad). La cobertura geográfica de ninguno de ellos es coherente con el espacio geográfico del destino turístico de Madrid (lugares de interés a menos de $2 \mathrm{~h}$ de Madrid). Por lo que, cuando la información que solicita el turista no está incluida en ninguno de los mapas disponibles, el personal de información recurre a Google maps.

En cuanto a la información de transportes, cuando el personal de las oficinas de turismo tiene que explicar algún recorrido en metro utiliza el mapa geográfico de metro del CRTM, ya que necesitan poder orientar al turista, no solo respecto a la ruta en metro, sino también en superficie. Por otro lado, no existen mapas con buena información de comunicaciones multimodales (combinaciones de metro y cercanías) y ningún mapa de las oficinas turísticas tiene información de autobuses. Finalmente, cabe resaltar que, con frecuencia, los mapas turísticos que incluyen información de transporte resultan poco claros debido al gran volumen de información que contienen en relación a sus dimensiones (Figura 4.6). 


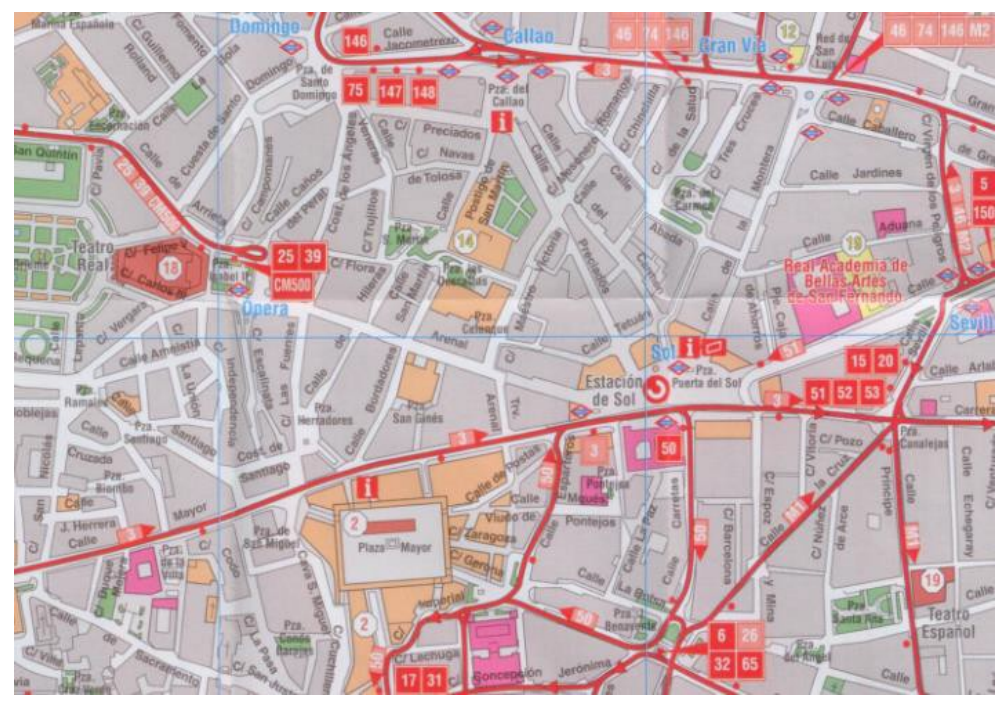

Figura 4.6: Mapa suministrado por el Consorcio Regional de Transportes de Madrid junto al Billete de Transporte Turístico.

Todo lo expuesto anteriormente refleja un considerable número de deficiencias y necesidades, no cubiertas por los mapas que utilizan actualmente los turistas de Madrid y pone en evidencia las limitaciones de los mapas en soporte papel.

\section{3) Punto de vista sobre el comportamiento de los turistas}

El personal del CRTM señaló que el medio de transporte más utilizado por los turistas es el metro, seguido de los autobuses públicos. En cuanto al bus turístico, indicaron que es un servicio con mucha demanda entre los turistas extranjeros (aspecto que confirmaron las informadoras turísticas de la CM).

Por otro lado, las informadoras del Ayuntamiento señalaron que, los extranjeros, con frecuencia, no saben dónde está situado el centro de la ciudad y que a veces llegan a Madrid pensando que el hotel que han reservado está en el centro, cuando no siempre es así. Este desconocimiento del espacio geográfico de la ciudad provoca que algunos turistas alquilen un coche antes de llegar, ya que no saben lo fácil que resulta visitar Madrid caminando y/o en transporte público. Este es un ejemplo de las posibles repercusiones negativas en la experiencia de los turistas, debidas a su desconocimiento de la ciudad, que un suministro adecuado de información geográfica podría evitar.

\section{4) Sugerencias aportadas de cara al diseño de los nuevos mapas}

\section{- Soporte}

Las personas contactadas coinciden en la conveniencia de suministrar mapas en soportes digitales, que faciliten la consulta vía internet durante el pre-viaje.

En cuanto a los mapas utilizados durante la visita, aunque algunos representantes de los grupos de interés apuestan por los soportes digitales móviles, el personal de las oficinas de información turística y de las entidades privadas 
contactadas comparte la opinión de que, hoy por hoy, el soporte más utilizado por los turistas, durante la visita, es el papel. El personal del CRTM apuesta también por el soporte papel, aunque son conscientes de la conveniencia de suministrar mapas en múltiples soportes.

\section{- Escalas y contenido}

Una de las informadoras turísticas de la CM sugirió que la toponimia no debería traducirse y que, la leyenda y el resto de información complementaria del mapa, deberían suministrarse en español e inglés.

Respecto a los mapas de transportes, el personal del CRTM resaltó la importancia de incluir intercambiadores, estaciones y paradas de transporte, lugares característicos entorno a ellos (monumentos, museos...), incidencias, frecuencias del servicio y la recomendación de rutas en función de criterios de medio de transporte, coste, distancia y tiempo. También recomendaron la inclusión de información de las líneas de autobuses, ya que algunos turistas prefieren este medio de transporte, ya que permite ir viendo la ciudad.

En cuanto a las visualizaciones esquemáticas de algunos mapas como el del metro, la mayoría de las personas consultadas las consideran útiles, pero siempre y cuando se puedan complementar con información geográfica de detalle.

Se recogieron opiniones coincidentes acerca de que los turistas manejan mapas poco claros que contienen información innecesaria y omiten otras de interés, como rutas y fotografías. También se detectó la necesidad de transmitir una "visión viva" de la ciudad, así como de proporcionar vías alternativas para explorarla como: rutas en bicicleta y recorridos temáticos (Madrid en el cine, Madrid literario, arquitectónico...).

En cuanto a la información suministrada sobre los atractivos turísticos de Madrid, ésta debería estar mejor estructurada ya que, por ejemplo, hay más de 100 museos y sería conveniente poder hacer búsquedas según las preferencias, presupuesto, disponibilidad de tiempo de los turistas...

\section{- Cobertura geográfica}

Actualmente la información está muy fragmentada y requiere que los turistas visiten diferentes páginas webs, aplicaciones móviles y oficinas de información para poder obtenerla. Las personas consultadas coincidieron en que el acceso a los mapas debería ser más sencillo y centralizado, y que éstos deberían abarcar el ámbito geográfico de la ciudad y la comunidad, así como de lugares próximos de interés como Toledo y Segovia.

\section{- Personalización}

Dada la amplia oferta turística de la ciudad y la diversidad de perfiles de turistas, todos los representantes de los grupos de interés consultados reconocieron la ventaja que supondría un suministro de mapas personalizados.

En relación a las sugerencias recopiladas para el diseño de mapas, aunque muchos de los representantes de los grupos de interés siguen defendiendo el papel, 
en esta investigación se apuesta por los dispositivos digitales que facilitan el suministro de mapas personalizados, generados al vuelo y más versátiles a la hora de poder incluir fotografías, rutas e información según diversos criterios (preferencias, costes, tiempo disponible...). Por otro lado, se consideraron oportunas algunas sugerencias como: el uso de colores para ilustrar diferentes zonas de la ciudad, iconos personalizados y toponimia en castellano. También se consideró interesante la posibilidad de diseñar visualizaciones que compaginen información muy esquematizada con otra de mayor nivel de detalle.

\section{T 2.2 Indagar sobre los turistas, las actividades que realizan y los factores que condicionan su ejecución}

Los turistas seleccionados para colaborar en esta tarea fueron ciudadanos extranjeros, que visitaban Madrid por primera vez, durante una estancia de al menos 2 noches. Estos requisitos se establecieron para evitar el sesgo debido a experiencias previas en la ciudad (turistas que repetían su visita) y para descartar a turistas que estuvieran de paso por la ciudad, durante menos de 36 horas.

En esta indagación participaron un total de 74 turistas, de entre 18 y 60 años, que suministraron información a través de cuestionarios y diarios en español e inglés. La información recopilada abarcó datos sobre: 1) Sus atributos; 2) Productos cartográficos que utilizan antes y durante su visita; 3) Intención de uso de medios de transporte antes de iniciar la visita y medios utilizados durante la misma; 4) Situaciones (lugar, momento y tarea) en las que consultan información turística o de transporte; 5) Dificultades al desplazarse por la ciudad; 6) Dificultades al utilizar productos cartográficos; 7) Conocimiento turístico-geográfico de la región; 8) Conocimiento de infraestructuras de transporte; 9) Percepción del destino turístico; 10) Valoración de los atractivos turísticos y 11) Valoración de su visita.

A continuación se describen cada una de las técnicas de diseño aplicadas en esta tarea:

\section{- Encuestas}

Esta técnica se ejecutó desde septiembre de 2013 a mayo de 2014 y en ella colaboró un psicólogo. Se elaboraron dos cuestionarios: uno para recopilar información a la llegada de los turistas, antes de tener su primer contacto directo con la ciudad (iniciales) y otro para hacerlo momentos previos a su partida, una vez finalizada su estancia (finales) (Anexos 10 y 11).

El objetivo de la encuesta fue caracterizar a los turistas y su experiencia en la ciudad, para lo cual se tuvieron en cuenta sus atributos y los factores que condicionaron sus actividades, identificados en la Fase 1 (Tareas 1.2 y 1.3). Los cuestionarios se elaboraron poniendo un especial hincapié en la recopilación de información relativa al conocimiento y la conceptualización espacial de la ciudad. Para ello se utilizaron tres vías complementarias de captura: en forma de texto a través preguntas (listas de libre recuerdo), en forma gráfica (mapa mental) y por 
último, a través de la identificación de fotografías de atractivos turísticos de Madrid y su localización en un mapa turístico.

Antes de comenzar a realizar la encuesta, se verificó que el contenido de los cuestionarios se entendía con claridad, para lo cual se solicitó a personas ajenas a la investigación, que los completaran. En base a este test se realizaron los cambios oportunos.

Los turistas completaron los cuestionarios en formato papel, bajo la supervisión de una persona y sin límite de tiempo. Se eligió esta vía ya que la opción on-line probablemente hubiera dificultado la captura de los mapas metales y no hubiera permitido tener la certeza de que los turistas no consultaban información externa al contestar. En este sentido, se sacrificó el tamaño de la muestra, en aras de garantizar que los datos fueran válidos. La encuesta a turistas recién llegados se realizó en el trayecto en cercanías, del aeropuerto a la estación de Atocha, que dura alrededor de 25 minutos. Los cuestionarios finales se completaron en el trayecto inverso de cercanías y dentro de la zona de embarque del aeropuerto. El procedimiento seguido consistió en verificar en primer lugar que el turista cumplía con los requisitos establecidos (extranjero, en su primera visita a Madrid y durante una estancia superior a 2 días) y una vez hecho esto, se le suministró el cuestionario para que lo completara. En cuanto a la captura de los mapas mentales, se indicó al turista que dibujara un mapa de la ciudad de Madrid, instándole a que incluyera en primer lugar, y con bolígrafo azul, los atractivos puntuales, calles y zonas de interés (Figura 4.7), así como la ubicación del norte, del aeropuerto y de su alojamiento. Una vez hecho esto, se proporcionó al turista un bolígrafo rojo, para que incorporara la información sobre las infraestructuras de transporte que recordara (estaciones, líneas...).

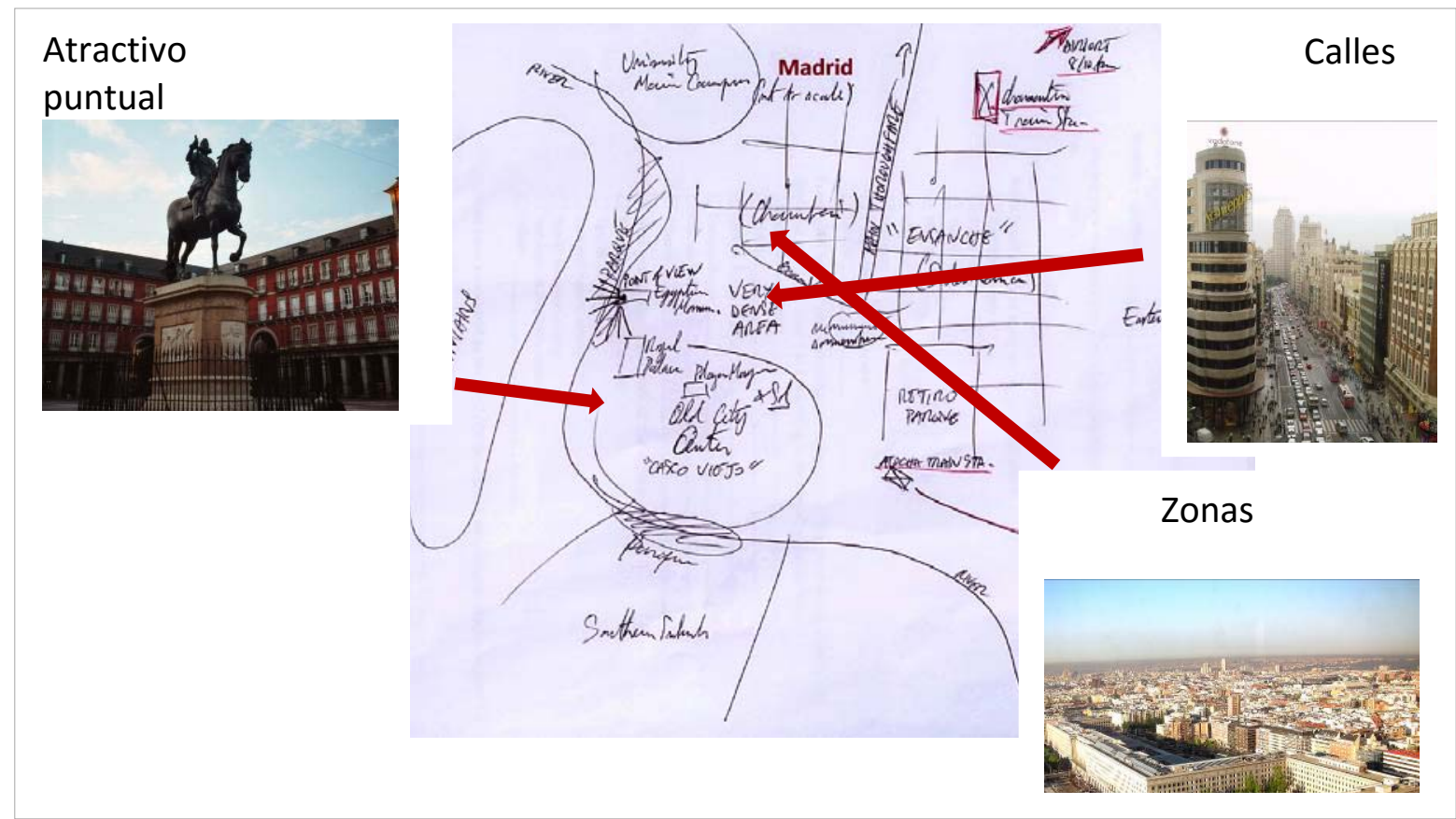

Figura 4.7: Mapa mental con: a) atractivos puntuales de interés: Plaza Mayor, b) eje: Gran vía y c) zonas: Barrio de Chamberí. 
Los turistas encuestados al inicio de la visita (17) no coincidieron con los consultados al final de ella (57), salvo en 6 ocasiones (turistas participantes en la técnica del diario). Se hizo más hincapié en la captura de datos al final la visita, ya que las actividades que más inciden en la experiencia de los turistas son las realizadas justo antes de ese momento.

En cuanto al tamaño de la muestra, este se consideró suficiente teniendo en cuenta el carácter cualitativo y semi-cuantitativo de la metodología y el número de participantes en los estudios cognitivos tomados como referencia (60 personas en el trabajo de Lynch (1960) y 51 en el de Moore (1973)).

\section{- Diarios}

Esta técnica se ejecutó durante los meses de abril y mayo de 2014. Los diarios permitieron comprender las experiencias de los participantes: sus motivaciones, necesidades, preferencias, intereses, comportamientos y forma de interpretar y dar sentido al espacio turístico.

Para llevar a cabo esta técnica se solicitó la colaboración de turistas a través de redes sociales (Facebook, Linkedln y Couch-surfing), listas de correo personales y mediante un anuncio en varias sedes internacionales del Instituto Cervantes. Con el fin de incentivar la participación de los turistas, se les ofreció alojamiento gratuito y sufragar sus gastos de transporte durante la visita. La Tabla 4.2 contiene información sobre los turistas que participaron en esta técnica y sus experiencias.

A lo largo de su estancia, se recopiló información de los desplazamientos (lugar de origen, lugar de destino, medio de transporte utilizado, información consultada y ruta seguida), lugares o eventos de interés especial que quisieran recordar del viaje, así como situaciones o aspectos incomprensibles o desconcertantes que no les gustaron o que dificultaron su visita. Los turistas documentaron su estancia a través de registros en forma de texto, audio, video, fotografías y rutas GPS. Completaron los cuestionarios y registraron en tres ocasiones sus mapas mentales de la ciudad (el primer día de su visita, a mitad de la estancia y al finalizarla). El Anexo 12 incluye los recursos y las pautas suministradas a los turistas.

El volumen y heterogeneidad de la información obtenida a través de las encuestas y los diarios, hizo necesaria su transcripción, armonización y destilación, para su posterior análisis. Para ello se aplicó la técnica de análisis de contenidos (Tabla 3.3). 


\begin{tabular}{|c|c|c|c|c|c|}
\hline Procedencia & Género & Edad & Estancia & Grupo & Perfil del turistas y características de su experiencia en Madrid \\
\hline México & M & 39 & 8 días & Solo & $\begin{array}{l}\text { Arquitecta que no suele viajar sola, salvo por trabajo. } \\
\text { Intereses: arquitectura, gastronomía, museos, monumentos y jardines. } \\
\text { Motivo del viaje: Asistencia a un congreso, para realizar una ponencia. } \\
\text { Alojamiento: En casa de la doctoranda durante } 4 \text { días antes del evento y el resto en el hotel concertado por la organización del } \\
\text { congreso. } \\
\text { Pre-viaje: Antes de llegar no tuvo tiempo de buscar información. } \\
\text { Visita: Durante los días previos al congreso dedicó parte de las jornadas a preparar su presentación y en sus ratos libres se dejó } \\
\text { guiar por amigos locales. Durante el congreso participó en las actividades de ocio suministradas por la organización. Aunque trajo } \\
\text { consigo varias guías de Madrid, prácticamente no las consultó. }\end{array}$ \\
\hline Argentina & $\mathrm{H}$ & 30 & 4 & Pareja & $\begin{array}{l}\text { Ambos tienen experiencia viajando por Latinoamérica. } \\
\text { Intereses: museos, monumentos y jardines. } \\
\text { Motivo del viaje: Su visita a Madrid formó parte de un recorrido de } 3 \text { meses de vacaciones por toda Europa. }\end{array}$ \\
\hline Argentina & M & 25 & 4 & Pareja & $\begin{array}{l}\text { Alojamiento: En la casa de una amiga de la doctoranda. } \\
\text { Pre-viaje: Buscaron información sobre los atractivos turísticos más destacados y seleccionaron juntos lugares a visitar. } \\
\text { Visita: Se focalizaron en los lugares seleccionados dejando margen a la espontaneidad, una vez cubiertos los objetivos marcados. } \\
\text { Actividades condicionadas por un bajo presupuesto. }\end{array}$ \\
\hline $\begin{array}{l}\text { UK } \\
\text { (nacido } \\
\text { en } \\
\text { India) }\end{array}$ & $\mathrm{H}$ & 34 & 6 & Solo & $\begin{array}{l}\text { Ejecutivo que suele viajar solo, tanto de vacaciones, como por trabajo. } \\
\text { Intereses: Asistir a espectáculos (toros, flamenco...) y tener un contacto directo con la cultura local. } \\
\text { Motivo: Su visita a Madrid estuvo motivada por un curso de formación organizado por su empresa. } \\
\text { Alojamiento: Antes de iniciar el curso, durante } 3 \text { días en casa de la doctoranda y el resto en un hotel. } \\
\text { Pre-viaje: Antes de llegar no tuvo tiempo de buscar información. } \\
\text { Visita: Durante los días previos al curso dedicó parte del tiempo a trabajar y, en los momentos de ocio, se desplazó solo por la } \\
\text { ciudad. Durante las jornadas del curso, a última hora del día salió con compañeros que tampoco habían visitado antes Madrid. }\end{array}$ \\
\hline Dinamarca & $\mathrm{H}$ & 49 & 12 & Pareja & $\begin{array}{l}\text { Persona con mucha experiencia viajando, de vacaciones en pareja y solo por trabajo. } \\
\text { Intereses: Tener contacto con la cultura local, además de ver los principales monumentos y jardines, ir de compras,... } \\
\text { Motivo: Él y su pareja compraron un vuelo a Alicante para pasar } 20 \text { días en España y decidieron visitar unos días Madrid. } \\
\text { Alojamiento: } 4 \text { días en casa de la doctoranda, } 4 \text { días en casa de otro residente local y otros } 4 \text { en un hotel. } \\
\text { Pre-viaje: Leyó un libro escrito por daneses que han vivido en Madrid, así como varias guías de viajes. }\end{array}$ \\
\hline Dinamarca & M & 52 & 12 & Pareja & $\begin{array}{l}\text { Siempre viaja con su pareja, por la que se deja guiar durante todo el viaje. } \\
\text { Si le apetece hacer algo durante la visita, se lo comenta a su compañero y éste busca la información y toma las decisiones. }\end{array}$ \\
\hline
\end{tabular}

Tabla 4.2: Características de los turistas que participaron en la técnica de los diarios y de sus experiencias. 


\section{- Estructuración y análisis de contenidos}

La información recopilada a través de los cuestionarios se integró en cuatro tablas Excel con la finalidad de facilitar su análisis y la generación de gráficas. Se crearon dos tablas para los registros iniciales y dos para los finales. En dos se incluyeron los datos relacionados con el conocimiento y la conceptualización espacial de Madrid. En las otras se almacenaron los atributos de los turistas y el resto de la información sobre los factores condicionantes de sus actividades. El Anexo 13 incluye imágenes de estas tablas. A continuación se incluye un resumen de la información recopilada.

\section{Atributos de los turistas encuestados}

La mayoría de los turistas encuestados vinieron de América del Sur (45\%) y de Europa (39\%). El $55 \%$ tenía menos de 45 años. El $48 \%$ fueron mujeres y el $52 \%$ hombres. El 50 \% tenía máster o doctorado y el $26 \%$ era graduado. El $51 \%$ había visitado más de 4 grandes ciudades y el $32 \%$ entre 2 y 4 . Y solo el $10 \%$ tenía experiencia en el uso de información geográfica. En el Anexo 14 puede consultarse más información, incluidas gráficas.

\section{Actividades realizadas por el turista y factores que las condicionan}

- Pre-viaje:

A continuación se incluye un resumen de la información recopilada. En el Anexo 15 pueden consultarse más detalles y los gráficos asociados.

La mayoría de los turistas encuestados vinieron a Madrid de vacaciones, seguidos de los que lo hicieron para visitar a familiares y amigos, de los que llegaron por trabajo y de los que aprovecharon y visitaron la ciudad, haciendo escala en ella hacia otro destino. Su principal interés turístico fue la oferta cultural, seguida de la gastronomía, los parques y jardines y las compras. El $83 \%$ de los encuestados vino acompañado, mientras que un $17 \%$ lo hizo solo. Al llegar a la ciudad, el $19 \%$ de los turistas manifestaron haber planificado totalmente la visita y un $44 \%$ indicaron no haberlo hecho nada o muy poco.

A continuación se expone la información sobre el conocimiento turísticoespacial de los turistas antes de tener un contacto directo con la ciudad, recabado a través de las tres vías expuestas:

\section{1) Registros en forma de texto.}

Entre los atractivos que los turistas mencionan que tienen previsto visitar destacan los museos (Tabla 4.3). Los ejes (calles y líneas de transporte) aparecen en un número muy inferior al de los atractivos puntuales (un total de 4) siendo la calle más frecuente el Paseo de la Castellana. Respecto a las zonas señaladas (un total de 10), el centro es la más frecuente (4 repeticiones). 


\begin{tabular}{lr}
\multicolumn{1}{c}{ Atractivos turísticos } & Repeticione \\
Museo del Prado & 6 \\
Museo Reina Sofía & 5 \\
Puerta del Sol & 5 \\
Estadio Santiago Bernabéu & 4 \\
Plaza Mayor & 4 \\
Palacio Real & 3 \\
Parque del Retiro & 3
\end{tabular}

Tabla 4.3: Atractivos turísticos puntuales que los turistas tienen previsto visitar en Madrid al inicio de su estancia y que se han mencionado en los cuestionarios iniciales en más de 2 ocasiones.

En cuanto al conocimiento de la ubicación del centro de la ciudad, un $47 \%$ de los encuestados manifestaron no saber dónde se encuentra, un $21 \%$ indicó que se sitúa en la Plaza Mayor y un 11 \% en puerta de Sol o cerca del Aeropuerto. El resto de los encuestados iniciales asociaron el centro con otros atractivos puntuales como Atocha o zonales, como el barrio de Salamanca.

Respecto a los lugares situados alrededor de la ciudad, los turistas conocen sobre todo Toledo ( $45 \%$ ).

2) Análisis de los mapas mentales

Un $16 \%$ de los encuestados, al llegar no dibujó ningún mapa, y las representaciones se caracterizaron en general por reflejar un nivel de conocimiento mínimo del destino turístico. Debido al escaso número de elementos contenidos en la mayoría de estos mapas no se profundizó en su análisis. En el Anexo 16 se incluyen todos ellos.

3) Identificación de fotografías de atractivos turísticos y ubicación en un $\underline{\text { mapa }}$

Las fotografías del estadio Santiago Bernabéu y el Palacio Real fueron las más reconocidas (40\%) y las que menos las del Rastro y la Calle Alcalá (14\%). Cabe destacar que, todos turistas que identificaron el Santiago Bernabéu también lo ubicaron en el mapa, mientras que ninguno de los que identificaron el Palacio Real supieron localizarlo (Anexo 15, Figura A38). Este hecho se debe quizás a la localización aislada del estadio y a su forma y color fácilmente diferenciable en el mapa, frente a los del Palacio Real (Anexo 10, pregunta 13).

En cuanto a los medios de transporte que los turistas tenían previsto utilizar durante su visita, estos manifestaron la intención de desplazarse, en primer lugar, en metro y como segunda opción "a pie" (Anexo 15, Figura A39).

\section{- Durante la visita:}

El motivo del viaje, el grupo y los intereses son factores que han sido considerados en el pre-viaje y que continúan repercutiendo a lo largo de la visita. A continuación se incluye un resumen los datos recogidos sobre los factores que 
inciden específicamente durante la visita y en el Anexo 17 pueden consultarse más detalles.

Un poco más de la mitad de los encuestados permanecieron entre 3 y 6 días (55\%), un $26 \%$ lo hizo más de 6 días y el resto tuvo una estancia de 2 días (19\%). El conocimiento que reflejan los turistas después de su visita, aunque superior al registrado antes de la estancia, sigue siendo escaso:

1) y 2) Análisis de los mapas mentales y de la información recopilada en forma de texto.

I. Atractivos turísticos puntuales.

En los mapas se identificaron un total de 80 atractivos diferentes y de 323 ocurrencias, frente a los 56 atractivos referenciados 268 veces en forma de texto. La siguiente tabla contiene los atractivos más frecuentes, considerando las repeticiones agregadas de los elementos incluidos en los mapas mentales y en forma de texto. El Anexo 17 (Tabla A3) incluye el listado completo desagregado.

\section{Atractivos turísticos puntuales}

Sol

Palacio Real

Parque del Retiro

Plaza Mavor

Museo del Prado

Museo Reina Sofía

Estadio Santiago Bernabéu

Puerta de Alcalá

Plaza de Cibeles

Templo de Debod

Catedral de la Almudena

Plaza de España

Atocha

Estadio Vicente Calderón

Mercado de San Miguel

Jardín Botánico

Ayuntamiento

Museo Thyssen-Bornemisza

Teatro Real

Caixa Fórum

Jardines de Sabatini

Callao

Ventas

\section{Repeticiones en mapa y}

56

56

47

47

42

27

26

24

19

18

16

16

13

12

11

10

10

8

7

7

7

7

6

Tabla 4.4: Atractivos turísticos puntuales de Madrid con más de 5 repeticiones (entre mapas y textos). 
Cabe destacar la dualidad perceptiva de algunas infraestructuras de transporte, cuyo conocimiento se asocia a su servicio y también a otro interés turístico complementario. Este es el caso del intercambiador de Príncipe Pío, que alberga un centro comercial y del intercambiador de Atocha, con un jardín tropical (Figura 4.8).

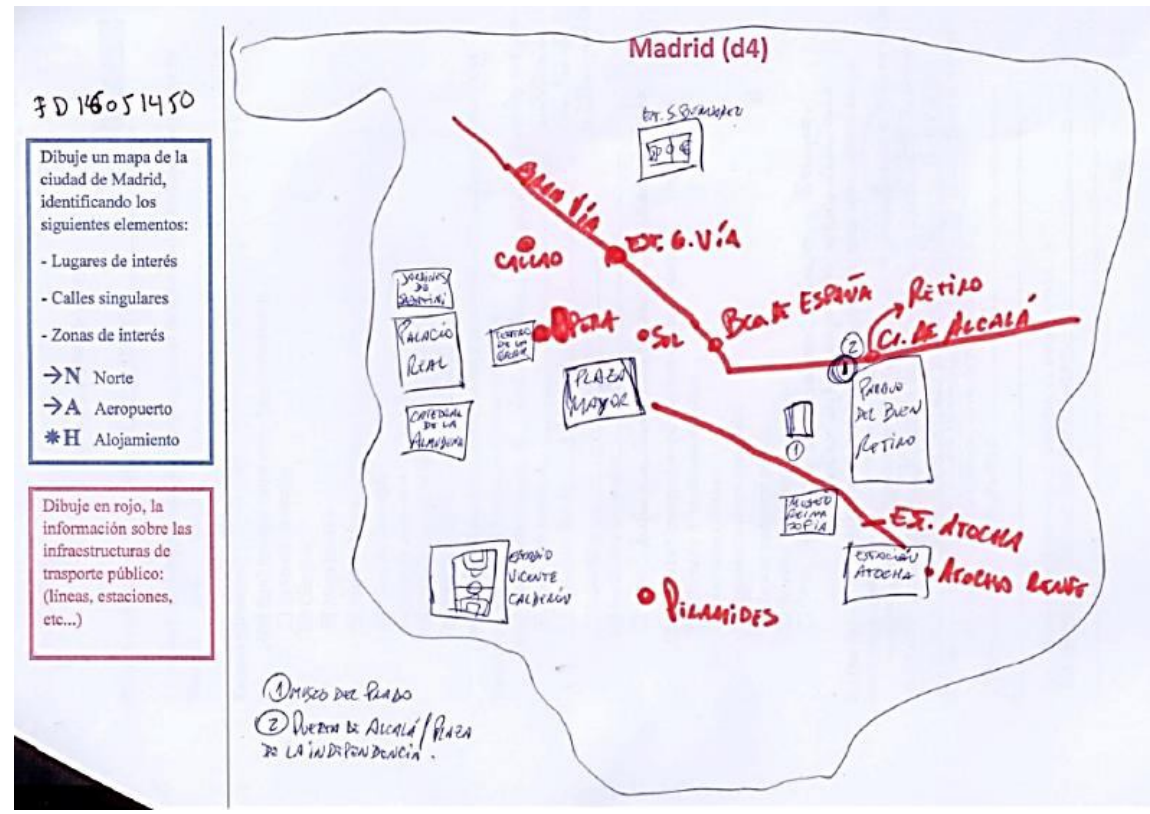

Figura 4.8: Mapa mental donde la Estación de Atocha aparece como atractivo turístico (color azul) y como estación (color rojo).

También se detectaron casos en los que un mismo atractivo recibió distintas denominaciones, como por ejemplo el Palacio de Cibeles, identificado por los turistas como Palacio de Comunicaciones, "Ayuntamiento" o "Correos". Posiblemente debido a que los mapas disponibles, denominan al citado atractivo de diversas maneras.

Para poder caracterizar la coherencia del conocimiento manifestado por los turistas acerca de los atractivos puntuales, se analizó las ocasiones en las que un atractivo puntual se registra de forma gráfica y textual en un mismo cuestionario. Como resultado, se obtuvo que un mismo atractivo aparece 106 ocasiones en ambos modos, lo que representa un $51 \%$ de los atractivos presentes en los mapas y el $62 \%$ de los registrados en forma de texto.

II) Ejes de Madrid.

El número de ejes en los mapas y en forma de texto es considerablemente inferior al número de atractivos puntuales. Se registraron un total de 29 calles distintas, de la cuales 19 aparecieron un total de 48 veces en los mapas; frente a las 22 , repetidas 44 veces en forma de texto. A continuación se incluye el listado de ejes con 3 o más repeticiones, considerando las ocurrencias agregadas en los mapas y en forma de texto. En el Anexo 17, Tabla A5 se puede consultar el listado completo desagregado. 


\section{Ejes}

Gran Vía

Paseo del Prado

Alcalá

Arenal

Princesa

Castellana

Huertas

Paseo de Recoletos

\section{Repeticiones en mapa y texto}

40

6

4

4

4

3

3

3

Tabla 4.5: Atractivos turísticos lineales de Madrid con más de 3 repeticiones (entre mapas y textos).

Destaca la calle Gran Vía sobre el resto. En segundo lugar el Paseo del Prado, que en los mapas se percibe con una interrupción en medio (la plaza de Neptuno) y con los nodos de Atocha y Cibeles (Figura 4.9a). De este eje salen, en ocasiones, otros hacia el centro cuya conexión se pierde (calle Huertas) (Figura 4.9b). En torno al Paseo del Prado suelen aparecer elementos puntuales como el Museo del Prado, Museo Reina Sofía, Caixa Fórum, Museo Thyssen-Bornemisza y el Jardín Botánico (Figura 4.10).

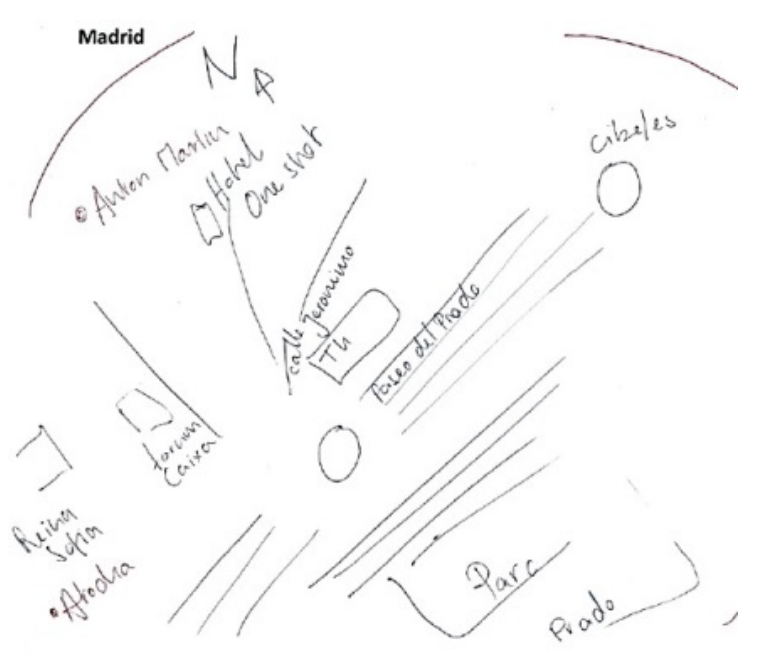

a

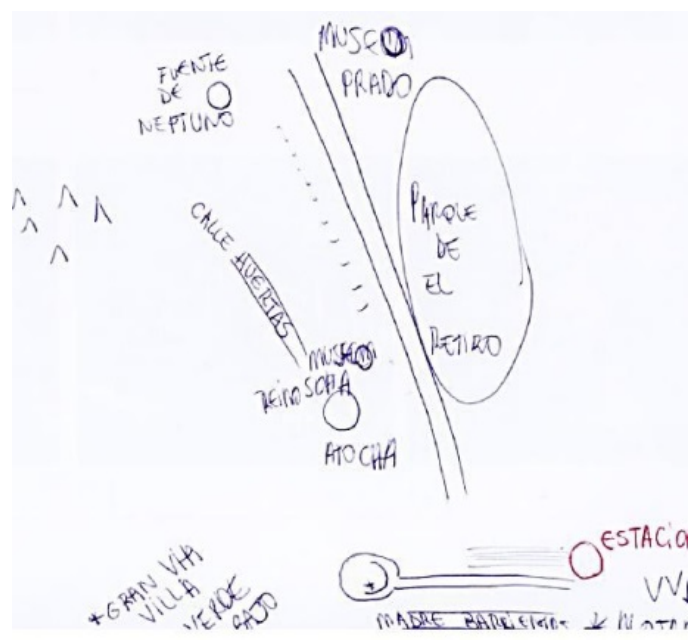

b

Figura 4.9: Mapas mentales que ilustran la presencia del eje del Paseo del Prado. 


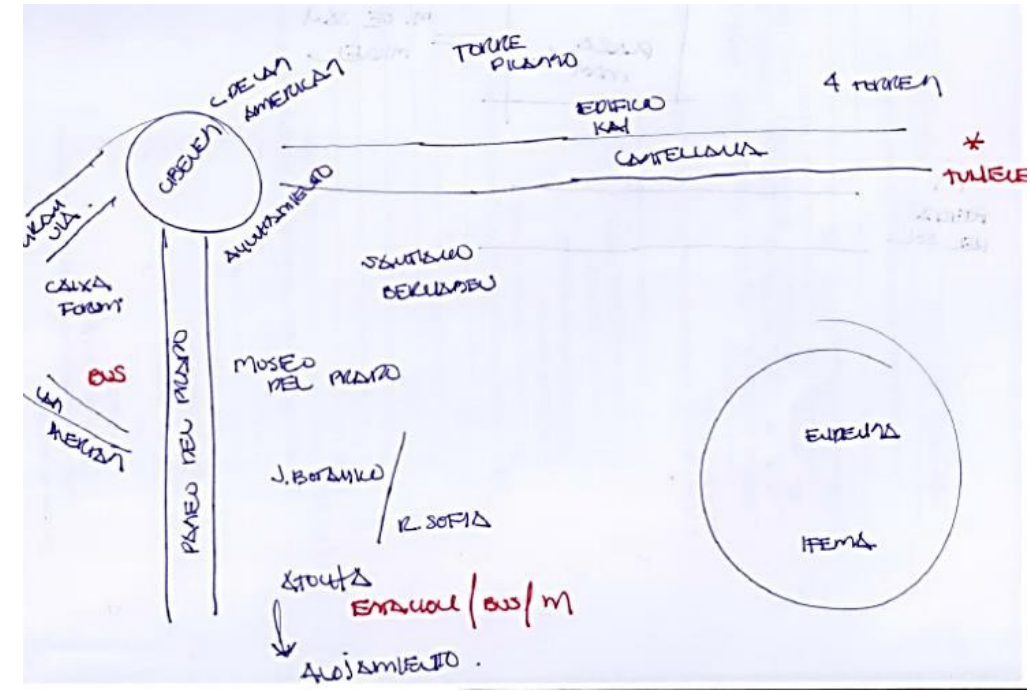

Figura 4.10: Mapa mental que ilustra la presencia del eje del Paseo del Prado y un gran número de atractivos puntuales en su entorno.

Por otro lado, la Gran Vía, aunque se conecte con la Plaza de España y con el edificio de Metrópolis, sin que se perciba en muchas ocasiones el quiebro en Callao, en algunos casos se prolonga hasta Cibeles (Figura 4.11a) y hasta Sol (Figura 4.11b). Dejando patente el reducido número de mapas que incluyen la calle Alcalá (3).

a
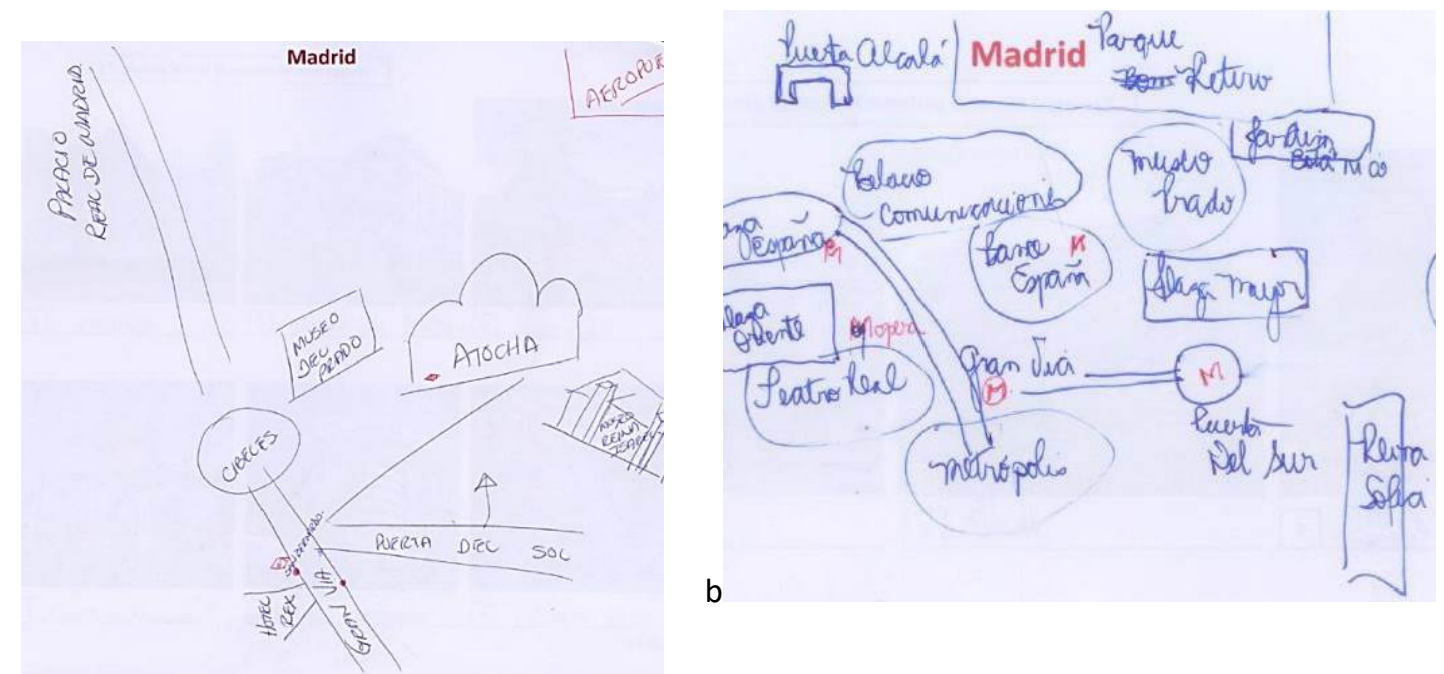

Figura 4.11: Mapas mentales que incluyen diferentes concepciones de la Gran Vía.

La ausencia generalizada de ejes en los mapas mentales denota el hecho de que un gran número de atractivos turísticos puntuales aparezcan representados como elementos sin conectar. Este suele ser el caso del conjunto situado al oeste de Sol, formado por el Palacio Real y la Catedral de la Almudena, a veces acompañados por el Campo del Moro y los Jardines de Sabatini y, en otras ocasiones, unidos a la Plaza de Oriente-Teatro Real-Ópera (Figura 4.12). 


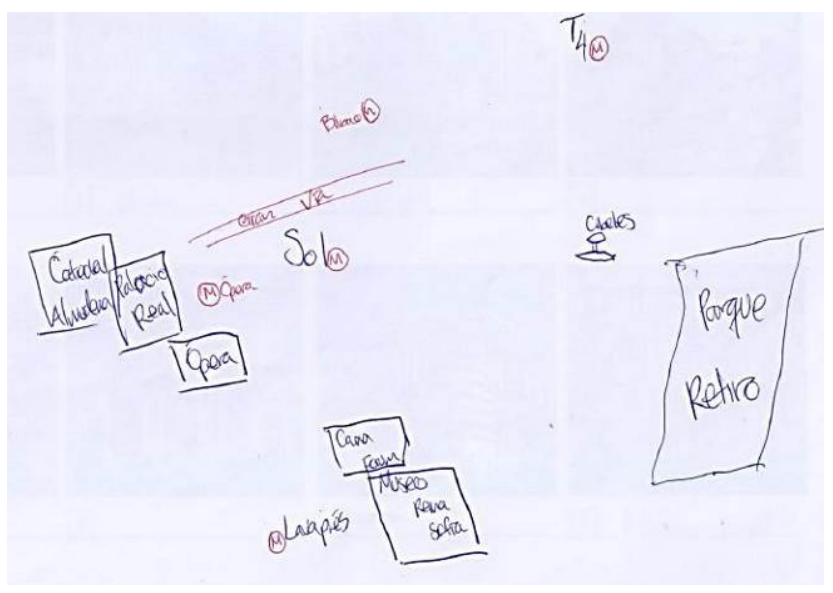

Figura 4.12: Mapas mentales con escasa presencia de ejes y atractivos puntuales sueltos.

Finalmente, destacan varios casos de mapas en los que los únicos ejes que aparecen son líneas de metro que sirven de "esqueleto" para referenciar la ubicación de atractivos puntuales (Figura 4.16 a y b).

El mapa de la Figura 4.13 ilustra los atractivos turísticos puntuales y ejes de referencia de los turistas internacionales encuestados, fruto de su experiencia en Madrid.

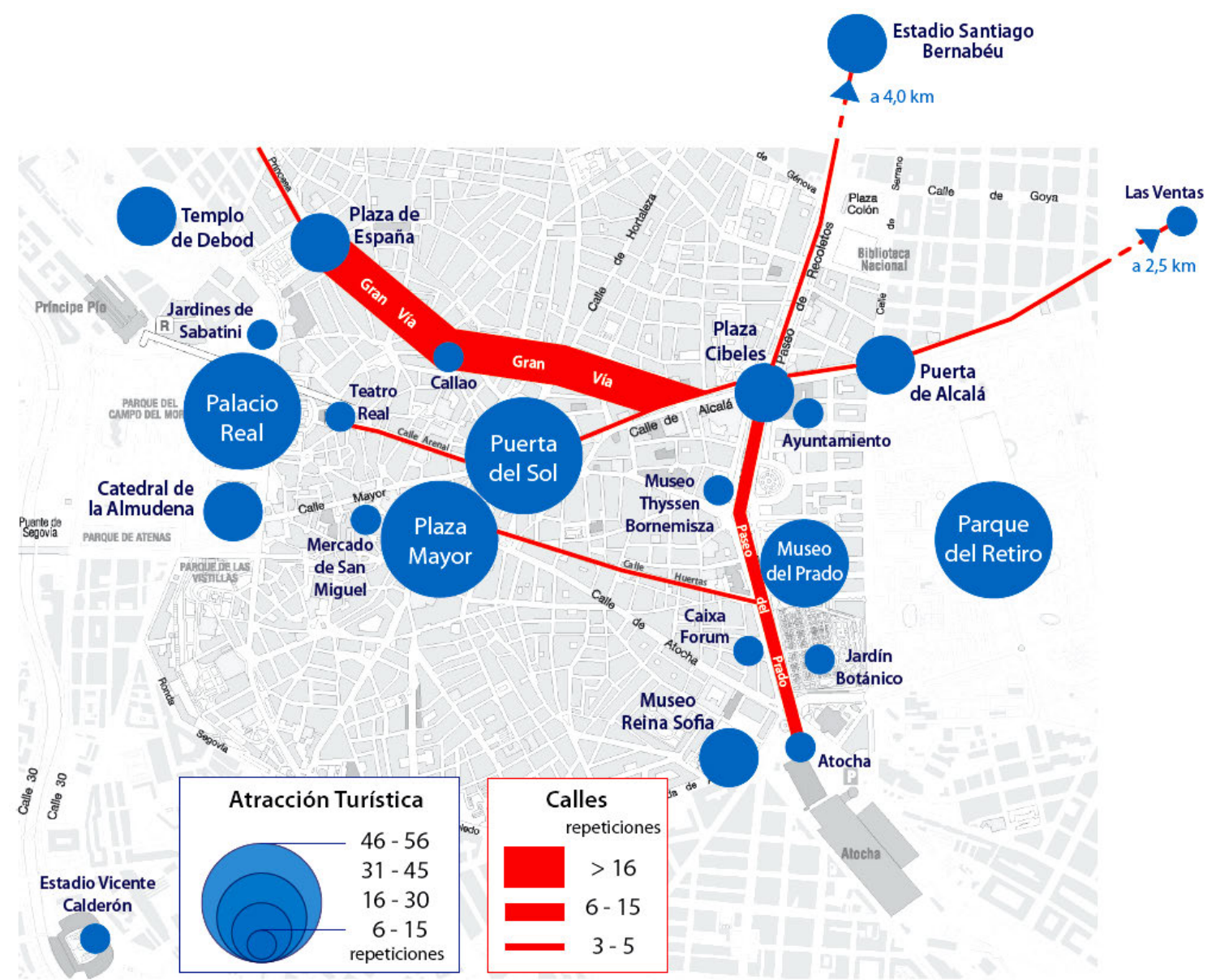

Figura 4.13: Atractivos turísticos puntuales y ejes de Madrid más conocidos por los turistas tras su visita. 


\section{III) Zonas turísticas de Madrid}

La información sobre zonas y barrios tanto, en los mapas mentales, como en forma de texto, suman un total de 24 elementos diferentes. Se da la peculiaridad de que algunos no son topónimos zonales de barrio o distrito, sino que obedecen a una concepción funcional de área de la ciudad, como por ejemplo: compras, museos, cultura o ambiente nocturno (Figura 4.14 y Tabla 4.6).

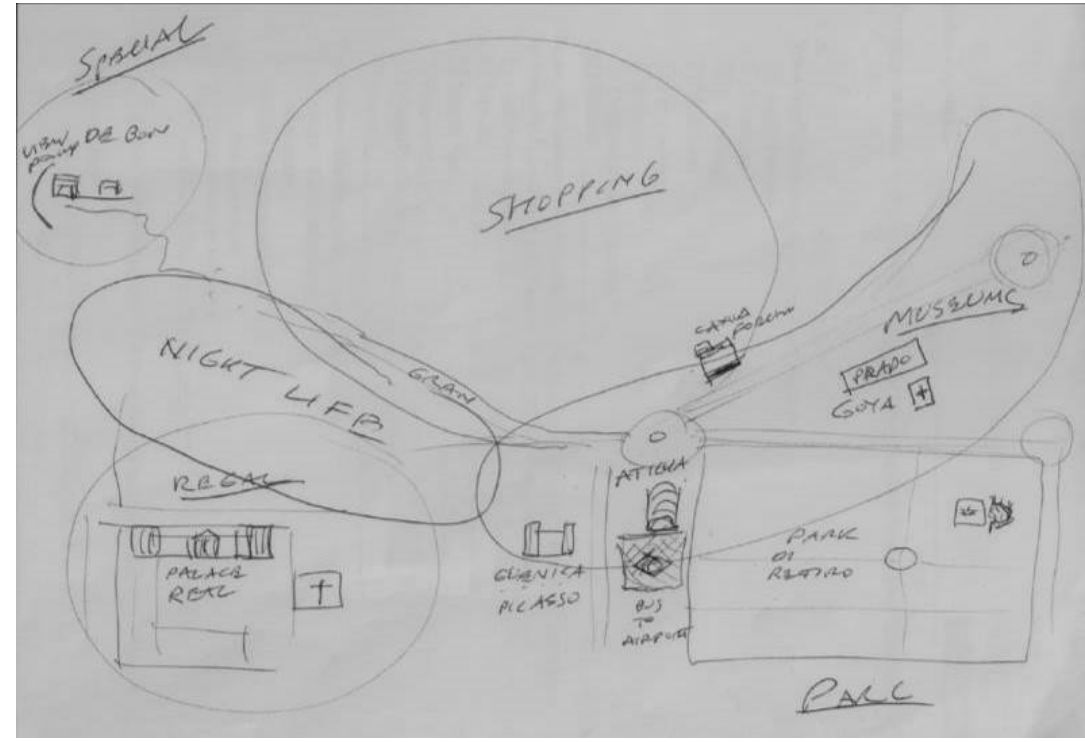

Figura 4.14: Mapa mental que incluye zonas de la ciudad caracterizadas por las actividades turística realizadas en ellas.

A continuación se incluye el listado de las zonas turísticas de la ciudad, considerando las ocurrencias agregadas en los mapas y en forma de texto. En el Anexo 17 (Tabla A6) se puede consultar el listado completo y desagregado.

$\begin{array}{lc}\text { Zonas turísticas } & \text { Repeticiones en mapa y texto } \\ \text { Centro } & 31 \\ \text { La Latina } & 8 \\ \text { "Museos" } & 6 \\ \text { Salamanca } & 4 \\ \text { Malasaña } & 4 \\ \text { Lavapiés } & 3 \\ \text { Chueca } & 2 \\ \text { Cuzco } & 2 \\ \text { Tribunal } & 2 \\ \text { "Compras" } & 2 \\ \text { Opera } & 2\end{array}$

Tabla 4.6: Zonas turísticas de Madrid con más de 2 repeticiones (entre mapas y textos). 
A diferencia de lo que ocurre con los atractivos puntuales y los ejes, el número de repeticiones de los registros de zonas en forma de texto (55) es considerablemente superior al gráfico (24). Este hecho puede deberse a la dificultad de definir perímetros zonales en los mapas mentales, por falta de conocimiento de su distribución espacial. Sin embargo, el número de elementos zonales diferentes, identificados por ambos medios, es muy similar: 15 en los mapas y 19 en forma de texto.

IV) Centro de Madrid.

El $32 \%$ de los turistas encuestados manifestaron no saber dónde se encuentra el centro de la ciudad una vez finalizada su visita. Este porcentaje es levemente inferior al de los turistas recién llegados (47\%).

El resto de los turistas consultados al finalizar su visita, sitúan el centro de la ciudad en la Puerta del Sol ( $40 \%$ ) o en algún lugar destacado en sus proximidades (Plaza Mayor, $12 \%$ ).

El centro de la ciudad se asocia en algunos casos a un interés específico (museos-El Prado), a infraestructuras de transporte (Atocha o incluso Vodafone-Sol) o a atractivos turísticos próximos al lugar de alojamiento (Plaza de España). También hay turistas que reflejan la concepción de un "doble" centro: uno asociado la faceta turística de la ciudad y otro a la de sus desplazamientos. Es el caso, por ejemplo, de un turista que indica haber visitado la "zona centro-sol" y que luego señala que el centro de la ciudad está en Atocha. Otro turista, que se alojó próximo al Aeropuerto, dibujó su mapa con foco en la boca de metro Callao (junto a la que escribe la palabra "start") pero, por otro lado, identificó Sol como centro de la ciudad (Figura 4.15).

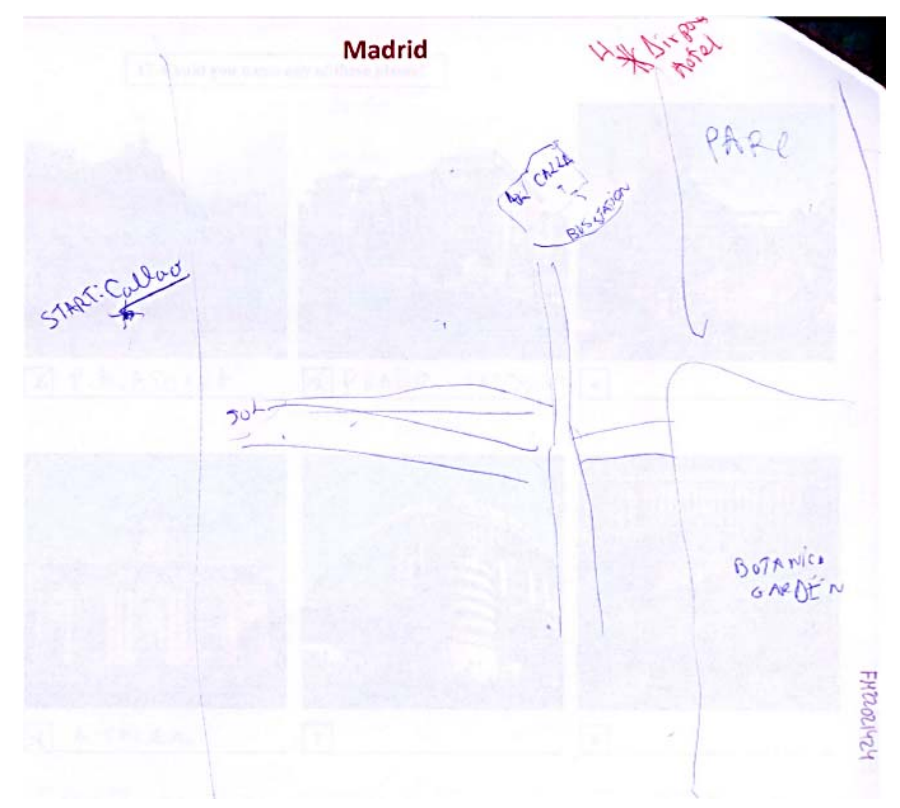

Figura 4.15: Mapa mental que incluye una infraestructura de transporte ("Start: Callao") como elemento clave en su experiencia cognitivo-espacial de Madrid. 
En cuanto a la percepción de la extensión de la "Zona Centro", los datos reflejan que es relativamente amplia, ya que, por ejemplo turistas que se alojan junto al metro Gregorio Marañón consideran hacerlo en el "centro".

V) Lugares de interés en los alrededores de Madrid.

Toledo es el lugar más conocido, mencionado por el $48 \%$ de los encuestados (Tabla 4.7). Tras Toledo y (con mucho menor nivel de incidencia), se encuentran localidades de la comunidad, ciudades de provincias próximas (Ávila y Segovia) y otras más alejadas como Zaragoza, Córdoba, San Sebastián y Sevilla. Para más detalles puede consultarse el Anexo 17 (Tabla A7).

$\begin{array}{cc}\text { Lugares de interés turístico alrededor de Madrid } & \text { Repeticiones } \\ \text { Toledo } & 23 \\ \text { El Escorial } & 4 \\ \text { Sierra de Guadarrama } & 4 \\ \text { Alcalá de Henares } & 3 \\ \text { Ávila } & 3\end{array}$

Tabla 4.7: Lugares de interés turístico alrededor de Madrid conocidos por los turistas encuestados al final de su visita (ubicaciones con más de 2 repeticiones).

En cuanto al conocimiento de las infraestructuras de transporte reflejado en los mapas mentales, el metro destaca por encima del resto. La estación de Sol es la que más se repite, seguida de Atocha y el Aeropuerto. En el Anexo 17 (Tabla A8) se incluyen más detalles.

\section{Estaciones de metro}

Sol

Atocha

Aeropuerto

Gran Vía

Opera

Callao

La Latina

\section{Repeticiones en el mapa}

19

12

11

8

6

5

4

Tabla 4.8: Estaciones de metro con más de 3 repeticiones en los mapas mentales de los cuestionarios finales.

Los turistas identifican las líneas de metro en sus mapas mentales a través de su número y nunca mediante el color. En algunos casos el uso de este medio de transporte ha incidido significativamente en la conceptualización de Madrid, como así lo reflejan los mapas en los que el espacio urbano se articula a través de las líneas utilizadas (Figura 4.16 a y b). 
También existen mapas en los que se incluyen infraestructuras de transporte asociadas al lugar de alojamiento $\mathrm{y}$ a intereses específicos (Metro Santiago Bernabéu).

Por otro lado, llama la atención la reducida presencia de líneas de autobús ( 2 ocurrencias) y de cercanías (1).
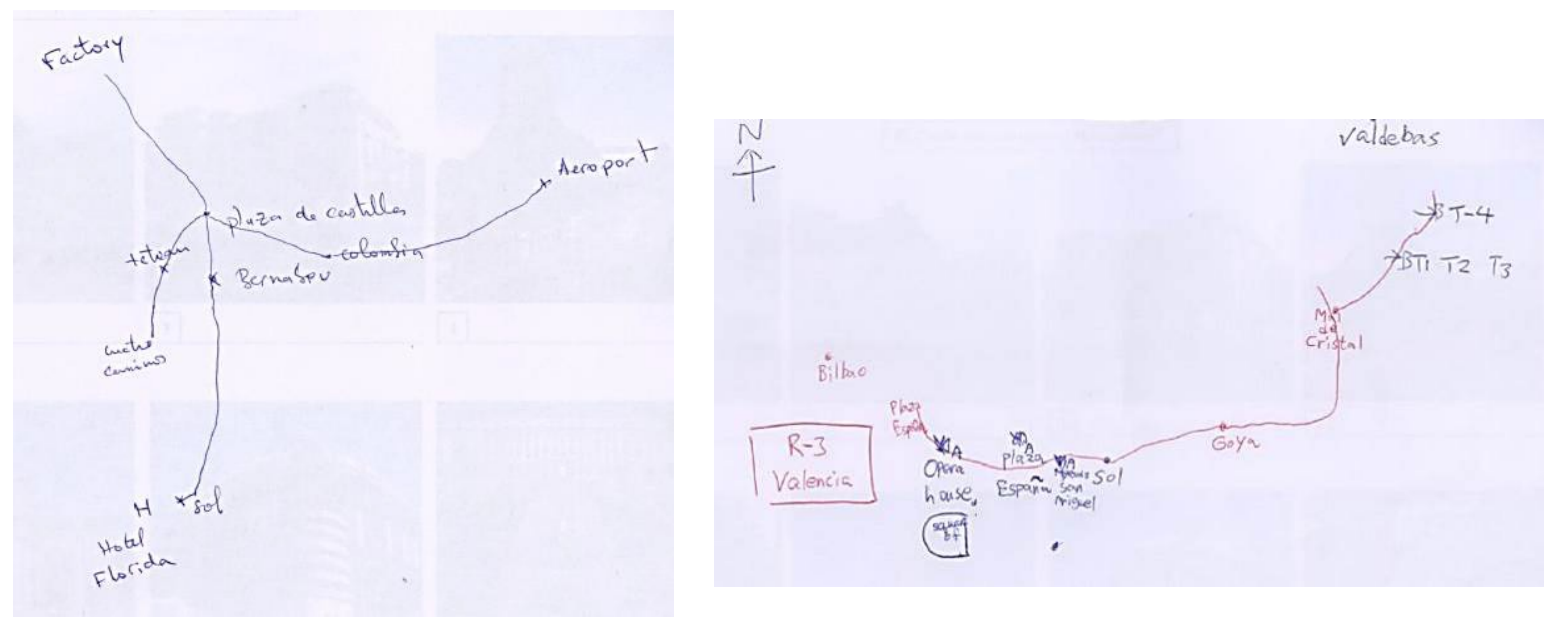

Figura 4.16: Mapas mentales cuyos ejes son líneas de metro: a) varias líneas de metro coordinadas y b) varios tramos de líneas que parecen formar parte de un mismo recorrido.

Tras finalizar la visita, el $60 \%$ de los turistas encuestados consideran los desplazamientos parte de la misma, el $20 \%$ son neutrales y el resto no los consideran parte de ella.

Finalmente, los turistas encuestados describieron Madrid como acogedora, hermosa e increíble y, el $88 \%$ de ellos, consideraron que la experiencia había cubierto sus expectativas en grado alto o muy alto. Al final del Anexo 17 se incluyen más detalles.

\section{T 2.3 Indagar sobre los mapas que utilizan los turistas}

A continuación se incluye un resumen de la información recopilada de los turistas sobre los productos cartográficos y mapas utilizados, los soportes o fuentes y el tipo de información geográfica consultada. El detalle se puede consultar en el Anexo 19.

\section{- Pre-viaje}

Un $13 \%$ de los turistas no utilizaron ningún producto cartográfico antes de llegar a Madrid y, los que sí lo hicieron, manejaron principalmente mapas turísticos (60\%) y fotografías (60\%).

Internet fue la fuente de información más usada (80\%), seguida de los soportes en papel (53 \%) y los familiares y amigos ( $40 \%$ ). En cuanto a la información consulta, en primer lugar buscaron la ubicación de atractivos y rutas de transporte (ambas con un $47 \%$ ). Cabe destacar, que el 47 \% de los turistas seleccionó la opción 
"otros tipos de información consultada" y que, de ellos, un 20 \% indicó la "búsqueda de la ubicación del alojamiento".

\section{- Durante la visita}

Un $15 \%$ de los turistas manifestaron no utilizar ningún producto cartográfico y, los que sí lo hicieron, utilizaron principalmente el mapa de metro (76 \%) y el mapa turístico (65\%). Los mapas se consultaron mayoritariamente en papel (69\%), seguidos de los utilizados en internet ( $47 \%$ ) y a través de aplicaciones móviles (30 $\%)$. Destaca que un $88 \%$ de los turistas que manejaron mapas en aplicaciones móviles, también usaron mapas en papel.

La información más consultada durante la visita es la ubicación de atractivos turísticos (65\%) seguida de rutas de transporte (49\%).

A través de los diarios se han detectado necesidades de información durante el viaje asociadas a preguntas del tipo: ¿cómo llegar a una determinada calle o lugar de interés (atractivo turístico, alojamiento, aeropuerto,...)?; ¿cuánto tiempo se tarda en llegar a un determinado lugar?; ¿dónde estoy?; ¿qué edificio está frente a mí?; ¿qué atractivos turísticos hay a mi alrededor?; quiero ir a un determinado lugar o tener acceso a un servicio específico (un parque tranquilo, un restaurante vegetariano...) ¿qué opciones tengo a mi alrededor?; tengo previsto ir a un lugar de interés; ¿qué otros atractivos próximos podría visitar ya que estoy allí?; guíame para llegar lo más rápido posible a un determinado lugar o para hacerlo a través de un recorrido que me permita disfrutar de atractivos afines a mis intereses y ¿dónde he estado hasta ahora y a que otros lugares puedo ir?.

\section{T 2.4 Indagar sobre el espacio geográfico asociado a la experiencia}

En esta tarea se analizan factores físicos que inciden en las actividades que realiza el turista, como las infraestructuras de transportes que utiliza y el lugar donde se aloja y cómo estos condicionan el espacio geográfico asociado a su experiencia de la ciudad.

\section{- Infraestructuras de transporte}

Respecto a los medios de transporte utilizados por los turistas, la Figura 4.17 ilustra que se desplazaron principalmente caminando y en metro, y que aunque utilizaron otros medios de transporte, la intensidad de uso fue significativamente inferior. 


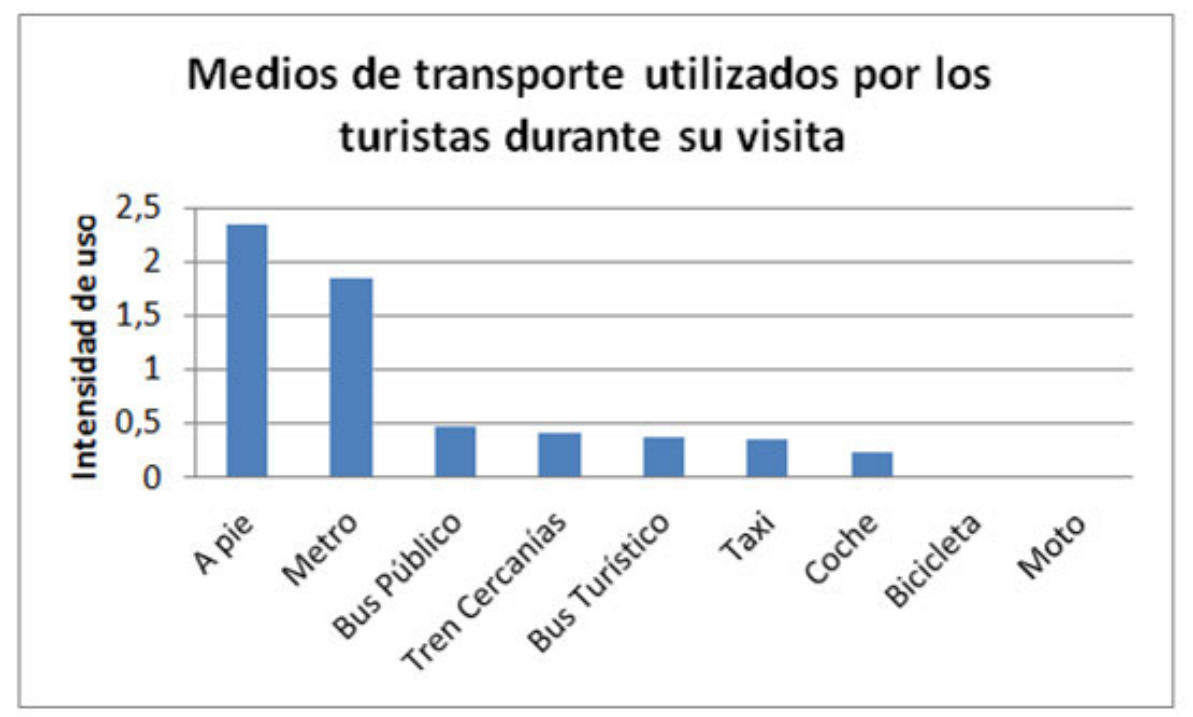

Figura 4.17: Medios de transporte que han utilizado los turistas encuestados durante su visita. Gráfica obtenida a partir de datos sobre los tres medios de transporte más utilizados por cada turista, ponderados por su intensidad de uso (peso 1 al que menos ha utilizado y peso 3 al más utilizado por cada turista).

Varios turistas que participaron en esta investigación valoraron las infraestructuras de transporte de la ciudad y destacaron favorablemente el servicio del bus turístico. Sin embargo, se identificaron las siguientes incidencias asociadas a su uso: dificultades para identificar el sentido de circulación de los trenes en las líneas del metro y de autobuses; información deficiente para el uso multimodal de transportes, dificultades al identificar estaciones con el mismo nombre en diferentes mapas por ejemplo, Nuevos Ministerios en el mapa de cercanías y en el de metro; dificultades para identificar la misma parada de metro en distintos mapas, por ejemplo, Príncipe Pío en el mapa turístico y en el de metro; problemas de desorientación para cambiar de línea de cercanías en intercambiadores como Atocha, ya que en los corredores no hay mapas y la información suministrada en forma de texto no resulta clara; dificultades para obtener información sobre las líneas de autobuses $y$, en algunos casos, los nombres de las estaciones resultan confusos, como ocurre en la parada de metro "Sierra de Guadalupe" y la estación de cercanías "Vallecas", que están ubicadas en el mismo lugar. También se recogieron sugerencias de mejora en el suministro de la información asociada al uso de medios de transporte, como por ejemplo: poder saber qué lugares de interés (museos, parques) o eventos (concierto, actividad gratuita) hay entorno a estaciones y paradas de metro y tener acceso a propuestas de rutas personalizadas para un determinado lapso de tiempo, en base a una serie de criterios específicos (actividades in-door o al aire libre, por debajo de un presupuesto,...).

\section{- Ubicación del alojamiento de los turistas}

El $34 \%$ de los encuestados no conocía la ubicación de su alojamiento al finalizar su visita y del $66 \%$ restante, un $42 \%$ se alojó en el distrito Centro y el resto lo hicieron, de una forma muy distribuida, en distintos distritos de la ciudad. La 
primacía del distrito Centro a la hora de elegir el lugar de alojamiento de los turistas encuestados es coherente con los datos recabados a través de fuentes documentales, en la Fase 1 (Tarea 1.4).

\subsubsection{Resultado de la exploración de la experiencia turística}

1) ¿Cuál es el contexto de las actividades que realizan los turistas?

La mayoría de los turistas vienen a Madrid de vacaciones, aunque también lo hacen para visitar a familiares y amigos, por trabajo y aprovechando la escala a otro destino. Destaca el bajo número de turistas encuestados que vinieron por motivos profesionales $5 \%$, frente al $20 \%$, según las fuentes documentales consultadas. EI principal interés de los turistas es la oferta cultural, seguida de la gastronomía, los parques y jardines, las compras y los espectáculos. En cuanto al grupo de viaje, la mayoría viene acompañado (pero no en un grupo organizado) y, según los datos recabados en esta investigación, un $17 \%$ lo hace solo, mientras que en base a fuentes documentales este porcentaje asciende al $48 \%$. Los niveles de planificación del viaje por parte de los turistas son heterogéneos, destacando que un $44 \%$ indica no planear apenas la visita. Y la duración de la estancia media de los turistas encuestados fue de 5 días, frente a los 7 de las fuentes documentales. La mayoría se alojó en el distrito centro.

2) ¿Cómo son los turistas a los que van destinados los mapas a diseñar?

Los turistas internacionales son relativamente jóvenes (menores de 45 años), con un alto nivel de estudios y homogéneo en género. Tienen una experiencia relativamente alta viajando a grandes ciudades, la mayoría utiliza información geográfica únicamente a nivel de usuario $y$, según las fuentes documentales, su presupuesto suele ser alto (159€ medios diarios).

3) ¿Cómo son los mapas que utilizan los turistas y cómo es su experiencia?

Antes de llegar a Madrid, los turistas utilizan, sobre todo, el mapa de metro y el turístico y lo hacen a través de internet, de guías, de folletos en papel. Sin embargo, un $13 \%$ manifestó no consultar ningún tipo de información geográfica durante el pre-viaje, lo que puede ser debido a la falta de interés o tiempo, a la facilidad de acceso a la información en destino, evitando tener que planificar los viajes con antelación o bien a que muchos turistas visitan la ciudad acompañados y por ello no consideran que sea necesario hacerlo. Todas estas razones pueden ser, parcialmente, las causas del bajo nivel de conocimiento espacial que tienen los turistas de la ciudad, antes de llegar a la misma. También pueden considerarse el motivo de algunas de las incidencias detectadas en su experiencia (reserva por error de un alojamiento lejos del centro o el innecesario alquiler de un coche para desplazarse durante la visita).

La experiencia turística de Madrid se concentra en su distrito Centro y, aunque un $15 \%$ de los turistas manifiesta no utilizar ningún producto cartográfico durante la visita, los que sí lo hacen, suelen usar más de uno. El soporte más 
utilizado en esta etapa es el papel. Aunque previsiblemente, en un futuro próximo, el uso de aplicaciones móviles y el acceso a fuentes de información on-line será mucho más extensivo, en un futuro próximo. Para satisfacer sus necesidades de información geográfica, el turista necesita utilizar varios productos cartográficos y combinar diferentes fuentes de información (mapas en papel, internet, aplicaciones móviles, servicios de información turística) lo que pone de manifiesto la necesidad de facilitarles un acceso más sencillo y centralizado a la información, que abarque todo el espacio geográfico del destino (ciudad y todo los lugares próximos de interés). Por otro lado, la falta de coherencia y de claridad en la información suministrada a través de los mapas, incide en la experiencia del turista (diferentes denominaciones de un mismo atractivo turístico, contenido publicitario en los mapas, dificultades al utilizar medios de transportes...). Además, la amplia oferta turística de la ciudad y la diversidad de perfiles de turistas, pone en evidencia la conveniencia de un suministro personalizado de información que tenga en cuenta aspectos como: la ubicación del alojamiento, la duración de la estancia, el ambiente en el que se encuentre en cada momento (lugar, meteorología, actividad que está realizando...) y sus intereses, entre otros. Finalmente, cabe destacar que el conocimiento de los turistas acerca de Madrid una vez finalizada su visita, aunque mayor que al inicio de la misma, sigue siendo considerablemente bajo. Este hecho se refleja en los mapas mentales turistas, en los que destaca la presencia de atractivos puntuales, por encima de ejes (calles y líneas de transporte) y de zonas.

\subsection{Fase 3: Síntesis de la experiencia de los turistas}

Tras realizar la exploración de la experiencia turística, se aborda el modelado de las interacciones entre el turista, el ambiente en el que desarrolla su experiencia y los mapas que utilizan. Las preguntas planteadas en esta fase fueron (Figura 3.5): ¿cuáles serán los ambientes en los que los turistas utilizarán los mapas?; ¿cómo serán las experiencias de los turistas a las que los mapas darán soporte? y ¿cómo serán los mapas a diseñar?

Para responder a estas preguntas, se realizaron tres tareas de síntesis de la experiencia de los turistas, mediante análisis cualitativos de la información recopilada en la de exploración: 1) Sintetizar la interacción entre el turista y el ambiente en el que desarrolla su experiencia; 2) Sintetizar la interacción entre el turista y el mapa que da soporte a su experiencia y 3) Sintetizar la interacción entre el mapa y el ambiente en el que se desarrolla la experiencia.

Como resultado de estas tareas se han podido: identificar diferentes enfoques de la experiencia turística; definir perfiles de turistas, asociados a cada enfoque y los escenarios en los que los mapas darán soporte a sus experiencias cognitivas, así como concretar la concepción de los mapas como interfaz. 


\subsubsection{Tareas de la Fase 3}

\section{T3.1 Identificación de los patrones de interacción entre el turista y el ambiente en el que se desarrolla su experiencia}

Esta tarea trata de responder a la pregunta ¿cómo abordan los turistas su experiencia?. Como resultado, se definieron tres enfoques de experiencia que aglutinan motivaciones, comportamientos y conceptualizaciones del espacio comunes a grupos de turistas.

Para llevar a cabo esta tarea, se contó con la colaboración de una geógrafa. Lo primero que se hizo fue evaluar los factores que condicionan las actividades de los turistas en base a los datos recopilados previamente (Tarea 2.2) y seleccionar los que más inciden en la experiencia turística. Estos factores fueron: el motivo del viaje, la duración de la visita, los intereses, el grupo de viaje, la forma de desplazarse durante la visita y el conocimiento turístico-geográfico de la ciudad (mapas mentales).

Una vez seleccionados los factores, sobre una copia de los mapas mentales, se incluyeron los datos extraídos de cada cuestionario. A continuación, se examinó individualmente el mapa y la información de los factores seleccionados. Cuando no se disponía de mapa se analizó todo el contenido del cuestionario.

Como resultado de la síntesis, se establecieron tres enfoques de la experiencia turística: explorador, guiado y condicionado. La Tabla 4.9 incluye la motivación o aspecto determinante de cada enfoque de la experiencia, así como el resto de información de detalle sobre los factores considerados para discernir cada enfoque. A continuación se incluye la descripción de cada uno de ellos:

\section{Explorador}

Las personas que abordan la experiencia desde este enfoque están interesadas en conocer la auténtica esencia de la ciudad. Viajan sobre todo de vacaciones y su visita incluye experiencias orientadas a la inmersión en la cultura local a través de actividades no dirigidas específicamente a turistas. En su visita incorporan algún atractivo turístico afín a sus intereses, que suelen ser más variados que el de los turistas con otros enfoques, y entre los que destaca una manifiesta atracción por la ciudad en sí misma y el estilo de vida local. Los turistas con este enfoque se caracterizan por viajar solos o acompañados, pero no en grupo organizado. Estos son los que más caminan al visitar la ciudad, aunque también utilizan el metro, así como el tren de cercanías y el autobús público. Sus mapas mentales se caracterizan por una concepción organizada de la ciudad en la que se articulan un elevado número de elementos (puntuales, ejes y zonas) en comparación con el resto de enfoques (Figura 4.18). 


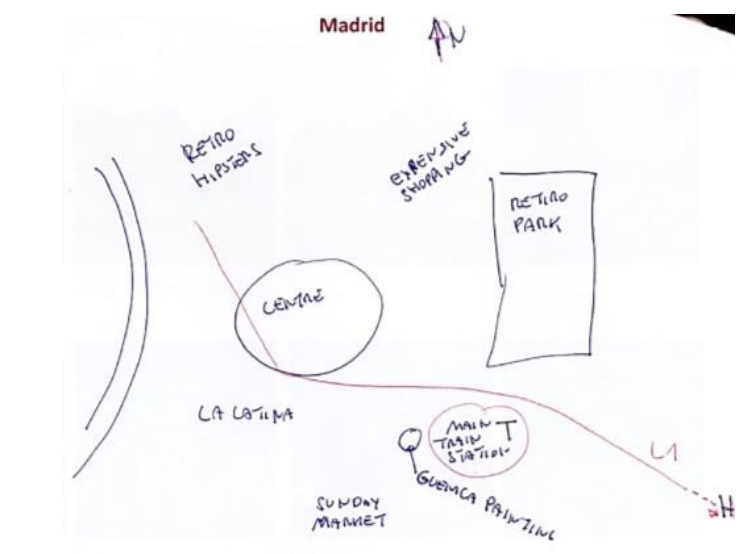

a

Figura 4.18: Mapas mentales de dos turistas con enfoque de experiencia de tipo explorador: a) al inicio de la visita y b) al finalizar la visita.

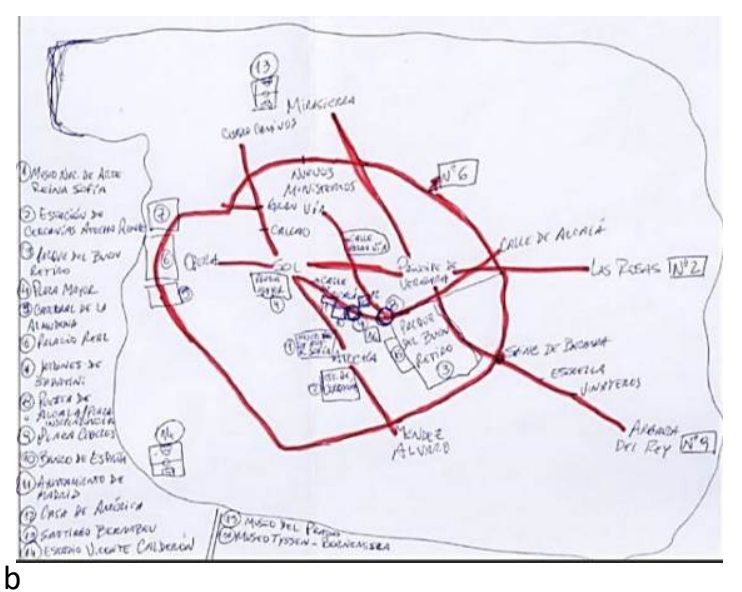

b

\section{Guiado}

Estas personas valoran, por encima de todo, la simplicidad y la facilidad. Vienen a Madrid principalmente por vacaciones o para visitar familiares o amigos, no viajan solos y se caracterizan por su inclinación a ser guiados, delegando la toma de decisiones en otro miembro del grupo de viaje (familiar, amigo local, acompañante, guía turístico,...). Los turistas con enfoque guiado pueden tener intereses más o menos variados y se desplazan por la ciudad principalmente caminando y en metro, aunque en menor medida también en autobús turístico, en taxi, en autobús público y en el coche particular de conocidos locales. Un alto porcentaje de ellos no dibujaron el mapa en su cuestionario ( $29 \%$ de los iniciales y $24 \%$ de los finales). Y sus mapas mentales se caracteriza por reflejar percepciones puntuales de la ciudad o asociadas a una o dos experiencias concretas, no relacionadas espacialmente, y por un reducido número de elementos puntuales, mientras que los ejes y zonas son prácticamente inexistentes (Figura 4.19).
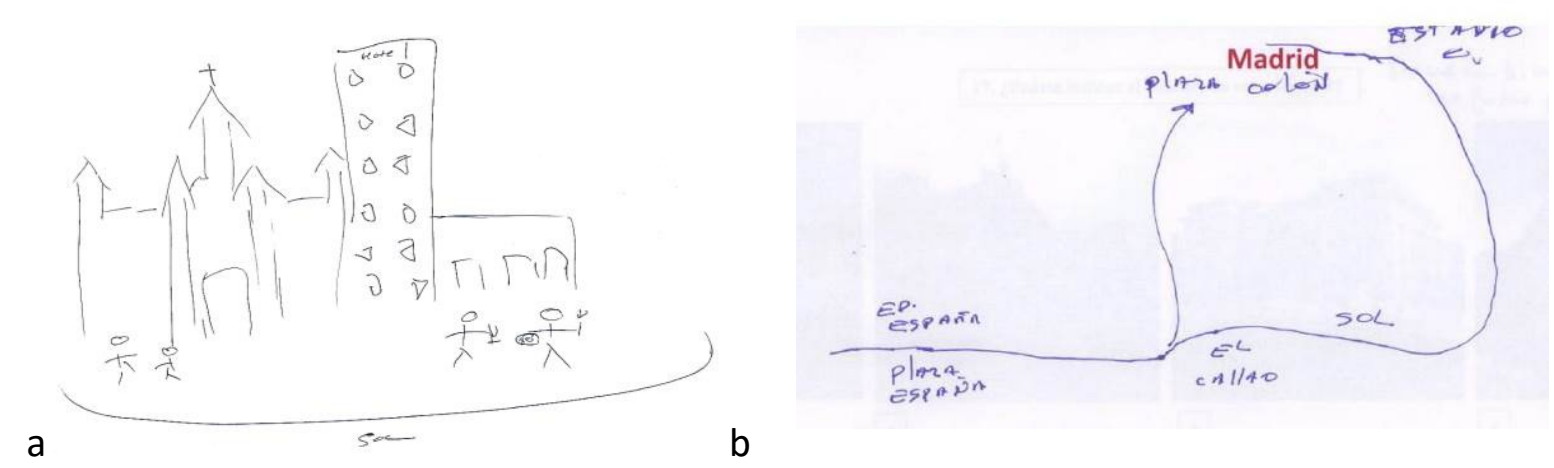

Figura 4.19: Mapas mentales de dos turistas con enfoques de experiencia de tipo guiado:

a) al inicio de la visita y b) al finalizar la visita. 


\section{Condicionado}

Su experiencia se caracteriza porque las fechas y/o los lugares del viaje están predeterminados. Estos "compromisos" pueden ser de tipo laboral o de estudios (asistir a una reunión, congreso o curso intensivo...), familiares (presenciar una boda) o incluso estar asociados a las propias vacaciones, si éstas fuesen motivadas por la asistencia a un evento deportivo (futbol) o condicionadas por un listado de lugares "obligatorios" que se desea ver por encima de todo. El motivo del viaje es más heterogéneo que el del resto (vacaciones, trabajo, formación...) y sus intereses pueden ser concretos o variados. La duración de su estancia es variada, aunque en un análisis de frecuencias destacan los que permanecen únicamente 2 días en la ciudad. Su grupo de viaje es muy heterogéneo (solos, en pareja, con familia o amigos), y sus experiencias pueden incluir comportamientos afines al enfoque explorador (dar un paseo por la ciudad buscando el contacto con lo local) o al guiado (recorrer la ciudad en el bus turístico) pero siempre que sus "obligaciones" queden cubiertas. Durante el viaje principalmente se desplazan caminando y en metro aunque también se mueven en tren de cercanías (como los exploradores) y en autobús turístico, taxi o en coche particular (como los guiados). Sus mapas mentales son "intermedios" en relación a los de los otros dos enfoques, abarcando representaciones de apariencia similar a las de los exploradores, con menos elementos; o a las de los guiados, con más elementos (Figura 4.20).
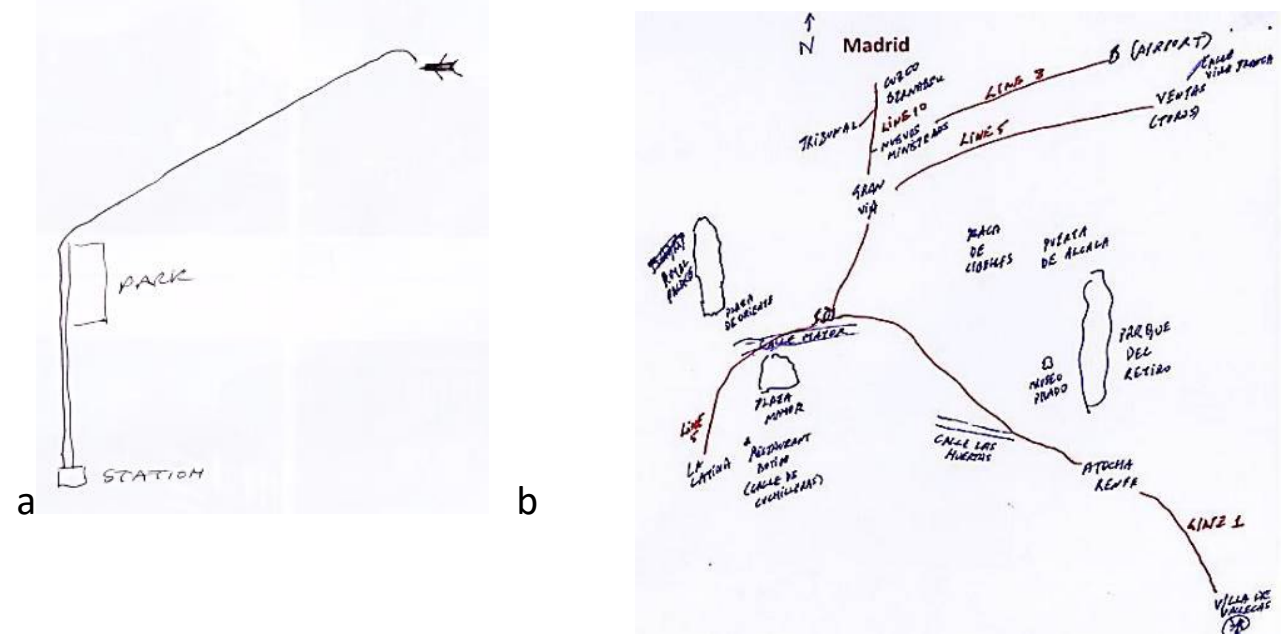

Figura 4.20: Mapas mentales de dos turistas con enfoques de experiencia de tipo condicionado: a) al inicio de la visita y b) al finalizar la visita.

Los tres enfoques de la experiencia turística se contrastaron con una profesional del turismo en Madrid, que lleva 10 años trabajando en contacto directo con los turistas.

Una vez agrupados los cuestionarios según el enfoque, el resultado fue:

-Exploradores: 6 cuestionarios iniciales y 11 finales.

-Guiados: 7 cuestionarios iniciales y 21 finales.

-Condicionados: 4 cuestionarios iniciales y 21 finales. 


\begin{tabular}{|c|c|c|c|c|c|c|c|}
\hline $\begin{array}{r}\text { Enfoques de } \\
\text { la experiencia }\end{array}$ & \begin{tabular}{|l}
$\frac{\text { Motivación o }}{\text { aspecto }}$ \\
$\frac{\text { determinante de }}{\text { la experiencia }}$ \\
turística
\end{tabular} & $\begin{array}{c}\text { Principal motivo del } \\
\text { viaje }\end{array}$ & $\begin{array}{c}\text { Duración de la } \\
\text { visita }\end{array}$ & Intereses $^{6}$ & $\begin{array}{l}\text { Grupo de } \\
\text { viaje }\end{array}$ & $\begin{array}{c}\text { Forma de desplazarse } \\
\text { durante la visita }\end{array}$ & $\begin{array}{c}\text { Mapas mentales de Madrid una vez } \\
\text { finalizada la visita } \\
\text { (caracterización general) }\end{array}$ \\
\hline Explorador & $\begin{array}{l}\text { Contacto con lo } \\
\text { local. }\end{array}$ & Vacaciones (94 \%). & $\begin{array}{l}\text { Variada ( } 70 \% \\
\text { entre } 3 \text { y } 6 \text { días } \\
\text { y solo un } 12 \% \\
\text { más de } 6 \text { días). }\end{array}$ & $\begin{array}{l}\text { No concretos. } \\
\text { Variados (75\%) } \\
\text { o muy variados } \\
(25 \%) .\end{array}$ & $\begin{array}{l}\text { Heterogéneo, } \\
\text { pero nunca en } \\
\text { viaje } \\
\text { organizado. }\end{array}$ & $\begin{array}{l}\text { Son lo que más caminan y } \\
\text { también utilizan el metro, } \\
\text { seguido del tren de } \\
\text { cercanías y autobús } \\
\text { público. }\end{array}$ & $\begin{array}{l}\text { Mapas que reflejan una concepción } \\
\text { organizada de la ciudad. } \\
\text { Alto nivel de diferenciación e integración } \\
\text { entre los elementos representados. } \\
\text { Relativamente elevado número de } \\
\text { elementos puntuales, seguidos de ejes y } \\
\text { zonas. }\end{array}$ \\
\hline Guiado & Facilidad. & $\begin{array}{l}\text { Vacaciones (66 \%) y } \\
\text { para visitar a } \\
\text { familiares y amigos } \\
(26 \%) .\end{array}$ & $\begin{array}{l}\text { Variada (18 \% } 2 \\
\text { días, } 53 \% \text { entre } \\
3 \text { y } 6 \text { días y } \\
29 \% \text { más de } 6 \\
\text { días). }\end{array}$ & $\begin{array}{l}\text { Concretos } \\
(11 \%), \\
\text { variados (70 \%) } \\
\text { o muy variados } \\
(19 \%) .\end{array}$ & Nunca solos. & $\begin{array}{l}\text { Sobre todo caminando y en } \\
\text { metro; también en bus } \\
\text { turístico, taxi, autobús } \\
\text { público y en coche } \\
\text { particular. }\end{array}$ & $\begin{array}{l}\text { Mapas que reflejan percepciones puntuales } \\
\text { de la ciudad o asociadas a una o dos } \\
\text { experiencias concretas, que no se relacionan. } \\
\text { Mínimo o inexistente diferenciación e } \\
\text { integración entre los elementos } \\
\text { representados. Reducido número de } \\
\text { elementos puntuales } \\
\text { y prácticamente inexistente de ejes y } \\
\text { zonas. }\end{array}$ \\
\hline Condicionado & $\begin{array}{l}\text { Restricciones o } \\
\text { énfasis. }\end{array}$ & $\begin{array}{l}\text { Vacaciones }(62 \%) \text { y el } \\
\text { resto por motivos } \\
\text { variados (trabajo, } \\
\text { evento deportivo,...). }\end{array}$ & $\begin{array}{l}\text { Variada ( } 26 \% \\
\text { únicamente } 2 \\
\text { días, } 52 \% \text { entre } \\
3 \text { y } 6 \text { día y } 22 \% \\
\text { más de } 6) .\end{array}$ & \begin{tabular}{|l|} 
Concretos ( 27 \\
$\%)$, variados (56 \\
$\%)$ y muy \\
variados (17 \%) \\
Con mucho peso \\
en los museos y \\
monumentos.
\end{tabular} & Heterogéneo. & $\begin{array}{l}\text { Sobre todo caminando y } \\
\text { en metro; en mucha } \\
\text { menor medida en autobús } \\
\text { público, en tren de } \\
\text { cercanías, en bus turístico } \\
\text { y en taxi. }\end{array}$ & $\begin{array}{l}\text { Mapas "intermedios" en relación a los de los } \\
\text { otros dos enfoques, abarcando } \\
\text { representaciones de apariencia similar a las } \\
\text { de los exploradores, pero con un número } \\
\text { inferior de elementos; o a las de los guiados } \\
\text { pero con más elementos. } \\
\text { Número intermedio de elementos } \\
\text { puntuales, ejes y zonas. }\end{array}$ \\
\hline
\end{tabular}

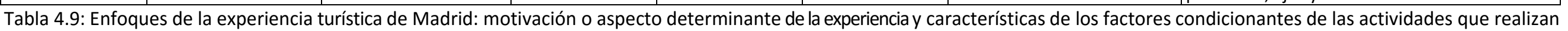
los turistas, incluida una caracterización general de sus mapas mentales, una vez finalizada la visita.

${ }^{6}$ Los intereses del turista se consideran concretos si son 1 o 2, variados si son de entre 3 y 5 , y muy variados si son más de 5 . 
Una vez agrupados los cuestionarios, se analizaron el resto de los factores que condicionan las actividades que desarrollan los turistas, según su enfoque. A continuación se resume el resultado:

- Procedencia: Los turistas proceden de diferentes contenientes con independencia del enfoque de su experiencia. Sin embargo se encontró que, tanto exploradores como guiados, comparten porcentajes similares de turistas procedentes de Europa y América del Sur (35\% y $53 \%$ respectivamente de los exploradores, frente a $30 \%$ y $52 \%$ de los guiados). Mientras que el número de turistas con enfoque condicionado procedentes de Europa ( $56 \%$ ) es algo mayor que en los grupos de los otros enfoques, en decremento de los de América del Sur (28\%).

- Edad: La edad de los turistas con enfoque guiado se distribuye homogéneamente entre los distintos rangos ( $29 \%$ entre 15 y 30 años, $32 \%$ entre 31 y 45 y $39 \%$ entre 46-60). Mientras que en entre los condicionados y aún más en el caso de los exploradores el rango entre 15 y 30 años es mayor (46\% en los condicionados y 59 $\%$ en los exploradores), manteniéndose en estos dos enfoques los dos rangos de edades restantes repartidos en partes prácticamente iguales.

- Género: El número de hombres y mujeres de tipo explorador es similar (44 \% y 56 $\%$ respectivamente) mientras que el número de mujeres es ligeramente superior entre los turistas de enfoque guiado (68\%) y el número de hombres es significativamente mayor entre los turistas condicionados ( $80 \%$ ) debido, quizás en parte, a los turistas que vienen a Madrid motivados por eventos deportivos.

- Nivel de estudios: El número de turistas con nivel universitario superior entre los exploradores (69 \%) destaca por encima de los guiados (48\%) y de los condicionados (50\%).

- Experiencia viajando a grandes ciudades: Todos los enfoques incluyen turistas con diferentes niveles de experiencia. Sin embargo, los que pertenecen al grupo del enfoque explorador son los que más experiencia tienen ya que el $69 \%$ ha viajado a más de 4 grandes ciudades antes de llegar a Madrid, mientras que a esta categoría solo pertenece un $50 \%$ de los guiados y un $57 \%$ de los condicionados.

- Experiencia en el uso de la información geográfica: Hay turistas con experiencia en su uso por motivos profesionales o formativos en todos los grupos, con independencia del enfoque, aunque su número es ligeramente superior entre los turistas exploradores ( $7 \%$ ) que en el resto (4\% en los guiados y $5 \%$ en los condicionados).

- Percepción de los desplazamientos: Un alto porcentaje de turistas de todos los enfoques considera que los desplazamientos forman parte de la visita (31 \% de los guiados, $38 \%$ de los exploradores y $26 \%$ de los condicionados). Sin embargo, el grupo de los turistas con enfoque guiado es el único que incluye encuestados que no consideran los desplazamientos parte de la visita y así lo manifiestan un $11 \%$ de ellos. 
- Nivel de planificación de la visita: Un $80 \%$ de los turistas con enfoque explorador, en la encuesta de inicio de su visita, manifestaron no saber exactamente los lugares que iban a visitar (valores entre 1 y 3 siendo el nivel máximo de planificación 5). Sin embargo un $83 \%$ de los turistas con enfoque guiado indicaron haber planificado bastante el viaje (con valores entre 3 y 5 de nivel de planificación). Mientras que los turistas encuestados con enfoque condicionado, al inicio de su visita, tuvieron niveles más heterogéneos de planificación.

- Información geográfica consultada: Los turistas con un enfoque guiado consultan significantemente menos información que el resto, ya que un $29 \%$ no consulta ningún producto cartográfico antes de llegar a Madrid y un $24 \%$ no lo hace incluso durante su visita. Los turistas con este enfoque que la utilizaron durante el pre-viaje, consultaron sobre todo fotografías, mapas turísticos e imágenes de satélite y lo hicieron principalmente a través de la web ( $80 \%)$, de guías y folletos en papel (40 $\%)$, de familiares y amigos (20\%) y de agencias de viaje (20\%). Los turistas con enfoque guiado que la consultaron durante el viaje utilizaron, sobre todo, el mapa de metro y el turístico y lo hicieron en primer lugar en soporte papel (81 $\%)$, seguido de la web (38\%) y de recomendaciones de amigos y familiares, probablemente locales (38\%). En cuanto a los de enfoque explorador, todos ellos la consultaron tanto en el pre-viaje, como durante el viaje. Utilizaron en el pre-viaje una gran variedad de información geográfica (fotografías, imágenes de satélite, callejeros, mapas turísticos y mapa de metro), en soporte papel (67\%), a través de sitios web (67\%) y foros (50\%). Los mapas utilizados durante su visita fueron principalmente el de metro y el turístico, seguidos del callejero y del de cercanías. Y para obtenerla recurrieron al formato papel (90\%), a la web (70\%), a aplicaciones móviles (50\%) y también consultaron a residentes locales (50\%). Un $33 \%$ de los turistas de enfoque condicionado no utilizó información geográfica en el pre-viaje (porcentaje superior al de los turistas con enfoque guiado) y un $5 \%$ tampoco lo hizo durante el viaje. Cuando lo hicieron, en el pre-viaje, consultaron principalmente el mapa de metro y mapas turísticos a través de la web. Éstos, durante el viaje utilizaron principalmente el mapa de metro, seguido del turístico y del callejero y para ello usaron fuentes en soporte papel (60\%), la web (60\%), aplicaciones móviles (45\%) y recomendaciones de residentes locales (45\%).

En base a la información expuesta, los factores de la experiencia turística seleccionados para identificar los enfoques de la experiencia de los turistas (motivo del viaje, intereses, grupo de viaje, forma de desplazarse durante la visita, duración de la estancia y mapas mentales) se consideraron acertados. El $93 \%$ de todos los cuestionarios (iniciales y finales) se asociaron a un enfoque de experiencia. Tan solo 4 de los 74 cuestionarios recopilados en la Fase 2 se descartaron y no se asignaron a ninguna categoría: uno debido a que no tenía mapa mental y a que el contenido del cuestionario no permitió identificar claramente si su enfoque era guiado o condicionado; y los otros tres por no contener datos de más de uno de los atributos seleccionados para la identificación del enfoque. En el anexo 20 se describen peculiaridades encontradas en los cuestionarios, al realizar esta tarea. 
Por último, respecto a los enfoques de experiencia identificados, cabe señalar que, aunque cada turista tiene un enfoque predominante asociado a su personalidad, en ciertas circunstancias puede abordar la experiencia desde otro enfoque. Por ejemplo, un turista que suele vivir sus experiencias como explorador, ante la oportunidad de verse acompañado por un amigo local que le enseñe la ciudad, lo hará como un guiado.

\section{T 3.2 Identificación de los patrones de interacción entre el turista y los mapas que dan soporte a su experiencia}

En esta tarea de síntesis se abordaron las preguntas: ¿qué elementos constituyen los mapas cognitivos de Madrid según los diferentes enfoques de la experiencia de los turistas? y ¿cómo se estructuran los elementos de los mapas cognitivos de cada enfoque?.

Para realizar esta tarea se utilizaron las 2 tablas con la información recogida del conocimiento de los turistas sobre Madrid, al inicio y al final de la visita. Cuyos registros estaban agrupados por el tipo de enfoque de la experiencia.

Para llevar a cabo esta síntesis, se tomaron como referencia las investigaciones de Lynch (1960) y Moore (1973, 1974) (capítulo 2 apartado 2.2). Lynch caracterizó los elementos que constituyen los mapas mentales de los núcleos urbanos como: nodo, confluencia de varias trayectorias; hito o punto de referencia; senda o eje de desplazamiento; borde o límite no transitable de áreas y barrio o región de la ciudad. Sin embargo, tras revisar los mapas mentales de los turistas y comprobar su reducido número de elementos se decidió reducir de 5 a 3 los tipos propuestos por Lynch, siguiendo pautas similares a las aplicadas en otros estudios (Goodey, 1971; Norberg-Schulz, 1971; Beck y Wood 1976). Con este fin se unificaron, por un lado, "nodos" y "puntos de referencia", pasándose a llamar "puntos" y, por otro, "límites no transitable de áreas" y "ejes de desplazamiento" denominándose "ejes". Teniendo esto en cuenta, se realizó un análisis cuantitativo del contenido de los mapas mentales asociados a cada enfoque de experiencia, identificando en ellos: 1) puntos: que abarcan fundamentalmente atractivos turísticos (Puntos de Interés Turístico, PIT) e infraestructuras de transporte; 2) ejes: que representan fundamentalmente calles y líneas de transporte y 3) zonas: que representan áreas o barrios de la ciudad.

Por otro lado, Moore (1973) considera importante, no solo el conocimiento que el sujeto tiene del espacio, sino la interacción que establece con él (actividad) y el uso que hace de él. Los sistemas de referencia aglutinan los elementos del contexto geográfico que tienen más relevancia cognitiva y Moore identifica en ellos tres estadios de diferenciación e integración crecientes: 1) egocéntrico e indiferenciado (en lo sucesivo denominado egocéntrico) donde el mapa está regido por las propias acciones y experiencias sobre el entorno y no hay posibilidad de distanciarse de él (Figura 4.21a); 2) diferenciado y parcialmente coordinado (en lo sucesivo denominado diferenciado) donde existe un distanciamiento del entorno, pero los distintos elementos o grupos de elementos que configuran el mapa no están coordinados entre sí, y la representación espacial se organiza en torno a elementos fijos y concretos de tipo lineal o puntual (Figura 4. 21b) y 3) 
abstractamente coordinado y jerárquicamente integrado (en lo sucesivo denominado coordinado) en el cual, la representación espacial se hace al margen de la experiencia concreta, coordina y secuencia distintos elementos, y es fruto de la abstracción (Figura 4. 21c).

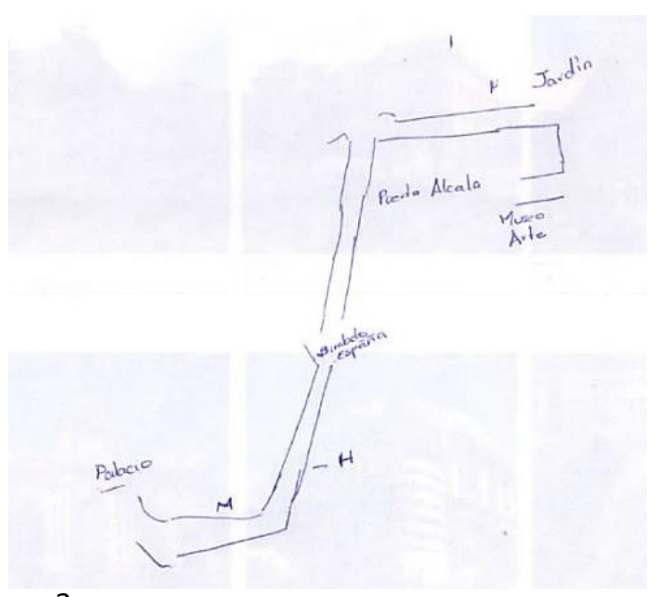

a
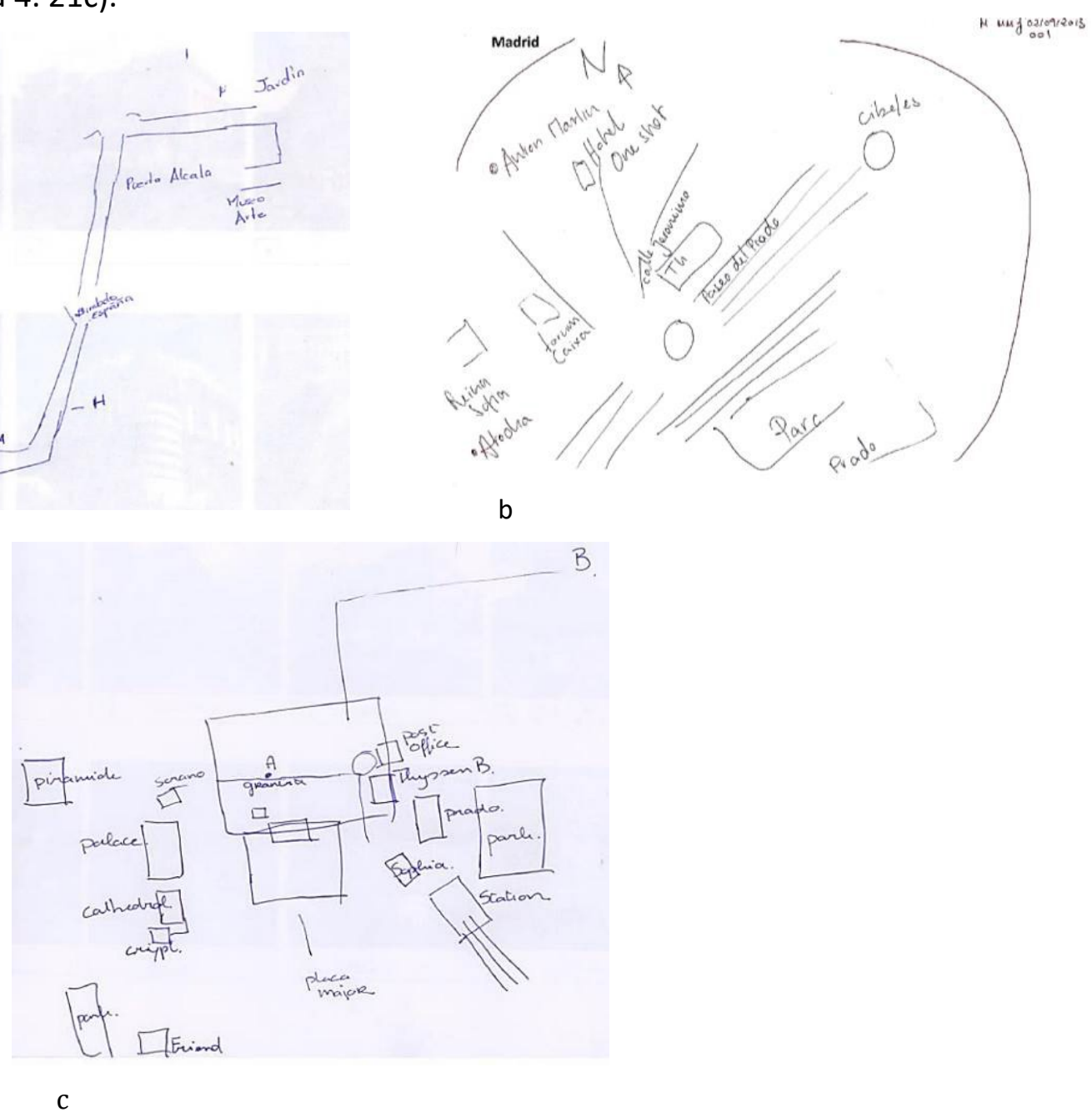

Figura 4.21: Mapas mentales dibujados por los turistas encuestados con sistemas de referencia: a) Egocéntrico, b) Diferenciado y c) Coordinado.

Para identificar el sistema de referencia de cada mapa se volvió a contar con la colaboración de un geógrafo. Se examinaron uno a uno los mapas de cada tipo de enfoque y se consensuaron sus sistemas de referencia. Durante la realización de esta labor, se consideró oportuno incorporar dos categorías adicionales a las de Moore, para poder caracterizar adecuadamente mapas que no encajaban en ninguno de los sistemas de referencia establecido por él. Estas fueron:

1) Puntual: El mapa contiene únicamente un elemento de interés o lugar de referencia.

2) Multi-puntual: El mapa contiene varios elementos de interés o lugares de referencia aislados, sin relaciones topológicas entre ellos.

Cada uno de estos sistemas de referencia pueden ser de tipo imagen o cartográfico (Figura 4.22 a, b, c y d). 

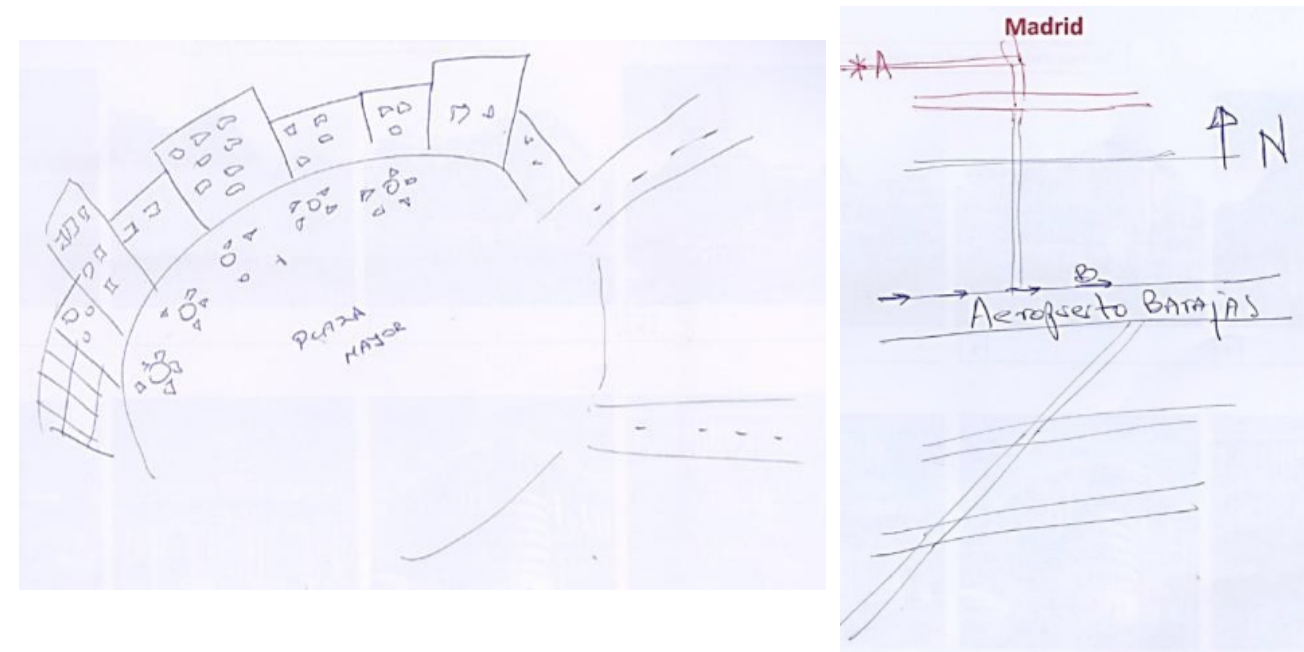

a

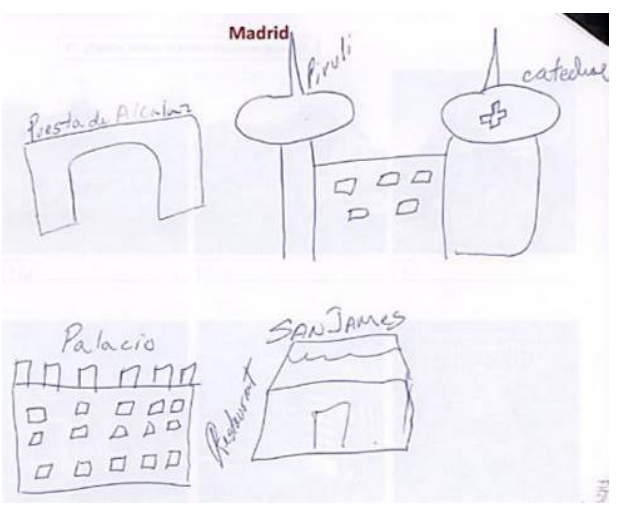

C $\mathrm{b}$

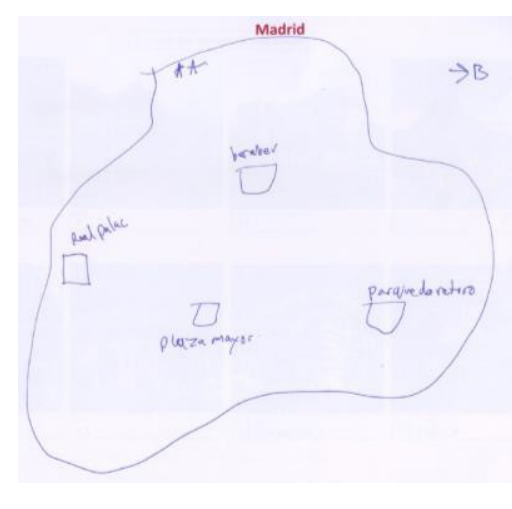

d

Figura 4.22: Mapas mentales de los turistas encuestados con sistemas de referencia adicionales a los establecidos por Moore $(1973,1974)$ : a) Puntual tipo imagen,

b) Puntual tipo cartográfico, c) Multi-puntual tipo imagen y d) Multi-puntual tipo cartográfico.

Por otro lado, se consideró oportuno caracterizar los mapas desde el punto de vista de las relaciones topológicas de sus elementos. Se volvieron a revisar y se definieron dos parámetros topológicos: marcos y focos de referencia. Se establecieron 5 marcos de referencia:

(1) Recorrido/s que integran puntos de interés turístico (PIT) (Figura 4.23a).

(2) Puntos de interés de los que parten ejes sueltos o que conectan con otros puntos de interés (Figura 4. 23b).

(3) Puntos de interés sin conexiones (Figura 4. 23c).

(4) Zonas o barrios (Figura 4. 23d).

(5) Referencias naturales (Figura 4.23d).

En cuanto a focos de referencia, se identificaron 3 tipos:

(a) Lugar de alojamiento (Figura 4.24a).

(b) Atractivo de interés turístico (Figura 4.24b).

(c) Sin foco de referencia destacado (Figura 4.24c). 
Finalmente, también se tuvo en cuenta la extensión de la zona urbana de la ciudad representada en los mapas, pudiendo ser ésta: puntual (si abarca uno o varios elementos próximos de la ciudad), sectorial (si abarca una zona de la ciudad y algún elemento fuera de ella) o global (si abarca dos o más zonas de la ciudad).

La tabla 4.10 resume los resultados de ésta síntesis: mapas mentales finales representativos de cada enfoque de experiencia $y$, elementos, sistemas de referencia, cobertura y focos de los mismos. El resto de detalles se puede consultar en el anexo 21.

a

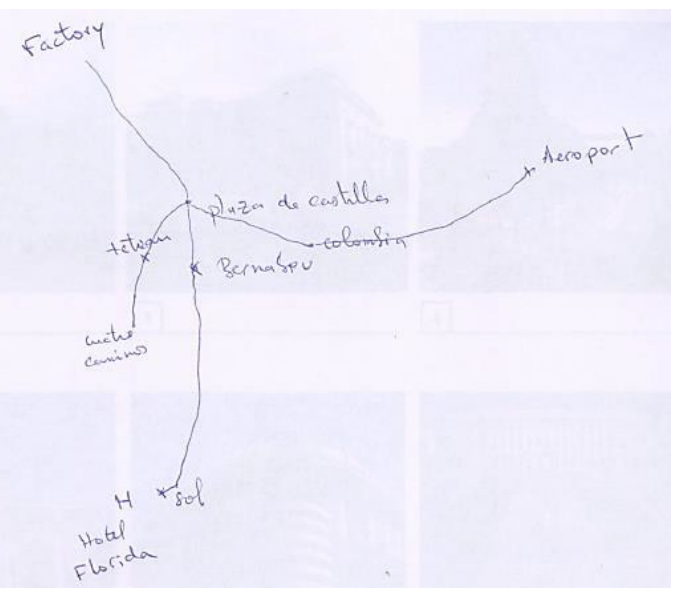

C

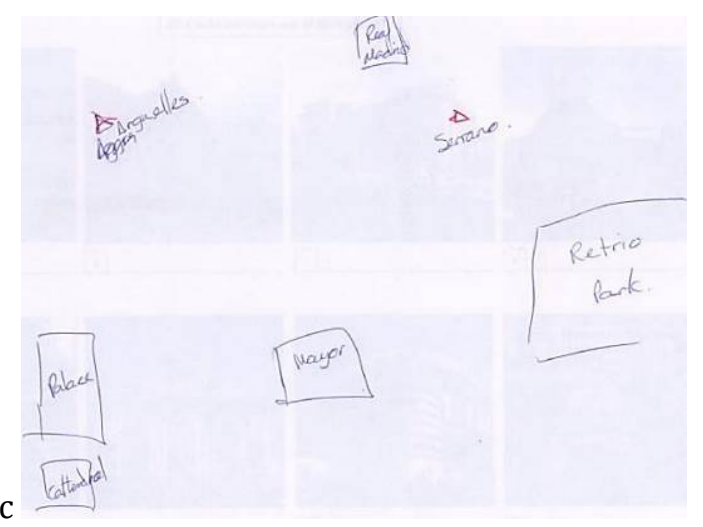

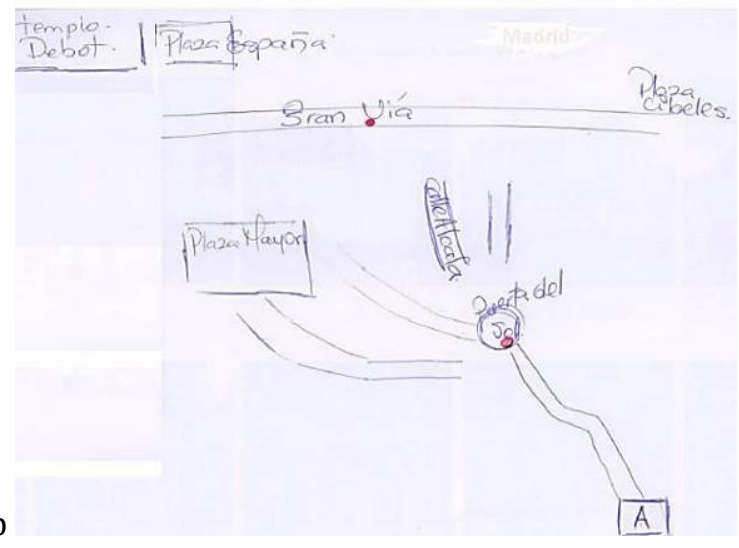

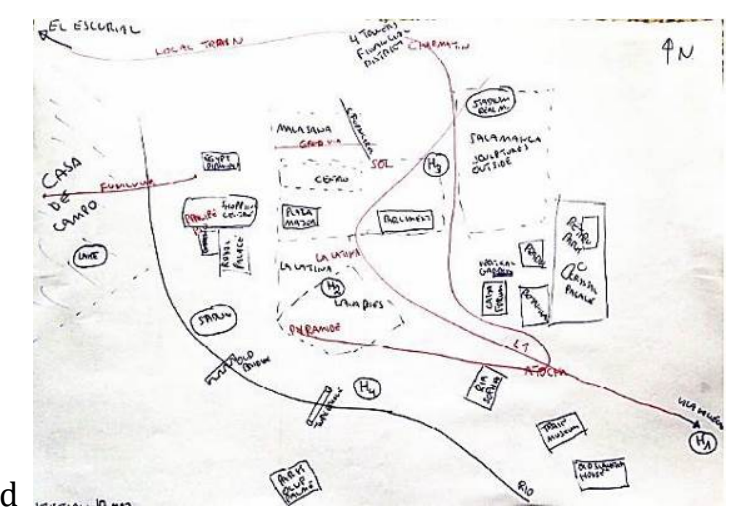

Figura 4.23: Mapas mentales caracterizados según sus marcos de referencia: Recorrido/s que integran puntos de interés turístico; b) Puntos de interés de los que parten ejes sueltos o que conectan con otros puntos de interés; c) Puntos de interés sin conexiones;

d) Zonas o barrios (ver líneas discontinuas) y referencias naturales (Río Manzanares en la parte inferior izquierda). 


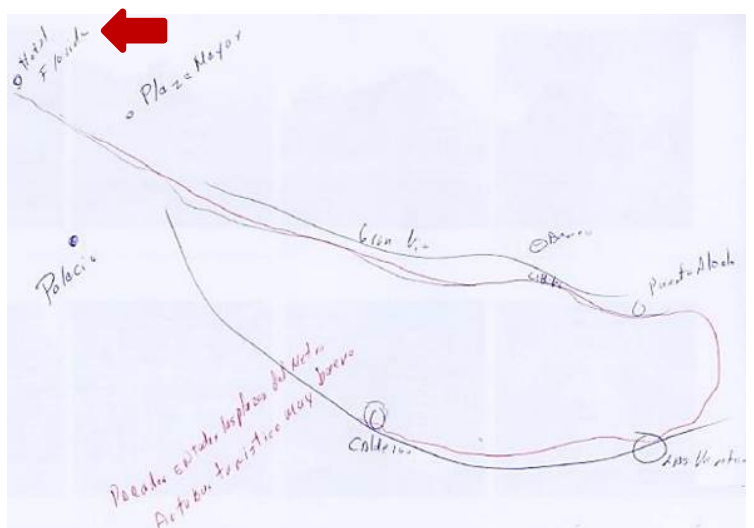

a

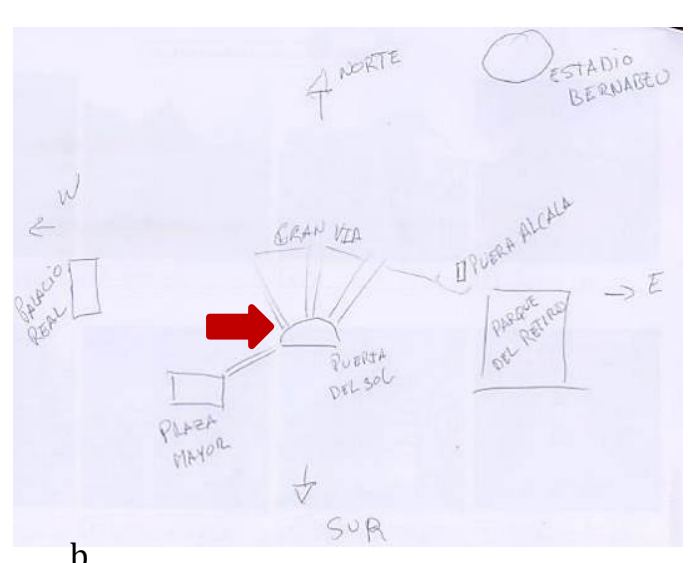

b

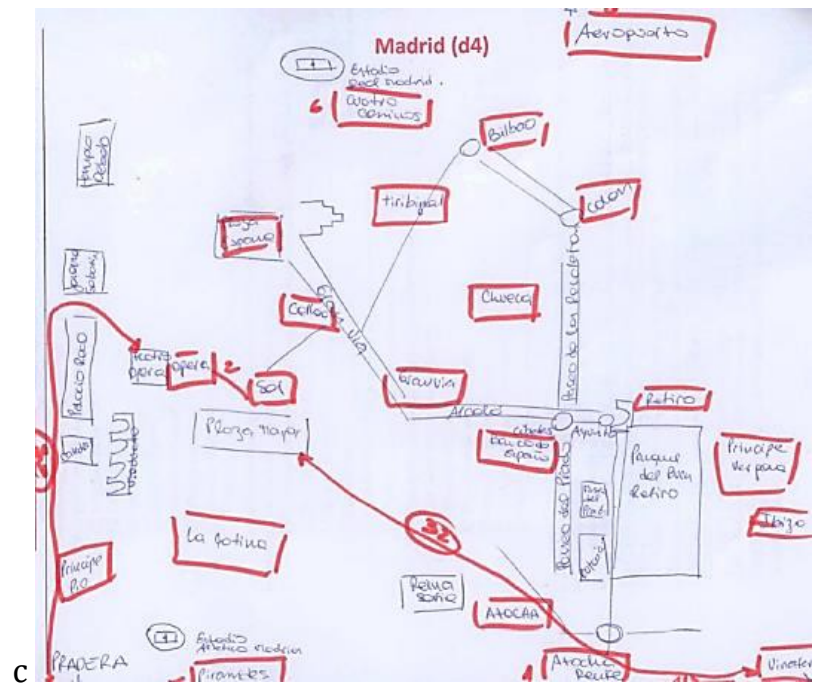

Figura 4.24: Mapas mentales caracterizados según sus focos de referencia:

a) Lugar de alojamiento; b) Atractivo de interés turístico y c) Sin foco de referencia destacado.

En cuanto a la evolución de los mapas mentales de los turistas (Figuras 4.25, 4.26 y 4.27 ), cabe destacar que, en coherencia con las observaciones de Moore (1973), el sistema de referencia asociado a la conceptualización espacial de cada turista permanece estable a lo largo de su visita.

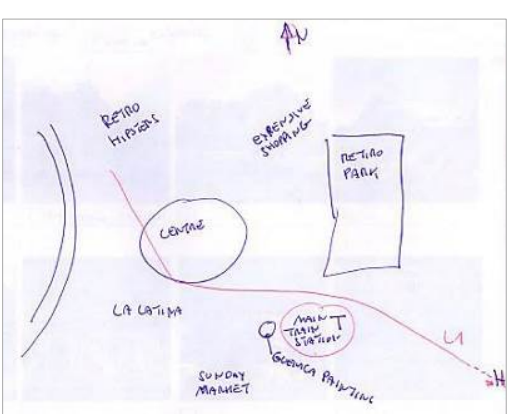

Día 1

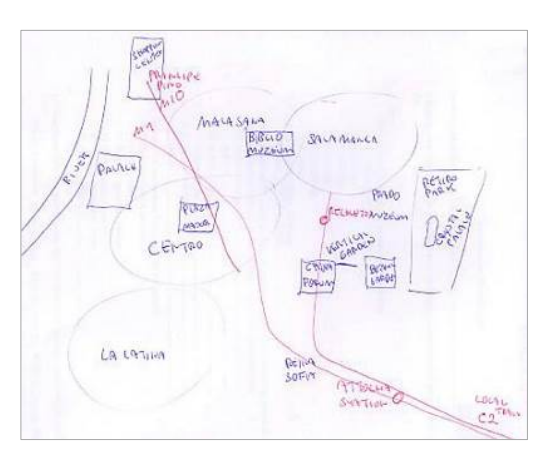

Día 6

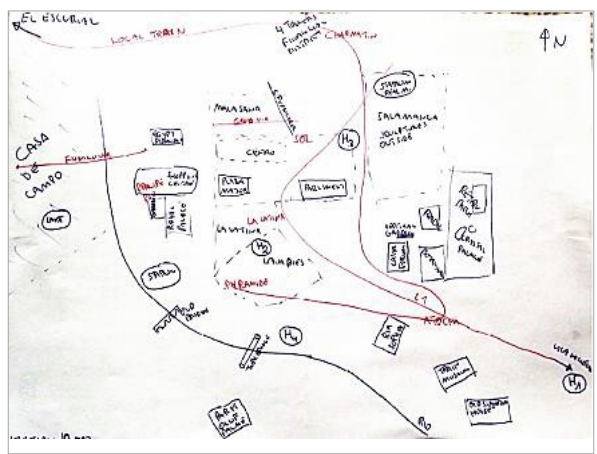

Día 12

Figura 4.25: Evolución de los mapas mentales del turista de Dinamarca que participó en la técnica de los diarios (Fase 2, Tarea 2.2) y cuyo enfoque de experiencia fue explorador. 


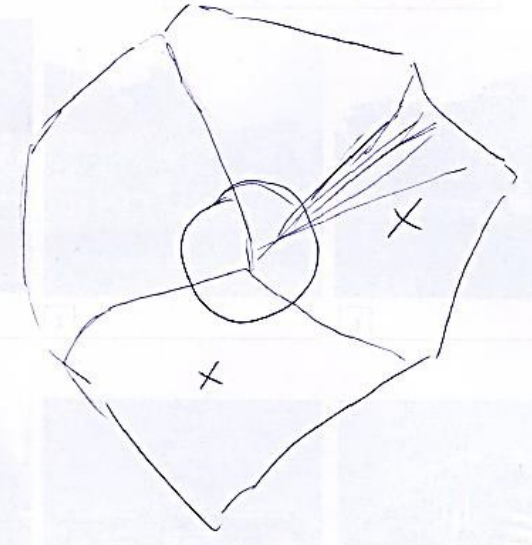

Día 1

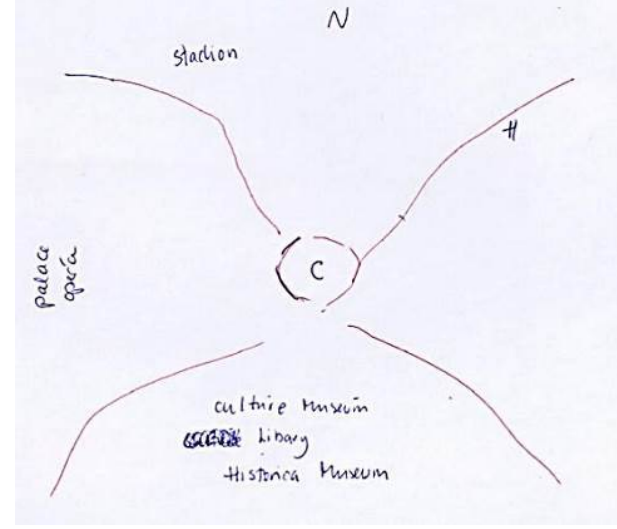

Día 6

Figura 4.26: Evolución de los mapas mentales de la turista de Dinamarca que participó en la técnica de los diarios (Fase 2, Tarea 2.2) y cuyo enfoque de experiencia fue guiado. Estos mapas son un ejemplo especialmente particular por el contraste con respecto a los del esposo (Figura 4.25) y por su cobertura global zonal, siendo el único caso con este tipo de cobertura entre los mapas finales de este enfoque.

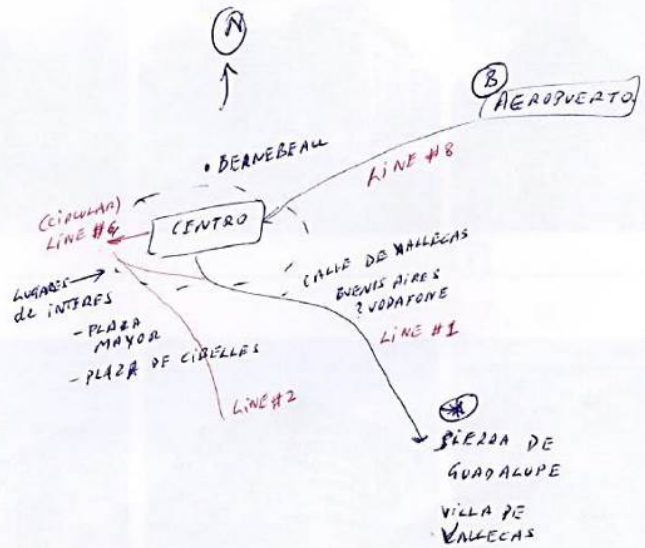

Día 1

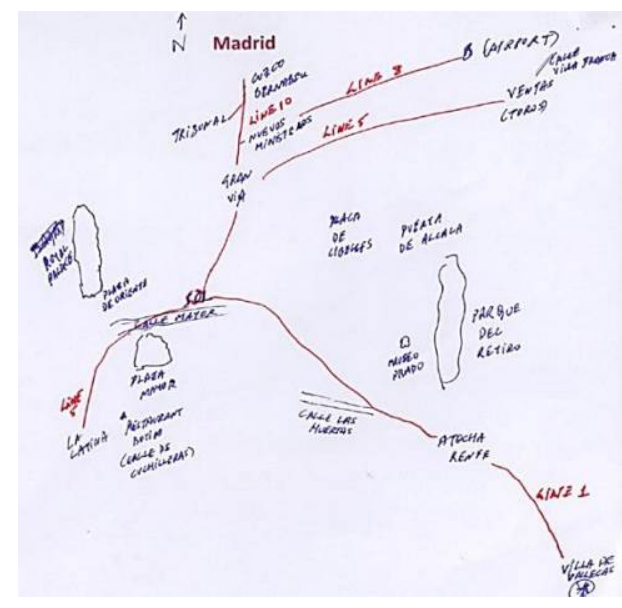

Día 3

Figura 4.27: Evolución de los mapas mentales del turista de UK que participó en la técnica de los diarios (Fase 2, Tarea 2.2) y cuyo enfoque de experiencia fue condicionado. Su visita duró 6 días, pero durante los últimos 3 asistió a un curso y no tuvo tiempo de hacer turismo, por lo que su mapa final fue el del día 3. 


\begin{tabular}{|c|c|c|c|c|c|c|}
\hline & $\begin{array}{l}\text { Puntual } \\
\text { (PIT representado } \\
\text { como una imagen o } \\
\text { de forma } \\
\text { cartográfica). }\end{array}$ & $\begin{array}{l}\text { Egocéntrico } \\
\text { (experiencia } \\
\text { secuencial a lo largo } \\
\text { de un recorrido que } \\
\text { integra PIT). }\end{array}$ & $\begin{array}{l}\text { Multi-puntual } \\
\text { (Varios PIT } \\
\text { representados en } \\
\text { forma de imagen o } \\
\text { cartográfica). }\end{array}$ & $\begin{array}{l}\text { Diferenciado } \\
\text { (una o varias } \\
\text { experiencias } \\
\text { disociadas de forma } \\
\text { explícita). }\end{array}$ & $\begin{array}{c}\text { Coordinado } \\
\text { (Representación al } \\
\text { margen experiencia } \\
\text { concreta, fruto de la } \\
\text { abstracción). }\end{array}$ & $\begin{array}{l}\text { Mapas mentales de Madrid, una vez finalizada } \\
\text { la visita } \\
\text { (Caracterización detallada: } \\
\text { ¿Qué elementos? y ¿ Cómo se estructuran?) }\end{array}$ \\
\hline $\begin{array}{l}\frac{0}{0} \\
\frac{0}{0} \\
\frac{0}{2} \\
\frac{2}{x}\end{array}$ & & & ind & 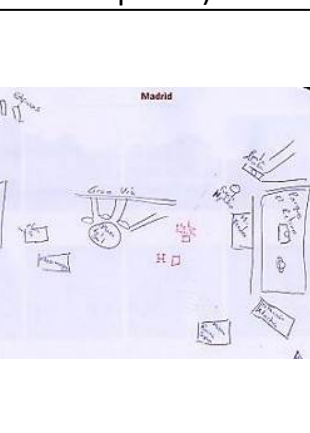 & $\underbrace{\infty}_{10}$ & $\begin{array}{l}\text { apas mentales ajenos a experiencias concretas. } \\
12 \text { PIT y } 6 \text { inf. trans., } 3 \text { ejes y } 2 \text { zonas. } \\
\text { Sistema de referencia multi-puntual, diferenciado } \\
\text { o coordinado, con foco vinculado a un punto de } \\
\text { interés o sin él. } \\
\text { Contenido representado a través de puntos sueltos } \\
\text { unidos mediante ejes (calles o líneas de transporte) } \\
\text { e integrados en zonas, con la posibilidad de incluir } \\
\text { referencias naturales (marcos } 2,3,4 \text { y } 5 \text { ). Cobertura } \\
\text { global. }\end{array}$ \\
\hline $\begin{array}{l}\frac{8}{\circ} \\
. \frac{0}{5} \\
5\end{array}$ & (4) & & $\sin$ & 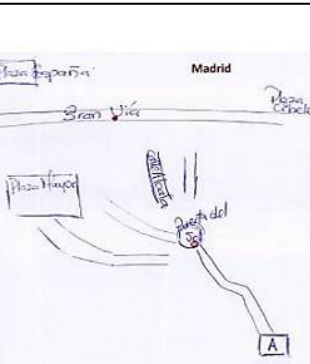 & & $\begin{array}{l}\text { Mapas que reflejan percepciones puntuales de la } \\
\text { ciudad o asociadas a una o dos experiencias } \\
\text { concretas, que no se relacionan. } \\
4 \text { PIT, } 1 \text { inf. trans., ningún eje y } 1 \text { zona. } \\
\text { Sistema de referencia, puntual, multi-puntual } \\
\text { (marco 3), egocéntrico (marco } 1 \text {, con un único } \\
\text { recorrido) y diferenciado (marco } 2 \text { y 3). } \\
\text { Cobertura puntual, sectorial y global. Con focos. }\end{array}$ \\
\hline 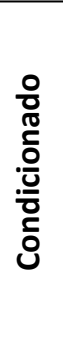 & & 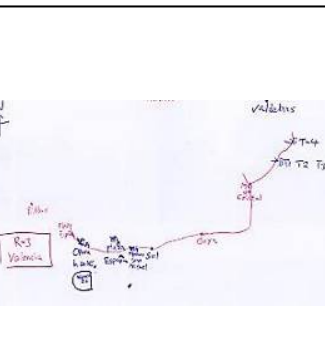 & & & & $\begin{array}{l}\text { Mapas "intermedios" en relación a los de los otros } \\
\text { dos enfoques, abarcando representaciones de } \\
\text { apariencia similar a las de los guiados (egocéntrico } \\
\text { y multi-puntual), o las de los exploradores } \\
\text { (diferenciados o coordinados), pero con un } \\
\text { número intermedio de elementos. } \\
5 \text { PIT, } 2 \text { inf. trans., } 1 \text { eje y } 1 \text { zona. } \\
\text { Cobertura sectorial y global. Con o sin focos. }\end{array}$ \\
\hline
\end{tabular}

Tabla 4.10: Mapas finales característicos de los turistas según la forma de abordar la experiencia (elementos, sistemas de referencia, cobertura y focos de los mismos). 


\section{T 3.3 Identificación de patrones de interacción entre los mapas y el ambiente urbano en el que se desarrolla la experiencia}

En esta tarea de síntesis se abordó la pregunta, ¿cuál es el ambiente asociado a la experiencia del turista?.

El ambiente da significado a lo que ocurre a lo largo del viaje y puede descomponerse en diferentes dimensiones o contextos: del usuario (enfoque de experiencia, intereses, preferencias...); físico (localización, meteorología...); temporal (hora del día, fecha, día en relación a la duración de la estancia...); históricoevolutivo (sitios del destino turístico en el que el turista ha estado previamente, consultas de información acerca del destino turístico realizadas hasta el momento...) y tecnológico (soporte del dispositivo, tamaño de pantalla, periféricos disponibles, conexiones de datos...). El ambiente se considera, una entidad de naturaleza dinámica que influye en la toma de decisiones del turista y, consecuentemente, en su comportamiento y experiencia.

Al abordar esta síntesis se definieron dos grandes contextos dentro del ambiente de la experiencia del turista, por un lado el del turista y su viaje, y por otro el de la actividad concreta.

En el ambiente del dominio del turista y su viaje se tuvieron en cuenta, por un lado, los distintos enfoques de la experiencia que aglutinan motivaciones, comportamientos y conceptualizaciones del espacio, comunes a grupos de turistas. Por el otro, las características específicas del turista tales como: intereses, preferencias y expectativas. También factores concretos, que condicionan las actividades de su viaje como: ubicación de alojamiento, duración de estancia, grupo de viaje,...

Respecto al ambiente relacionado con una actividad concreta, se consideró adecuado tener en cuenta: la etapa del viaje, la actividad que está realizando el turista y el conocimiento que tiene de la ciudad en ese momento; las necesidades de IG en relación a la actividad que está llevando a cabo, su ubicación espacial y temporal (hora, fecha, día de la semana, estación del año y momento en relación al intervalo de tiempo de la estancia), su orientación, aspectos meteorológicos y del entorno físico (iluminación, ruido,...) y tecnológico (dispositivos con los que puede interactuar el turista, conexiones de datos, recursos periféricos como impresoras y sensores,...).

La información de las dos dimensiones del ambiente definidas, se pueden considerar e integrar en el diseño de los mapas, de tal manera que éstos "narren" la experiencia del viaje.

\subsubsection{Resultados de síntesis de la experiencia turística}

1) ¿Cómo serán las experiencias de los turistas a las que los mapas darán soporte?

Los mapas a diseñar darán soporte a los turistas, teniendo en cuenta los tres enfoques diferentes con los que abordan su experiencia: 


\section{Explorador}

Las personas que abordan la experiencia desde éste enfoque son espontáneas y flexibles, se interesan por conocer la auténtica esencia de la ciudad y en sumergirse en la cultura y en la forma de vida local. Visitan Madrid principalmente por vacaciones y suelen tener experiencia viajando a grandes ciudades y contar con una educación universitaria superior. Estos turistas se caracterizan por viajar solos o acompañados, pero no en grupo organizado. Sus intereses son muy variados y sienten una especial predilección por conocer la ciudad en sí misma y el estilo de vida local. Durante el pre-viaje solo suelen gestionar la compra del billete para llegar a la ciudad y el alojamiento, en caso de considerar necesario hacerlo con antelación. Este tipo de turistas son los que más inclinación tienen por alquilar casas particulares o incluso una habitación en un piso compartido con residentes locales, para tener la oportunidad de tener un contacto más cercano con la realidad de la ciudad y una experiencia más auténtica. Antes de llegar a la ciudad, les gusta indagar sobre la auténtica esencia y los genuinos atractivos que ofrece Madrid, a diferencia de otros destinos urbanos. Para ello, suelen consultar gran cantidad de información (fotografías, imágenes de satélite, callejeros, mapas turísticos, de metro, de cercanías...) en soporte papel y web, así como a través de recomendaciones de amigos y en foros de viajeros, con los que comparte su mismo enfoque de experiencia. Sin embargo, cuando estos turistas llegan a la ciudad desconocen lo que van a hacer exactamente durante su visita, ya que prefieren dejarse llevar por la experiencia y tener la posibilidad de tomar decisiones sobre la marcha, en base a las inspiraciones que vaya recibiendo del ambiente. Durante el viaje les gusta comer lo que comen los lugareños y hacer lo que ellos hacen en su tiempo libre, en lugar de lo que hacen los turistas. Buscan experiencias orientadas a lograr una inmersión en lo local, a través de actividades espontáneas y no dirigidas a turistas, aunque en su visita suelen incluir alguno de los principales atractivos turísticos del destino. Las personas que abordan su experiencia desde éste enfoque son los que más predisposición tienen a recorrer espacios de la ciudad fuera de las áreas más turistas (zonas complementarias y de renovación en el Anexo 4), y a visitar lugares en los alrededores del destino. En cuanto a los medios de transporte, imitan a los locales y en este sentido disfrutan de los recorridos a pie y del transporte público utilizando sobre todo el metro, pero también los trenes de cercanías y los autobuses públicos de Madrid. Durante el viaje consultan mapas turísticos y de transportes (metro, cercanías...) así como callejeros. Lo hacen en soporte papel, a través de internet, de aplicaciones móviles o realizando consultas a locales. En este sentido, el hecho de que el nivel de inglés de los residentes en Madrid no sea muy bueno (Tarea 1.2) puede repercutir más en la experiencia de estos turistas que no hablen castellano, que en la del resto. Finalmente, la conceptualización del espacio más evolucionada de los turistas con este enfoque, se caracteriza por ser ajena a experiencias concretas, por un sistema de referencia coordinado con marco de referencia tipo 2, 3, 4 y 5 y por un relativamente elevado número de elementos en comparación con el resto de enfoques, tanto puntuales (12 PIT y 6 infraestructura de transporte de media), como ejes (3) y zonas (2). 


\section{Guiado}

Las personas que abordan la experiencia desde este enfoque vienen a Madrid sobre todo por vacaciones o para visitar a algún familiar o amigo. Valoran de la experiencia la facilidad y sencillez durante todas las etapas del viaje. Estos turistas se caracterizan por viajar acompañados, por su inclinación a ser guiados y por ser los que menos información geográfica consultan durante toda la experiencia. Durante el pre-viaje, con frecuencia optan por evaluar un número reducido de propuestas personalizadas con todo incluido (alojamiento, visitas guiadas,...), con la intención de no tener que preocuparse por nada, una vez tomada la decisión. Para ello acuden a agencias de viaje y consultan a familiares y amigos, folletos en papel, fotografías y mapas turísticos en internet. Los intereses de estos turistas pueden ser más o menos variados, incluyendo: museos y monumentos, gastronomía, compras, parques...Cuando llegan a Madrid pueden saber en menor o mayor medida lo que van a hacer durante su visita. Si durante el viaje hace falta tomar alguna decisión, estos turistas están dispuestos a delegarla en otro miembro del grupo (familiar, amigo local, guía turístico...) para evitar así tener que realizar averiguaciones por sí mismos. Caminan y utilizan el metro, el taxi, el bus turístico y también se desplazan en el coche particular de algún familiar o amigo, que les acompaña. A lo largo de su estancia, los productos que más consultan son el mapa de metro y el turístico y lo hacen en soporte papel, web o solicitan la información que necesitan a sus conocidos locales o al guía que les acompaña. La conceptualización del espacio más evolucionada de los turistas con este enfoque, refleja percepciones asociadas a varias experiencias concretas de la ciudad que no relacionan entre sí, representadas a través de un sistema de referencia diferenciado (marco de referencia tipo 2 y 3) y por un reducido número de elementos puntuales (4 PIT y 1 infraestructura de transporte), 1 o ningún eje y 1 o ninguna zona.

\section{Condicionado}

La experiencia turística abordada desde el enfoque condicionado se caracteriza porque fechas y lugares del viaje están predeterminados por compromisos laborales, de estudios, familiares (asistir a una reunión, a un congreso o a una boda) e incluso asociados a actividades turísticas como por ejemplo, asistir a un evento deportivo, disfrutar de una exposición temporal o visitar todos los atractivos turísticos considerados como de obligada visita. Estas obligaciones establecen limitaciones importantes a la hora de tomar decisiones, ya que la prioridad de la persona es cumplir con el compromiso que ha motivado la visita. El grupo de viaje de los turistas que vienen a Madrid con este enfoque es heterogéneo (solos, en pareja, con familia o amigos) y sus actividades turísticas pueden incluir comportamientos afines al enfoque explorador (tomar decisiones de forma espontánea) o al guiado (recorrer la ciudad en una ruta organizada). El nivel de implicación de estos turistas en el pre-viaje está muy condicionado por el motivo del viaje. Por ejemplo, si un turista viene a Madrid por trabajo, posiblemente no tendrá que preocuparse del vuelo, ni del lugar de alojamiento y, si tiene tiempo antes de viajar, quizás eche un vistazo a alguna fuente de información sobre la ciudad. Mientras que, si para un turista aprovechar al máximo sus vacaciones urbanas significa no perderse ninguno de los atractivos turísticos afines a sus 
intereses, se asegurará de recabar toda la información necesaria para no omitir ningún atractivo importante en su lista y de viajar en las fechas y alojarse en la ubicación más conveniente. Los turistas que abordan la experiencia desde este enfoque tienen, con frecuencia, unas fechas de viaje específicas y la ubicación del alojamiento también suele estar determinada por el compromiso principal de viaje (próximo al lugar de la reunión, bien comunicado con la universidad donde va a tomar el curso intensivo...). Los intereses turísticos y de ocio de estos turistas pueden ser desde muy concretos hasta muy variados, destacando por encima de todos los museos y los monumentos de Madrid. Durante su visita, los turistas están focalizados en su objetivo y cualquier consejo, servicio o información que les ayude en esta dirección les resulta bienvenida. Por ejemplo, si un grupo de amigos ha venido a Madrid para ver un partido de fútbol y hay una incidencia en la línea de metro que les tiene que llevar del alojamiento al estadio el día del partido, agradecerán recibir un aviso e información sobre la mejor alternativa para llegar a tiempo. La experiencia para estos turistas está condicionada por el objetivo que han venido a cumplir y por las actividades de ocio llevadas a cabo en el tiempo restante. Durante el viaje, se desplazan por la ciudad principalmente caminando y en metro, aunque también utilizan, pero en menor medida, el autobús público (como los exploradores) y el autobús turístico, el taxi o un coche particular (como los guiados). Consultan principalmente el mapa de metro, el turístico y el callejero y recurren, para ello, a mapas en soporte papel, sitios web, aplicaciones móviles y recomendaciones de residentes locales. Los mapas mentales de los turistas con este enfoque se caracterizan por un nivel heterogéneo de abstracción y coordinación, abarcando representaciones de apariencia similar a las de los guiados (egocéntrico, con marco de referencia tipo 1 y multi-puntual, con marco de referencia tipo 3), o las de los exploradores (diferenciados, con marco de referencia 2 y 3 o coordinados, con marco de referencia 2, 3 y 4). Estos mapas incluyen un número intermedio de elementos puntuales, ejes y zonas en relación a los registros de los turistas con enfoque explorador y guiado (5 PIT de media, 2 infraestructuras de transporte, 1 eje y 1 zona).

\section{2) ¿Cómo serán los mapas a diseñar?.}

El mapa como interfaz se plantea como una herramienta de conexión entre el destino (Madrid) y el turista, con el fin de dar soporte a su experiencia cognitiva, mediante información geográfica cuya visualización permite distintas interacciones.

Los mapas se conciben como representaciones flexibles, dinámicas y evocadoras, que se adaptan: al enfoque con el que el turista aborda la experiencia, a sus mapas mentales, a sus características (intereses, preferencias...) y al contexto en el que se encuentra en cada momento.

A continuación se describen aspectos asociados a los enfoques de la experiencia, a tener en cuenta a la hora de concretar el diseño de los mapas como interfaz. Seguidamente se incluye una tabla resumen de los mismos (Tabla 4.11). 


\section{Explorador}

- Experiencias deseadas: Los turistas que abordan la experiencia con este enfoque buscan vivencias auténticas que no se vean limitadas por la tecnología. El suministro sutil y oportuno de información, sobre todo a modo de sugerencias inspiradoras de experiencias locales, es la clave para este tipo de turistas. Debido a su espontaneidad pueden requerir información en todo lugar y momento.

- Nivel de personalización: Bajo. No están interesados en que los datos de sus experiencias o preferencias en otros viajes se utilicen en su experiencia presente. Sin embargo, sí que están abiertos a sugerencias variadas y flexibles en lugar de a las estrictamente personales. Son exigentes y pueden sospechar que las recomendaciones que reciben tienen su origen en intereses comerciales, por lo que solo las propuestas especiales, imaginativas y sorprendentes serán acordes a sus necesidades. Idealmente su fuente de información son los lugareños, por lo que la información se les debe suministrar teniendo esto en cuenta.

- Oportunidades de influencia: Durante la etapa de ejecución del viaje es donde mayor posibilidad de influencia se da. Ya que, durante el pre-viaje, realizan la reserva de los mínimos servicios necesarios, porque prefieren vivir la experiencia con la mayor libertad posible y tomar decisiones en el momento en el que sea realmente necesario hacerlo.

- Dispositivos: La tecnología debe ser invisible para este tipo de turistas y no debe interferir en sus experiencias. Utilizarán el móvil o la tablet durante la realización del viaje, pero no tanto para la navegación, ya que prefieren la orientación de residentes locales y consideran que las mejores experiencias pueden surgir al deambular por la ciudad, fuera de los típicos recorridos turísticos. Usarán dispositivos para recibir información que les aproxime a la auténtica esencia de la ciudad: saber si hay algún evento interesante, si existe algún lugar que merece la pena ver cerca de donde se encuentran...Los dispositivos podrán ser por ejemplo, wearables como gafas o relojes, a través de las cuales recibir información de forma visual o auditiva, que les ayude a comprender el entorno donde se encuentren.

\section{Guiado}

- Experiencias deseadas: Los turistas de este enfoque delegan, en la medida de lo posible la responsabilidad del éxito de su viaje pero, antes de tomar la decisión de viajar, pueden desear consultar algún tipo de información que les aporte la tranquilidad deseada. Son los más abiertos a planteamientos personalizados durante el pre-viaje, por lo que cabe esperar que sean receptivos a aceptar propuestas de experiencias personalizadas e inspiradoras. Sin embargo, a la hora de tomar decisiones desean barajar pocas opciones para que la tarea resulte fácil y rápida. Las interacciones con estos turistas, una vez iniciada la visita, deben limitarse al suministro de información de soporte y ayuda utilizando notificaciones no intrusivas, ya que siempre irán acompañadas de personas de apoyo.

- Nivel de personalización: Alto. Estos turistas esperan un extremadamente alto nivel de personalización alineado con sus intereses, preferencias y necesidades, y a cambio de facilitarles el viaje, están dispuestos a proporcionar la información necesaria.

- Oportunidad de influencia: La etapa en la que más receptivos están para recibir información es durante el pre-viaje, ya que buscan planificar todo el viaje 
(paquete) de la forma más sencilla posible, con el fin de despreocuparse y limitar al máximo las decisiones durante el viaje.

- Dispositivos: Durante el pre-viaje preferirán utilizar un único producto, que les permita por ejemplo, ver videos o visualizaciones de realidad aumentada, que les aporten lo necesario para hacerse una idea del destino, el lugar de alojamiento,... y tomar decisiones. Durante el viaje optarán por interacciones a través de dispositivos no intrusivos como tecnologías wearables (gafas,...) que den soporte a la interacción a través de la voz, que no requieran teclear o mirar a una pantalla y que permitan plantear preguntas de forma sencilla, ofreciendo respuestas concretas y fáciles de comprender, que les facilite su relación con el entorno. Por ejemplo, durante el recorrido en bus turístico un turista con enfoque guiado podrá plantear al sistema la consulta: "¿Cerca de la próxima parada hay un restaurante vegetariano? y este contestará: "Si, hay uno a 50 metros caminando,...टंquieres ir?" y si el turista contesta que sí, cuando se baje del autobús el sistema le indicará a través de audio como llegar hasta allí. En caso necesario también utilizarán tablets o móviles.

\section{Condicionado}

- Experiencias deseadas: Las experiencias anheladas por estos turistas pueden ser muy variadas, aunque todas ellas tendrán en común el aprovechamiento en la medida de lo posible de las circunstancias (máximo rendimiento de su tiempo de vacaciones u ocio). Para ello será necesario asistir al turista en las actividades vinculadas a su objetivo principal y al mismo tiempo a sus otras necesidades de ocio. Si por ejemplo, se trata de un turista que está por un día en Madrid de paso a otro destino, y tiene predisposición a ser guiado, el sistema puede recomendarle realizar una ruta en el bus turístico por la ciudad, a lo largo de la cual se le asistirá para que aproveche al máximo su experiencia $y$, al mismo tiempo, si hubiera alguna incidencia que afectara a su conexión con el siguiente vuelo, el sistema se ocuparía de todo lo necesario para facilitar al turista su gestión. Mientras que otra persona que viene a Madrid por trabajo, durante 5 días y que disponga de 3 horas al final de cada jornada, para conocer la verdadera esencia del estilo de vida de los madrileños, agradecerá recibir sugerencias que le ayuden a disfrutar del contacto con lo local.

- Nivel de personalización: Variable, dada su necesidad de adaptarse con flexibilidad a las circunstancias en el pre-viaje y a las que surjan durante el viaje. El motivo del viaje de estos turistas es muy heterogéneo, aunque tienen en común un objetivo principal que condiciona su experiencia. Para asistir a los turistas que busquen equilibrar las obligaciones con los momentos de ocio, será necesario el manejo de los datos necesarios, para entender sus circunstancias.

- Oportunidad de influencia: En el pre-viaje el viajero dedicará la mayor parte de su tiempo a necesidades relacionadas con el cumplimiento del objetivo principal y, solo en el caso de que éste esté relacionado con actividades turísticas, será más factible influir durante esta etapa del viaje. Por ejemplo, si el objetivo de la visita es cumplir con una lista de lugares turísticos que no se pueden perder, una serie de mapas podrían asistir al turista a la hora de elaborar dicha lista y configurar los recorridos óptimos en función de sus intereses y preferencias. Durante el viaje, las 
oportunidades de influencia de los mapas como interfaz serán mayores, ya que buscarán optimizar al máximo el tiempo de ocio con el que cuentan los viajeros y satisfacer al mismo tiempo su objetivo principal.

- Dispositivos: Los turistas que abordan la experiencia desde este tipo de enfoque son los que utilizan dispositivos más variados pudiendo ser: ordenador de sobremesa (durante el pre-viaje), móvil, wearables o tablet.

\begin{tabular}{|c|c|c|c|c|}
\hline & $\begin{array}{c}\text { Experiencias } \\
\text { deseadas }\end{array}$ & $\begin{array}{c}\text { Nivel de } \\
\text { personalización }\end{array}$ & $\begin{array}{c}\text { Oportunidad de } \\
\text { influencia }\end{array}$ & Dispositivos \\
\hline Explorador & $\begin{array}{c}\text { Auténticamente } \\
\text { locales. }\end{array}$ & Bajo. & Durante el viaje. & $\begin{array}{c}\text { Múltiples durante el } \\
\text { pre-viaje: } \\
\text { Móvil-Tablet y wearables } \\
\text { durante el viaje. }\end{array}$ \\
\hline Guiado & Fáciles y sencillas. & Alto. & Pre-viaje. & $\begin{array}{c}\text { Ordenador (pre-viaje), } \\
\text { móvil-tablet } \\
\text { y wearables. }\end{array}$ \\
\hline Condicionado & Productivas. & $\begin{array}{c}\text { Variable } \\
\text { Según afinidad a } \\
\text { los exploradores o } \\
\text { a los guiados. }\end{array}$ & $\begin{array}{c}\text { Según afinidad a } \\
\text { los exploradores o } \\
\text { a los guiados. }\end{array}$ & $\begin{array}{c}\text { Múltiples durante el } \\
\text { pre-viaje: } \\
\text { móvil-tablet, } \\
\text { y wearables } \\
\text { durante el viaje. }\end{array}$ \\
\hline
\end{tabular}

Tabla 4.11: Experiencias deseadas, nivel de personalización, oportunidades de influencia y dispositivos afines a cada turista según su enfoque.

Con el fin de poder abordar el diseño de prototipos concretos de estos mapas, se definieron unos perfiles de turistas $y$, unos escenarios, que ilustran las interacciones entre los turistas y el espacio, a través de los mapas.

3) ¿Cuáles serán los ambientes en los que los turistas utilizarán los mapas?

El ambiente de la experiencia turística está compuesto de dos contextos. Por un lado, el del turista (enfoque de experiencia, motivaciones, comportamientos...) y su viaje (ubicación de alojamiento, duración de la estancia, motivo de la vista...). Por otro lado, el de la actividad concreta que esté ejecutando en un momento dado (actividad, conocimiento que el usuario tiene en ese momento de la ciudad, ubicación espacio-temporal...). Puesto que el componente más importante en el ambiente de la experiencia cognitiva es el turista, se decidió describir los ambientes en base a perfiles de turistas que aglutinasen todas las características del ambiente.

Cada turista tiene un enfoque predominante al abordar su experiencia turística aunque, como se ha mencionado, las circunstancias específicas de cada viaje pueden provocar que un turista afín a un determinado enfoque, tenga comportamientos puntuales característicos de otro. Con el fin de simplificar el proceso, se decidió establecer tres perfiles de turistas cuyos enfoques de experiencia se mantienen constantes a lo largo de todo su viaje y para los que serán diseñados los mapas.

Por otro lado, para especificar el contexto de la actividad, en el que cada perfil de turista utilizará los mapas a diseñar, se definieron una serie de escenarios, 
teniendo en cuenta el conocimiento sobre la experiencia turística obtenido en la Fase 2 y los enfoques de experiencia turística definidos en esta fase. Cada escenario se caracterizó especificando la etapa del viaje, el contexto de la actividad en el que se encuentra la "persona" y lo que espera la "persona" del sistema que suministra los mapas (necesidades, preferencias...).

Para poder sintetizar adecuadamente el ambiente en el que cada perfil utilizará los mapas a diseñar se decidió aplicar la técnica de "personas" (ver Tabla 3.4). Como resultado de esta técnica se obtuvo una ficha descriptiva de cada "persona" (perfil de turista) que incluye la información necesaria para caracterizar los ambientes en los que los mapas a diseñar darán soporte a sus experiencias.

A continuación se incluye para cada "persona": una descripción general de su experiencia turística y de los escenarios contemplados para el diseño de sus mapas, junto a su ficha descriptiva.

\section{Kristian: Explorador}

Kristian es un hombre de 45 años, que reside con su mujer en Dinamarca. Cada vez que pueden realizan una escapada, y deciden pasar 10 días de vacaciones en España. Con un mes de antelación, compran un vuelo a Alicante y piensan en la posibilidad de escaparse durante su visita 5 días a Madrid. Antes del viaje, Kristian compra un libro escrito por daneses que han vivido en Madrid, para hacerse una idea de la esencia local de la ciudad a través de su experiencia. También ve un par de películas ambientadas en Madrid y echa un vistazo a un foro de viajeros que, como él, disfrutan descubriendo la auténtica esencia de los lugares que visitan y huyen de los recorridos turísticos. Una vez en Alicante, y tras disfrutar de los primeros días en España, Kristian se pone en contacto con varios residentes en Madrid que alquilan habitaciones a turistas en su casa. Un día antes de llegar a Madrid, reserva el alojamiento: 3 días en un piso en Conde de Casal y 2 días en otro junto a Atocha. Kristian aprovecha el contacto con sus futuros anfitriones para averiguar la mejor manera de llegar desde Alicante a Madrid, y optan por ir en tren. Al llegar al piso de Conde de Casal, Juan les está esperando. Les hace las primeras recomendaciones para aprovechar el resto del día y quedan para cenar juntos unas horas más tarde, en un bar de tapas de la Latina. El resto del viaje será una aventura por descubrir. Eso sí, Kristian utilizará su sistema (reloj, tablet y auriculares) para recibir sugerencias y realizar consultas si en algún momento echa en falta alguna recomendación o inspiración, que le ayude a disfrutar la verdadera esencia de Madrid y el estilo de vida de los madrileños.

- Escenario 1: Sábado a las 9:00 A.M. (segundo día de estancia). Kristian y su mujer salen de su alojamiento y entran en el Metro de Conde de Casal con la intención de ir al Parque del Capricho. Van a la taquilla y compran dos billetes. El sistema ya sabe a dónde quieren ir. Llegan al andén y aún quedan 5 minutos para el próximo tren. EI sistema consulta a Kristian si desea echar un vistazo a varias sugerencias de lugares que pueden resultarle de interés y a los que podría ir camino a su destino. Kristian acepta la propuesta. Una de las sugerencias es pararse a desayunar un típico café con churros en una taberna taurina en las proximidades de las Ventas y aprovechar para ver el exterior de la plaza. La otra propone visitar el Parque Quinta de los Molinos y ver sus almendros en flor. La primera opción le parece espacialmente 
atractiva y, tras consultar a su mujer, decide incorporar esa parada en el trayecto. Por fin llega el tren, Kristian aprovecha estos desplazamientos para observar a la gente, pero un sábado a esas horas solo hay un par de pasajeros. El sistema sugiere a Kristian recibir información sobre lugares de la ciudad por los que van a pasar a lo largo del recorrido. El sistema muestra escenas de la superficie de la ciudad (fotografías de una tienda curiosa especializada en apicultura, del Hospital 12 de Octubre, de la Casa de la Moneda, de Torrespaña...) mientras escuchan las explicaciones vía audio. Unos minutos después, llegan a Manuel Becerra donde hacen transbordo y tras tomar la línea 2 llegan a Ventas. El trayecto en metro ha sido toda una experiencia (Figuras 4.31-4.36 y Tabla 4.12).

- Escenario 2: Domingo a las 22:15 (tercer día de estancia). Kristian y su mujer llegan a su alojamiento, después pasar el día visitando Madrid. Antes de acostarse, Kristian quiere planear que van a hacer a la mañana siguiente. Primero echa un vistazo a los lugares y zonas de la ciudad donde ya han estado y luego decide ver algunas sugerencias de sitios a visitar en los alrededores de la ciudad. Consulta información de detalle sobre la propuesta de Toledo, que consiste en disfrutar de las vistas de la ciudad a lo largo de un recorrido de 4 horas, por el que solo transitan locales. Además ve que una de las opciones para llegar a Toledo es tomando un tren en Atocha $y$, como al día siguiente tienen que mudarse allí, les viene perfecto (Figuras 4.37-4.42 y Tabla 4.13).

A continuación se incluye la ficha de Kristian. 


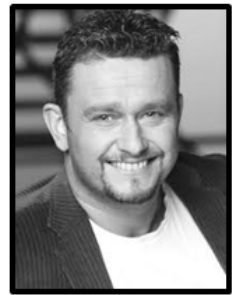

Kristian/Explorador

42años/Dinamarca/Máster

Experiencias auténticamente locales

Bajo nivel de personalización

Influenciable durante el viaje

Dispositivos: móvil y relo

Experiencia viajando: Alta

Motivo del viaje: Vacaciones

Alojamiento: Local Conde de Casal 3 días y Atocha 2 días

Grupo de viaje: Con su mujer

Medios de transporte: A pié, metro, autobús urbano

Estancia: 5 días. Viernes-Martes. Abril.

\section{Dinámica:}

Viernes 16-22: Gran vía, Callao, Sol, Plaza Mayor, Palacio y la Latina

Sábado 9:30-21:00: las Ventas, el Capricho, el Prado y Huertas

Domingo 10-21: el Rastro, el Retiro y espectáculo flamenco

Lunes 10-21: Toledo

Martes 11-14: Compras

\section{Mapa:}

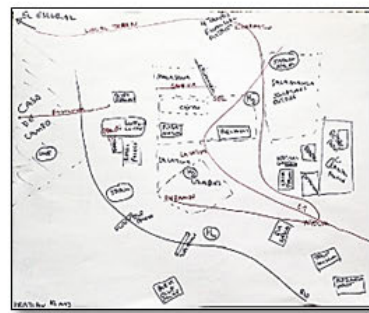

Marcos:2,3,4 y 5

\section{Enfoque de experiencia}

Tiempo disponible/día

Presupuesto máximo/día

Percepción desplazamientos

Intereses: Gastronomía

Parques/Naturaleza

Compras

Monumentos

Ocio nocturno

Museos

Eventos

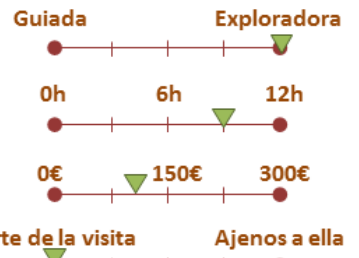

\section{Pats}

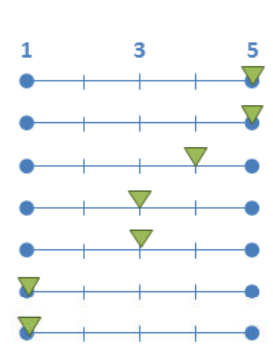

Escenario 1: Sábado 9:30

Kristian y su mujer toman el metro para ir al Capricho.

Kristian quiere recibir sugerencias si a lo largo del recorrido

hay algún lugar próximo que le pueda interesar y también

quiere saber sobre las zonas por las que van pasando.

Escenario 2: Domingo 23:00

Kristian y su mujer llegan a su alojamiento después de un

largo día. Kristian quiere planear lo que hacer al día

siguiente y echa un vistazo a los lugares y zonas de la ciudad en los que ya han estado. Deciden que quieren salir fuera de Madrid y consultan sugerencias.

Figura 4.28: "Persona” Exploradora: Kristian. 


\section{Mary: Guiada}

Mary es una mujer soltera de 52 años de UK, a la que una vez al año le gusta visitar un país extranjero y suele hacerlo siempre con su amiga Kate. Kate se encarga de organizar la compra de los billetes, el hotel y las actividades a realizar durante su visita a Madrid. Las dos tienen gustos muy parecidos y Mary confía plenamente en el criterio de su amiga, aunque le gusta echar un vistazo al plan de viaje antes de confirmar las reservas. Cuando llegan a Madrid, toda su visita está organizada: alojamiento en un hotel cerca de la Puerta del Sol y una perfecta combinación de actividades que incluye un tour en bus turístico por la ciudad, la visita al Prado y al Parque del Retiro, compras en el Rastro y en la zona de Serrano y un pequeño paseo por la Plaza Mayor y el mercado de San Miguel el último día antes de tomar de vuelta el avión. Mary se deja guiar por su amiga durante todo el viaje y cuando lo desea, consulta su sistema personal a través de la tablet.

- Escenario 1: 1 mes antes del viaje. Kate envía a Mary el enlace a un vídeo que ilustra el plan de viaje. A medida que Mary visualiza el video va indicando los lugares que le gustaría visitar y los que no. Al finalizar la visualización, Mary quiere echar un vistazo al mapa del viaje. El sistema muestra a Mary un mapa de cada día de estancia y los atractivos que visitarán, ilustrados con fotografías capturadas del video. Este mapa refleja el "Madrid de Mary", le servirá de referencia y podrá consultarlo en su versión impresa o digital (Figuras 4.43- 4.48 y Tabla 4.14).

- Escenario 2: Lunes a las 12:00 (tercer día de estancia). Kate y Mary se levantan y desayunan tranquilamente. Hoy por la mañana visitarán el Retiro, Kate tiene previsto ir hasta allí en taxi. Cuando llegan al Retiro dan un paseo por el parque, visitan el gran Lago y se sientan en un banco a disfrutar de la buena temperatura. Mary está encantada con el viaje y decide echar un vistazo en su tablet a los lugares que han visto hasta ahora y los que les quedan por visitar. El sistema muestra a Mary por un lado, los principales lugares visitados, ilustrados con las fotografías que ella ha ido realizando $y$, por otro, los que les quedan por ver, ilustrados con las capturas de pantalla del video que Mary visualizó antes de llegar a Madrid (Figuras A.49-A.54 y Tabla 4.15).

A continuación se incluye la ficha de Mary. 


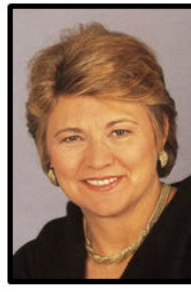

Mary/Guiada

52/Reino Unido/Educación secundaria

Experiencias fáciles y sencillas

Alto nivel de personalización

Influenciable en el pre-viaje

Dispositivos: ordenador y tablet

Experiencia viajando: Alta

Motivo del viaje: Vacaciones

Alojamiento: Hotel en Sol

Grupo de viaje: Con una amiga que organiza el viaje

Medios de transporte: Bus turístico, taxi y a pié

Estancia: 4 días. Sábado-Martes. Septiembre.

Dinámica:

Sábado 12-21: Recorrido en bus turístico

Domingo 10-21: Rastro y Museo del Prado

Lunes 10-21: Parque del Retiro y compras por Serrano

Martes 11-14: Plaza Mayor y Mercado de San Miguel

Mapa:

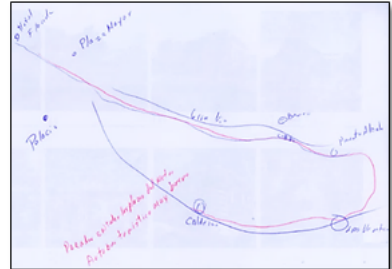

Egocéntrico

Marcos: 1 y 3

PIT y 2 inf. trans.

1 eje y 1 zona.

Cobertura sectorial

Con foco
Enfoque de experiencia

Tiempo disponible/día

Presupuesto máximo/día

Percepción desplazamientos

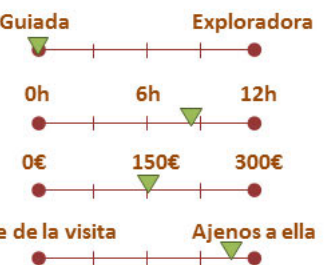

Intereses: Museos

Monumentos

Compras

Gastronomía

Parques/Naturaleza

Espectáculos

Eventos

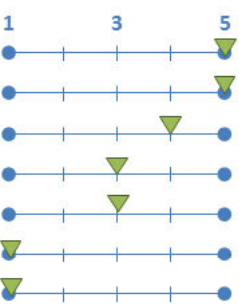

Escenario 1: 1 mes antes del viaje

Mary esta en casa y recibe un e-mail de su amiga Kate con un enlace a un video resumen del plan de viaje. Mary tiene que indicar a su amiga los lugares a los que sí que quiere ir y a los que no. Y le gustaría disponer de un mapa en papel y en versión digital que ilustre el plan de viaje.

Escenario 2: Lunes en el parque del Retiro

Mary esta sentada con su amiga en un banco del parque, el viaje está resultando una experiencia estupenda y decide echar un vistazo a los lugares que ya ha visto y a los que les quedan por ver.

Figura 4.29: "Persona” Guiada: Mary. 


\section{Adriana: Condicionada}

Adriana es una arquitecta de éxito de 32 años, que trabaja en una multinacional en Méjico D.F. Su jefe le acaba de comunicar que el próximo mes asistirá a un congreso durante tres días en Madrid. Adriana tendrá que realizar una presentación en el congreso. Es la primera vez que participa en un evento de este tipo y tiene la responsabilidad de dejar en buen lugar a su empresa, así que antes del viaje dedica todo el tiempo posible a preparar su ponencia. Por otro lado, Adriana nunca ha estado en Madrid, así que decide tomarse un día libre una vez finalizado el congreso, para poder disfrutar de la ciudad una vez cumplido el objetivo principal de su viaje. Se pone en contacto con el departamento de viajes de su empresa, indica las fechas de los vuelos y solicita que se alargue su estancia una noche más en el hotel previsto, a su coste. Adriana llega a Madrid a última hora de la tarde y toma un taxi que la lleva al hotel, donde también se celebrará el congreso, situado en la zona financiera de las Cuatro Torres. El congreso comienza al medio día del día siguiente, así que decide acostarse pronto y aprovechar para trabajar en su presentación por la mañana. Al día siguiente, Adriana conoce a muchas personas $y$, al finalizar las sesiones termina exhausta. Además, a la mañana siguiente tiene su presentación, así que decide no salir del hotel, cenar poco y acostarse pronto. El día " $D$ ", Adriana realiza exitosamente su presentación y, al finalizar la jornada, disfruta con el resto de los asistentes de un breve recorrido arquitectónico por Madrid organizado por el congreso y de una cena al aire libre en un restaurante exquisito del centro. El congreso finaliza el día siguiente por la tarde $y$, tras despedirse de sus principales contactos, Adriana se dispone a disfrutar de las 36 horas libres que le quedan por delante. El congreso ha sido bastante intenso, así que decide ponerse el bañador y disfrutar del sol en la piscina de la azotea del hotel. Después de darse un baño, está lista para organizar su día libre en Madrid. Cuando Adriana viaja por vacaciones nunca lo hace sola y suele delegar las decisiones en su pareja, así que, siguiendo la recomendación del sistema, esa noche tomará un taxi e irá a cenar a un restaurante del centro de la ciudad y, al día siguiente, recorrerá Madrid en un bus turístico que le permitirá ver los atractivos principales de la ciudad, realizar paradas en los mejores lugares para hacer compras y disfrutar de la gastronomía antes de tomar su vuelo de vuelta esa misma noche. Adriana está tranquila ya que el principal objetivo por el que vino a Madrid está cubierto y el sistema la acompañará por la ciudad en lo que le queda de viaje.

- Escenario 1: Durante el viaje. Recorrido en el bus turístico. Adriana recibe asistencia del sistema para asimilar información sobre los atractivos que está viendo durante el recorrido y también para saber las paradas más adecuadas en las que bajarse para hacer unas compras o poder comer en un buen restaurante (Figuras 4.55-4.57 y Tabla 4.16).

A continuación se incluye la ficha de Adriana. 


\section{Tiempo disponible/día}

Presupuesto máximo/día

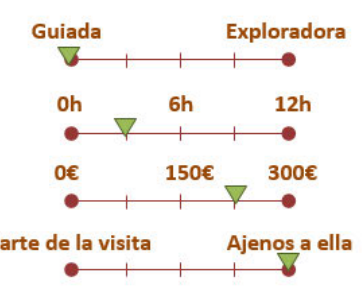

Percepción desplazamientos

Motivo del viaje: Trabajo

Intereses: Monumentos

Gastronomía

Compras

Parques/Naturaleza

Museos

Espectáculos

Eventos

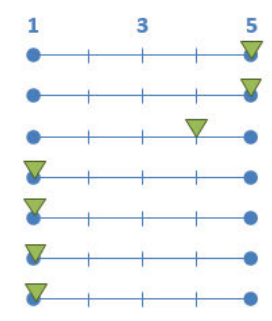

Dinámica:

Martes:

Miércoles:

Jueves 20-23: Recorrido arquitectónico por Madrid

Viernes 21 -23: Cena en el centro

Sábado: 10-21: Recorrido en bus turístico y compras

\section{Mapa:}

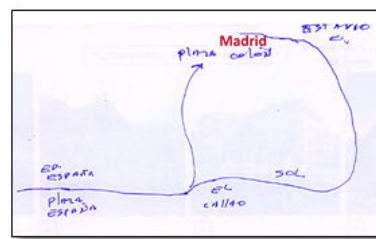

Egocéntrico

Marcos: 1 y 3

5 PIT y 2 inf. trans.

1 eje y 1 zona.

Cobertura sectorial

Con focos
Escenario 1: Sábado en el bus turístico

Adriana esta disfrutando del recorrido en el bus turístico y desea que el sistema le asista para aprovechar y hacer algunas compras y comer en algún restaurante de paellas próximo a la ruta de bus. 


\subsection{Fase 4: Diseño de los prototipos de los mapas para los turistas}

Para poder abordar el diseño de los mapas a utilizar por cada "persona", en cada uno de los escenarios, se utilizó la técnica del storyboard (Tabla 3.5) ya que permite ilustrar las diferentes situaciones que tienen lugar a lo largo del escenario, identificando aquellas en las que se utilizan mapas. Por otro lado, cada storyboard se complementó con una tabla con información de detalle sobre las interacciones, la experiencia de usuario, el contenido y las funcionalidades necesarias en cada situación del escenario.

A continuación se incluyen los storyboards, las tablas descriptivas y los diseños de los mapas de cada uno de los escenarios, definidos previamente para cada "persona".

Antes de elaborar los prototipos digitales de los mapas (Tabla 3.5), se examinaron los mapas de diversos productos cartográficos con el fin de recabar inspiraciones (Anexo 22) y se realizaron diversos bocetos de los mapas, dibujándolos a mano en papel (Anexo 23). 
Explorador-Escenario 1: Durante el viaje-Desplazamiento en metro
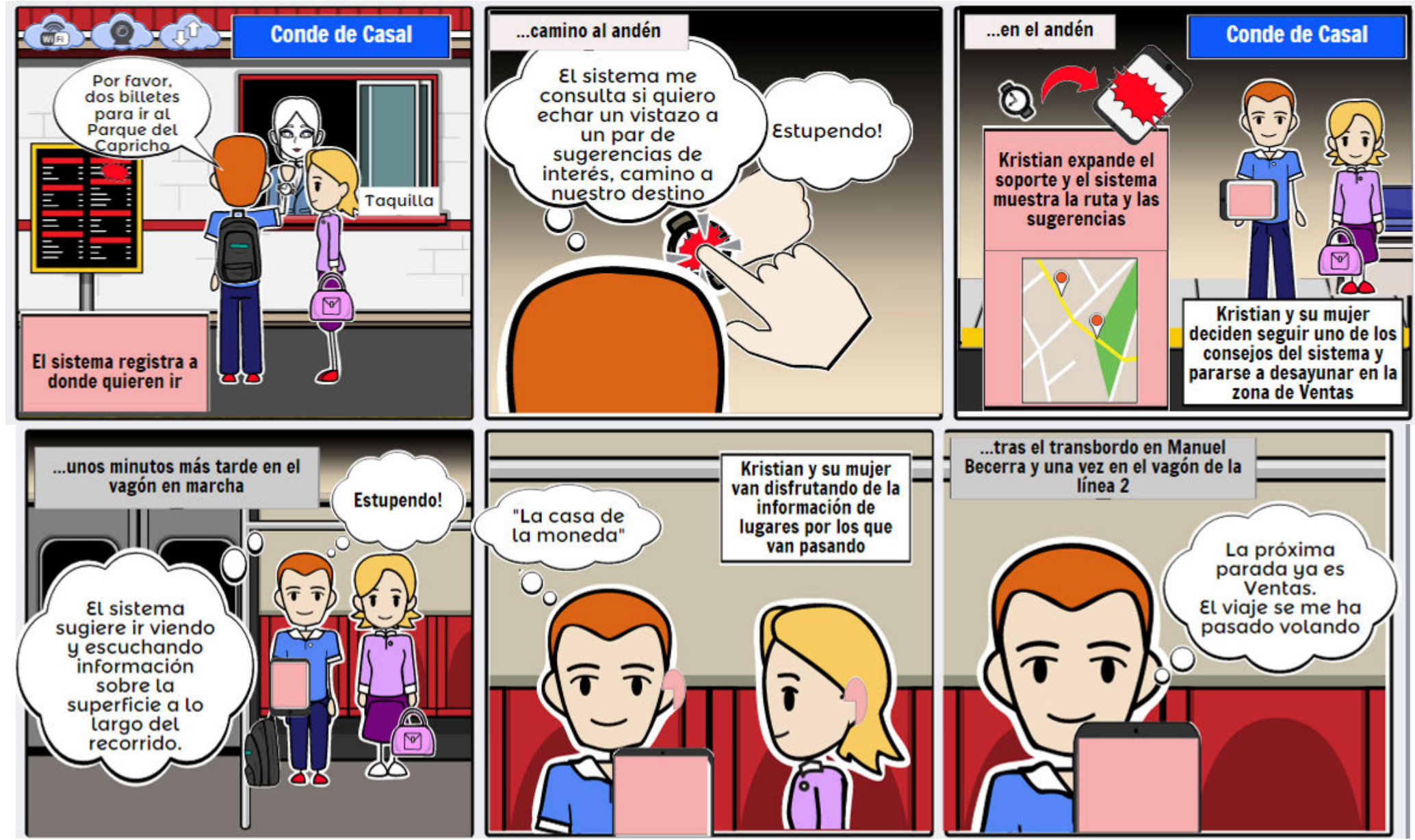

Figura 4.31: Storyboard Explorador-Escenario 1: Durante el viaje-Desplazamiento en metro. 


\begin{tabular}{|c|c|c|c|c|c|c|}
\hline \multicolumn{7}{|c|}{$\begin{array}{l}\text { Explorador-Escenario 1: Durante el viaje-Desplazamiento en metro. Contexto: Kristian y su mujer toman el metro para visitar el Parque del Capricho. } \\
\text { Necesidad/preferencia: Kristian tiene dificultades para acceder a información que le facilite tener contacto con lo local y con la verdadera esencia de la ciudad. } \\
\text { El sistema plantea a Kristian la posibilidad de hacer una parada camino a su destino, para visitar algún lugar que les pueda interesar. } \\
\text { El sistema sugiere a Kristian aprovechar el desplazamiento en metro para saber más sobre lugares de la ciudad por los que están pasando. }\end{array}$} \\
\hline $\begin{array}{ll}\frac{0}{10} \\
\frac{2}{2} \\
\frac{8}{2} \\
\frac{0}{4} \\
\qquad\end{array}$ & $\begin{array}{c}\mathbf{1} \\
\text { Taquilla del } \\
\text { metro en Conde } \\
\text { de Casal } \\
\text { Kristian y su } \\
\text { mujer compran } \\
\text { dos billetes para } \\
\text { ir al Parque del } \\
\text { Capricho. }\end{array}$ & $\begin{array}{c}\mathbf{2} \\
\text { Camino al andén } \\
\text { El reloj de Kristian vibra } \\
\text { avisándole de que a lo } \\
\text { largo del recorrido hay } \\
\text { lugares que podrían } \\
\text { resultarle de interés. } \\
\text { Kristian acepta ver las } \\
\text { sugerencias. }\end{array}$ & $\begin{array}{c}\text { 3 } \\
\text { Mapa 1 + Vista detalle } \\
\text { En el andén } \\
\text { Kristian expande el soporte, } \\
\text { visualiza un mapa que muestra la } \\
\text { ruta completa y las tres } \\
\text { sugerencias. Ve detalles de una de } \\
\text { ellas y decide hacer una parada } \\
\text { antes de visitar el Capricho. }\end{array}$ & \begin{tabular}{|c|}
$\mathbf{4}$ \\
En el vagón \\
El sistema sugiere ir \\
viendo y escuchando \\
información sobre las \\
zonas de la ciudad por las \\
que van pasando a lo \\
largo del recorrido y \\
Kristian acepta.
\end{tabular} & \begin{tabular}{|c|}
$\mathbf{5}$ \\
Mapa 2 \\
Durante el recorrido Kristian y su mujer \\
disfrutan de la información proporcionada \\
por el sistema. Y 5 segundos antes de llegar \\
a la parada donde tienen que hacer \\
transbordo el sistema les avisa.
\end{tabular} & $\begin{array}{c}6 \\
\text { Mapa } 3 \\
\text { Cuando están próximos a la } \\
\text { parada en la que tienen que salir } \\
\text { a la superficie, el sistema muestra } \\
\text { un mapa con información para } \\
\text { tomar la salida adecuada y para } \\
\text { llegar a su primer destino del día. }\end{array}$ \\
\hline & $\begin{array}{l}\text { Modo taquilla } \\
\text { Ambiente- } \\
\text { >Sistema } \\
\text { El sistema sabe que } \\
\text { Kristian está con su } \\
\text { mujer en la } \\
\text { estación y } \\
\text { a dónde quiere ir. }\end{array}$ & $\begin{array}{l}\text { Modo tránsito andén } \\
\text { Ambiente->Sistema } \\
<->\text { Usuario } \\
\text { El sistema verifica si } \\
\text { Kristian se dirige al } \\
\text { andén adecuado y } \\
\text { propone el servicio de } \\
\text { sugerencias. } \\
\end{array}$ & $\begin{array}{c}\text { Modo andén } \\
\text { Servicio de sugerencias. } \\
\text { Ambiente->Sistema<->Usuario } \\
\text { El sistema muestra el mapa. } \\
\text { Kristian puede consultar } \\
\text { información de detalle. } \\
\text { El sistema avisa a Kristian } 5 \\
\text { segundos antes de llegar el vagón. }\end{array}$ & \begin{tabular}{|c|} 
Modo vagón \\
Ambiente->Sistema<- \\
$>$ Usuario \\
El sistema sabe que \\
Kristian está el vagón y \\
propone el servicio de \\
información en tránsito. \\
Kristian lo acepta. \\
\end{tabular} & \begin{tabular}{|c|} 
Modo vagón \\
Servicio información en tránsito \\
Ambiente->Sistema<->Usuario \\
El sistema va mostrando información \\
sincronizada con el recorrido. \\
Kristian puede indicar que algún lugar le sea \\
sugerido más tarde o parar el suministro de \\
la información. \\
\end{tabular} & $\begin{array}{c}\text { Modo salida } \\
\text { Servicio asistencia salida } \\
\text { Ambiente->Sistema<-> Usuario } \\
\text { Cuando quedan } 5 \text { segundos para } \\
\text { llegar a la parada en la que tienen } \\
\text { que salir, el sistema les avisa y } \\
\text { muestra el mapa. }\end{array}$ \\
\hline 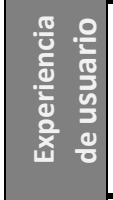 & & $\begin{array}{c}\text { Kristian está dispuesto a } \\
\text { cambiar los planes si le } \\
\text { gusta alguna sugerencia y } \\
\text { acepta. }\end{array}$ & $\begin{array}{l}\text { Kristian asimila nuevo } \\
\text { conocimiento de la ciudad al } \\
\text { evaluar las sugerencias. Una } \\
\text { sugerencia le gusta y decide hacer } \\
\text { una parada camino al Capricho. } \\
\end{array}$ & \begin{tabular}{|c} 
Kristian se alegra de poder \\
aprovechar el \\
desplazamiento para \\
saber más de la ciudad.
\end{tabular} & $\begin{array}{l}\text { Kristian asimila nuevo conocimiento de la } \\
\text { ciudad a lo largo del recorrido. }\end{array}$ & $\begin{array}{l}\text { Kristian echa un vistazo a la } \\
\text { información y pone el sistema en } \\
\text { stand-by, ya que con lo que sabe } \\
\text { ahora tiene suficiente. }\end{array}$ \\
\hline 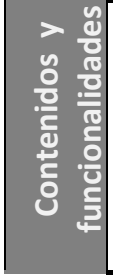 & & $\begin{array}{l}\text { Aviso de disponibilidad } \\
\text { de servicio de } \\
\text { sugerencias. } \\
\text { Aviso si Kristian no se } \\
\text { dirige al andén } \\
\text { adecuado. }\end{array}$ & $\begin{array}{c}\text { Grafico global de la ruta (paradas, } \\
\text { tiempos de recorrido...) e } \\
\text { información de lugares sugeridos. } \\
\text { Información de detalle de lugares } \\
\text { sugeridos. } \\
\text { Aviso de aproximación de vagón. }\end{array}$ & $\begin{array}{l}\text { Aviso de disponibilidad } \\
\text { de servicio de } \\
\text { información en tránsito. }\end{array}$ & $\begin{array}{c}\text { El sistema muestra fotografías de las } \\
\text { zonas de la ciudad por las que van } \\
\text { pasando y el lugar del recorrido donde se } \\
\text { encuentran. Kristian puede indicar que un } \\
\text { lugar mostrado le interesa, puede parar el } \\
\text { servicio, activar el servicio de sugerencias } \\
\text { o poner el sistema en stand-by. }\end{array}$ & $\begin{array}{l}\text { El sistema muestra un gráfico con el } \\
\text { nombre de la parada, los segundos } \\
\text { hasta llegar, dirección hacia donde } \\
\text { caminar al salir del vagón, salida, } \\
\text { recorrido fuera del metro, tiempo } \\
\text { estimado de recorrido y direcciones } \\
\text { de interés. }\end{array}$ \\
\hline
\end{tabular}

Tabla 4.12: Descripción del Explorador-Escenario 1: Durante el viaje-Desplazamiento en metro. 
Mapa 1

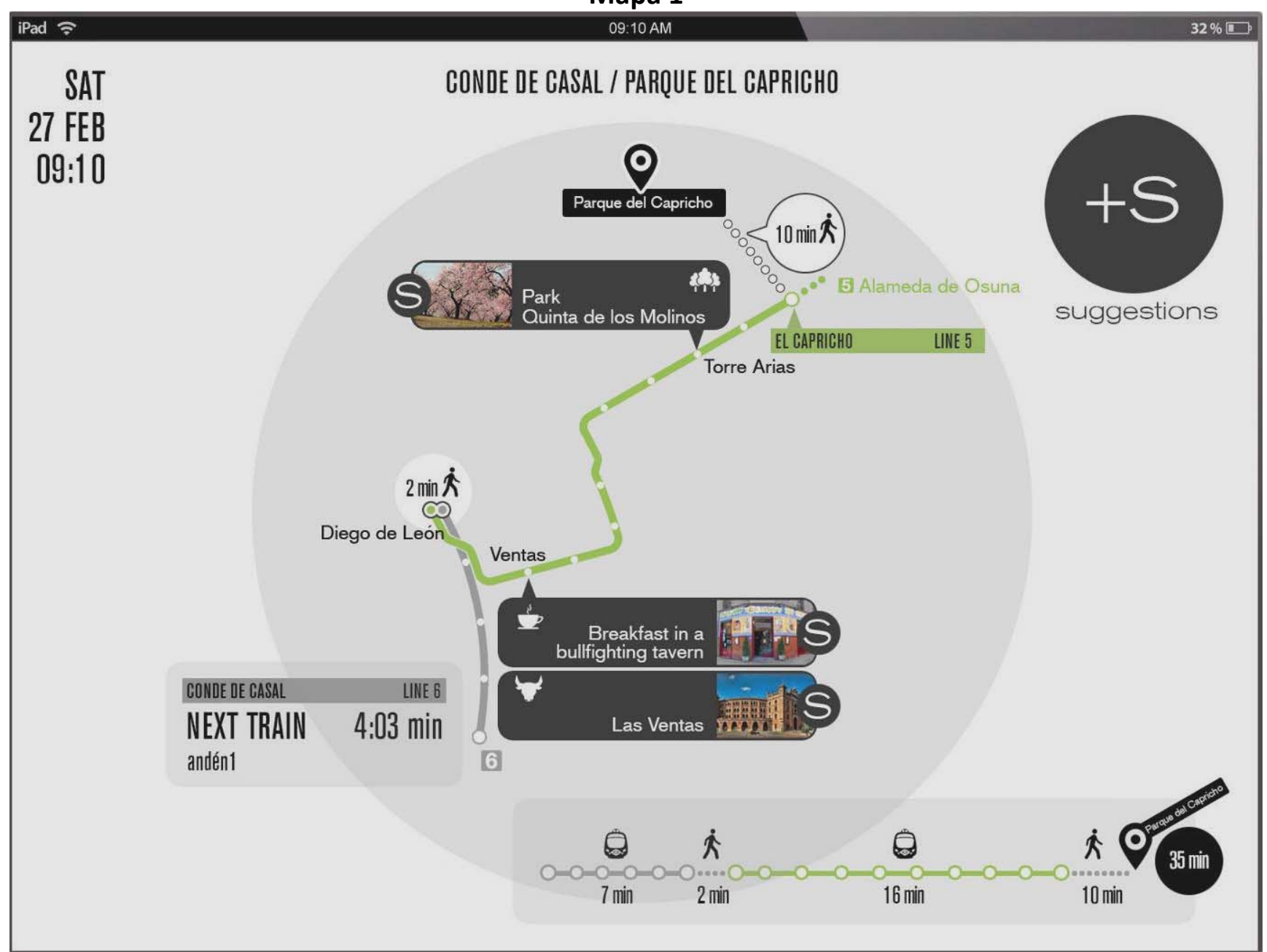

Figura 4.32: Kristian y su mujer se encuentran en el andén del metro de Conde de Casal y tienen previsto ir al Parque del Capricho. El mapa muestra a Kristian 3 sugerencias de lugares que les pueden resultar de interés camino a su destino. 
Vista detalle

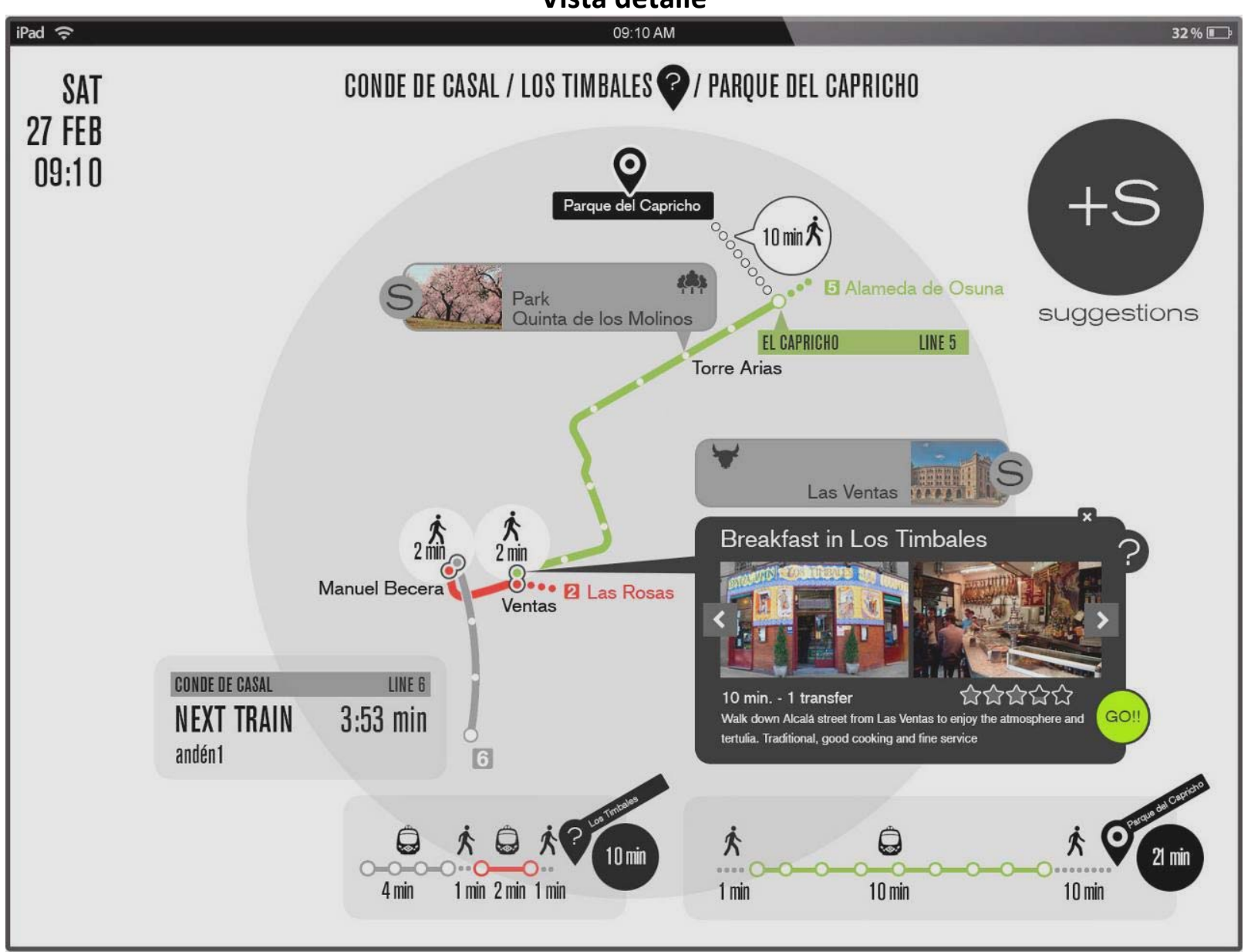

Figura 4.33: Kristian selecciona uno de los lugares sugeridos (Breakfast in Los Timbales) y el mapa muestra las modificaciones en el recorrido en caso de que decidiera ir a ese lugar, camino a su destino final. Kristian decide hacer una parada en el lugar sugerido (selecciona "Go"). 
Mapa 1 actualizado

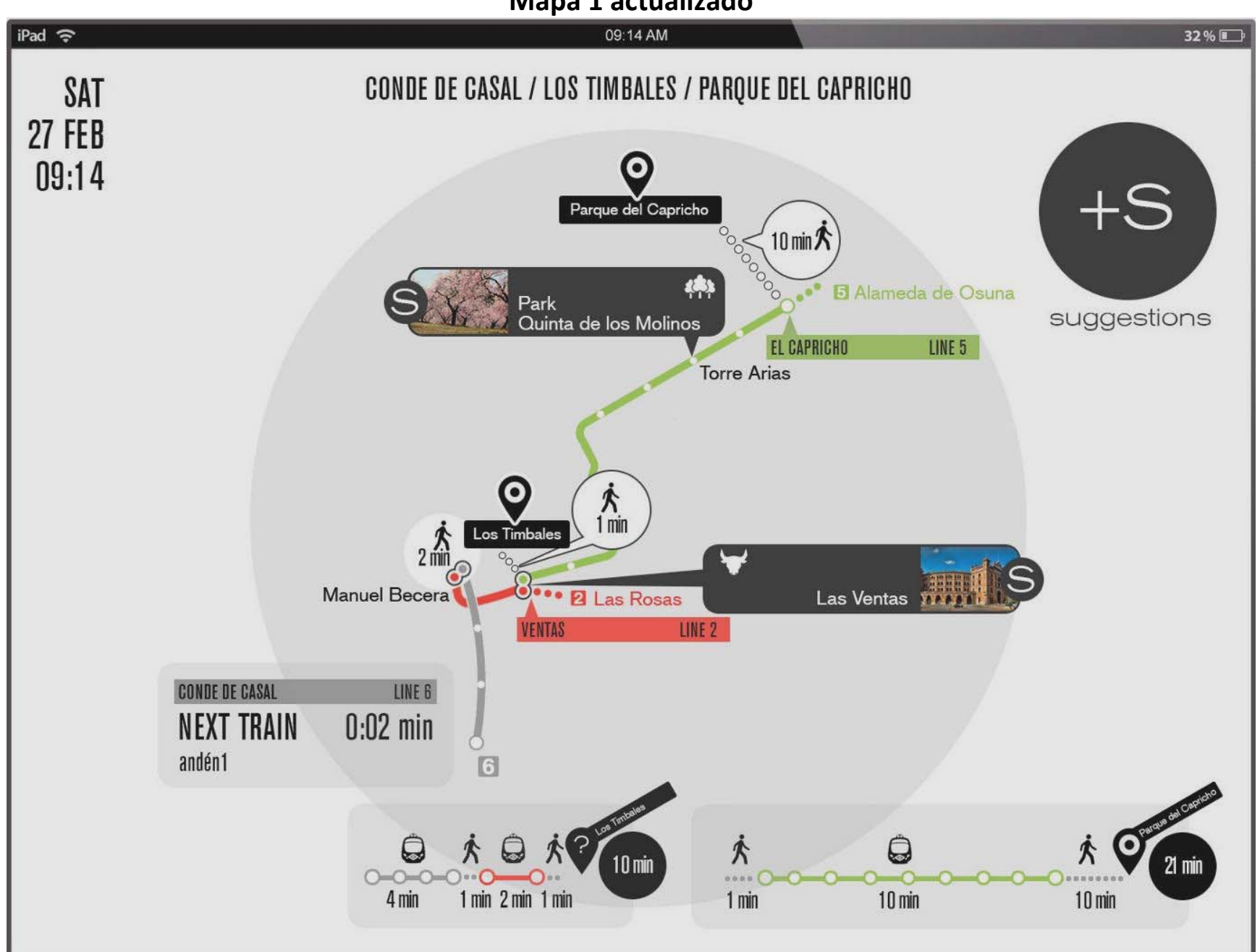

Figura 4.34: El sistema actualiza el recorrido al incorporar la nueva visita camino al Parque del Capricho (Los Timbales), segundos antes de de que llegue el metro. 
Mapa 2

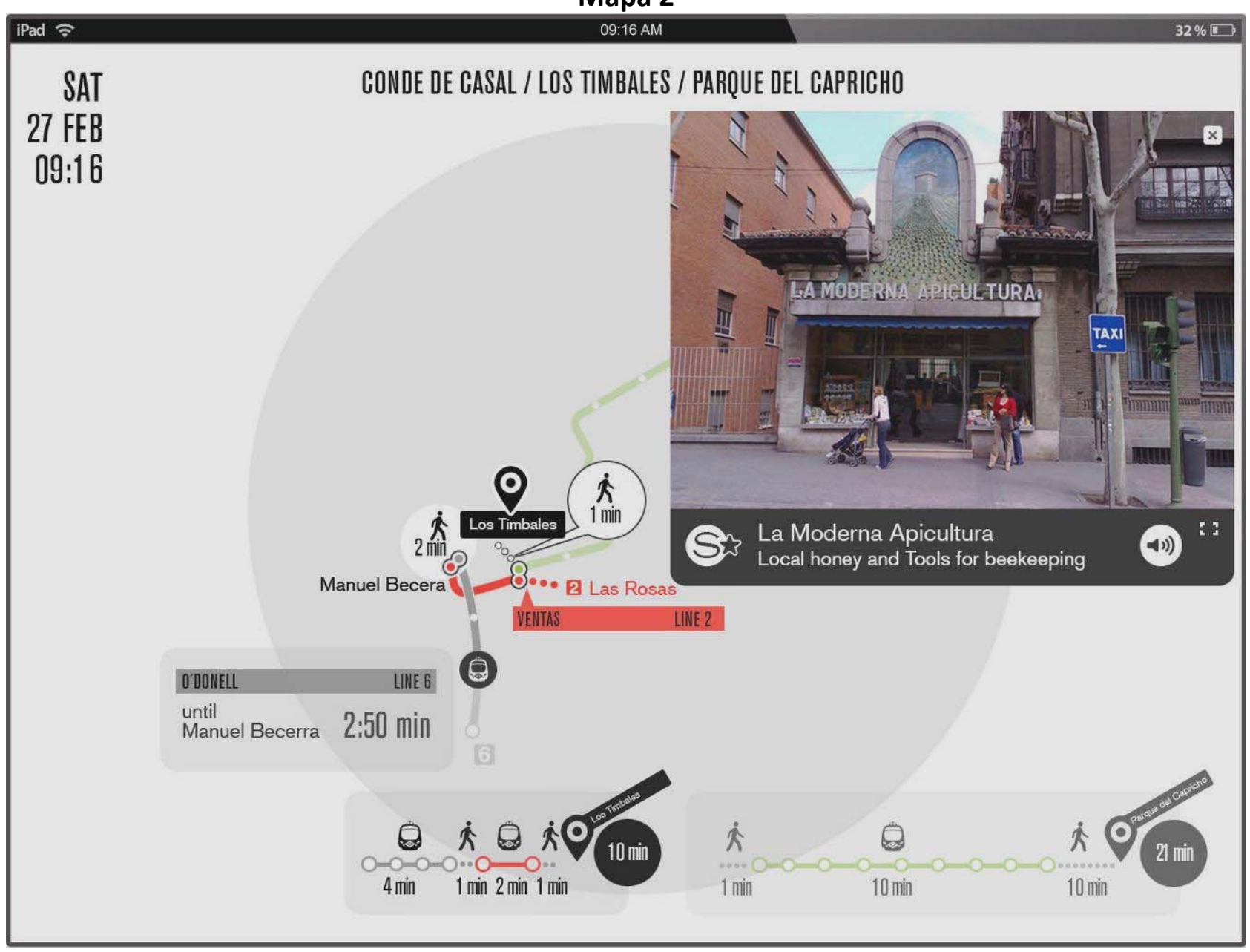

Figura 4.35: Kristian y su mujer ya están en el vagón camino a Los Timbales. El sistema muestra fotografías de lugares de interés por los que van pasando y en el mapa se puede ver el lugar del recorrido donde se encuentran en cada momento. 
Mapa 3

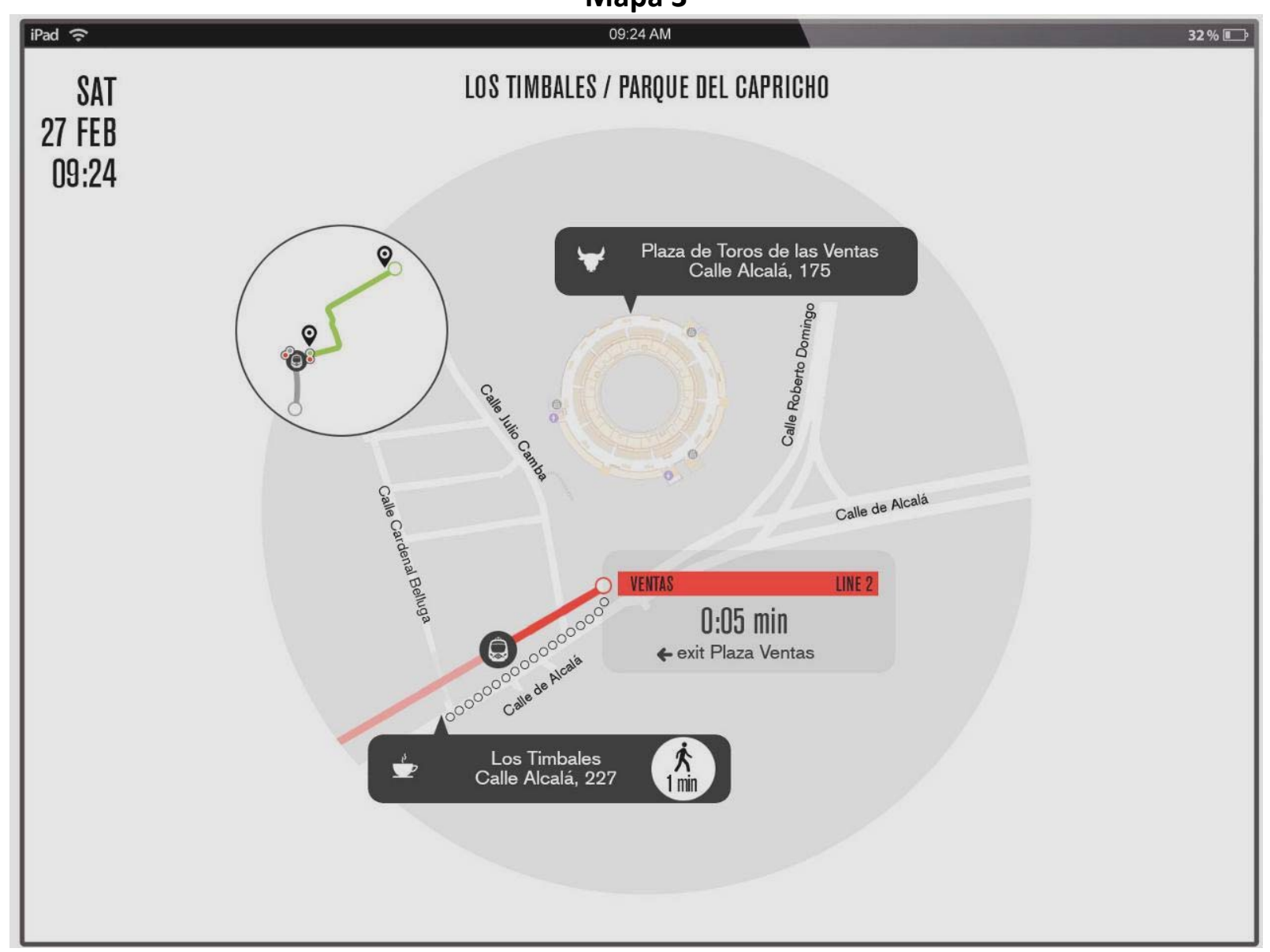

Figura 4.36: Kristian y su mujer están a punto de llegar a la parada de metro donde tienen que salir para ir a "Los Timbales". El sistema muestra el tiempo restante para llegar, la salida que tienen que tomar y la dirección en la que tienen que ir al salir del vagón, así como información geográfica de interés de la superficie como la ubicación de "Los Timbales" y de otro atractivo turístico próximo (la plaza de toros de las Ventas). 
Explorador-Escenario 2: Planeando que hacer al día siguiente
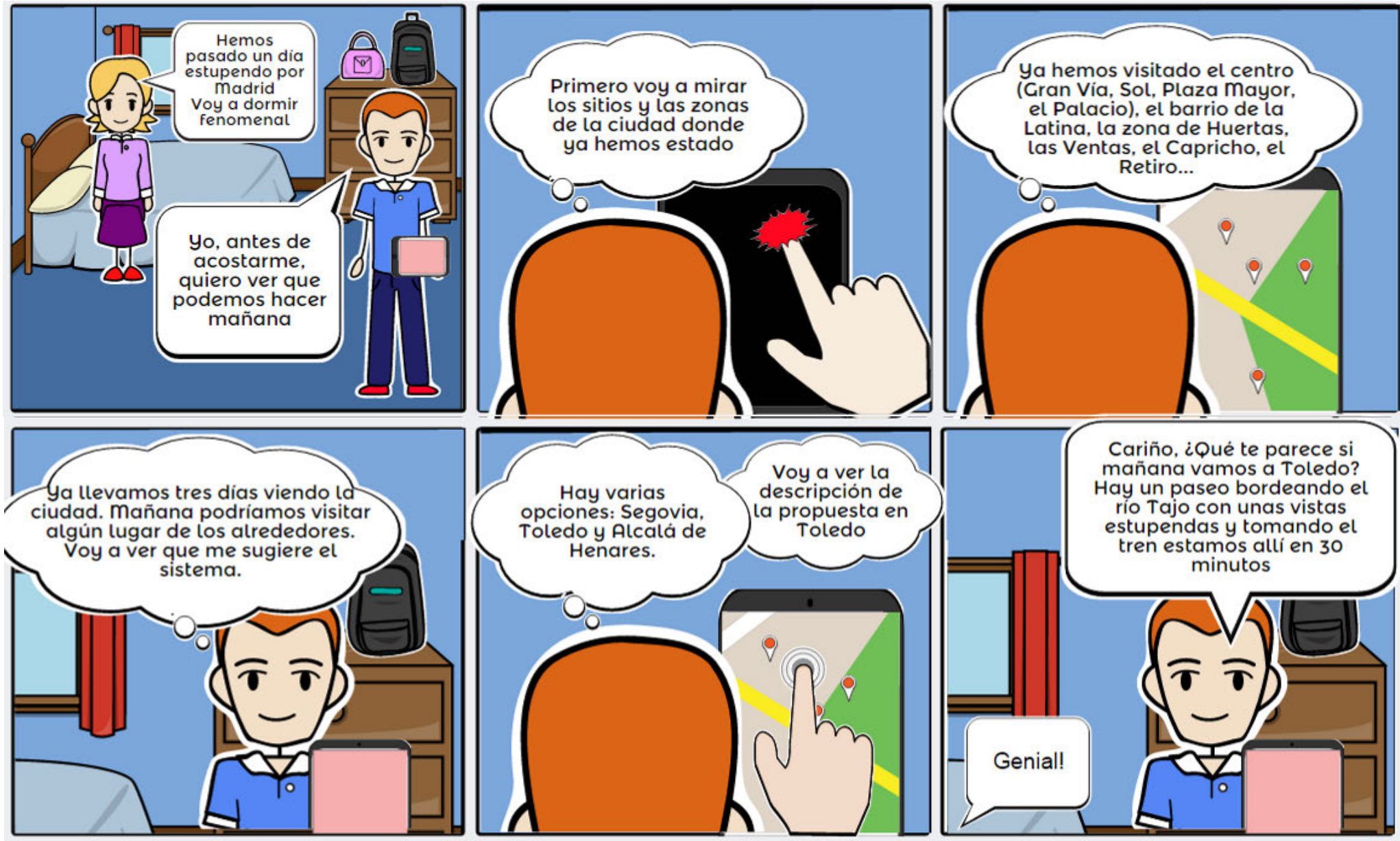

Figura 4.37: Storyboard Explorador-Escenario 2: Planeando que hacer al día siguiente. 


\begin{tabular}{|c|c|c|c|c|c|c|}
\hline \multicolumn{7}{|c|}{$\begin{array}{l}\text { Resumen: Kristian y su mujer llegan a su alojamiento después de su tercer día de visita en Madrid. } \\
\text { Antes de acostarse, Kristian quiere planear lo que hacer al día siguiente. } \\
\text { Kristian primero echa un vistazo a las zonas y atractivos de la ciudad donde ya han estado, para ver qué áreas les quedan por explorar. } \\
\text { Kristian decide que al día siguiente podrían salir de Madrid y visitar algún lugar de los alrededores, pero necesita sugerencias de actividades fuera de las rutas turísticas. }\end{array}$} \\
\hline & \begin{tabular}{|c|}
$\mathbf{1}$ \\
En alojamiento \\
Kristian y su \\
mujer llegan a su \\
habitación \\
tras pasar el día \\
visitando la \\
ciudad.
\end{tabular} & \begin{tabular}{|c|}
$\mathbf{2}$ \\
En alojamiento \\
Kristian quiere ver \\
primero las zonas y \\
lugares de la ciudad \\
donde ya han estado \\
para ver qué áreas les \\
quedan por explorar.
\end{tabular} & \begin{tabular}{|c|} 
Mapa 1 ciudad-esquemático \\
(Figura 4.38) \\
En alojamiento \\
Kristian echa un vistazo a las zonas y \\
lugares de la ciudad donde ya han \\
estado.
\end{tabular} & \begin{tabular}{|l|}
$\mathbf{4}$ \\
En alojamiento \\
Kristian decide visitar algún \\
lugar en los alrededores de \\
$\quad$ Madrid.
\end{tabular} & \begin{tabular}{|c|}
5 Mapa 2 alrededores-esquemático + \\
detalle + confirmación \\
(Figura 4.39-4.41) \\
En alojamiento \\
Kristian visualiza el mapa \\
$\begin{array}{c}\text { con los lugares de interés de alrededor de la } \\
\text { ciudad y los planes sugeridos por el sistema. A } \\
\text { continuación Kristian consulta información de } \\
\text { detalle de la propuesta en Toledo. }\end{array}$
\end{tabular} & \begin{tabular}{|c|c}
$\mathbf{6}$ \\
Mapa 3 \\
alrededores-geográfico \\
(Figura 4.42) \\
En alojamiento \\
\\
Krsitian visualiza el mapa de \\
los lugares de interés \\
alrededor de Madrid en su \\
versión geográfica.
\end{tabular} \\
\hline & $\begin{array}{c}\text { Modo } \\
\text { alojamiento } \\
\text { Ambiente- } \\
\text { >Sistema } \\
\text { El sistema sabe } \\
\text { que Kristian está } \\
\text { en su } \\
\text { alojamiento. } \\
\end{array}$ & $\begin{array}{l}\text { Modo alojamiento } \\
\text { Usuario <->Sistema } \\
\text { Kristian ordena al } \\
\text { sistema verbalmente o } \\
\text { seleccionando la opción } \\
\text { correspondiente. } \\
\text { El sistema activa el } \\
\text { servicio "Mi Madrid". }\end{array}$ & \begin{tabular}{|c|} 
Modo alojamiento \\
Servicio "Mi Madrid". \\
Sistema<->Usuario \\
El sistema muestra a Kristian el mapa de \\
"Su Madrid", donde puede consultar \\
información de detalle.
\end{tabular} & $\begin{array}{l}\text { Modo alojamiento } \\
\text { Usuario <->Sistema } \\
\text { Kristian ordena al } \\
\text { sistema la opción } \\
\text { correspondiente } \\
\text { El sistema activa el } \\
\text { servicio de "sugerencias } \\
\text { alrededores". } \\
\end{array}$ & \begin{tabular}{|c|} 
Modo alojamiento \\
Servicio "sugerencias alrededores" \\
Sistema<->Usuario \\
El sistema muestra los lugares de interés a \\
menos de 2 horas del centro de la ciudad y \\
Kristian consulta información de detalle de \\
uno de los planes sugeridos (Toledo) y decide \\
realizarlo al día siguiente.
\end{tabular} & \begin{tabular}{|} 
Modo alojamiento \\
Servicio "sugerencias \\
alrededores" \\
Usuario <->Sistema \\
Kristian selecciona Toledo y el \\
mapa. \\
\end{tabular} \\
\hline$\frac{5}{\frac{c}{2}}$ & $\begin{array}{c}\text { Kristian quiere } \\
\text { consultar al } \\
\text { sistema. }\end{array}$ & & $\begin{array}{l}\text { Kristian refuerza su conocimiento } \\
\text { sobre los lugares donde ya ha estado. }\end{array}$ & $\begin{array}{l}\text { Kristian decide recurrir de } \\
\text { nuevo al sistema para } \\
\text { recibir sugerencias. }\end{array}$ & $\begin{array}{c}\text { Kristian asimila nuevo conocimiento sobre } \\
\text { Madrid y dispone de la información necesaria } \\
\text { decidir qué hacer al día siguiente. }\end{array}$ & \begin{tabular}{|c|} 
Kristian asimila nuevo \\
conocimiento de Toledo y \\
propone el plan a su mujer.
\end{tabular} \\
\hline 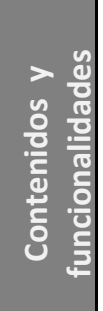 & & & $\begin{array}{l}\text { Mapa esquemático, sin foco, con PITs, } \\
\text { calles destacadas, zonas visitadas y } \\
\text { líneas de transporte utilizadas. Iconos } \\
\text { personalizados de atractivos clave, con } \\
\text { posibilidad de selección. Opción de } \\
\text { visualizar el mismo mapa en su versión } \\
\text { geográfica, navegar por el mapa, y } \\
\text { solicitar al sistema sugerencias. }\end{array}$ & & $\begin{array}{l}\text { Mapa con foco en Madrid y lugares de } \\
\text { interés en esquema radial de tiempo } \\
\text { mínimo para llegar a ellos. Opción de } \\
\text { visualización geográfica. Posibilidad de } \\
\text { consultar detalles de los planes propuestos } \\
\text { o solicitar más sugerencias. }\end{array}$ & $\begin{array}{c}\text { Mapa con información de } \\
\text { detalle sobre las opciones de } \\
\text { transporte Madrid-Toledo y la } \\
\text { descripción de la propuesta } \\
\text { (una ruta bordeando el río Tajo) } \\
\text { y fotografías de ella. }\end{array}$ \\
\hline
\end{tabular}

Tabla 4.13: Descripción del Explorador-Escenario 2: Planeando que hacer al día siguiente. 
A continuación se incluye una descripción de los desplazamientos realizados y los lugares visitados por Kristian y su esposa hasta el momento en el que tiene lugar la situación descrita en este escenario. Esta información sirve para ilustrar el contexto de los prototipos de los mapas que aparecen seguidamente.

- Viernes 9 de Marzo: Después de dejar sus maletas en el alojamiento, Kristian y su mujer toman el metro en Pacífico a las 16:00 y van hasta Gran Vía. Pasean por la Gran Vía hasta Callao, llegan a Sol bajando por la calle Preciados, recorren la calle Arenal y llegan al Palacio Real y a la Catedral de la Almudena. Después se dirigen a la Plaza Mayor y seguidamente callejean por la Latina-El Rastro y cenan en un restaurante que no les resulta especialmente relevante. Después de cenar caminan hasta Tirso de Molina y toman el bus 32 hasta su alojamiento.

- Sábado 10 de Marzo: Kristian y su esposa deciden visitar el Parque del Capricho y toman el metro en Conde de Casal (9:30). Cuando se encuentran en el andén esperando al tren, el sistema les sugiere varios lugares de interés camino a su destino y deciden hacer una parada en Ventas para desayunar en una taberna taurina y ver por fuera la plaza de las Ventas. Después de visitar el Parque del Capricho, regresan a casa y descansan un rato. Por la tarde toman el autobús 14 para visitar el Museo del Prado. Después de ver el museo, cenan en un restaurante gallego en la calle huertas que les gusta mucho y regresan de nuevo a casa en el autobús 14.

- Domingo 11 de Marzo: Es domingo y quieren visitar el Rastro, para ello toman el metro en Pacífico, hasta Tirso de Molina. Pasan la mañana en el Rastro y deciden comer de tapas en un bar de la zona que les encanta. Después toman el autobús circular al final de la calle de Ribera de Curtidores hasta la Avenida de Menéndez Pelayo para visitar el Retiro. Pasean por el Retiro y van al alojamiento caminando. Después de descansar un rato, toman el metro en Pacífico hasta Portazgo para ver un espectáculo flamenco en "El Cortijo". 


\section{Mapa 1 El Madrid de Kristian-Esquemático}

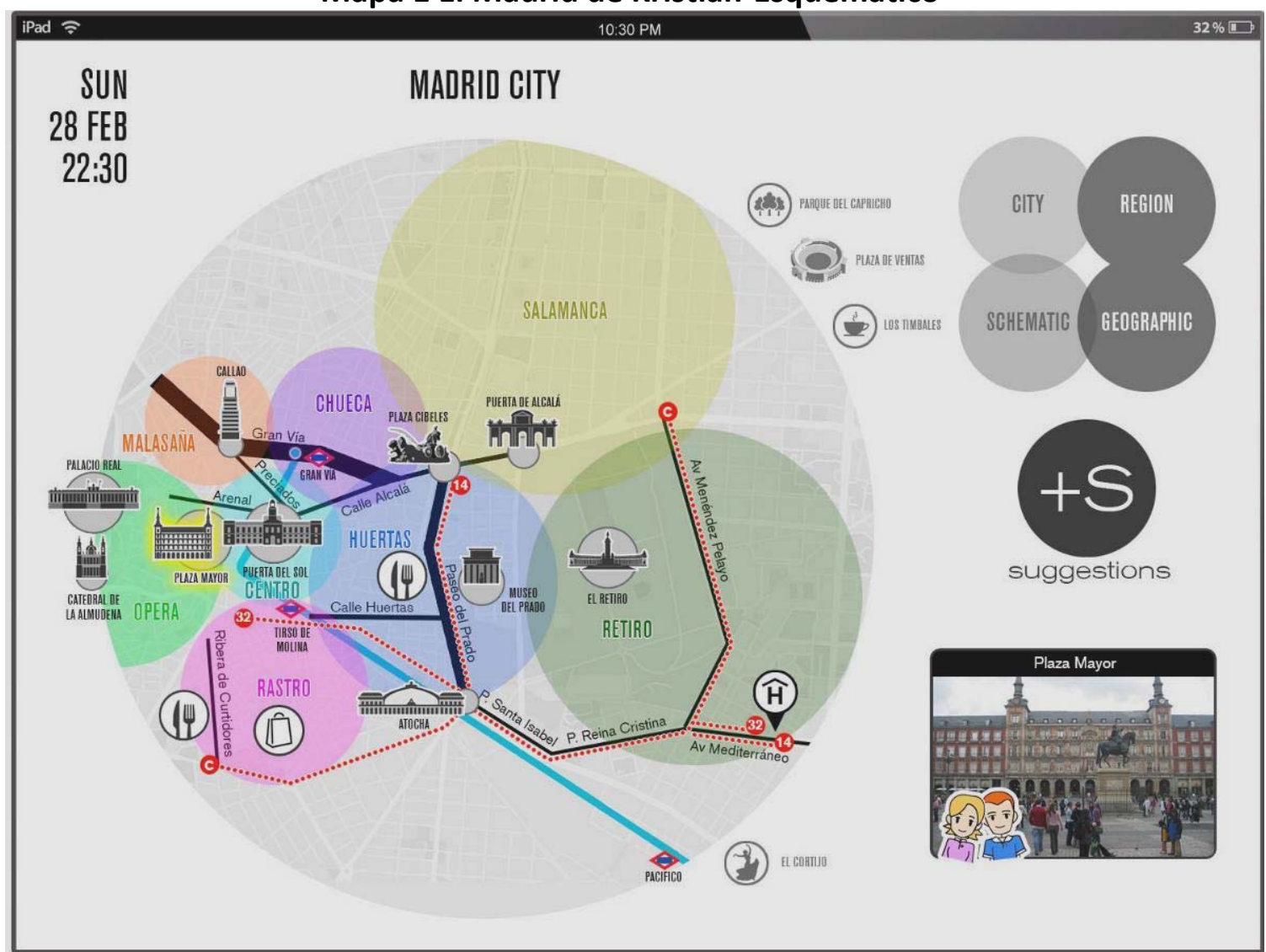

Figura 4.38: Kristian visualiza el mapa esquemático de "Su Madrid". Este mapa no presenta foco e incluye los puntos de interés turístico, ejes destacados y zonas visitadas, así como las líneas de transporte utilizadas. Iconos personalizados de atractivos clave sobre círculos cuyo tamaño está determinado por el peso que cada uno de ellos tiene en el mapa mental agregado de los turistas de Madrid (Figura 4.13) y servicios que Kristian ha valorado de forma destacada (restaurantes, lugares de compras y espectáculos), con posibilidad de selección para ver información asociada. Kristian puede visualizar el mismo mapa en su versión geográfica y consultar sugerencias. 
Mapa 2 alrededores-esquemático

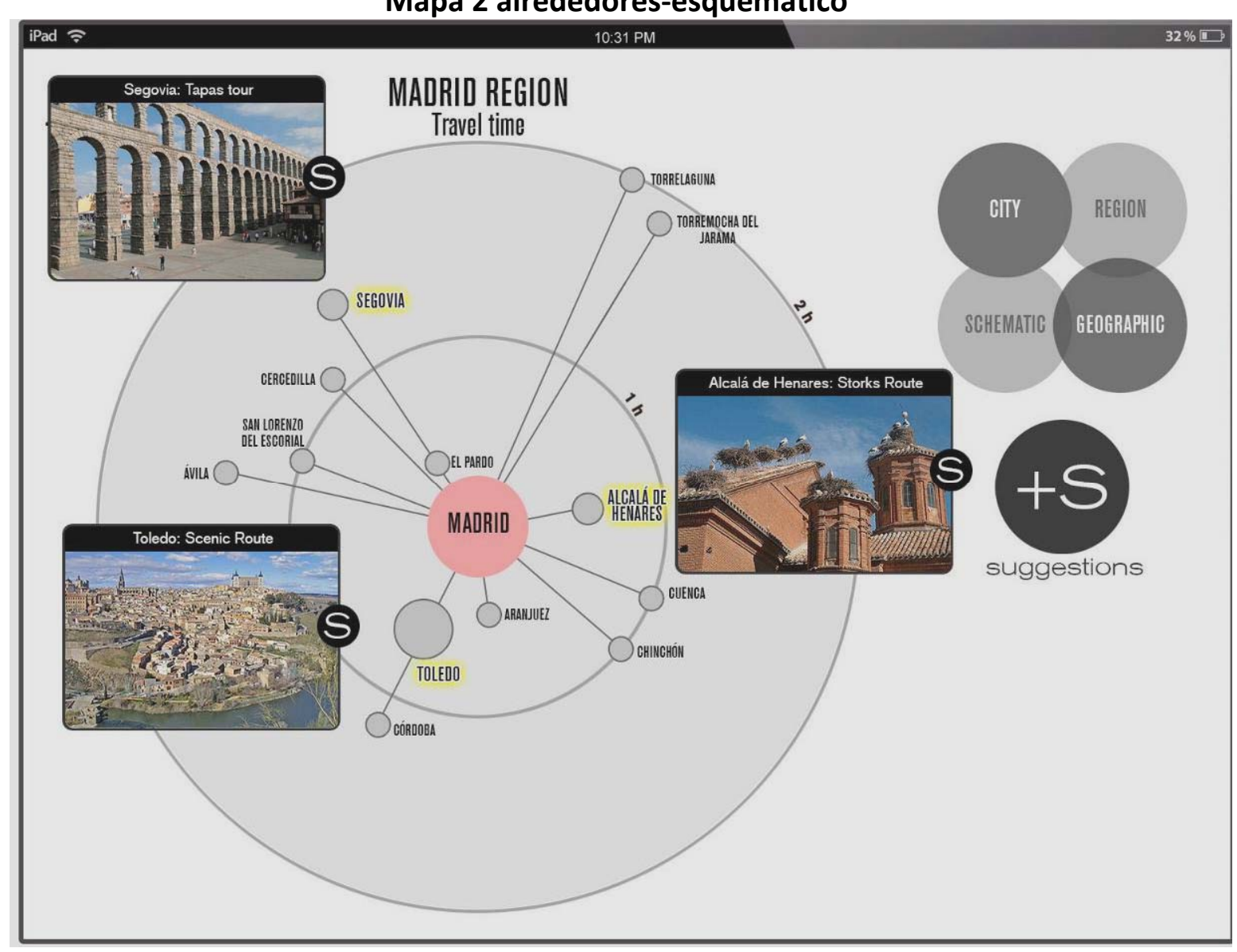

Figura 4.39: Cuando Kristian selecciona el botón "Region" el sistema mantiene el modo de visualización esquemático y muestra una selección de lugares afines a sus intereses a menos de 2 horas de Madrid y tres sugerencias (una ruta panorámica en Toledo, un recorrido para ver cigüeñas en Alcalá de Henares y un tour de tapas por Segovia). Los círculos que representan los lugares tienen un tamaño acorde con el peso que éstos tienen en el mapa cognitivo agregado de los turistas de Madrid. Los lugares se ubican en su dirección geográfica y a una distancia equivalente al tiempo de acceso más rápido en transporte público desde Madrid. 
Mapa 2 alrededores-esquemático + detalle

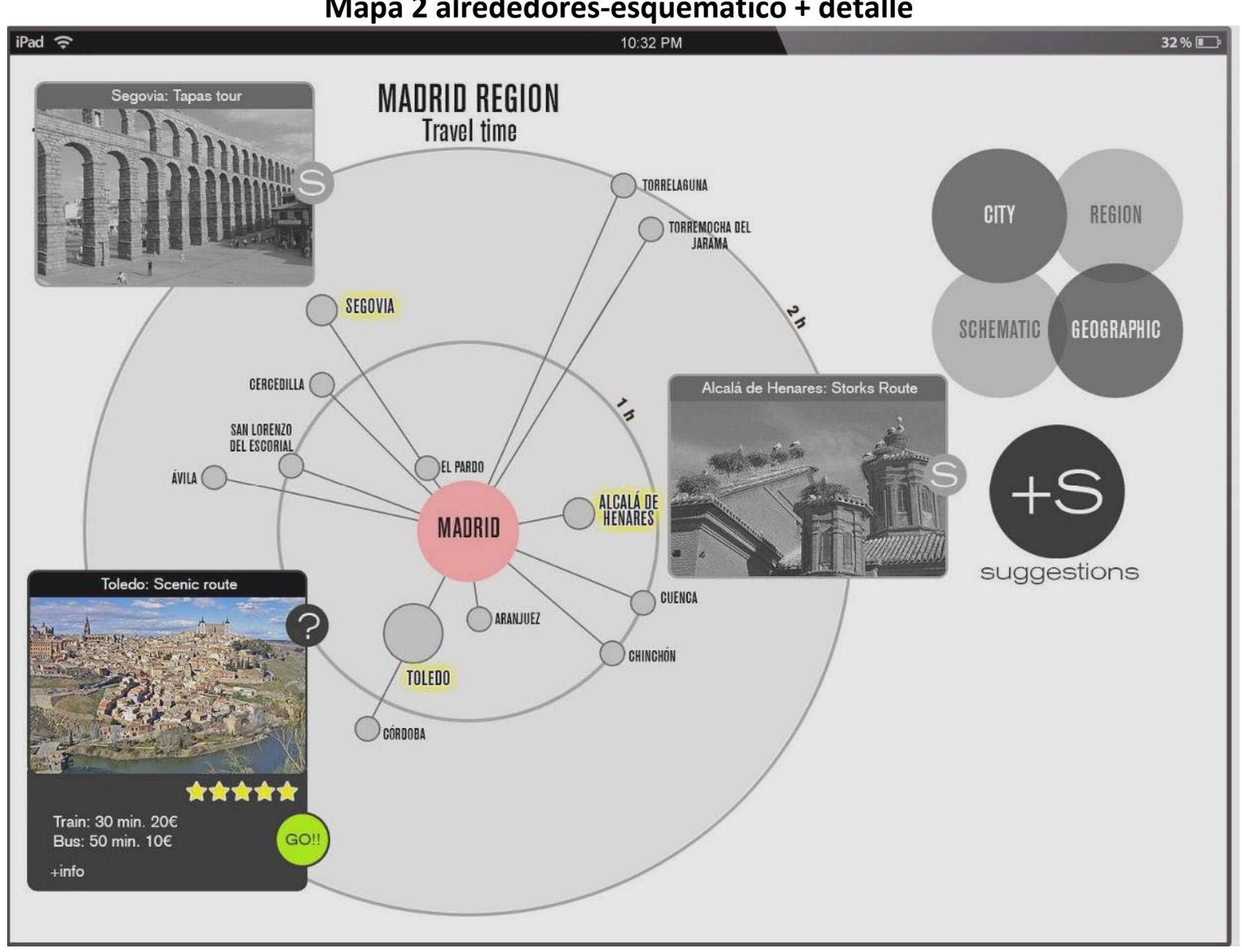

Figura 4.40: Kristian decide ver más detalles del plan sugerido en Toledo. El sistema muestra a Kristian información de detalle de la ruta panorámica: valoración de otros turistas exploradores, medios de transporte disponibles y precios. Kristian puede expandir la información de detalle para ver horarios, ubicación de estaciones... Tras consultar a su esposa, Kristian indica al sistema que irán a Toledo. 


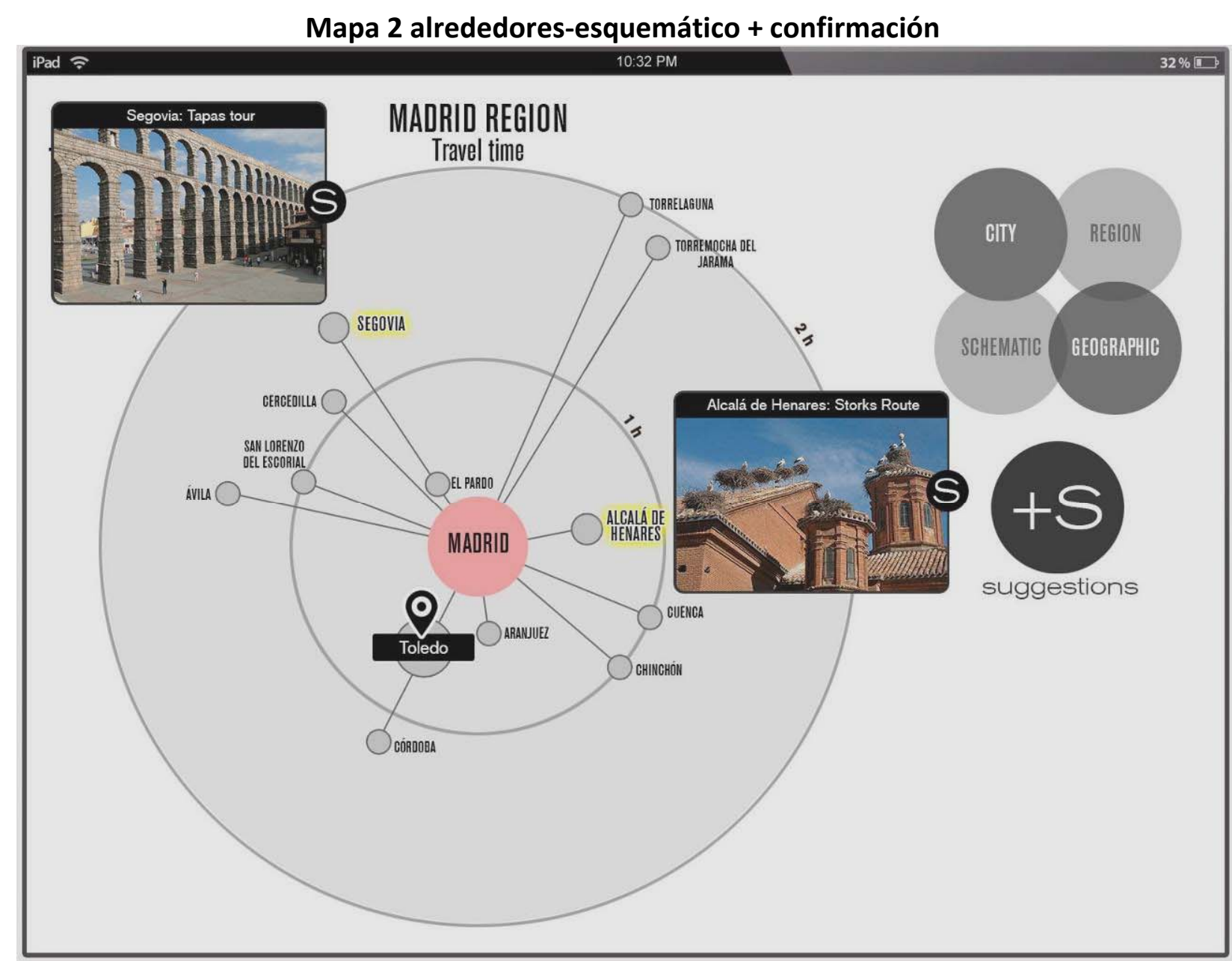

Figura 4.41: Kristian ha decidido que al día siguiente irán a Toledo y el sistema muestra el mapa esquemático de los alrededores de Madrid con el nuevo destino incorporado. Kristian decide entonces echar un vistazo a la ubicación geográfica de Toledo. 
Mapa 3 alrededores-geográfico

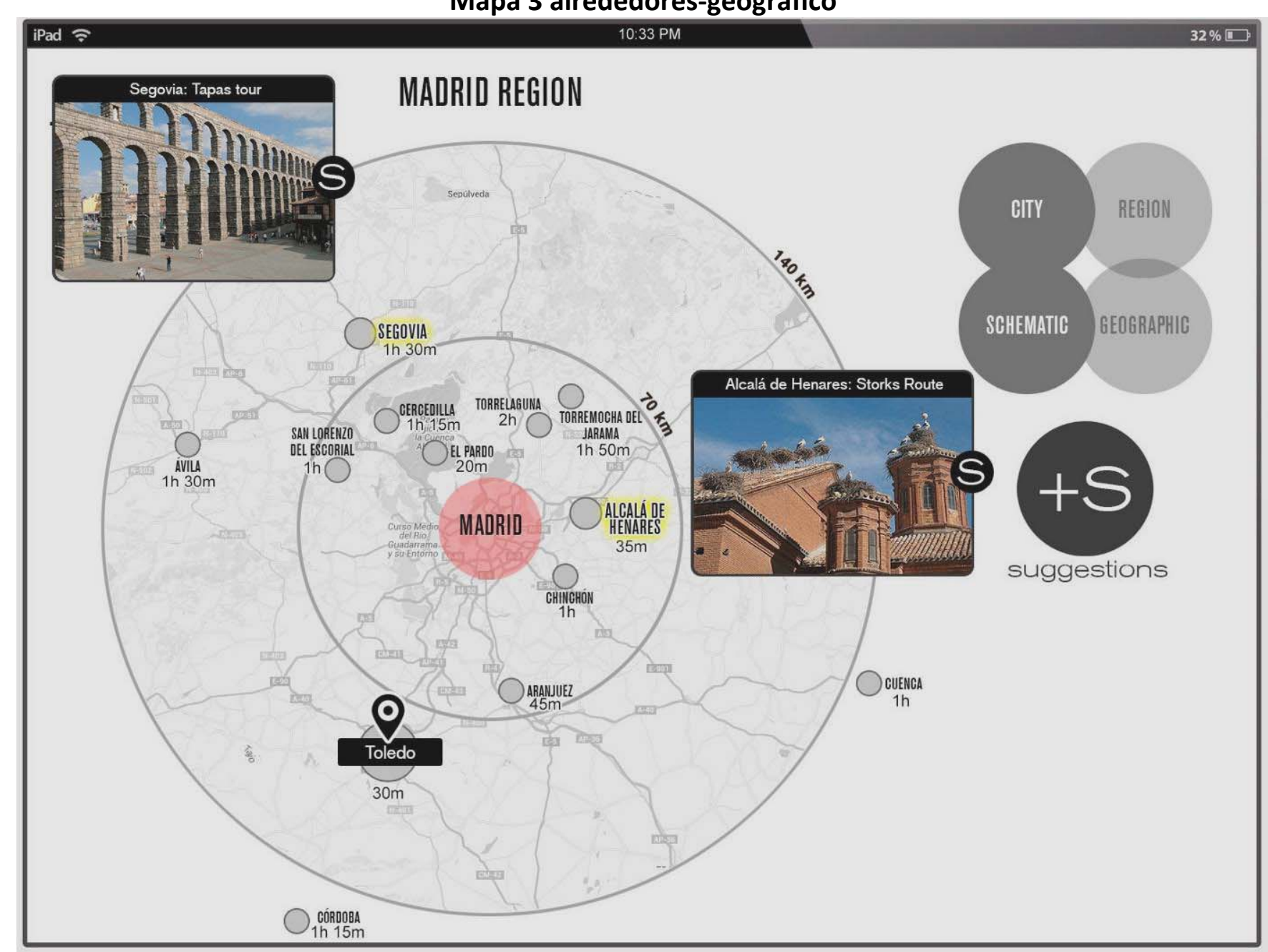

Figura 4.42: Representación geográfica de lugares de interés alrededor de Madrid, el destino seleccionado para ir al día siguiente (Toledo) y dos sugerencias. 
Guiado-Escenario 1: Planeando el viaje a Madrid
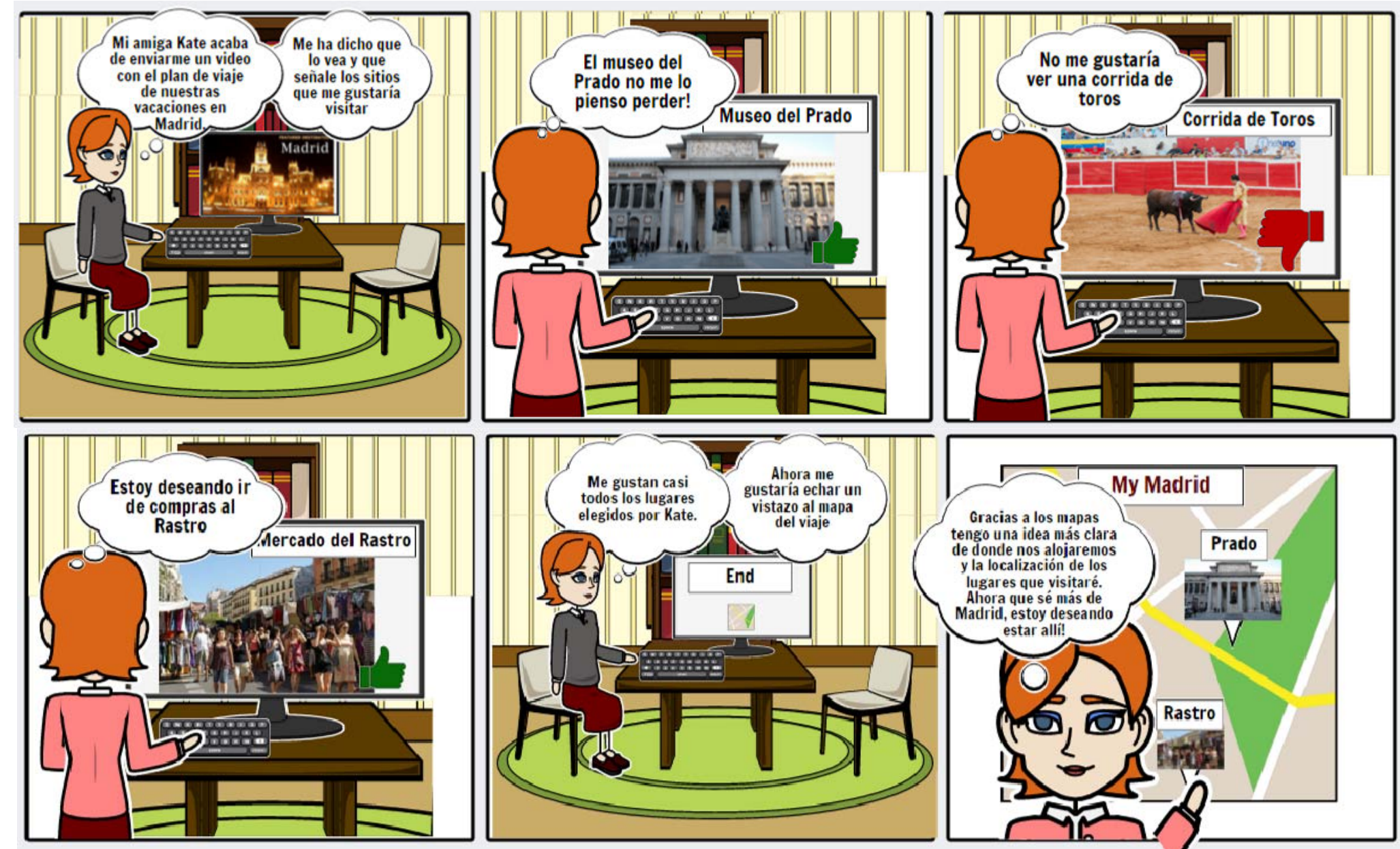

Figura 4.43: Storyboard Guiado-Escenario1: Planeando el viaje. 


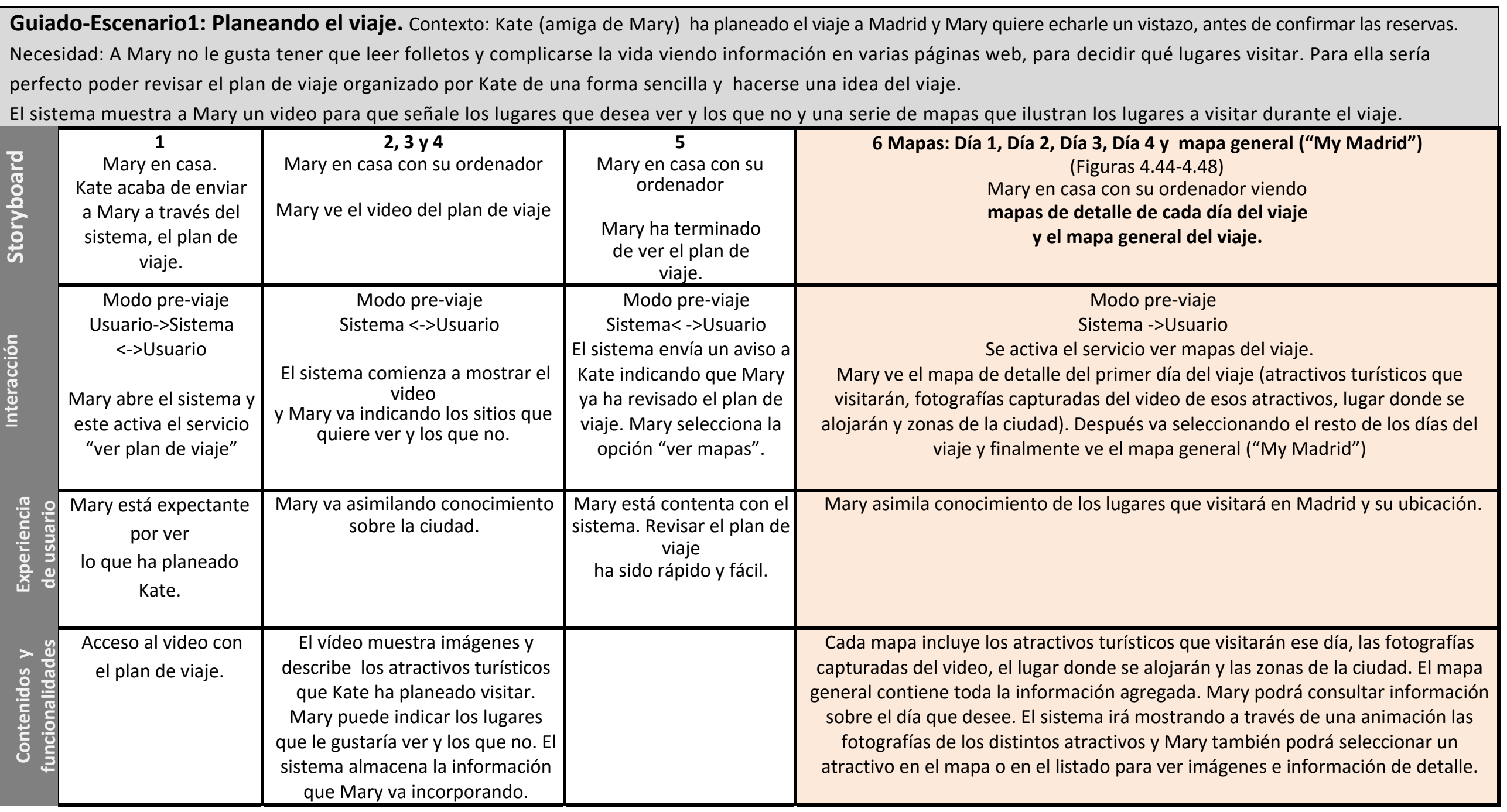

Tabla 4.14: Descripción del Guiado-Escenario 1: Planeando el viaje. 


\section{Mapa del día 1}

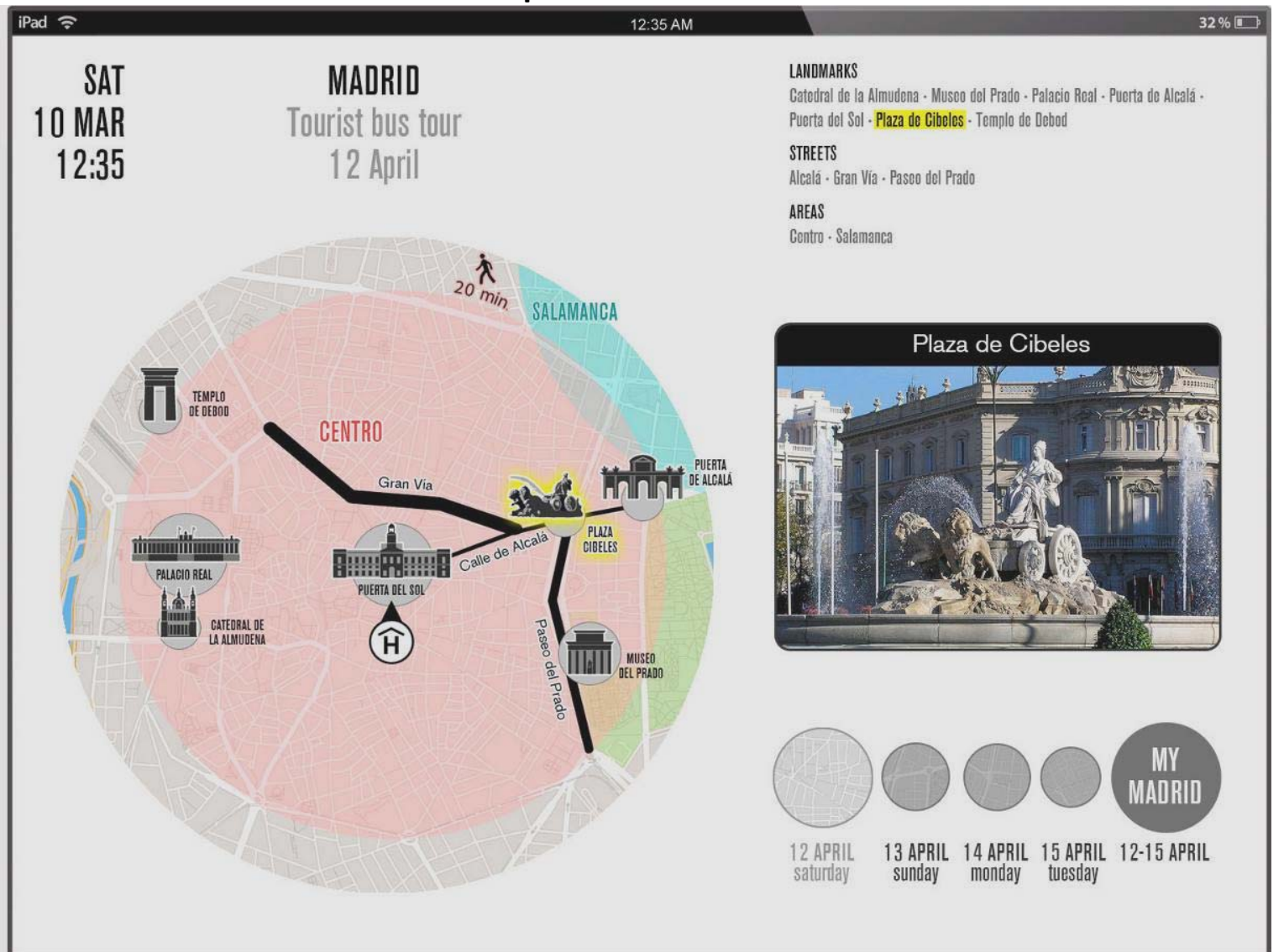

Figura 4.44: El sistema muestra un mapa con foco en el lugar de alojamiento y los atractivos que visitarán el primer día, así como fotografías capturadas del video y principales calles de referencia según la exploración realizada de los mapas mentales de los turistas (Figura 4.13). Mary puede seleccionar los atractivos que desee para obtener más información y consultar otro día de la estancia. Antes de realizar el viaje se considera intrascendente el recorrido que realizará el bus turístico y se da prioridad a los atractivos que se visitarán ese día, sin embargo al consultar la misma información durante la visita el recorrido del bus turístico sí que se incluye (Escenario 2, Figura 4.50). 


\section{Mapa del día 2}

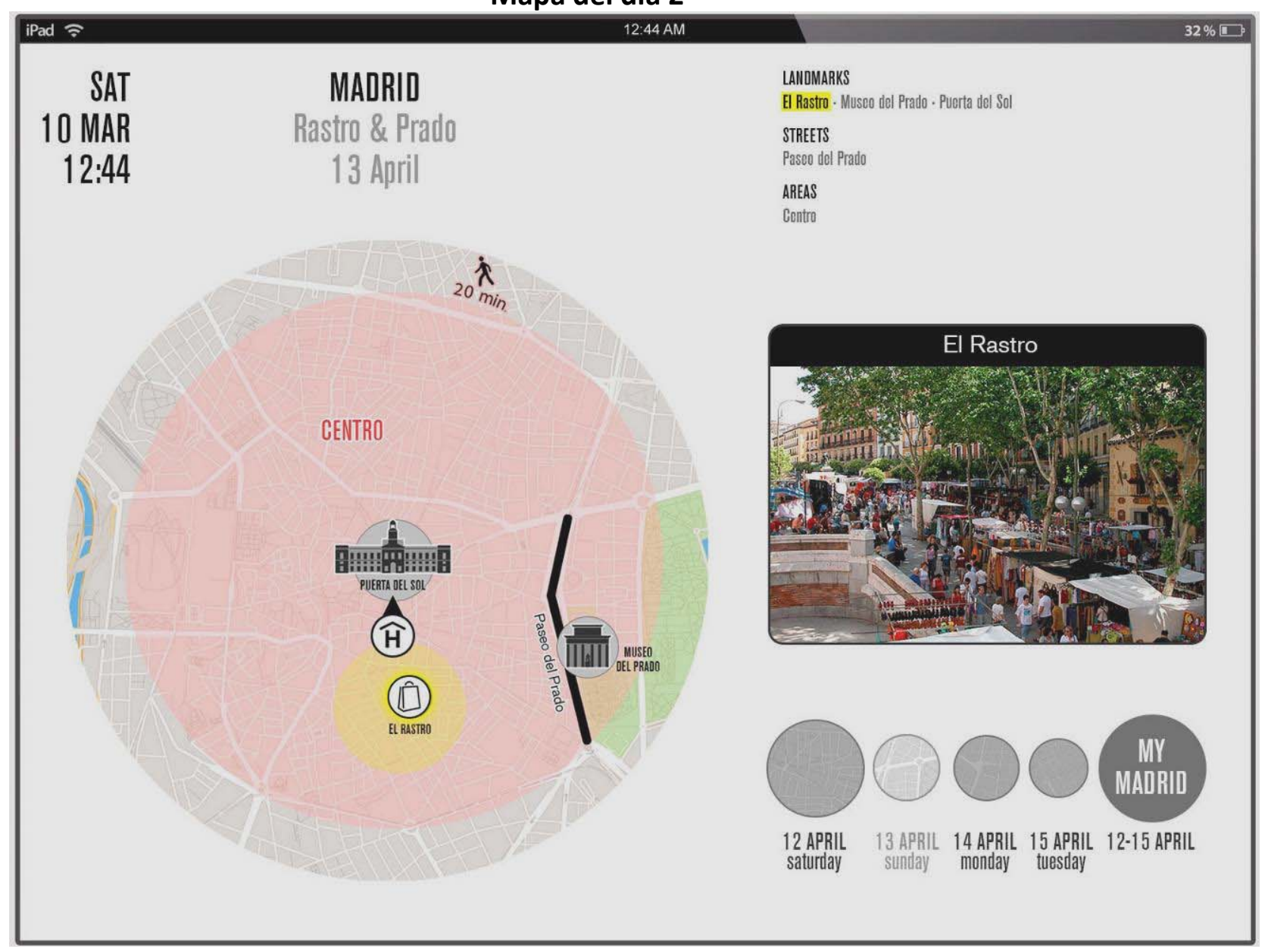

Figura 4.45: El sistema muestra los atractivos que visitarán el segundo día. Los iconos de los mapas están personalizados siguiendo las pautas de varios mapas mentales recogidos de los turistas (Figura 4.8, 4.11b, 4.14 y $4.22 c$ ). 
Mapa del día 3

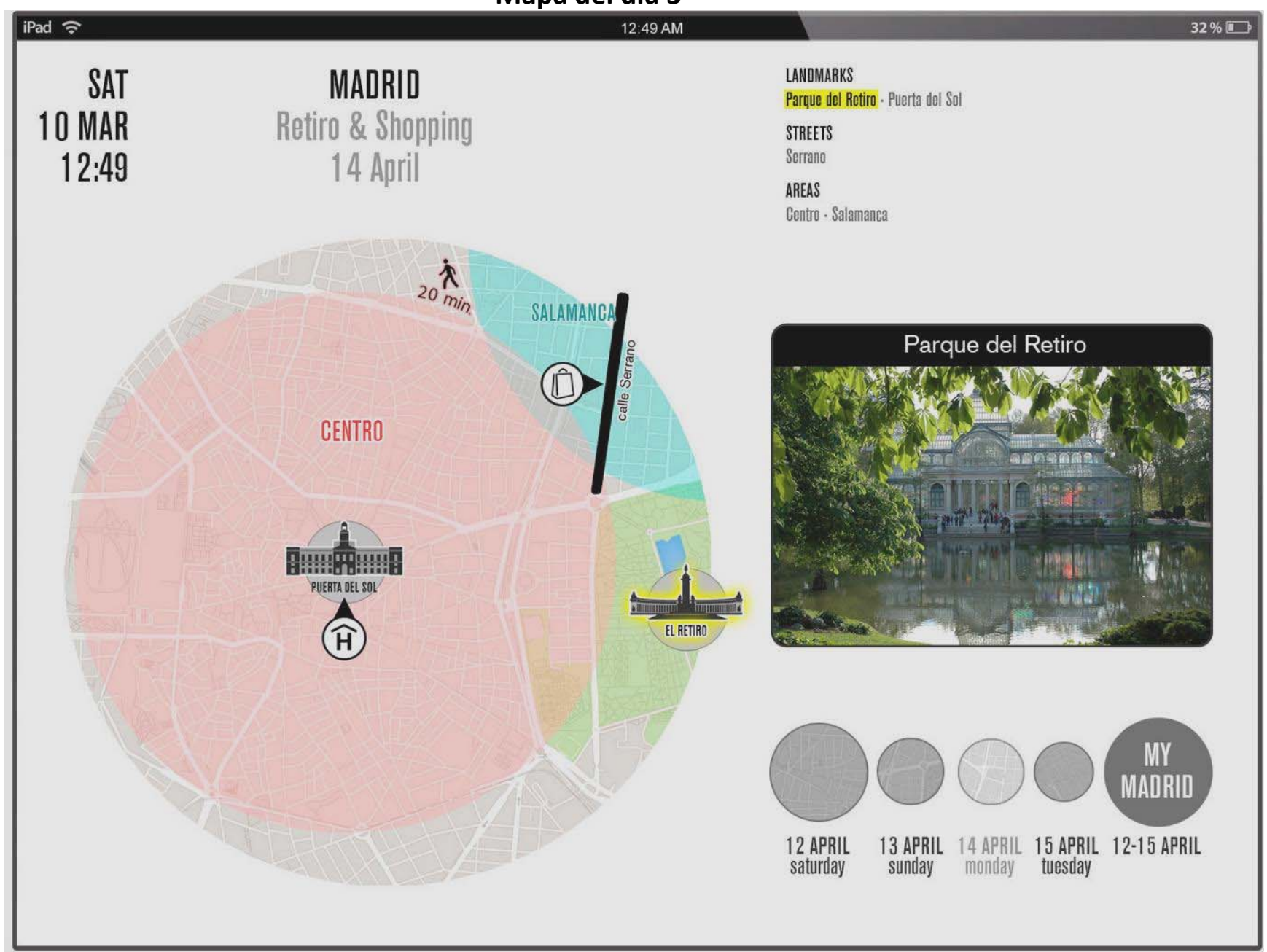

Figura 4.46: El sistema muestra los atractivos que visitarán el tercer día. El sistema resalta en el mapa y en la lista de texto, el atractivo correspondiente a la imagen mostrada, para facilitar la asimilación de conocimiento. 
Mapa del día 4

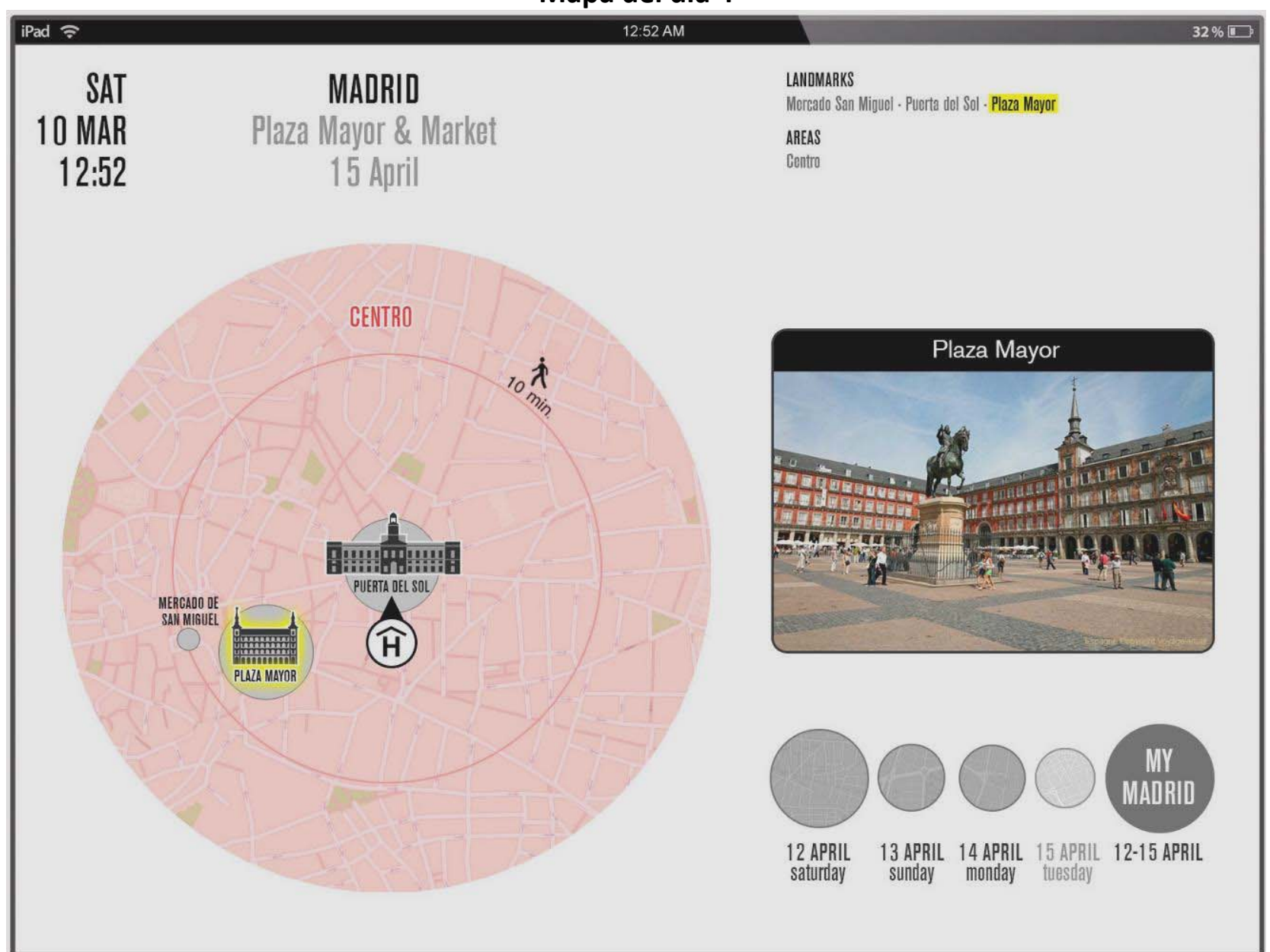

Figura 4.47: El sistema muestra los atractivos que visitarán el cuarto día. El mapa está focalizado en el lugar de alojamiento y como este día visitarán varios lugares próximos andando, se incluye una refrencia geográfico-temporal (anillo de 10 minutos andando desde el alojamiento). 
Mapa del Madrid de Mary

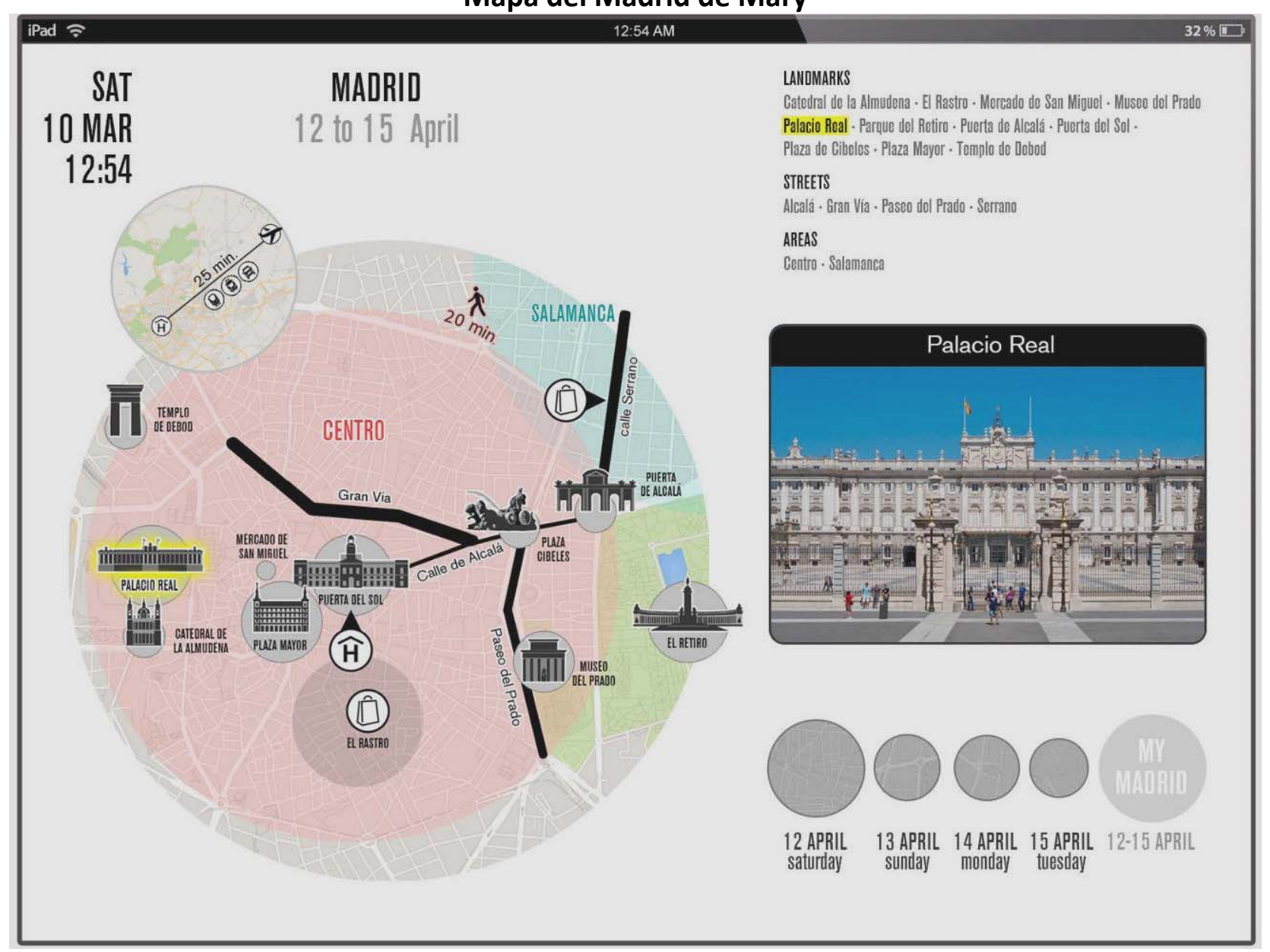

Figura 4.48: El sistema muestra los atractivos que Mary y Kate visitarán a lo largo de su estancia. Mary, como turista guiado, es posible que tenga dificultades para integrar geográficamente la ubicación los atractivos visitados a lo largo de su estancia. Por esta razón, se ha propuesto una visualización individualizada por días y una integrada, que de soporte a Mary en sus procesos cognitivos asociados a la asimilación de conocimiento espacial de Madrid. 
Guiado-Escenario 2: Consultando información sobre el viaje durante la visita a Madrid.
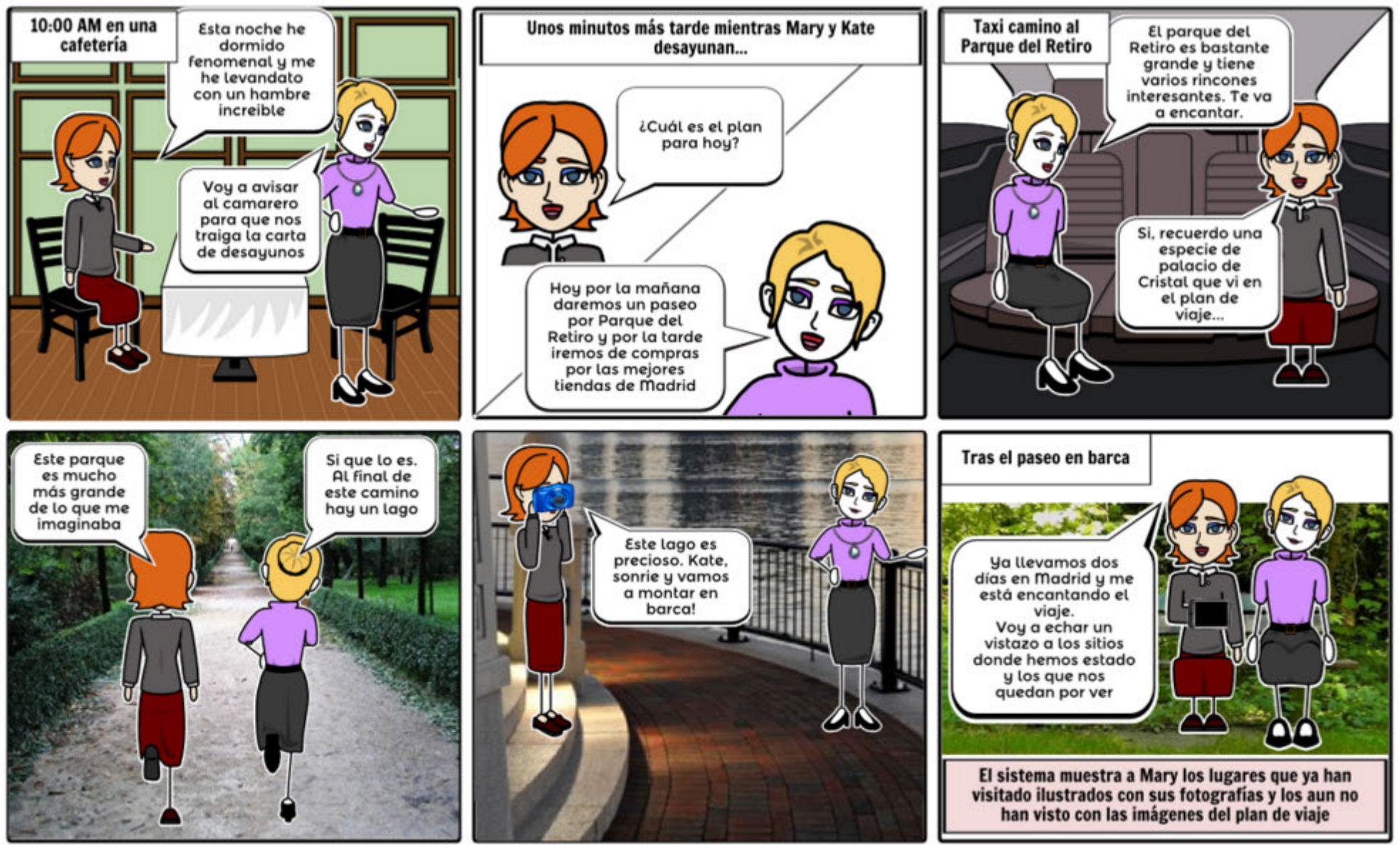

Figura 4.49: Storyboard Guiado-Escenario2: Consultando información sobre el viaje durante la visita. 


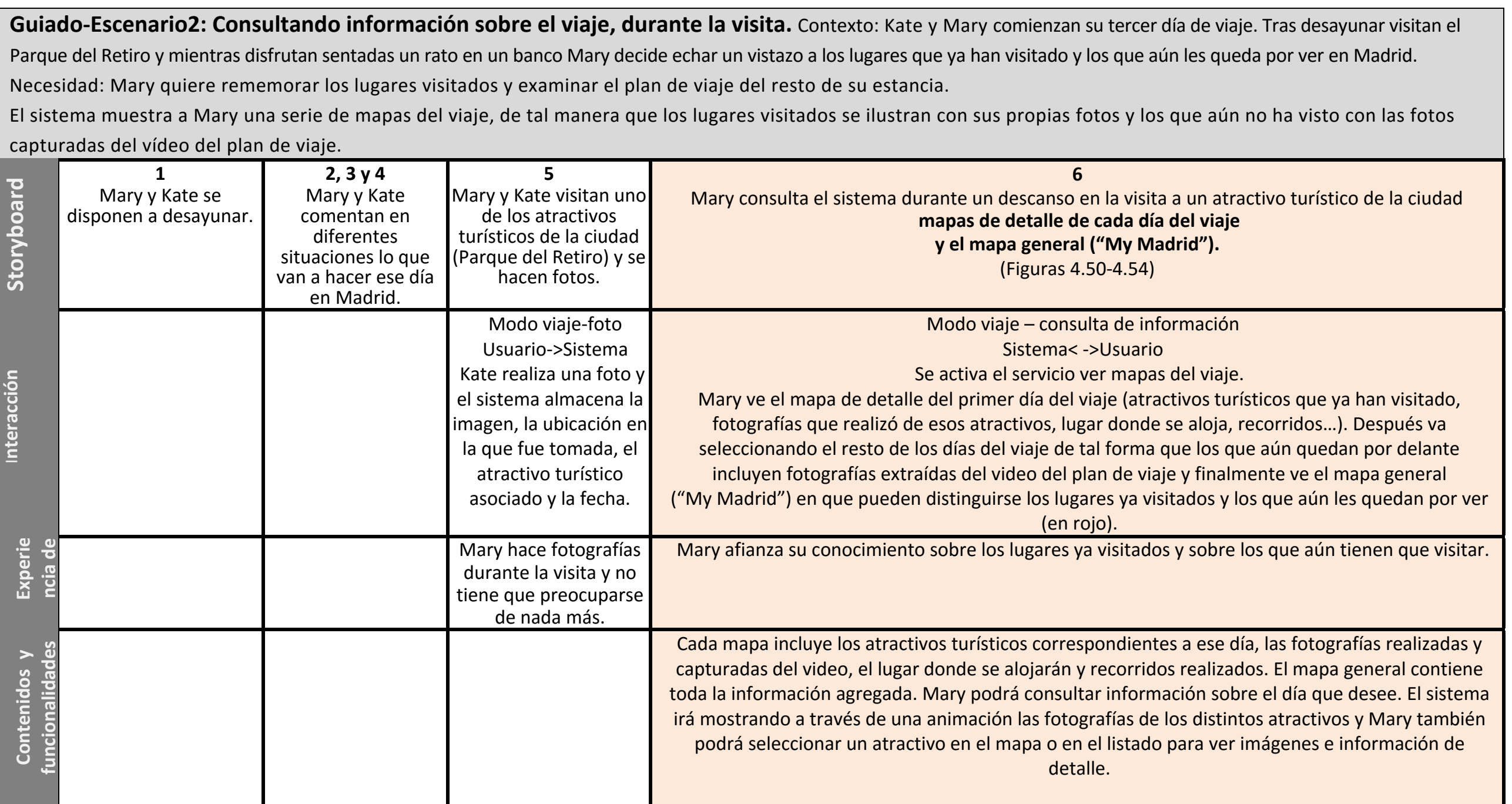

Tabla 4.15: Descripción del Guiado-Escenario 2: Consultando información sobre el viaje, durante la visita. 
Mapa del día 1

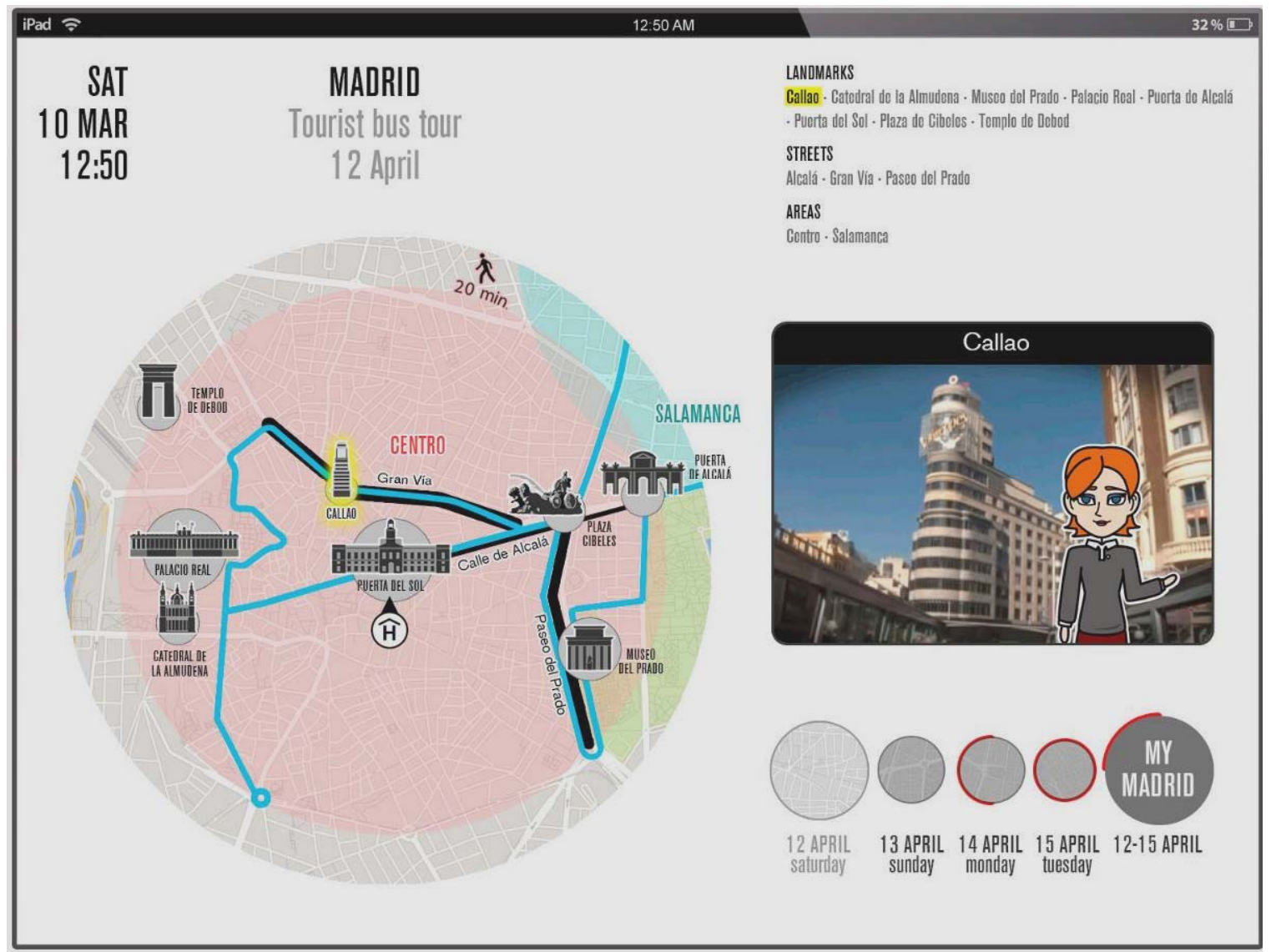

Figura 4.50: El sistema muestra los atractivos que Mary y Kate visitaron el primer día de su estancia en Madrid, en el que recorrieron la ciudad en bus turírico. El menú de botones de los días de la estancia indica con contornos en rojo actividades por realizar. El último botón permite a Mary acceder a una visualización que integra todos los atractivos y recorridos realizados y por realizar durante el viaje. 
Mapa del día 2

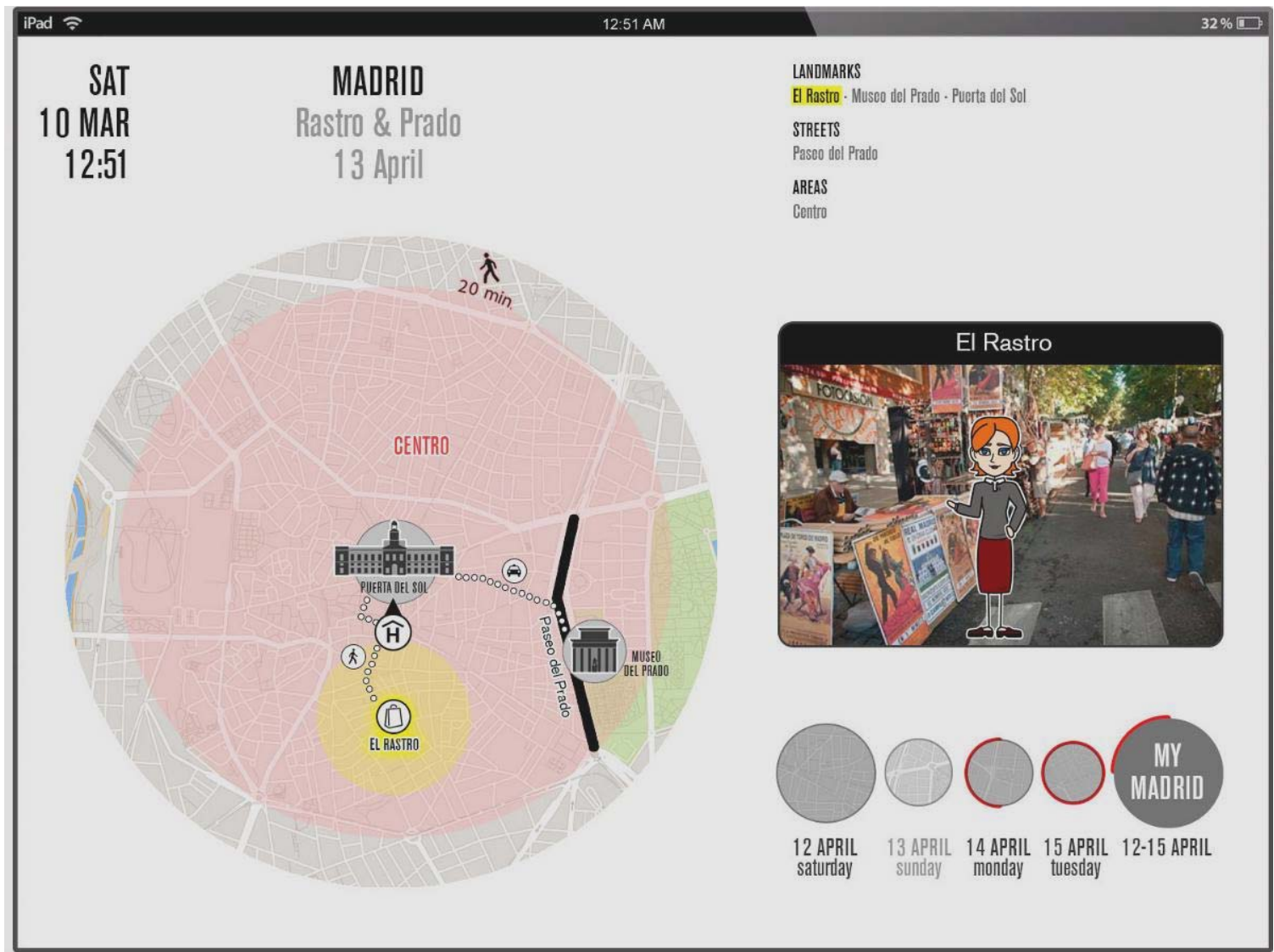

Figura 4.51: El sistema muestra los atractivos que Mary y Kate visitaron el segundo día de su estancia en Madrid. Por la mañana fueron andando al Rastro donde hicieron unas compras y por la tarde tomaron un taxi para ir al Prado. Las fotografías tomadas por Mary ilustran sus experiencias de ese día. 
Mapa del día 3

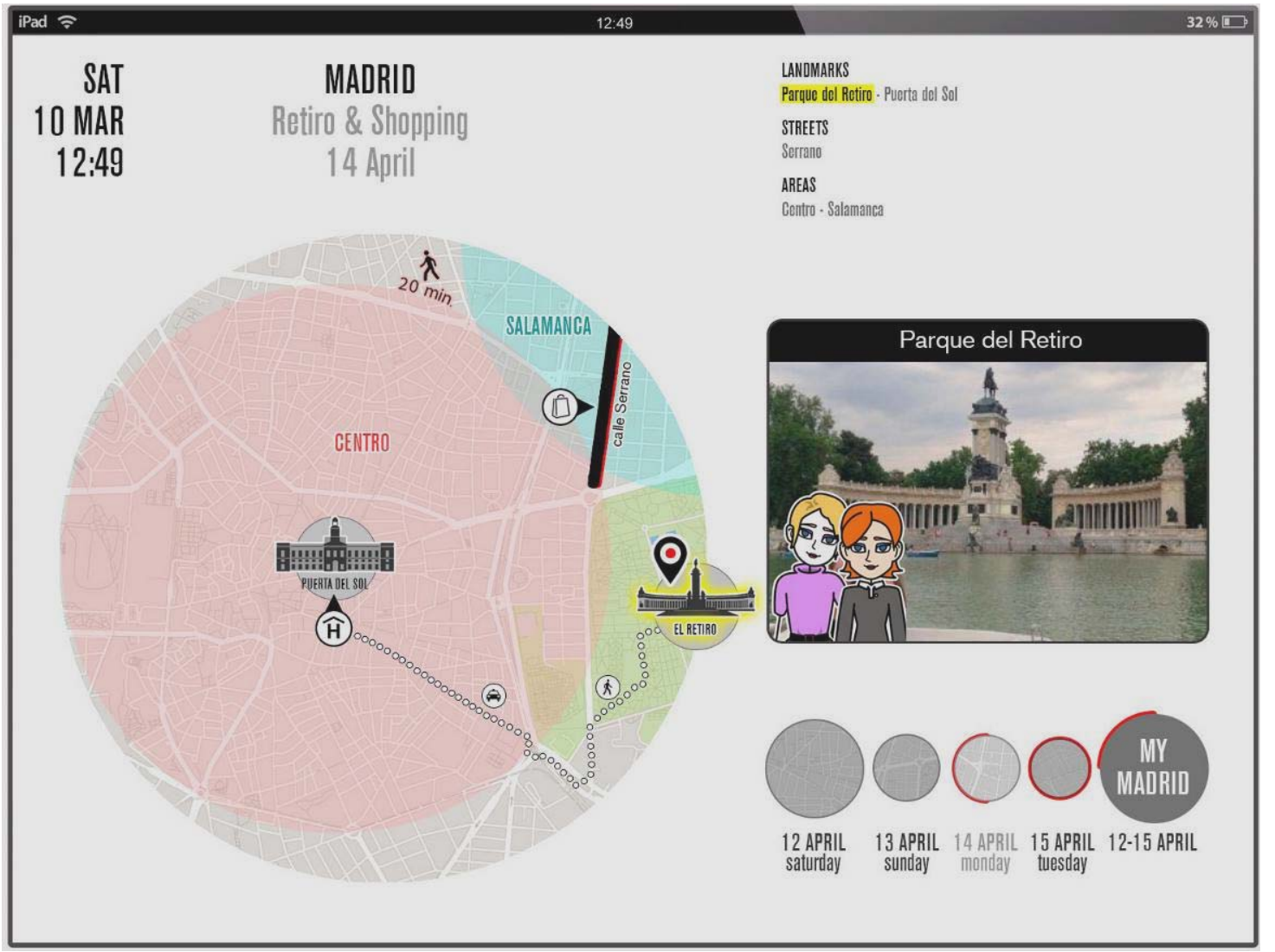

Figura 4.52: El sistema muestra donde se encuentran Mary y Kate en ese momento (en el Parque del Retiro), los atractivos que aun les quedan por disfrutar durante el resto del día (compras por Serrano) y los recorridos realizados (taxi desde el alojamiento al parque y paseo dentro de él). 


\section{Mapa del día 4}

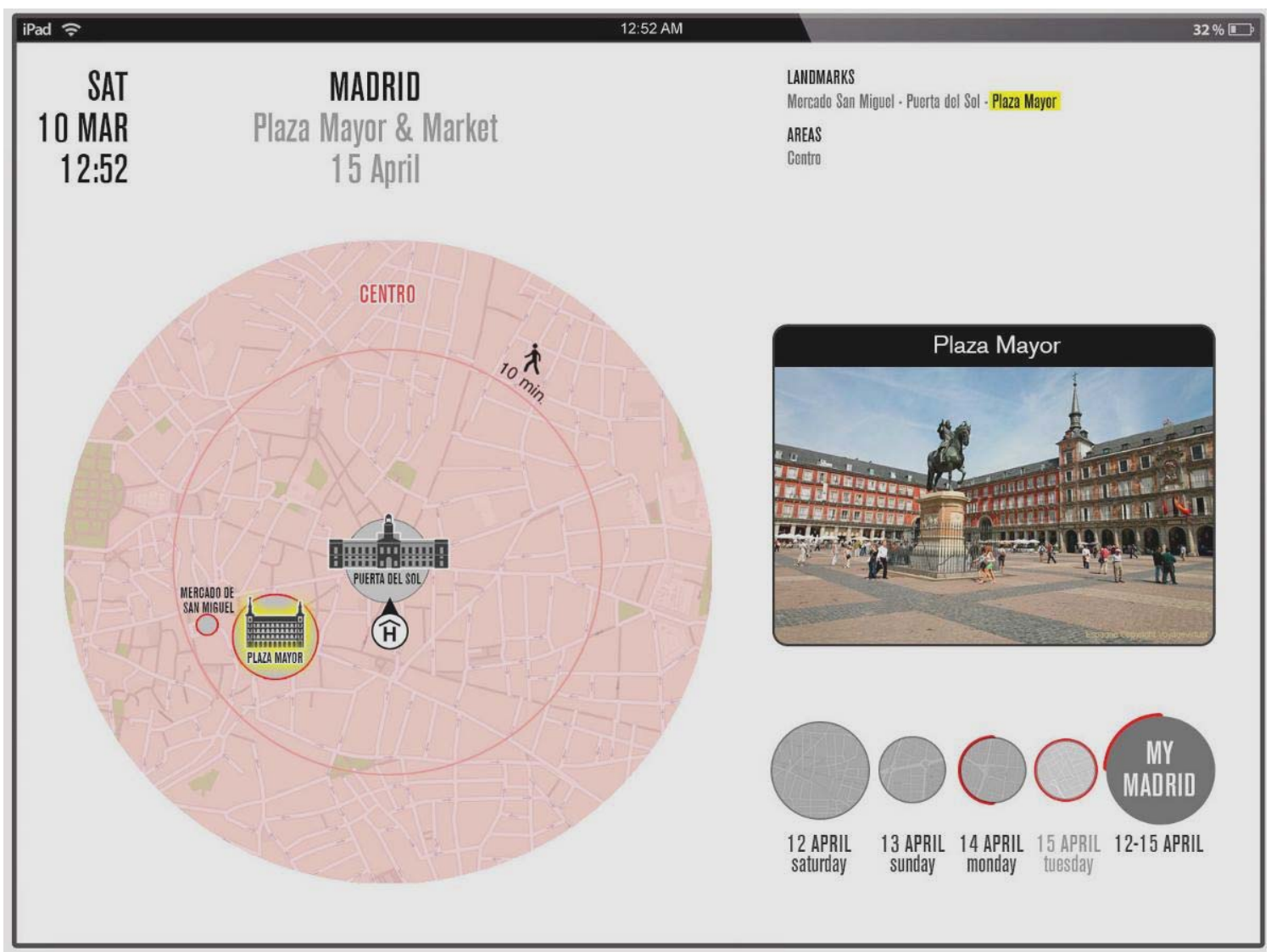

Figura 4.53: Mary selecciona el botón del 15 de Abril y el sistema muestra los atractivos que visitarán al día siguiente (el Mercado de San Miguel y la Plaza Mayor). A diferencia de las pantallas anteriores, en esta las fotografías son las capturadas del vídeo del plan de viaje, aunque serán sustituidas por las realizadas por Mary en cuanto visite estos atractivos. 


\section{Mapa del Madrid de Mary}

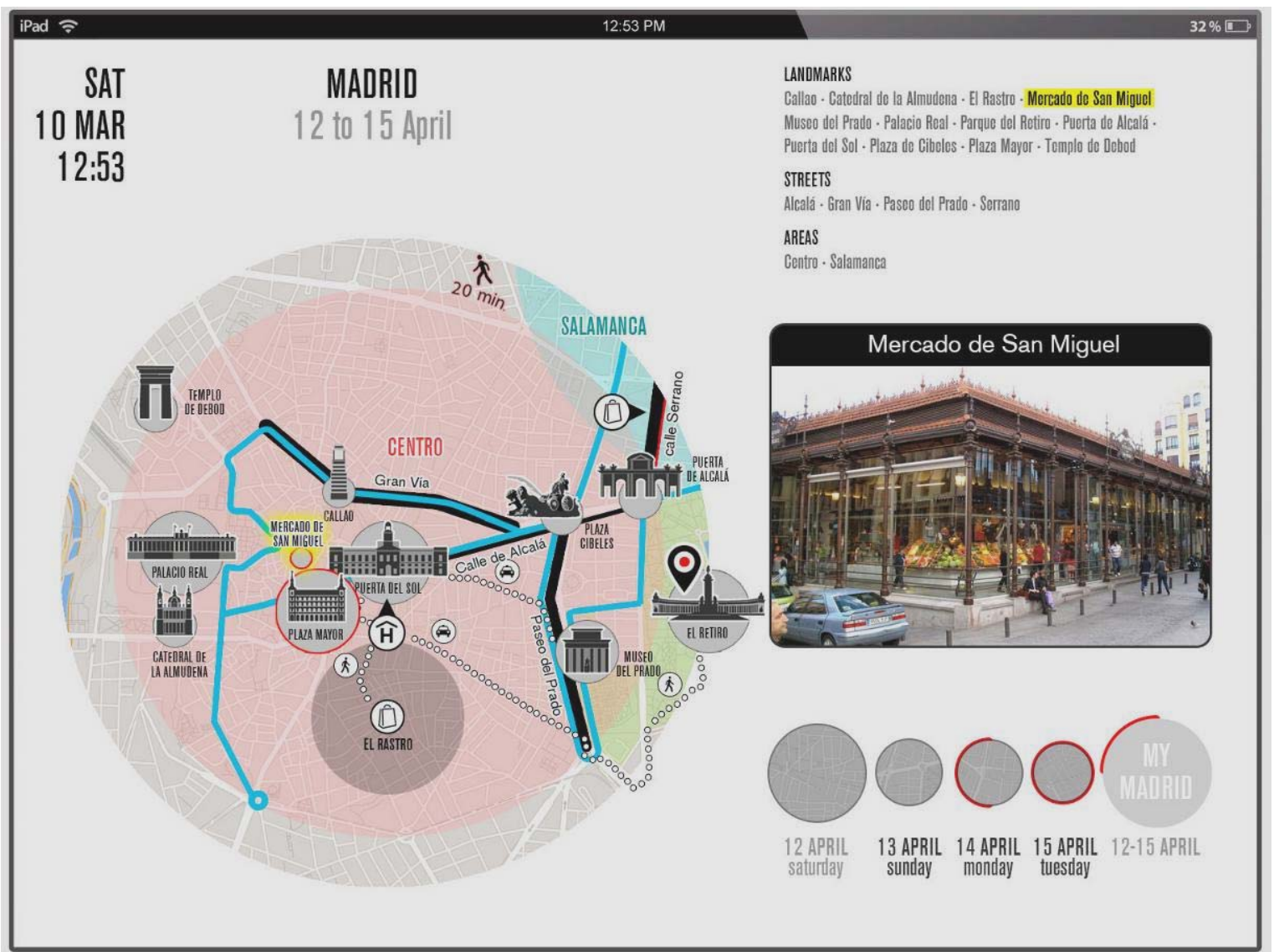

Figura 4.54: Mary selecciona "My Madrid" y el sistema muestra todo el contenido del viaje: atractivos visitados, recorridos realizados y lugares por descubrir. Esta vista da soporte al desarrollo del mapa cognitivo de Mary ayudándola a integrar todos los espacios de la ciudad asociados a su experiencia turística. 
Condicionado-Escenario 1: Visitando Madrid en el bus turístico
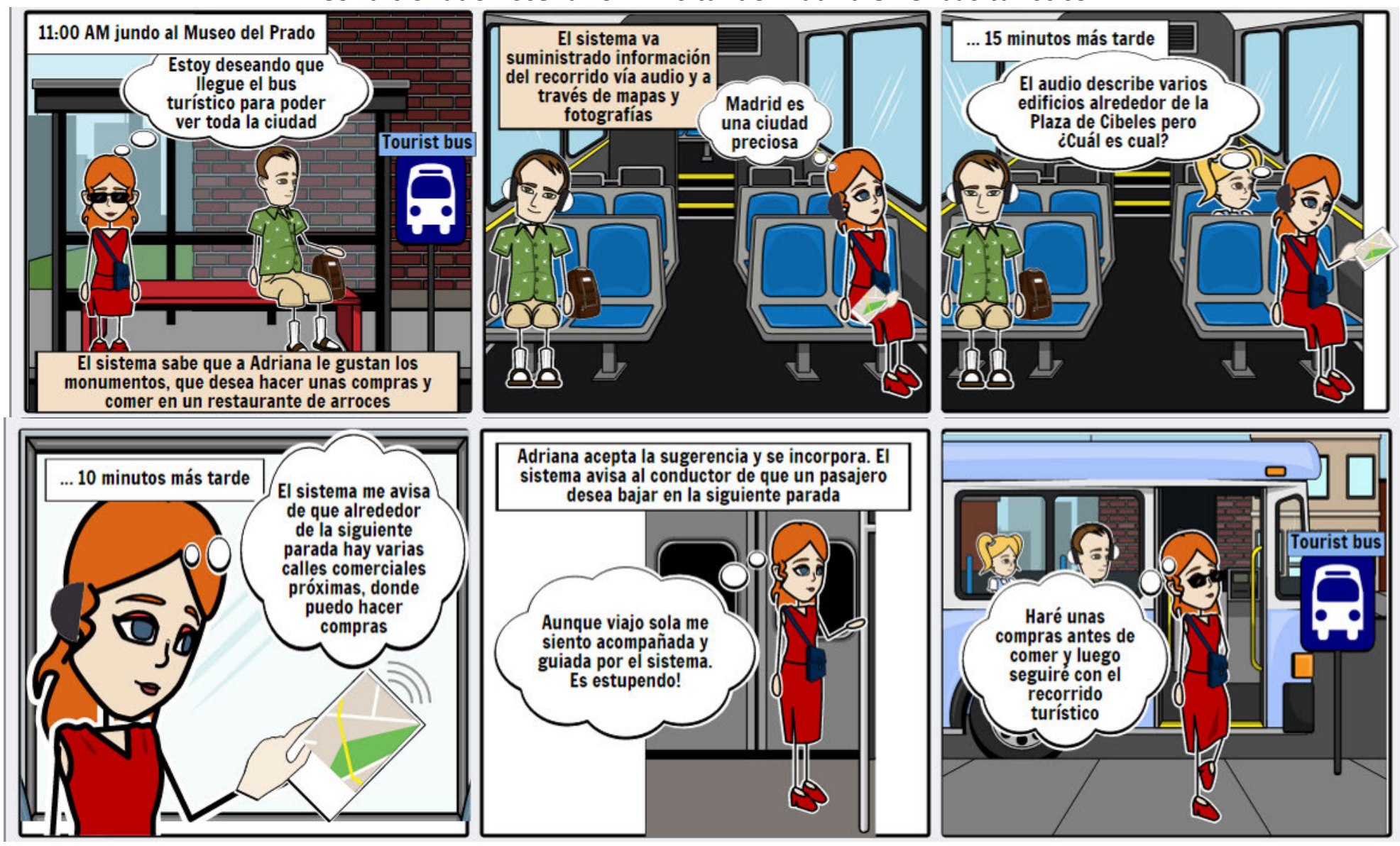

Figura 4.55: Storyboard Condicionado-Escenario1: Visitando Madrid en el bus turístico. 


\begin{tabular}{|c|c|c|c|c|c|}
\hline \multicolumn{6}{|c|}{$\begin{array}{l}\text { Condicionado-Escenario1: Visitando Madrid en el bus turístico. Contexto: Ha finalizado el congreso por el que Adriana vino a Madrid y por fin } \\
\text { tiene tiempo para visitar la ciudad. } \\
\text { Necesidad: Adriana dispone de pocas horas para visitar Madrid y el sistema sugiere que realice un recorrido en bus turístico. Adriana desea } \\
\text { además hacer unas compras antes de regresar a Méjico y poder disfrutar de una buena paella. } \\
\text { El sistema asiste a Adriana a lo largo del recorrido turístico en bus para facilitar su comprensión de los atractivos que está viendo y avisa a } \\
\text { Adriana cuando el recorrido se aproxima a una zona donde puede realizar compras. }\end{array}$} \\
\hline & $\begin{array}{c}\mathbf{1} \\
\text { Adriana está esperando } \\
\text { al próximo bus turístico } \\
\text { para iniciar el recorrido. }\end{array}$ & $\begin{array}{c}\text { 2 } \begin{array}{c}\text { M } \mathbf{3} \\
\text { Mapa } 1 \\
\text { (Figura 4.56) }\end{array} \\
\text { Adriana se encuentra dentro del bus } \\
\text { turístico disfrutando del recorrido. }\end{array}$ & $\begin{array}{c}4 \\
\text { Mapa 2 } \\
\text { (Figura 4.57) } \\
\\
\text { Adriana sigue en el autobús y el sistema le } \\
\text { avisa de que alrededor de la siguiente } \\
\text { parada hay varias calles comerciales donde } \\
\text { puede hacer compras. }\end{array}$ & \begin{tabular}{|c|}
$\mathbf{5}$ \\
Adriana acepta la sugerencia del \\
sistema y se incorpora para \\
bajarse en la siguiente parada.
\end{tabular} & $\begin{array}{c}6 \\
\text { Adriana se baja } \\
\text { del autobús para } \\
\text { hacer sus } \\
\text { compras, comery } \\
\text { luego seguir con } \\
\text { el recorrido. }\end{array}$ \\
\hline & " & $\begin{array}{c}\text { Modo viaje en bus turístico } \\
\text { Sistema <->Usuario } \\
\text { El sistema va suministrando información } \\
\text { del recorrido vía audio y a través de } \\
\text { mapas y fotografías. }\end{array}$ & $\begin{array}{c}\text { Modo viaje en bus turístico } \\
\text { Sistema ->Usuario } \\
\text { Cuando se aproximan a una zona de } \\
\text { compras, el dispositivo del sistema vibra y } \\
\text { avisa a Adriana de que puede ser una } \\
\text { buena idea bajar en la siguiente parada. }\end{array}$ & \begin{tabular}{|c|} 
Modo viaje en bus turístico \\
Usuario->Sistema \\
Sistema->ambiente \\
Adriana acepta la sugerencia del \\
sistema. El sistema avisa al \\
conductor para que pare en la \\
siguiente parada.
\end{tabular} & \\
\hline 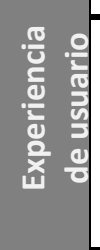 & & $\begin{array}{c}\text { Adriana va escuchando las explicaciones } \\
\text { vía audio y observando los atractivos a lo } \\
\text { largo del recorrido. Cuando tiene dudas } \\
\text { sobre cuál es el atractivo descrito o el que } \\
\text { está viendo por la ventana, mira el mapa } \\
\text { proporcionado por el sistema. }\end{array}$ & $\begin{array}{c}\text { Adriana se percata del aviso del sistema. } \\
\text { Echa un vistazo al mapa donde se muestran } \\
\text { las calles comerciales próximas a la } \\
\text { próxima parada e imágenes de las mismas } \\
\text { y se alegra de que el sistema facilite su } \\
\text { visita. }\end{array}$ & $\begin{array}{l}\text { Adriana se siente acompañada } \\
\text { por el sistema en todo } \\
\text { momento. No tiene que } \\
\text { preocuparse de nada y disfruta } \\
\text { al máximo de su visita. }\end{array}$ & \\
\hline 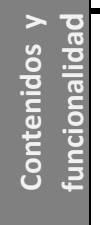 & & $\begin{array}{c}\text { El sistema muestra a Adriana donde se } \\
\text { encuentra espacial y temporalmente a } \\
\text { lo largo del recorrido, así como } \\
\text { imágenes de los atractivos que puede } \\
\text { ver en ese momento y sus nombres. }\end{array}$ & $\begin{array}{c}\text { El sistema avisa a Adriana y muestra un } \\
\text { mapa que ilustra las calles próximas donde } \\
\text { puede hacer compras. Adriana puede } \\
\text { aceptar o rechazar la sugerencia de bajar } \\
\text { en la próxima parada. }\end{array}$ & & \\
\hline
\end{tabular}

Tabla 4.16: Descripción del Condicionado-Escenario 1: Visitando Madrid en el bus turístico. 
Mapa 1

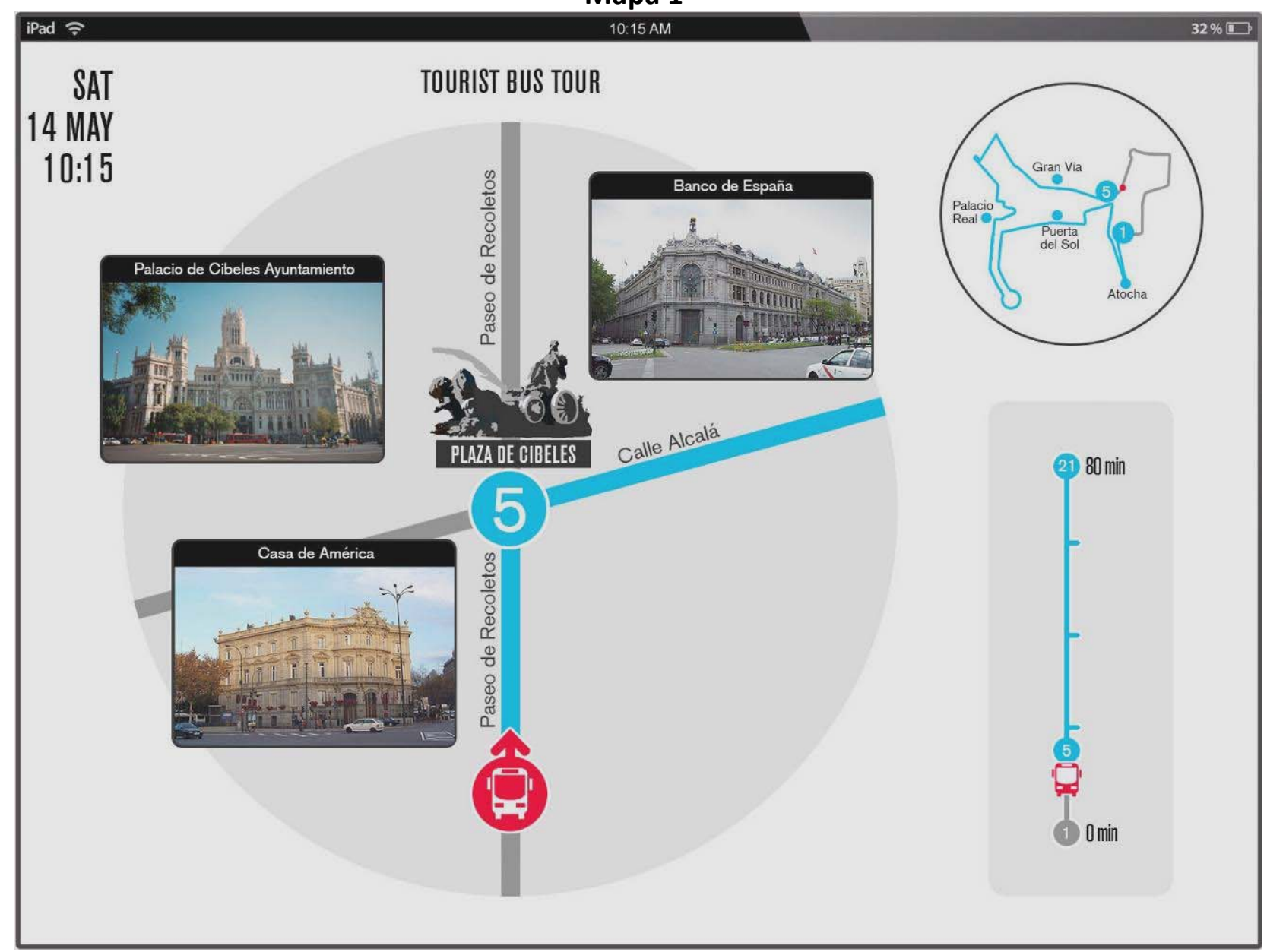

Figura 4.56: El sistema muestra a Adriana donde se encuentra espacial y temporalmente a lo largo del recorrido, así como fotografías de los atractivos que puede ver en ese momento y sus nombres. 
Mapa 2

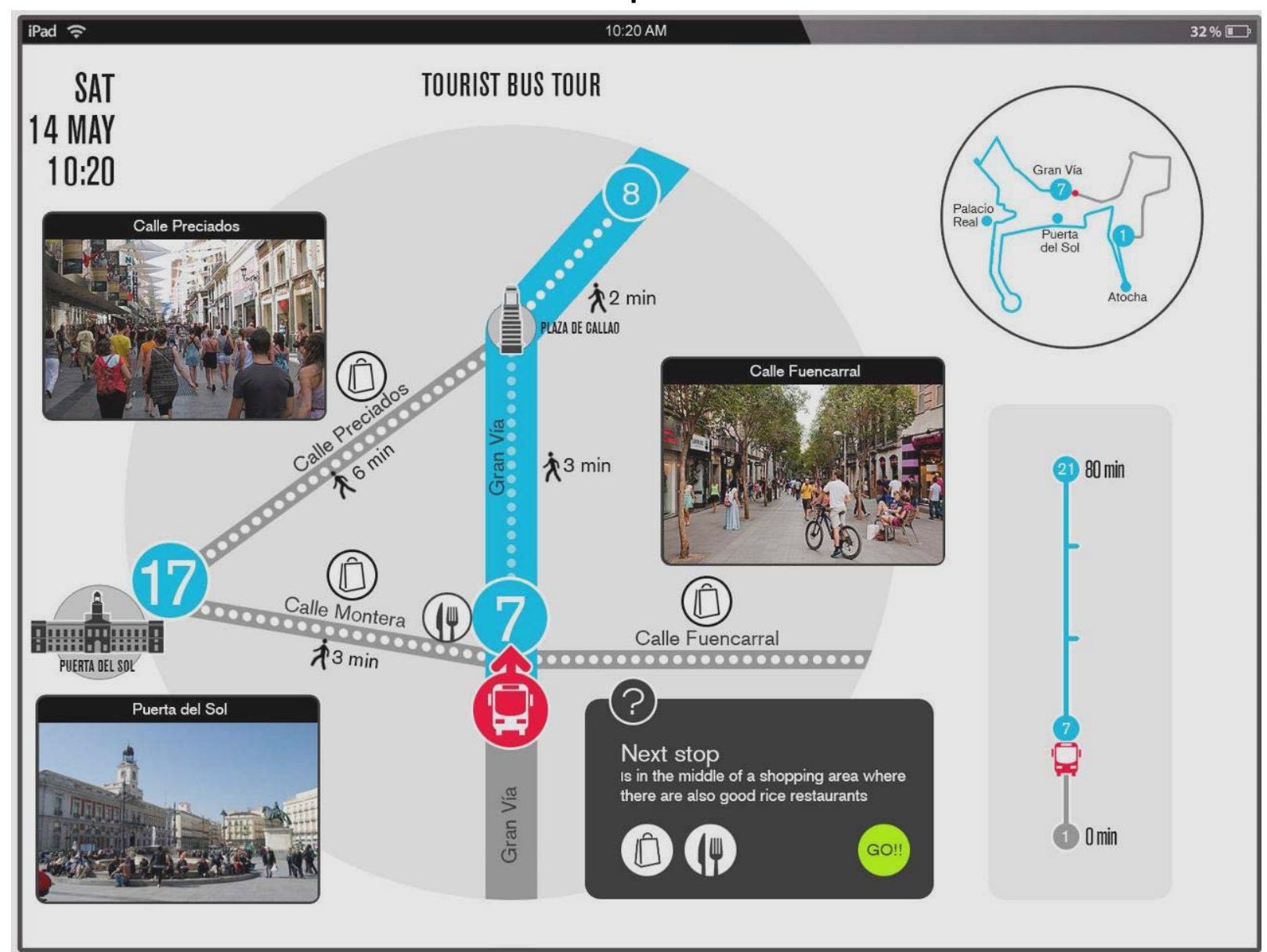

Figura 4.57: El sistema sugiere a Adriana que puede ser una buena idea bajarse en la siguiente parada y muestra un mapa que ilustra las calles próximas donde puede hacer compras y comer. 


\section{CONCLUSIONES}

En este último capítulo de la tesis se exponen las contribuciones científicas que este trabajo aporta, se da respuesta a las cuestiones de investigación planteadas en la introducción; y finalmente, se describen las líneas de investigación que quedan abiertas, como futuros trabajos a abordar.

En primer lugar, se resaltan las contribuciones científicas aportadas por este trabajo:

La propuesta de un proceso para el desarrollo de mapas, fundamentado en una conceptualización de la actividad para la que el mapa da soporte, en base a una comprensión de la forma en la que el usuario aborda su experiencia del espacio urbano.

Se ha expuesto y aplicado una metodología para el desarrollo de mapas en base a:

1) La identificación del contexto de su diseño, de los potenciales usuarios, de las actividades a las que darán soporte y de la visión de los mapas. Todo ello teniendo en cuenta el rol que los mapas desempeñan para los usuarios en el momento de realizar el estudio, así como el que podrían tener si su diseño se fundamentara en sus experiencias.

2) La exploración de la experiencia que tienen los usuarios, en relación al espacio urbano, a través de la información recopilada de los grupos de interés y de los propios usuarios, teniendo en cuenta sus atributos, las actividades que realizan y los factores que las condicionan (mapas cognitivos, mapas que utilizan, lugares vinculados del espacio urbano...).

3) La síntesis de la experiencia de los usuarios, por medio del modelado de las interacciones entre ellos, los ambientes o entornos del espacio urbano y los mapas que utilizan. De tal manera que:

- La síntesis de la interacción entre los usuarios y los ambientes del espacio permiten identificar los diferentes enfoques con los que los usuarios abordan su experiencia. Esto es posible, en base al análisis y detección de relaciones entre los factores condicionantes de las actividades que realizan los usuarios, asociadas al espacio urbano.

- La síntesis de la interacción entre los usuarios y los mapas permite identificar los elementos que constituyen sus mapas cognitivos y la forma en la que se estructuran. Esto es posible, en base a la identificación de los elementos más significativos en los mapas mentales de los usuarios y a la detección de patrones en su contenido y forma de estructurarse, una vez que estos se agrupan conforme a 
los diferentes enfoques con los que los usuarios abordan la experiencia.

- La síntesis de la interacción entre los mapas y el ambiente urbano permite identificar los contextos del ambiente en el que se desarrollan las actividades de los usuarios y que condicionan su experiencia del espacio.

- $\quad$ El diseño de mapas, considerando la forma en la que el usuario aborda la experiencia del espacio urbano y la incidencia de ésta en su mapa cognitivo.

Se han diseñado varios prototipos de mapas en base a:

- Los enfoques con los que los usuarios abordan sus experiencias del espacio, haciendo de éstos un marco que permite caracterizar experiencias concretas del usuario a los que los mapas deben dar soporte (perfiles de usuarios y escenarios).

- Representaciones espaciales cognitivamente adecuadas, teniendo en cuenta los elementos comunes de los mapas mentales del colectivo de usuarios y las características específicas de los mapas mentales de los usuarios de cada enfoque (elementos y forma en la que se estructuran). Representaciones que crecen y evolucionan, a medida que lo hace la conceptualización que posee el usuario del espacio urbano, a lo largo de su experiencia.

- Los contextos que caracterizan el ambiente en el que se utilizan los mapas, siendo su componente más importante es el contexto del usuario (enfoque con el que aborda la experiencia, actividad que realiza en un momento dado, ubicación...)

\subsection{Revisión de las preguntas de investigación}

Para facilitar la revisión y respuesta de las cuestiones de investigación planteadas en el capítulo 1, éstas se vuelven a presentar.

La principal pregunta de investigación de esta tesis es:

¿Cómo desarrollar mapas que den soporte a la experiencia cognitiva de un usuario, asociada a un espacio urbano?

Para abordar esta pregunta de investigación se plantean las siguientes cuestiones complementarias:

¿Bajo qué factores asociados a las actividades que realiza un usuario (comportamiento, mapas que utiliza, conocimiento del espacio geográfico...) se 
pueden desarrollar mapas que den soporte a su experiencia cognitiva de un espacio urbano?

¿Bajo qué criterios de contexto (actividades, entorno físico...) se pueden desarrollar mapas teniendo en cuenta la experiencia cognitiva de un usuario?

¿Bajo qué criterios de contenido (elementos, forma en la que se estructuran,...) se pueden desarrollar mapas teniendo en cuenta la experiencia cognitiva de un usuario?

\subsubsection{Proceso para el desarrollo de mapas, en base al diseño de experiencias del usuario}

El objetivo de esta tesis es averiguar cómo se pueden desarrollar mapas que den soporte a la experiencia cognitiva de un usuario, asociada a un espacio urbano.

La metodología utilizada para responder a esta cuestión de investigación ha consistido en proponer un nuevo proceso para el desarrollo de mapas, teniendo en cuenta la forma en la que el usuario afronta la experiencia del espacio a representar y estableciendo correspondencias entre el mapa cognitivo del usuario y los mapas a diseñar. Este nuevo proceso consta de cuatro fases que abordan: 1) la concepción del contexto asociado a la experiencia de los usuarios; 2) la exploración de la experiencia de los usuarios; 3 ) la síntesis de la experiencia de los usuarios y, finalmente, 4) el diseño de prototipos de los mapas.

Este proceso se ha fundamentado en dos premisas: a) los dispositivos basados en las nuevas tecnologías (nanotecnologías, loT, wearables,...) son capaces de identificar, reconocer y proponer a cada usuario, de forma activa y en tiempo real, mapas que le asistan en sus experiencias y b) las interacciones del usuario con los mapas inciden en su adquisición de conocimiento del espacio representado $y$, por lo tanto, en su experiencia cognitiva del mismo.

La hipótesis de esta tesis es que los mapas se pueden considerar instrumentos activos en los procesos cognitivos de los usuarios, que inciden en su comportamiento y en sus experiencias cognitivas del espacio urbano. Esta hipótesis ha quedado validada a través del proceso propuesto para el desarrollo de mapas basado en el diseño de experiencias del usuario, tal y como se ha probado en el caso de estudio del turismo en Madrid. Como resultado, se han diseñado varios mapas adaptados a turistas, que afrontan su experiencia en Madrid de diferentes maneras y en distintos ambientes, con el fin de dar soporte a su experiencia cognitiva de la ciudad.

\subsubsection{Factores y criterios a tener en cuenta para desarrollar mapas, a través de la experiencia cognitiva del usuario}

Pregunta de investigación: ¿Bajo qué factores asociados a las actividades que realiza el usuario (comportamiento, mapas que utilizan, conocimiento del espacio geográfico...) se pueden desarrollar mapas que den soporte a su experiencia cognitiva de un espacio urbano? 
Los factores asociados a las actividades que realiza el usuario, vinculadas a un determinado espacio urbano, pueden ser diferentes en función del contexto de diseño (turístico, urbanístico, de emergencias,...). La selección de los factores en los que fundamentar el desarrollo de los mapas, parte de su identificación y exploración, a través de datos obtenidos de fuentes documentales, y de los propios usuarios. Una vez hecho esto, el cartógrafo debe analizar la información recopilada y llevar a cabo una labor de abstracción fundamentada en su conocimiento adquirido sobre las experiencias de los usuarios. Estas tareas permiten al cartógrafo seleccionar aquellos factores asociados a las actividades que mejor caracterizan los enfoques con los que los usuarios abordan la experiencia cognitiva del espacio.

En el caso de estudio del turismo en Madrid, los factores asociados a las actividades de los turistas se agruparon en: humanos (motivo de la visita, intereses relacionados con la visita, grupo de viaje, conocimiento turístico-espacial del destino turístico urbano, conocimiento de infraestructuras de transporte, percepción de los desplazamientos, percepción de la ciudad como destino turístico y valoración de la experiencia); físicos (productos cartográficos utilizados, configuración espacial del destino turístico, atractivos turísticos del destino, infraestructuras de transporte del destino turístico, infraestructuras de transporte utilizada y ubicación del alojamiento) y temporales (duración de la estancia y época del año). Una vez identificados estos factores, se indagó acerca de ellos y se seleccionó los que más inciden en la experiencia turística, siendo estos: el motivo y el grupo de viaje, la duración de la visita, los intereses del turista, la forma de desplaza durante la visita y el conocimiento turístico-geográfico de la ciudad (mapas mentales). Una vez seleccionados, se procedió al análisis de sus datos, lo que permitió identificar tres enfoques de la experiencia turística (explorador, guiado y condicionado) en base a los cuales fundamentar el desarrollo de los mapas a diseñar.

Pregunta de investigación: ¿Bajo qué criterios de contenido (elementos, representaciones,...) se pueden desarrollar mapas teniendo en cuenta la experiencia cognitiva de un usuario?

Las experiencias cognitivas que tienen los usuarios de un espacio urbano se reflejan en sus mapas cognitivos. Para dar soporte a la experiencia cognitiva del usuario se partió de la premisa de que el diseño de los mapas debía tener en cuenta una correspondencia entre éstos y los mapas cognitivos de los usuarios. En base a ello, el establecimiento de los criterios de contenido de los mapas parte de la identificación de las etapas de la experiencia del usuario en las que pueden estructurarse las actividades que realiza y los mapas cognitivos asociados. Una vez hecho esto, se recaba información de estos mapas cognitivos, con el fin de identificar sus elementos característicos y la forma en la que estos se estructuran. Finalmente, estos datos se agrupan en base al enfoque con el que los usuarios, de los que se ha extraído la información, abordan su experiencia del espacio (tipologías establecidas previamente). Los resultados obtenidos (número de elementos de diferentes tipos, identificados en los mapas cognitivos y forma de representarlos) constituyen los criterios de contenido de los mapas a diseñar. 
En el caso de estudio del turismo en Madrid, se identificó que la experiencia turística se estructura en tres etapas: pre-viaje, ejecución de la visita y post-viaje. El alcance del caso de estudio se limitó al pre-viaje y a la ejecución de la visita. Teniendo esto en cuenta, se recogió información de los mapas cognitivos de los turistas en ambas etapas de su experiencia. Se recopilaron los mapas mentales de los turistas, sus listas de libre recuerdo sobre atractivos turísticos, calles y zonas de la ciudad, así como datos sobre la identificación y la ubicación de fotografías de Puntos de Interés Turístico de Madrid, tanto en el momento en el que llegaron a la ciudad (mapas cognitivos tras el pre-viaje), como una vez finalizada su visita. Los datos recogidos permitieron identificar los elementos del espacio urbano que tienen más incidencia en la experiencia de los turistas. Además, una vez agrupados según el enfoque con el que los turistas abordaron su experiencia (explorador, guiado y condicionado), se determinó el número de elementos puntuales (atractivos e infraestructuras de transporte), ejes (calles y líneas de transporte) y zonas. También se identificaron los sistemas, marcos de referencia y focos característicos de los mapas cognitivos de cada tipología de turista. Estos resultados, sirvieron para establecer pautas de diseño para la esquematización del contenido de los mapas de cada tipología de turista.

Pregunta de investigación: ¿Bajo qué criterios de contexto (actividad, entorno físico...) se pueden desarrollar mapas teniendo en cuenta la experiencia cognitiva de un usuario?

El ambiente se considera, una entidad de naturaleza dinámica que influye en el comportamiento y la experiencia del usuario. El ambiente asociado a una experiencia concreta se puede caracterizar en base a diferentes contextos a los que se deben adaptar los mapas (esquematización y personalización). Estos contextos deben fundamentarse en base a criterios definidos a partir de los datos de los atributos de los usuarios y los factores condicionantes de las actividades que realizan. Pueden ser, por ejemplo: del usuario (edad, género, nacionalidad, enfoque con el que aborda la experiencia, actividad que está realizando es un momento dado, ubicación, orientación, velocidad y aceleración si esta en movimiento...); físico (localización, condiciones de iluminación, meteorológicas y de tráfico, niveles de ruido...); temporal (hora, día de la semana, fecha y estación del año); históricoevolutivo (experiencias previas del usuario en el espacio urbano, consultas de información geográfica efectuadas con anterioridad...) y tecnológico (especificaciones técnicas del dispositivo en el que se visualizan los mapas, conexiones inalámbricas de datos y recursos periféricos como impresoras, sensores...).

En el caso de estudio del turismo en Madrid, se identificaron dos grandes contextos dentro del ambiente en el que se desarrollan las experiencias del turista: el del turista y su viaje, y el de la actividad que está realizando en cada momento. Los criterios que se consideraron dentro del contexto del turista y su viaje fueron: los enfoques de la experiencia del turista, que aglutinan motivaciones, comportamientos y formas de conceptualizar el espacio (mapas cognitivos), y los factores que condicionan todas las actividades del viaje, como la ubicación del alojamiento, la duración de la estancia y el grupo de viaje. Respecto a los criterios 
que se consideraron en el contexto de la actividad, se tuvieron en cuenta: la etapa del viaje, la actividad concreta que está realizando el turista y el conocimiento que tiene de la ciudad en ese momento, las necesidades de IG en relación a la actividad que está llevando a cabo, su ubicación espacial y temporal, los dispositivos con los que puede interactuar el turista.... Estos criterios permitieron caracterizar los contextos del ambiente en el que turista utilizará cada mapa a diseñar e inciden en su personalización y esquematización.

\subsection{Futuras líneas de investigación}

Consideramos que los resultados de esta investigación son relevantes, aunque dejan abierta la posibilidad de continuar trabajando en aspectos que no se han podido abarcar en esta tesis y de abordar nuevas líneas de investigación en el futuro.

En primer lugar, resultaría interesante poder realizar test con los prototipos de los mapas diseñados, con el fin de depurarlos $y$, posteriormente, evaluar su incidencia en la experiencia cognitiva de los turistas de Madrid.

Por otro lado, el carácter geográfico de la experiencia turista, hace que los resultados de la aplicación del caso de estudio (los mapas diseñados) sean únicamente aplicables al ámbito turístico en la ciudad de Madrid. Sin embargo, el proceso propuesto para el desarrollo de mapas y el ejemplo de cómo ha sido aplicado, puede servir de referencia para el diseño de otros mapas que den soporte a experiencias cognitivas del espacio en otros contextos (emergencias, urbanismo...) y ámbitos espaciales que no sean urbanos.

Además, en esta tesis no se han considerado ciertas fuentes de información de los usuarios como podrían ser, por ejemplo, la información geográfica voluntaria, obtenida a través de fotografías realizadas por los turistas y publicadas en las redes sociales, o grandes volúmenes de datos (Big data) derivados, por ejemplo, de las transacciones realizadas con sus tarjetas de crédito. Una de las aplicaciones de la información geográfica voluntaria y del Big Data, puede ser la de extraer información de los usuarios a partir de lo que hacen (fotografías o compras) y utilizar ese conocimiento para suministrar al usuario mapas personalizados. El uso de este tipo de información requiere tener en cuenta cuestiones de privacidad de los datos, cuya regulación está siendo polémica en muchos países. Para obtener información de estos datos, al igual que se ha hecho con los datos de los turistas manejados en la presente investigación, habría que trabajar con ellos y tratar de encontrar patrones e información que pueda ser relevante de cara al diseño de los mapas.

Otra línea de investigación por explorar es la de internet de las cosas (IOT) que, por un lado amplia las funcionalidades a las que el usuario puede tener acceso a través de dispositivos cotidianos $y$, por otro, revoluciona las posibilidades de captura de datos de los usuarios, a través de la monitorización de todas sus actividades en tiempo real. Esta información sobre el entorno que rodea al usuario, se puede utilizar para enriquecer su experiencia del espacio y facilitar sus actividades a través del suministro de mapas. Por ejemplo, las ciudades inteligentes albergarán sistemas configurados por objetos interconectados, que podrán ser empleados para el desarrollo de mapas que mejoren actividades cotidianas que se 
llevan a cabo en una ciudad, como buscar aparcamiento o encontrar un lugar que cumpla con una serie de requisitos.

Por otro lado, están las tecnologías wearables: dispositivos como lentillas, auriculares, relojes y brazaletes o pulseras inteligentes, que pueden capturar datos acerca del comportamiento del usuario que permitan personalizar los mapas que utilizan y visualizarlos en estos nuevos soportes. Los dispositivos wearables representan una nueva evolución de la tendencia móvil, lo que supone nuevos retos a la hora de abordar el desarrollo de mapas con el fin de dar soporte a la experiencia cognitiva de los usuarios.

Finalmente, esta tesis se ha focalizado en la dimensión cognitiva de la experiencia del usuario. Sin embargo, tal y como exponen Tussyadiah \& Zach (2012), las geo-tecnologías y sus posibilidades de uso son susceptibles de asistir a las personas en otras dimensiones de la experiencia del espacio geográfico, como la físico-sensorial (asociación de olores, sonidos, sabores... a lugares), la afectiva (conexión emocional con ciertos lugares como el gusto o el rechazo hacia ellos) o la social (interacción con personas en un lugar). Por ejemplo, en el contexto turístico urbano de una ciudad inteligente del futuro, interacciones multimodales con dispositivos wearables e interconectados (IOT) podrían dar soporte a los turistas en la asociación de sonidos y olores a los lugares que visitan (experiencia físicosensorial), a sus conexiones emocionales con ellos (experiencia emocional) y a las posibilidades de relacionarse con otros turistas próximos y residentes locales (experiencia social). 


\section{CONCLUSIONS}

In this final chapter we set out the scientific contributions of this thesis, we provide the answers to the research questions stated in the introduction and we describe the lines of research that remain open to be addressed in future works.

To begin with, we highlight the scientific contributions of this work:

- The proposal of a process for developing maps based upon the conceptualization of the activity the map supports and based on an understanding of how the user approaches his/her urban space experience.

We have presented and implemented a methodology for the development of maps based on:

1) identifying their design context, their potential users, the activities that they will support and the vision of the maps that takes into account the role that maps play for users at the time of the study, as well as the role they might play if their design were based on their experiences;

2) exploring the experience that users have of urban spaces, using the information provided by stakeholders and users regarding their characteristics, their activities and their conditioning factors (cognitive maps, maps they use, locations of the urban space, etc.);

3) synthesizing the user experience through the modeling of interactions between the user, the locations or environments in the urban space and the maps. This is done in such a way that:

- the synthesis of the interaction between users and locations in urban space allows us to identify the different approaches users have towards their experience. This is possible thanks to the analysis and detection of relations between the conditioning factors of the activities performed by users and the urban space;

- the synthesis of the interaction between users and maps allows us to identify the elements that are part of their cognitive maps and their structure. We can do this by identifying the most significant elements in the users' mental maps and by detecting patterns in their content and structure once the mental maps are grouped according to the different user experience approaches;

- the synthesis of the interaction between the maps and the urban environment allows us to identify the environmental contexts in which user activities take place, affecting the user's experience of the space. 
- $\quad$ The map's design considers the way in which the users experience urban space and the way this affects their cognitive map.

We have designed several prototypes of maps taking into account:

- The approaches of the users towards their experiences of the space, by using them as a framework to characterize specific user experiences which the maps must support (user profiles and scenarios).

- Cognitively appropriate spatial representations, considering the common elements of the users' mental maps and the specific characteristics of each experience approach (their elements and structure). These representations grow and evolve along with the users' conceptualization of the urban space throughout their experience.

- The contexts that characterize the environment in which the maps are used, its most important component being the user's context (the experience approach, the activity performed by the user in a specific time and place, etc.).

\subsection{Review of the research questions}

To facilitate the review of and to answer the research questions raised in Chapter 1, they are presented below once again.

The main research question of this thesis is:

How do we develop maps that support the cognitive experience of a user in relation to an urban area?

To address this research question the following additional questions have been considered:

What are the factors related to the activities the users carry out (behavior, maps, geographic space knowledge, etc.) that make it possible to develop maps that support the user's cognitive experience of urban space?

Which content criteria (elements, structures, etc.) make it possible to develop maps that take into account the user's cognitive experience?

Which context criteria (activities, physical environment, etc.) make it possible to develop maps that take into account the user's cognitive experience? 


\subsubsection{Process for the development of maps through the design of user experiences}

The objective of this thesis is to know how to develop maps that support the user cognitive experience with respect to an urban area.

The methodology used to answer the main research question has been to propose a new process for developing maps that takes into account the way in which users approach their experience of urban spaces to represent and establish correspondences between the users' cognitive map and the maps being designed. This process consists of four phases which address: 1 ) the association between context and experience, 2) an exploration of the user experience, 3) a synthesis of this experience and, lastly, 4) the design of map prototypes.

This process has been based on two premises: a) devices based on new technologies (nanotechnology, loT, wearables, etc.) are able to identify, recognize and propose to each user, actively and in real time, maps to assist in their experience and b) user interactions with the maps affect their acquisition of knowledge about the space represented, and, thus, affect their cognitive experience of it.

The hypothesis of this thesis is that maps can be considered active instruments in the users' cognitive processes, affecting their behavior and urban space cognitive experiences. This hypothesis has been validated in the proposed process for the development of maps based on the design of a user experience, which was tested in the case study of tourism in Madrid. As a result, we have designed several maps tailored to tourists approaching their experience of Madrid in different ways and in different environments, in order to support their cognitive experience of the city.

\subsubsection{Factors and criteria to consider for developing maps through the user's cognitive experience}

Research question: What are the factors related to the activities the users carry out (behavior, maps, geographic space knowledge, etc.) that make it possible to develop maps that support the user's cognitive experience of urban space?

Factors related to user activities linked to a particular urban space may be different depending on the design context (tourism, urban development, emergency, etc.). Selecting the factors on which to base the development of the maps starts with exploring and identifying them by looking at the data obtained from documentary sources and users. Once this is done, the cartographer must analyze the information gathered and conduct a work of abstraction based on what was learned from and about the experiences of users. These tasks enable the cartographer to select those factors associated with the activities that best characterize the approaches with which users address the cognitive experience of space. 
In the case study of tourism in Madrid, the factors associated with the tourists' activities were grouped into human factors (reason for visiting, user interests, travel group, tourism-spatial knowledge of the urban destination, knowledge of transport infrastructure, perception of journeys, perception of the city as a tourist destination and value of the experience), physical factors (cartographic products used, spatial configuration of the destination, urban attractions, transportation infrastructure of the destination, transport infrastructure used and location of accommodation) and time factors (length of stay and season). After selecting the factors, we proceeded to analyze their data, which allowed us to identify three approaches to the tourism experience: explorer, guided and conditioned. Based on these approaches, we developed the design of the maps, and, most specifically, their personalization.

Research question: Which content criteria (elements, structures, etc.) make it possible to develop maps that take into account the user's cognitive experience?

The cognitive experiences that users have of an urban space are reflected in their cognitive maps. To support the user's cognitive experience it was assumed that the design of the maps should take into account the links between the maps and the users' cognitive map. On this basis, establishing the criteria for map content depends on identifying the user experience stages in which the activities can be structured and their associated cognitive maps. Once this is done, the data from these cognitive maps is collected in order to identify their features and their structure. Finally, this information is grouped according to the user approach to the space experience (typologies previously established), and the results (number of different types of elements identified in the cognitive maps and ways of representing them) form the basis for the content criteria for the maps being designed.

In the case study of tourism in Madrid, three stages of the tourist experience were identified: pre-trip, visit execution and post-trip. The scope of the case study was limited to pre-trip and visit execution, and, with this in mind, cognitive mapping information was collected from tourists at both stages of their experience. We collected tourists' mental maps, free memory lists of attractions, streets and areas of the city, as well as data about the identification and the location of Madrid touristic landmarks by using pictures when the tourists arrived in the city (cognitive mapping information after the pre-trip stage) and after their visit. On the one hand, the data gathered allowed us to identify the elements of the urban space that have had the most impact on the tourist experience. On the other, once the data was classified according to the tourist experience approach (explorer, guided and conditioned), we were able to identify the particular elements (tourist attractions and transit infrastructure), axes (streets and transit lines) and areas, as well as the systems, frames of reference and particular focus characteristic of the cognitive maps corresponding to each tourist experience typology. These result were used to establish design guidelines for the schematization of the content of the map for each tourist experience type. 
Research question: Which context criteria (activities, physical environment, etc.) make it possible to develop maps that take into account the user's cognitive experience?

The environment is considered an entity of dynamic nature, which influences the user's behavior and experience. The environment associated with a particular experience can be characterized according to the different contexts to which maps must be adapted (schematization and personalization). These contexts must be based on criteria defined by using the data about the users' characteristics and the conditioning factors of their activities, which may be, for example: the user context (age, gender, nationality, experience approach, activity being performed at a given time, and location, direction, speed and acceleration if he/she is in motion, etc.), the physical context (location, lighting conditions, weather and traffic, noise, etc.), temporal context (time, day, date and season), the historical-evolutionary context (previous user experiences in the urban space, prior geographic information queries, etc.) or the technological context (technical specifications of the device that displays the maps, data and wireless peripheral resources such as printers, sensors, etc.).

In the case study of tourism in Madrid, we identified two main contexts in the environment in which tourists are having their experiences: the tourist and his/her travel context, and the activity that he/she is doing at a given time. The criteria that we considered within the context of tourist and travel were: approaches of the tourist experience that agglutinate motivations, behaviors and ways of conceptualizing the space (cognitive maps) and factors that influence all activities of the trip, such as the location of accommodation, the length of stay and the travel group. In regards to the criteria to be considered in the context of the activity, we considered: the travel stage, the specific activity being undertaken by the tourist and the knowledge that he/she has of the city at that time, IG needs in relation to the activity being carried out, its spatial and temporal location, devices that the tourist can interact with, etc. These criteria enable us to characterize the environment contexts of each map, influencing their schematization and personalization.

\subsection{Future research}

We consider that the results of this research are relevant and open the possibility to continue working on issues that could not be covered in this thesis and to address new lines of research in the future.

First, it would be interesting to carry out tests of the prototypes of the maps designed in order to first debug and then assess their impact on the cognitive experience of Madrid tourists.

Although the geographical character of the tourist experience makes the results of the case study (the maps designed) only applicable to the tourism sector in the city of Madrid, the proposed map development process and the example of its implementation may serve as a reference for designing other maps that support 
cognitive experiences of space in other contexts (emergencies, town planning, etc.) and in non-urban spatial areas.

Furthermore, in this thesis we have not considered sources of user information such as volunteered geographic information $\neg$, such as, for example, photographs taken by tourists of Madrid published in social networks, or large amounts of data (Big Data) derived from the tourists' credit cards transactions. One of the applications of volunteered geographic information and Big Data may be to extract user information from what they do (photographs or purchases) and use that knowledge to provide the user with personalized maps. The use of this type of information requires taking into account privacy issues of data, whose regulation is still controversial in many countries. To obtain information from this data, as has been done with the tourist data used in this research, it's necessary to work on it to try to find patterns and information that may be relevant to the design of the maps.

Other line of research to explore is the Internet of Things (IOT) that extends the functionalities the user can access through everyday devices and revolutionizes the possibilities of capturing user data through the monitoring of all his/her activities in real time. This information about the environment surrounding the user can be utilized to enrich his/her space experience and to facilitate their activities through the provision of maps. For example, smart cities will host systems composed of interconnected objects that can be used to develop maps that enhance activities carried out in a city, such as looking for parking or finding a place that meets certain requirements.

On the other hand, there are wearable technologies: devices such as contact lenses, headphones, watches and intelligent bracelets that can capture data about user behavior, which can personalize maps and then display them in these new supports. Wearable devices represent a new evolution of the mobile trend, which poses new challenges in addressing the development of maps that support the cognitive experience of users.

Finally, this thesis has focused on the cognitive dimension of the user experience. However, as shown by Tussyadiah \& Zach (2012), the geo-technologies and their possible uses are likely to assist people in other dimensions of space experience, such as the physical-sensory (association of smells, sounds, flavors, etc., to places), affective (emotional connection with certain places, like the positive consideration or rejection of them) or social (interaction with people in a place). For example, in the urban tourism context of a smart city of the future, multimodal interactions with wearables and interconnected devices (IOT) could support tourists in the association of sounds and smells to the places they visit (physical-sensory experience), their emotional connections with them (emotional experience) and the opportunities to interact with other nearby tourists and local residents (social experience). 


\section{REFERENCIAS}

Agnew, J. (2011). Space and place. In J. A. Agnew \& D. N. Livingstone (Eds.), The SAGE Handbook of Geographical Knowledge (pp. 316-330). London: SAGE Publications Limited.

Aissi, S., \& Gouider, M. (2012). Personalization in Geographic information systems: A survey. arXiv Preprint arXiv:1208.0153.

Appleyard, D. (1970). Styles and methods of structuring a city. Environment and Behavior, 2, 100-118.

Arhippainen, L., \& Tähti, M. (2003). Empirical evaluation of user experience in two adaptive mobile application prototypes. In 2nd International Conference on Mobile and Ubiquitous Multimedia (pp. 27-34). Norrköping, Sweden.

Avelar, S. (2008). Visualizing public transport networks: an experiment in Zurich. Journal of Maps, v2008, 134-150.

Ayuntamiento de Madrid. (n.d.). Información estadística del área de turismo y eventos. Retrieved July 14, 2015, from http://www.madrid.es/portales/munimadrid/es/Inicio/Ayuntamiento/Estadistic a/Areas-de-informacion-estadistica/Turismo-y-eventos/Turismo/Encuesta-deOcupacionHotelera?vgnextfmt=detNavegacion\&vgnextoid $=5$ ca8525b2a969210VgnVCM20 00000c205a0aRCRD\&vgnextchannel=

Barkowsky, T., \& Freksa, C. (1997). Cognitive Requirements on Making and Interpreting Maps. In S. H. and A. Frank (Ed.), Spatial Information Theory A Theoretical Basis for GIS (pp. 347-361). Berlin: Springer.

Beck, R. J., \& Wood, D. (1976). Cognitive transformation of information from urban geographic fields to mental maps. Environment and Behavior, 8 (2), 199-238.

Berendt, B., Barkowsky, T., Freksa, C., \& Kelter, S. (1998). Spatial representation with aspect maps. In Spatial cognition - an interdisciplinary approach to representing and processing spatial knowledge (pp. 313-336). Berlin Heidelberg : Springer.

Bertin, J. (1983). Semiology of graphics. Madison: University of Wisconsin Press.

Bertin, J. (1967). Sémiologie graphique: les diagrammes, les réseaux, les cartes. Paris: Mouton.

Bollmann, J. (1996). Kartographische Modellierung-Integrierte Herstellung und Nutzung von Kartensystemen. In Tagungsband zum Kartographenkongress (pp. 35-54). Interlaken, Switzerland. 
Bramwell, B. (1998). User satisfaction and product development in urban tourism. Tourism Management, 19 (1), 35-47.

Caballero Garcia, A. (2002). Desarrollo de la representación espacial. EduPsykhé: Revista de Psicología y Psicopedagogía. Universidad Camilo José Cela, 1(1), 4168.

Campbell, J. (1998). Map Use \& Analysis. New York: McGraw-Hill.

Caquard, S. (2014). Cartography III: A post-representational perspective on cognitive cartography. Progress in Human Geography, 39, 225-235. doi:10.1177/0309132514527039

Card, S. K., Mackinlay, J. D., \& Schneiderman, B. (1999). Readings in information visualization: Using vision to think. San Francisco: Morgan Kaufmann Publishers.

Cartwright, W., \& Peterson, M. (2007). Multimedia cartography. Berlin Heidelberg: Springer.

Cartwright, W., Crampton, J., Gartner, G., Miller, S., Mitchell, K., Siekierska, E., \& Wood, J. (2001). Geospatial information visualization user interface issues. Cartography and Geographic Information Science, 28(1), 45-60.

Cartwright, W. (1997). New media and their application to the production of map products. Computers \& Geosciences, 23(4), 447-456.

Casakin, H., Barkowsky, T., Klippel, A., \& Freksa, C. (2000). Schematic maps as wayfinding aids. In Spatial cognition II:Integrating abstract theories, empirical studies, formal methods, and practical applications (pp. 54-71). Berlin Heidelberg: Springer.

Castaño, J. M., Moreno, A., \& Crego, A. (2006). Factores psicosociales y formación de imágenes en el turismo urbano: un estudio de caso sobre Madrid. PASOS Revista de Turismo Y Patrimonio Cultural, 4(3), 287-299.

Chalmers, D., Dulay, N., \& Sloman, M. (2004). A framework for contextual mediation in mobile and ubiquitous computing applied to the context-aware adaptation of maps. Personal and Ubiquitous Computing, 8(1), 1-18. doi:10.1007/s00779-0030255-6

Cheng, P. (2002). Electrifying diagrams for learning: principles for complex representational systems. Cognitive Science, 26(6), 685-736.

Cheng, P., \& Barone, R. (2007). Representing complex problems: A representational epistemic approach. In D. H. Jonassen (Ed.), Learning to solve complex scientific problems (pp. 97-130). Mahmah, N.J.: Lawrence Erlbaum Associates. 
Cleveland, W., \& McGill, R. (1984). Graphical perception: Theory, experimentation, and application to the development of graphical methods. Journal of the American Statistical Association, 79, 531-554.

Cools, E., Broeck, H. van Den, \& Bouckenooghe, D. (2006). The cognitive style indicator: development of a new measurement instrument. Vlerick Leuven Gent Management School.

Couclelis, H., Golledge, R., Gale, N., \& Tobler, W. (1987). Exploring the anchor-point hypothesis of spatial cognition. Journal of Environmental Psychology, 7(2), 99122.

Dent, B. (1999). Cartography-thematic map design. Boston: McGraw-Hill.

Departamento de Atención Acogida e Información Turística. (2014). Informe estadístico de los Servicios de Atención e Información Turística Enero-Diciembre 2013. Madrid.

Dewey, J. (1958). Experience and nature. (2nd ed.). New York: Dover.

Downs R. M. \&. Stea, D. (1973). Cognitive maps and spatial behavior: Process and products. R. M. Downs, \& D. Stea (Eds.), Image and environment (pp. 8-26). Chicago: Aldine.

Dziekan, K. (2008). The transit experience of newcomers to a city: learning phases, system difficulties and information search strategies. In Proceedings of the 87th Transportation Research Board Meeting. Washington, DC.

Edsall, R. (2007). Globalization and cartographic design: Implications of the growing diversity of map users. In ICA, Proceedings of the XXIII International Cartographic Conference ôCartography for Everyone and for You. Roskart, Moscow.

Evans, G. (1980). Environmental cognition. Psychological Bulletin, 88(2), 259.

Flink, H.-M., Oksanen, J., Pyysalo, U., Rönneberg, M., \& Sarjakoski, L. T. (2011). Usability evaluation of a map-based multi-publishing service. In Ruas, A., (ed.), Advances in Cartography and GIScience (pp. 239-257). Berlin: Springer.

Forlizzi, J., \& Battarbee, K. (2004). Understanding experience in interactive systems. In Proceedings of the 5th conference on Designing interactive systems: processes, practices, methods, and techniques (pp. 261-268). ACM, New York.

Francescato, D., \& Mebane, W. (1973). How citizens view two great cities: Milan and Rome. In D. Downs R. M. \&. Stea (Ed.), Image and environment . Chicago: Aldine. 
Freksa, C. (1999). Spatial aspects of task-specific wayfinding maps. In Visual and spatial reasoning in design (pp. 15-32). Sydney: University of Sydney.

Freksa, C. (1991). Qualitative spatial reasoning. In D. M. Mark \& A. Frank (Eds.), Cognitive and Linguistic Aspects of Geographic Space. (pp. 361-372). Netherlands: Springer.

Garling, E., \& Golledge, R. (2000). Cognitive mapping and spatial decision-making. In S. Kitchin, R. and Freundschuh (Ed.), Cognitive mapping: past, present, and future (pp. 44-65). London \& New York: Routledge.

Gervais, E., Liu, H., Nussbaum, D., Roh, Y. S., Sack, J. R., \& Yi, J. (2007). Intelligent map agents-An ubiquitous personalized GIS. ISPRS Journal of Photogrammetry and Remote Sensing, 62(5), 347-365.

Gibson, H. (2002). Tourist roles. Needs and the Lifecourse. Annals of Tourism Research, 29(2), 358-383.

Gomez, B., \& Jones III, J. P. (2010). Research methods in geography: a critical introduction. UK: Blackwell Publishing Ltd.

Goodey, A. W. Duffett, J. R. Gold and D. Spencer (1971). City scene: an exploration into the image of central Birmingham as seen by area residents. University of Birmingham, Centre for Urban and Regional Studies, Research Memomndum 10.

Gould, P. (1975). Acquiring spatial information. Economic Geography, 51, 87-99.

Gould, P., \& White, R. (1974). Mental Maps Baltimore: Penguin Books.

Guo, Z. (2011). Mind the map! The impact of transit maps on path choice in public transit. Transportation Research Part A: Policy and Practice, 45(7), 625-639.

Haklay, M., \& Tobón, C. (2003). Usability evaluation and PPGIS: towards a usercentred design approach. International Journal of Geographical Information Science, 17(6), 577-592.

Hannes, E., Janssens, D., \& Wets, G. (2006). Proximity is a state of mind: exploring mental maps in daily activity travel behaviour. In 11th International Conference on Travel Behaviour Research. Kyoto, Japan.

Hassenzahl, M. (2014). User Experience and Experience Design. In R. F. Soegaard, Mads and Dam, Rikke Friis (Eds.), The Encyclopedia of Human-Computer Interaction. Aarhus, Denmark: The Interaction Design Foundation. 
Hassenzahl, M. (2010). Experience design: Technology for all the right reasons. Synthesis Lectures on Human-Centered Informatics, 3(1), 1-95.

Hassenzahl, M., Diefenbach, S., \& Göritz, A. (2010). Needs, affect, and interactive products - Facets of user experience. Interacting with Computers, 22(5), 353362. doi:10.1016/j.intcom.2010.04.002

Hassenzahl, M. (2003). The thing and I: understanding the relationship between user and product. In A. Blythe, A. Monk, K. Overbeeke, \& P. Wright, (Eds.) Funology: From Usability to Enjoyment (pp. 31-41). New York: Kluwer Academic Publishers.

Hegarty, M. (2011). The Cognitive Science of Visual-Spatial Displays: Implications for Design. Topics in Cognitive Science, 3(3), 446-474. doi:10.1111/j.17568765.2011.01150.x

Heskett, J. (2005). Design: A very short introduction. Oxford: Oxford University Press.

Hirtle, S. C., \& Raubal, M. (2013). Many to Many Mobile Maps. In Cognitive and Linguistic Aspects of Geographic Space (pp. 141-157). Berlin, Heidelberg: Springer. doi:10.1007/978-3-642-34359-9

Holahan, C., \& Dobrowolny, M. (1978). Cognitive and Behavioral Correlates of the Spatial Environment An Interactional Analysis. Environment and Behavior, 10(3), 317-333.

Hollands, J., \& Wickens, C. (1999). Engineering psychology and human performance. Englewood Cliffs, NJ: Prentice-Hall.

Instituto de Turismo de España. (2013). Informe anual 2012. Encuesta de Movimientos Turísticos en Fronteras. Encuesta de Gasto Turístico. https://www.google.es/url?sa=t\&rct=j\&q=\&esrc=s\&source=web\&cd=2\&cad=rja \&uact $=8 \&$ ved $=0$ ahUKEwignomu5ejJAhWJ1hoKHV1vArwQFgg|MAE\&url=http\%3A $\% 2 \mathrm{~F} \% 2 \mathrm{Festadisticas.tourspain.es \% 2 \textrm {Fes } -}$

ES\%2Festadisticas\%2Fegatur\%2FAnuales\%2FMovimientos\%2520Tur\%25C3\%25A Dsticos\%2520en\%2520Fronteras\%2520(Frontur)\%2520y\%2520Encuesta\%2520d e\%2520Gasto\%2520Tur\%25C3\%25ADstico\%2520(Egatur)\%25202012.pdf\&usg=A FQjCNFbomsKhOiVVe2fbH 0v5xLtUOCZA\&sig2=9yXA56wign1MXAebBwa7kA (Consulta: 19/12/2015).

International Congress and Convention Association. (2014). ICCA 2013 Statistics Report. http://www.iccaworld.com/dcps/doc.cfm?docid=1696 (Consulta: 19/12/2015).

ISO (1988). 9241-11: 1988 Ergonomic requirements for office work with visual display terminals (VDTs) --Part 11: Guidance on usability. International Organization for Standardization. 
ISO (2010). 9241-210: 2010 Ergonomics of human system interaction-Part 210: Human-centred design for interactive systems (revises ISO 13407:1999). International Organization for Standardization.

Kabassi, K. (2010). Personalizing recommendations for tourists. Telematics and Informatics, 27(1), 51-66.

Kankainen, A. (2002). Thinking model and tools for understanding user experience related to information appliance product concepts. PhD Thesis, Helsinki University of Technology.

Kaplan, S. (1973). Cognitive maps, human needs and the designed environment. In H. and R. Stroudsburg (Ed.), Environmental Design Research (Vol. 1, pp. 275-283). Stroudsberg, PA: Dowden, Hutchinson \& Ross.

Kinsella, J., \& Caulfield, B. (2011). An Examination of the Quality and Ease of Use of Public Transport in Dublin from a Newcomer's Perspective. Journal of Public Transportation, 14(1), 69-81.

Klippel, A., Lee, P. U., Fabrikant, S. I., Montello, D. R., \& Bateman, J. (2005). The cognitive conceptual approach as a leitmotif for map design. In Reasoning with Mental and External Diagrams: Computational Modeling and Spatial Assistance (pp. 90-95). Stanford, California: AAAI Press.

Klippel, A., Richter, K.-F., Barkowsky, T., \& Freksa, C. (2005). The cognitive reality of schematic maps. In Liqiu Meng, Alexander Zipf, Tumasch Reichenbacher (Eds.), Map-based Mobile Services (pp. 55-71). Berlin: Springer.

Knobel, M., \& Hassenzahl, M. (2013). A trip into the countryside: An experience design for explorative car cruises. $\mathrm{CHI}^{\prime} 13$ Extended Abstracts on Human Factors in Computing Systems (pp.565-570).

Kolácný, A. (1969). Cartographic Information-a Fundamental Concept and Term in Modern Cartography. Cartographic Journal, 6, 47-49.

Konečný, M. (2011). Cartography: challenges and potential in the virtual geographic environments era. Annals of GIS 17(3),135-145.

Konečný, M., \& Staněk, K. (2010). Adaptive cartography and geographical education. International Research in Geographical and Environmental Education, 19(1), 7578.

Konečný, M. (2008). Cartography New Perspectives in Crises Management Context. In V. M. K. and N.S. Kasimov \& C. Vandemotten (Eds.), Geography, environment, sustainability (Vol. 1, pp. 46-67). Moscow: MGU Press.

Kosslyn, S. M. (2006). Graph design for the eye and mind . New York: Oxford University Press. 
Kraak, J., \& Brown, A. (2001). Web cartography, developments and prospects. London: Taylor \& Francis.

Kramers, E. R. (2008). Interaction with Maps on the Internet - A User Centred Design Approach for The Atlas of Canada. The Cartographic Journal, 45(2), 98-107. doi:10.1179/174327708X305094

Law, E., Roto, V., Hassenzahl, M., Leicester, L., Vermeeren, A., \& Kort, J. (2009). Understanding, scoping and defining user experience: a survey approach. In Proceedings of the CHI 2009 Conference on Human Factors in Computing Systems. (pp. 719-728). New York.

Lew, A., \& McKercher, B. (2006). Modeling tourist movements: A local destination analysis. Annals of Tourism Research, 33(2), 403-423.

Lloyd, D. (2009). Evaluating human-centered approaches for geovisualization. PhD Thesis, City University London.

Lloyd, R. (2000). Self-Organized Cognitive Maps. Professional Geographer, 52(3), 517 $-531$.

Lloyd, R. (1993). Cognitive processes and cartographic maps. Advances in Psychology, 96, 141-169.

Look, G., \& Shrobe, H. (2007). Towards intelligent mapping applications: a study of elements found in cognitive maps. Proceedings of the 12th International Conference on Intelligent User Interfaces(pp. 309-312). Honolulu, Hawaii, USA.

Lynch, K. (1960). The image of the city (Vol. 11). Cambridge, Mass: the MIT Press.

MacEachren, A. M. (2013). Cartography as an Academic Field: A Lost Opportunity or a New Beginning? The Cartographic Journal, 50(2), 166-170. doi:10.1179/0008704113Z.00000000083

MacEachren, A. M., \& Kraak, M.-J. J. (2001). Research challenges in geovisualization. Cartography and Geographic Information Science, 28(1), 3-12. doi:10.1559/152304001782173970

Madrid Visitors \& Convention Bureau. (2012). Plan estratégico de turismo. Ciudad de Madrid 2012-2015. https://madridaldiagrupoa.files.wordpress.com/2013/10/plan-estratc3a9gicode-turismo-2012-21051.pdf (Consulta: 19/12/2015).

McCarthy, J., \& Wright, P. (2004). Technology as experience. Interactions, 11(5), 4243. 
McDonald, T., \& Pellegrino, J. (1993). Psychological perspectives on spatial cognition. In T. Garling \& R. G. Golledge (Ed.), Behavior and Environment: Psychological and geographical approaches (pp. 47-82). Amsterdam: Elsevier.

Medyckyj-Scott, D., \& Board, C. (1991). Cognitive cartography: A new heart for a lost soul. In J.C. Müller (Ed.), Advances in cartography (pp. 201-230). London: Elsevier.

Meilinger, T., Hölscher, C., Büchner, S. J., \& Brösamle, M. (2007). How much information do you need? Schematic maps in wayfinding and self localisation. In Barkowsky, T., Knauff, M., Ligozat, G., Montello, D.R. (eds.) Spatial Cognition V (pp. 381-400). Berlin: Springer.

Meng, L. (2005). Ego centres of mobile users and egocentric map design. In A. Z. L. Meng \& and T. Reichenbacher (Eds.), Map-based Mobile Services. Theories, Methods and Implementations (pp. 87-105). Berlin: Springer.

Messick, S. (1984). The nature of cognitive styles: Problems and promise in educational practice. Educational Psychologist, 19(2), 59-74.

Milgram, S. (1977). The individual in a Social World: Essays and Experiments, (M. Reading, Ed.). New York: Addison-Wesley.

Milgram, S., \& Greenwald, Kessler, McKenna, and W. Waters (1972). A psychological map of New York city. American Scientist, 60(2), 194-200.

Montello, D. R. (2002). Cognitive map-design research in the twentieth century: Theoretical and empirical approaches. Cartography and Geographic Information Science, 29(3), 283-304. doi:10.1559/152304002782008503

Moore, G. (1979). Knowing about environmental knowing the current state of theory and research on environmental cognition. Environment and Behavior, 11(1), 3370 .

Moore, G. T. (1974). The development of environmental knowing: An overview of an interactional-consructivist theory and some data on within-individual development variations.". In T. Canter, D; Lee (Ed.), Psycology and the Built Environment. (pp. 184-194). London: Architectural Press.

Moore, G. T. (1973). Developmental differences in environmental cognition. In W. Preisser (Ed.), Environmental Design Research: Symposia and workshops (pp. 232-239). Stroudsburg: Hutchinson \& Ross.

Morrison, J. L. (1994). The paradigm shift in cartography: the use of electronic technology, digital spatial data, and future needs. Advances in GIS Research, 1, 1-15. 
Neisser, U. (1981). Procesos cognitivos y realidad: Principios e implicaciones de la Psicología Cognitiva. Madrid: Marona.

Niaraki, A., \& Kim, K. (2009). Ontology based personalized route planning system using a multi-criteria decision making approach. Expert Systems with Applications, 36(2), 2250-2259.

Nivala, A. M. (2007). Usability perspectives for the design of interactive maps. Department of Computer Science and Engineering. PhD Thesis, Helsinki University of Technology.

Nivala, A. M., Tiina Sarjakoski, L., \& Sarjakoski, T. (2007). Usability methods' familiarity among map application developers. International Journal of HumanComputer Studies, 65(9), 784-795.

Nivala, A., \& Sarjakoski, L. T. (2003). Need for Context-Aware Topographic Maps in Mobile Devices. In Proceedings of the 9th Scandinavian Research Conference on Geographic Information Science (ScanGIS 2003) (pp. 15-29). Espoo, Finland.

Norberg-Schulz, C. (1971). Existence, space \& architecture. Londres: Studio Vista.

Ooms, K. (2012). Maps, how do users see them?: an in depth investigation of the map users' cognitive processes. PhD Thesis, Ghent University.

Pearce, P. L. (1988). The Ulysses Factor. Springer New York.

Peterson, M. (2003). Maps and the Internet. Elsevier.

Peterson, D. (1996). Forms of representation: an interdisciplinary theme for cognitive science. Wiltshire, GB: Cromwell Press.

Pockock, D. (1972). The city of the mind: a review of mental maps in urban areas. Scotitish Geographical Journal, 88, 116-124.

Pontis, S. V. (2008). La esquemática, ciencia de la visualización del dato, como la interficie próxima del conocimiento. In Latin American Symposium of Systems, Cibernetics and Information Technology. Orlando, Florida, US: CISCI 2008.

Reichenbacher, T. (2004). Mobile cartography: adaptive visualisation of geographic information on mobile devices. PhD Thesis, Institut für Photogrammetrie und Kartographie. Technischen Universität München.

Reichenbacher, T. (2003). Adaptive methods for mobile cartography. In ICC 2003: the 21st International Cartographic Conference (pp. 1311-1322). Durban, South Africa.

Rich, E. (1983). Users are individuals: individualizing user models. International Journal of Man-Machine Studies, 18(3), 199-214. 
RocaSalvatella \& Telefónica. (2014). Big data y turismo: Nuevos indicadores para la gestión turística.

http://www.rocasalvatella.com/sites/default/files/big data y turismo-castinteractivo.pdf (Consulta: 19/12/2015).

Roth, R. (2015). Interactivity and Cartography: A Contemporary Perspective on User Interface and User Experience Design from Geospatial Professionals.

Cartographica, 50(2), 94-115.

Roth, R. E. (2013). Interactive maps: What we know and what we need to know. Journal of Spatial Information Science, 6(6), 59-115.

doi:10.5311/JOSIS.2013.6.105

Rystedt, B. (2003). A Strategic Plan for the International Cartographic Association 2003-2011.

http://icaci.org/files/documents/reference_docs/ICA_Strategic_Plan_20032011.pdf (Consulta: 19/12/2015).

Sanders, E. B.-N. N. (2002). From user-centered to participatory design approaches. In J. Frascara (Ed.), Design and the social sciences: Making connections (pp. 1-8). London: Taylor \& Francis.

Savage, D. M. I. (2006). The Advantages and Disadvantages of Three-dimensional Maps for Focused and Integrative Map Analysis Performance by Novice and Experienced Users. PhD Thesis, North Carolina State University.

Scaife, M., \& Rogers, Y. (1996). External cognition: how do graphical representations work? International Journal of Human-Computer Studies, 45(2), 185-213. doi:10.1006/ijhc.1996.0048

Schobesberger, D. (2012). Towards a Framework for Improving the Usability of Webmapping Products. PhD Thesis, University of Vienna.

Shedroff, N. (1994). Information interaction design: A unified field theory of design. In R. E. \& Jacobson (Eds.), Information design (pp. 267-292). Cambridge: MIT Press.

Shekhar, S., \& Xiong, H. (2008). Encyclopedia of GIS. Springer.

Shoval, N., \& Raveh, A. (2004). Categorization of tourist attractions and the modeling of tourist cities: based on the co-plot method of multivariate analysis. Tourism Management, 25(6), 741-750.

Slocum, T. a., Blok, C., Jiang, B., Koussoulakou, A., Montello, D. R., Fuhrmann, S., \& Hedley, N. R. (2001). Cognitive and usability issues in geovisualization. Cartography and Geographic Information Science, 28(1), 61-75. 
Stanek, K. \& Friedmannová, L., (2010). Cartographically Augmented Reality. In ISDE digital earth summit - digital earth in the service of society: sharing information, building knowledge-proceedings (.pp. 1-9). Nessebar, Bulgaria.

Sternberg, R., \& Grigorenko, E. (1997). Are cognitive styles still in style? American Psychologist, 52(7), 700-712.

Tussyadiah, I. P. (2013). Toward a Theoretical Foundation for Experience Design in Tourism. Journal of Travel Research, 53(12), 543-564. doi:10.1177/0047287513513172

Tussyadiah, I. P., \& Zach, F. J. (2012). The role of geo-based technology in place experiences. Annals of Tourism Research, 39(2), 780-800. doi:10.1016/j.annals.2011.10.003

Tversky, B. (2000). Some ways that maps and diagrams communicate. In C. Freksa, C., Habel \& K. F. Wender (Eds.), Spatial Cognition II. Berlin: Springer.

Van Elzakker, C. P. J. M., \& Griffin, A. L. (2013). Focus on geoinformation users : cognitive and use/user issues in contemporary cartography. GIM International, 27(8), 20-23.

Van Elzakker, C. P. J. M., \& Wealands, K. (2007). Use and users of multimedia cartography. In Cartwright W., Peterson M.P., Gartner G. (Eds.), Multimedia cartography (pp. 487-504). Berling: Springer.

Van Elzakker, C. P. J. M. (2004). The use of maps in the exploration of geographic data. PhD Thesis, Faculteit Geowetenschappen Universiteit Utrecht. ITC. Netherlands Geographical Studies.

Vertesi, J. (2008). Mind the Gap : The London Underground Map and Users' Representations of Urban Space. Social Studies of Science, 38(1), 7-33. doi:10.1177/0306312707084153

Vicente, K. (2002). Ecological interface design: Progress and challenges. Human Factors: The Journal of the Human Factors and Ergonomics Society, 44(1), 6278.

Villafañe Gallego, J. (1981). Fundamentos metodológicos de la teoría de la imagen:(referidos a la imagen fija). PhD Thesis, Universidad Complutense de Madrid.

Walmsley, D. J. J., \& Jenkins, J. M. M. (1992). Tourism cognitive mapping of unfamiliar environments. Annals of Tourism Research, 19(2), 268-286. doi:10.1016/0160-7383(92)90081-Y 
Wilson, D., Bertolotto, M., \& Weakliam, J. (2010). Personalizing map content to improve task completion efficiency. International Journal of Geographical Information Science, 24(5), 741-760. doi:10.1080/13658810903074490

Witkin, H. A., Moore, C. A., Goodenough, D. R., \& Cox, P. W. (1975). Field-dependent and field-independent cognitive styles and their educational implications. ETS Research Bulletin Series, 2, 1-64.

Wood, D., \& Beck, R. (1990). Tour personality: The interdependence of environmental orientation and interpersonal behavior. Journal of Environmental Psychology, 10(3), 177-207.

Woods, D. (1984). Visual momentum: a concept to improve the cognitive coupling of person and computer. International Journal of Man-Machine Studies, 21(3), 229-244.

Wright, P., McCarthy, J., \& Meekison, L. (2005). Making sense of experience. In M. Blythe et al., (Eds.), Funology (pp. 43-53). Netherlands: Springer. 


\section{ANEXOS}

\section{Anexo 1. Atributos de los turistas de Madrid, en base a fuentes documentales consultadas.}

El turismo es un encuentro entre personas (visitantes) y lugares a los que se desplazan por motivos personales o profesionales, durante un período de tiempo limitado y en el que realizan actividades. Dependiendo de lo que dure su estancia, los visitantes pueden ser: turistas (si su viaje incluye al menos una pernoctación) o excursionistas (visitante del día). Y en función de su procedencia: residentes (nacionales) o no residentes (internacionales) ${ }^{9}$.

En base a la documentación consultada, los turistas de Madrid se caracterizan por:

\section{- País de procedencia}

La Figura $\mathrm{A} 1$ a) ilustra el número de viajeros nacionales e internacionales que llegaron a la Comunidad de Madrid (CM) entre el 2009 y el 2013. El número de turistas nacionales fue superior al de internacionales. Y la progresión interanual de los turistas internacionales fue superior a la de los nacionales, salvo entre el 2011 y el 2012 (Figura A1 b).

\section{Número de viajeros nacionales e internacionales en la CM}

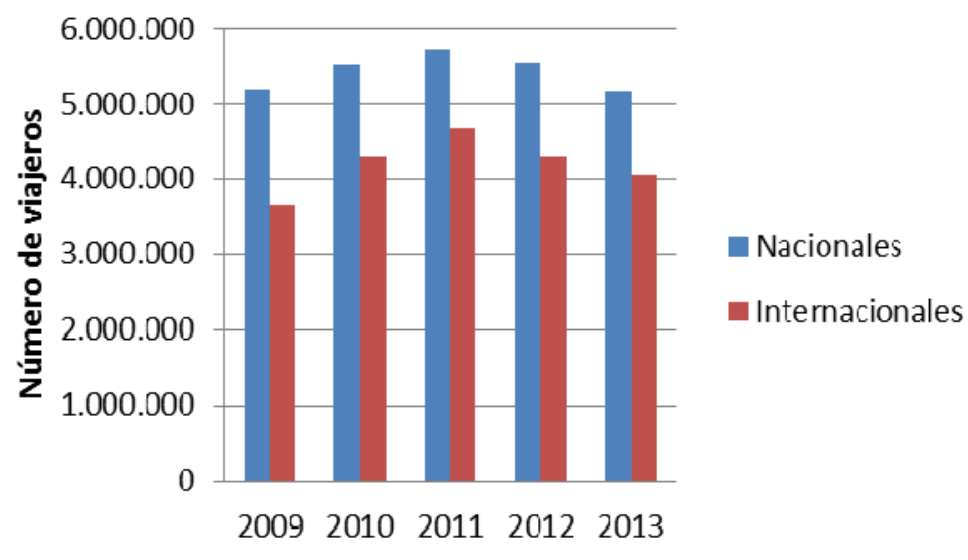

a)

${ }^{9}$ Entender el turismo: Glosario básico de la Organización Mundial del Turismo OMT.

Fuente: http://media.unwto.org/es/content/entender-el-turismo-glosario-basico 


\section{Evolución interanual de viajeros nacionales e internacionales en la $\mathrm{CM}$}

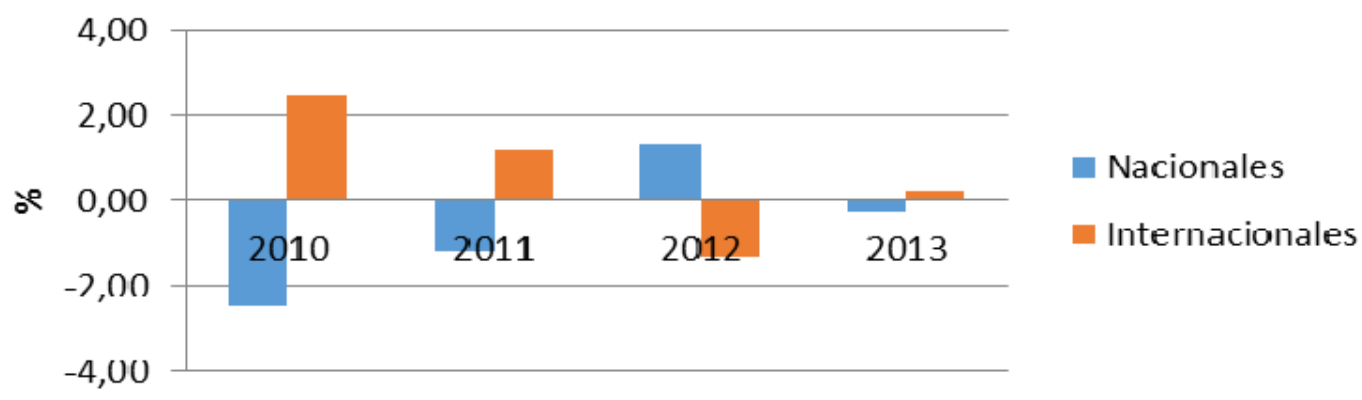

b)

Figura A1 Viajeros nacionales e internacionales en la CM entre el 2009 y el 2013:

a) Número de viajeros, b) Incremento interanual de porcentajes de viajeros.

Fuente: Instituto de Estadística de la CM, n.d.

Por otro lado, la afluencia de turistas extranjeros entre el 2010 y el 2014 en la CM fue inferior a la de otras comunidades de España como: Cataluña, Baleares, Canarias, Andalucía y Comunidad Valenciana. (Figura A2).

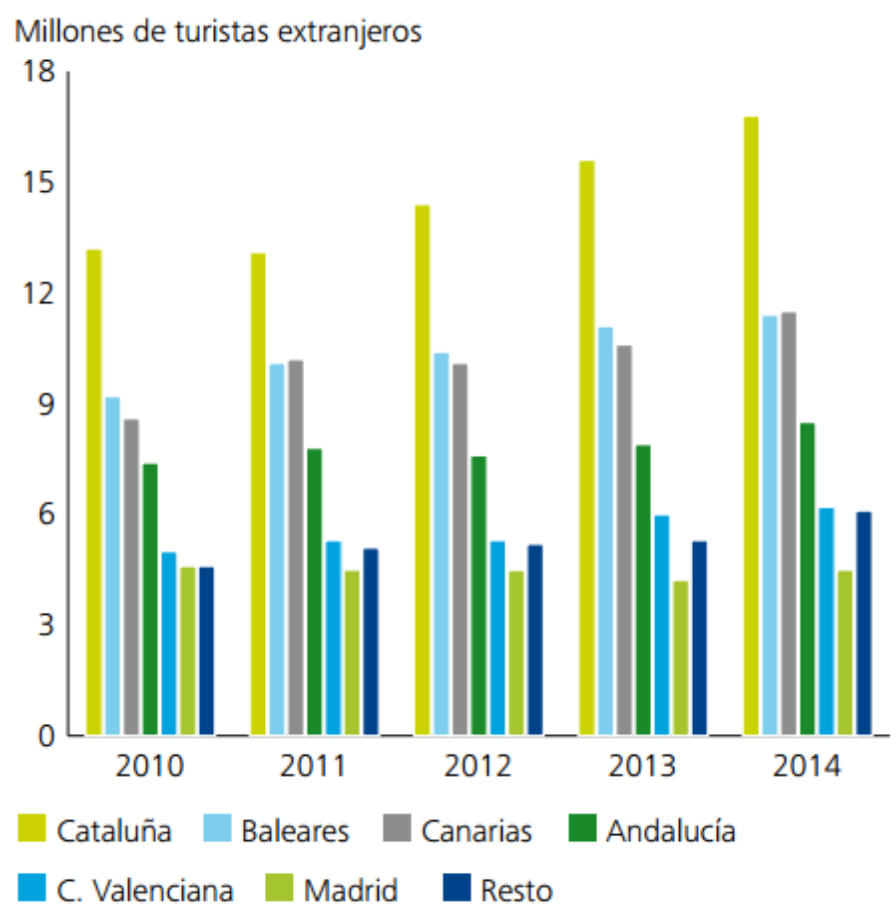

Figura A2: Evolución del número de turistas extranjeros en diferentes Comunidades Autónomas de España entre el 2010 y el 2014. Fuente: Deloitte (2015).

Los documentos analizados prevén que los turistas internacionales tienen mayor potencial en el destino turístico de Madrid, sin embargo su crecimiento en los últimos años no ha sido tan positivo como en otras Comunidades Autónomas. 


\section{- Edad}

Según una encuesta realizada por el Ayuntamiento de Madrid (Madrid Visitors \& Convention Bureau, 2012), los turistas internacionales con edades comprendidas entre 25 y 40 años representan la mitad y el resto se reparte en porcentajes iguales entre menores de 25 años y mayores de 40.

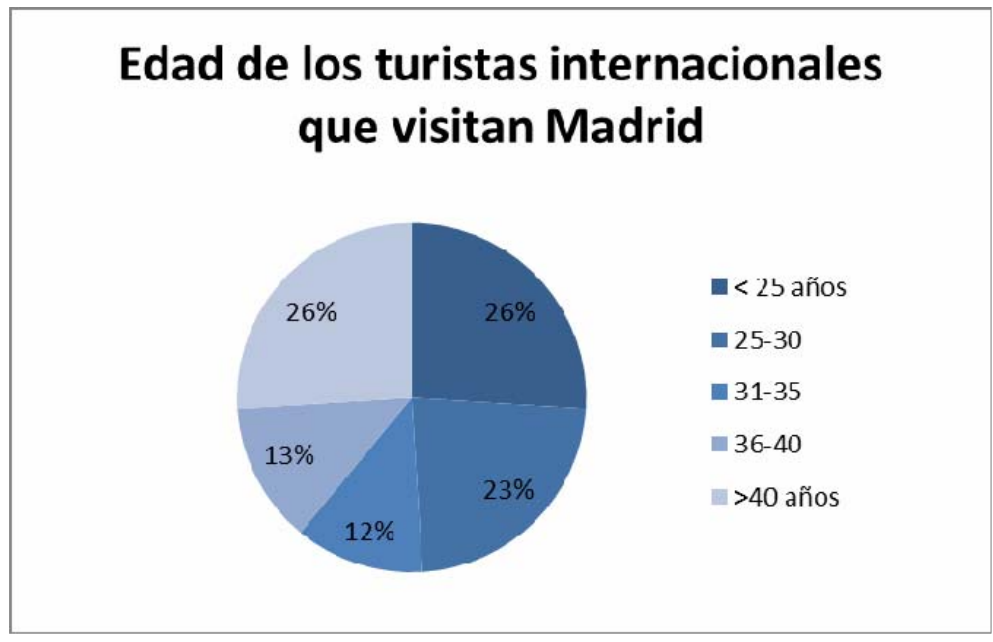

Figura A3: Edad de los turistas internacionales que visitan Madrid. Fuente: Madrid Visitors \& Convention Bureau (2012).

\section{- Género}

Según la misma encuesta del Ayuntamiento para el Plan Estratégico 20122015 , el $57 \%$ de los turistas son hombres y el $43 \%$ mujeres.

\section{- Nivel económico}

Los turistas internacionales de la CM en el 2012 fueron los que mayor renta media y media-alta tuvieron de toda España. Ese año, el $96 \%$ de sus turistas internacionales que llegaron a Madrid pertenecían a las dichas categorías (Instituto de Turismo de España, 2013).

En cuanto al gasto efectuado, en el 2012 el gasto medio diario de los turistas de la CM fue de $159 €$, siendo este el más alto entre todas las comunidades de España (Instituto de Turismo de España, 2013). Por otro lado, para un $14 \%$ de los turistas internacionales prima mucho más la exclusividad que el precio, identificándose este porcentaje de turistas con el sector del lujo (Madrid Visitors \& Convention Bureau, 2012. Se puede concluir, por tanto, que el gasto diario de los turistas de Madrid es considerablemente elevado.

En cuanto a la distribución del gasto, la Figura A4 ilustra su distribución en diferentes partidas: en el anillo exterior los visitantes internacionales de España y en el anillo interior los que llegaron a la CM. En esta figura cabe destacar que los visitantes internacionales de Madrid dedican un $35 \%$ de su gasto al transporte, frente al $25 \%$ que este concepto supone en el presupuesto de los turistas recibidos en toda España. 
Total turismo receptor

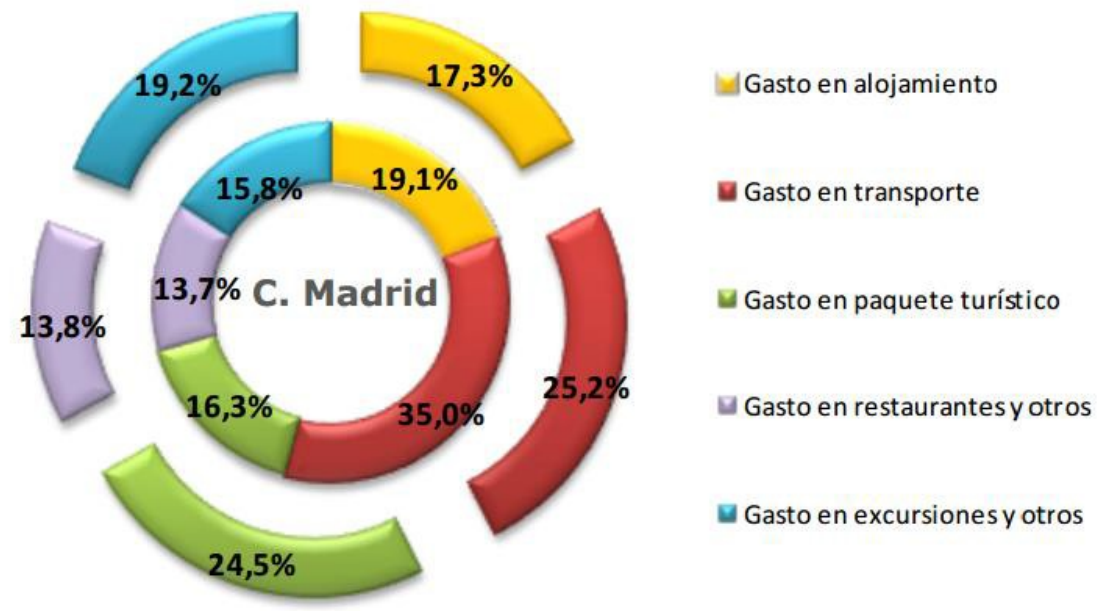

Figura A4: Distribución de gasto total del turismo receptor de España (anillo exterior) y el de la CM (anillo interior). Fuente: Instituto de Turismo de España (2013).

\section{- Nivel de estudios}

El $82 \%$ de los turistas internacionales que llegaron a Madrid en 2012 poseían estudios superiores y el $17 \%$ estudios medios, siendo la CM la comunidad de España que recibió los turistas con mayor nivel formativo ese año (Instituto de Turismo de España, 2013). 


\section{Anexo 2. Factores humanos y temporales que condicionan las actividades de los turistas de Madrid, en base a fuentes documentales consultadas.}

Factores humanos que condicionan las actividades de los turistas internacionales de Madrid:

- Motivo del viaje a Madrid

La mayoría de los turistas que vienen a Madrid lo hacen por vacaciones y ocio. Además, destaca el porcentaje de turistas que llegan motivados por negocios y trabajo (20 \%) y por estudios (4 \%). Sin embargo, en el 2012 hubo un importante descenso de visitantes internaciones por motivo laboral (-10,3\%). Mientras que, los visitantes internacionales que llegaron por motivo estudios ese año se incrementaron respecto al año anterior, cerca de un 48\% (Instituto de Turismo de España, 2013).

Por otro lado, en 2013 se celebraron en Madrid 186 congresos internacionales, hecho que demuestra su consolidación mundial como destino turístico de congresos y negocios, tras Paris (International Congress and Convention Association, 2014).

- Intereses relacionados con la visita

Los turistas internacionales que visitaron la CM en el 2012 se interesaron principalmente por el patrimonio, los monumentos, los museos y las actividades culturales (43\%) y también destacan los amantes de la gastronomía (20 \%) (Instituto de Turismo de España, 2013).

- Grupo de viaje

El grupo de viaje está formado por los visitantes que realizan juntos el viaje y que comparten gastos vinculados al mismo.

Según datos del informe anual 2012 del Instituto Turístico de España, la CM es la que menor número de turistas recibe en grupos organizados (14.2 \%) y a la que más turistas llegan solos (48\%).

Por otro lado, el Plan Estratégico de la ciudad también incluye información de los grupos de viaje de los turistas internacionales en Madrid, tal y como muestra la Figura A5.

- Percepción de la ciudad como destino turístico

La Figura A6 ilustra la percepción que tienen los turistas de Madrid sobre diferentes aspectos de la ciudad como destino turístico. 


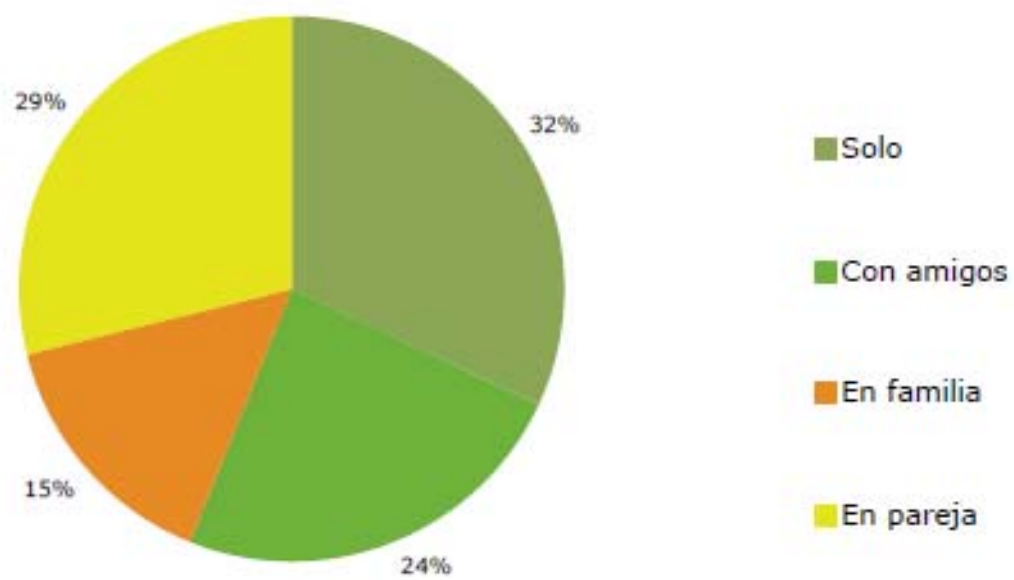

Figura A5: Grupos de viaje de turistas internacionales de Madrid. Fuente: Madrid Visitors \& Convention Bureau (2012).

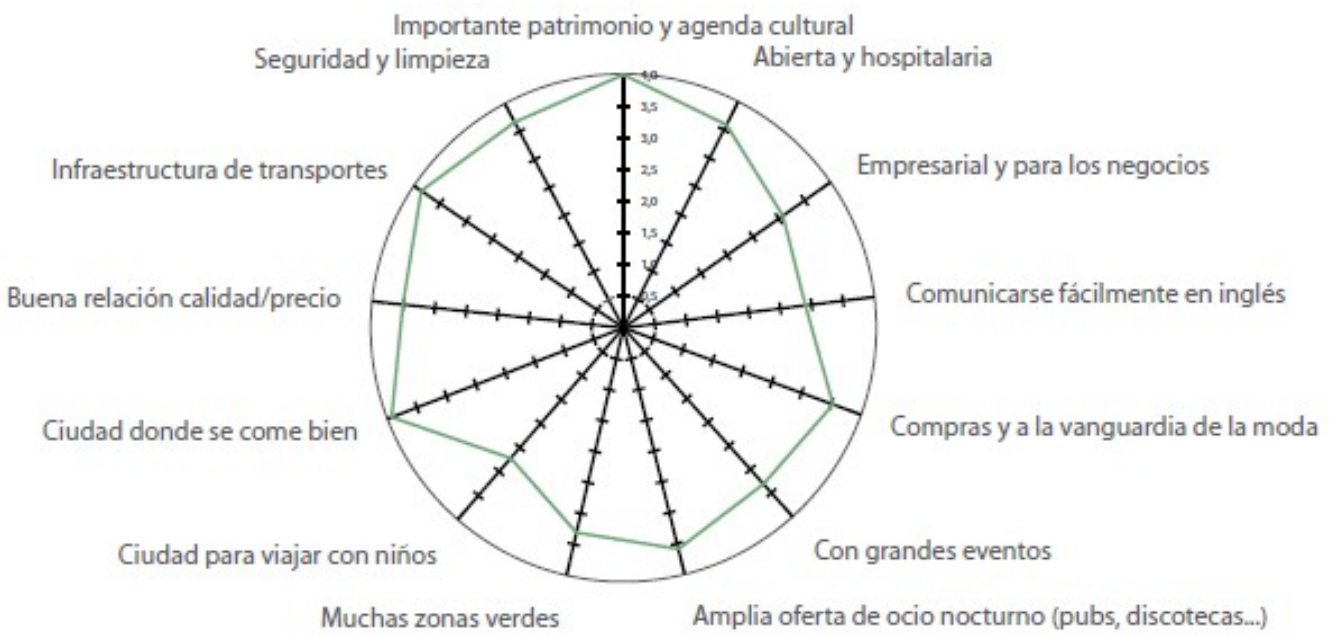

Figura A6: Percepción de la ciudad de los visitantes internacionales de Madrid Fuente: Madrid Visitors \& Convention Bureau (2012).

\section{- Valoración de la experiencia}

La satisfacción de los turistas internacionales tras final del viaje supera sus expectativas en cuanto a la infraestructura de transporte y a la gastronomía se refiere. Mientras que la valoración de la ciudad por sus grandes eventos y para los negocios es acorde con las expectativas y la facilidad para poder comunicarse en inglés queda por debajo de ellas (Figura A7). 


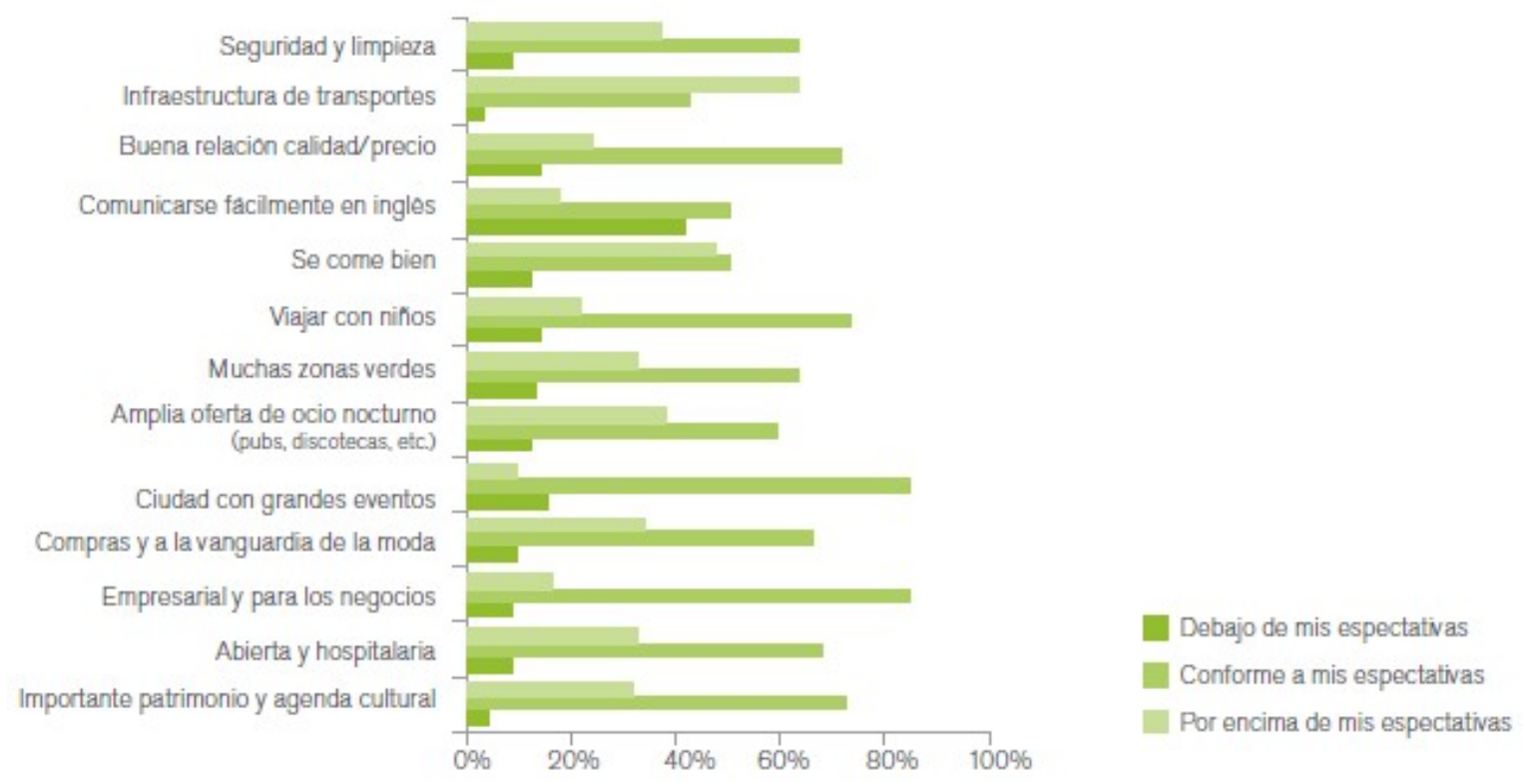

Figura A7: Valoración de la experiencia turística en Madrid por parte de los turistas internacionales Fuente: Madrid Visitors \& Convention Bureau (2012).

\section{Factores temporales:}

\section{- Duración de la estancia}

La estancia media de los visitantes de Madrid es tan solo de 1,9 días (Madrid Visitors \& Convention Bureau, 2012). En la Figura A8 se puede apreciar la variación y la evolución de la estancia media de los viajeros entre los años 2011 y 2013.

\section{Evolución de la estancia media de los viajeros (nacionales e internacionales)}

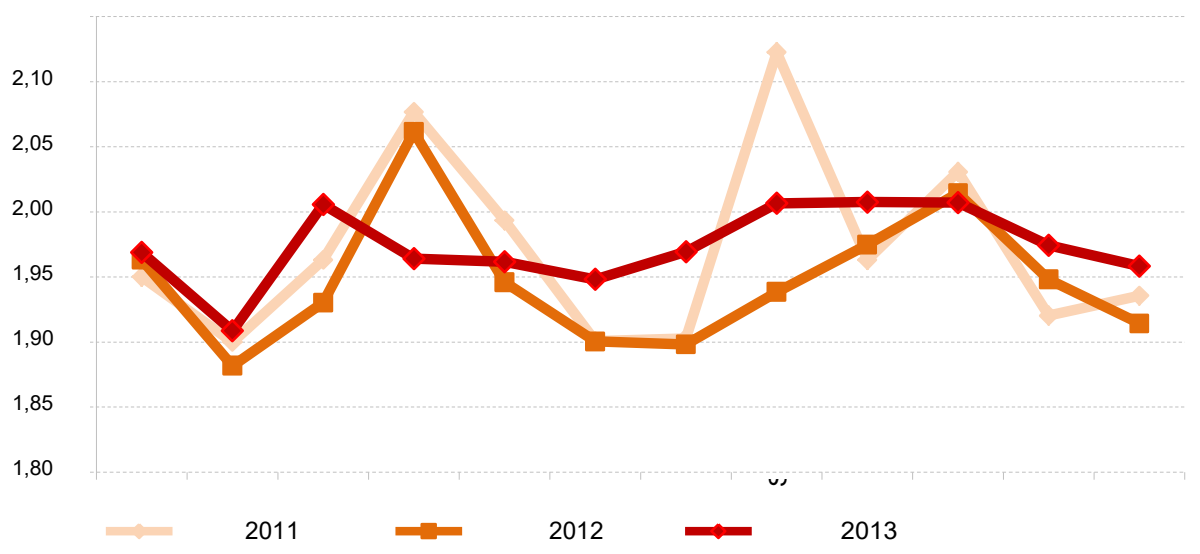

Figura A8: Evolución de la estancia media de los viajeros (nacionales e internacionales) en la ciudad de Madrid. Fuente: Ayuntamiento de Madrid, n.d.

Estos datos son coherentes con los obtenidos en base a un estudio a partir de la actividad de los terminales móviles extranjeros en las ciudades de Madrid y Barcelona durante el mes de octubre del 2012 (RocaSalvatella \& Telefónica, 2014). 
En este estudio destacan los datos de días de estancia en ambas ciudades, según intervalos de días (Figura A9), que resultan más significativos que los de la estancia media (Figura A10).

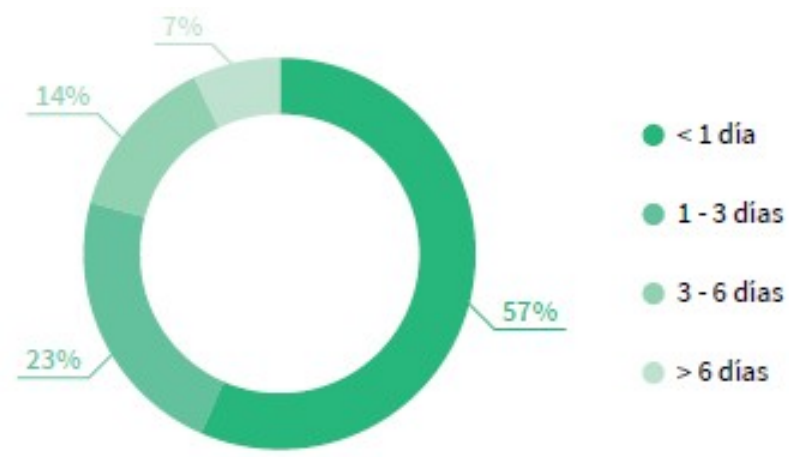

Figura A9: Duración de la estancia de viajeros extranjeros que usaron móvil en Barcelona y Madrid, en el mes de octubre del 2012, por rangos de días. Fuente: RocaSalvatella \& Telefónica (2014).

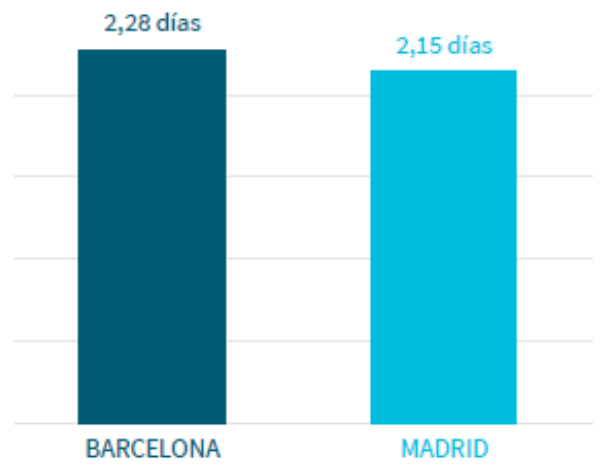

Figura A10: Estancia media de viajeros extranjeros que usaron móvil en Barcelona y Madrid durante el mes de octubre del 2012. Fuente: RocaSalvatella \& Telefónica (2014)

La estancia media de los turistas internacionales (2,15 días) contrasta significativamente con la estancia media de los turistas internacionales (excluidos los excursionistas extranjeros que no pernoctan en la $\mathrm{CM}$ ), ya que ésta fue de 7,3 noches, en el 2012. Los turistas internacionales permanecieron de media en hoteles de la Comunidad de Madrid 4,6 noches y en alojamientos no hoteleros (viviendas en propiedad, viviendas de familiares o amigos, vivienda alquilada y otros alojamientos) 15,3 noches. La estancia media de los que se alojan en hoteles se ve afectada por el peso de los que vienen a Madrid por motivo laboral, ya que su estancia es mucho menor que la del resto de turistas que vienen por vacaciones (Instituto de Turismo de España, 2013). Destaca también que la estancia media de los turistas internacionales en la CM (7,3 noches) es inferior a la media de los turistas internacionales que llegan a España que es de 8,9 noches (Instituto de Turismo de España, 2013). 


\section{- Época del año}

Los meses de baja ocupación en Madrid son: enero, febrero, agosto y diciembre. Mientras que los de alta ocupación son: abril, mayo, junio, septiembre y octubre (Ver Figura A11). Si se hace la media de los viajeros que llegan a Madrid a lo largo de los cuatro trimestres del año, se puede concluir que es un destino sin estacionalidad.

\section{Evolución de pernoctaciones de viajeros}

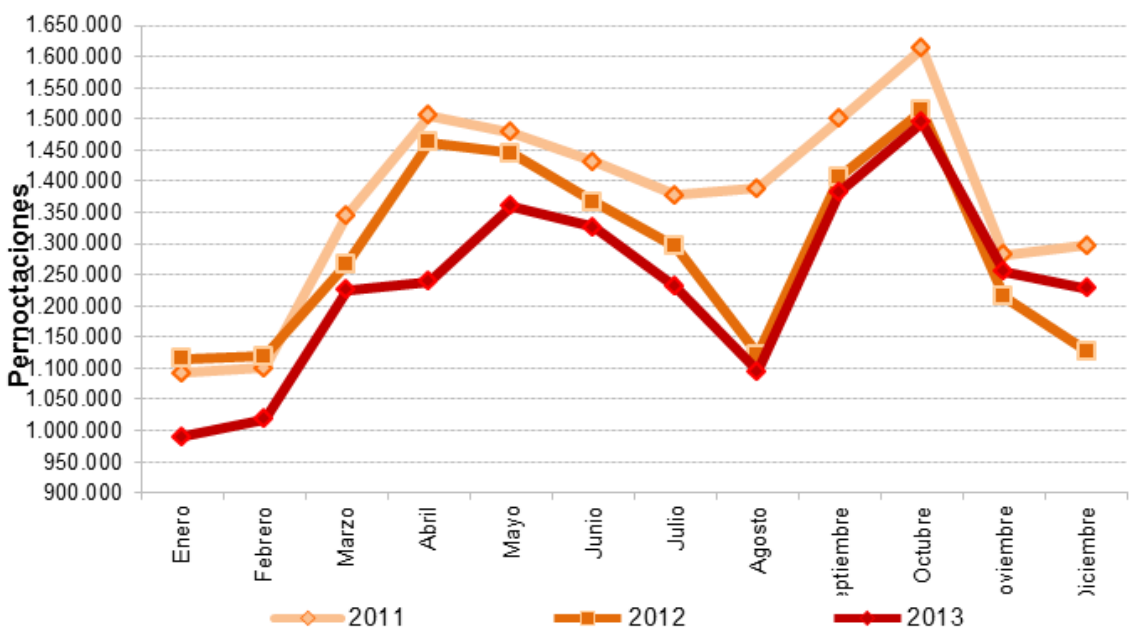

Figura A11: Evolución de pernoctaciones de viajeros (nacionales e internacionales) en la ciudad de Madrid. Fuente: Ayuntamiento de Madrid, n.d. 


\section{Anexo 3. Productos y servicios cartográficos utilizados por los turistas.}

En este anexo se describen los productos y servicios cartográficos disponibles para los turistas de Madrid. Los productos se pueden clasificar, en función de su soporte, como:

Mapas turísticos en papel:

- Mapas elaborados por la CM y por el Ayuntamiento como el mapa turístico del centro de la ciudad (Figura A12).

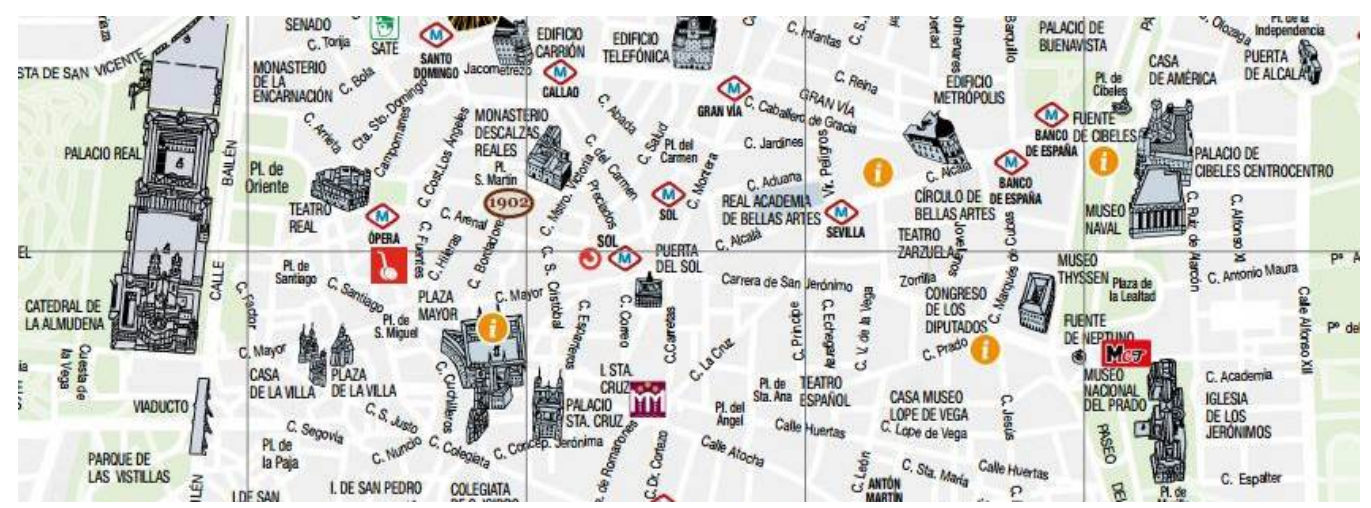

Figura A12: Mapa turístico del centro de la ciudad elaborado por el Ayuntamiento de Madrid.

En la oficina central de información turística del Ayuntamiento (situada en la Plaza Mayor) los turistas disponen de una aplicación interactiva que, a partir de un conjunto de datos que han de introducir (grupo de viaje, duración de la estancia, número de visitas previa, edad y presupuesto), les proporciona un listado de lugares recomendados. Este listado incluye coordenadas alfanuméricas, para facilitar su localización en el mapa genérico en papel del ayuntamiento (Figura A12)

- Mapas del CRTM: "Haciendo Turismo en Transporte público por el Centro de Madrid" (Figura A13), "Haciendo Turismo en Transporte Público por la Comunidad de Madrid" y el plano incorporado en el Abono Turístico de Transporte.

- Mapas suministrados por empresas como Metro de Madrid (Figura A14) o El Corte Inglés (Figura A15) y

- Mapas en papel incluidos en guías de viaje de la ciudad. 


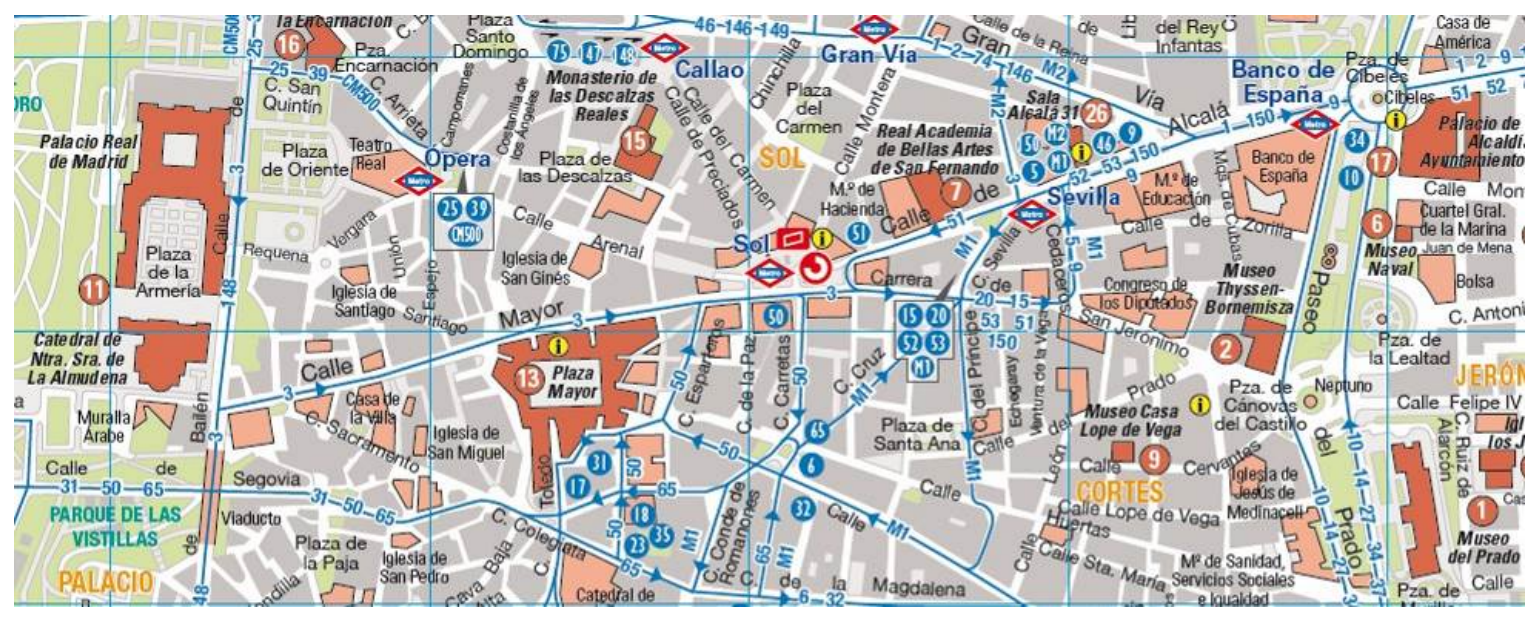

Figura A13: Mapa turístico del centro de la ciudad del Consorcio de Transportes de Madrid.

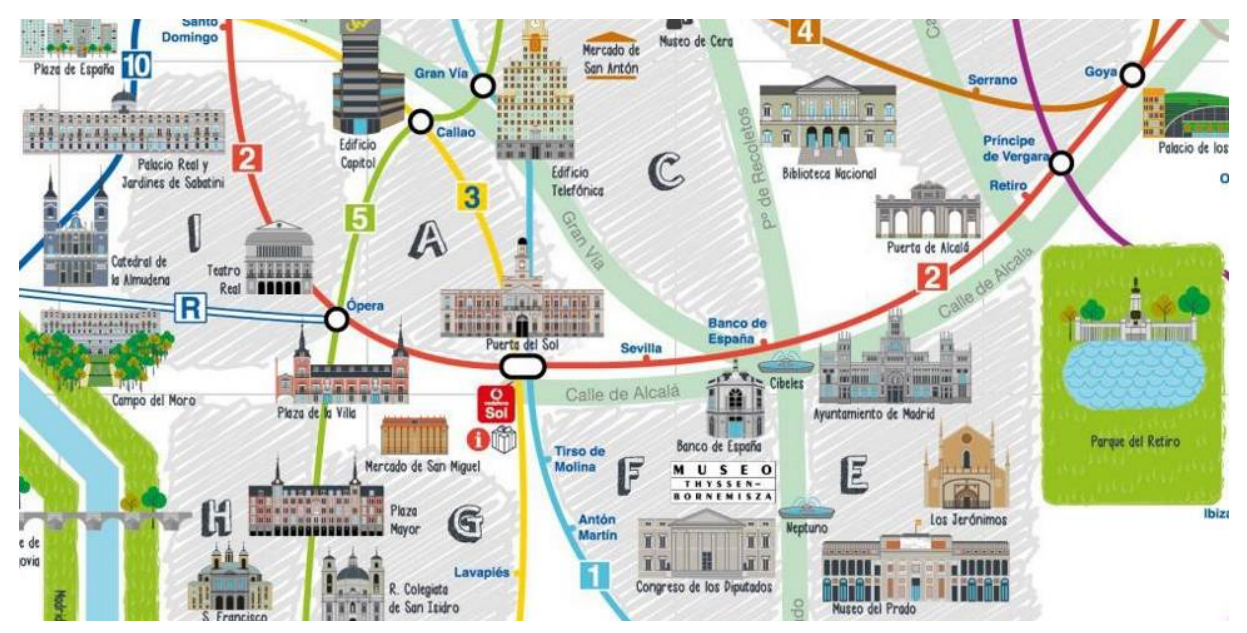

Figura A14: Mapa turístico de metro de Madrid.

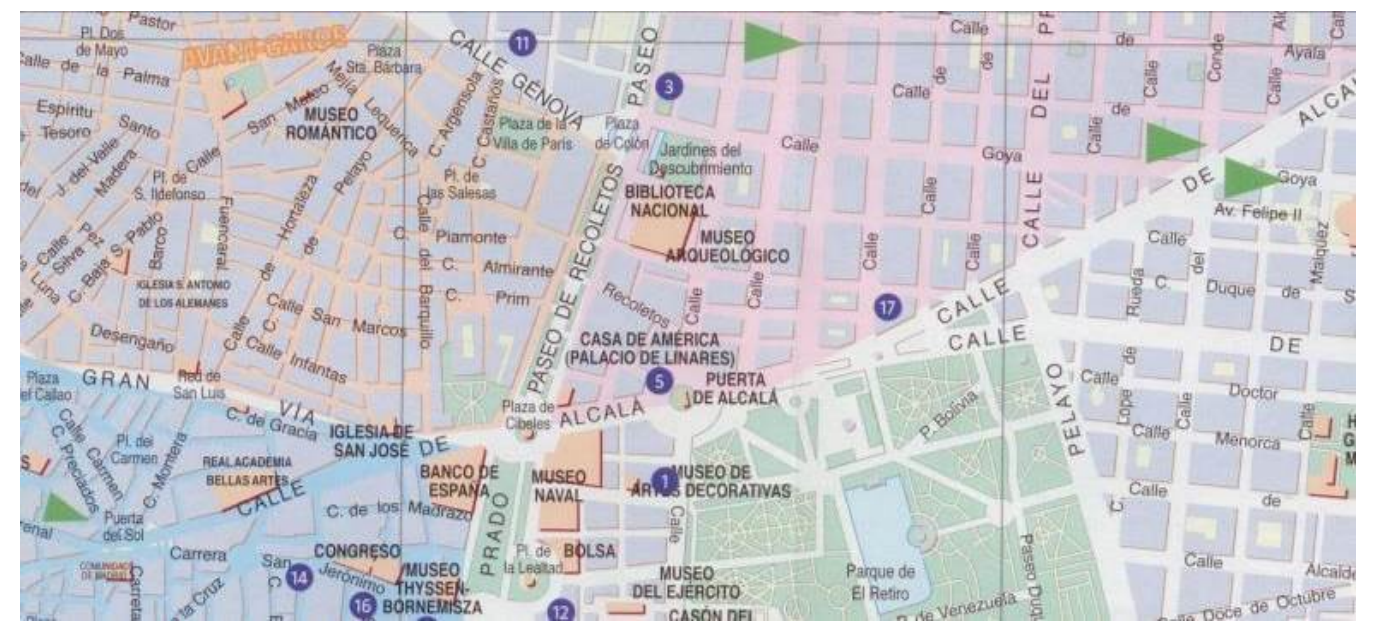

Figura A15: Mapa turístico de Madrid de la empresa El Corte Inglés.

La solicitud más frecuente de los turistas, en los Servicios de Atención e Información Turística del Ayuntamiento de Madrid es la de planos e información sobre la ubicación de atractivos (Tabla A1). 


\begin{tabular}{|c|c|}
\hline \multicolumn{2}{|c|}{ Enero-Diciembre 2013} \\
\hline Tipo de pregunta formulada & \% sobre el total de preguntas \\
\hline Petición plano y orientación & $32,88 \%$ \\
\hline Cultura (Museos) & $13,71 \%$ \\
\hline Transporte & $8,93 \%$ \\
\hline Preguntas entorno puesto & $9,11 \%$ \\
\hline Ocio & $7,36 \%$ \\
\hline Esmadrid magazine & $7.57 \%$ \\
\hline M. City Tour (Autobus Turístico) & $4,67 \%$ \\
\hline Alrededores & $2,99 \%$ \\
\hline Visitas Guiadas & $2,95 \%$ \\
\hline Madrid Card (Tarjeta turística) & $3,05 \%$ \\
\hline Restaurantes & $1,25 \%$ \\
\hline Tiendas & $0,99 \%$ \\
\hline SATE Denuncia & $0,59 \%$ \\
\hline Deportes & $0,33 \%$ \\
\hline Toros & $0,25 \%$ \\
\hline Alojamiento & $0,23 \%$ \\
\hline SATE Información & $0,13 \%$ \\
\hline Consulta correo electrónico & $0,09 \%$ \\
\hline Spain Rail Pass & $0,00 \%$ \\
\hline Otros & $2,92 \%$ \\
\hline
\end{tabular}

Tabla A1: Tipos de preguntas formuladas a los Servicios de Atención e Información Turística del Ayuntamiento de Madrid. Fuente: Empresa Municipal Madrid Destino.

- Páginas Web cartográficas: Existen numerosos sitios web con información turístico-geográfica de Madrid. Destacan: (1) la web turística del Ayuntamiento de Madrid (www.esmadrid.com, )que ofrece en formato pdf los mapas oficiales en papel disponibles en sus oficinas turísticas. (2) La web asociada a la tarjeta turística "Madrid card" (http://geoportal.madridcard.com/), cuyo geoportal permite consultar lugares de interés, realizar visitas virtuales y compartir rutas con otras personas sobre cartografía de referencia de Google Maps (Figura A16). (3) La web turística de la CM (www.madrid.org) en la que el turista puede consultar información turística y meteorológica, también sobre la base cartográfica de Google Maps (Figura A17). (4) Y otras web ajenas a organismos públicos como la "Madrid city tour" con información del bus turístico de la ciudad, que incluye varios mapas en formato pdf con sus rutas (https://www.madridcitytour.es/), "Tripadvisor" (www.tripadvisor.es) (Figura A18) y el propio Google Maps (https://www.google.es/maps/).

- Aplicaciones móviles (Apps) con información turístico-geográfica de Madrid: También hay numerosas aplicaciones móviles como: (1) la "Guía Oficial de Madrid" de la empresa municipal Madrid Destino Cultura, Turismo y Negocio, con entre 50.000 - 100.000 descargas en google play (Figura A.19). (2) "Madrid card" asociada a la tarjeta turística oficial, con entre 500 - 1.000 descargas (Figura 4.20). (3) "Metro de Madrid oficial" con entre 500.000 - 1.000 .000 descargas (Figura A21). (4) Y la guía turística "Madrid city guide" de TripAdvisor con entre 500.000 - 1.000 .000 de descargas (Figura A22). 


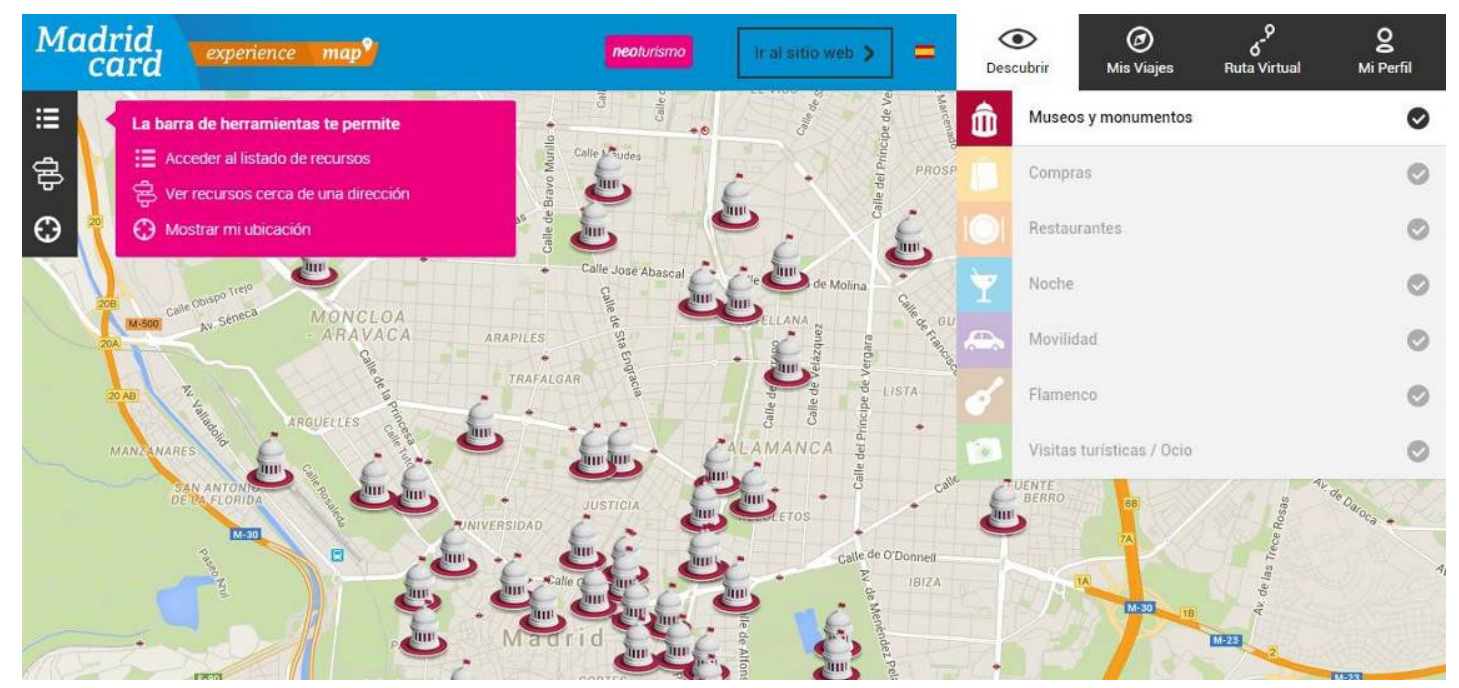

Figura A16: Geoportal de “Madrid card” http://geoportal.madridcard.com/.

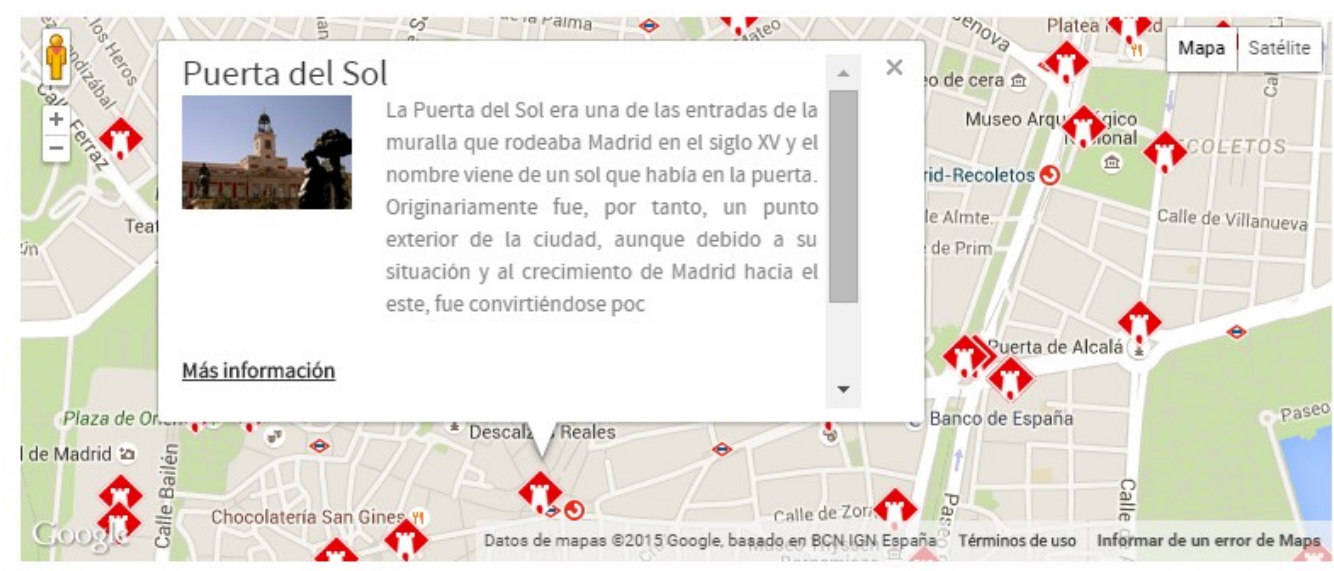

Figura A17: Aplicación cartográfica de la web turística de la Comunidad de Madrid http://turismomadrid.es/es/organizate/mapas.html

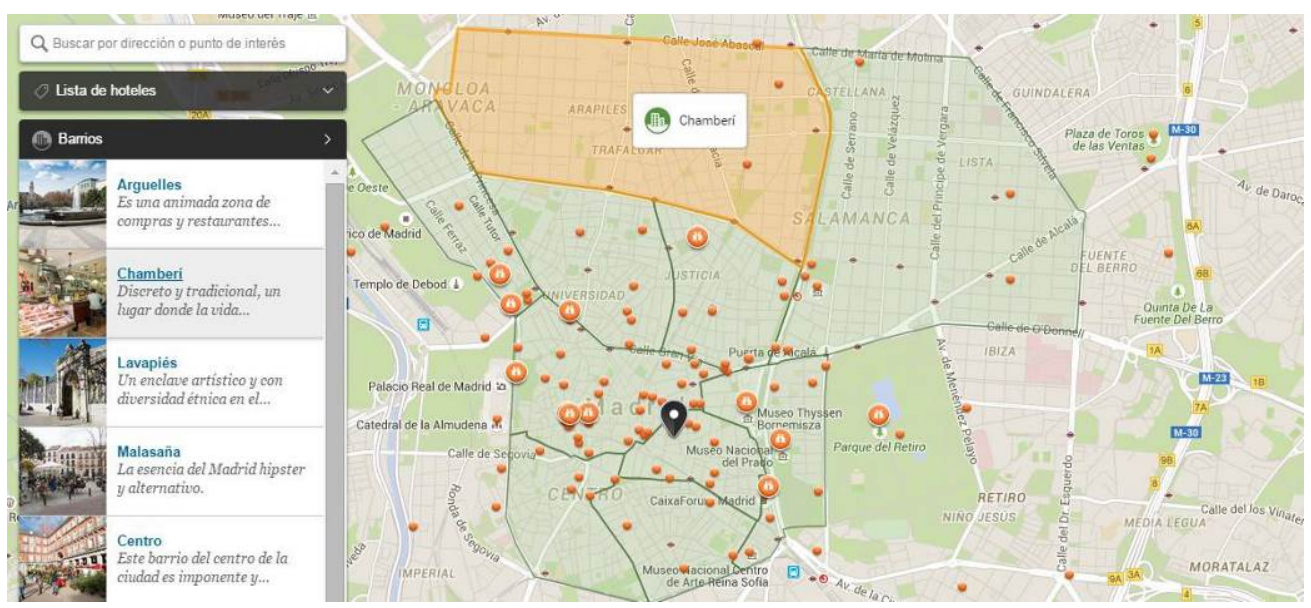

Figura A18: Visualizador cartográfico de la web turística de TripAdvisor-Madrid http://www.tripadvisor.es/Tourism-g187514-Madrid-Vacations.html\#MAPVIEW 


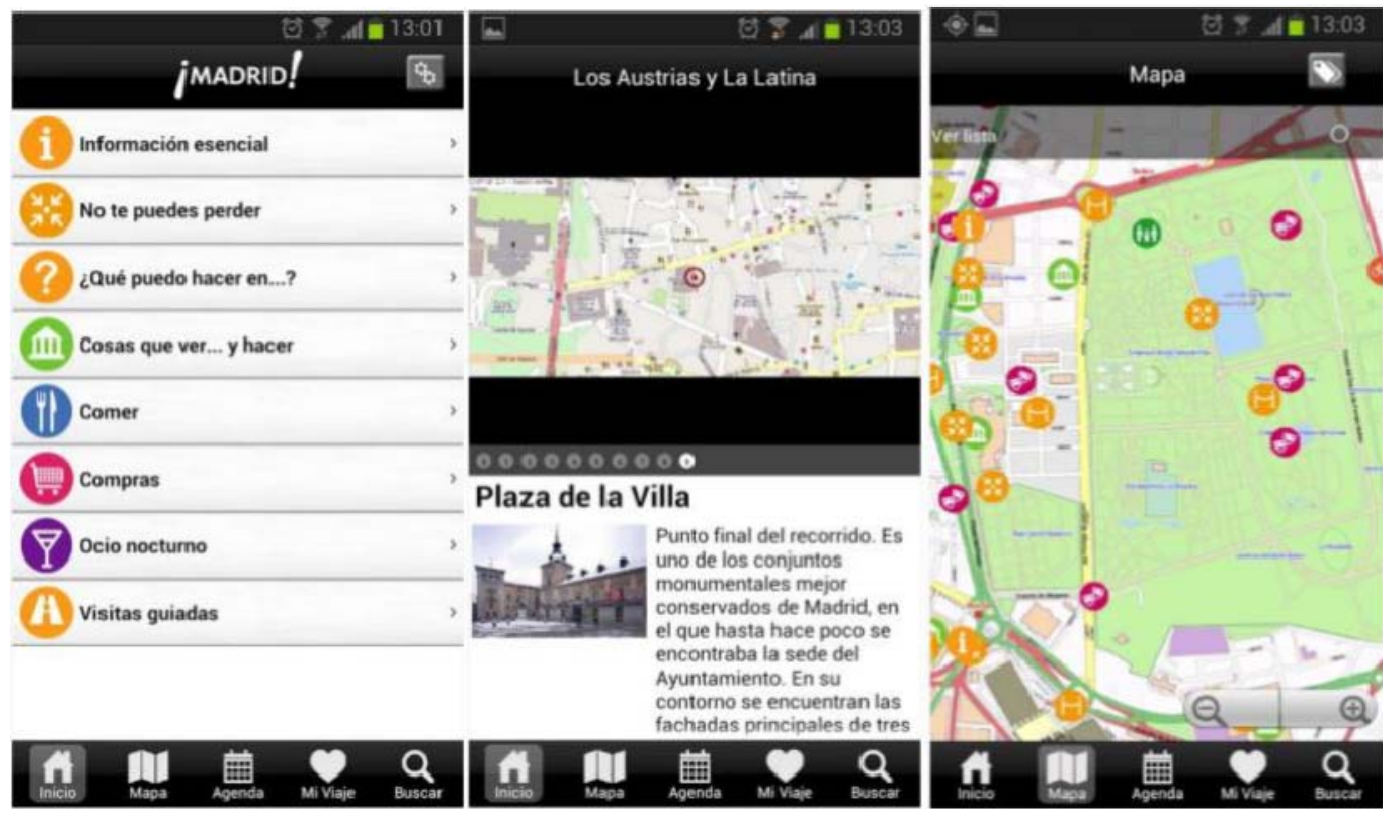

Figura A19: App "Guía Oficial de Madrid”, de la empresa municipal Madrid Destino Cultura, Turismo y Negocio.
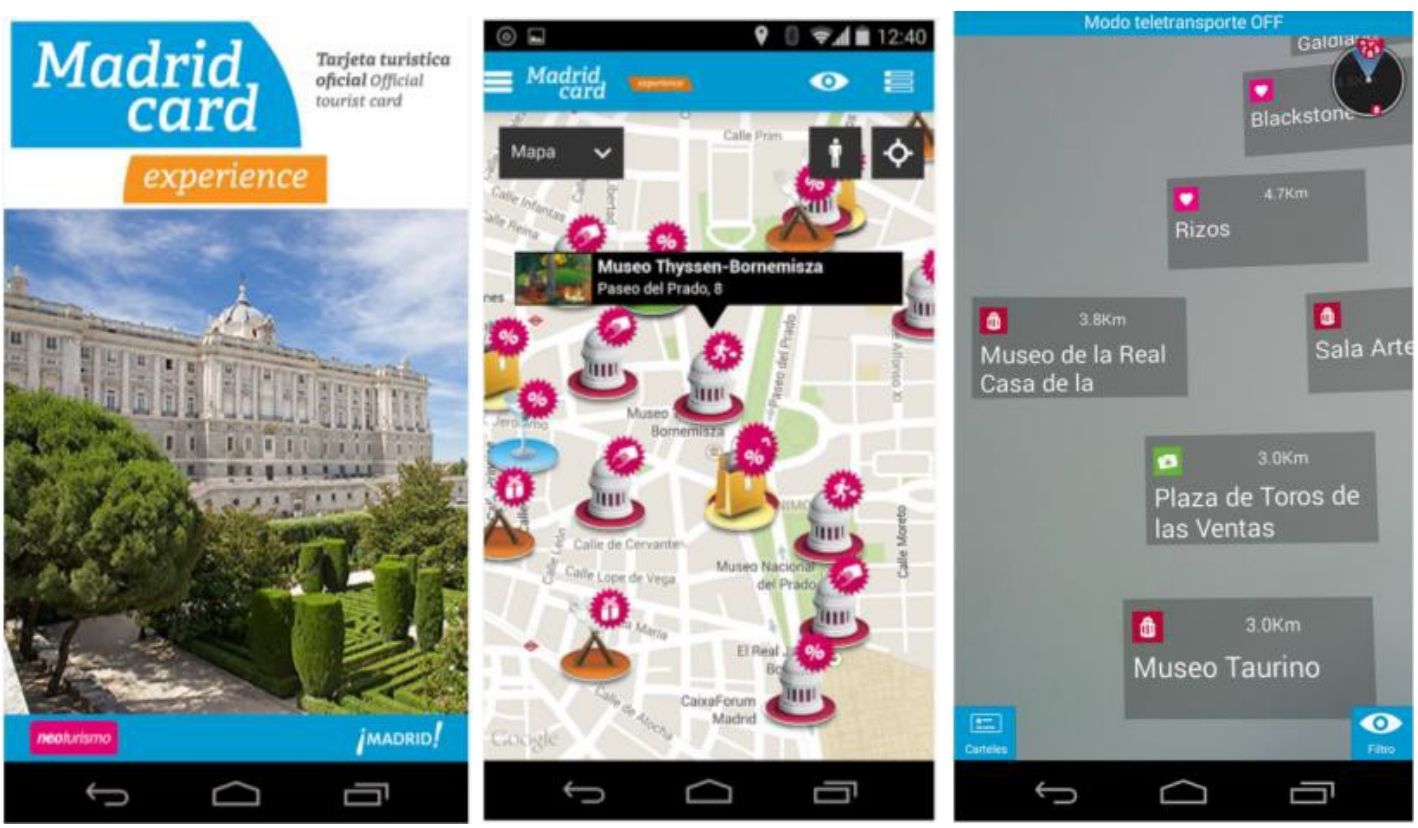

Figura A20: App “Madrid card” asociada a la tarjeta turística oficial del Ayuntamiento de Madrid. 

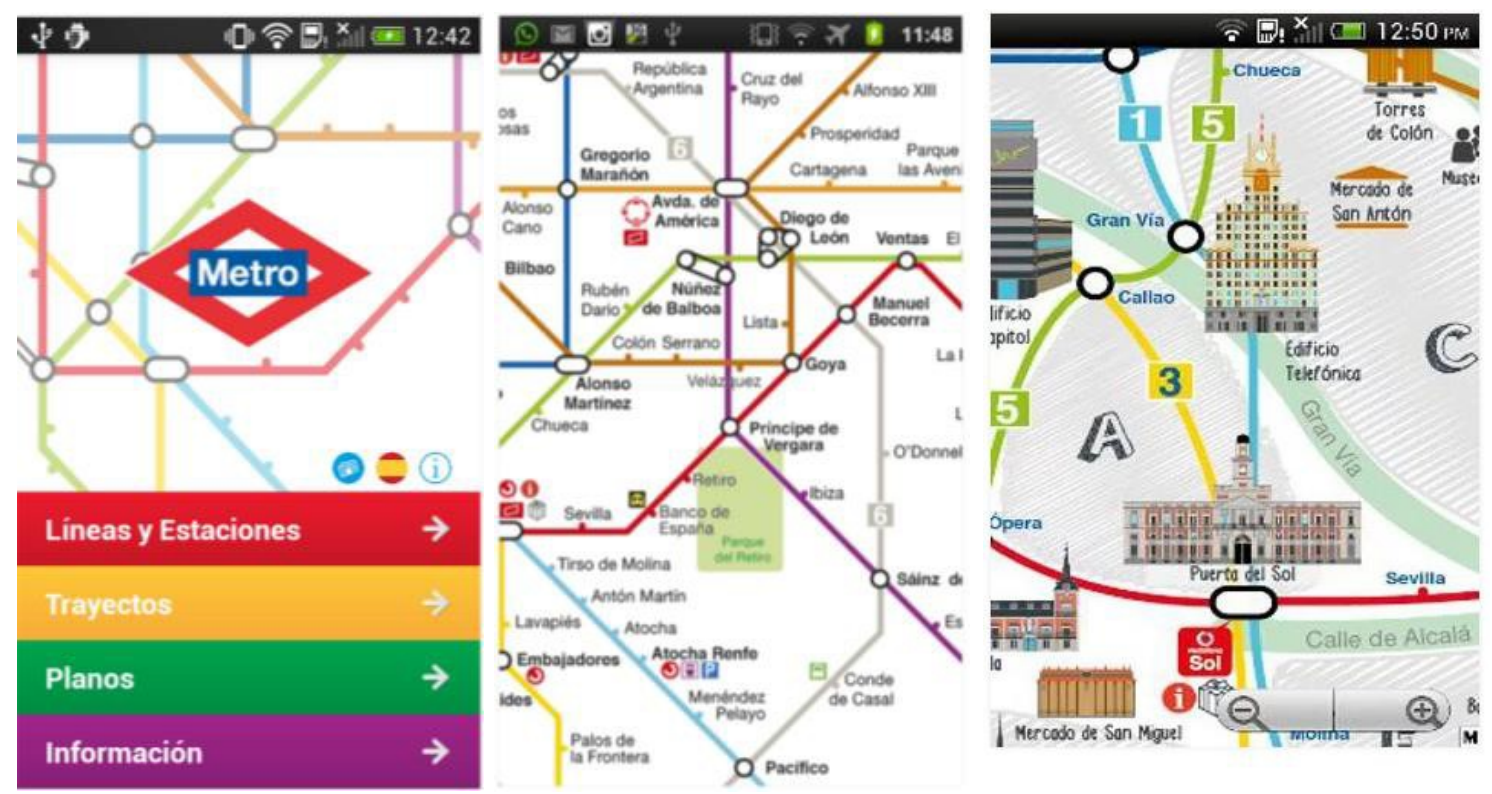

Figura A21: App "Metro de Madrid Oficial": Pantalla principal, Mapa de metro y Mapa turístico.

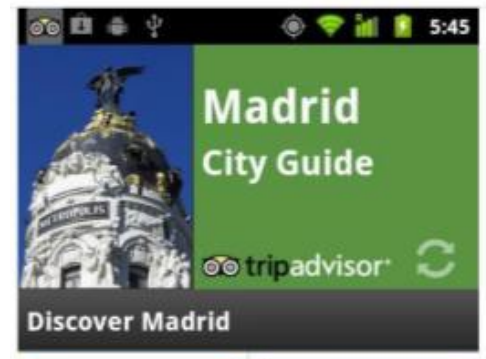

Tickets/ Tours City Map

(11) Restaurants

Hotels

(15) Attractions

(9) Suggested Itineraries

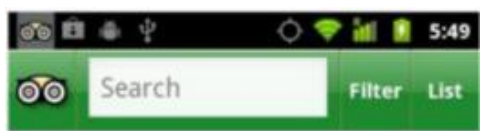

\section{Hh Prado Museum}

(0) O000 1952 reviews

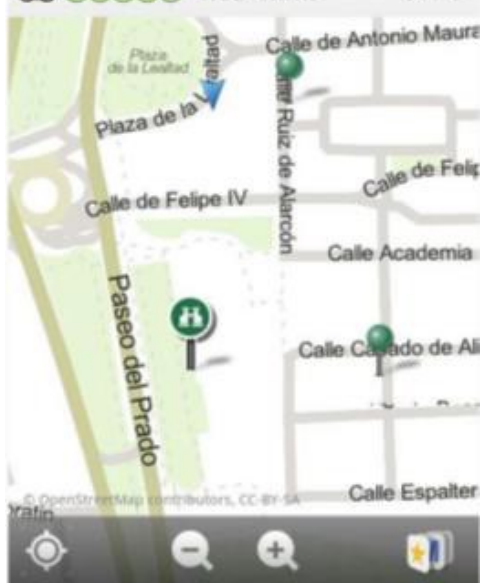

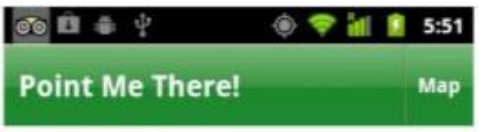

\section{in Prado Museum}

बr 000001952 reviews $844 \mathrm{ft}$

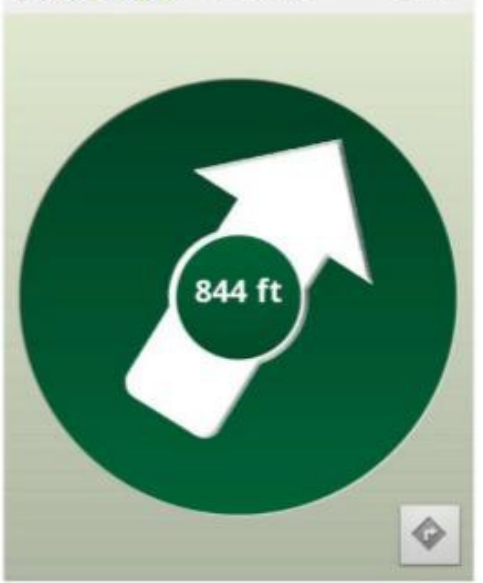

Figura A22: App “Madrid city guide” de TripAdvisor. 


\section{Anexo 4. Zonas turísticas de Madrid según la relevancia y la tipología de los atractivos turísticos.}

La Figura A23 define las zonas turísticas de Madrid, según la relevancia y la tipología de sus atractivos turísticos

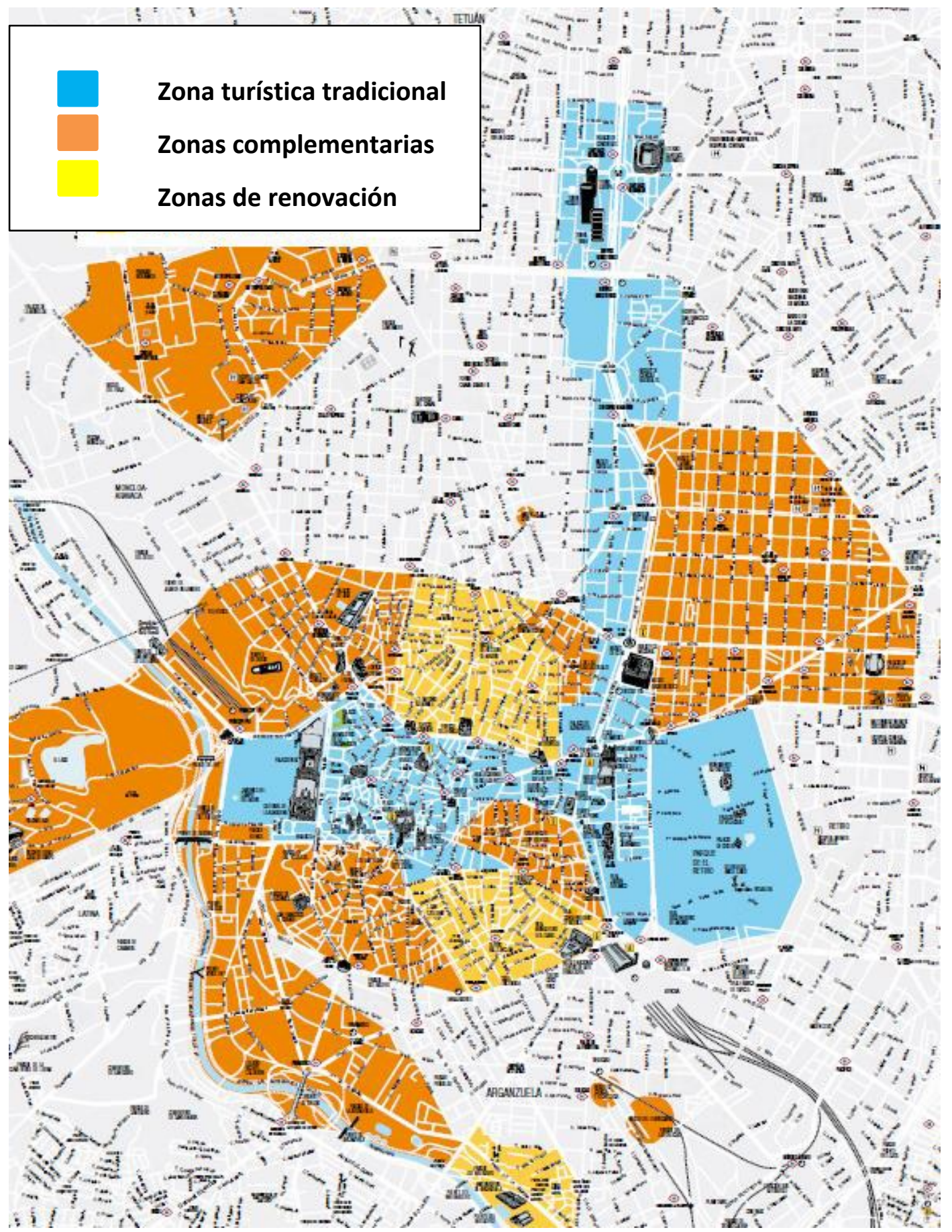

Figura A23: Zonas turísticas de Madrid según la relevancia y la tipología de los atractivos turísticos: Tradicional (azul), Complementarios (naranja) y de Renovación (amarillo). Fuente: Madrid Visitors \& Convention Bureau (2012). 


\section{Anexo 5. Ventas de billetes turísticos de transporte.}

La venta de billetes turísticos de transporte en 2013 fue de 469.667, un 18 $\%$ menor que 2012. En parte, en coherencia con el decremento del número de turistas internacionales ese año (que fue un $6 \%$ menor). En cuanto a la distribución de la venta del billete turístico por zonas y número de días, destaca que un $97 \%$ de los billetes turísticos vendidos fueron de la Zona A (Figura A24) y que en ambas modalidades los billetes de un día fueron los más vendidos (Figura A25).

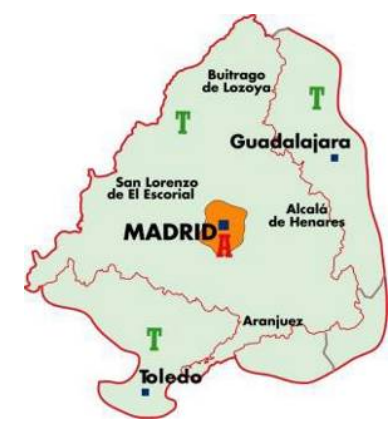

Figura A24: Zonas de los billetes turísticos de transporte del CRTM.

\section{Distribución de la venta de Billete Turistico por zonas}
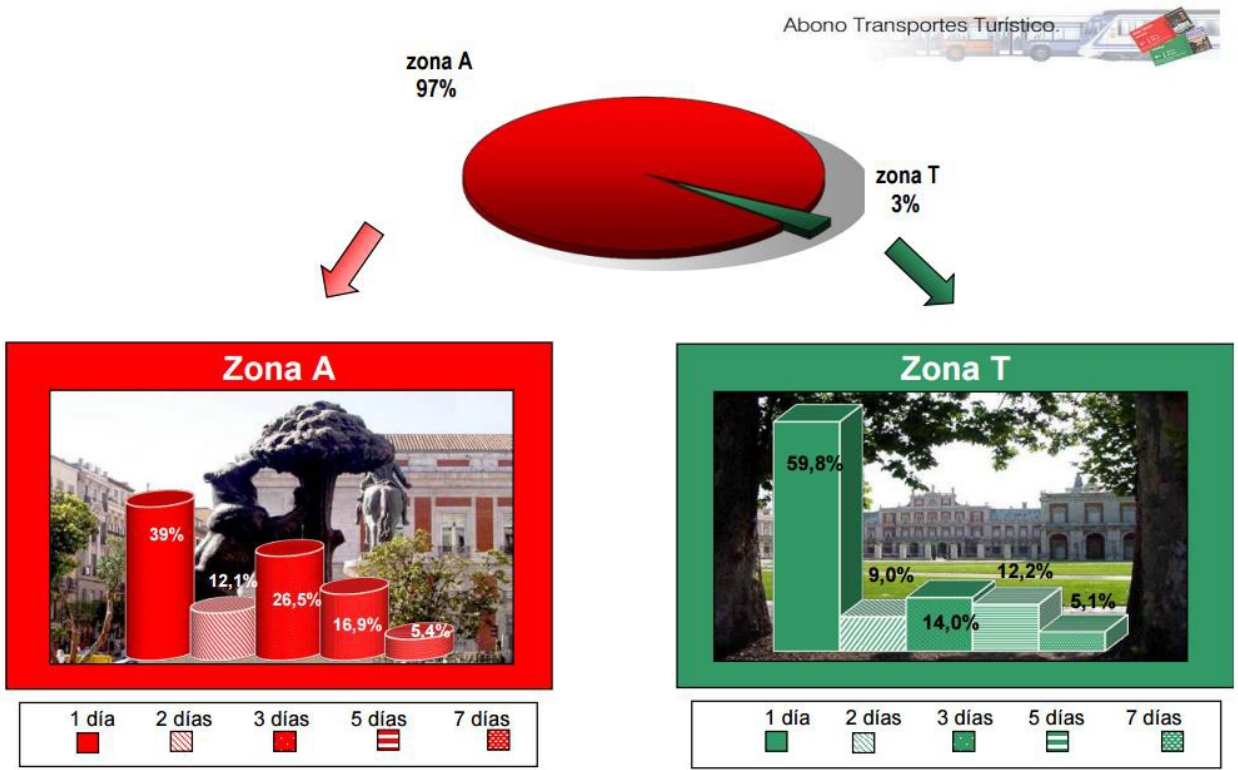

Figura A25: Ventas de los billetes turísticos de transporte del CRTM durante el 2013. 


\section{Anexo 6. Infraestructura hotelera y localización del alojamiento de los turistas internacionales de Madrid.}

Madrid cuenta con una competitiva oferta hotelera y el $75,4 \%$ de turistas llegados durante el 2012 eligieron este tipo de alojamiento (Instituto de Turismo de España, 2013). La Figura A26 ilustra el porcentaje de pernoctaciones de turistas extranjeros en los diferentes distritos de Madrid, durante el mes de octubre de 2012. Se puede apreciar que más del $40 \%$ de los turistas internacionales se alojaron en el distrito Centro, mientras que el porcentaje en el resto de distritos fue significativamente inferior.

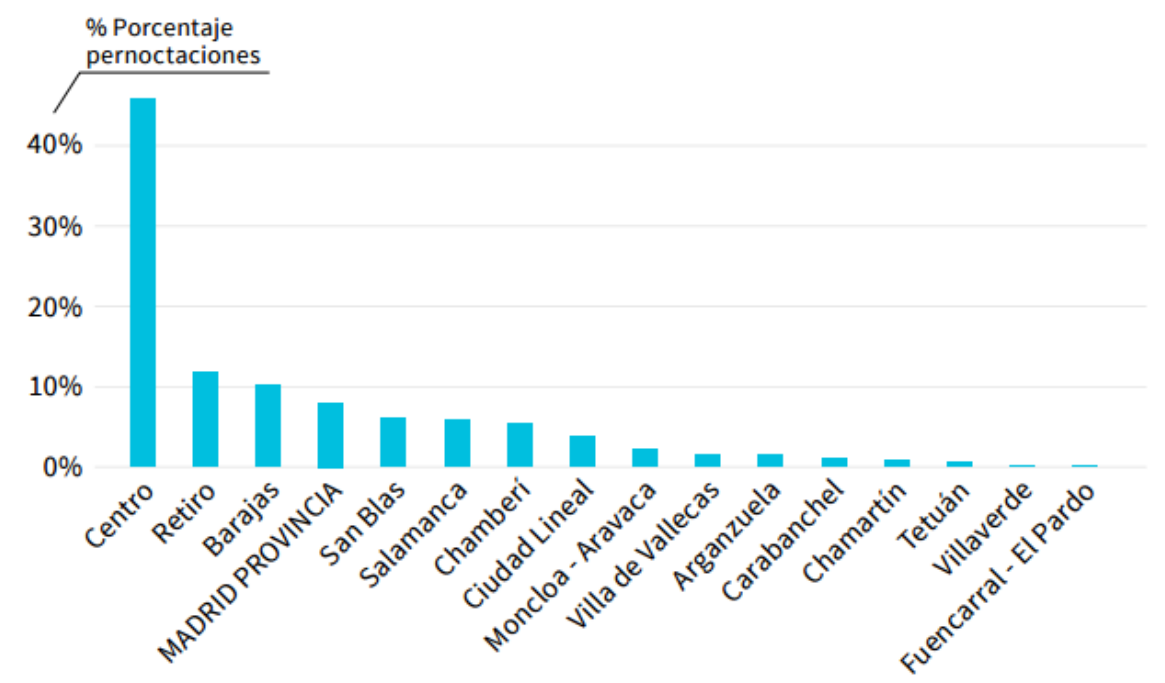

Figura A26: Porcentaje de pernoctaciones en los distritos de Madrid de turistas internacionales, en base a pagos con tarjetas extranjeras, durante Octubre del 2012. Fuente: RocaSalvatella \& Telefónica ( 2014)

Merece la pena destacar el notable crecimiento del alojamiento turístico en vivienda particular, compartida o alquilada, gestionada a través de sitios web y de aplicaciones móviles como airbnb o couchsurfing. En 2012 el número de turistas que utilizaron estos alojamientos fue un 29 \% superior al 2011 (Instituto de Turismo de España, 2013). 


\section{Anexo 7. Guion de las entrevistas realizadas en la Fase 2 Tarea 2.1: Indagar sobre los grupos de interés asociados a la experiencia turística de Madrid.}

A continuación se incluye el guion que se elaboró para entrevistar al personal gestor de Turismo del Ayuntamiento de Madrid, y que se utilizó como referencia para el resto de las entrevistas realizadas:

La investigación que estamos llevando a cabo tiene como objetivo desarrollar mapas orientados a facilitar el descubriendo de la oferta turística de Madrid y los desplazamientos en la ciudad. Esta entrevista se realiza con el propósito de conocer el punto de vista del Ayuntamiento de Madrid en relación a varios aspectos clave de la gestión turística y, más concretamente, de los productos turístico-cartográficos de la ciudad.

Las preguntas planteadas tienen un enfoque constructivo y una doble finalidad:

- fundamentar la investigación, considerando la visión del principal organismo gestor del turismo.

- realizar el trabajo de forma que los resultados puedan tener una utilidad práctica.

Los turistas que desean visitar Madrid tienen a su disposición varios productos turístico-cartográficos (mapa turístico del Consorcio de Transportes, mapa de rutas del bus turístico, mapa turístico del centro de Madrid, mapa turístico para desplazamientos en bus y el mapa turístico de metro, entre otros).

(1) ¿Existe algún tipo de coordinación entre las distintas entidades para el desarrollo de estos productos?

(2) ¿Cuál es el papel del Ayuntamiento de Madrid en la gestión de la información turística suministrada de la ciudad y de los lugares de interés turístico de los alrededores (Comunidad de Madrid, Toledo, Segovia... a través de mapas?

(3) A la hora de suministrar información ¿Existe alguna segmentación de usuarios?

En caso afirmativo: ¿Podría describir los criterios considerados?

(4) ¿Qué productos cartográficos orientados a turistas suministra actualmente el Ayuntamiento de Madrid en soporte papel, web y móvil?

(5) ¿Durante el desarrollo de estos productos se aplica alguna técnica en la que participen turistas (entrevistas, test de usuarios, cuestionarios de satisfacción...)?

(6) ¿Se ha identificado alguna necesidad o deficiencia en los productos turístico cartográficos?

El Plan Estratégico de Turismo de Madrid 2012-2015 expone el concepto "Destino gran Madrid" como el Madrid formado por todos aquellos lugares que el viajero visita durante su estancia en la ciudad incluyendo: Toledo, Segovia, Córdoba, Valencia... 
Por otro lado, el plan de acción turístico de la ciudad concreta tres grandes programas de actuación vinculados a espacios geográficos de la ciudad, perfectamente delimitados: Turismo imprescindible, complementario y de renovación.

(7) ¿Considera importante que los turistas conozcan que zonas son de interés turístico y cuáles no?

(8) ¿Existen estrategias turísticas orientadas a potenciar atractivos concretos?

En caso afirmativo: ¿podría indicar cuáles?

(9) ¿Existen colectivos de turistas de interés prioritario?

En caso afirmativo: ¿podría indicar cuáles?

(10) ¿Se ha puesto en marcha o está previsto el desarrollo de nuevos productos turístico-cartográficos o la mejora de alguno de los existentes?

(11) En caso afirmativo: ¿Puede darme algún detalle sobre el desarrollo de estos productos: soportes (papel, móvil, web...), escala, contenidos, colectivo objetivo...?

(11) En caso negativo: ¿Considera que sería interesante mejorar o desarrollar algún producto turístico-cartográfico?

El actual Plan Estratégico de Turismo indica que la oferta turística de la ciudad es en gran parte desconocida, incluso para los residentes.

(12) ¿Existe algún listado oficial de atractivos turísticos de Madrid?

En caso afirmativo: ¿Esta categorizado?, ¿Y jerarquizado?, ¿Podría tener acceso al mismo?

(13) ¿Tiene constancia de que exista algún estudio específico sobre el conocimiento de la oferta turística de Madrid por parte de los turistas?

En caso afirmativo: ¿Sería posible tener acceso a los datos del estudio?

Existen grandes núcleos urbanos en los que se han puesto en marcha iniciativas para potenciar que turistas y residentes se desplacen a pie. Este es el caso por ejemplo del proyecto "Legible London", en la ciudad de Londres (http://www.tfl.gov.uk/microsites/legible-london/).

(14) ¿Existe por parte del Ayuntamiento un interés específico en potenciar el desplazamiento de los turistas a pie o el uso de unos medios de transporte frente a otros (bicicleta, metro, bus...)?

(15) ¿Conoce estudios que analicen la forma de desplazarse de los turistas por Madrid?

En caso negativo: ¿Los consideraría de interés?

A través del proyecto "Legible London", Londres dispone actualmente de mapas de diseño homogéneo que incluyen información turística destacada de acceso colectivo a través de señalética en las calles, e individual en versión impresa, web y para móviles.

(16) ¿Está previsto el desarrollo de un diseño de comunicación turísticocartográfica común al mayor número de productos posible que favorezca la transmisión coherente de información turística de Madrid?

En el Plan Estratégico se insta a identificar nuevas tecnologías y a fomentar 
su uso como aliadas para mejorar la competitividad de la ciudad e interactuar con el turista final.

(17) ¿Existe algún estudio de las preferencias por parte de los turistas de unos soportes de información frente a otros (papel, web, apps)?

En la oficina de turismo de la Plaza Mayor, existe una aplicación táctil que permite a los usuarios obtener una propuesta de atractivos turísticos a visitar en forma de listado de texto, adaptada a su perfil (1. Número de personas con las que viaja, 2. Duración de la estancia, 3. Número de veces que ha estado previamente, 4. Edad y 5. Presupuesto).

(18) ¿Qué opina sobre la posibilidad de poder ofrecer a los turistas mapas personalizados, en base a un conjunto de parámetros, siguiendo un enfoque similar al utilizado por esta aplicación?

(19) ¿Qué opina sobre la posible influencia de productos turísticocartográficos en la percepción de Madrid como destino turístico?

Existen estudios que reflejan un déficit en el manejo de idiomas en Madrid, lo que se percibe como una debilidad de la oferta turística:

(20) ¿Considera que los productos turístico-cartográficos pueden contribuir a solventar la dificultad que encuentran los turistas en relación al idioma?

Por mi parte la entrevista ha llegado a su fin:

¿Tiene alguna pregunta que hacerme?,

¿Le resultaría de interés estar al corriente de los progresos de la investigación?. 


\section{Anexo 8. Cuestionario utilizado para encuestar al personal del CRTM}

\section{Investigación UPM sobre mapas de turismo y transporte de Madrid}

El propósito de esta investigación es el desarrollo de mapas, orientados a facilitar el descubrimiento de la oferta turística de Madrid y los desplazamientos en la ciudad.

Este cuestionario tiene como objetivo conocer el punto de vista del Consorcio Regional de Transportes de Madrid respecto a los productos turísticocartográficos de la ciudad, que integran información de transporte público. Las preguntas tienen un enfoque puramente constructivo y una doble finalidad: por un lado, fundamentar la investigación teniendo en cuenta la visión del principal organismo coordinador de las infraestructuras de transporte de la ciudad, y por otro, afrontar el trabajo a realizar de forma que los resultados puedan tener una utilidad práctica.

Antes de comenzar, agradezco su colaboración.

\section{Cuestionario}

Los turistas que desean visitar Madrid tienen a su disposición varios productos turístico-cartográficos oficiales, que incluyen información del transporte público: el mapa turístico del CRTM Serie 2a, el mapa turístico del centro de Madrid del Ayuntamiento, el plano turístico de los autobuses de la EMT (Empresa Municipal de Transportes) y el reciente mapa turístico de Metro de Madrid, entre otros.

Pregunta 1: ¿Existe algún tipo de coordinación entre las distintas entidades para el desarrollo de estos productos?.

En caso afirmativo, ¿podría describir las ventajas y limitaciones de la coordinación?

Pregunta 2: ¿Qué papel desempeña el CRTM en relación al desarrollo de productos cartográficos de Madrid?

Pregunta 3: ¿Cuáles cree que son los productos más apropiados para los turistas?

(a) mapas en papel para uso individual,

(b) mapas en papel para su visualización en instalaciones de transporte,

(c) cartografía integrada en páginas web o

(d) cartografía integrada en aplicaciones móviles,...

Pregunta 4: ¿Qué información vinculada al transporte de la ciudad considera importante transmitir al turista?

Pregunta 5: ¿Consulta el CRTM a usuarios del transporte público para el diseño de sus productos?, ¿Analiza los niveles de satisfacción de los productos una vez lanzados? 
Según datos del Instituto de Estudios Turísticos, la ciudad de Madrid es el principal atractivo turístico urbano de España con un record anual de 8.3 millones de turistas en el 2011. Desde el 2004 los turistas disponen de un billete especial, acorde a sus necesidades de transporte público en la ciudad.

Pregunta 6: ¿Se realizó algún tipo de estudio previo a la puesta en marcha de este producto?.

En caso afirmativo, ¿podría describirlo en términos de objetivos y principales resultados?

Pregunta 7: ¿Existe algún análisis sobre la venta del billete turístico en sus distintas modalidades (días y extensión geográfica)?

En caso afirmativo, ¿Sería posible tener acceso a él?

Pregunta 8: El billete turístico viene acompañado de un mapa en papel, que asiste al turista en sus desplazamientos por la ciudad.

¿En base a qué criterios se estableció el contenido de este mapa?.

¿Existe algún aspecto del mismo que considere especialmente conveniente mejorar?

En cuanto a la movilidad, recientemente en grandes núcleos urbanos se han puesto en marcha iniciativas para potenciar que turistas y residentes se desplacen a pie, como el proyecto "Legible London" (http://www.tfl.gov.uk/microsites/legiblelondon/) en la ciudad de Londres.

Pregunta 9: ¿Existe algún tipo de estrategia de movilidad orientada a fomentar el uso de un determinado medio de transporte público o los desplazamientos a pie en Madrid?

En caso afirmativo, ¿podría describirla brevemente?

Muchas gracias por su colaboración y quedo a su disposición para cualquier tipo de sugerencia, recomendación o comentario que considere oportuno realizarme. 


\section{Anexo 9. Iniciativas para el desarrollo y suministro de productos turístico-cartográficos de Madrid}

\section{- Turismo del Ayuntamiento de Madrid}

En relación al suministro de productos turístico-cartográficos oficiales, el Ayuntamiento de Madrid es la entidad que menos relación tiene con el resto de organismos públicos. El sitio web turístico oficial del Ayuntamiento (www.madrid.es), no da acceso a los mapas elaborados por el resto de organismos públicos contactados y en sus oficinas de información turística no se suministran mapas turísticos de la CM, ni mapas de metro de la ciudad, aunque si el mapa turístico de transportes del Centro de la ciudad elaborado por el CRTM; además de una amplia gama de folletos y mapas generados por iniciativas privadas (Museo Thyssen Bornemisza, Tous,...).

En cuanto al desarrollo de los productos turístico-cartográficos del Ayuntamiento, los de soporte papel se realizan con recursos internos del Área de Urbanismo y Vivienda, mientras que los que se suministran vía web y móvil, se desarrollan a través de colaboraciones con entidades privadas y se basan en cartografía de Google. Merece la pena destacar la profusión de publicidad en todos los productos del Ayuntamiento, llegando incluso a incluirse en las representaciones espaciales, junto con el resto del contenido de interés turístico. También llamó la atención la falta de productos cartográficos que apoyen las pautas territoriales del Plan Estratégico de Turismo del Ayuntamiento de Madrid 2012-2015 de cara por ejemplo, a la promoción turística de nuevas zonas de la ciudad y a la transmisión de la inclusión de atractivos de interés turístico situados en localidades próximas a Madrid como parte del destino turístico, más allá de sus límites administrativos.

Por otro lado, el Centro de Inteligencia Turística del Ayuntamiento de Madrid trabaja con fuentes de información que permiten analizar los comportamientos de visitantes. Un ejemplo es el estudio que han realizado en colaboración con el banco BBVA, en base a la traza que dejan los pagos que realizan los visitantes con sus tarjetas de crédito y débito en los comercios de la ciudad. Este tipo de datos permite calcular por ejemplo, la duración de la estancia en función de la primera y la última compra, las zonas donde los turistas realizan mayor gasto (Figura A27) y el ritmo de consumo según nacionalidades (Figura A28). Sin embargo, la información obtenida a través de este tipo de estudios no se utiliza para mejorar el suministro de información a los turistas. 


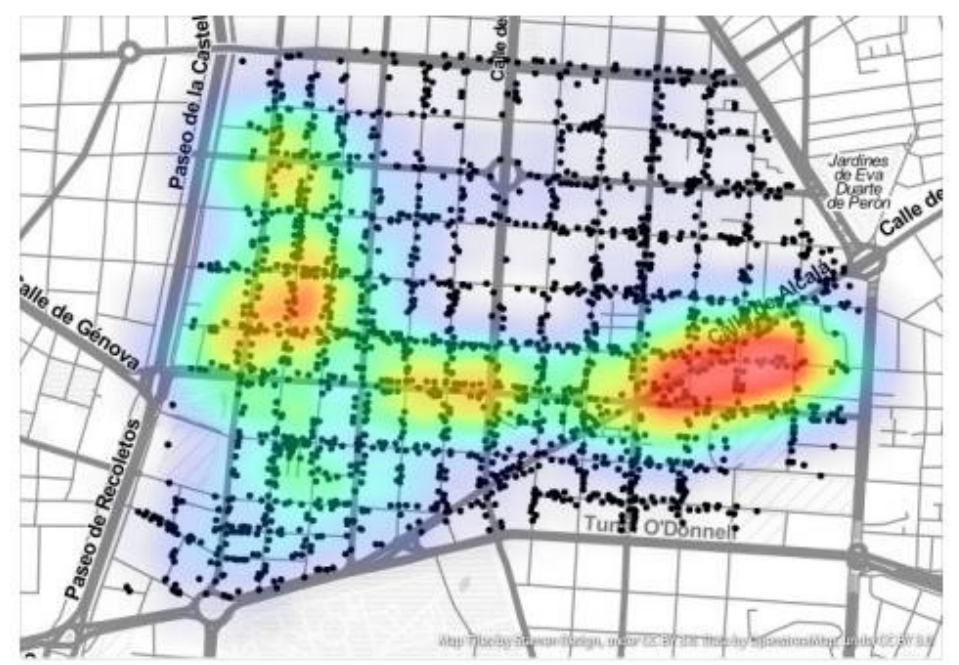

Figura A27: Mapa de calor de las 297.444 transacciones realizadas por visitantes españoles de fuera de Madrid durante 2012 y que han sumado compras en el barrio de Salamanca por valor de 24.914.120€. Fuente: BBVA y Ayuntamiento de Madrid (2013).

RITMO DE COMPRA - No DE HORAS ENTRE COMPRAS EN ALGUNA DE LAS 8 ZONAS 40 NACIONALIDADES CON MÁS TARJETAS EN 2011 Y 2012

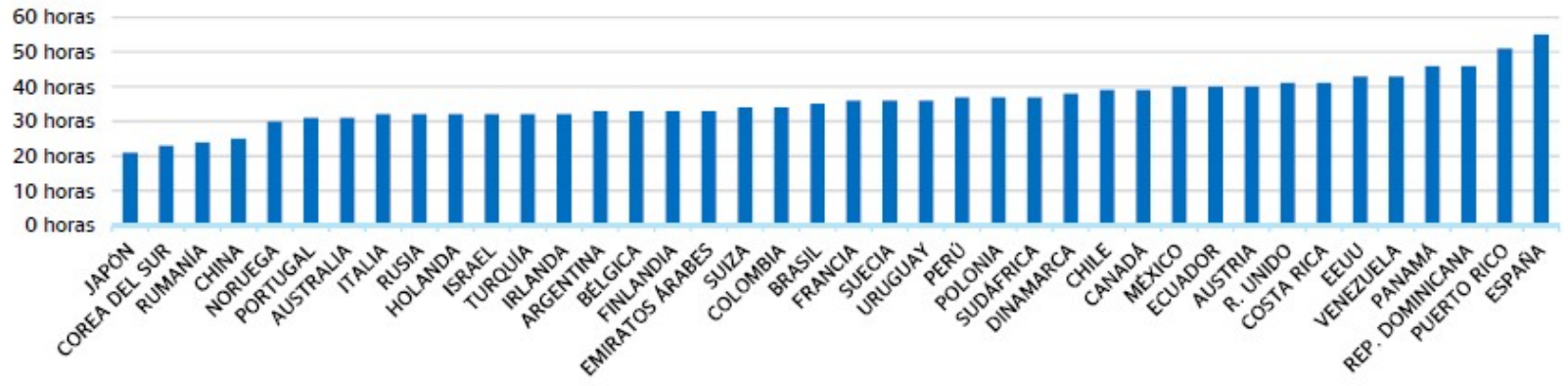

Figura A28: Ritmo de compra de turistas internacionales. Número de horas entre compras en las 8 zonas más comerciales y turísticas de Madrid según nacionalidad. Fuente: BBVA y Ayuntamiento de Madrid (2013).

\section{- Turismo de la Comunidad de Madrid}

En cuanto a la CM, no existe ningún tipo de coordinación entre los servicios y los productos suministrados a través de sus oficinas de turismo y los que se proporcionan en las oficinas homólogas del Ayuntamiento. La página web de turismo de la CM no suministra acceso a mapas elaborados por el resto de los organismos públicos contactados, pero si a una aplicación cartográfica interactiva basada en la cartografía de Google. Sin embargo, sí que existe colaboración entre la CM y el CRTM ya que por ejemplo, la Comunidad suministra listados de elementos de interés a incluir en los mapas turísticos de transporte y distribuye mapas del CRTM en sus oficinas turísticas; mientras que el CRTM ha colaborado puntualmente con Turismo de la $\mathrm{CM}$ en el desarrollo de productos cartográficos en formato papel y pdf. Por otro lado, la situación económica también ha afectado al suministro de productos cartográficos por parte de la CM que, entre el 2011 y mediados del 2014 no lanzó ninguna tirada de mapas en soporte papel. De manera que, los mapas 
suministrados a los turistas en sus oficinas durante este período fueron los elaborados por el CRTM y por empresas privadas. Finalmente, merece la pena señalar que en el momento en el que se recabó esta información y en el contexto del Plan de Acción Turística de la Comunidad 2013-2016 se estaba desarrollando una aplicación móvil con contenido cartográfico.

\section{- Consorcio Regional de Transportes de Madrid}

Este organismo no participa en estrategias conjuntas para el desarrollo de sus productos cartográficos, ni con el Ayuntamiento de Madrid ni con la CM, aunque sí que ha llegado a acuerdos con ellas para la distribución de sus mapas turístico-cartográficos en soporte papel. Estos mapas se elaboran con recursos propios y el personal que trabaja en las oficinas turísticas de ambos organismos públicos los valora muy positivamente. Sin embargo, sus tiradas y actualizaciones se han reducido drásticamente en los últimos años, debido a la crisis. En cuanto a las aplicaciones móviles, en el momento en el que se contactó con el CRTM estaban desarrollando una aplicación en colaboración con una empresa privada para suministrar información multimodal de transporte de toda la $\mathrm{CM}$, utilizando cartografía de Google. Por otro lado, cabe destacar que el CRTM hace un especial hincapié en facilitar la información de las redes de transportes de la CM a distintos organismos públicos (Ayuntamiento de Madrid, CM, Empresa Municipal de Transportes de Madrid (EMT)..., y a grandes empresas privadas como Google.

Respecto a las relaciones entre las entidades públicas y privadas del sector, estas últimas son las que están llevando a cabo la mayoría de los desarrollos web y móvil de los productos oficiales. 
Anexo 10. Cuestionario utilizado para encuestar a los turistas al inicio de su primera visita a Madrid 


\section{Cuestionario para turistas al iniciar su visita}

Código:

1. ¿Cuál es el principal motivo de su visita a Madrid?: (Elija uno)

Vacaciones/Turismo/Ocio

Trabajo/Negocios (Ferias/congresos)

Estudios

2. ¿Cómo es su grupo de viaje?

$\square$ Viajo solo

En pareja

En familia
Visitar familiares/amigos

Escala a otros destinos

Otros:

Con compañeros de trabajo/estudios

En un grupo organizado

Otros:

3. Numere del 1 al 5 sus intereses relacionados con su visita a Madrid (siendo 1 el más importante y 5 el menos importante):

$\square$ Museos y Monumentos $\quad \square$ Compras

Espectáculos

Parques temáticos $($ Zoo,...) $\square$ Gastronomía

$\square$ Ocio nocturno
Eventos deportivos

Parques y jardines

Visitas familiares/amigos

Otros:

4. ¿Hasta qué punto ha planificado este viaje? (sitúese en la siguiente escala):

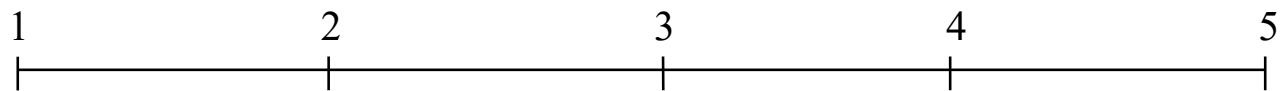

Nada;

Totalmente;

No he planificado con

He planificado con antelación nada de lo antelación todas las que voy a ver visitas que voy a hacer.

5. Indique la información que conozca de la ubicación de su alojamiento:

- Barrio/distrito:

- Calle:

- $\quad$ Parada/s de autobús más cercana/s:

- $\quad$ Estación/es de Metro más cercana/s

- $\quad$ Estación/es de tren Cercanías más cercana/s: 
6. ¿Antes de venir, ha consultado alguna fuente de información turísticogeográfica de Madrid? $\square$ Sí $\square$ No

En caso afirmativo,

¿Qué tipo? (marque tantas como haya consultado):

$\square$ Imágenes de satélite

$\square$ Callejero

$\square$ Mapa turístico

$\square$ Mapa de Metro

$\square$ Mapa de Cercanías

$\square$ Mapa de autobuses

$\square$ Fotos de lugares de interés

$\square$ Otras:

¿De qué fuente? (marque tantas como haya consultado):

$\square$ Folleto/guía en papel:

Sitios Web turísticos:

Aplicación móvil:

Foros/Blog:

Familiares/Amistades:

Otras:

¿Qué buscaba? (marque las opciones que correspondan):

$\square$ Ubicación de atractivos turísticos

Itinerarios turísticos

Recomendaciones personales

Ruta en transporte público

Servicios (restaurantes, tiendas...)

Otras: 
7. ¿Qué lugares tiene previsto visitar en la ciudad?

Atractivos turísticos:

Calle singular (por sus edificios, oferta de ocio, cultural...):

Barrio o zona (área cultural, histórica, de compras, ocio...):

8. Numere del 1 al 3 los medios de transporte que tiene previsto utilizar (siendo el 1 el de más uso y 3 el de menos uso):
A pie
Autobús turístico
$\square$ Moto
Bicicleta
Autobús público
$\square$ Otros:
Coche particular
Metro
Taxi
Tren de Cercanías

9. ¿Podría indicar cuál es el centro de Madrid?

10. ¿Conoce algún lugar de interés turístico en los alrededores de Madrid?

\begin{tabular}{l}
- \\
\hline- \\
\hline- \\
\hline
\end{tabular}




\begin{tabular}{l} 
11. Dibuje un mapa de \\
la ciudad de Madrid, \\
identificando los \\
siguientes elementos: \\
- Lugares de interés \\
- Calles singulares \\
- Zonas de interés \\
$\rightarrow \mathbf{N}$ Norte \\
$\rightarrow \mathbf{A}$ Aeropuerto \\
(líneas, estaciones, \\
etc...) Alojamiento \\
\hline Dibuje en rojo, la \\
información sobre las \\
infraestructuras de
\end{tabular}

\section{Madrid}




\section{2. ¿Podría indicar el nombre de estos lugares?}
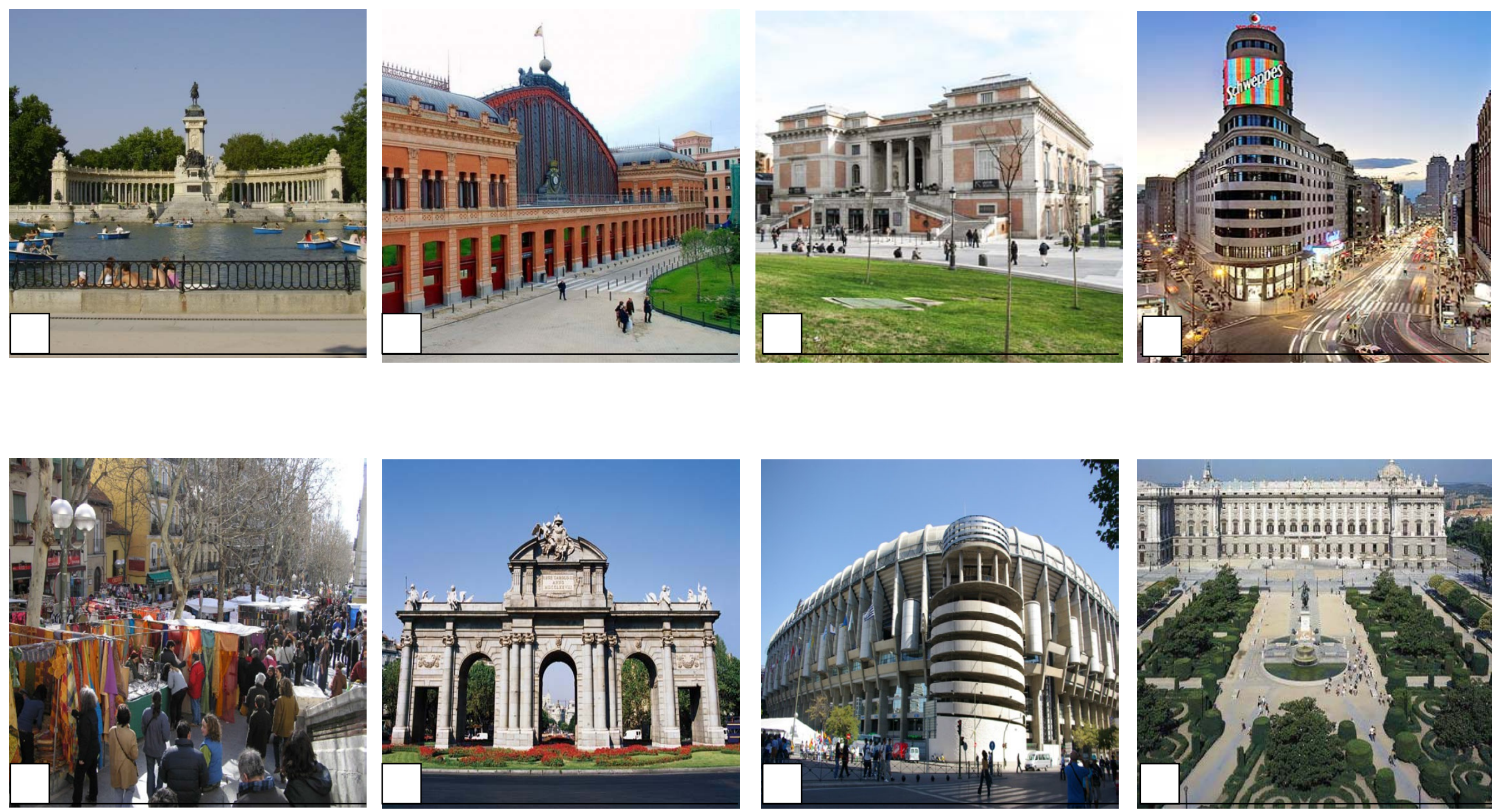


\section{Ubique y numere en este mapa los atractivos turísticos mostrados en las imágenes}

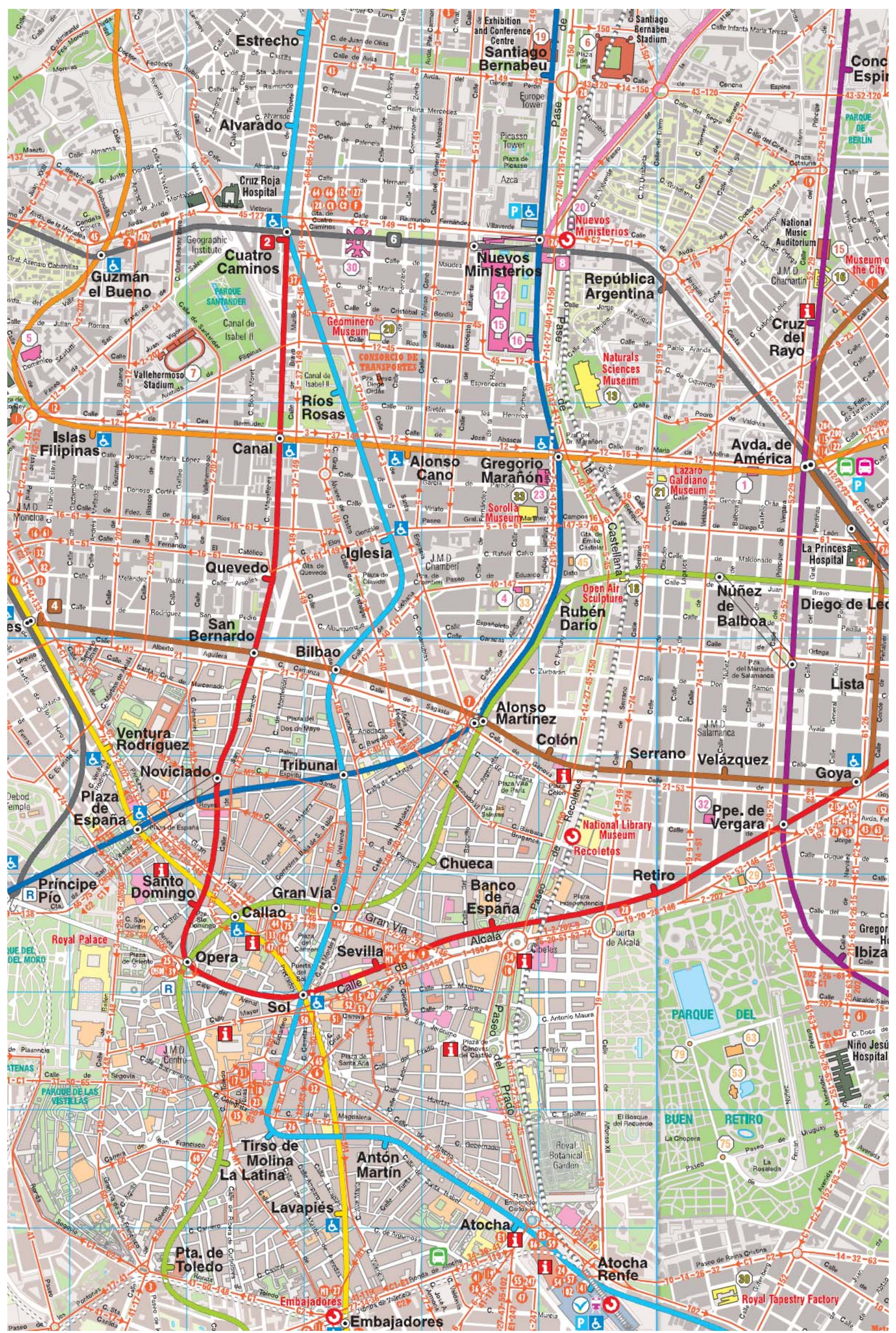


14. Edad: años

15. Sexo: $H \square \quad M \square$

16. País y lugar de residencia:

17. Indique su nivel de estudios:

$\square$ Sin estudios

Educación Primaria

Educación Secundaria

Educación Universitaria Básica

Educación Universitaria Superior

18. ¿Ha estudiado o trabajado en algún ámbito relacionado con la información geográfica?

$\square$ No

$\square$ Sí ¿Qué?/ ¿Dónde?

19. ¿En qué otras grandes ciudades ha estado?

20. ¿Cuándo visita una gran ciudad considera los desplazamientos entre puntos de interés como parte de su visita? (sitúese en la siguiente escala):

En absoluto;
$\begin{aligned} & \text { Me centro en los } \\ & \text { puntos de interés }\end{aligned}$

Si desea seguir participando en nuestro estudio en un futuro, indíquenos su correo electrónico (por favor, escriba en mayúsculas):

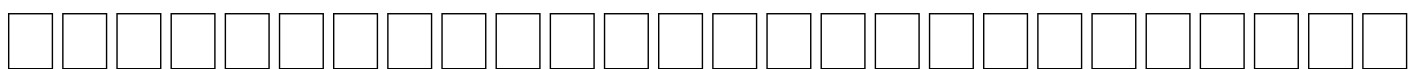


Anexo 11. Cuestionario realizado a turistas al finalizar su primera visita a Madrid 


\section{Cuestionario para turistas al finalizar su visita}

Código:

1. ¿Cuál ha sido el principal motivo de su visita a Madrid?: (Elija uno)
$\square$ Vacaciones/Turismo/Ocio
$\square$ Visitar familiares/amigos
$\square$ Trabajo/Negocios (Ferias/congresos)
$\square$ Escala a otros destinos
$\square$ Estudios
$\square$ Otros:

2. ¿Cómo ha sido su grupo de viaje?
$\square$ Viajo solo
En pareja
En familia

Con amigos

$\square$ Con compañeros de trabajo/estudios

$\square$ En un grupo organizado

Otros:

3. Numere del 1 al 5 sus intereses relacionados con su visita a Madrid (siendo 1 el más importante y 5 el menos importante):

$\square$ Museos y Monumentos $\quad \square$ Compras

$\square$ Eventos deportivos

$\square$ Espectáculos

$\square$ Gastronomía

$\square$ Parques y jardines

$\square$ Parques temáticos (Zoo, $\square$ Ocio nocturno

$\square$ Visitas familiares/amigos

parque de atracciones)

Otros:

4. ¿Hasta qué punto planificó su viaje a Madrid? (sitúese en la siguiente escala):

1
$\begin{aligned} & \text { Nada; } \\ & \text { No planifiqué nada de } \\ & \text { lo que iba a ver. }\end{aligned}$

\section{Indique la información que recuerde de la ubicación de su alojamiento:}

- Barrio/distrito:

- Calle:

- $\quad$ Parada/s de autobús más cercana/s:

- $\quad$ Estación/s de Metro más cercana/s:

- $\quad$ Estación/s de tren Cercanías más cercana/s:

6. ¿Durante su visita, ha consultado alguna fuente de información turísticogeográfica de Madrid? $\square$ Sí $\square$ No 


\section{En caso afirmativo,}

¿Qué tipo? (marque tantas como haya consultado):

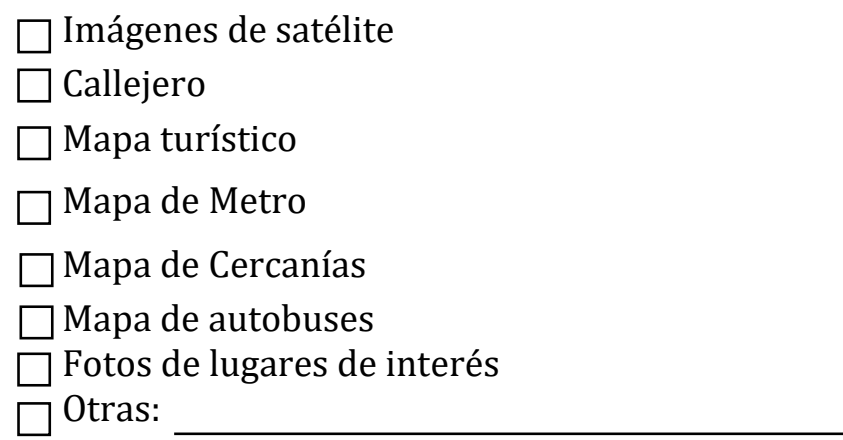

¿De qué fuente? (marque tantas como haya consultado, señale con un asterisco la más usada y puntúela del 1 al 5 según su nivel de satisfacción):

$\square$ Folleto/guía en papel:
$\square$ Sitios Web turísticos:
$\square$ Aplicación móvil:
$\square$ Foros/Blog:
$\square$ Familiares/Amistades:
$\square$ Otras:

¿Qué buscaba? (marque las opciones que correspondan):
$\square$ Ubicación de atractivos turísticos
$\square$ Itinerarios turísticos
$\square$ Recomendaciones personales
$\square$ Ruta en transporte público
$\square$ Servicios (restaurantes, tiendas...)
$\square$ Otras:

7. ¿Qué lugares de la ciudad ha visitado? (De los que indique, rodee con un círculo los que más le han gustado):

Atractivos turísticos:

Calle singular (por sus edificios, oferta de ocio, cultural...):

Barrio o zona (área cultural, histórica, de compras, ocio...): 
8. Numere del 1 al 3 los medios de transporte que ha utilizado en Madrid (siendo el 1 el de más uso y 3 el de menos uso):
$\square$ A pie
$\square$ Autobús turístico
$\square$ Bicicleta
$\square$ Autobús público
$\square$ Otros:
$\square$ Coche particular
$\square$ Metro
$\square$ Taxi
$\square$ Tren de Cercanías

9. ¿En algún momento ha tenido la intención de ir a un lugar y ha tenido dificultades para encontrar el camino

... Si

No

10. ¿Podría indicar cuál es el centro de Madrid?

11. Enumere tres atractivos turísticos que hacen de Madrid un sitio único:

1.

2.

3.

12. ¿Qué tres palabras utilizaría para describir Madrid a un amigo?

1.

2.

3.

13. ¿Hay alguna zona o lugar de Madrid que recomendaría visitar a otros turistas?

14. ¿Conoce algún lugar de interés en los alrededores de Madrid?

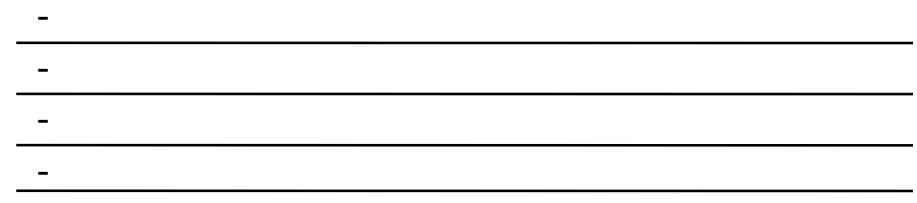

15. ¿En qué grado Madrid ha cubierto sus expectativas?

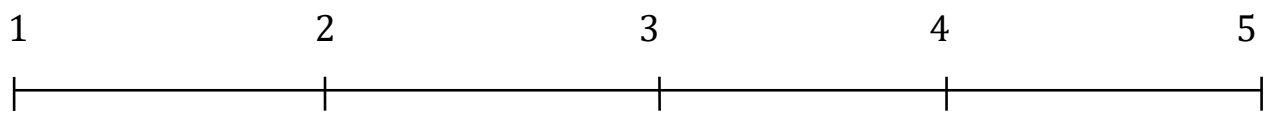

En absoluto

Totalmente 


\begin{tabular}{l} 
16. Dibuje un mapa de \\
la ciudad de Madrid, \\
identificando los \\
siguientes elementos: \\
- Lugares de interés \\
- Calles singulares \\
- Zonas de interés \\
$\rightarrow \mathbf{N}$ Norte \\
$\rightarrow \mathbf{B}$ Aeropuerto \\
A Alojamiento \\
(líneas, estaciones, \\
etc...) \\
infraestructuras de \\
información sobre las \\
\hline ibuje en rojo, la
\end{tabular}

Madrid 

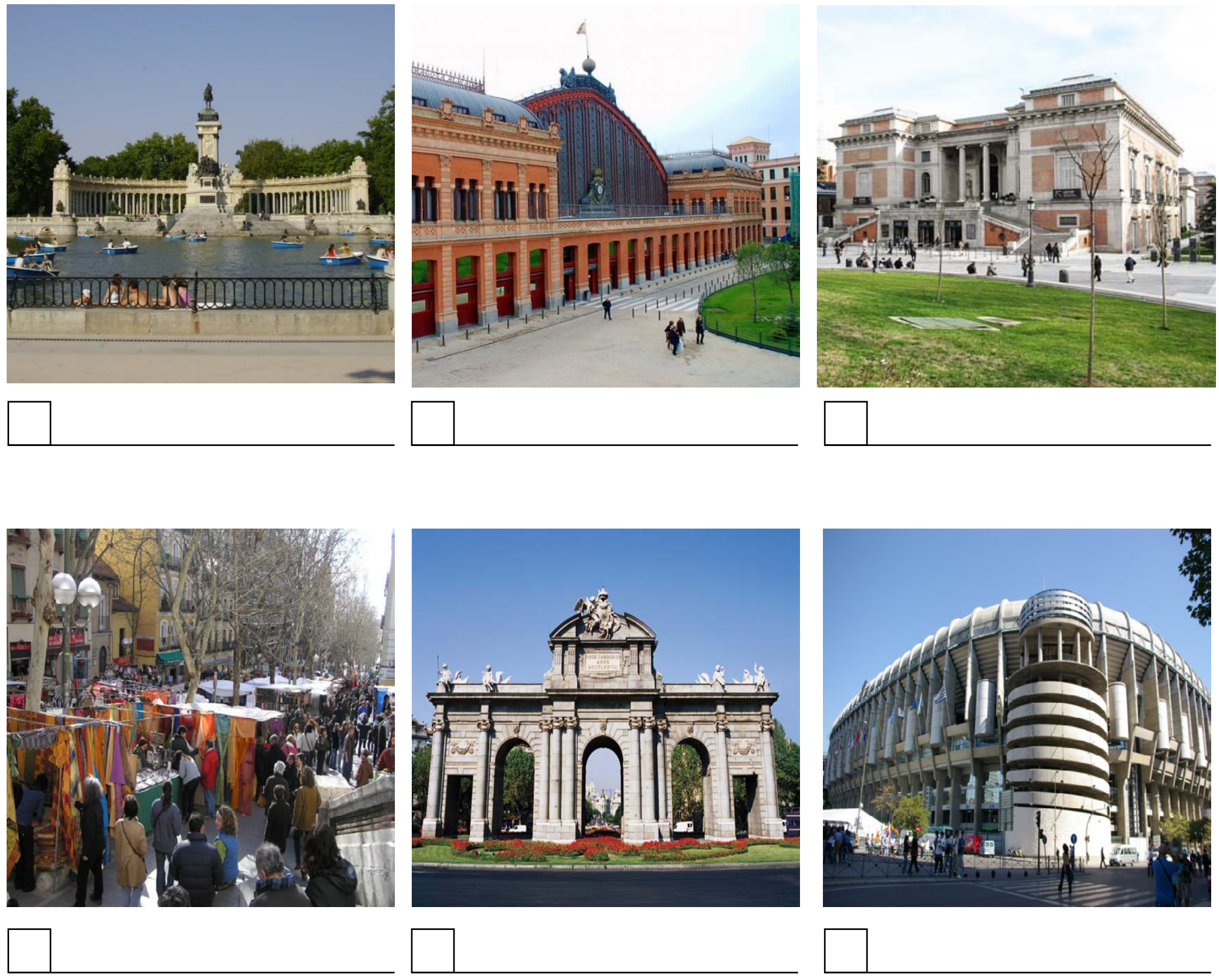
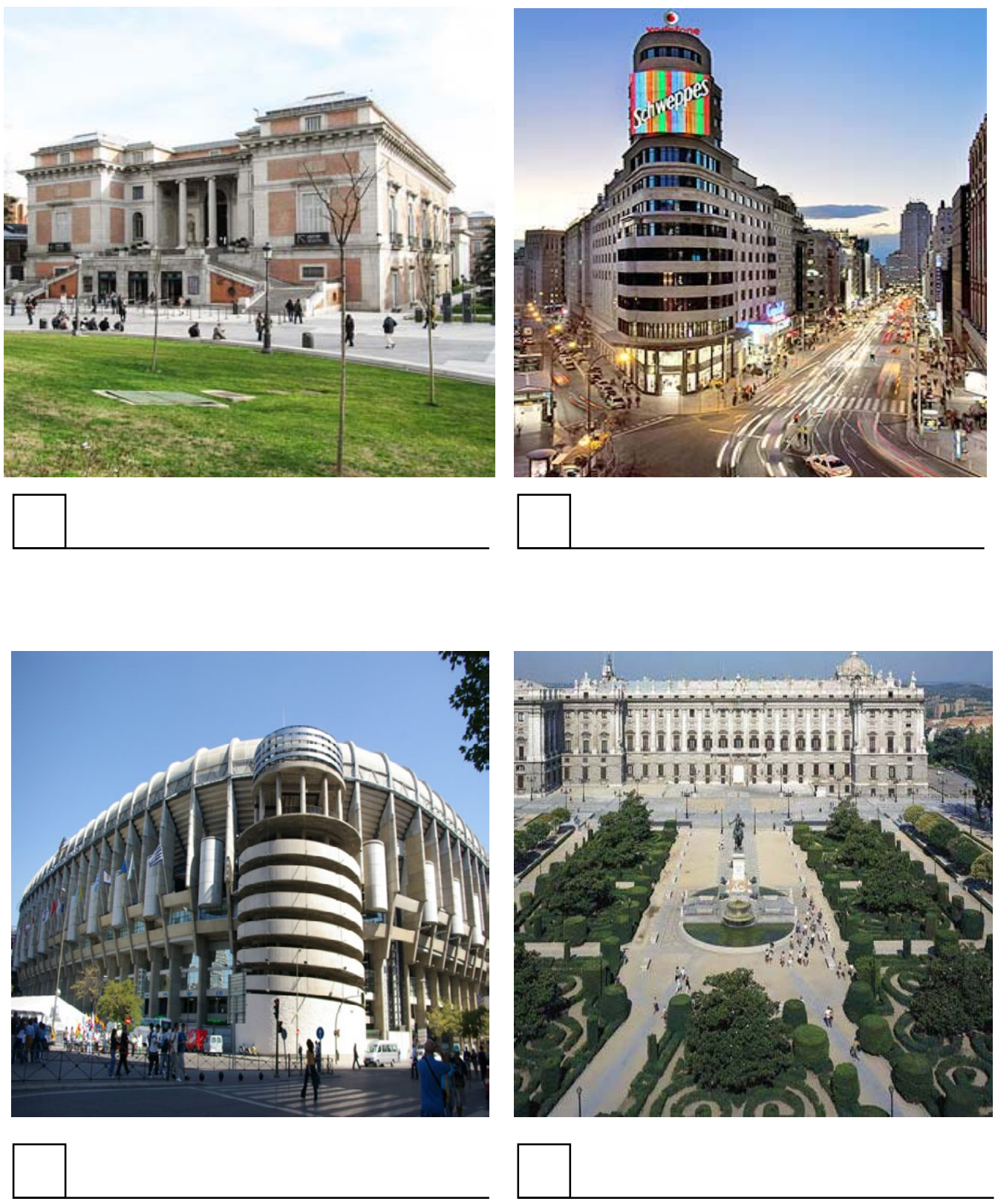


\section{Ubique y numere en este mapa los atractivos turísticos mostrados en las imágenes}

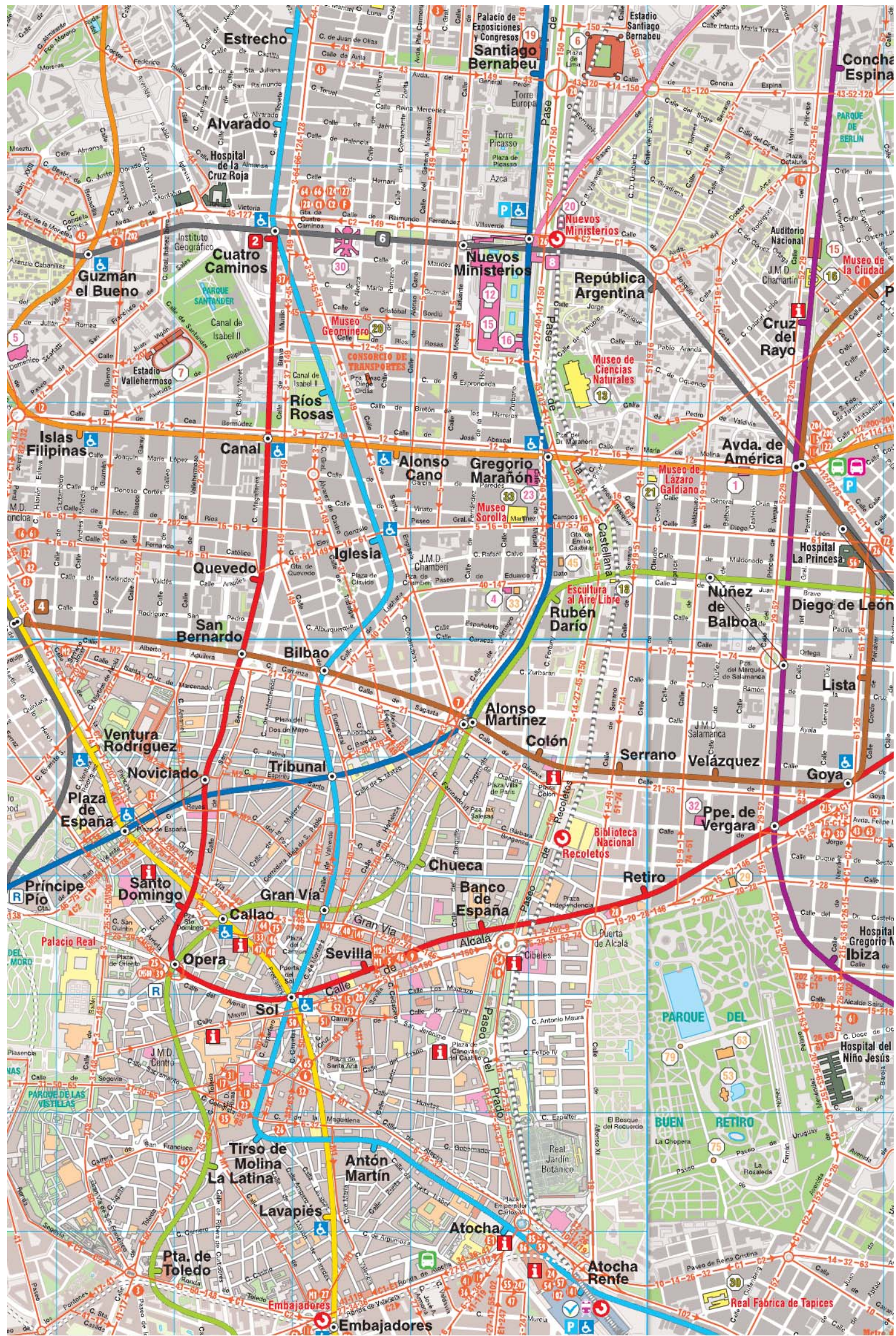


19. Edad:__ años

20. Sexo: $\square \mathrm{H} \quad \square \mathrm{M}$

21. País y lugar de residencia:

22. Indique su nivel de estudios:

$\square$ Sin estudios

Educación Primaria

Educación Secundaria

Educación Universitaria Básica

Educación Universitaria Superior

23. ¿Ha estudiado o trabajado en algún ámbito relacionado con la información geográfica?

No

Sí $\square$ ¿Qué?/ ¿Dónde?

24. ¿En qué otras grandes ciudades ha estado?

25. ¿Cuándo visita una gran ciudad considera los desplazamientos entre puntos de interés como parte de su visita? (sitúese en la siguiente escala):

\begin{tabular}{l|r|r} 
En absoluto; & 2 & 4 \\
Me centro en los & & $\begin{array}{r}\text { Totalmente; } \\
\text { Considero los }\end{array}$ \\
puntos de interés & & $\begin{array}{r}5 \\
\text { desplazamientos }\end{array}$ \\
como parte de la visita
\end{tabular}

Si desea seguir participando en nuestro estudio en un futuro, indíquenos su correo electrónico (por favor, escriba en mayúsculas): 


\section{Anexo 12. Recursos y pautas utilizadas en la técnica de los diarios.}

Para poder llevar a cabo la técnica del diario se puso a disposición de los turistas:

-un móvil con la App "The Traveler", que permite grabar los desplazamientos realizados y la integración en los registros GPS notas de texto, audio, imagen y video (Figura A29);

- libretas para tomar notas y

- mapas turísticos de la ciudad en papel.

Además, cada turista pudo utilizar los recursos propios que deseara para registrar la información (como sus cámaras de fotos, mensajes vía WhatsApp, emails...).
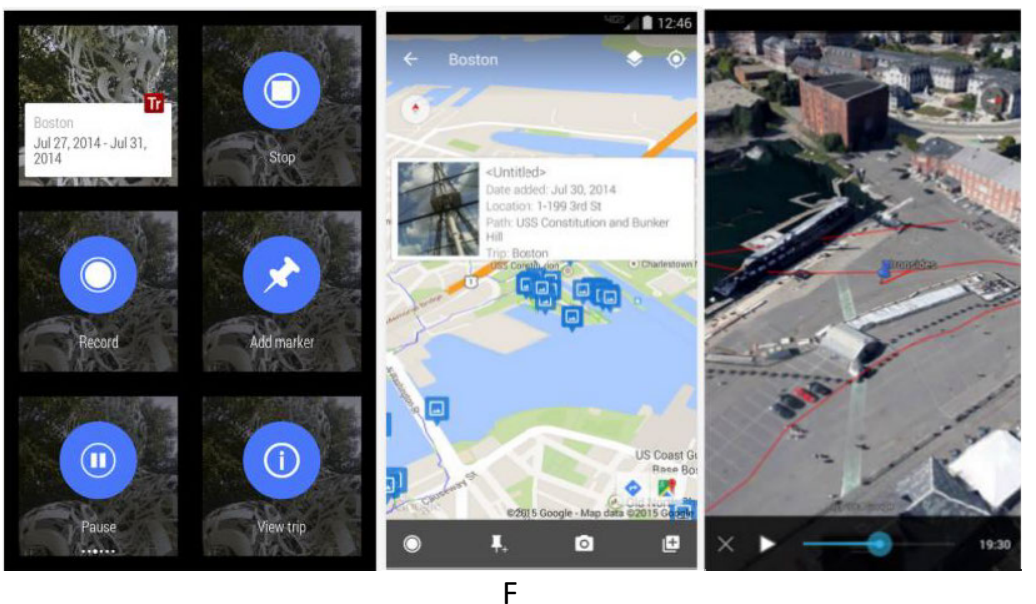

Figura A29: App "The Traveler" para Android utilizada en la técnica de los diarios Fuente: https://play.google.com/store/apps/details?id=edu.bsu.android.apps.traveler

A continuación se incluyen las pautas suministradas a los turistas para llevar a cabo esta técnica.

\section{Instrucciones}

Para poder registrar toda la información necesaria para la investigación, tienes a tu disposición un teléfono móvil. La aplicación a utilizar se llama "Traveler" y se puede acceder a ella a través del icono correspondiente en el escritorio del móvil.

La aplicación tiene tres apartados principales:

- "Trip info": donde verás un registro con tu/vuestro nombre. No necesitarás utilizar este apartado.

-"Paths": para la grabación automática de tus desplazamientos por la ciudad.

-"Media": para crear registros de texto, audio, foto y video.

Utilizarás "Traveler" con el fin de registrar todos tus desplazamientos por la ciudad, así como una serie de eventos: 
-Desplazamientos: Para grabar los desplazamientos únicamente tienes que ir al apartado "Paths" y comenzar a grabar cada mañana al salir de casa. La grabación debe permanecer activa durante todo el día hasta que regreses a casa. Una vez activada la grabación, no tienes que volver a entrar en este apartado en el resto de la jornada.

-Eventos: Es necesario que documentes las actividades o situaciones que se indican a continuación. Para ello podrás realizar registros de texto, audio, fotografía o video disponibles en "Media". Eventos a documentar:

A) INFORMACIÓN VINCULADA A DESPLAZAMIENTOS: En el momento de iniciar un desplazamiento de un lugar a otro, indicar mediante una nota de texto o audio:

- Lugar de origen,

- Lugar de destino,

- Medio de transporte elegido (metro, bus, pie...),

- Motivo de la elección del medio de transporte (el más rápido) y el lugar de destino (visita al Palacio Real),

- Información consultada: ¿qué información has necesitado? (lugares de interés cerca de mi ubicación actual) y ¿dónde o cómo la has adquirido? (mapa turístico en aplicación móvil, persona en la calle...) y

- Ruta (línea 1 de metro entre de $X$ a $Y$, bus número $X$, a pie callejeando por la ciudad...).

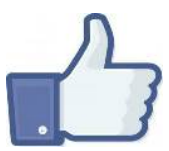

B) LUGARES o EVENTOS DE INTERÉS ESPECIAL que te gustaría recordar de tu viaje:

- Nombre del lugar o título descriptivo del evento,

- Imagen o vídeo y

- Motivo de interés.

C) SITUACIONES O COSAS INCOMPRENSIBLES O DESCONCERTANTES que no te han gustado o que han dificultado de alguna forma tu visita:

- Imagen o vídeo y

- Descripción de la situación (por ejemplo, te encuentras en un lugar y no sabes el camino seguir, consultas un mapa en papel pero no encuentras la calle...).

- Información que te hubiera facilitado la situación.

No te olvides de registrar la información de todos tus desplazamientos (A). Registra todos los lugares (B) o situaciones (C) especialmente significativos para ti. Tus pensamientos y sentimientos son importantes para la investigación, más allá de la calidad de las imágenes o los videos. 
Anexo 13. Tablas elaboradas con la información recogida en la encuesta a los turistas.

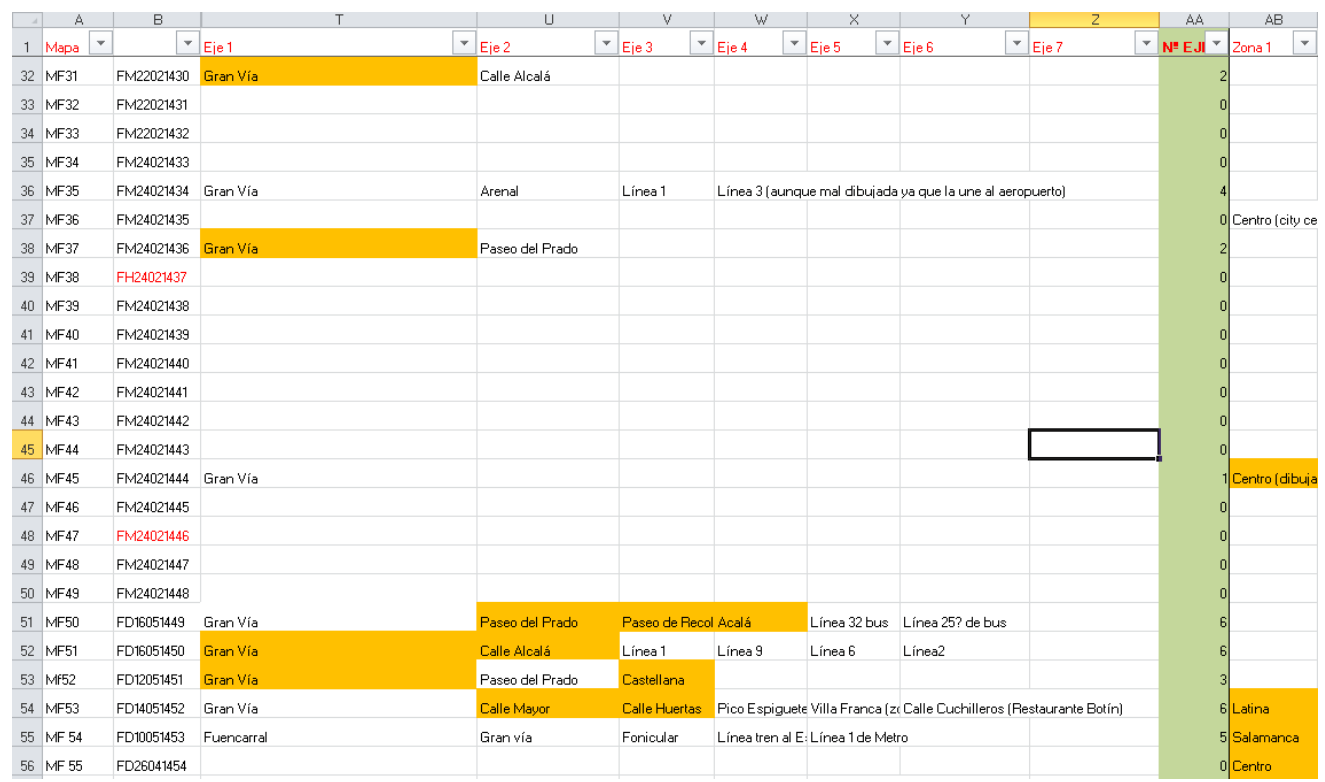

Figura A30: Tabla de Excel con las respuestas de los cuestionarios finales relativas al conocimiento del espacio de Madrid.

\begin{tabular}{|c|c|c|c|c|c|c|c|c|c|c|c|c|c|}
\hline$\Delta$ & A & C & H & J & $\mathrm{K}$ & L & barra a & de tormulas & & 0 & & $\mathrm{P}$ & \\
\hline 1 & Código & Momen = & País & Nv.Estudic $=$ & Est.Carto & ¿Qué? ¿Dónde? & Ciudades & Desplz & - & Días_Visita & $\cdot$ & Motivo & - \\
\hline 21 & FM26121301 & & 2 Brasil & 5 & & 1 & & 0 & 4 & & 3 & & 1 \\
\hline 22 & FM26121302 & & 2 Brasil & 5 & & 1[ & & 5 & 5 & & 5 & & 1 \\
\hline 23 & FH27121303 & & 2 Venezuela & 5 & & 1 & & 3 & 3 & & 6 & & 1 \\
\hline 24 & FM27121304 & & 2 Suiza & 5 & & 1 & & 7 & 5 & & 5 & & 4 \\
\hline 25 & FH27121305 & & 2 Brasil & 5 & & 1 & & 2 & 5 & & 5 & & 4 \\
\hline 26 & FH03011406 & & 2 Brasil & 5 & & 1 & & 4 & 4 & & 3 & & 1 \\
\hline 27 & FH03011407 & & 2 EEUU & 5 & & 1 & & 8 & 5 & & 2 & & 1 \\
\hline 28 & FH03011408 & & 2 Alemania & 4 & & 1 & & 4 & 4 & & 6 & & 1 \\
\hline 29 & FH07011409 & & 2 Argentina & 5 & & 1 & & 0 & 3 & & 3 & & 1 \\
\hline 30 & FH07011410 & & 2 Argentina & 4 & & 1 & & 3 & 4 & & 3 & & 5 \\
\hline 31 & FM21021411 & & 2 UK & 3 & & 1 & & 7 & 5 & & 5 & & 1 \\
\hline 32 & FM21021412 & & 2 Francia & 5 & & 1 & & 1 & 4 & & 3 & & 1 \\
\hline 33 & FM21021413 & & 2 Venezuela & 4 & & 2 Marino mercante & & 0 & 4 & & 10 & & 1 \\
\hline 34 & FM21021414 & & 2 Irlanda & 5 & & 2 & & 12 & & & 7 & & 1 \\
\hline 35 & FM21021415 & & 2 Irlanda & 4 & & 1 Asignatura de geogr & & 12 & 3 & & 7 & & 1 \\
\hline 36 & FM21021416 & & 2 Marruecos & 3 & & 1 GPS Surving enginee & & 0 & 5 & & 5 & & 1 \\
\hline 37 & FM21021417 & & 2 México & 4 & 4 & 1 & & 5 & 2 & & 5 & & 1 \\
\hline 38 & FM21021418 & & 2 México & 3 & & 1 & & 6 & 5 & & 3 & & 1 \\
\hline 39 & FM21021419 & & 2 Chile & 4 & & 1 & & 10 & 5 & & 3 & & 1 \\
\hline 40 & FH21021420 & & 2 Reino Unido & 3 & & 1 & & 4 & 2 & & 3 & & 1 \\
\hline 41 & FH21021421 & & 2 México & 5 & & 1 & & 6 & 4 & & 2 & & 1 \\
\hline 42 & FH21021422 & & 2 Corea del Sur & 4 & & 1 & & 6 & 1 & & 2 & & 5 \\
\hline 43 & FH22021423 & & 2 México & 5 & & 1 & & 4 & 4 & & 3 & & 1 \\
\hline 44 & FH22021424 & & 2 Rumania & 4 & 4 & 1 & & 8 & 4 & & 2 & & 1 \\
\hline 45 & FM22021425 & & 2 Japón & 4 & 7 & 1 & & 5 & 4 & & 1 & & 1 \\
\hline 46 & FM22021426 & & 2 Costa Rica & 5 & & 2 G.I.S & & 9 & 2 & & 3 & & 5 \\
\hline
\end{tabular}

Figura A31: Tabla de Excel con los atributos de los turistas encuestados al final de su visita y el resto de información sobre los factores condicionantes de sus actividades. 


\section{Anexo 14. Atributos de los turistas encuestados Procedencia}

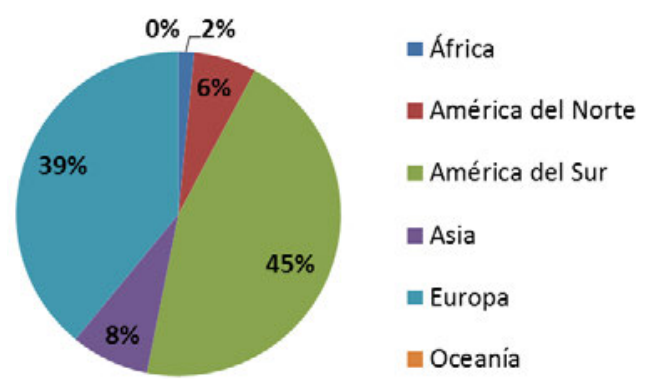

a

b

Edad

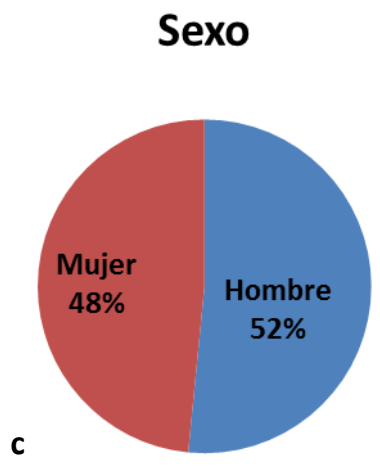

\section{Experiencia visitando grandes ciudades}

d

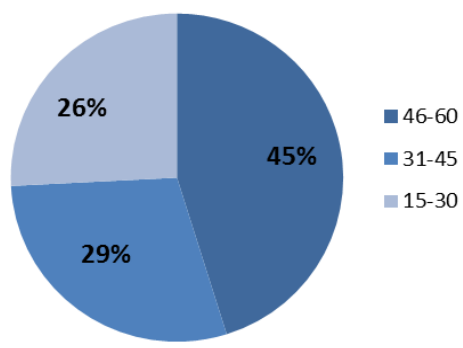

Nivel de estudios

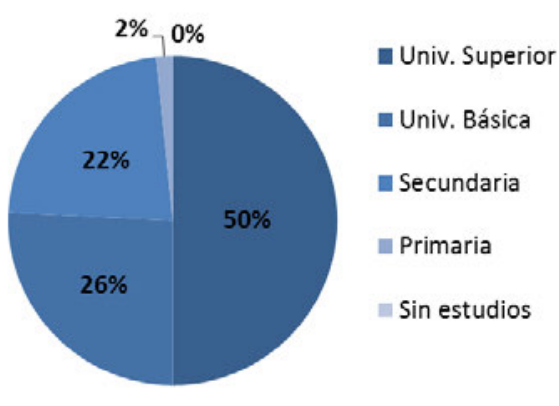

Experiencia en el uso de información geográfica por estudios o trabajo

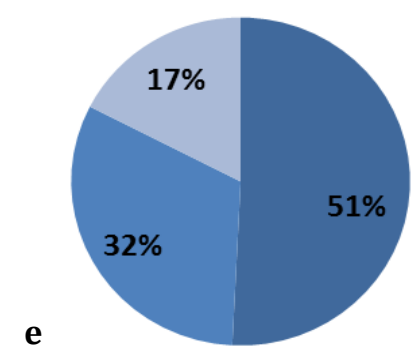

ש >4 ciudades

- 2-4 ciudades

0-1 ciudades

f

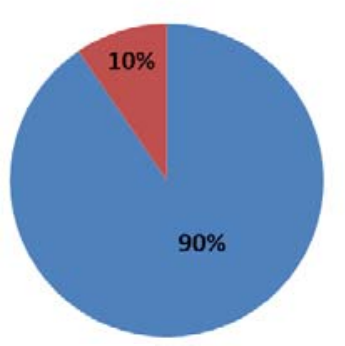

- Sin experiencia

- Con experiencia

Percepción de los desplazamientos durante la vista

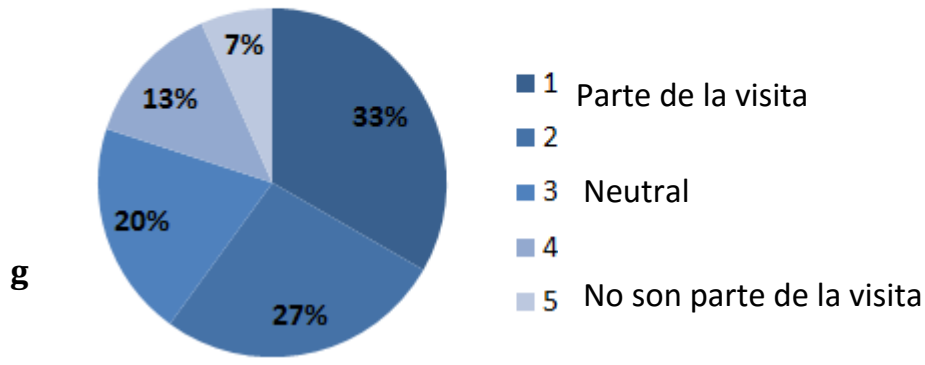

Figura A32: Características de los turistas encuestados: a) Edad, b) Género, c) Nivel de estudios,

d) Procedencia, e) Experiencia visitando grandes ciudades, f) Experiencia en el uso de IG y

g) Percepción de los desplazamientos. 


\section{Anexo 15. Factores que condicionan las actividades de los turistas en el pre-viaje}

Ante la dificultad de hacer un seguimiento de las actividades realizadas por los turistas antes de llegar a Madrid, se decidió plantearles al inicio de su visita una serie de preguntas con la finalidad de recabar información acerca de factores que influyen en esta etapa del viaje:

a) motivo de la visita a Madrid

El principal motivo de la visita determina en gran medida las actividades que se ejecutan en el pre-viaje. Así, por ejemplo, el turista que venga a Madrid de vacaciones tendrá que buscar información y seleccionar Madrid entre otros destinos turísticos. Mientras que, otra una persona que tenga que venir a Madrid por trabajo y que decida extender su estancia un par de días más para visitar la ciudad, es posible que esté muy ocupada para informase acerca de los atractivos turísticos de la ciudad y que no lo haga hasta que finalicen sus obligaciones laborales. La Figura A33 ilustra el motivo del viaje a Madrid de los turistas encuestados.

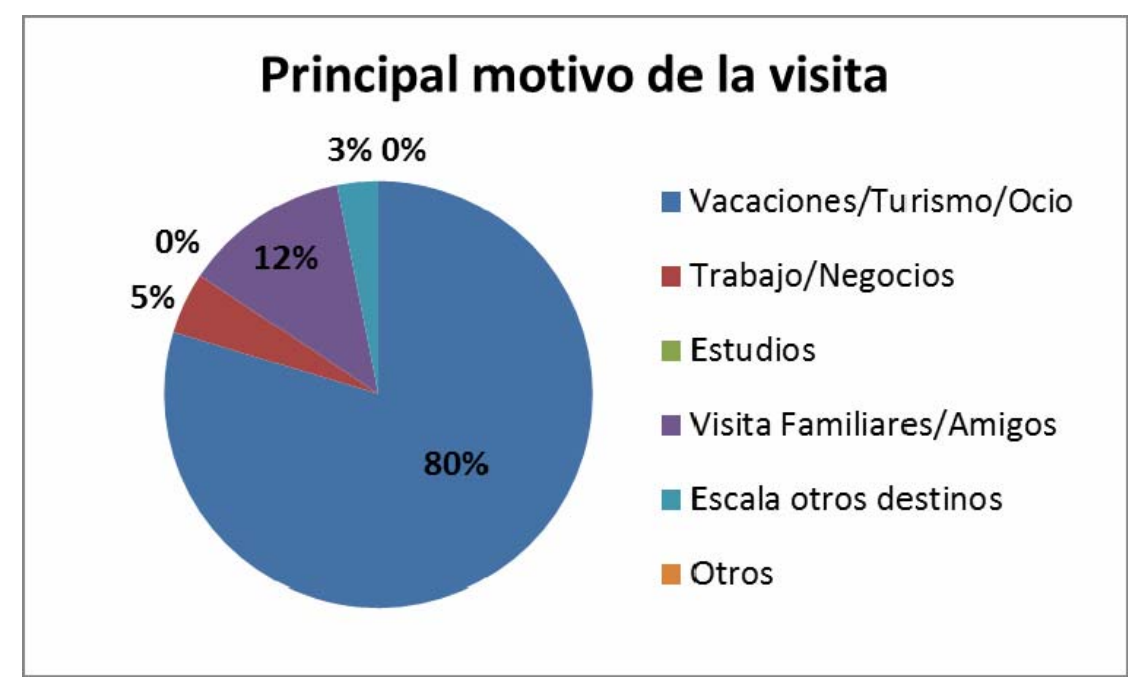

Figura A33: Principal motivo de la visita de los turistas encuestados (iniciales y finales).

Además del motivo del viaje, otros aspectos como el grupo y las expectativas del turista en relación a la experiencia también intervienen en las actividades que realiza durante el pre-viaje. Así, un turista que venga por vacaciones y desee minimizar al máximo la toma de decisiones y la consulta de información tanto durante el pre-viaje, como en el destino, buscará probablemente un paquete (vuelo, alojamiento, transporte del aeropuerto al hotel y visitas guiadas por la ciudad en un grupo de viaje). Mientras que otro turista al que le guste: organizar hasta el más mínimo detalle de sus viajes, informarse a fondo antes de visitar un lugar y asegurarse de que no se pierde ningún atractivo de su interés, posiblemente lo que hará es recabar toda la información necesaria para asegurarse de que las decisiones que toma son las adecuadas para lograr su objetivo. 
b) grupo de viaje

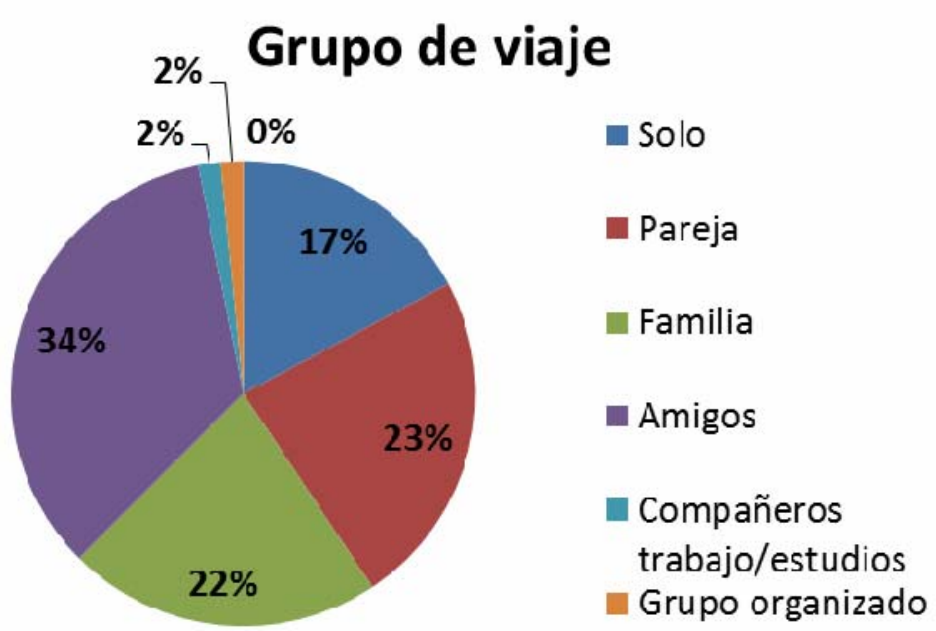

Figura A34: Grupo de viaje de los turistas encuestados (iniciales y finales).

c) intereses relacionados con su visita

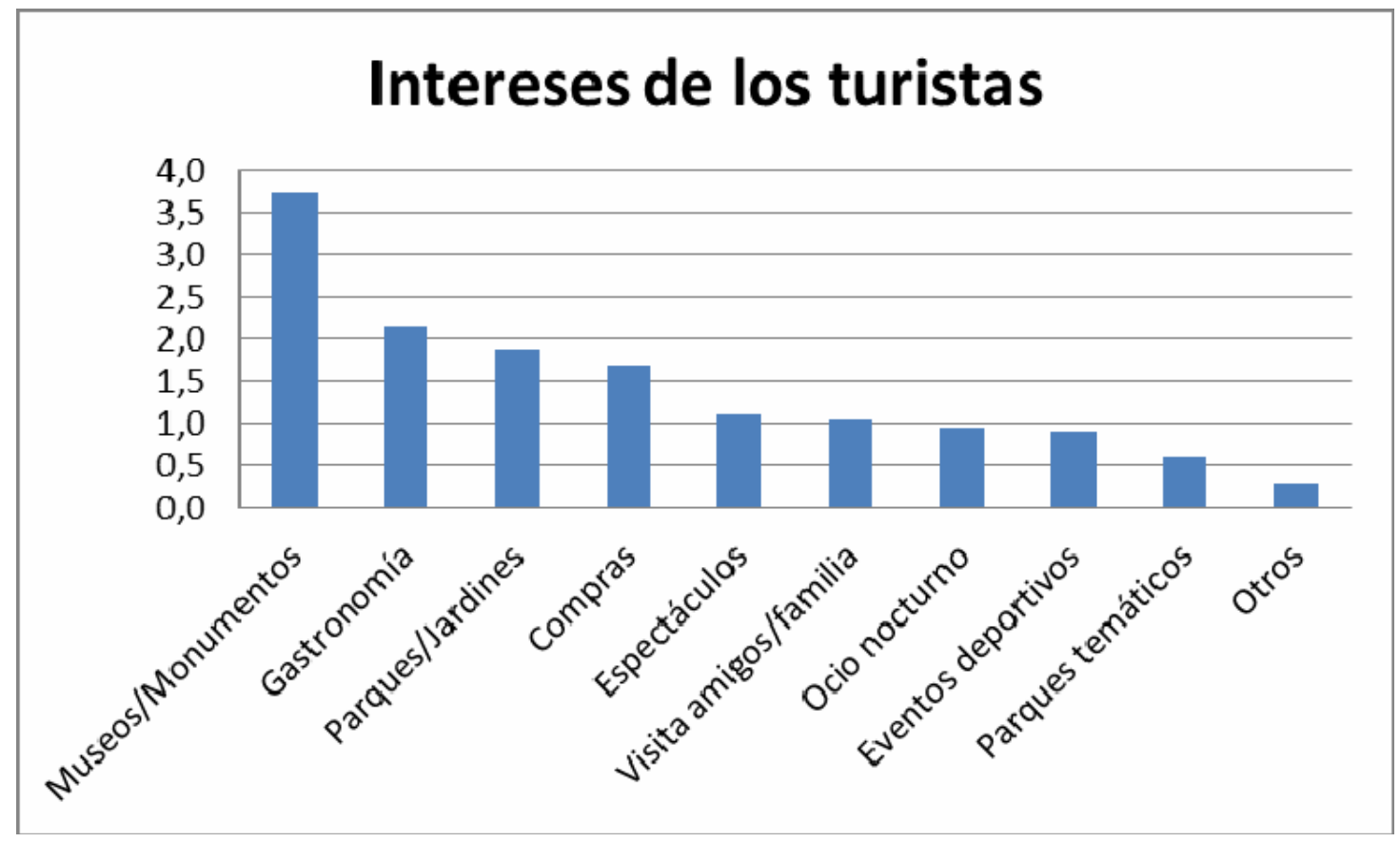

Figura A35: Intereses manifestados por los turistas encuestados (iniciales y finales). Gráfica obtenida a partir de información sobre los cinco intereses principales de cada turista, ponderados según la importancia y promediados. 
d) nivel de planificación del viaje antes de llegar a Madrid

\section{Nivel de planificación del viaje de los turistas recien llegados}

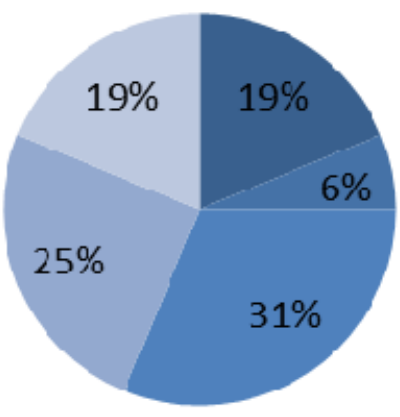

Totalmente

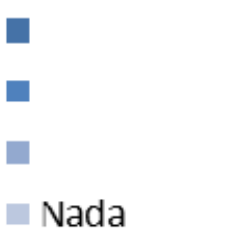

Figura A36: Nivel de planificación del viaje de los turistas recién llegados (iniciales).

e) conocimiento turístico-espacial de Madrid

- Listas de libre recuerdo en forma de texto:

$\begin{array}{lc}\quad \text { Atractivo turístico } & \text { Repeticiones en texto } \\ \text { Museo del Prado } & 6 \\ \text { Museo Reina Sofía } & 5 \\ \text { Puerta del Sol } & 5 \\ \text { Estadio Santiago } & 4 \\ \text { Plaza Mayor } & 4 \\ \text { Palacio Real } & 3 \\ \text { Parque del Retiro } & 3 \\ \text { Catedral de la Almudena } & 1 \\ \text { El Rastro } & 1 \\ \text { Las Ventas } & 1 \\ \text { Madrid Río } & 1 \\ \text { Museo Thyssen- } & 1 \\ \text { Plaza de Cibeles } & 1 \\ \text { Plaza de España } & 1 \\ \text { Opera } & 1\end{array}$

Tabla A2: Lugares que los turistas tienen previsto visitar en Madrid al inicio de su estancia y número de veces que se han mencionado en los cuestionarios iniciales. 
- Mapas mentales de Madrid.

El Anexo 16 incluye todos los mapas registrados; y

- Reconocimiento de fotografías y su localización en un mapa.

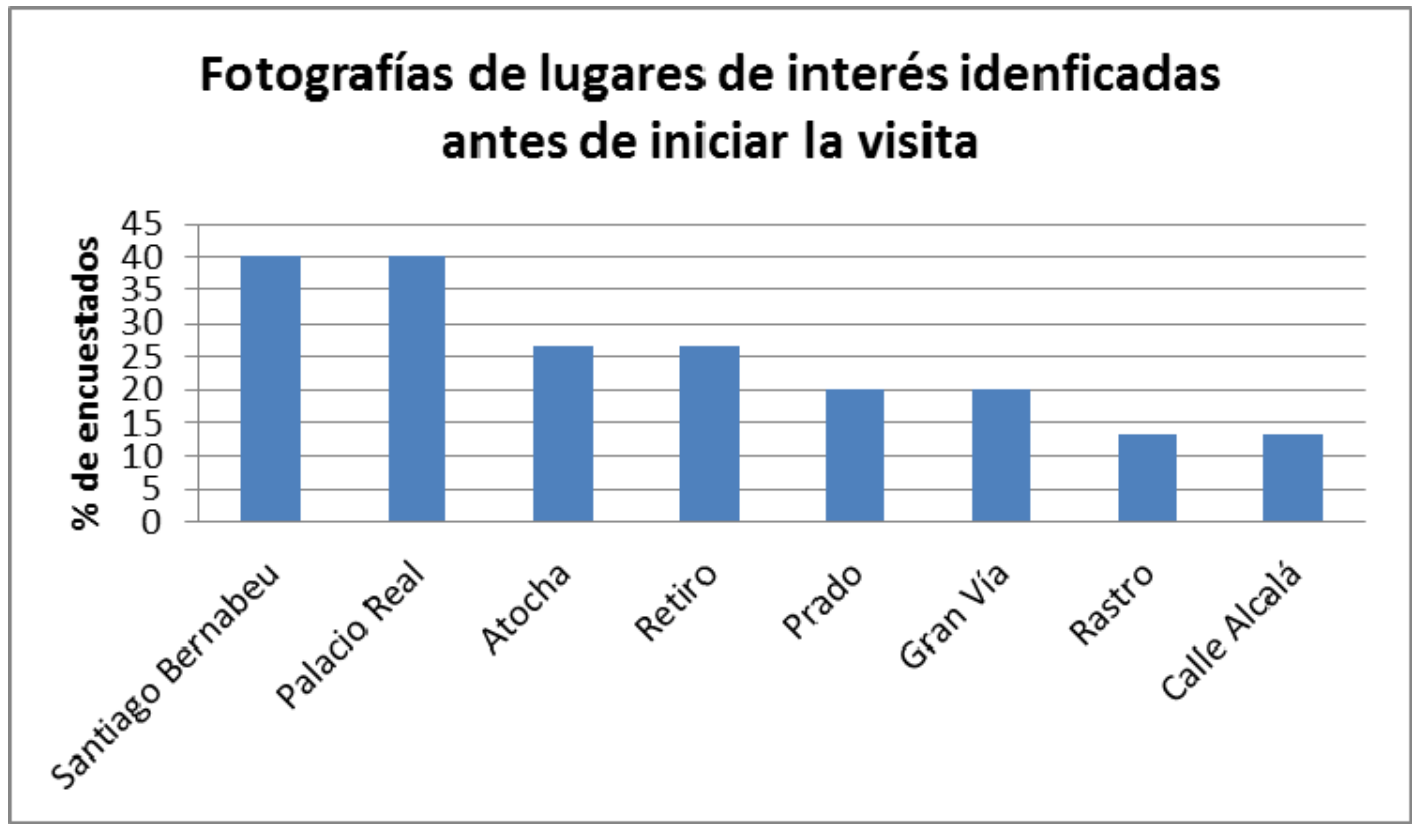

Figura A37: Porcentaje de encuestados antes de inicar la visita que identifican fotografías de lugares de interés de Madrid.

\section{Lugares de interés identificados en fotografías y localizados en un mapa, antes de iniciar la visita}

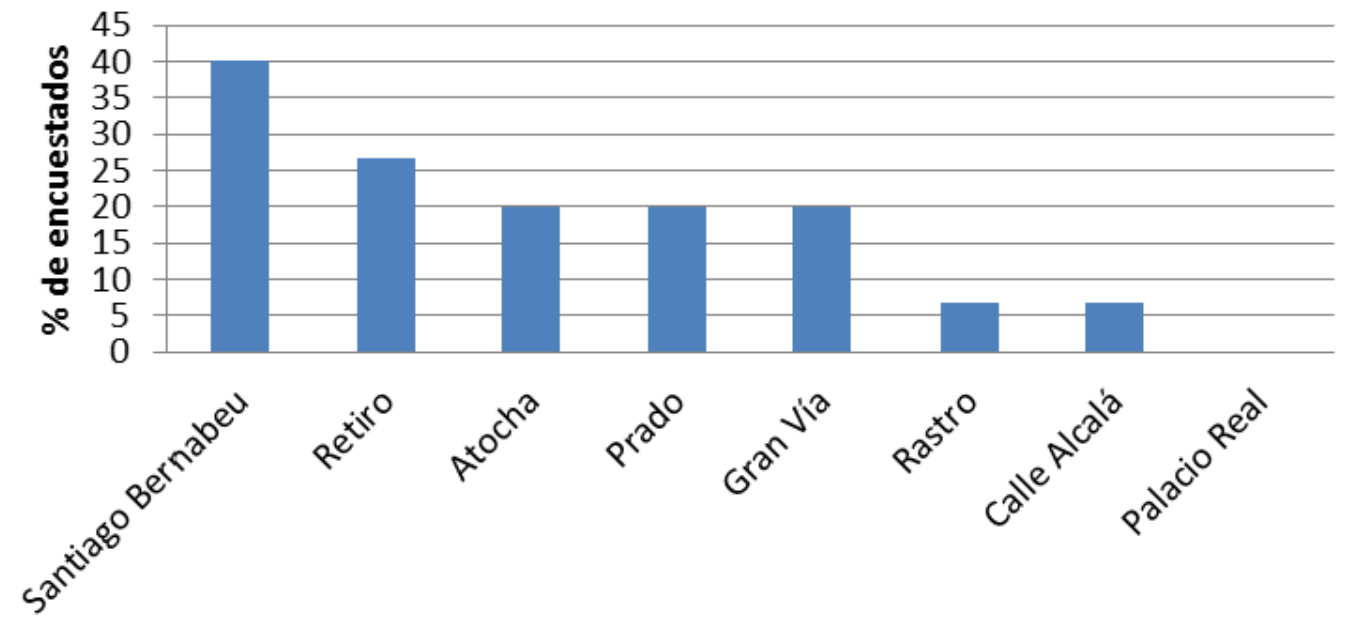

Figura A38: Porcentaje de encuestados antes de inicar la visita que identifican las fotografías de lugares de interés y los localizan en un mapa. 


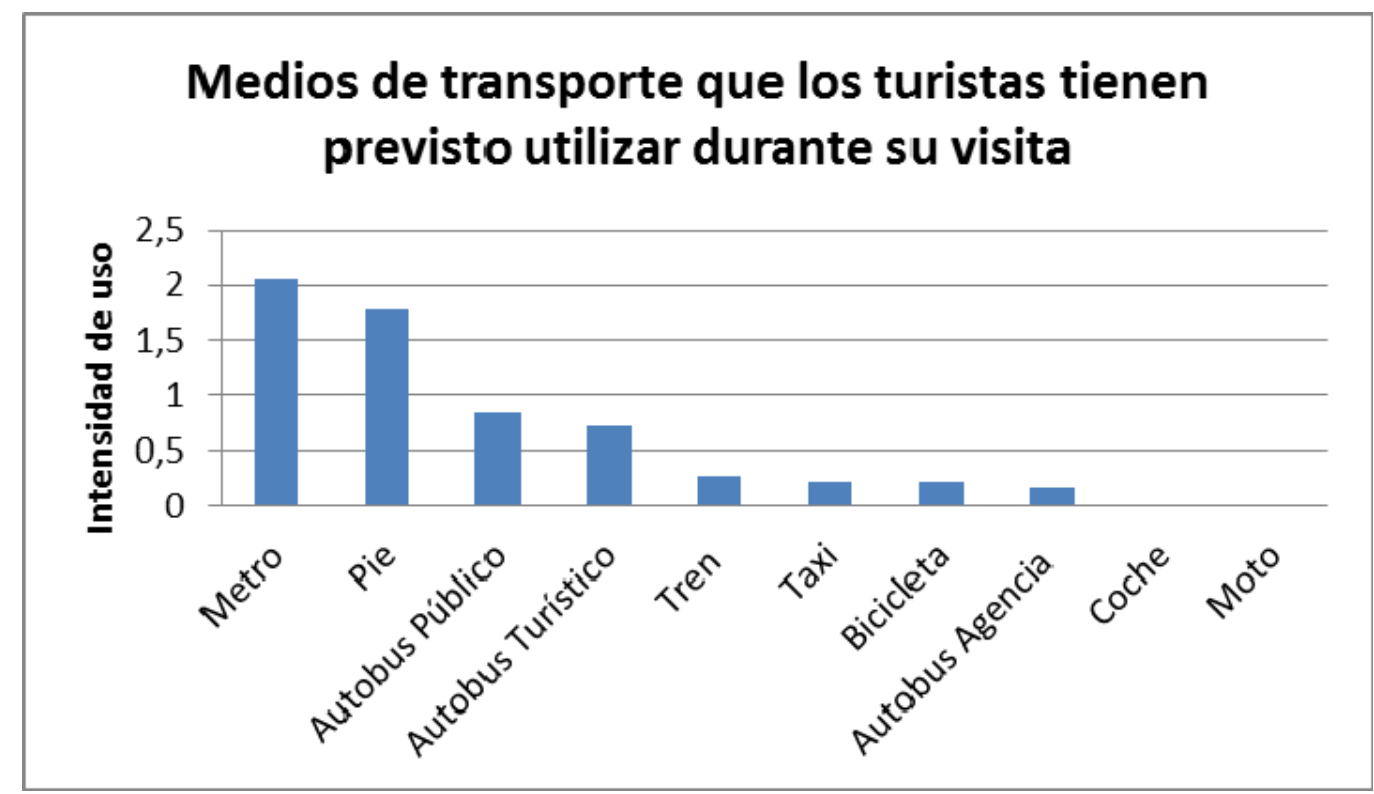

Figura A39: Medios de transporte que los turistas tienen previsto utilizar en Madrid, antes de comenzar su vista (iniciales). Gráfica obtenida a partir de datos sobre los tres medios de transporte que el turista tiene intención de utilizar, ponderados por su estimación de intensidad de uso y promediados. 
Anexo 16. Mapas mentales de los turistas encuestados al inicio de su visita 


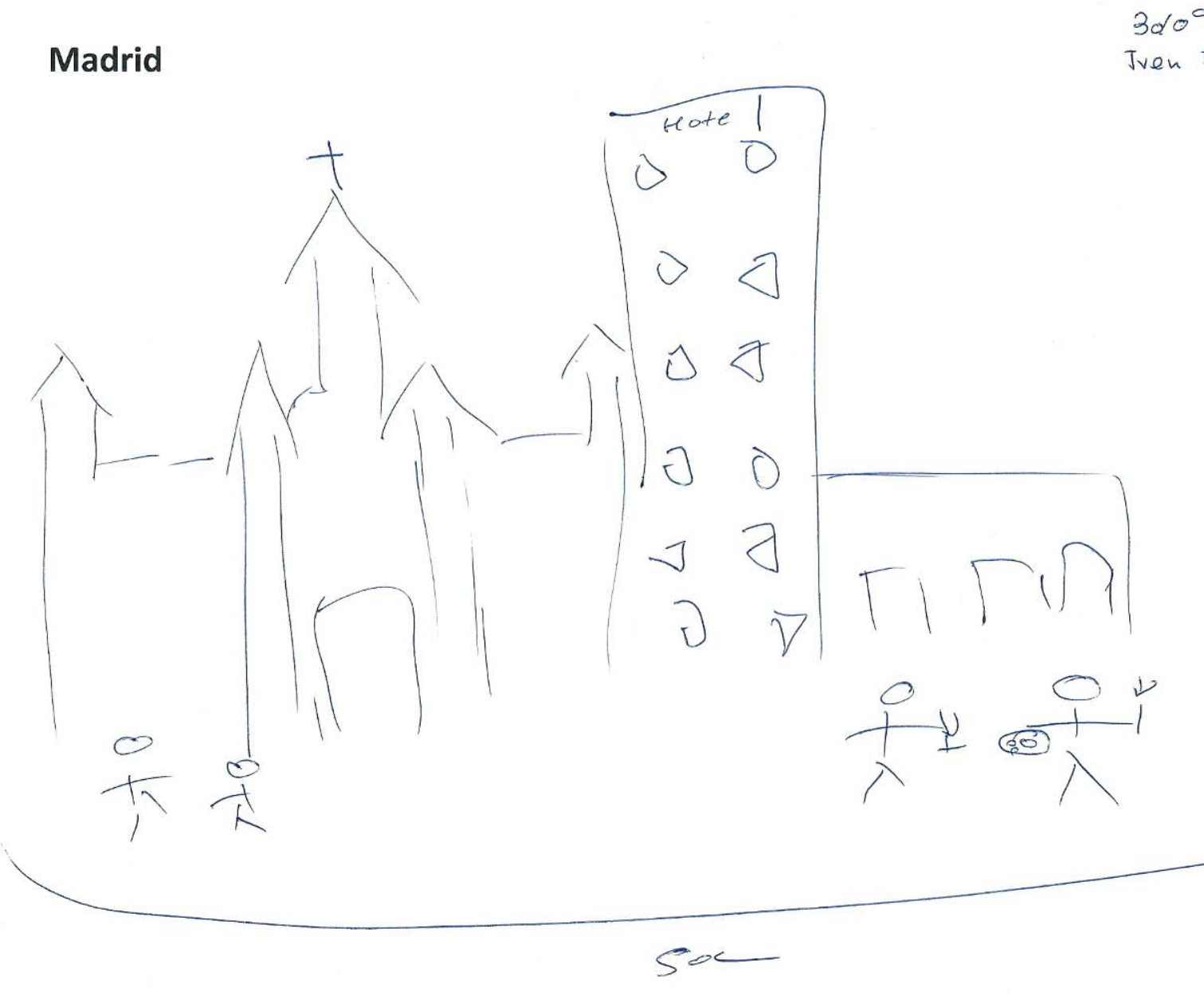

do9/13 llol

ven 14 - NM. 
HO2 HMi O2/09/2013

\section{Madrid}

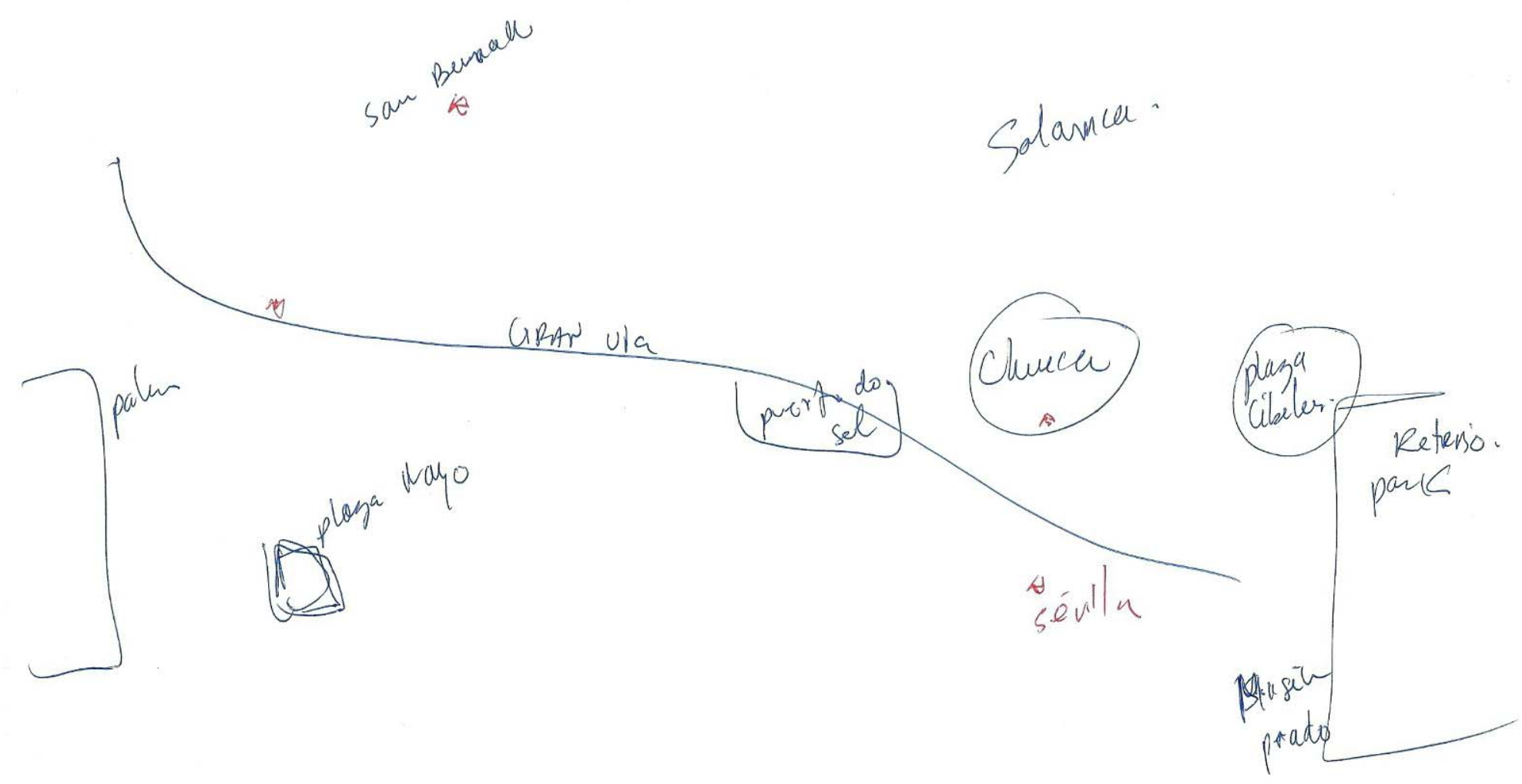



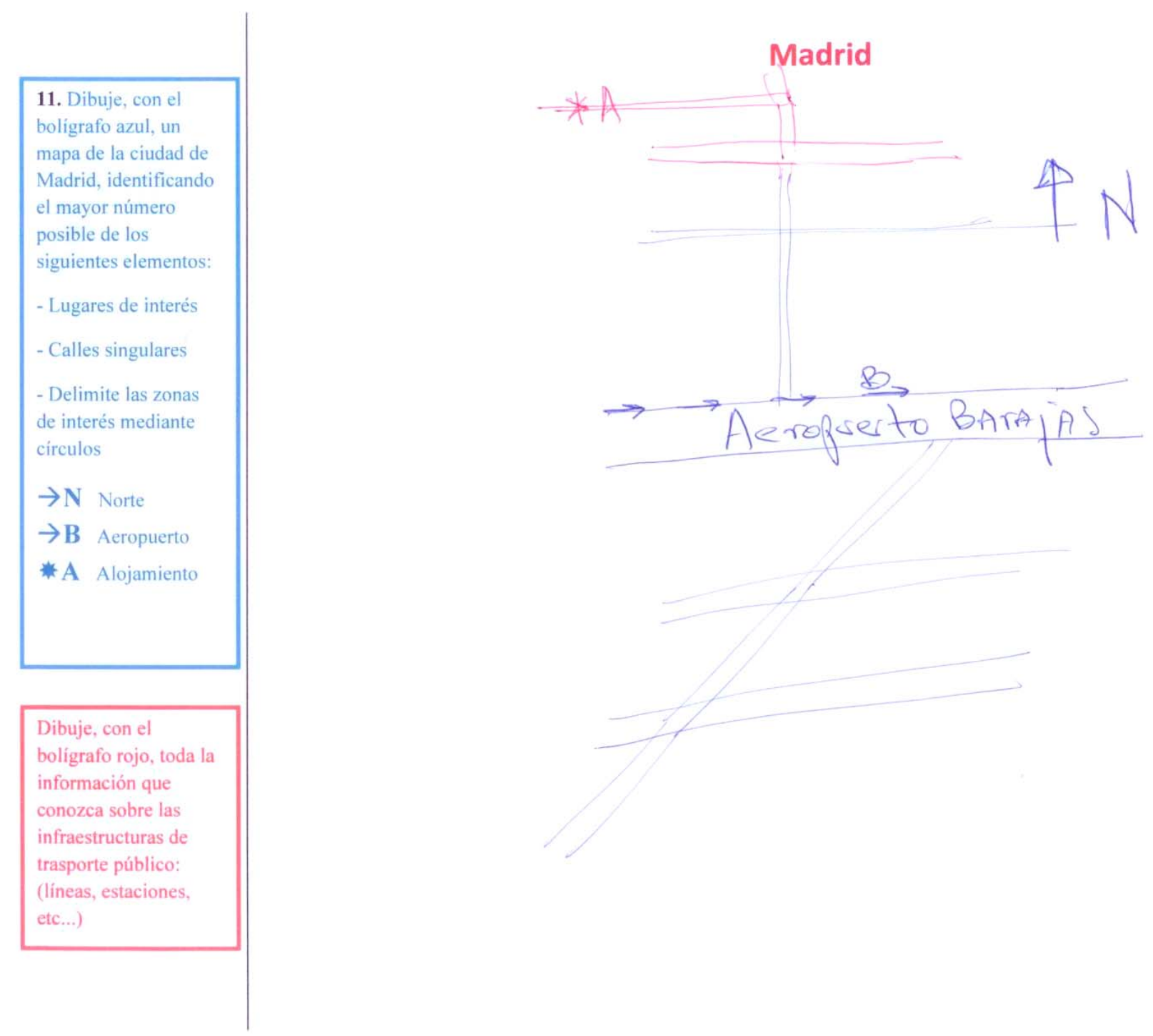

$+7$

olígrafo azul, u

Madridente

mayor número

Lugares de interés

Delimite las zona

oligrafo rojo, toda la

información que

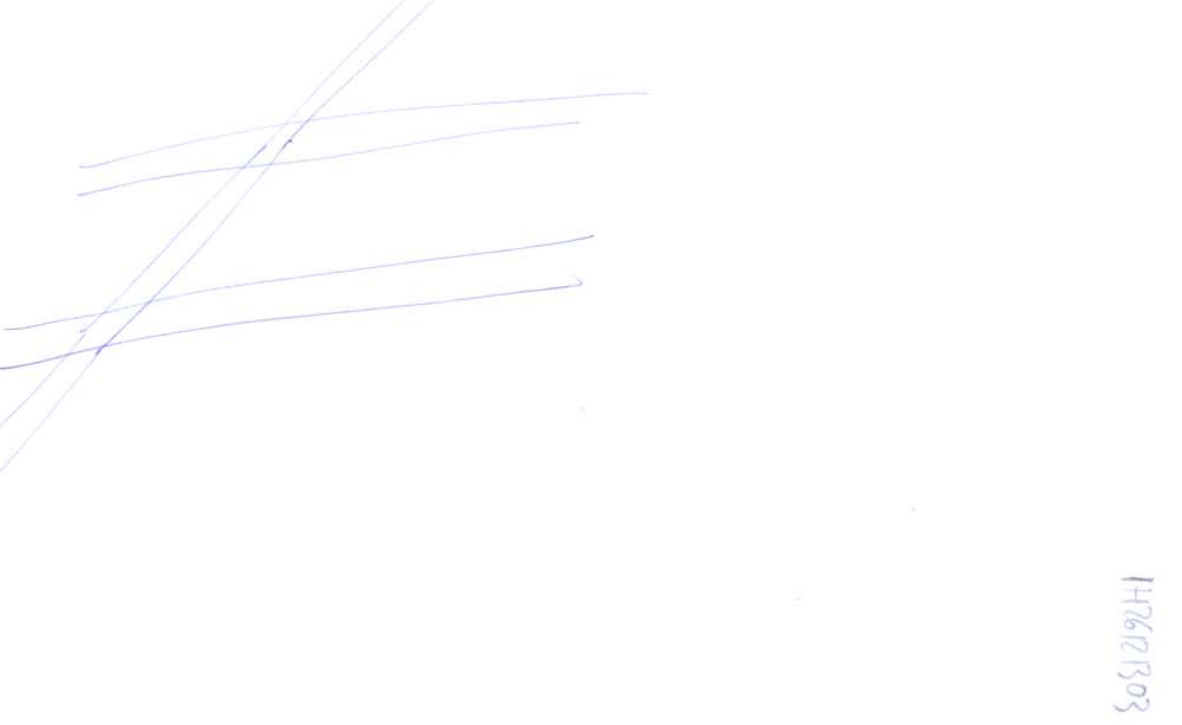




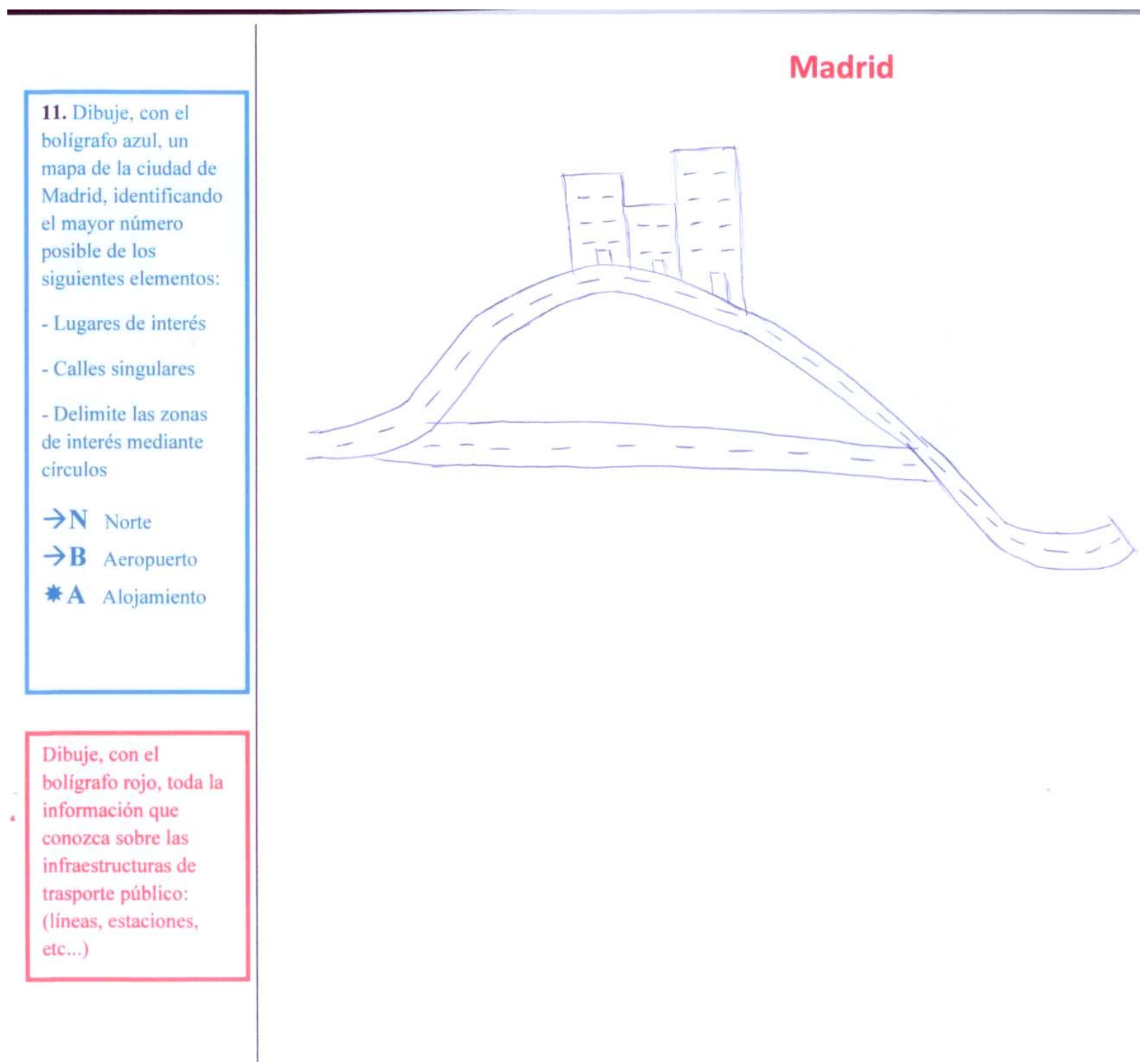

11. Dibuje, con

iguientes elementos:

Lugares de interés

Calles singulares

Delimite las zonas

de interés mediante

circulo

$\rightarrow \mathbf{N}$ Norte

$\rightarrow$ B Aeropuerto

* A Alojamiento 


\section{Madrid}

11. Draw, with blue

pen, a map of the city

of Madrid, identifying

the most of the

following elements:

Places of Interest

- Prominent Street

- Identify areas of

interest by circles

$\rightarrow \mathbf{N}$ North

$\rightarrow$ B Airport

- A Accommodation

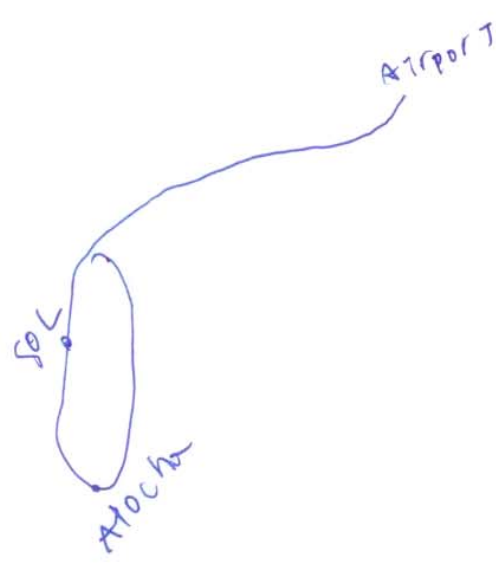

Draw, with red pen,

information on public

transport

infrastructure (lines,

stations, etc ...) 


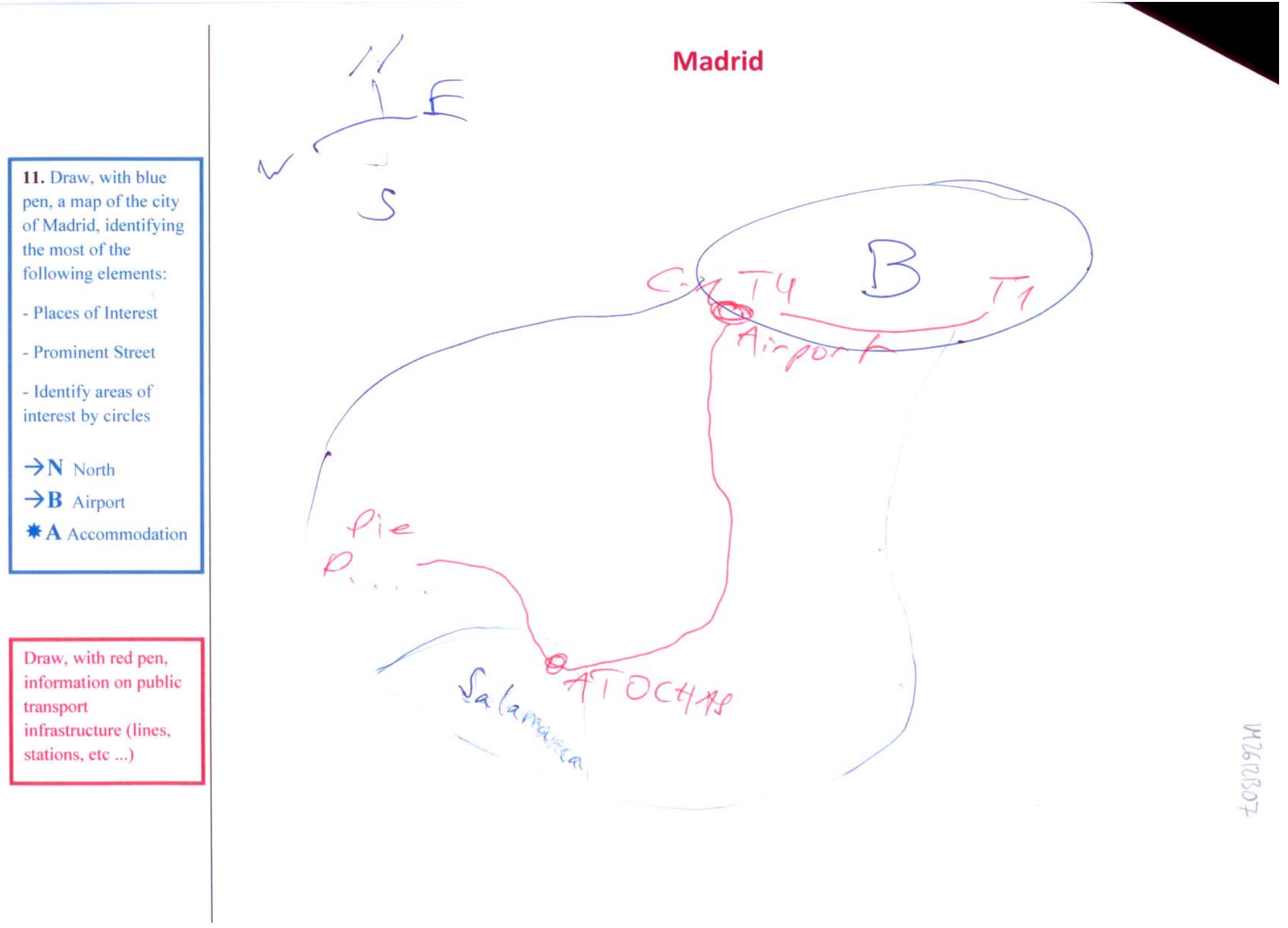




\section{Madrid}

11. Dibuje un mapa de
la ciudad de Madrid,
identificando los
siguientes elementos:
- Lugares de interés
- Calles singulares
- Zonas de interés
$\rightarrow \mathbf{N}$ Norte
$\rightarrow \mathbf{B}$ Aeropuerto
- A Alojamiento

Dibuje en rojo, la información sobre las

infraestructuras de

trasporte público:

(líneas, estaciones,

etc...) 


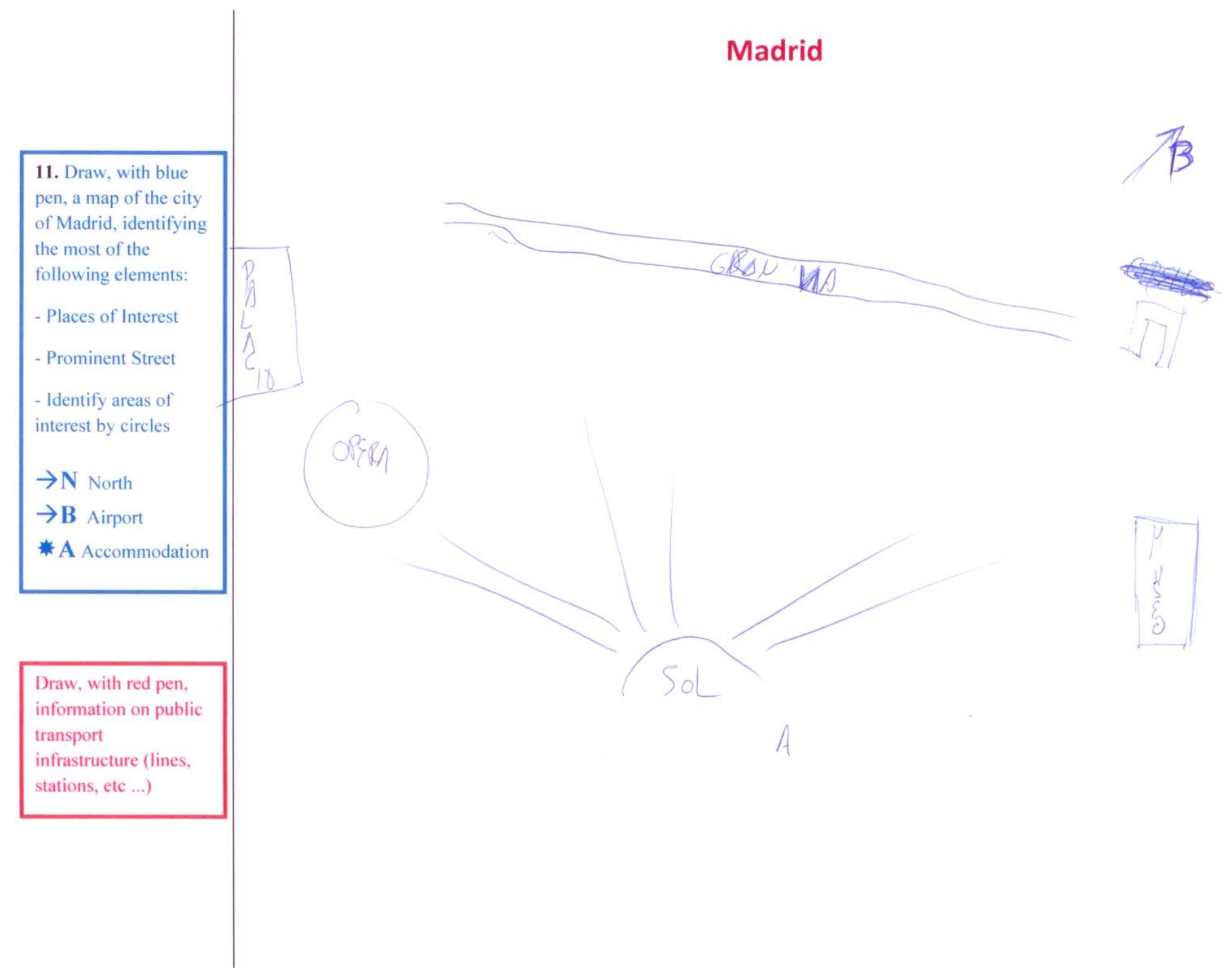




\section{ID12051410}

6. Dibuje un mapa de

la ciudad de Madrid,

identificando los

siguientes elementos:

- Lugares de interés

Calles singulares

- Zonas de interés

$\rightarrow \mathbf{N}$ Norte

$\rightarrow$ B Aeropuerto

* A Alojamiento

Dibuje en rojo, la

información sobre las

infraestructuras de

trasporte público:

(líneas, estaciones,

etc...)

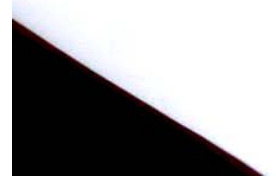

\section{Madrid}

N

peisal

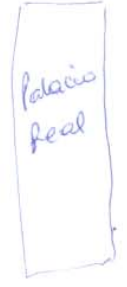

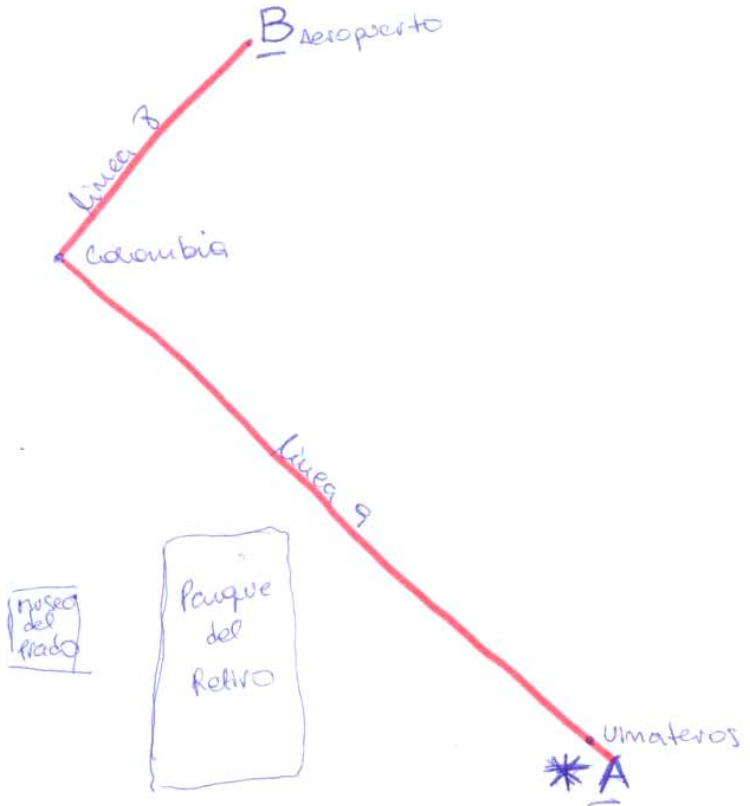




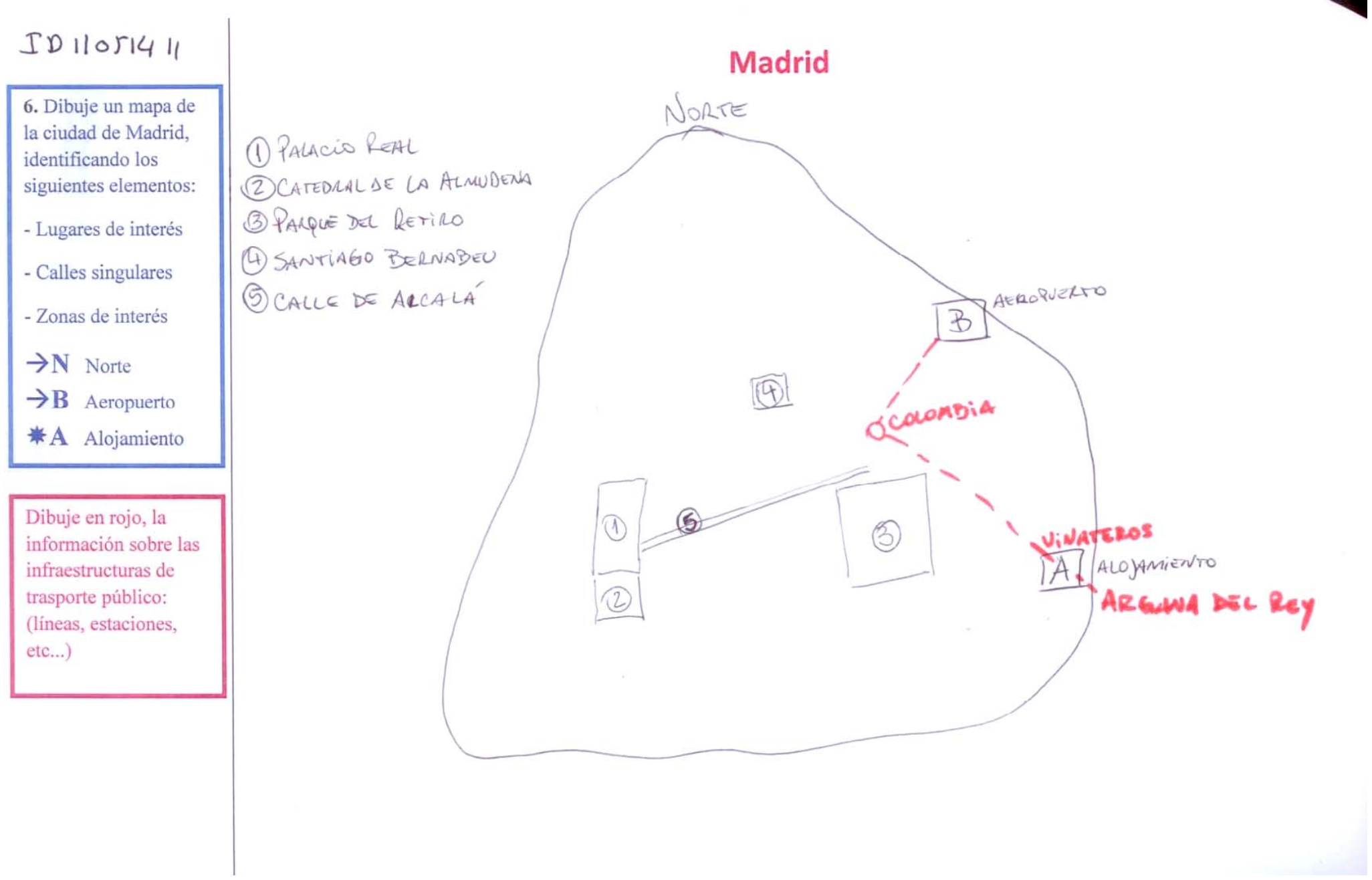




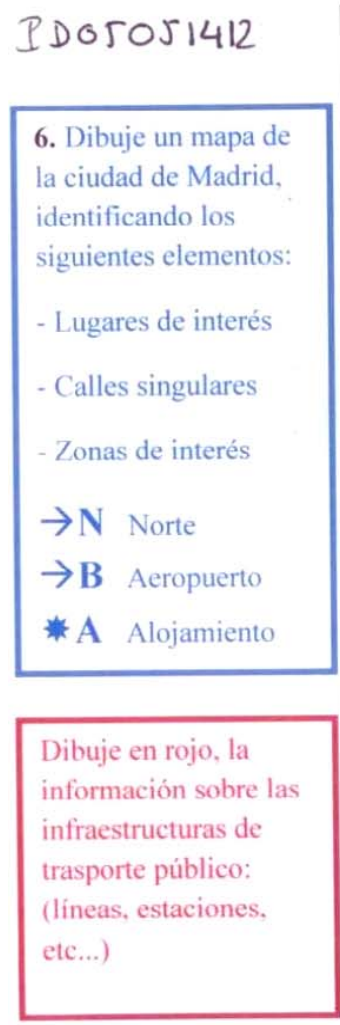

\section{Madrid}

2oul MUVEO

REIIA SUFIL

DEL pRONO
Xigamiento

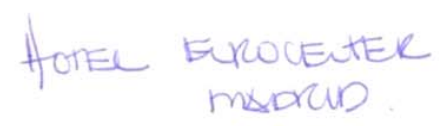

Alubeunan 
ID09051413

6. Dibuje un mapa de

la ciudad de Madrid,

identificando los

siguientes elementos:

- Lugares de interés

- Calles singulares

- Zonas de interés

$\rightarrow \mathbf{N}$ Norte

$\rightarrow$ B Aeropuerto

* A Alojamiento

Dibuje en rojo, la

información sobre las

infraestructuras de

trasporte público:

(lineas, estaciones,

etc...)

\section{Madrid}

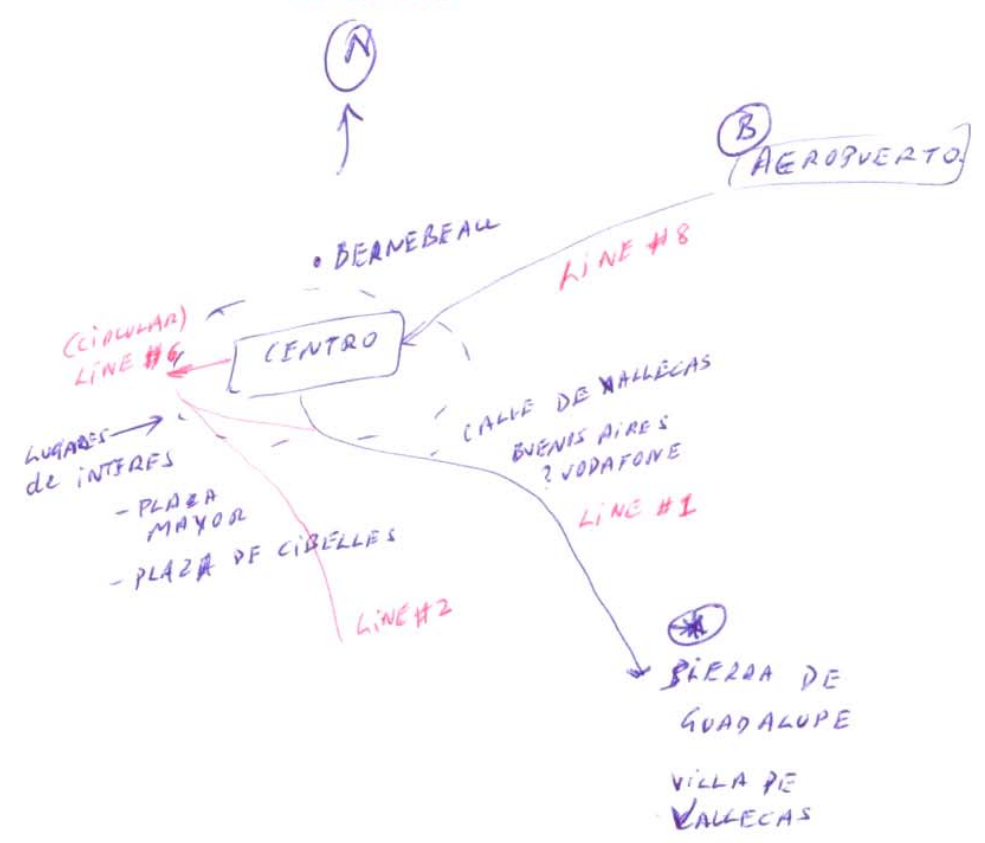



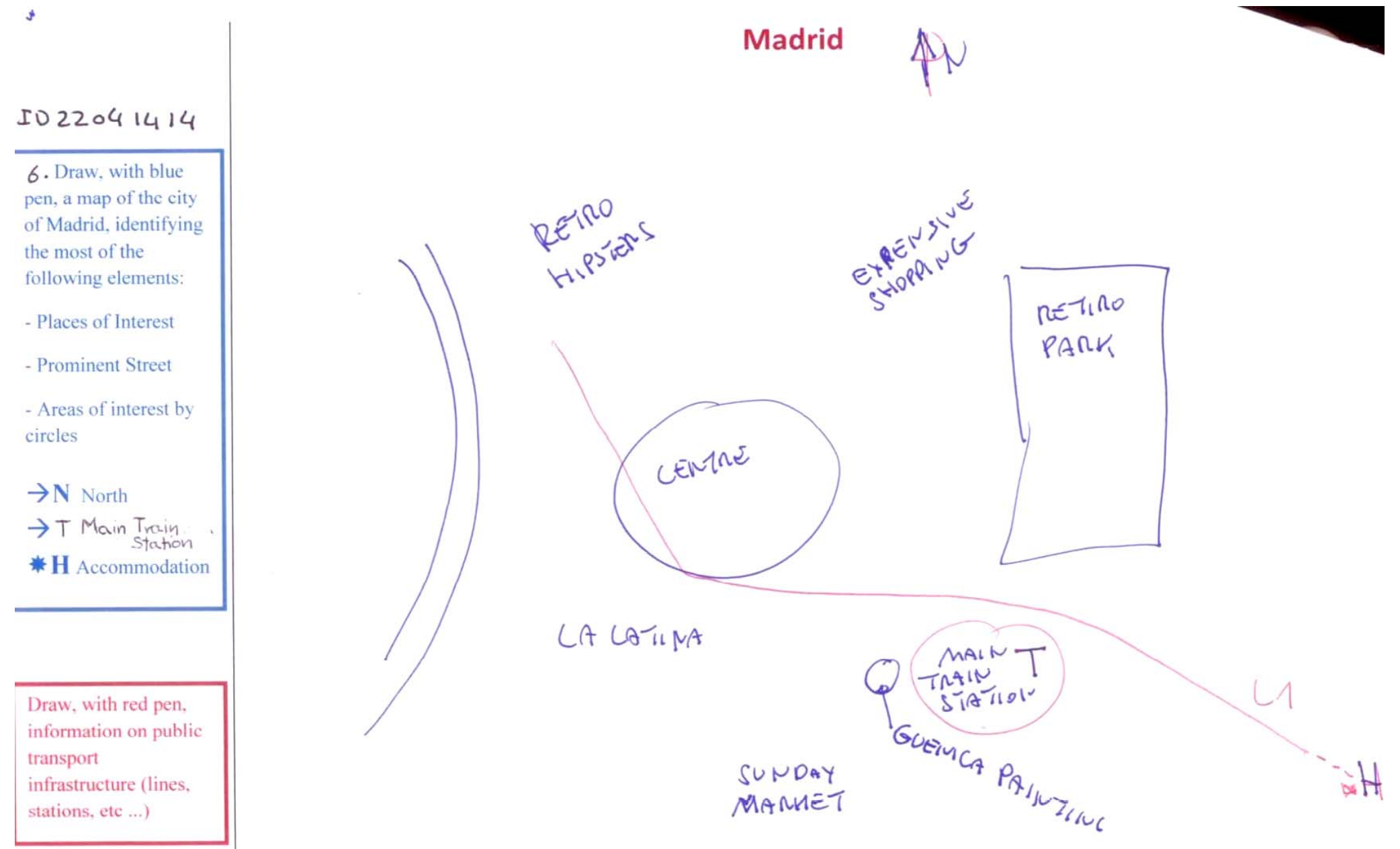


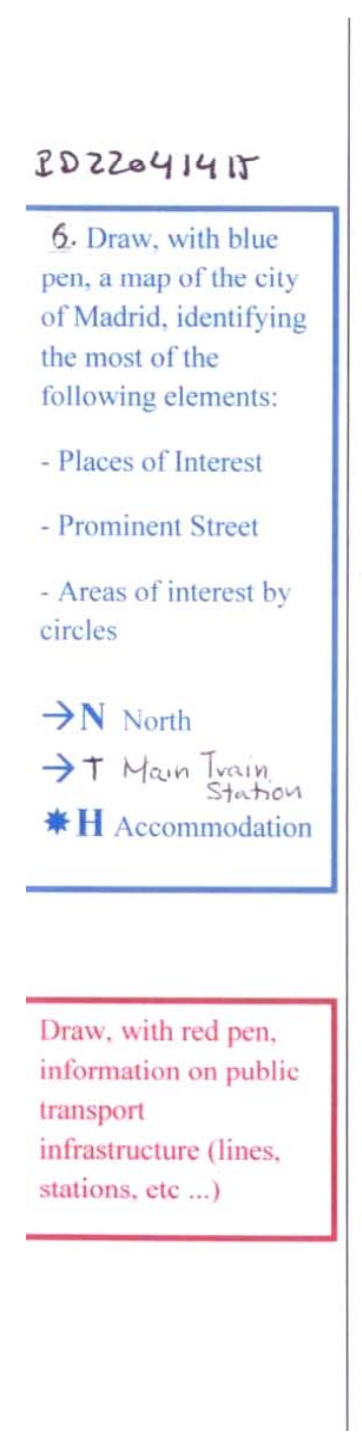

\section{Madrid}

7

Prominent Street

- Areas of interest by

$\rightarrow$ Main Train

Draw, with red pen.

information on public

stations, etc ...) 


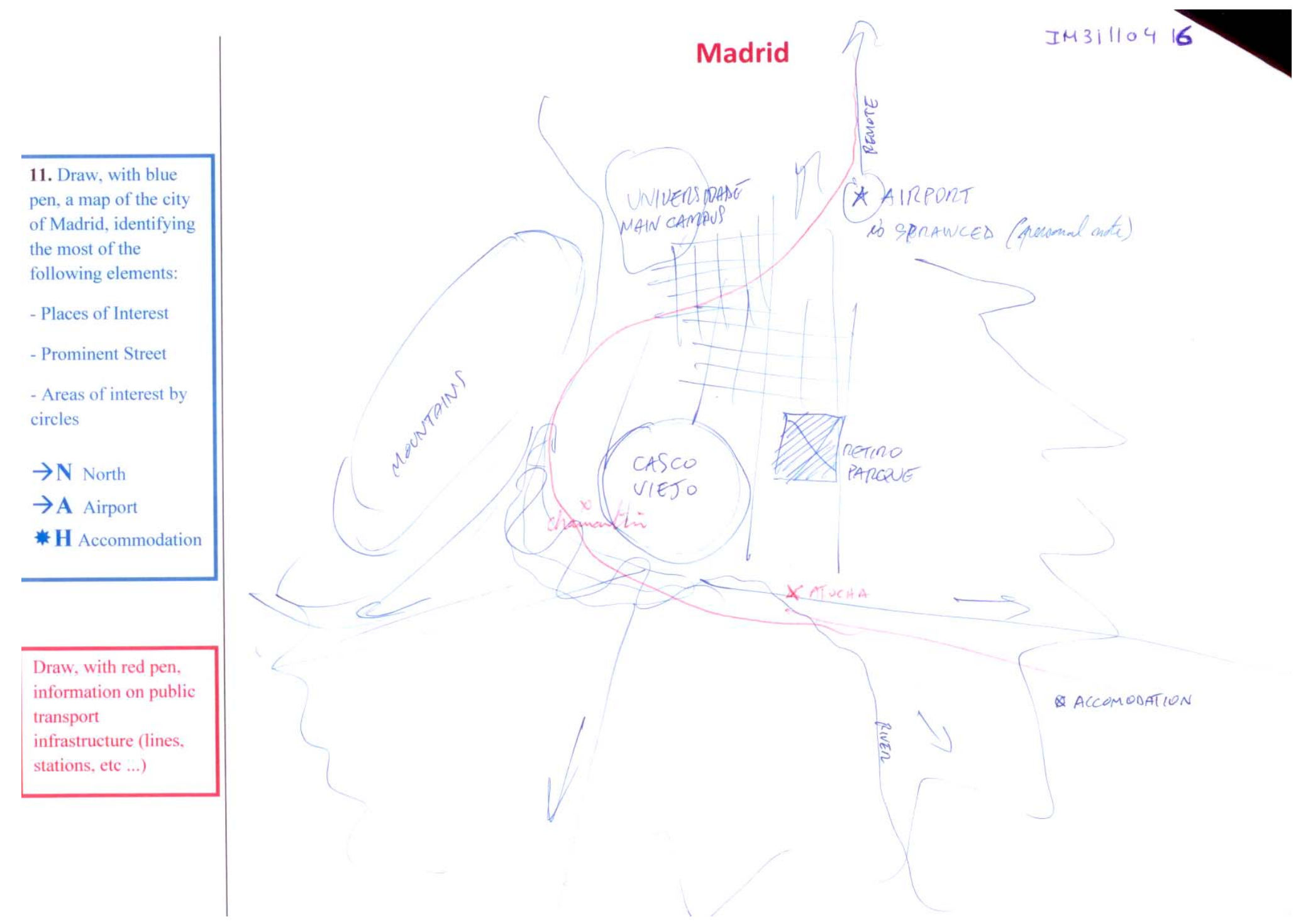




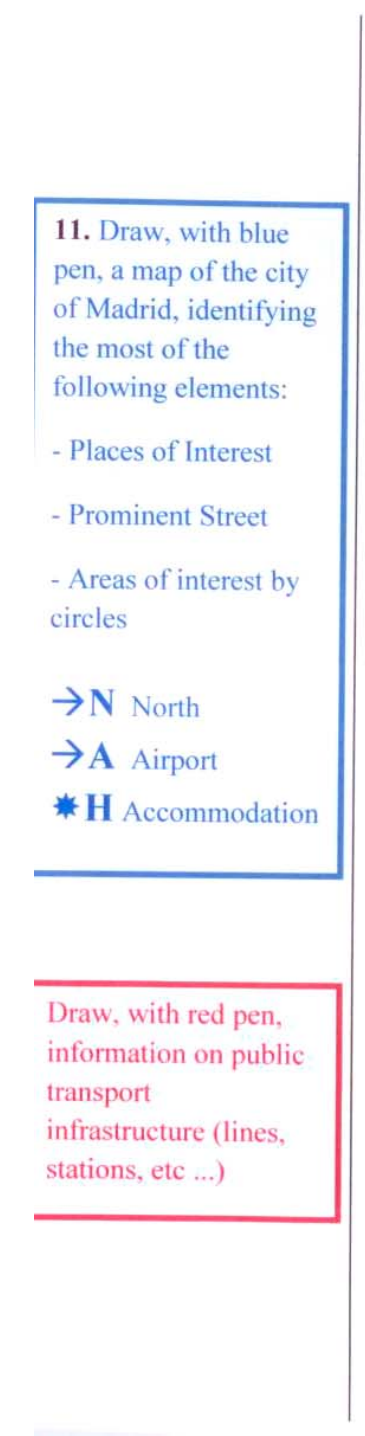

Madrid

IM31110417

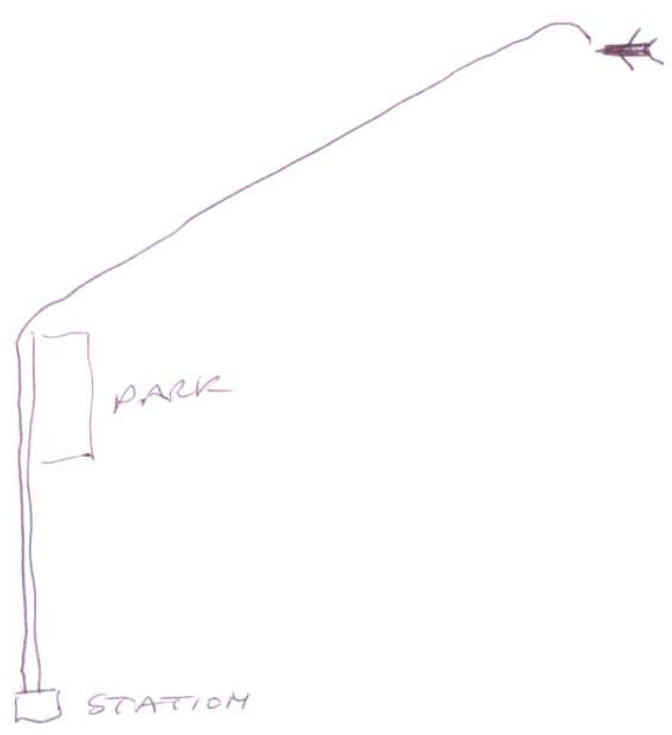




\section{Anexo 17. Factores que condicionan las actividades de los turistas durante su visita}

a) Duración de la estancia

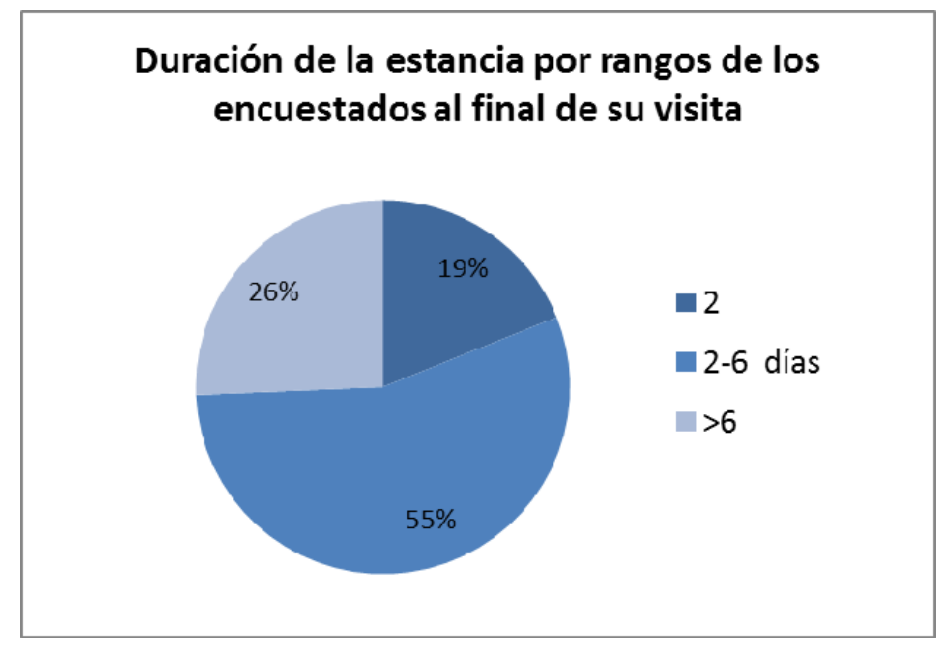

Figura A40: Duración de la estancia de los turistas encuestados al finalizar su visita por rangos de días.

b) Conocimiento turístico-espacial de la Madrid

I. Atractivos turísticos puntuales.

\section{Atractivos turísticos}

1 Sol

2 Palacio Real

3 Plaza Mayor

4 Parque del Retiro

5 Museo del Prado

6 Plaza de Cibeles

7 Estadio Santiago Bernabéu

8 Puerta de Alcalá

9 Museo Reina Sofía

10 Atocha

11 Plaza de España

12 Catedral de la Almudena

13 Templo de Debod

14 Palacio de Cibeles

15 Jardín Botánico

16 Estadio Vicente Calderón

17 Teatro Real

18 Callao

19 Caixa Fórum

20 Jardines de Sabatini

21 Banco de España

22 Museo Thyssen-Bornemisza
Repeticiones en mapa Repeticiones en

Diferencia

$$
27
$$

\section{9}

2

3


23 Plaza de Neptuno

24 Mercado de San Miguel

25 Plaza de Colón 3

26 Madrid Río

27 Ventas

284 Torres

29 Plaza de Oriente

30 Plaza de Santa Ana

31 Rastro

32 Viaducto

33 Casa de las Américas

34 C.C. de Príncipe Pío

35 Valdebebas

36 Edificio Endesa

37 Restaurante Botín

38 Escorial

39 Parlamento

40 Lago de la Casa de Campo

41 Casa de Campo

42 Viejo puente de Madrid Rio

43 Pirulí

44 Tubo de Madrid Rio

45 Chocolatería de San Ginés

46 Parque de San Isidro

47 Esculturas de la Castellana

48 Campo del Moro

49 IFEMA

50 Palacio de Cristal del Retiro

51 Plaza Diversia

52 Torre Picasso

53 Jardín Vertical

54 Sierra de Guadarrama

55 Instituto Cervantes

56 Parroquia San Jerónimo el Real

57 Campus Universitario

58 Ermita San Antonio Florida

59 Factory

60 Edificio España

61 Príncipe Pío

62 Corte Inglés

63 Museo Arqueológico

64 Ateneo

65 Biblioteca Nacional

66 Cortijo (flamenco)

67 Feria del Arte (Arco)

68 Gavia

69 Iglesia de los Jerónimos

70 Kilómetro 0 
71 Matadero

72 Museo Artes Decorativas

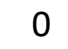

$-1$

73 Museo de Ciencias Naturales

0

\section{1}

74 Plaza de la Paja

0

0

75 Plaza de la Villa

0

76 Plaza de Pablo Ruiz Picasso

0

77 Pradera de San Isidro 0

78 Teatro Victoria 0

79 Teleférico

80 C.C. Xanadú (pista de esquí)

0

0

Total

323

$\begin{array}{ll}1 & -1 \\ 1 & -1\end{array}$

$1-1$

$1-1$

$1-1$

$1-1$

$1-1$

$1-1$

$1-1$

Tabla A3: Atractivos turísticos puntuales de Madrid incluidos en los mapas mentales y en las listas de libre recuerdo de los cuestionarios finales.

Los 5 atractivos con mayor presencia tanto en los mapas como en forma de texto son coincidentes: Sol, Palacio Real, Plaza Mayor, Parque del Retiro y Museo del Prado. Los atractivos con diferencias superiores a 5 en el número de repeticiones entre el registro gráfico y el realizado en forma de texto han sido: Plaza de Cibeles y Estación de Atocha con 9 repeticiones más en el mapa que en el texto, el Palacio Real y el Ayuntamiento con 6 repeticiones de diferencia, apareciendo en este caso el Palacio Real más veces en el texto que en el mapa y el Banco de España y la Plaza de España con 5 de repeticiones de diferencia a favor en el registro gráfico.

La siguiente tabla ilustra los porcentajes de los distintos rangos de atractivos agrupados por el número de repeticiones. Como se puede apreciar, los porcentajes de los diferentes rangos son muy similares entre los mapas mentales y los realizados en forma de texto.

$\begin{array}{lcr} & \text { Mapa } & \text { Texto } \\ \text { Atractivos con más de } 15 \text { repeticiones } & 8 \% & 9 \% \\ \text { Atractivos con entre } 10 \text { y } 14 \text { repeticiones } & 9 \% & 5 \% \\ \text { Atractivos con entre } 5 \text { y } 9 \text { repeticiones } & 14 \% & 11 \% \\ \text { Atractivos con entre } 2 \text { y } 4 \text { repeticiones } & 17 \% & 28 \% \\ \text { Atractivos con } 1 \text { repetición } & 52 \% & 47 \%\end{array}$

Tabla A4: Porcentajes por rangos de repeticiones de atractivos turísticos puntuales en los mapas mentales y en las listas de libre recuerdo de los cuestionarios finales.

II) Ejes de Madrid.

Ejes

Gran Vía

Paseo del Prado

Alcalá

Castellana

Huertas

Arenal

Bailén (Viaducto)
Repeticiones en mapa Repeticiones en

23

17

4

2

31

2 1

2 1

1

1 


$\begin{array}{llcc}8 & \text { Cuchilleros (Restaurante Botín) } & 1 & 1 \\ 9 & \text { Mayor } & 1 & 1 \\ 10 & \text { Carretas } & 1 & 0 \\ 11 & \text { Delicias } & 1 & 1 \\ 12 & \text { Funicular } & 1 & 0 \\ 13 & \text { Fuencarral } & 1 & 1 \\ 14 & \text { Jerónimo } & 1 & 0 \\ 15 & \text { Paseo del Pintor Rosales } & 1 & 0 \\ 16 & \text { Paseo de Recoletos } & 1 & 2 \\ 17 & \text { Princesa } & 1 & 3 \\ 18 & \text { Pico Espigüete (alojamiento } & 1 & 0 \\ 19 & \text { Villa Franca } & 1 & 0 \\ 20 & \text { Atocha } & 0 & 1 \\ 21 & \text { Cava Baja } & 0 & 1 \\ 22 & \text { Preciados } & 0 & 1 \\ 23 & \text { Cervantes } & 0 & 1 \\ 24 & \text { Serrano } & 0 & 1 \\ 25 & \text { Espíritu Santo } & 0 & 1 \\ 26 & \text { Padre Damián } & 0 & 1 \\ 27 & \text { Callejón de San Ginés } & 0 & 1 \\ 28 & \text { Sagasta } & 0 & 1 \\ 29 & \text { Príncipe Pío } & 0 & 1 \\ & & \text { Total } & \text { Total } \\ & & 48 & 44\end{array}$

Tabla A5: Ejes de Madrid incluidos en los mapas mentales y en las listas de libre recuerdo de los cuestionarios finales.

Tras la Gran Vía, se aprecian ciertas discrepancias en los pesos del resto de los ejes entre la captura gráfica y la realizada en forma de texto, que son en cualquier caso relativas, dada la baja repetitividad de las mismas en todo su conjunto. Cabe destacar en ambos casos la presencia de calles asociadas a aspectos concretos de la experiencia del turista como la calle Cuchilleros y el Callejón de San Ginés donde se ubican respectivamente el restaurante Botín y una conocida chocolatería; la calle Fuencarral o Serrano vinculadas a compras y otras asociadas al lugar de alojamiento como la calle Pico Espigüete o Delicias.

Caben destacar varios casos en los que aparecen dibujados ejes en torno a Sol, en la mayoría de las ocasiones sin identificar y donde se puede intuir una posible influencia en su representación, de los productos cartográficos consultados. 


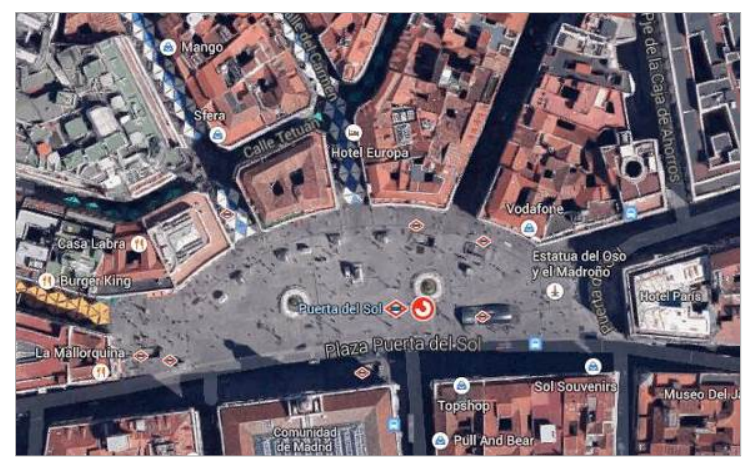

a

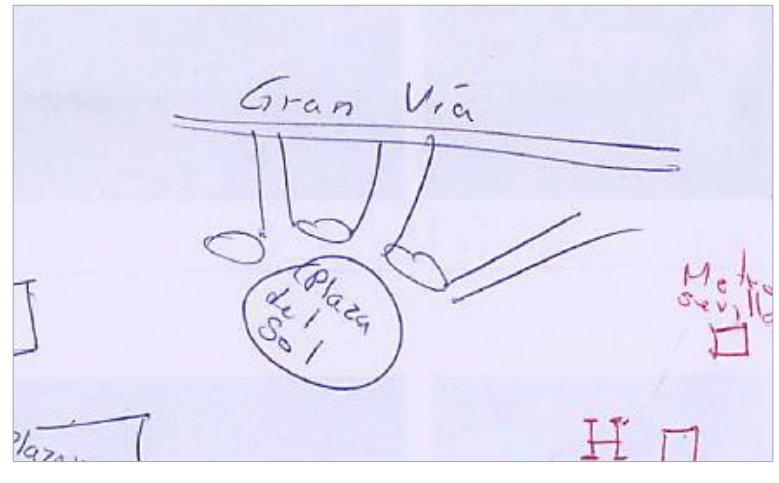

C

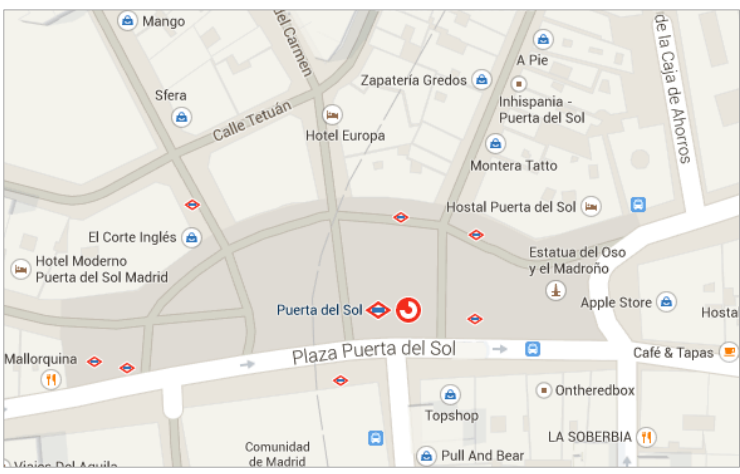

b

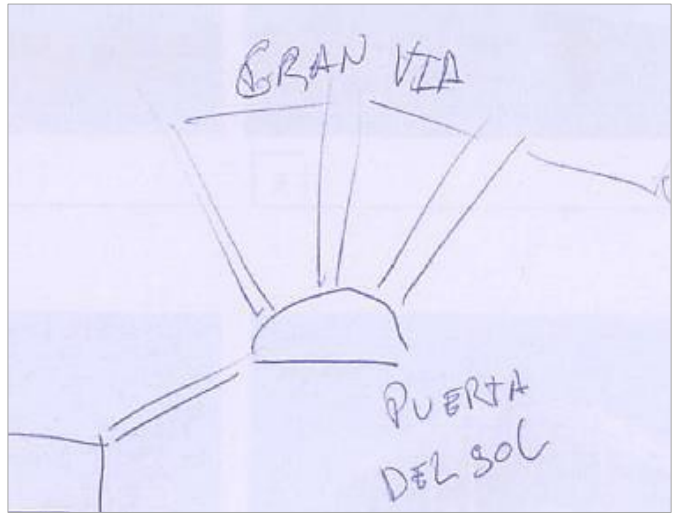

d

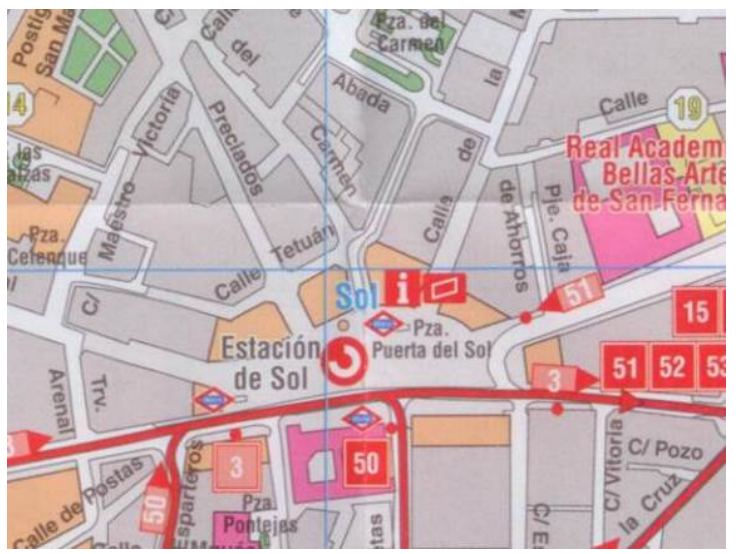

e

Figura A41: Zona de Sol en a) imagen de satélite de Google Maps, b) mapa de Google Maps, c) y d) mapas mentales de dos turistas de Madrid cuyos ejes entorno a Sol se representan de forma muy similar a como lo hace Google Maps y e) Zona de Sol en el mapa en papel suministrado con el billete turístico de transporte del CRTM, cuya representación difiere significativamente de las anteriores. 


$\begin{array}{ll}1 & \text { Centro } \\ 2 & \text { La Latina } \\ 3 & \text { Lavapiés } \\ 4 & \text { Salamanca } \\ 5 & \text { Argüelles } \\ 6 & \text { Chamberí } \\ 7 & \text { Chueca } \\ 8 & \text { Serrano } \\ 9 & \text { Cuzco } \\ 10 & \text { Malasaña } \\ 11 & \text { Tribunal } \\ 12 & \text { Chamberí } \\ 13 & \text { "Museos" } \\ 14 & \text { "Vida nocturna" } \\ 15 & \text { "Compras" } \\ 16 & \text { Opera } \\ 17 & \text { Delicias } \\ 18 & \text { "Cultural" } \\ 19 & \text { Las Letras } \\ 20 & \text { Huertas } \\ 21 & \text { Retiro } \\ 22 & \text { Vallecas } \\ 23 & \text { Callao } \\ 24 & \text { Aeropuerto } \\ & \end{array}$

$\begin{array}{cc}6 & 25 \\ 4 & 4 \\ 2 & 1 \\ 1 & 3 \\ 1 & 0 \\ 1 & 0 \\ 1 & 1 \\ 1 & 0 \\ 1 & 1 \\ 1 & 3 \\ 1 & 1 \\ 1 & 0 \\ 1 & 5 \\ 1 & 0 \\ 1 & 1 \\ 0 & 2 \\ 0 & 1 \\ 0 & 1 \\ 0 & 1 \\ 0 & 1 \\ 0 & 1 \\ 0 & 1 \\ 0 & 1 \\ 0 & 1 \\ \text { Total } & 1 \\ 24 & 55\end{array}$

Tabla A6: Zonas turísticas de Madrid incluidas en los mapas mentales y en las listas de libre recuerdo de los cuestionarios finales. 
Lugares de interés turístico
alrededor de Madrid

Toledo

El Escorial

Sierra de Guadarrama

Alcalá de Henares

Ávila

Segovia

Sevilla

Alcobendas

Córdoba

San Sebastián

Valle de los Caídos

Zaragoza

\section{Repeticiones}

23

4

4

3

3

2

2

1

1

1

1

1

Tabla A7: Lugares de interés turístico alrededor de Madrid mencionados por los turistas al final de su visita.

c) Conocimiento de infraestructuras de transporte

\section{Estaciones de metro}

Sol

Atocha

Aeropuerto

Gran Vía

Opera

Callao

La Latina

Atocha Renfe

Banco de España

Bilbao

Cuatro Caminos

Plaza de España

Nuevos Ministerios

San Bernardo

Santiago Bernabéu

Tribunal

Vinateros (alojamiento de la cartógrafa)
Repeticiones en el

mapa

19

12

11

8

6

5

4

3

3

3

3

3

2

2

2

2

2

Tabla A8: Estaciones de metro incluidas en los mapas mentales de los cuestionarios finales. 
Líneas de metro

Línea 1

Línea 2

Línea 3

Línea 8

Línea 9

Línea 4

Línea 6

Línea 10
Repeticiones en el mapa

5

2

2

2

2

1

1

1

Tabla A9: Líneas de metro incluidas en los mapas mentales de los cuestionarios finales.

d) Percepción de la ciudad como destino turístico

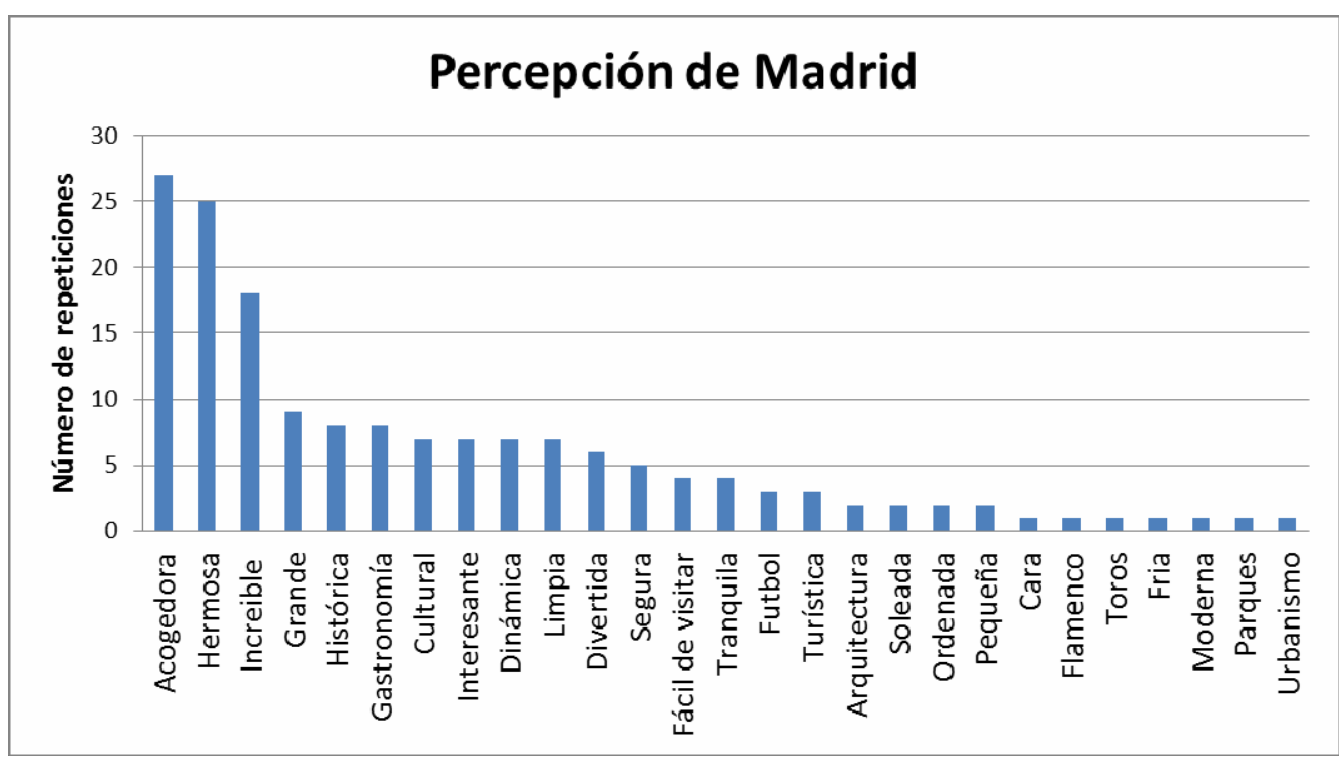

Figura A42: Adjetivos utilizados por los turistas para describir Madrid una vez finalizada su visita.

e) Valoración de la experiencia

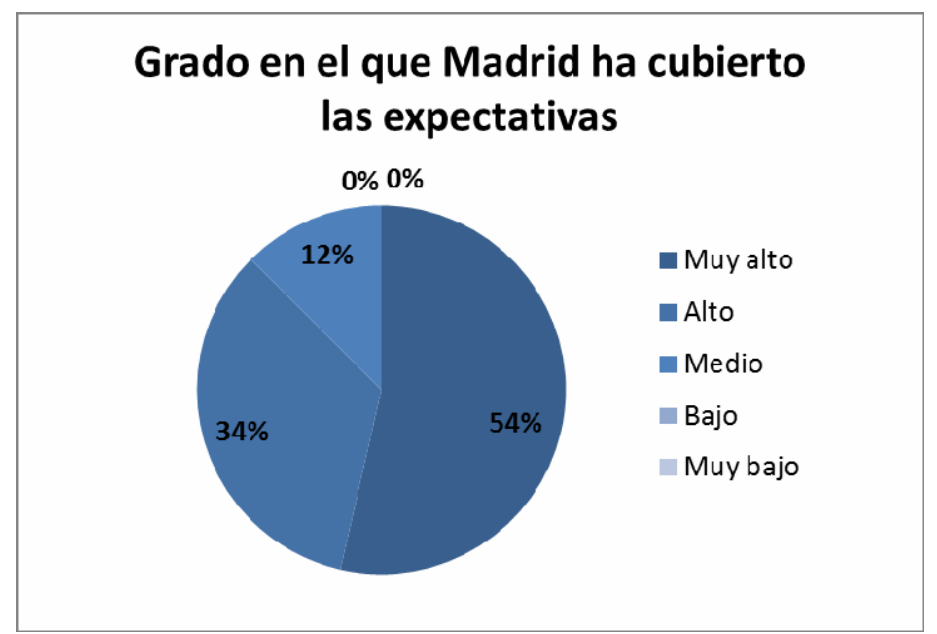

Figura A43: Grado en el que Madrid ha cubierto las expectativas de los turistas encuestados al finalizar su visita. 
Anexo 18. Mapas mentales de los turistas encuestados al final de su visita. 


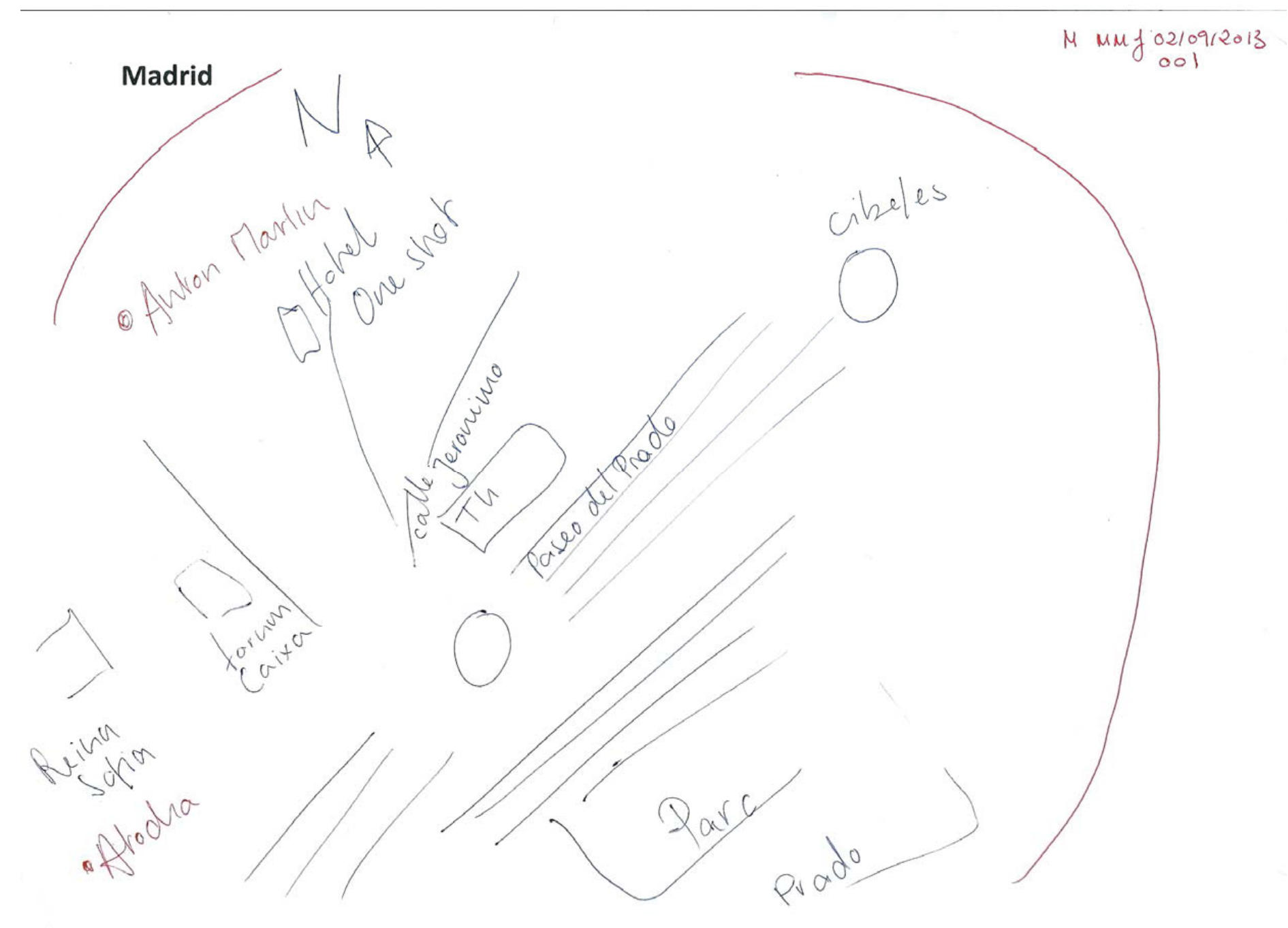



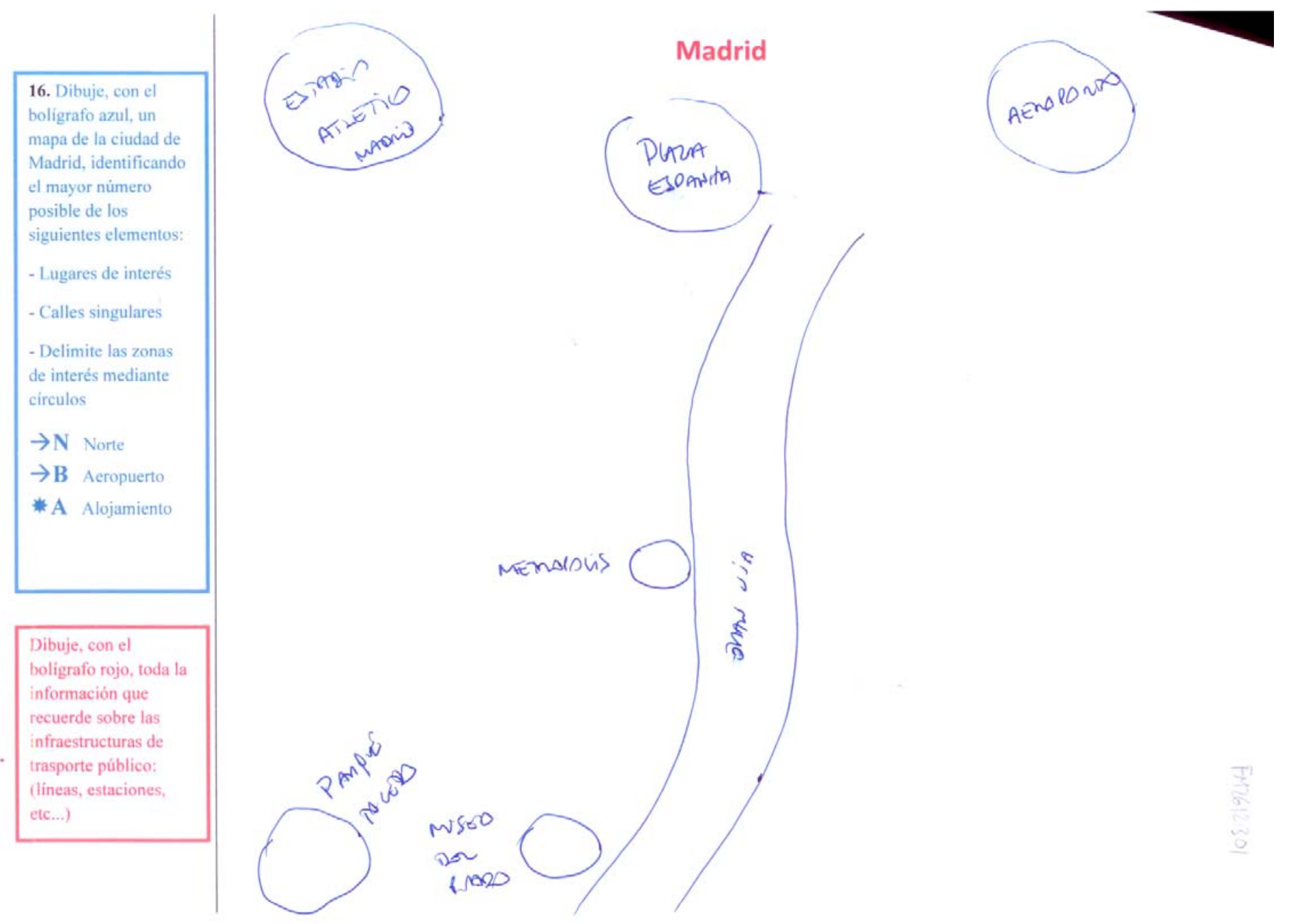


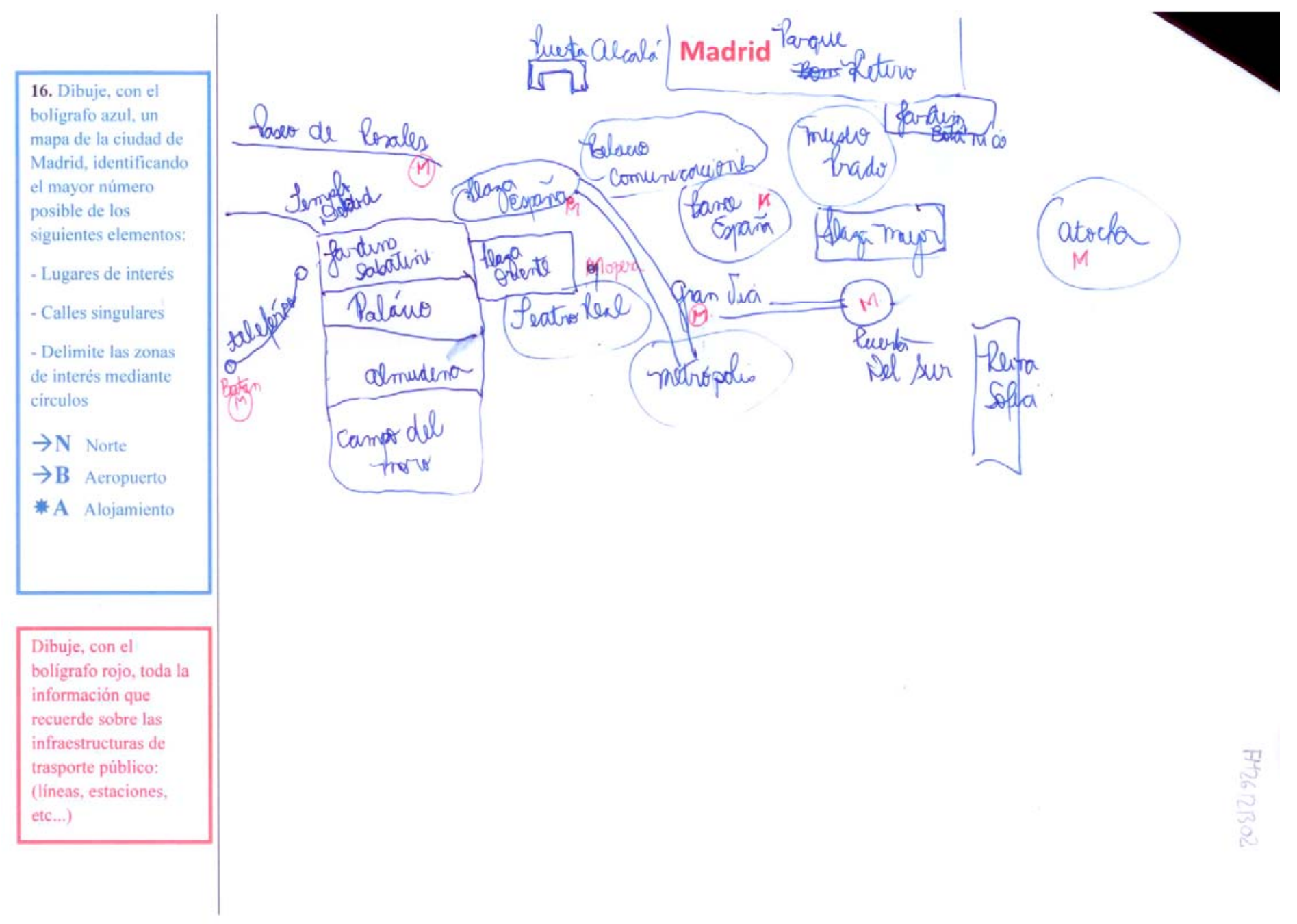




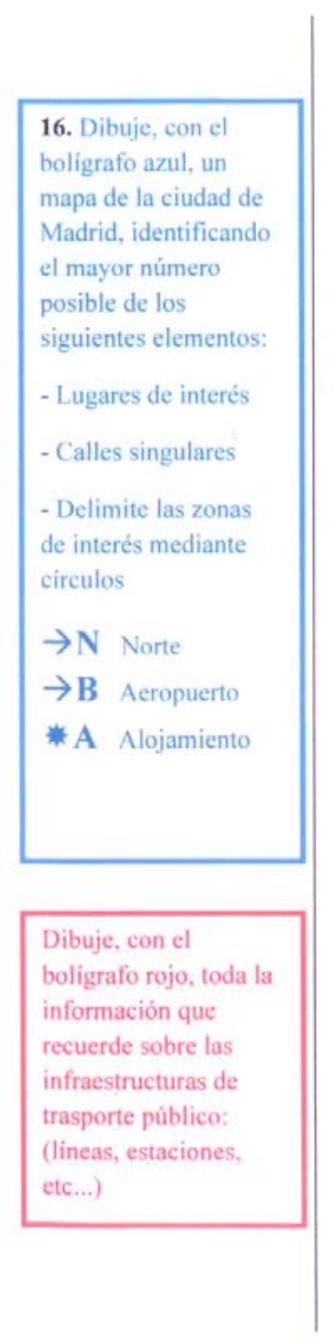

Madrid

$+$

- Lugares de interés

de interés mediante

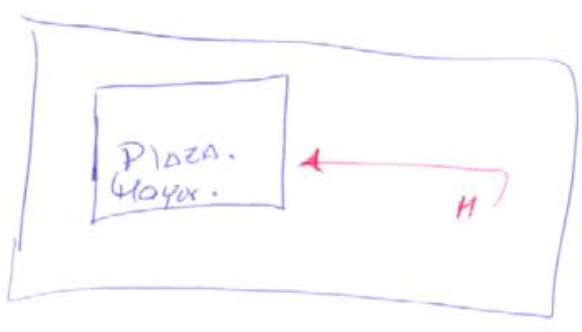




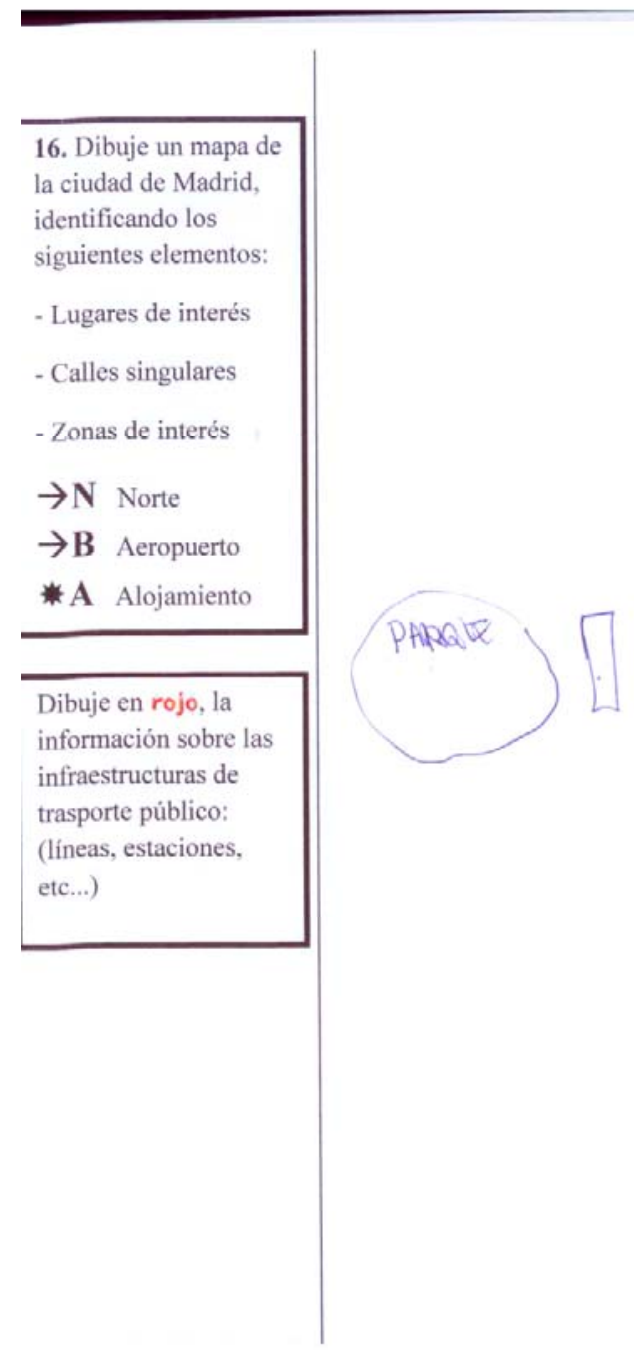

Madrid

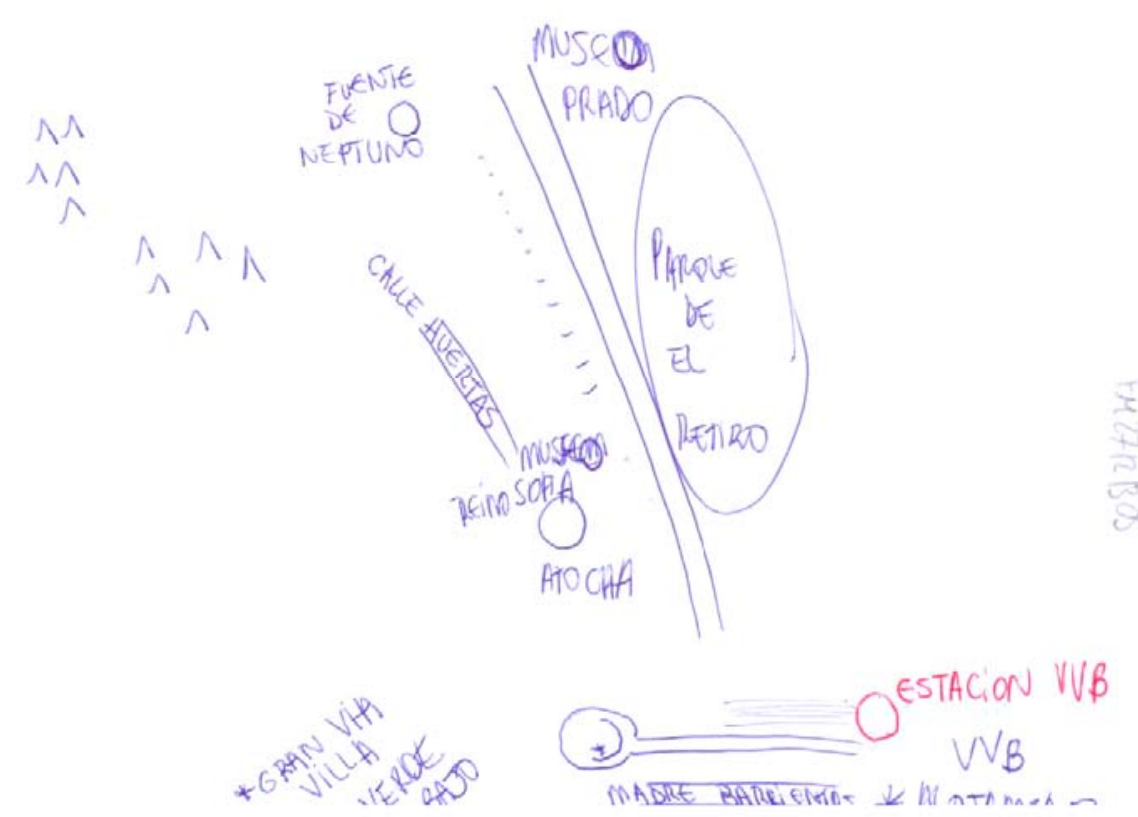




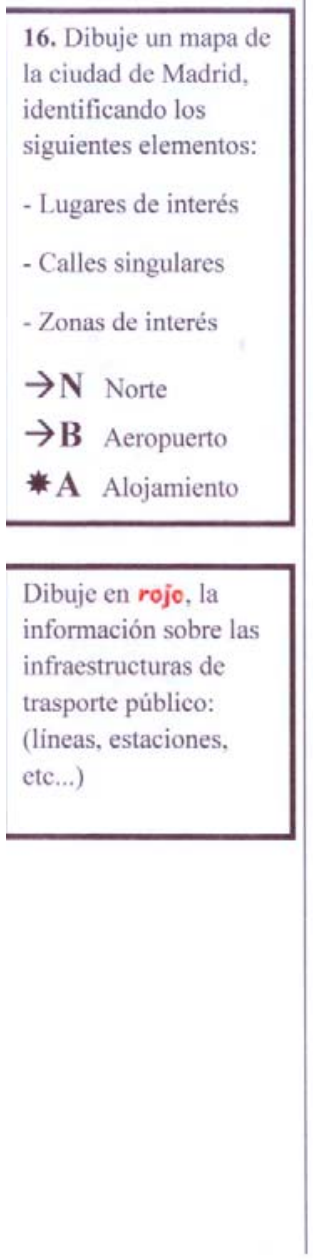

Madrid
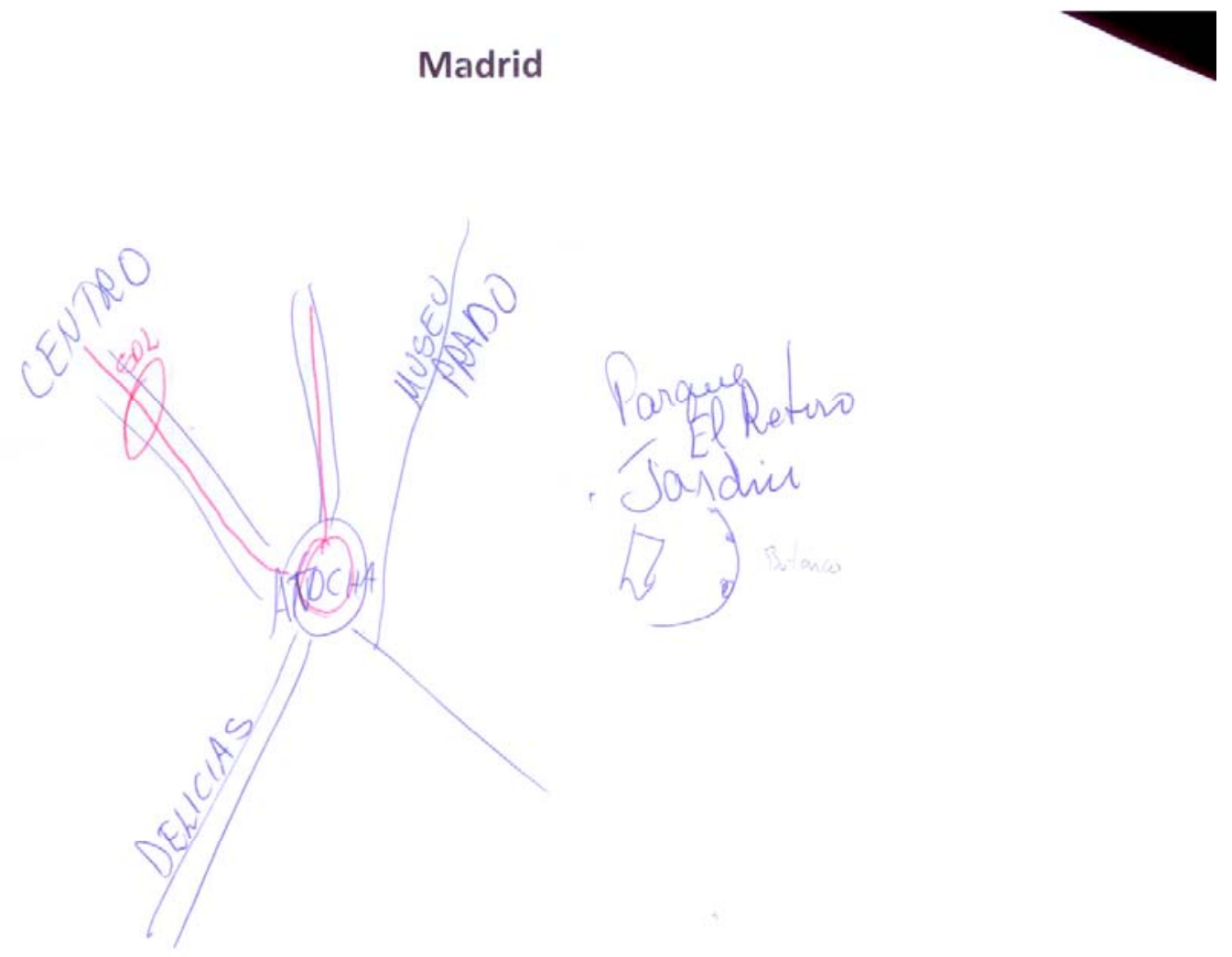


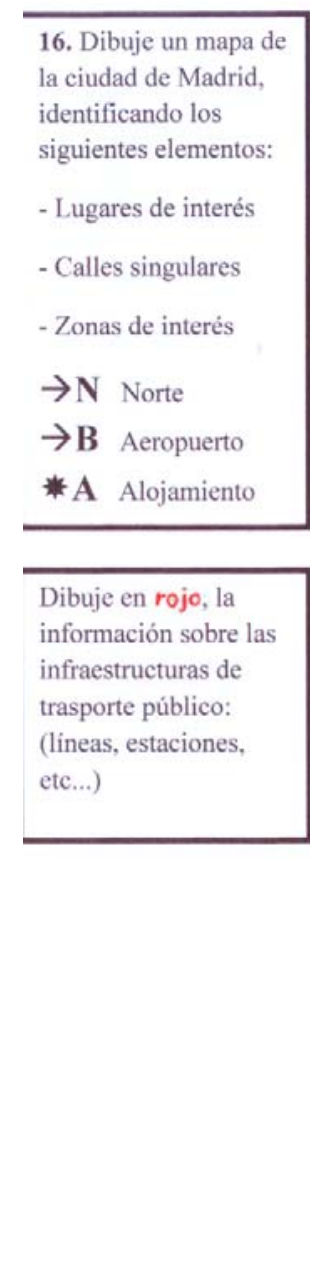

Madrid

intos:

- Lugares de interés

calles singulares

Tonas de interis
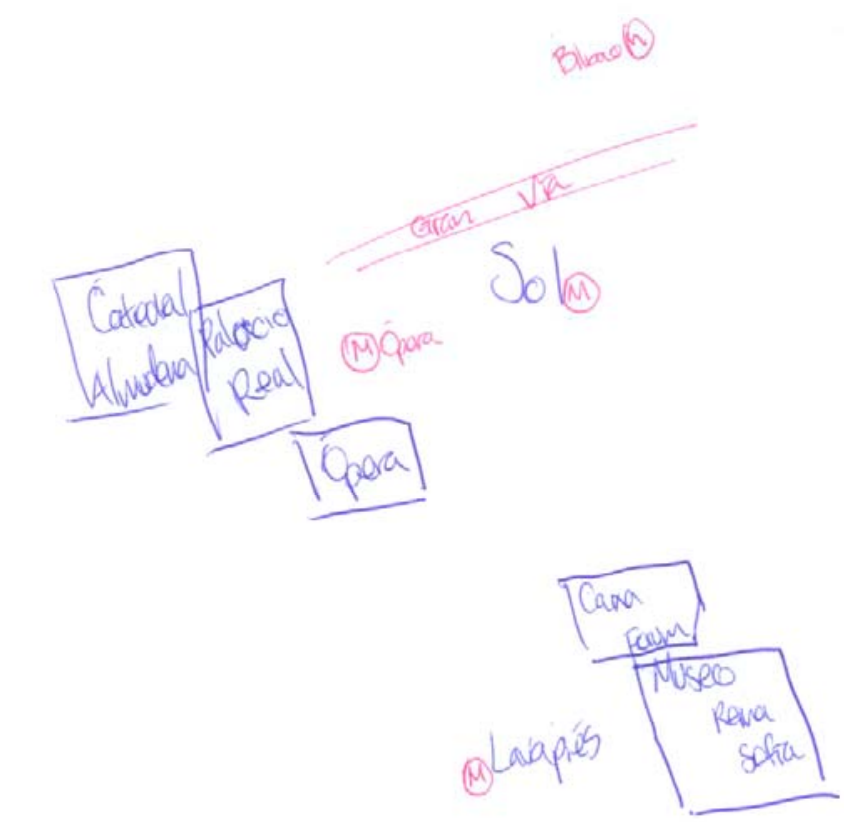

$T_{4 a}$

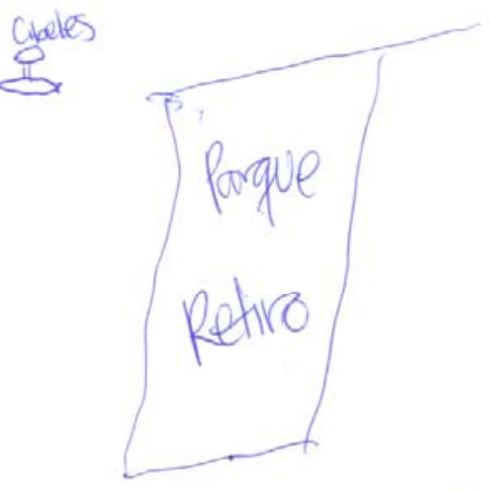




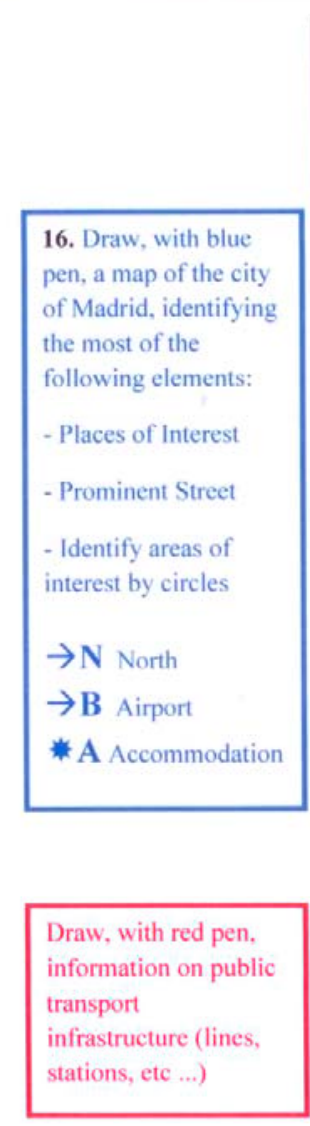

Madrid

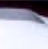

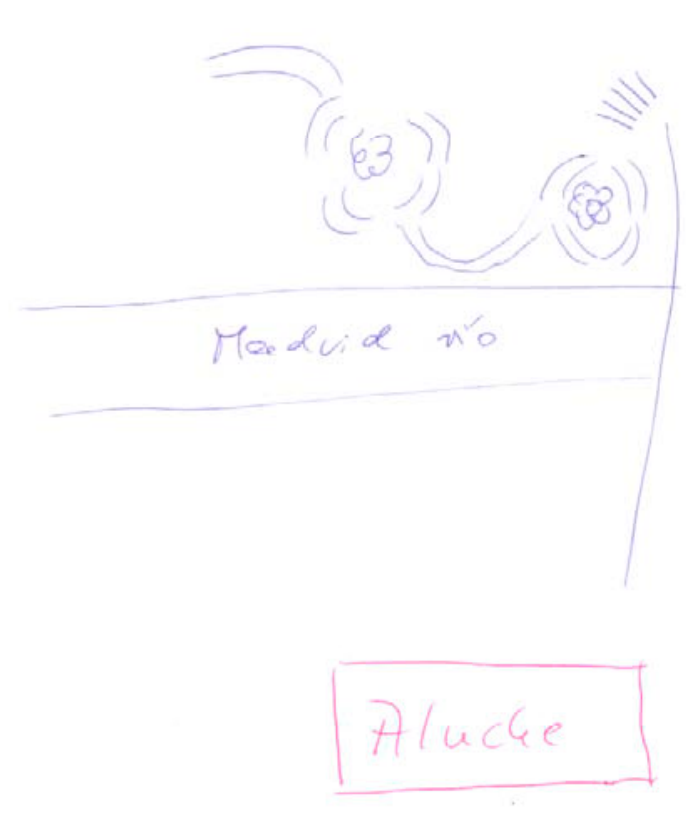




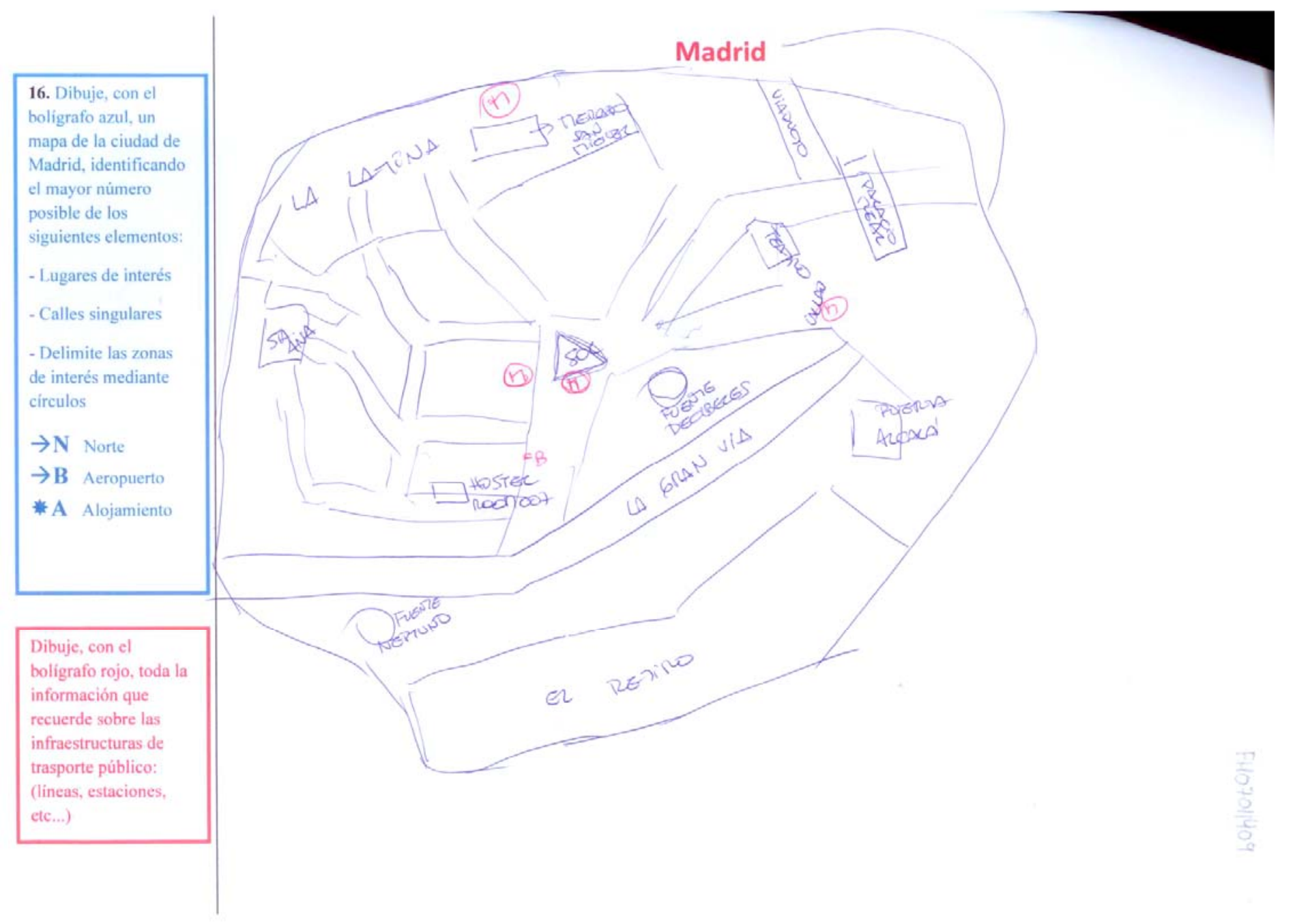




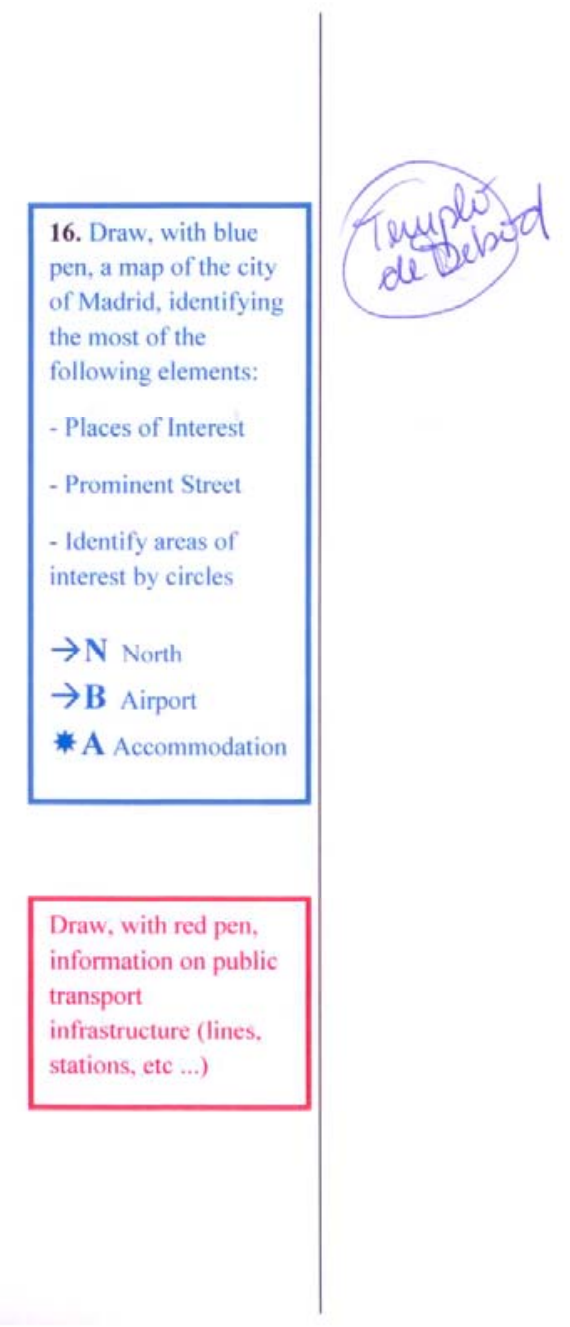

Madrid

$\checkmark$

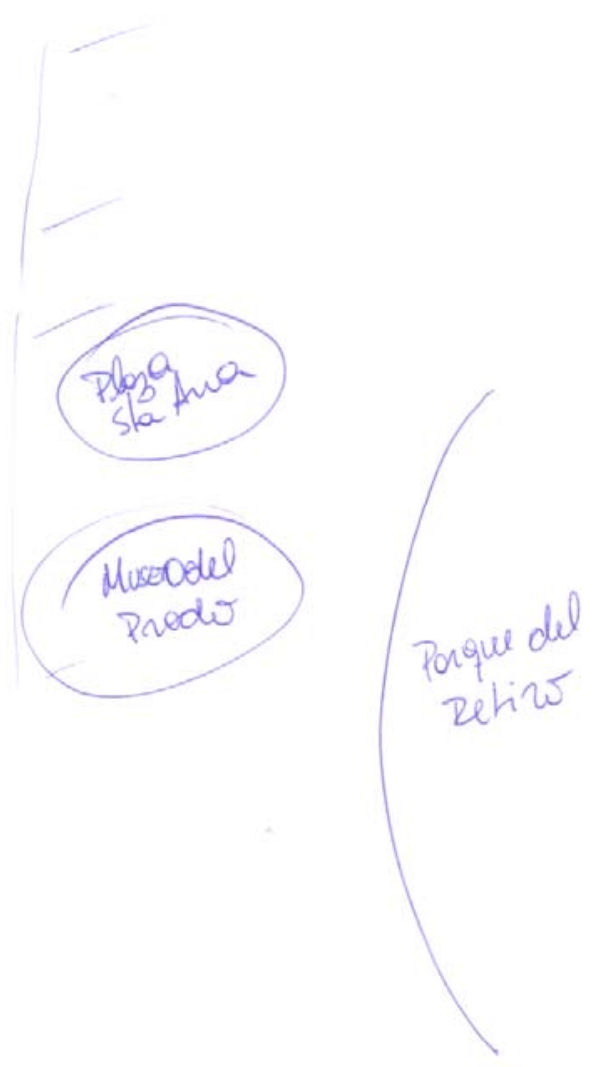




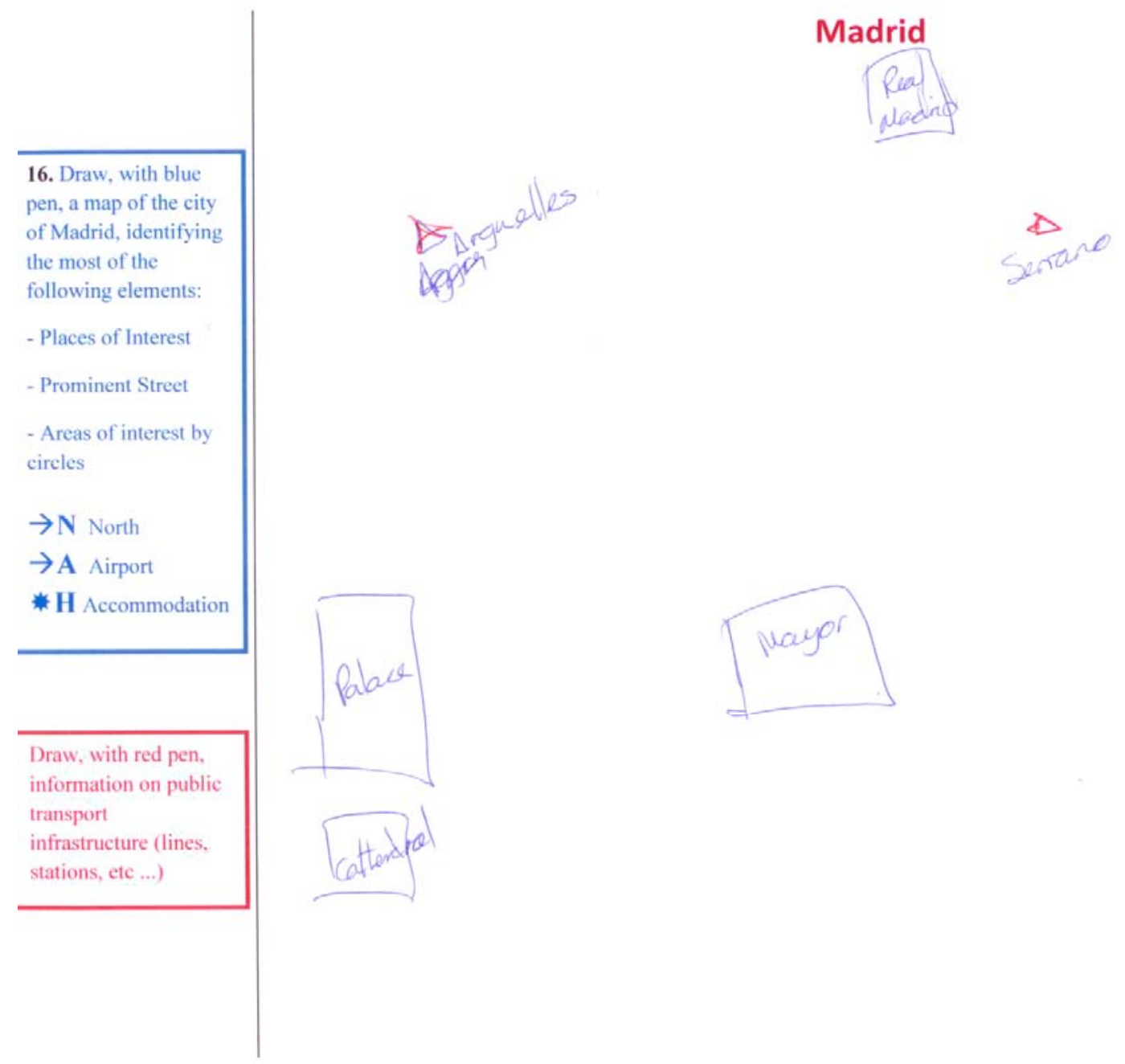

\section{Madrid}

proas
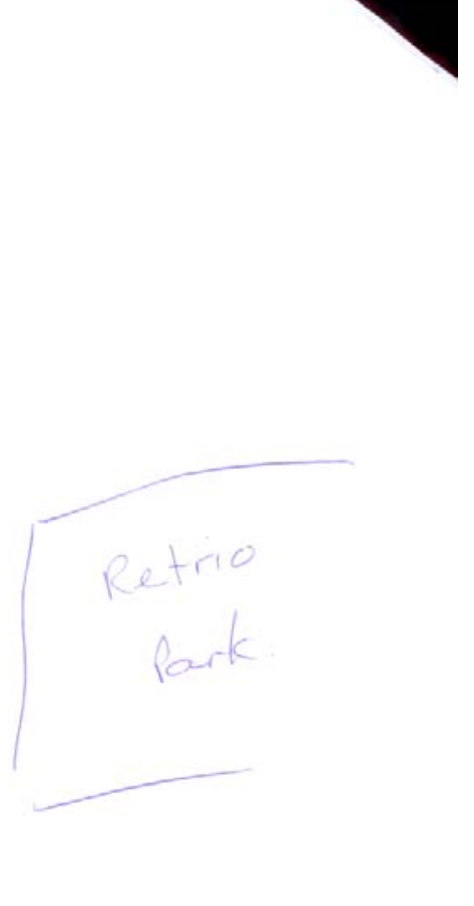

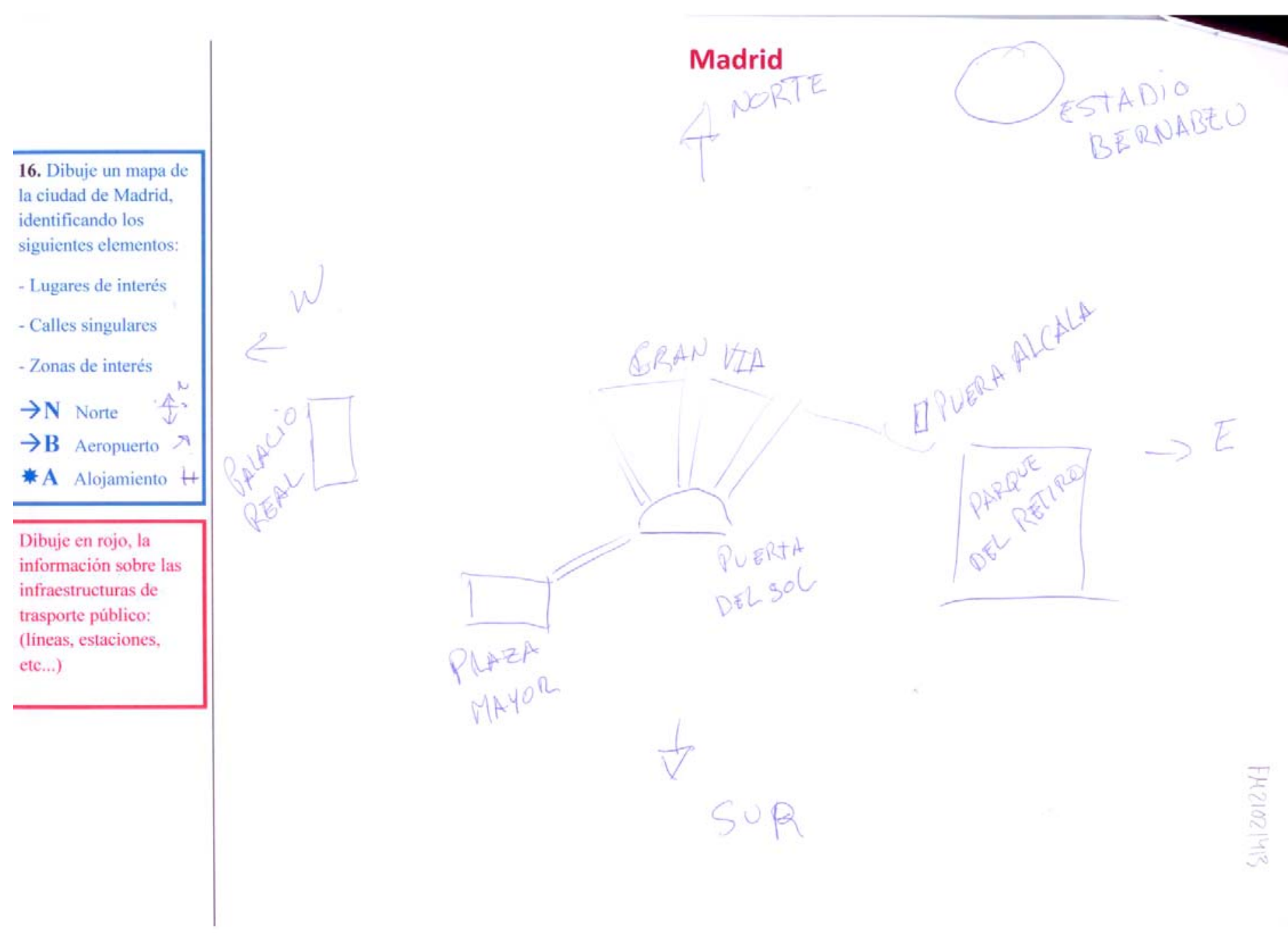


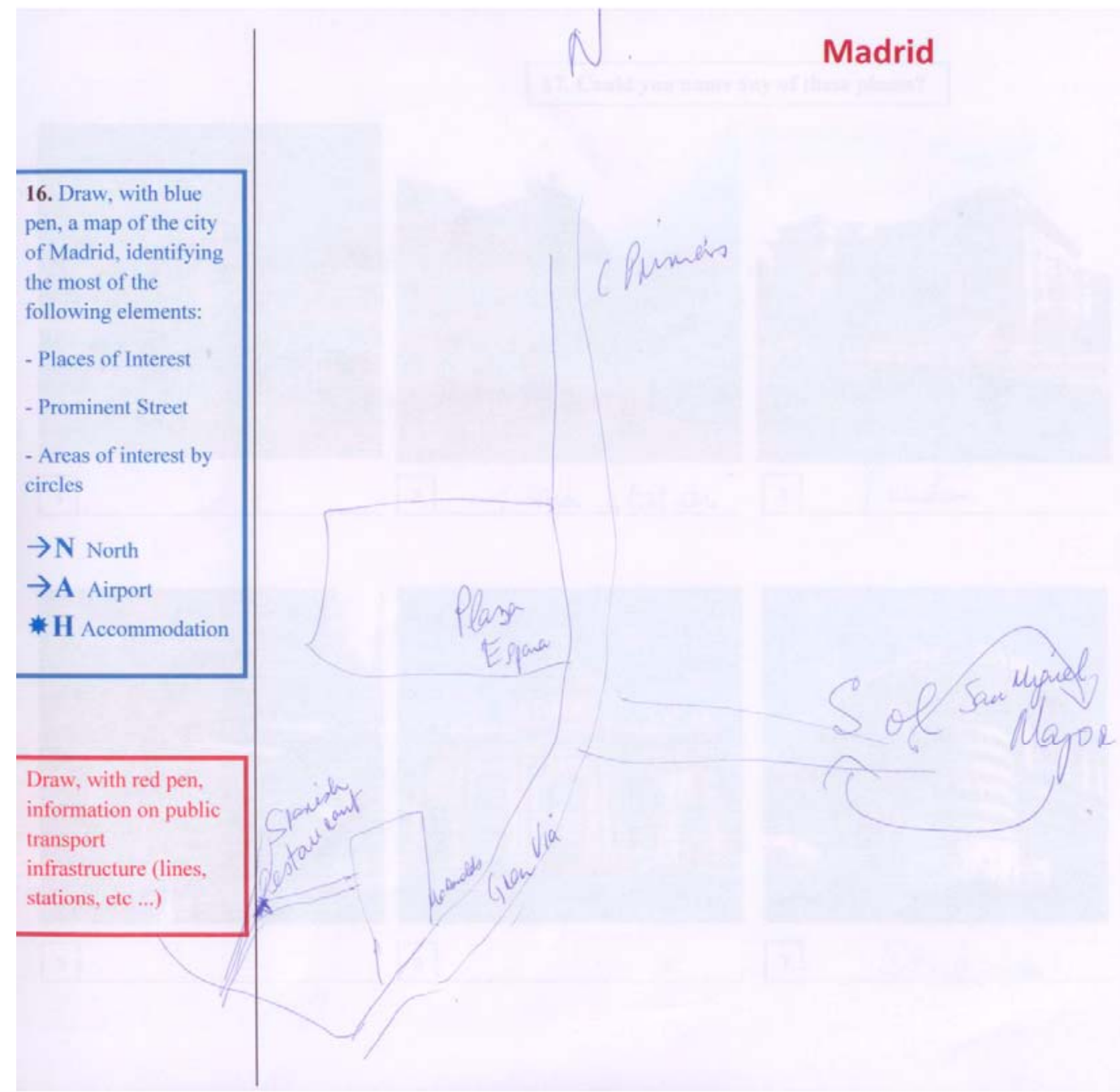

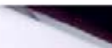

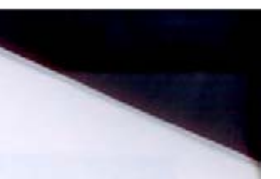

16. Draw, with blue

pen, a map of the city

he most of the

following elements:

Places of Interest

Prominent Stret

Areas of interest by

$\rightarrow \mathrm{N}$ North

* H Accommodatio 

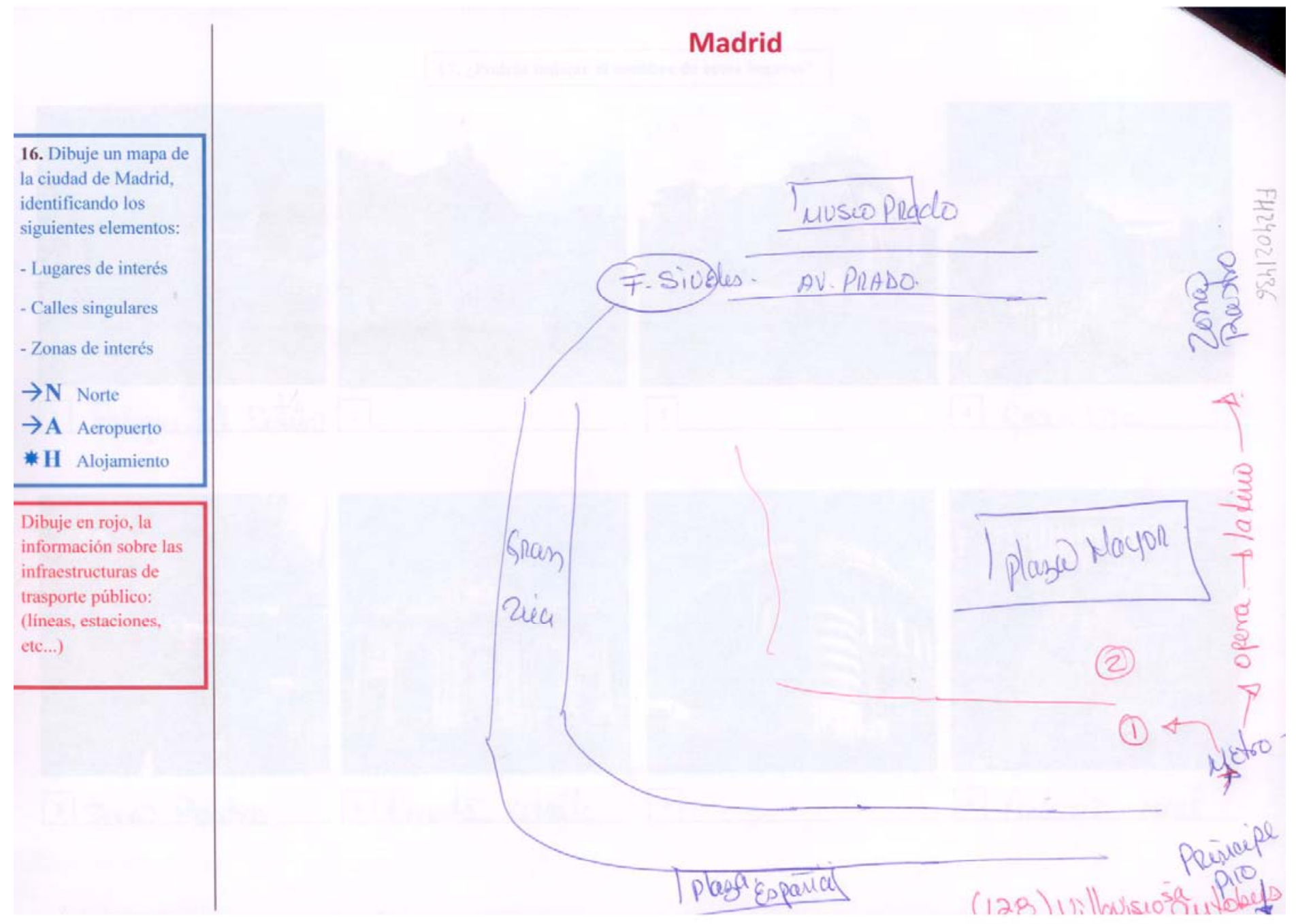


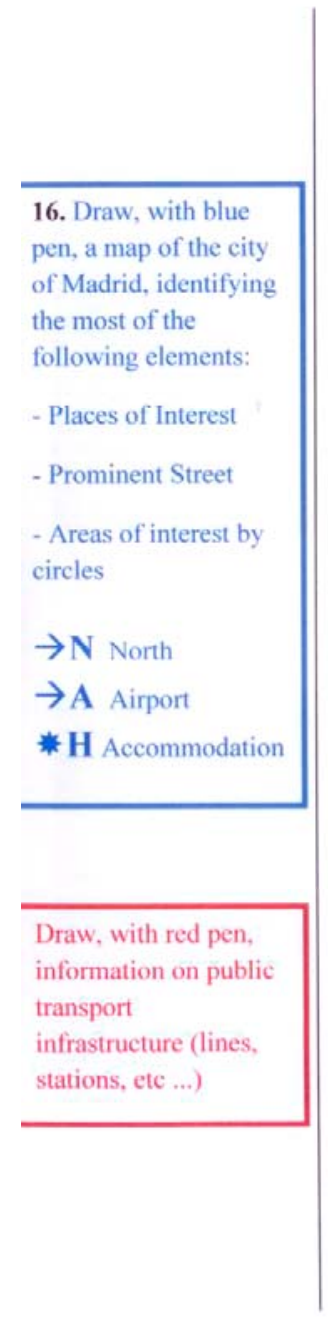

Madrid

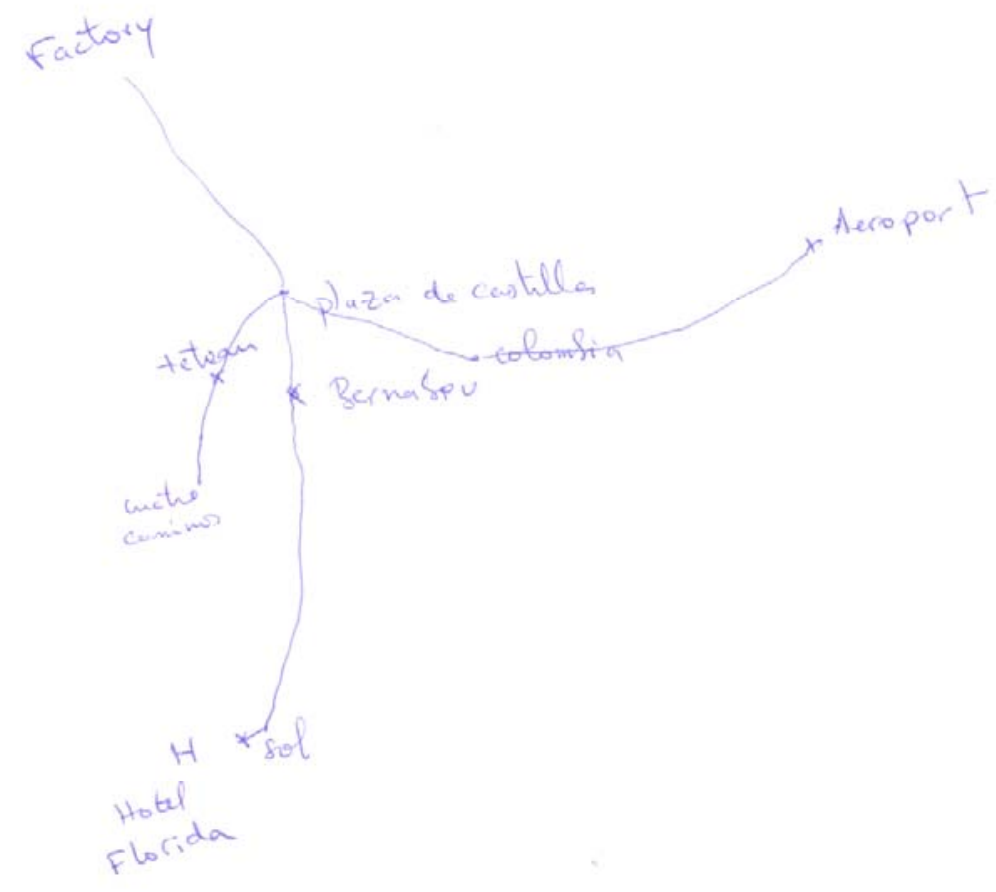




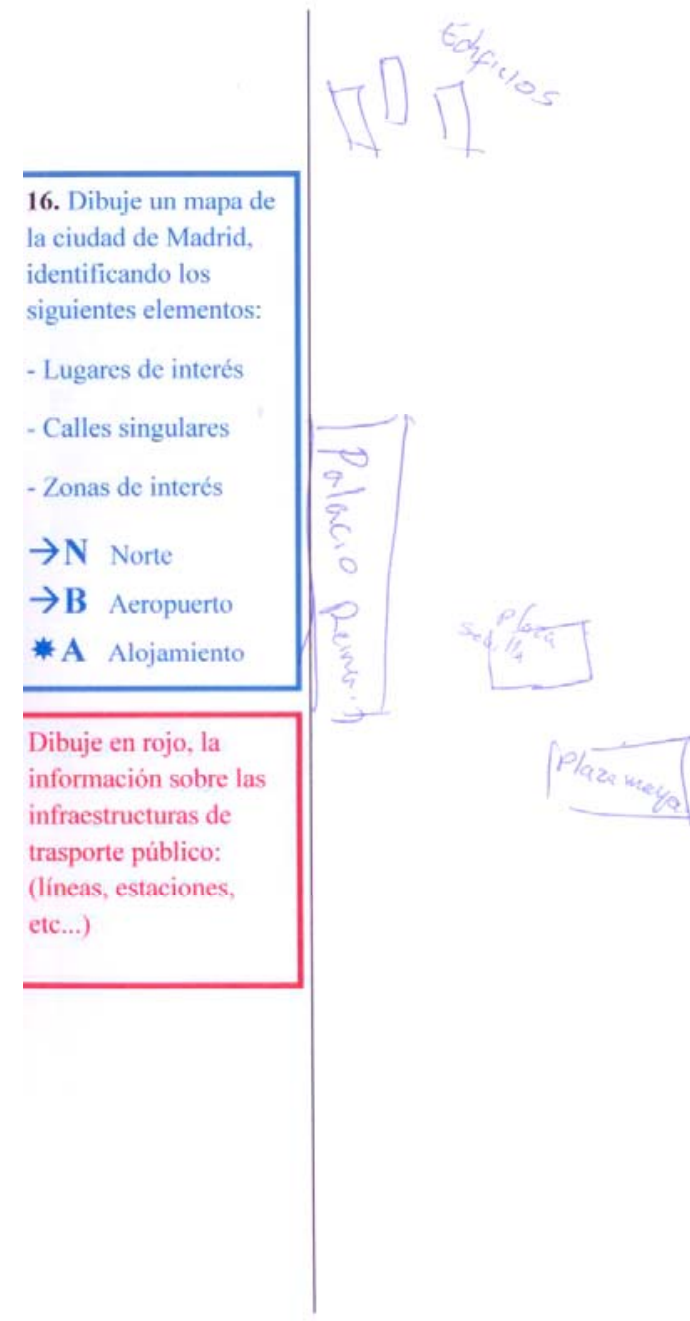

Madrid
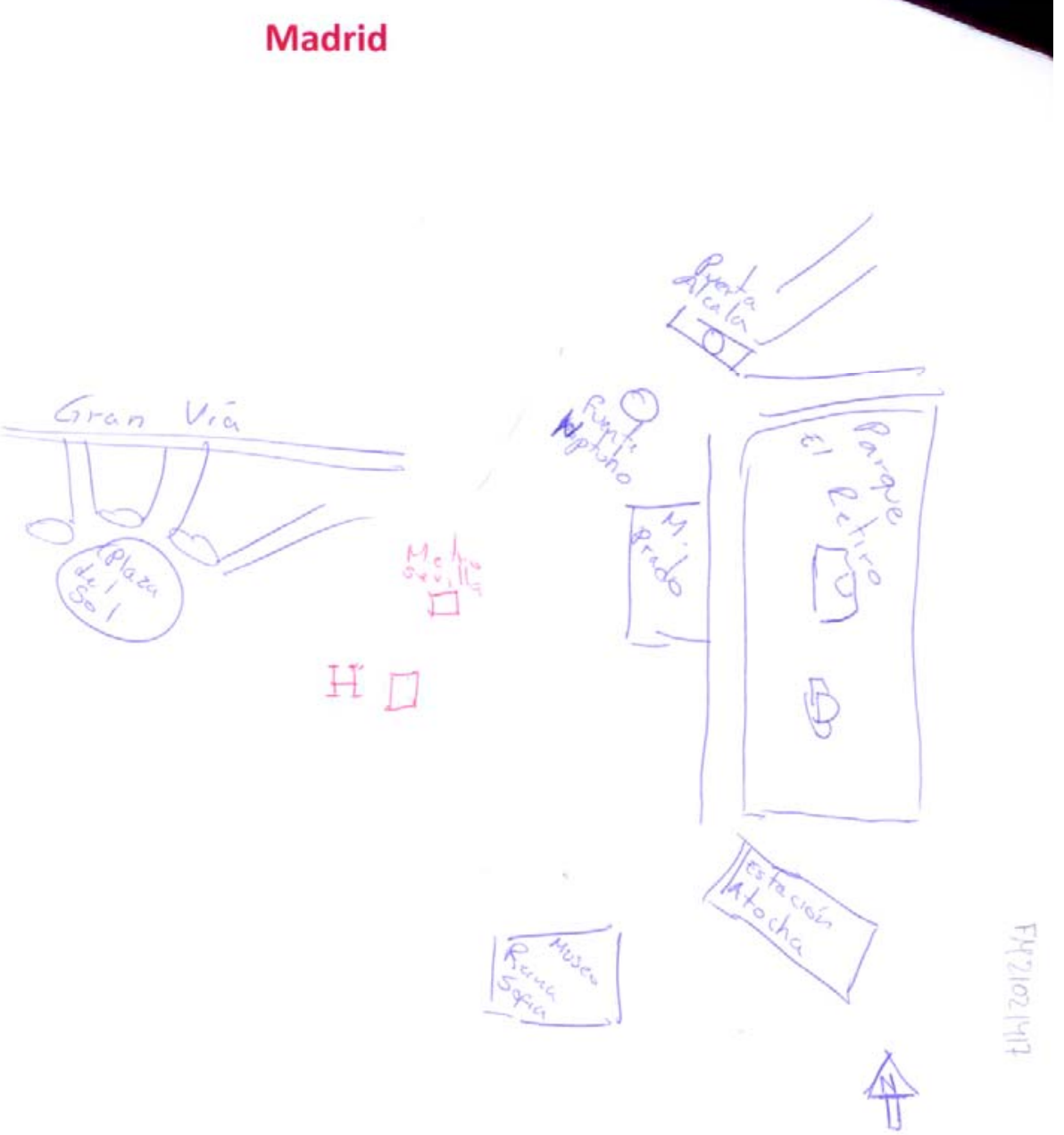
16. Dibuje un mapa de la ciudad de Madrid.

identificando los

siguientes elementos:

Lugares de interés

Calles singulares

- Zonas de interés

$\rightarrow \mathrm{N}$ Nort

$\rightarrow$ B Aeropuerto

* A Alojamiento

Dibuje en rojo, la

información sobre las

infraestructuras de

trasporte público:

(lineas, estaciones,

etc...)

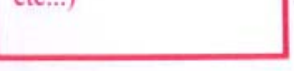

Madrid

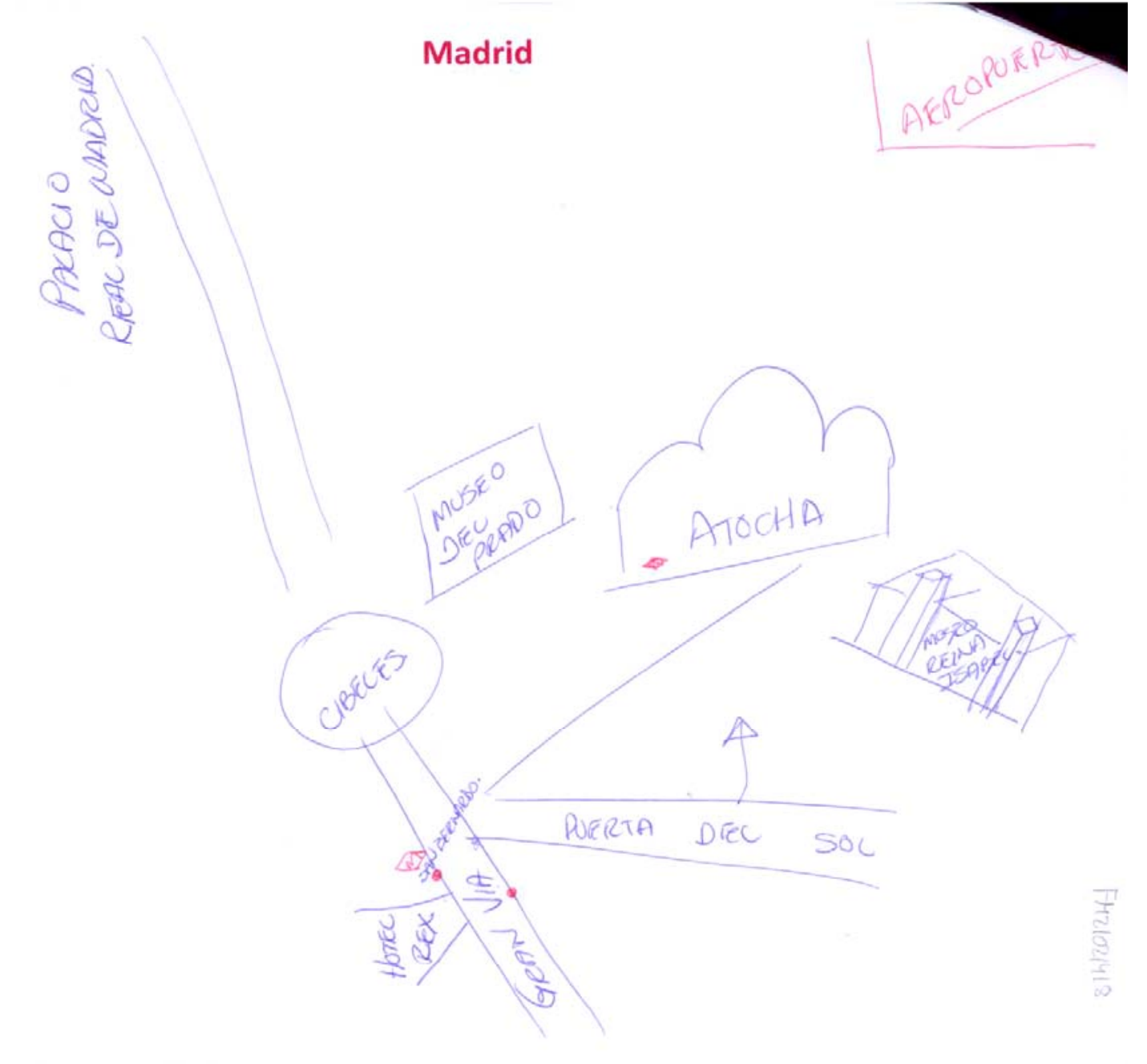




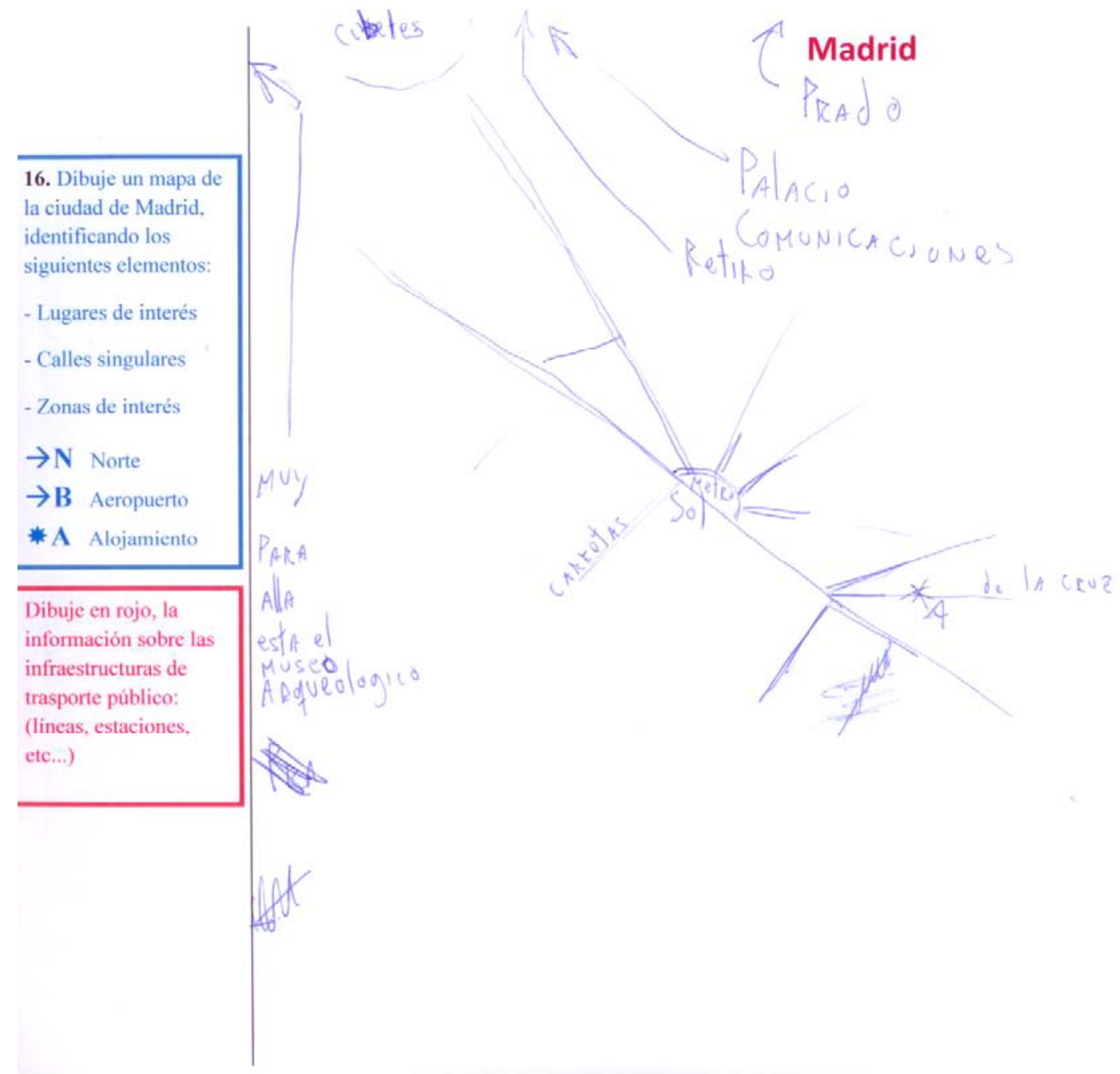

$-1$ 


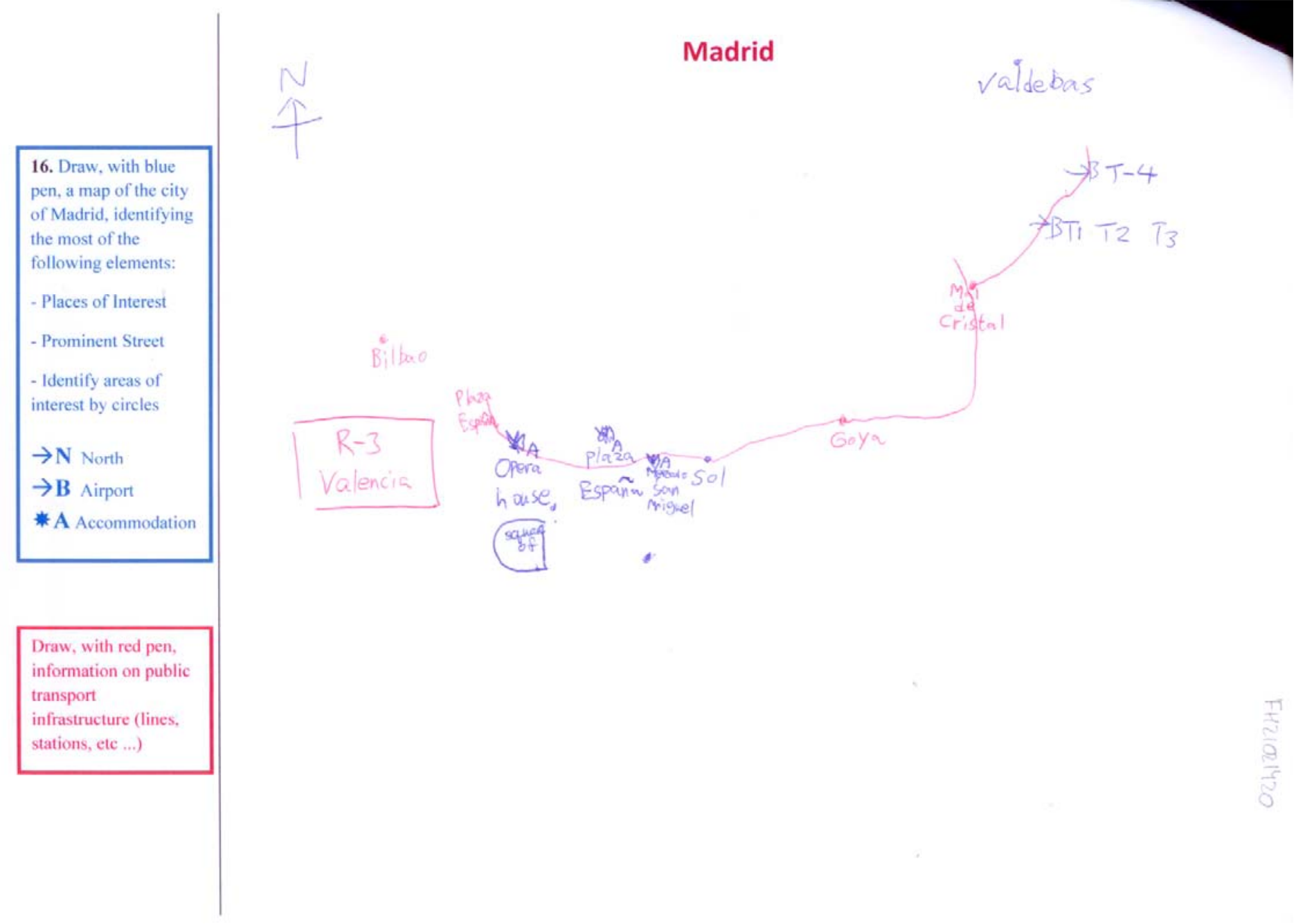




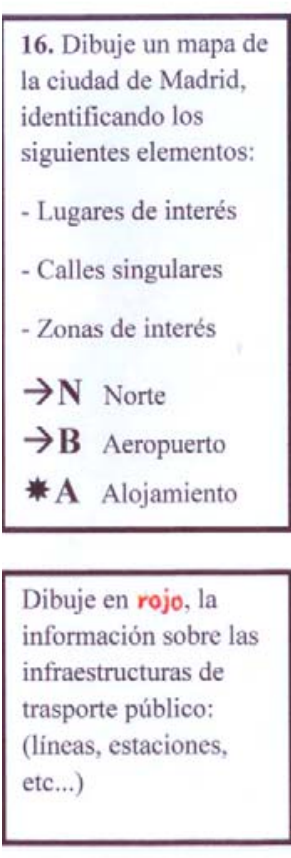

Madrid

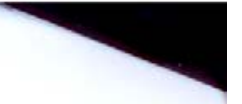

de Madrid,

do los

ugares de interés

Calles singulare

B Aeropuerı

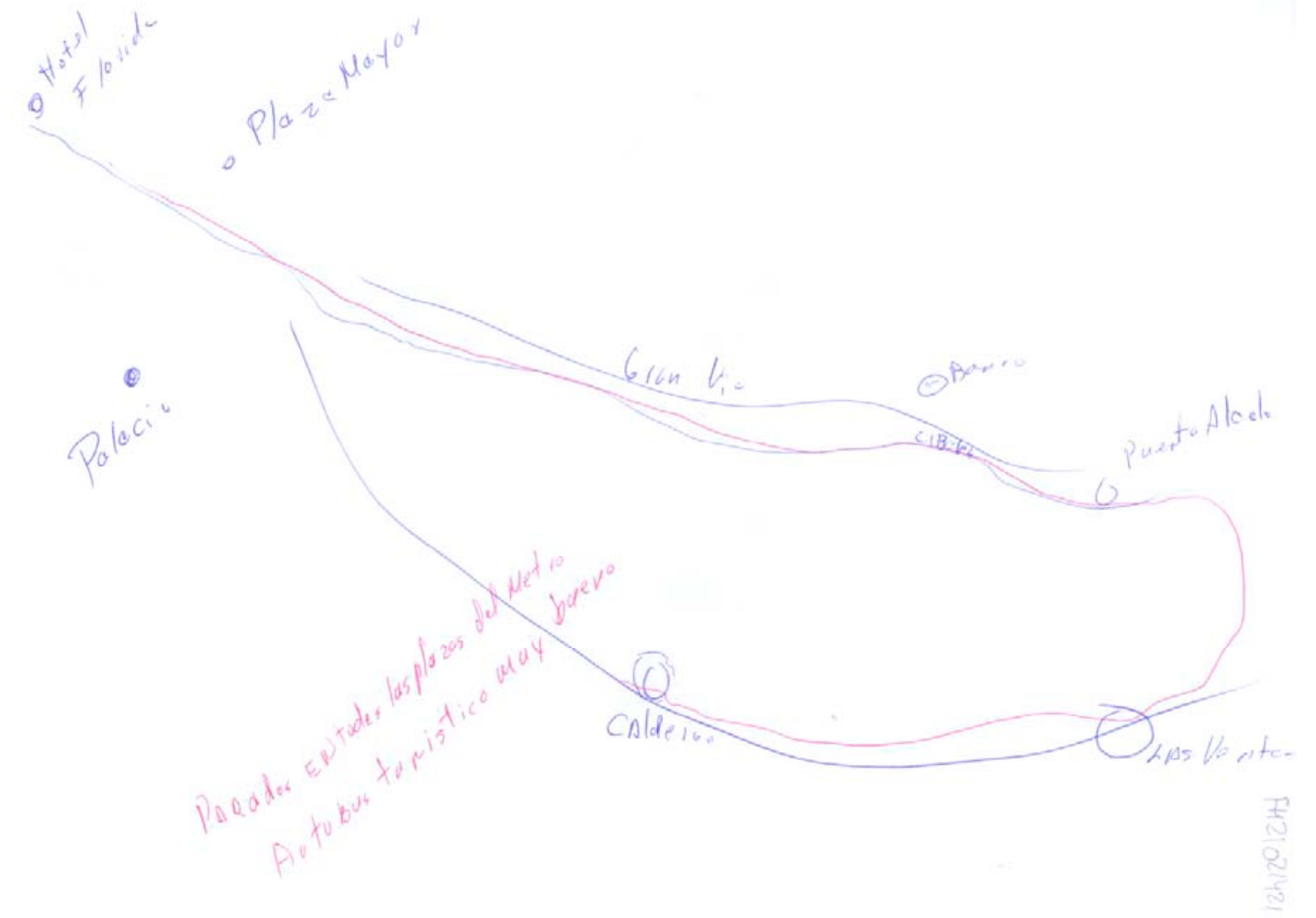




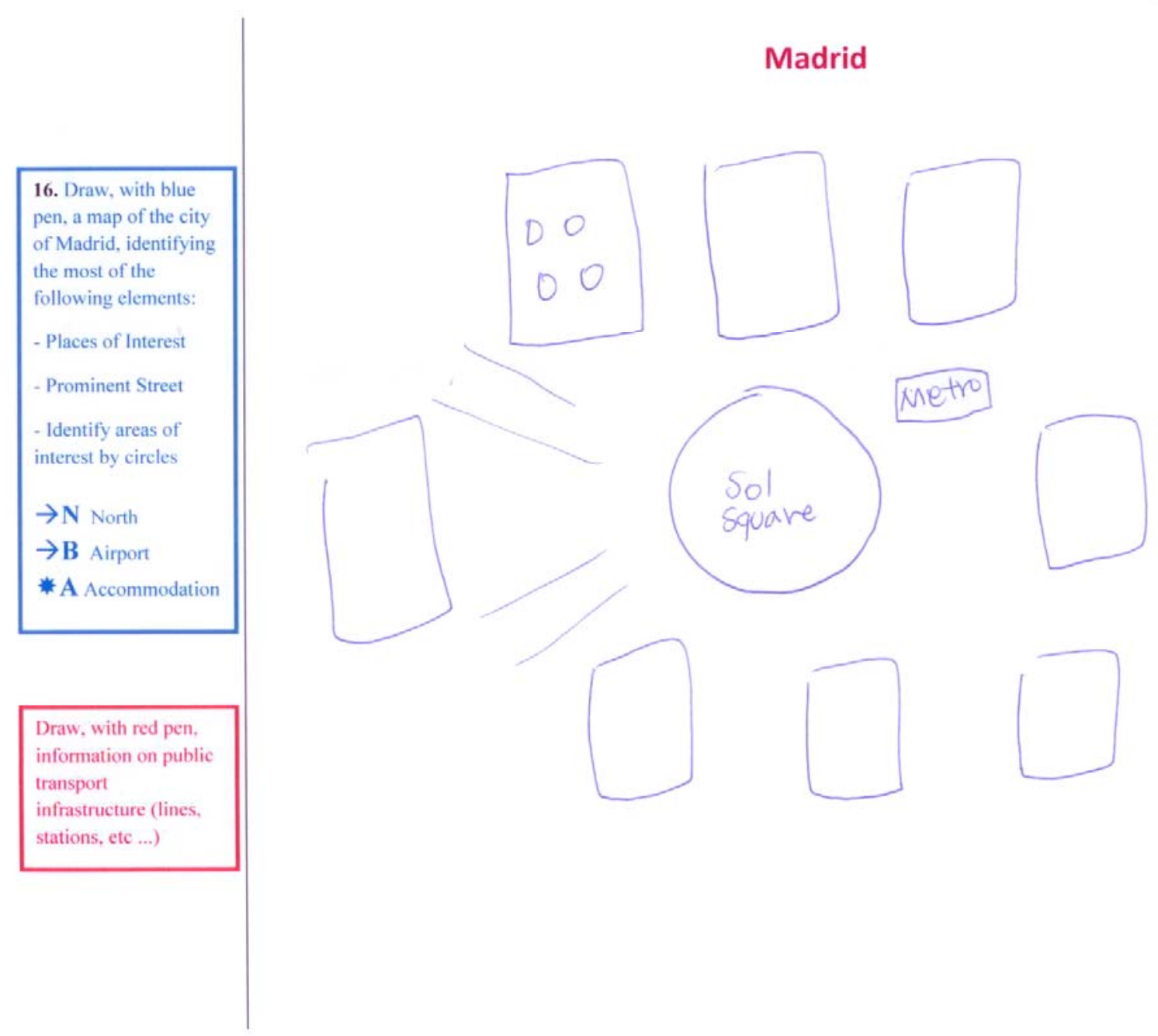

$\longrightarrow$

Identify areas of

interest by circles

N North

$\rightarrow$ B Airport

* A Accommodation

information on public

transport

stations, etc ...) 


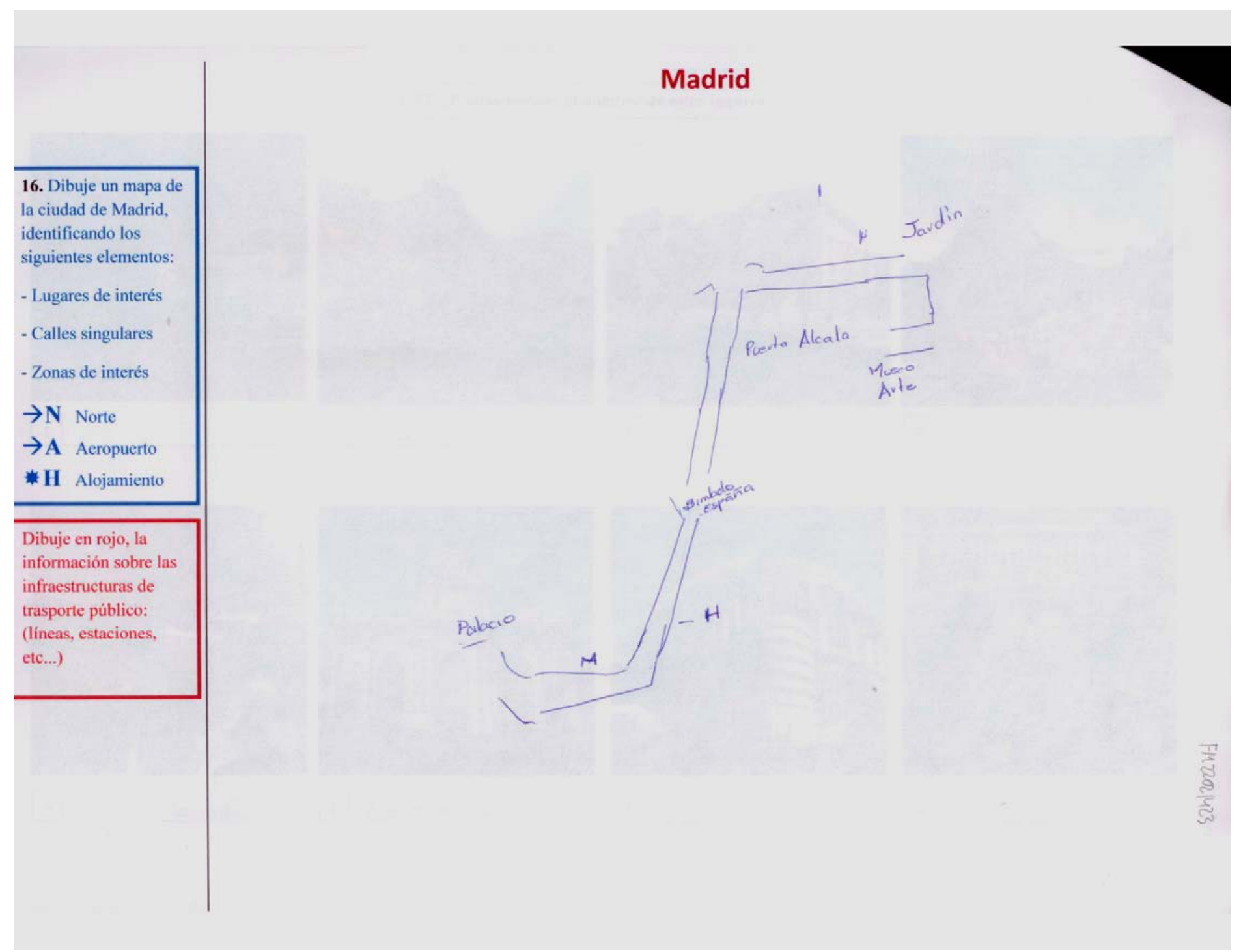




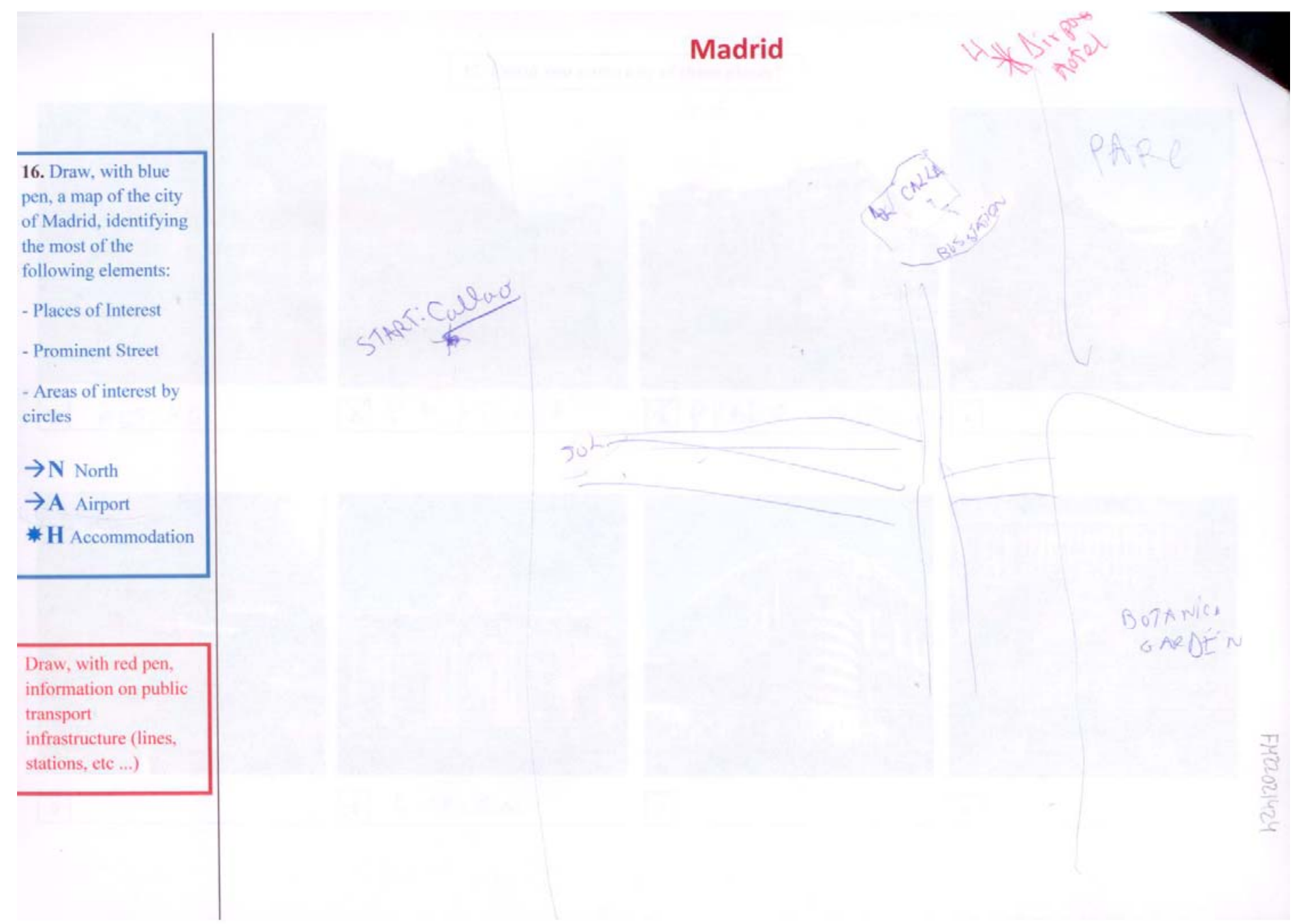




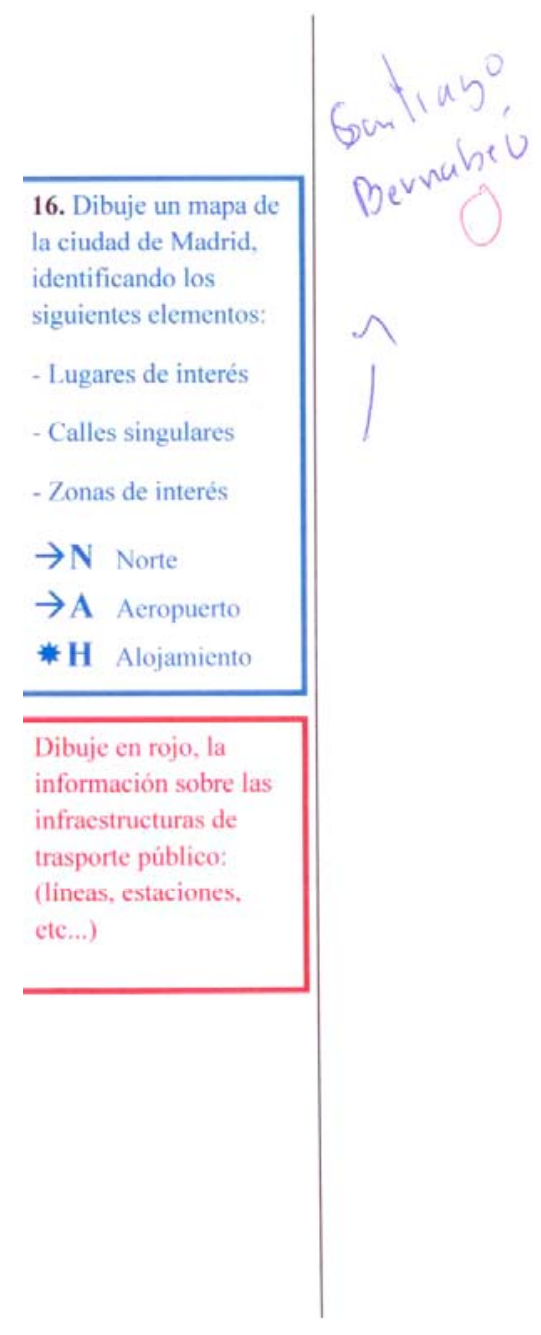

Madrid

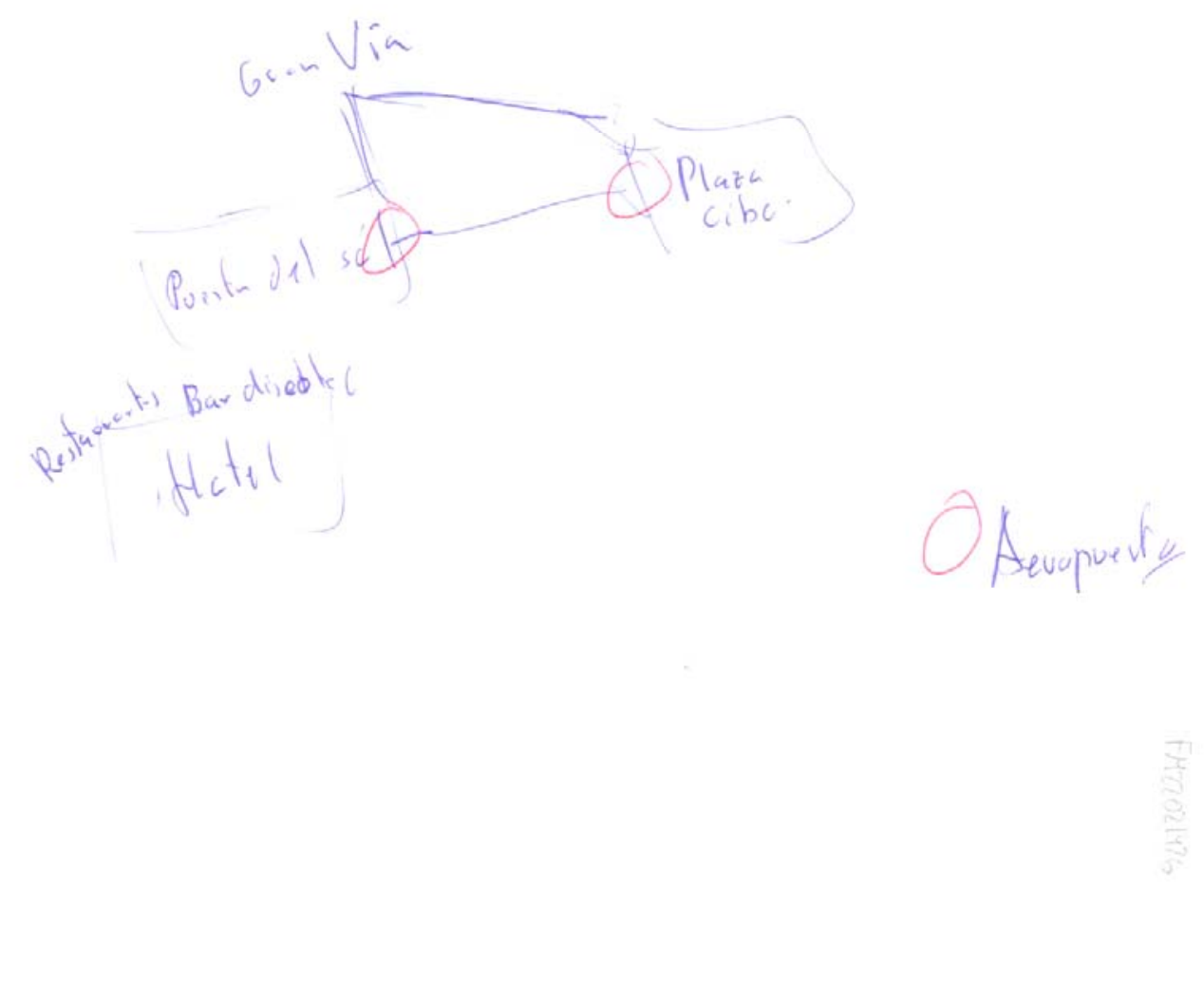



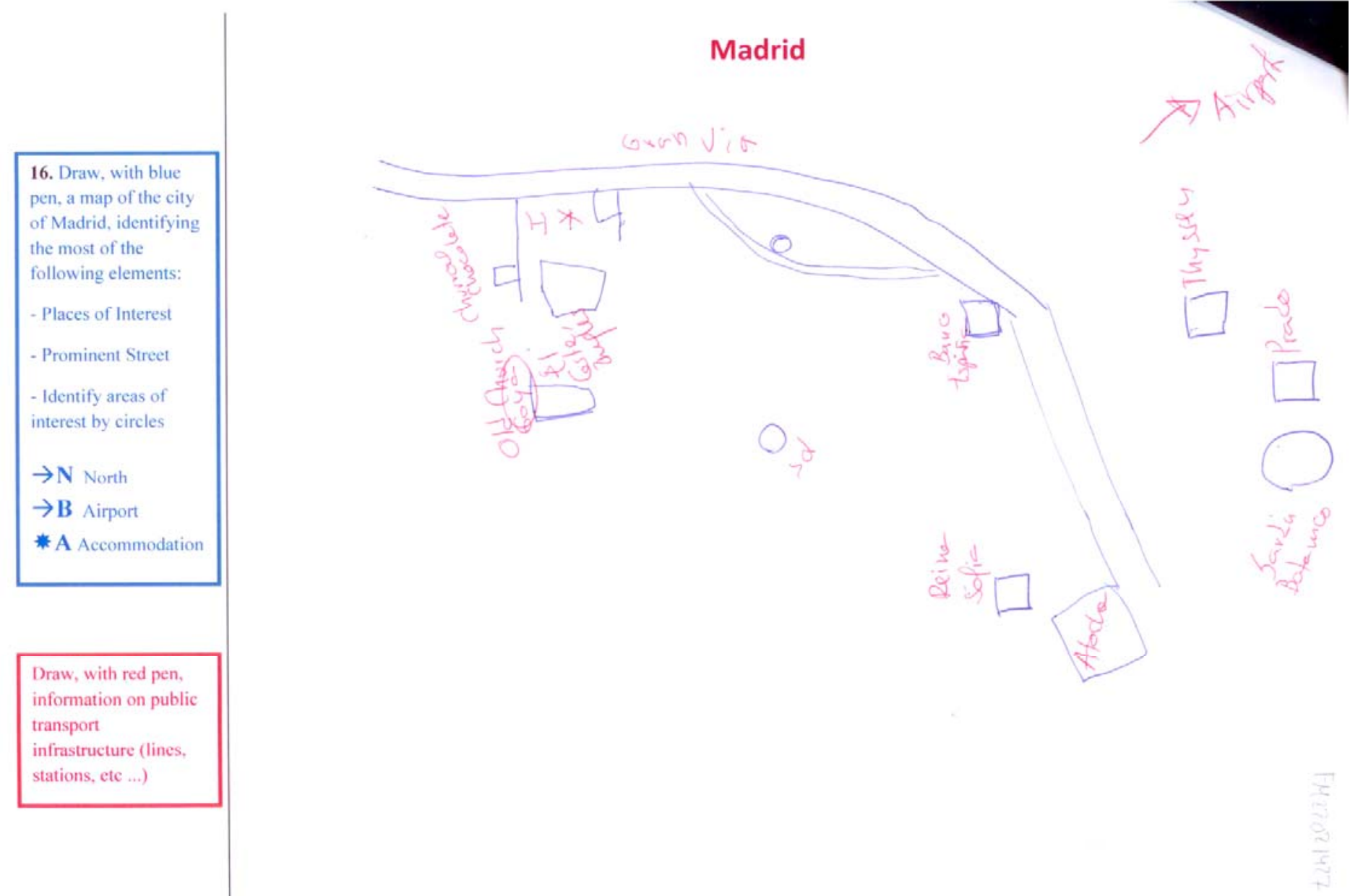


\begin{tabular}{l} 
16. Dibuje un mapa de \\
la ciudad de Madrid, \\
identificando los \\
siguientes elementos: \\
- Lugares de interés \\
- Calles singulares \\
- Zonas de interés \\
$\rightarrow \mathbf{N}$ Norte \\
$\rightarrow \mathbf{A}$ Aeropuerto \\
*H Alojamiento \\
\hline Dibuje en rojo, la \\
información sobre las \\
infraestructuras de \\
trasporte público: \\
(lineas, estaciones, \\
etc...) \\
\hline
\end{tabular}
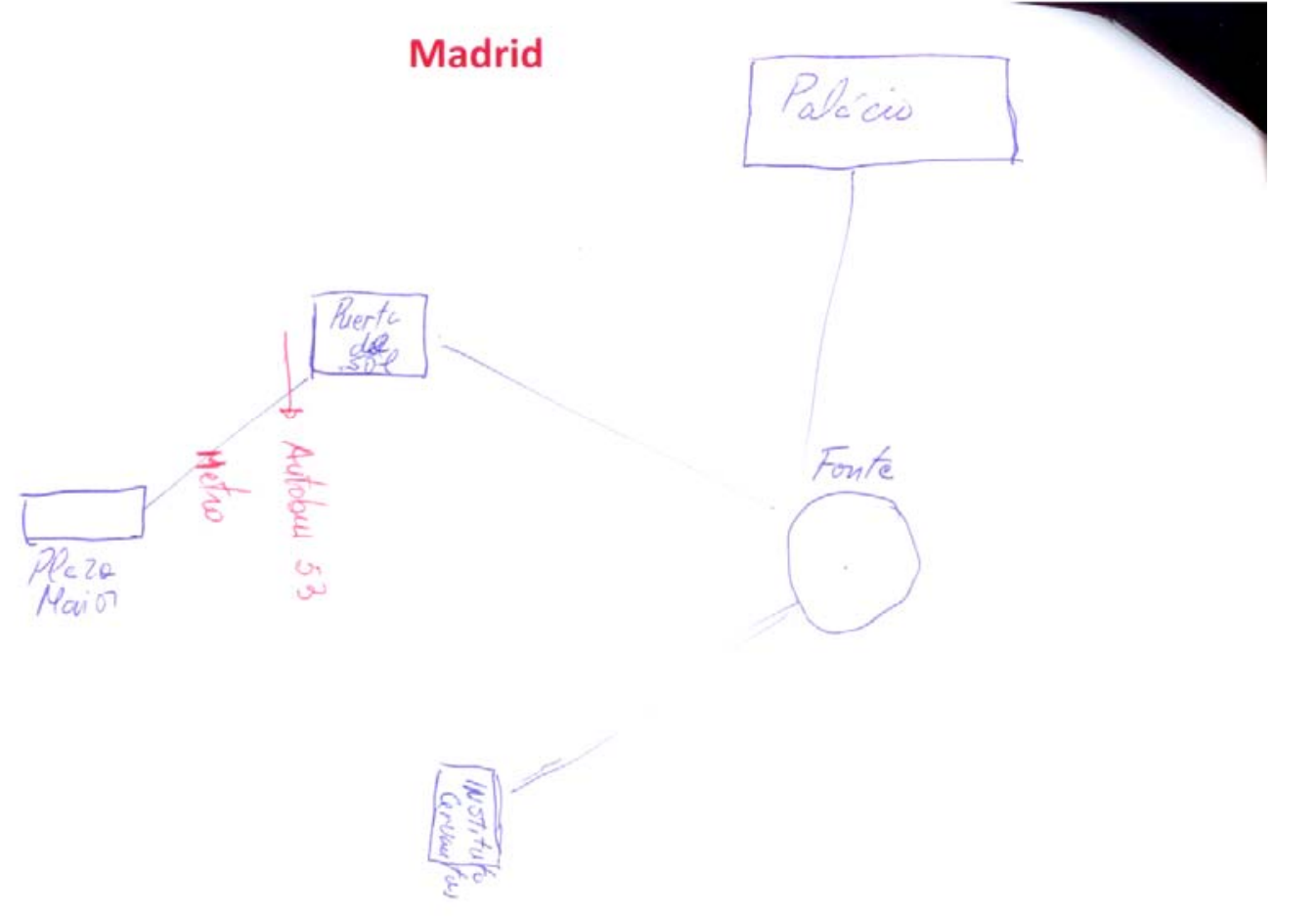
16. Dibuje, con el

boligrafo azul, un

mapa de la ciudad de

Madrid, identificando

el mayor número

posible de los

siguientes elementos:

- Lugares de interés

- Calles singulares

- Delimite las zonas

de interés mediante

circulos

$\rightarrow \mathbf{N}$ Norte

$\rightarrow$ B Aeropuerto

* A Alojamiento

Dibuje, con el

boligrafo rojo, toda la

información que

recuerde sobre las

infraestructuras de

trasporte públice:

(lineas, estaciones,

etc...)

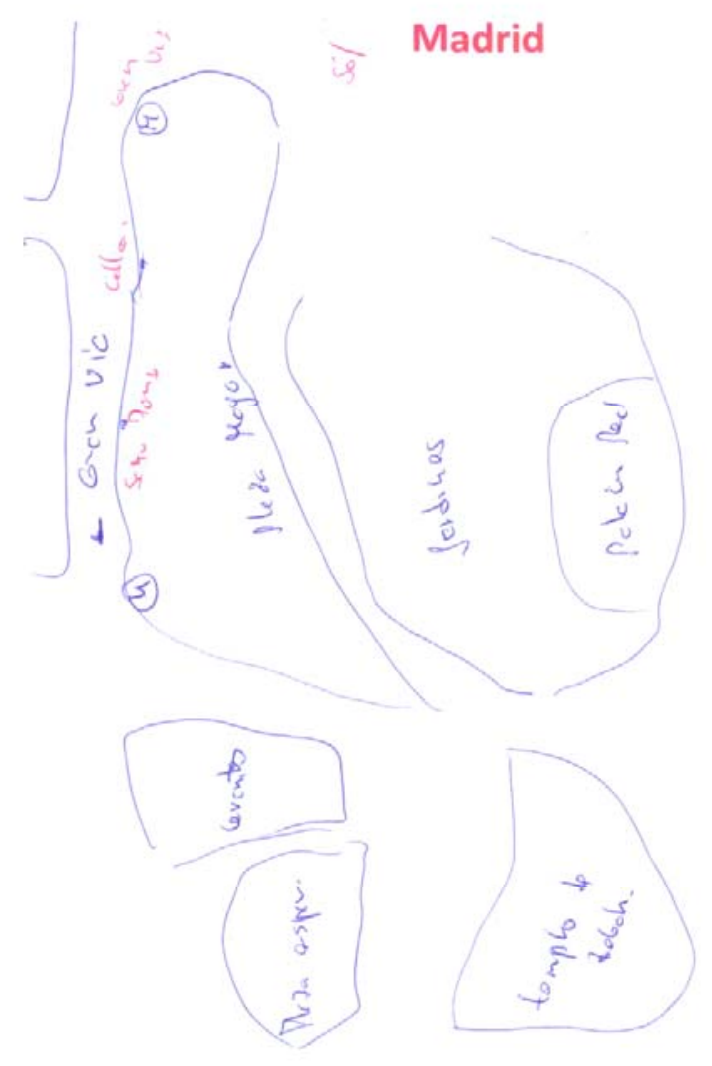

$+$ 


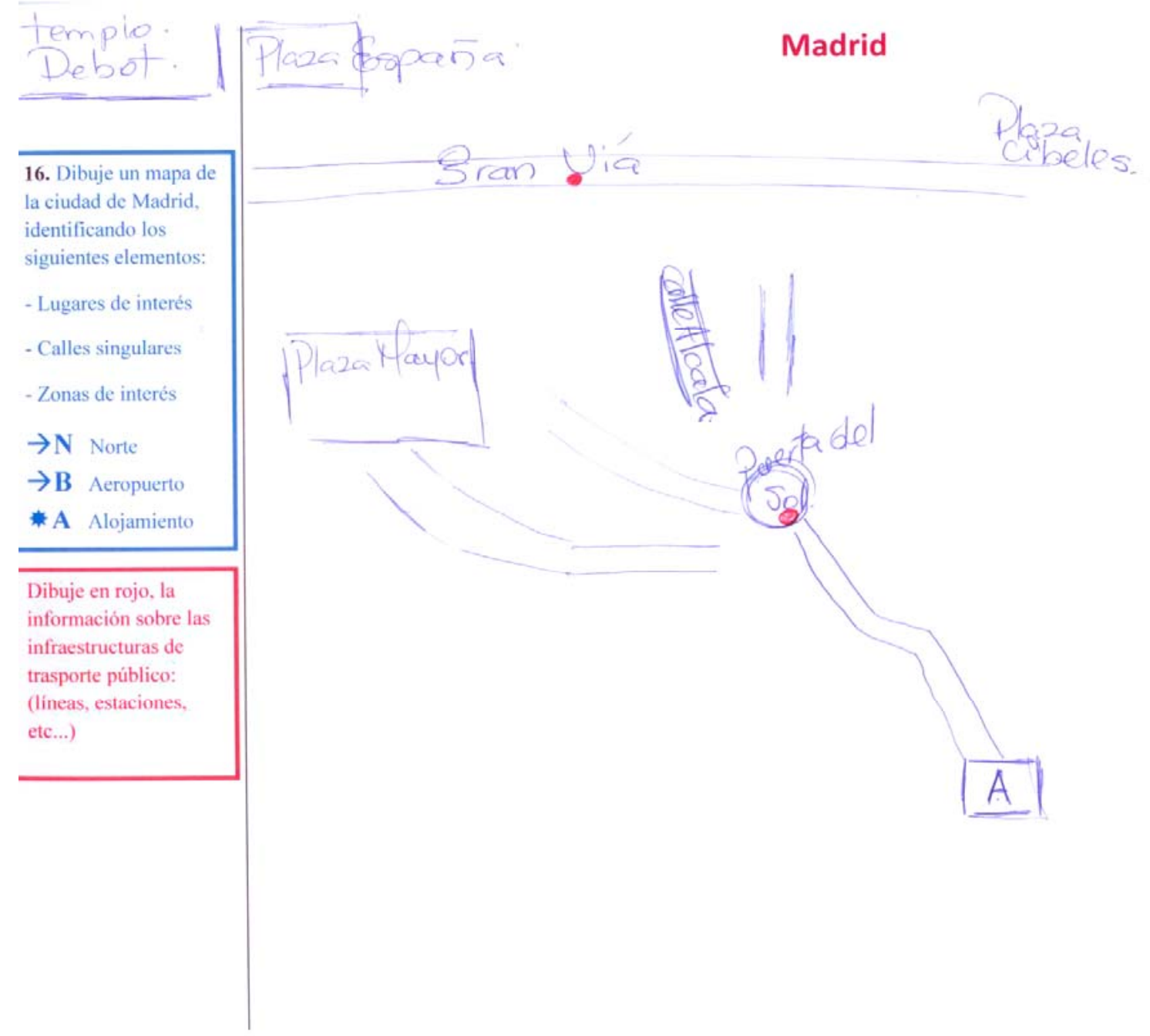

$+$ 


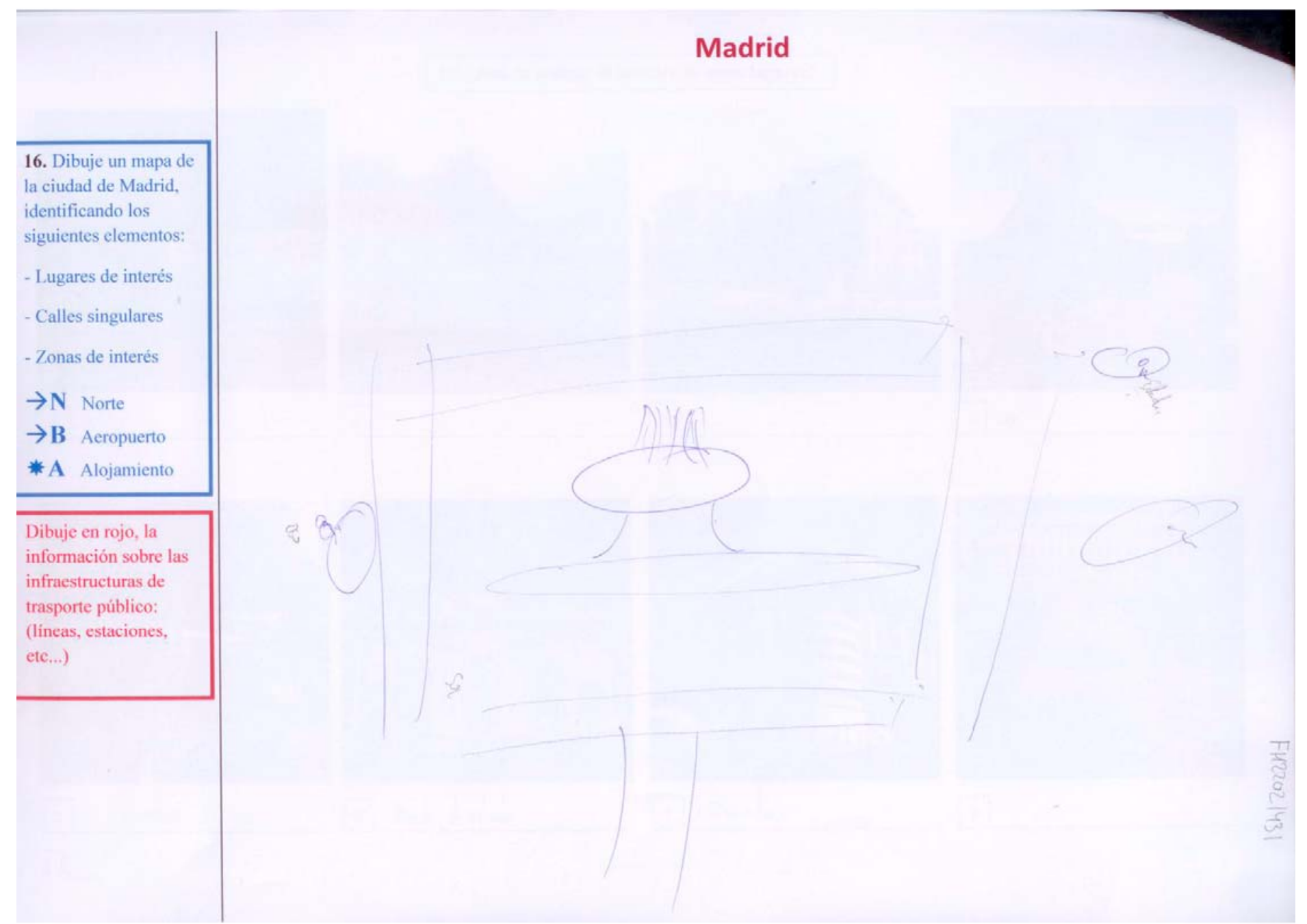




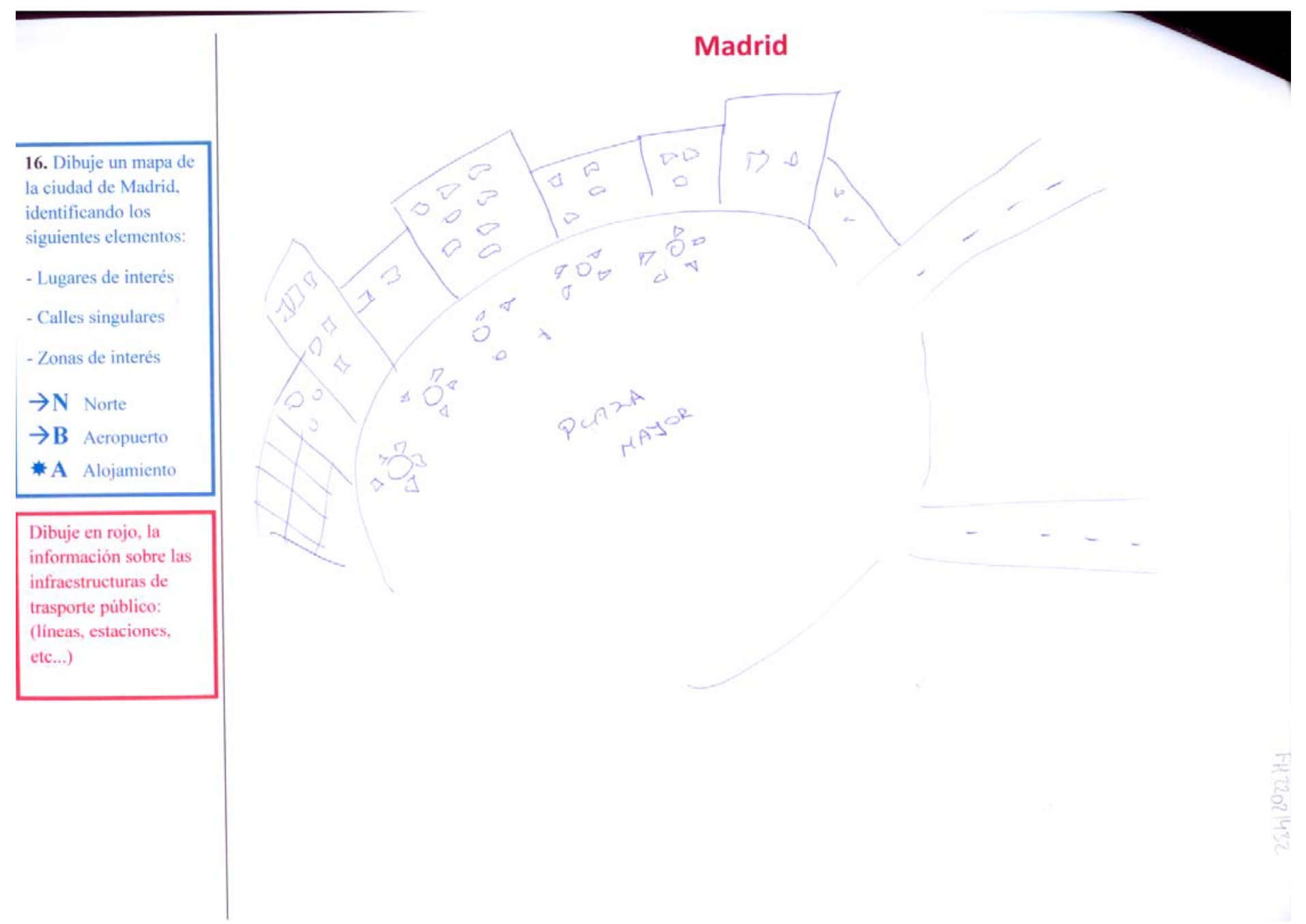




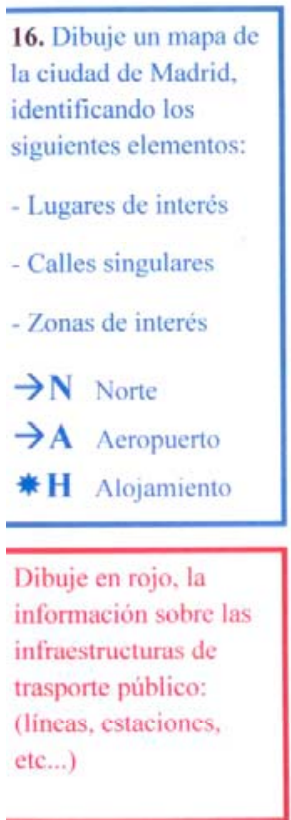
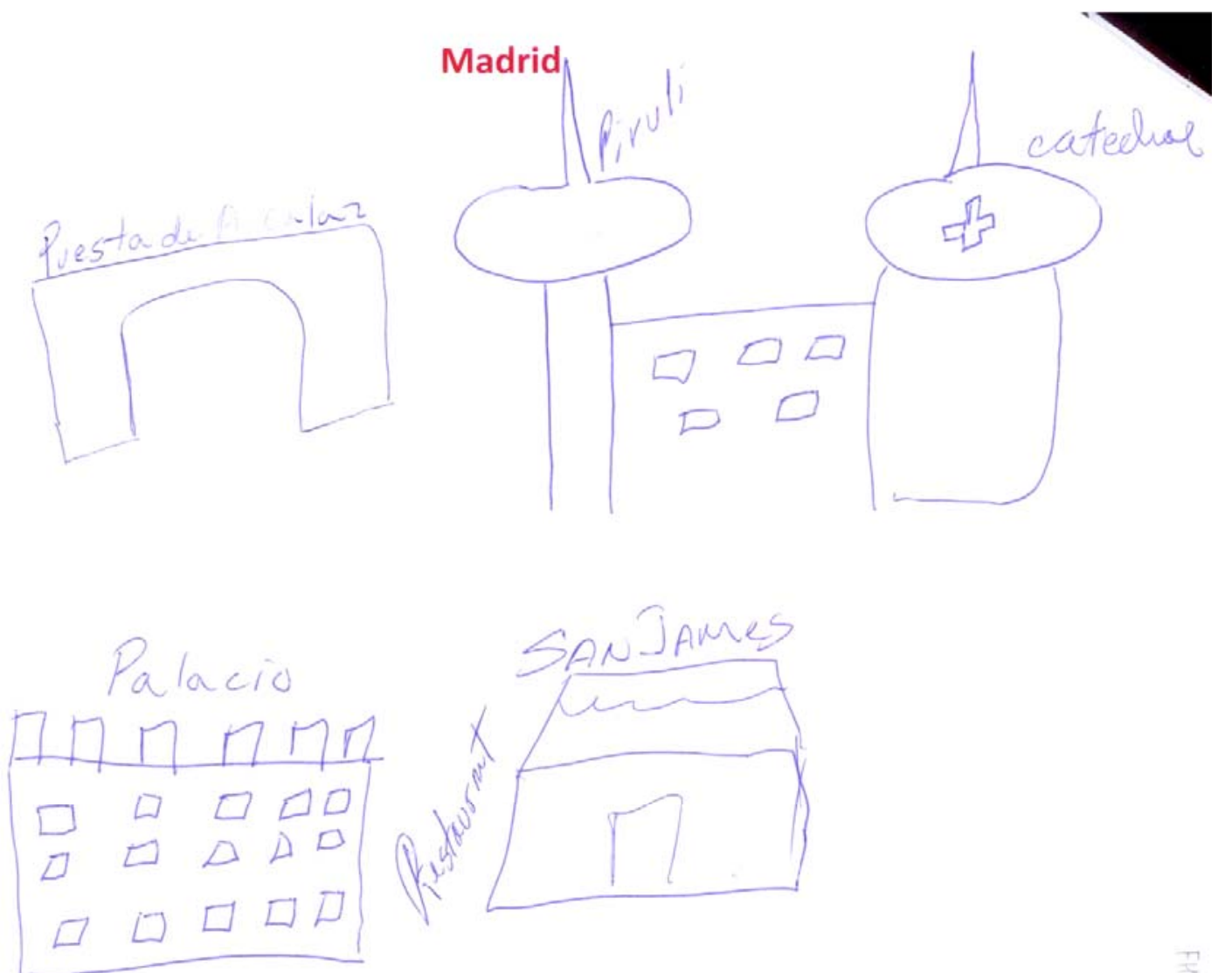


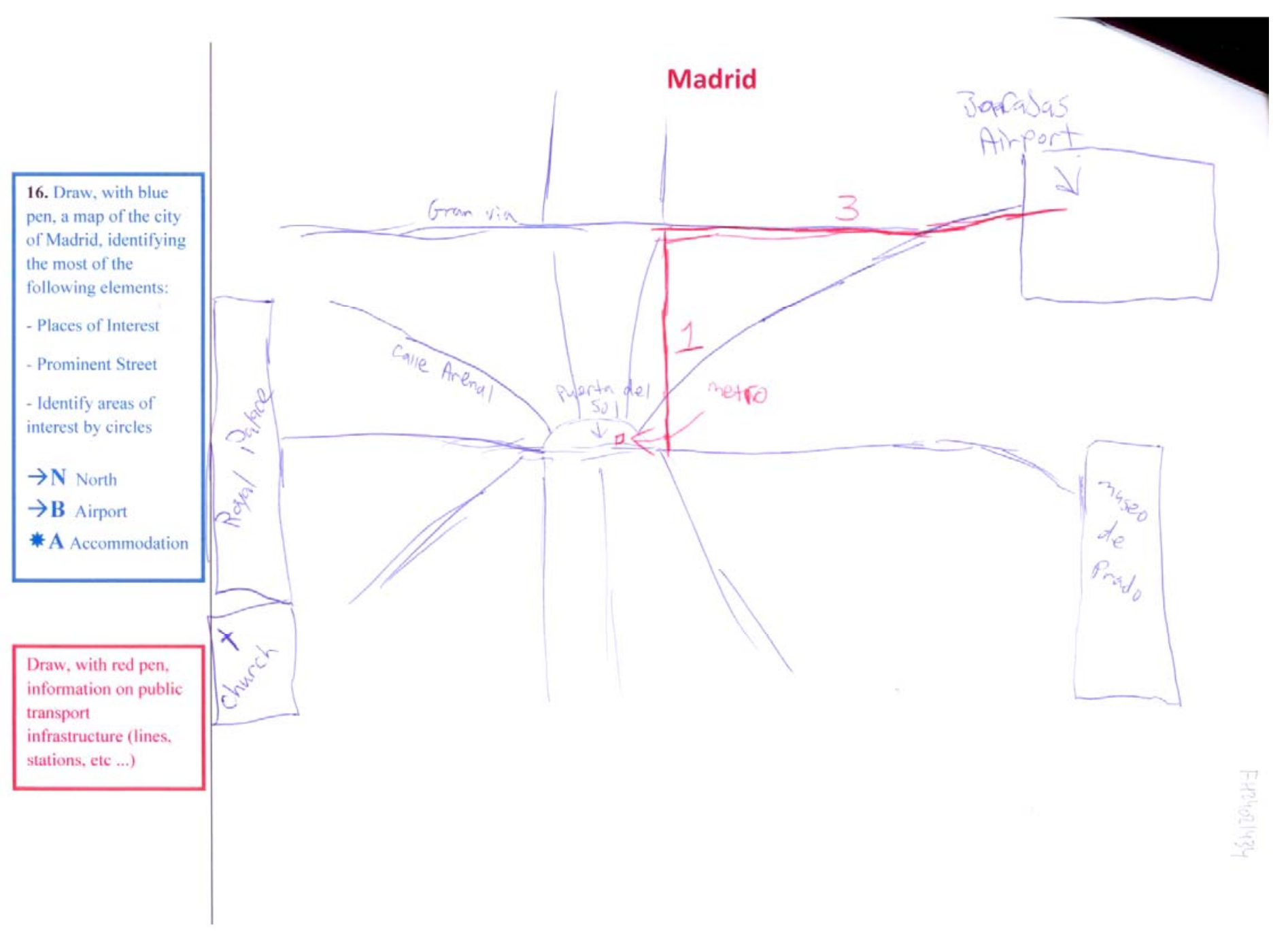




\begin{tabular}{|c|}
\hline $\begin{array}{l}\text { 16. Draw, with blue } \\
\text { pen, a map of the city } \\
\text { of Madrid, identifying } \\
\text { the most of the } \\
\text { following elements: }\end{array}$ \\
\hline - Places of Interest \\
\hline - Prominent Street \\
\hline $\begin{array}{l}\text { - Identify areas of } \\
\text { interest by circles }\end{array}$ \\
\hline$\rightarrow \mathrm{N}$ North \\
\hline$\rightarrow$ B Airport \\
\hline * A Accommodation \\
\hline
\end{tabular}

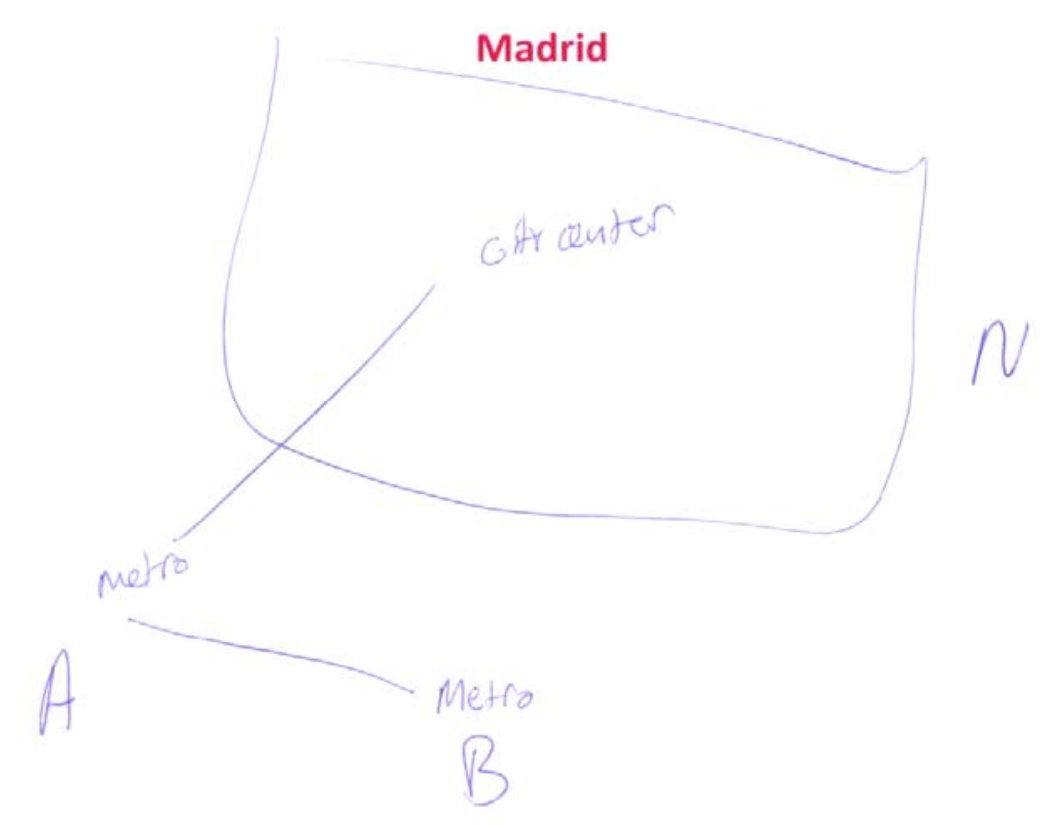

$y_{4}$

Draw, with red pen.

information on public

transport

infrastructure (lines.

stations, etc ...) 

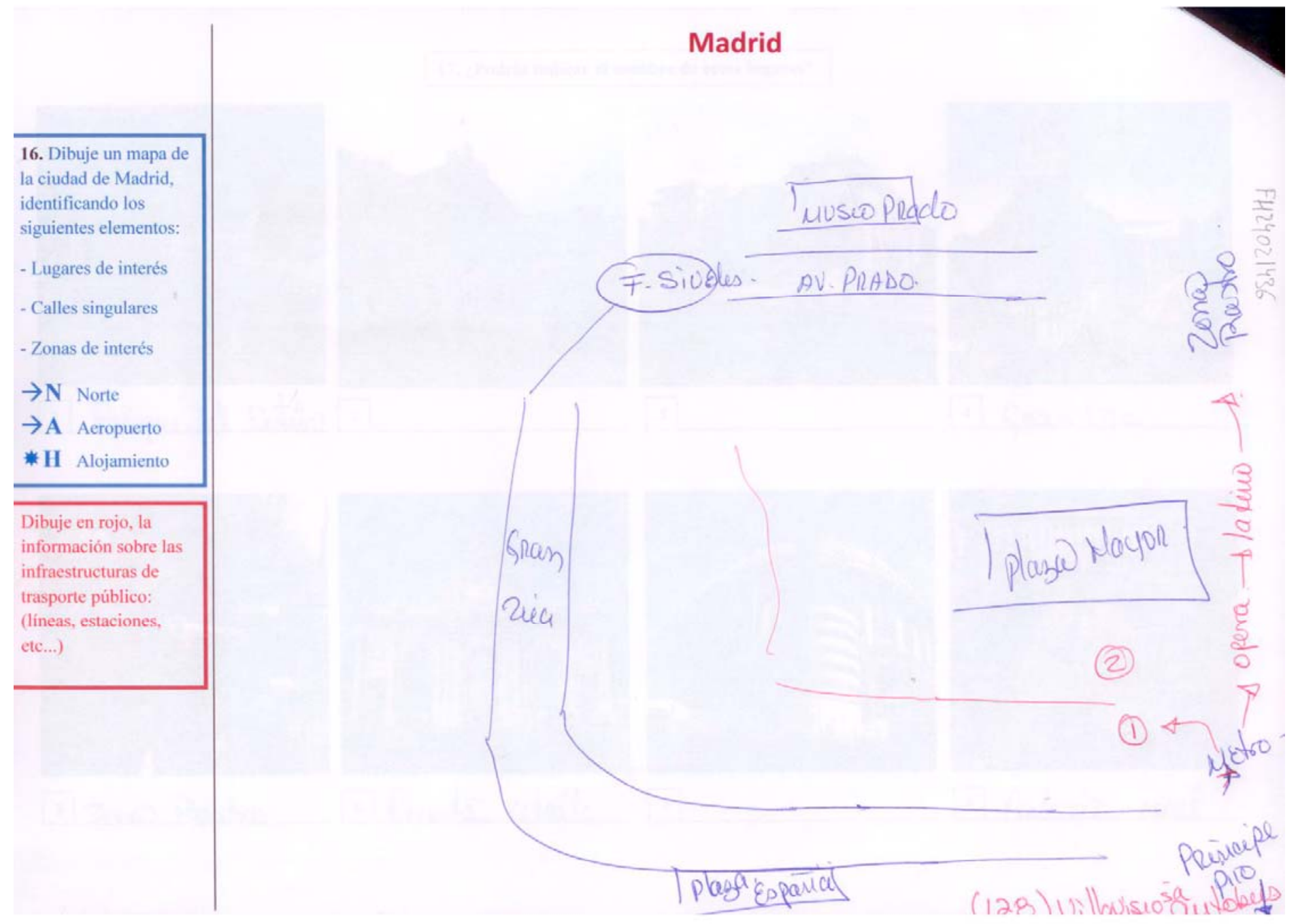


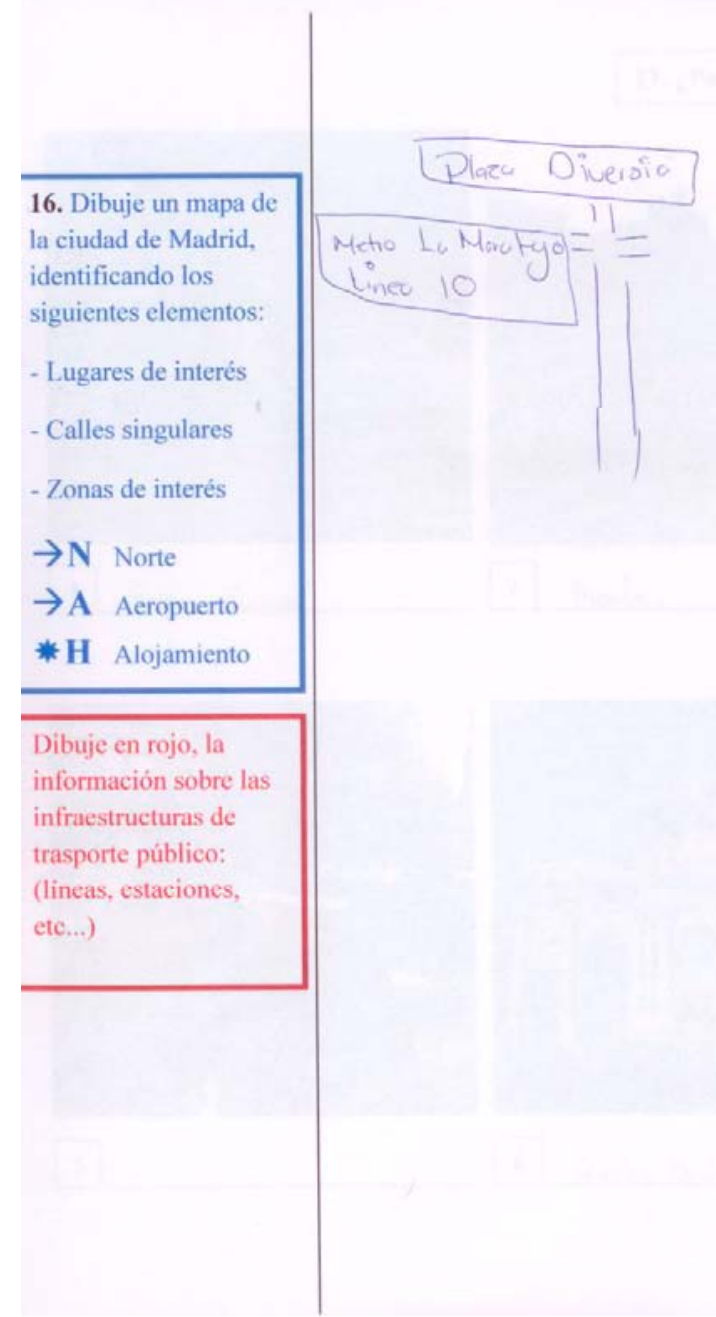




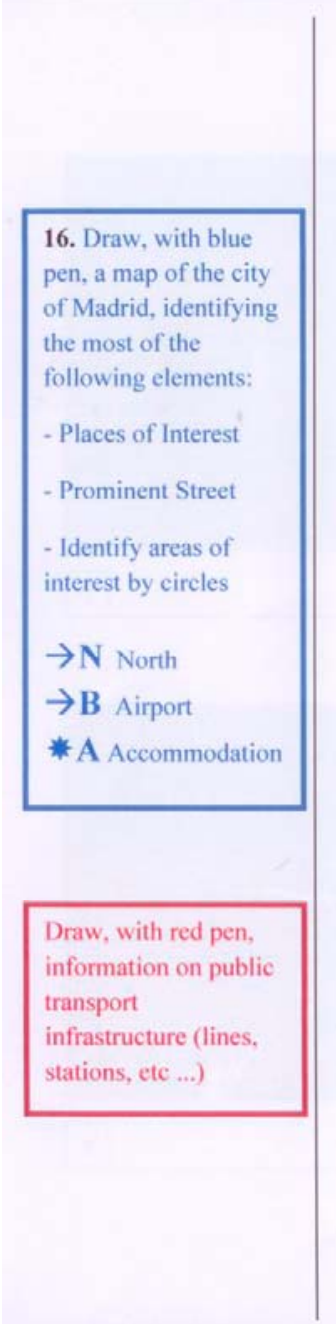

Madrid

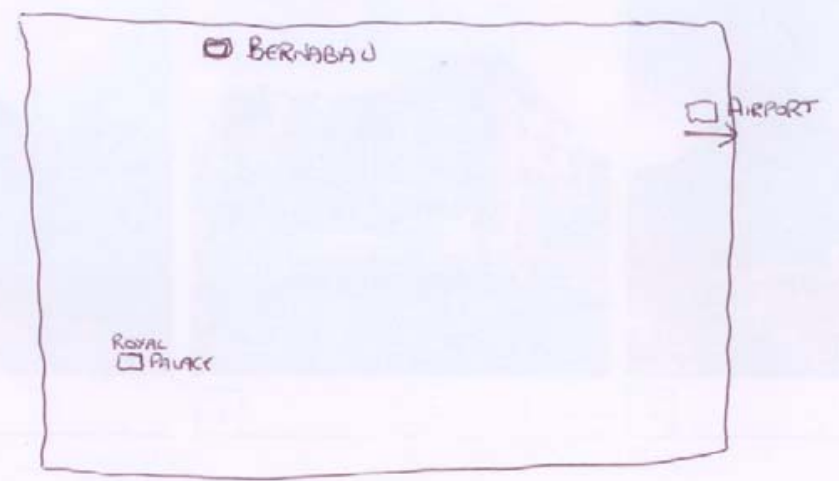




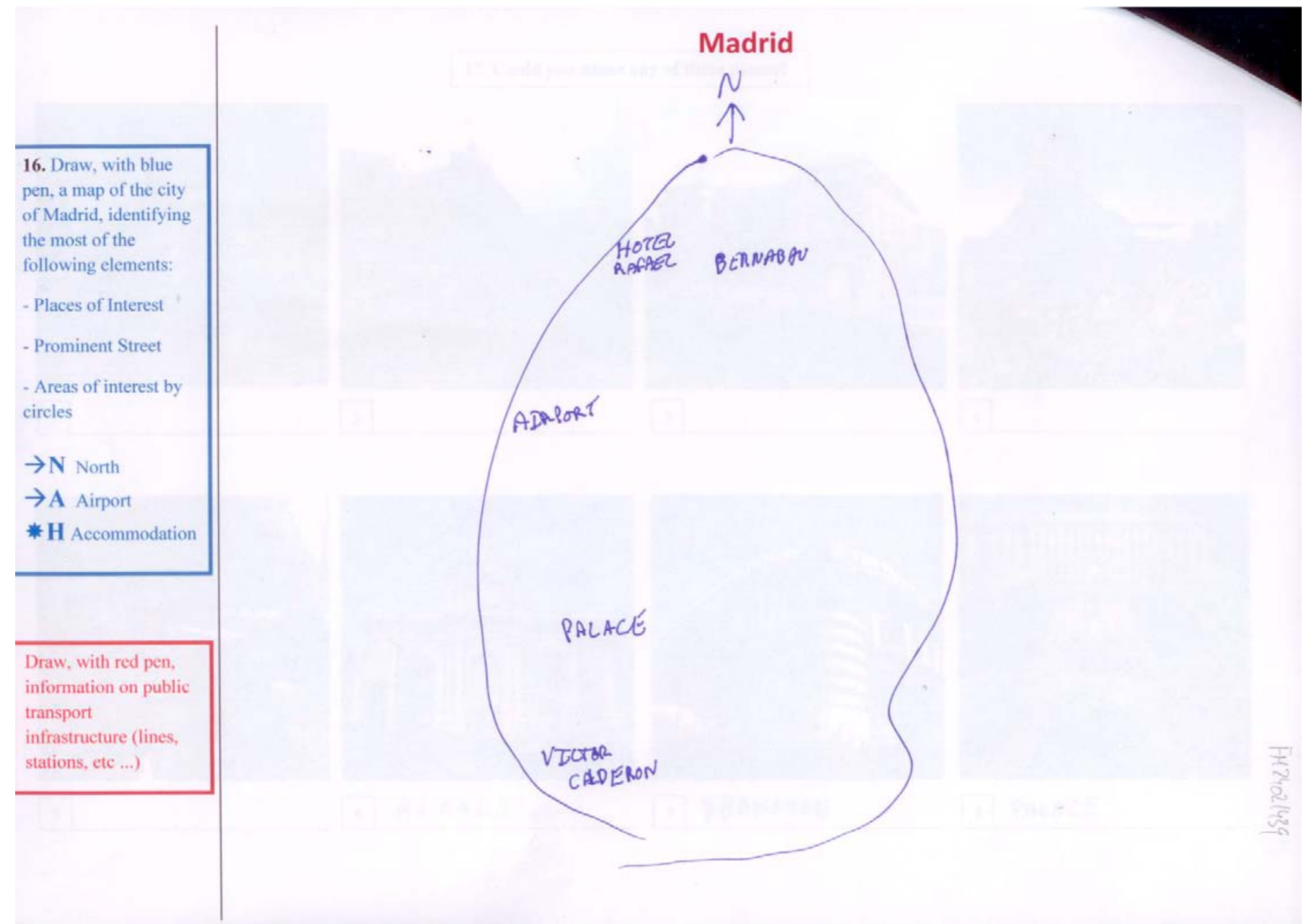




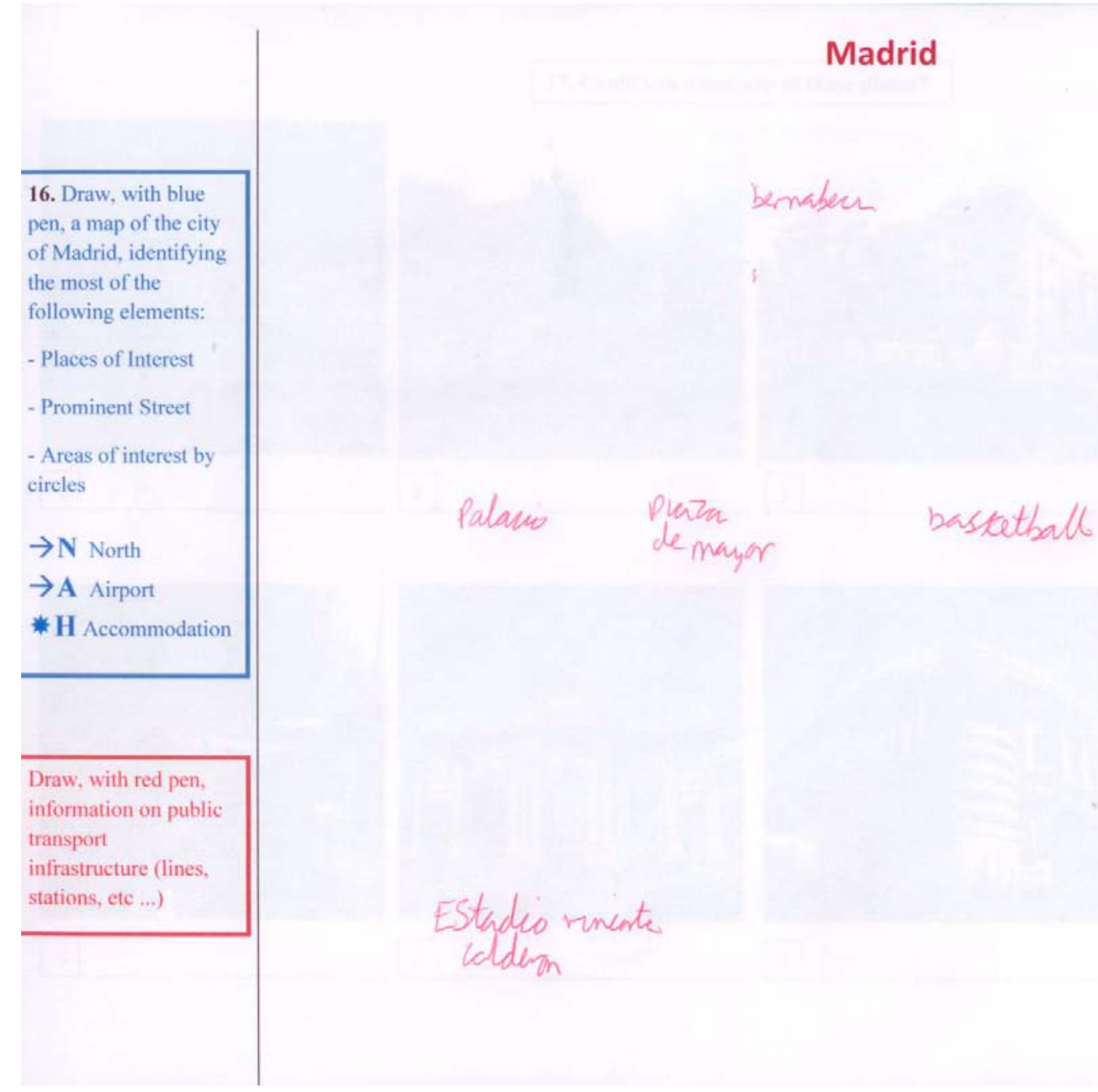

16. Draw, with blue

emaber

$\rightarrow \mathrm{N}$ North

Palano

prain

basketball

Draw, with red pen,

information on public

ransport

Estadio rineate

colden 


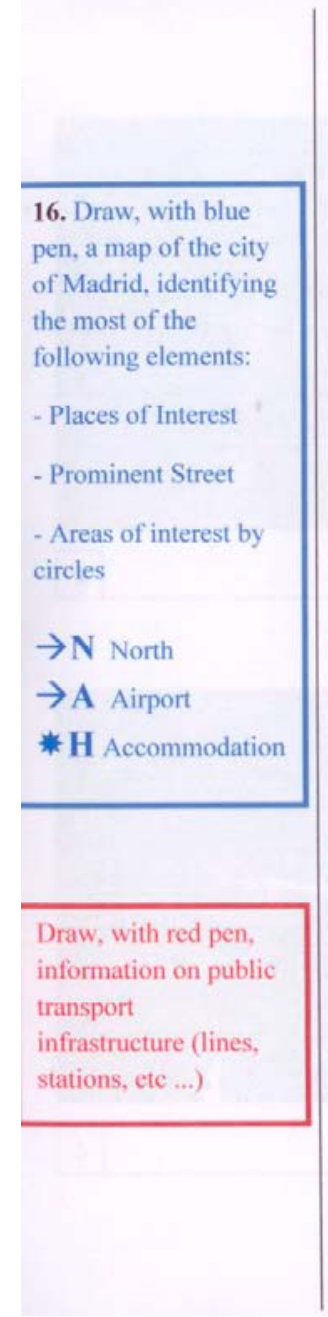

Madrid

$+1$

Bernabey

Buskettal

Palace

Athehco Madrid 


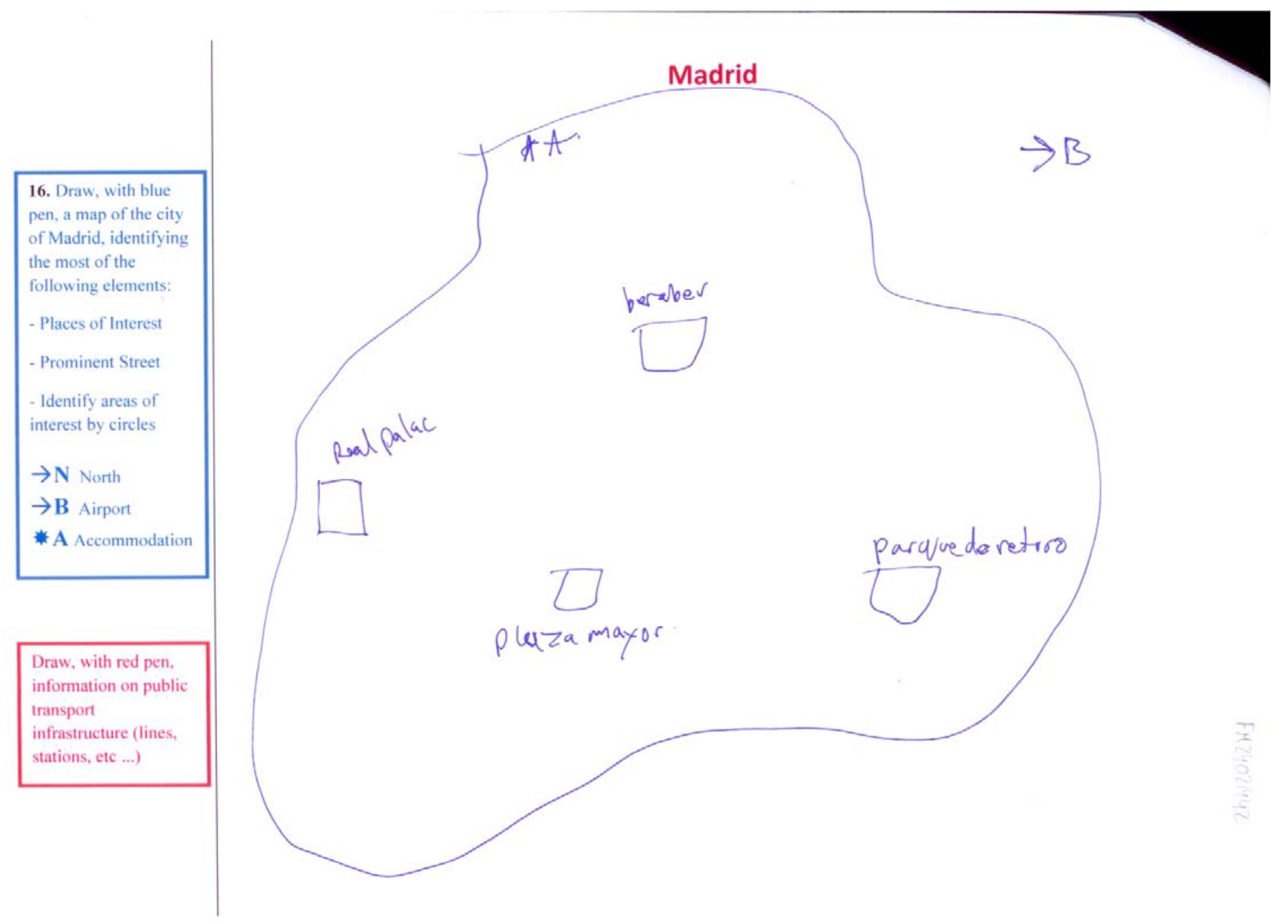




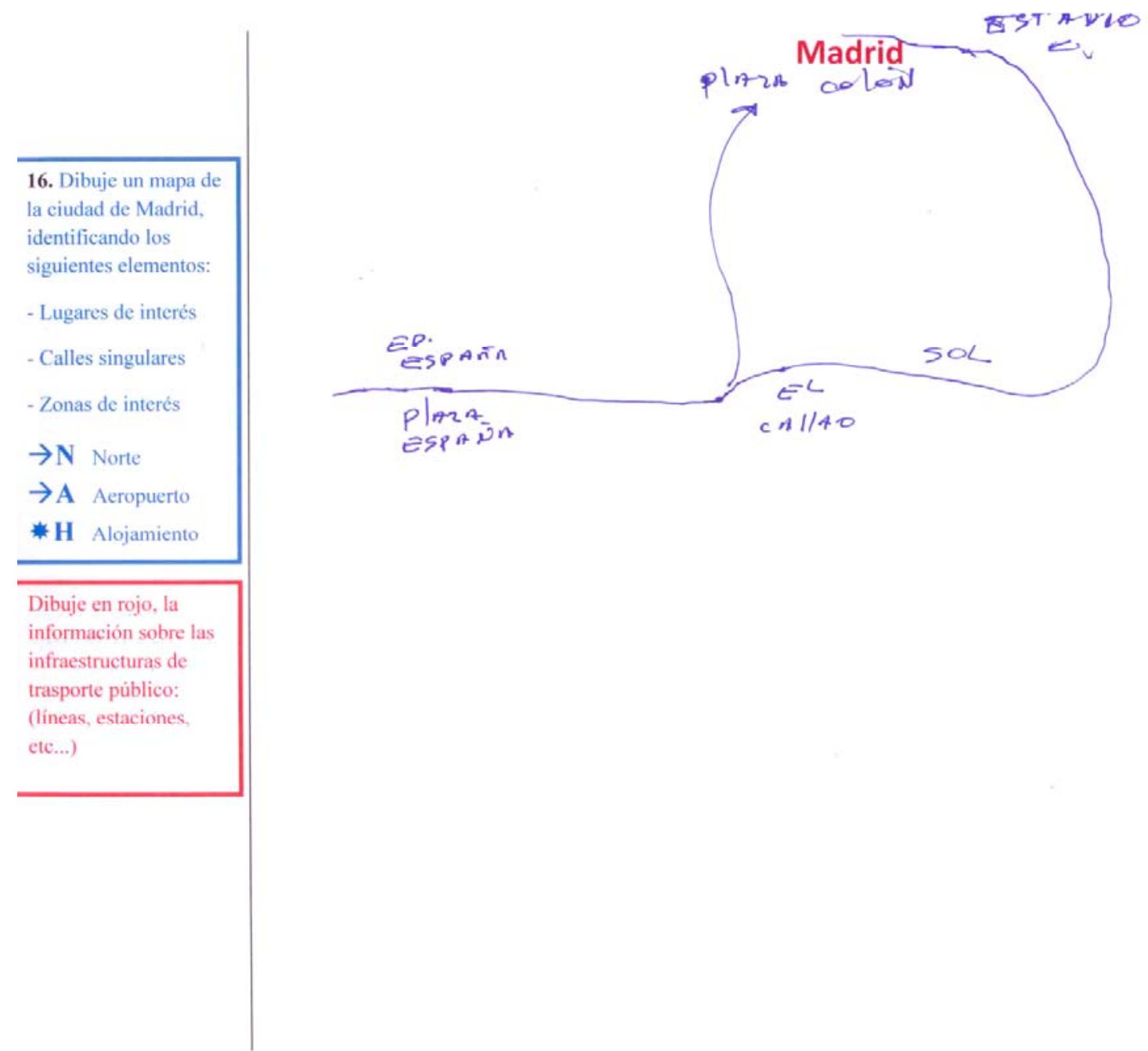




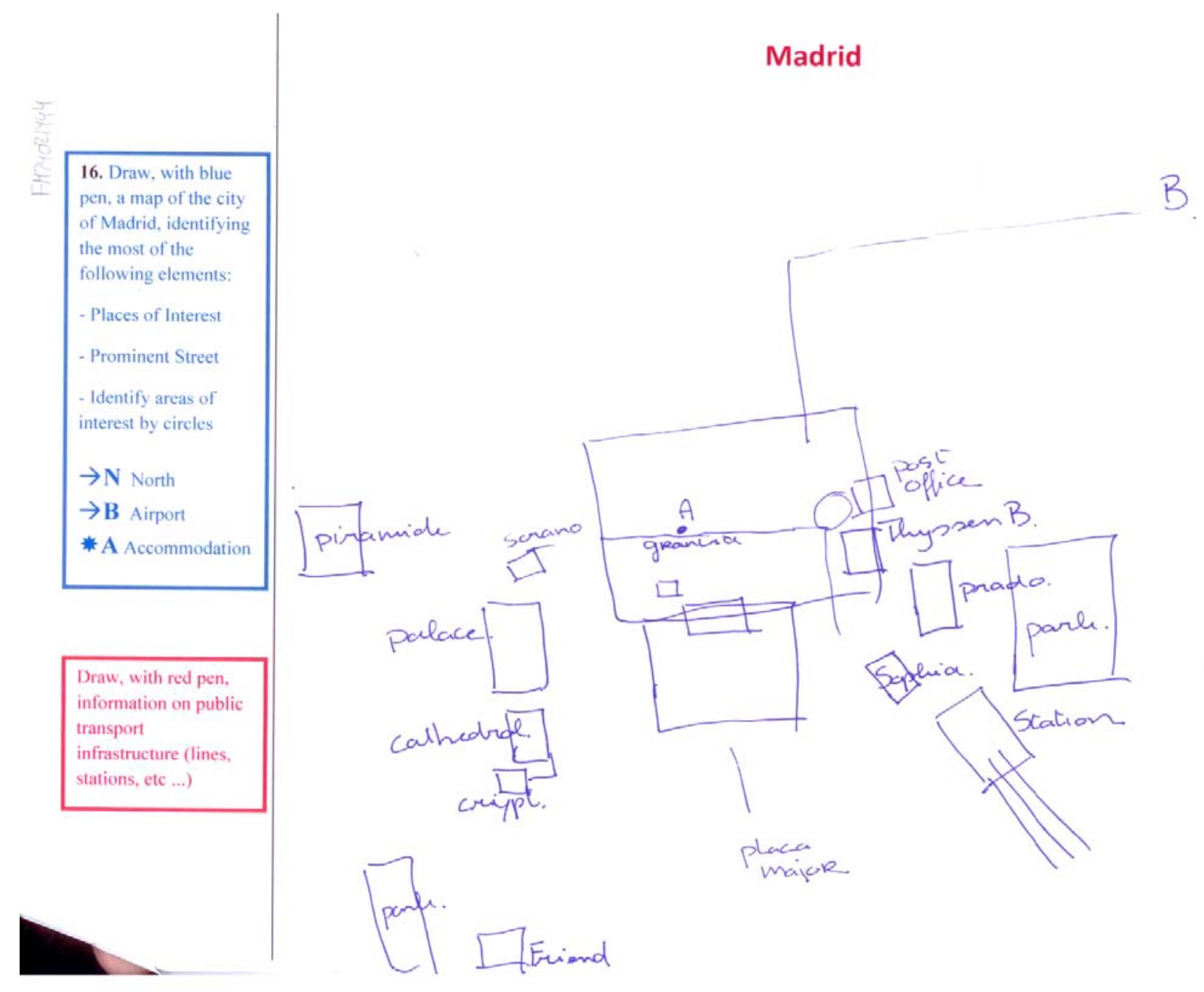




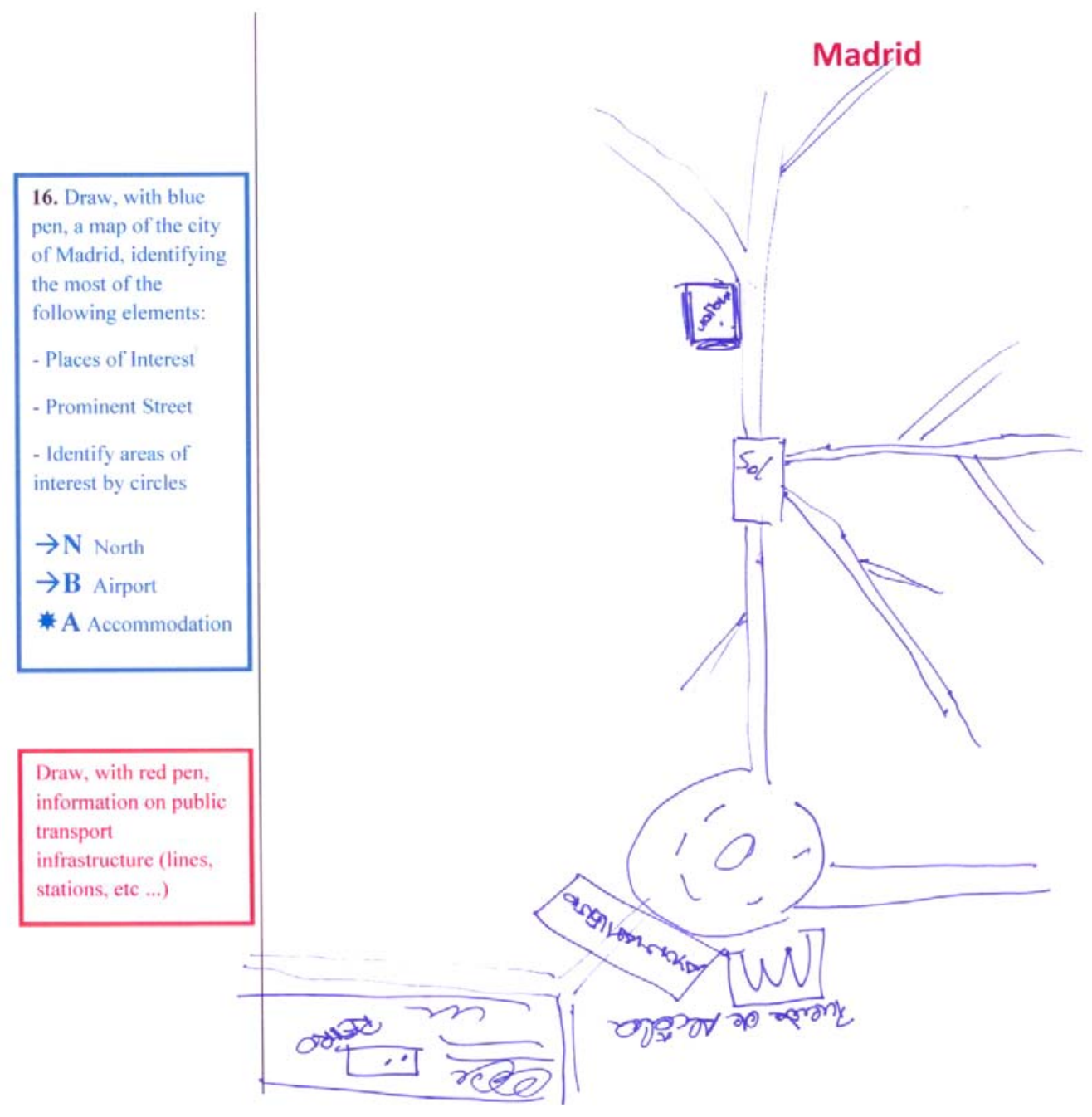




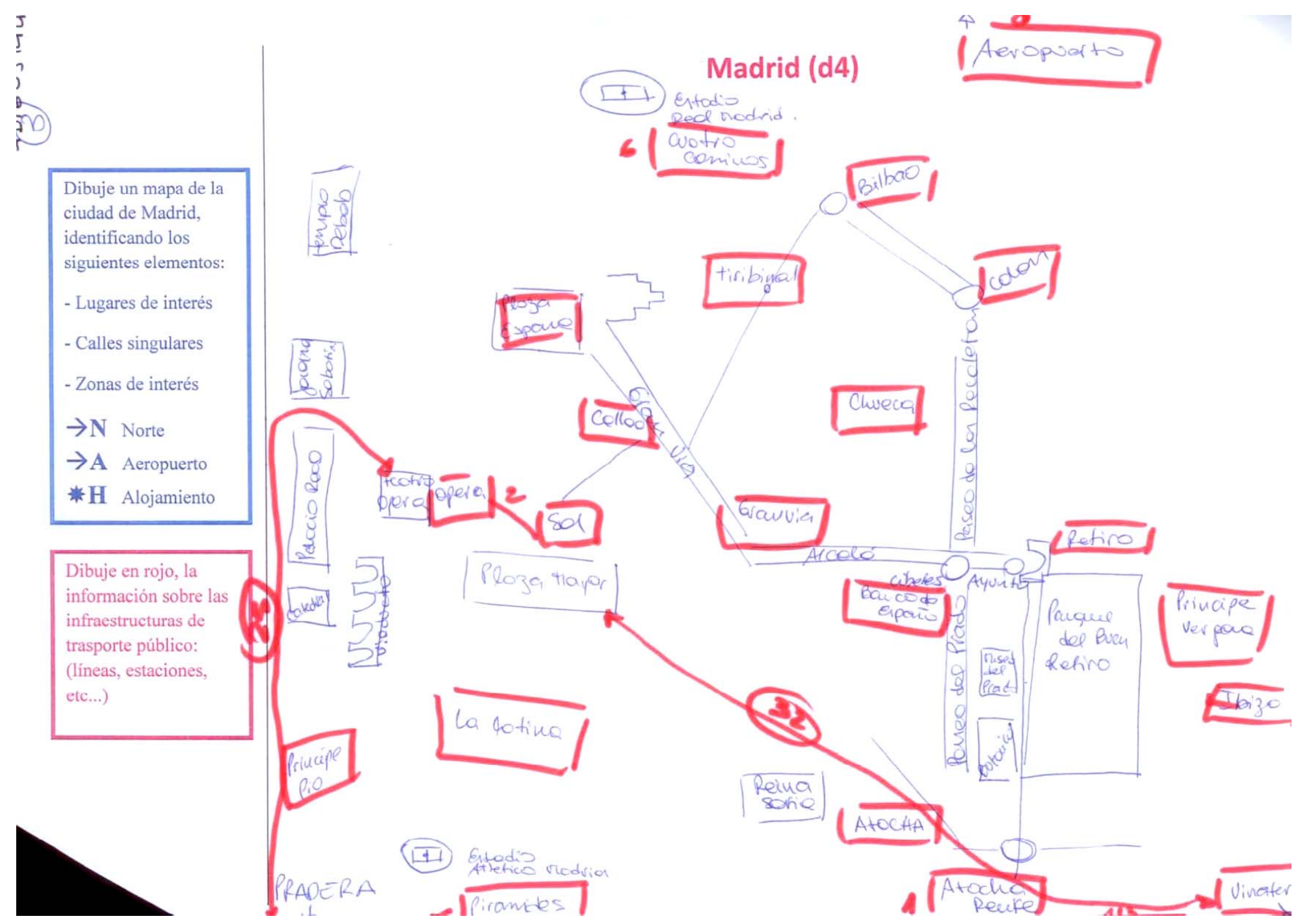




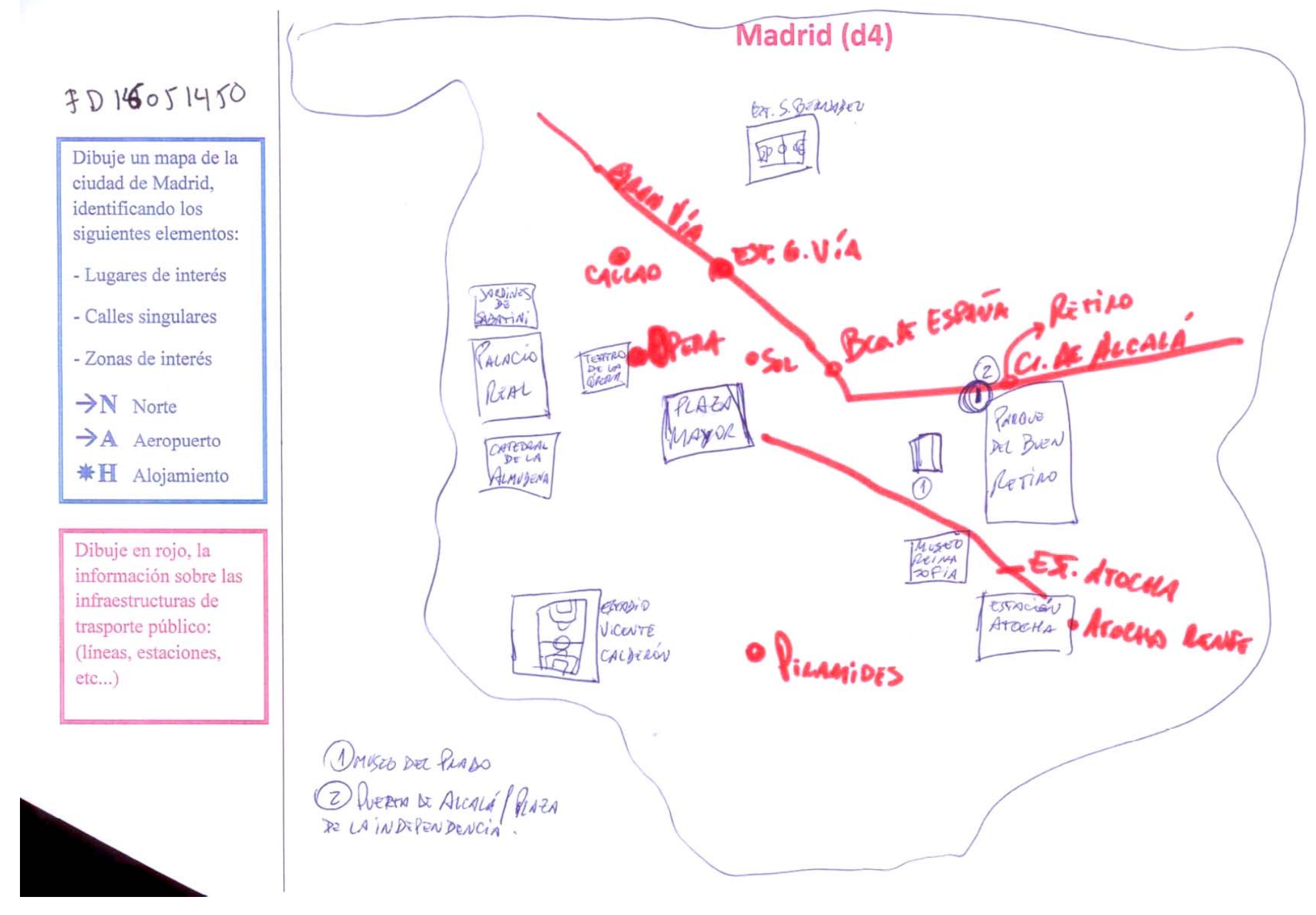


(FD 14051452)

MD 12051403

11. Draw, with blue

pen, a map of the city

of Madrid, identifying

the most of the

following elements:

Places of Interest

Prominent Street

Identify areas of

interest by circles

$\rightarrow \mathbf{N}$ North

$\rightarrow$ B Airport

* A Accommodation

Draw, with red pen.

information on public

transport

infrastructure (lines.

stations, etc ...)

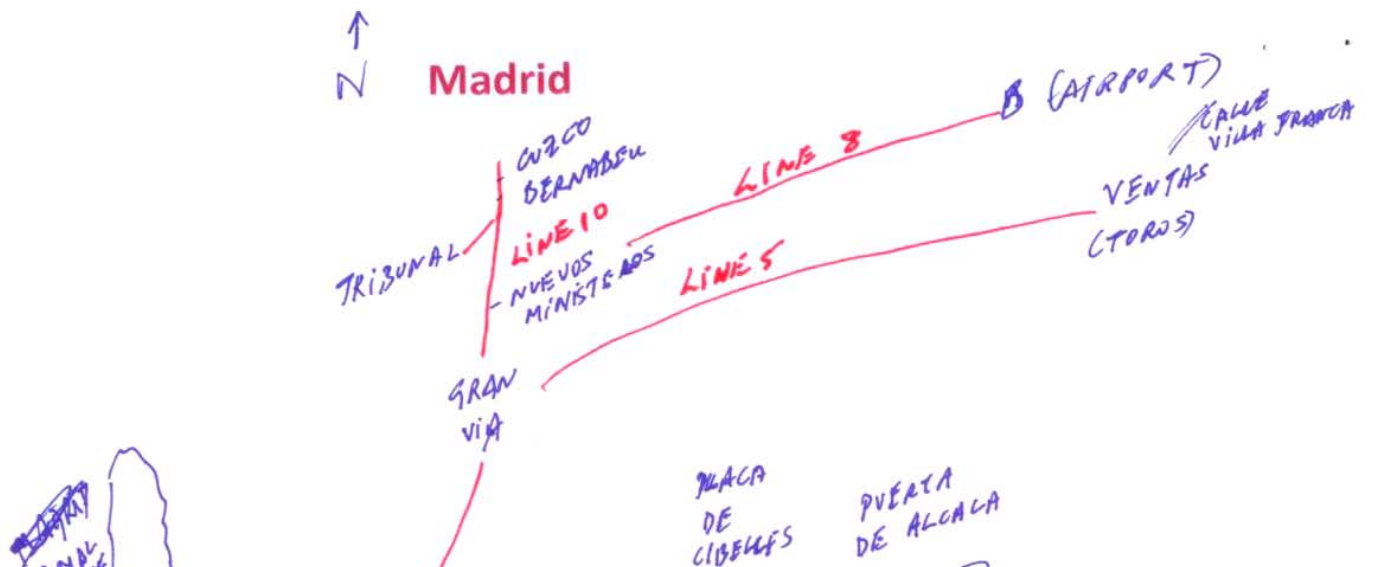

DE DESS DE ALCACA
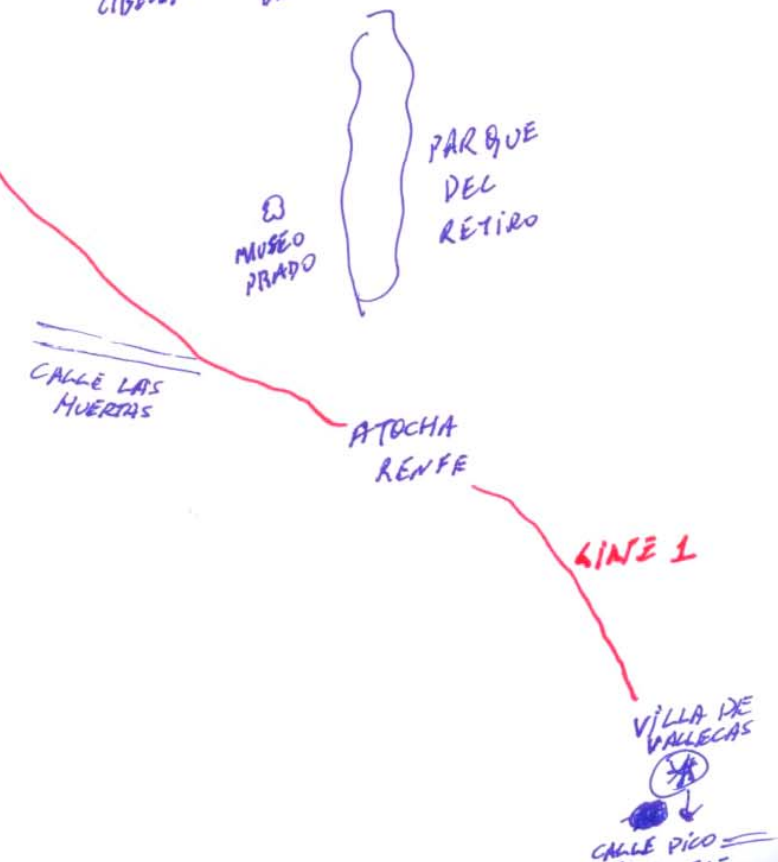

CALLE PICO= 
FD 12051451

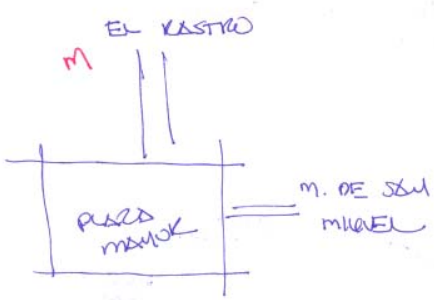

$$
\begin{aligned}
& \text { Mn } \\
& \text { PEERTS SOC }
\end{aligned}
$$

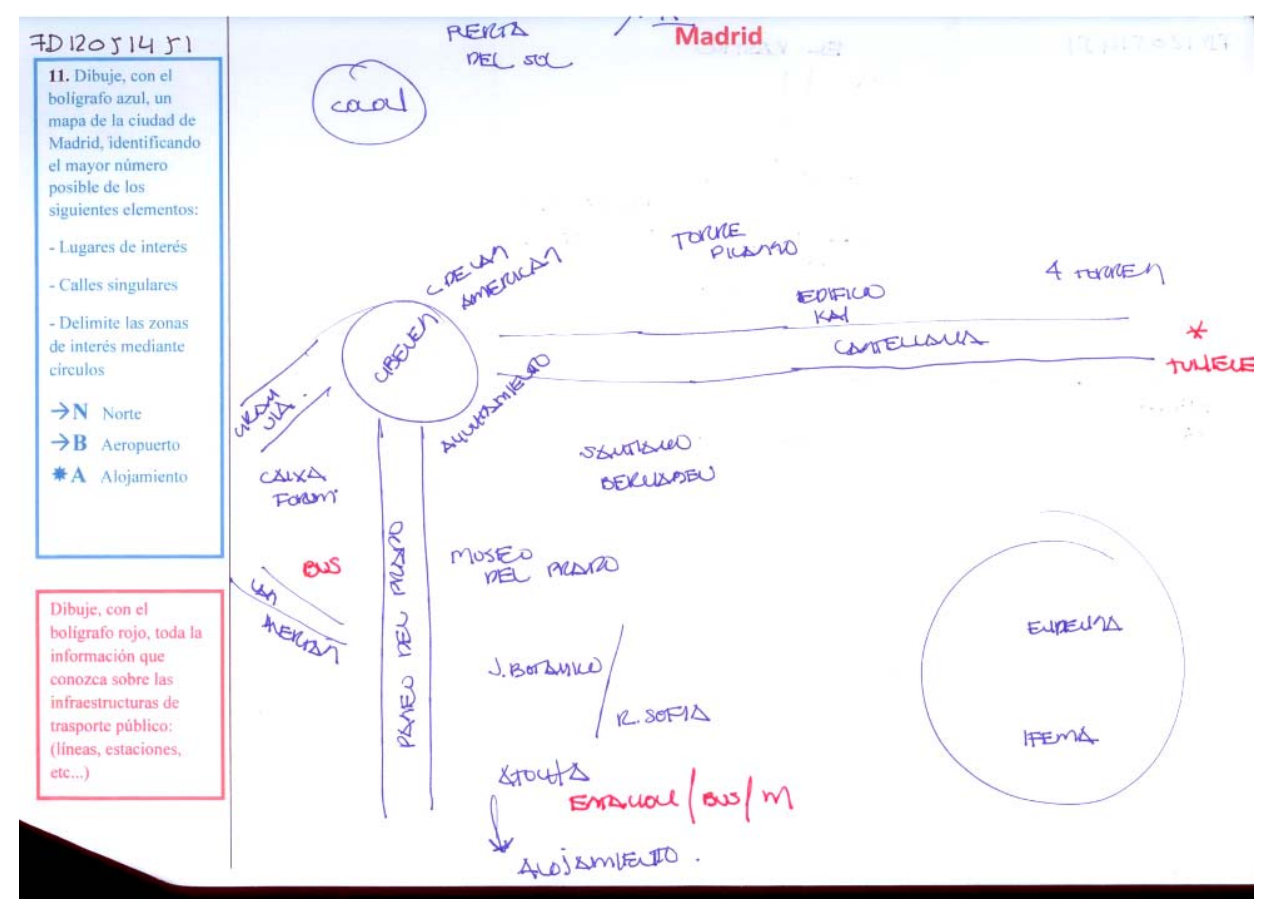

309 


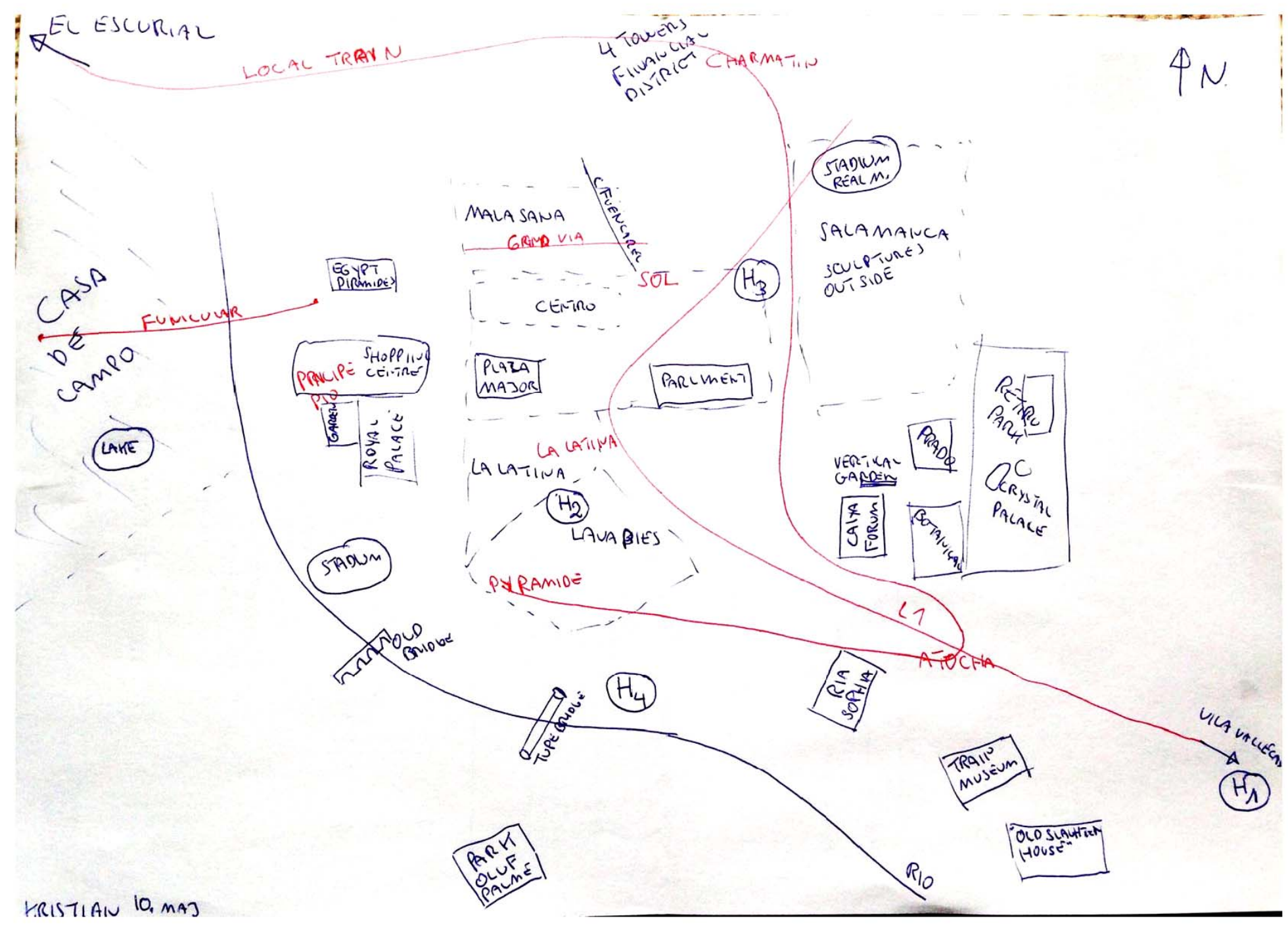

310 


\section{5}

Draw, with blue pen, a map of the city of

Madrid, identifying

the most of the

following elements:

Places of Interest

Prominent Street

- Areas of interest by

circles

$\rightarrow \mathbf{N}$ North

$\rightarrow$ A Airport

* H Accommodation

Draw, with red pen,

information on public

transport

infrastructure (lines,

stations, etc ...)

Uiv

24 Apuil

\section{Madrid (d4)}

N

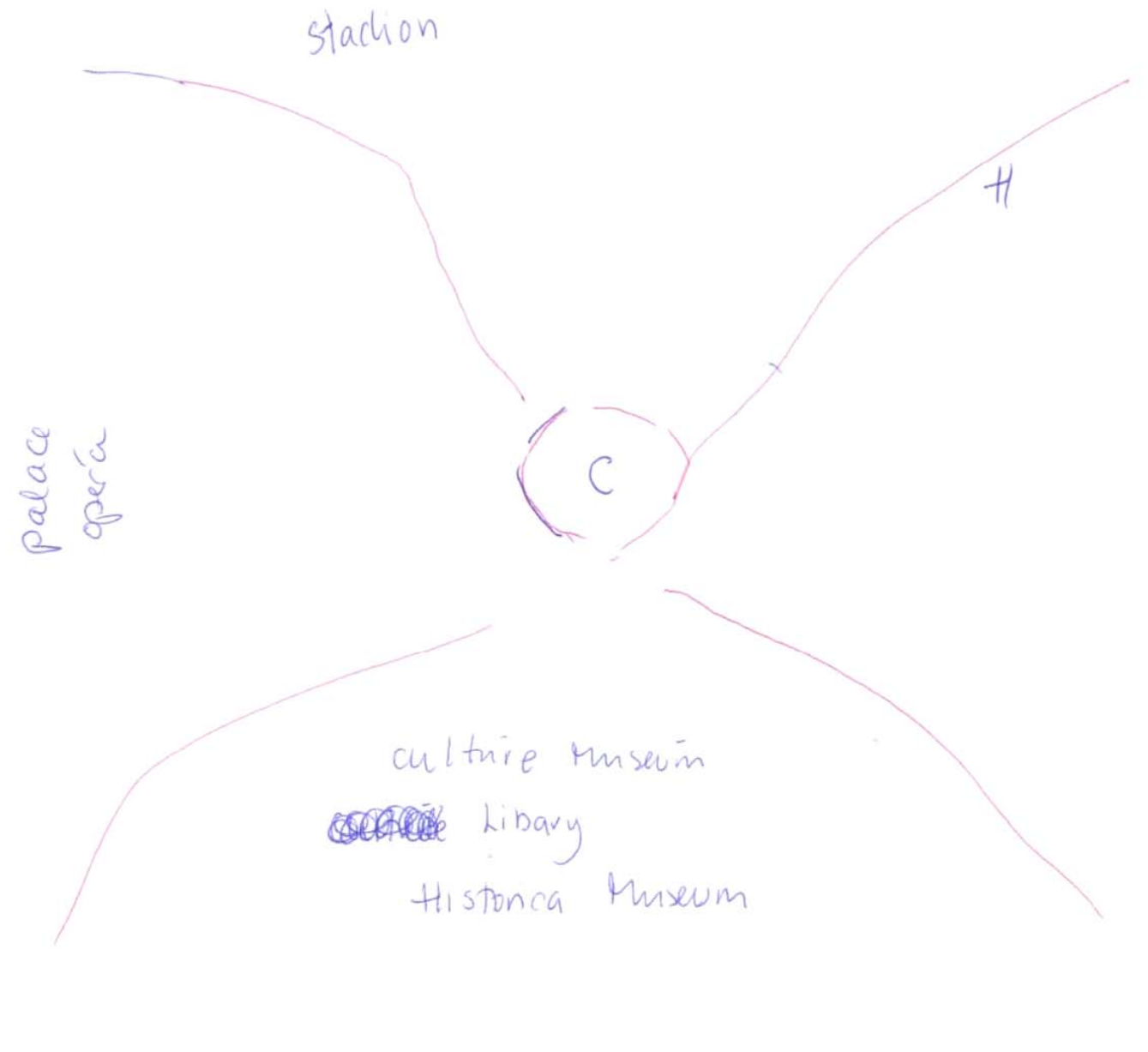


FHO3111455 16. Draw, with blue pen, a map of the city of Madrid, identifying the most of the following elements: - Places of Interes - Prominent Street - Identify areas of interest by circles

$\rightarrow \mathbf{N}$ North

$\rightarrow$ B Airport

* A Accommodation

Draw, with red pen, information on public transport

infrastructure (lines,

stations, etc ...)

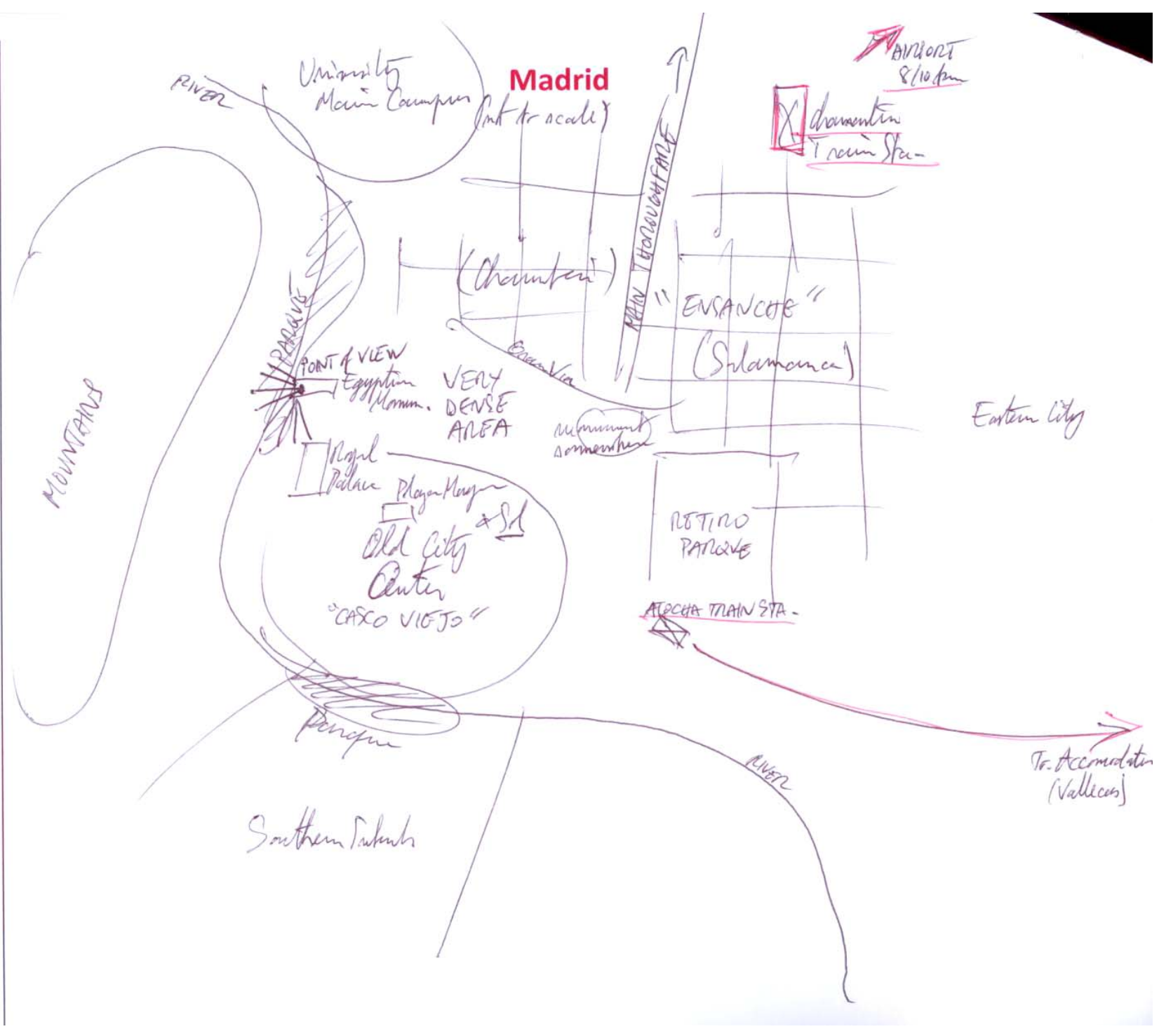




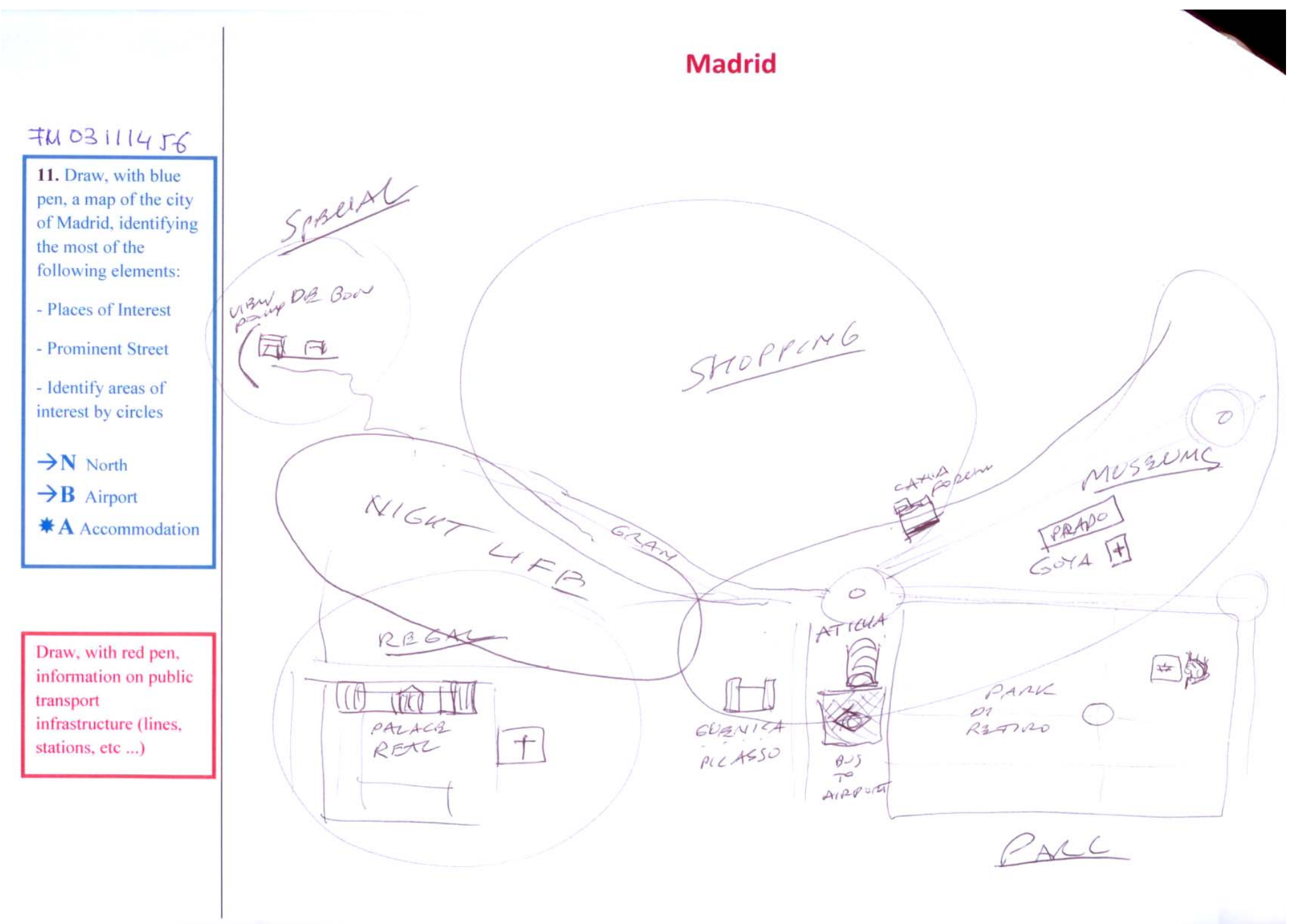


Anexo 19. Productos cartográficos que utilizan los turistas encuestados

- Pre-viaje:

\section{Productos turístico-cartográficos consultados durante el pre-viaje}

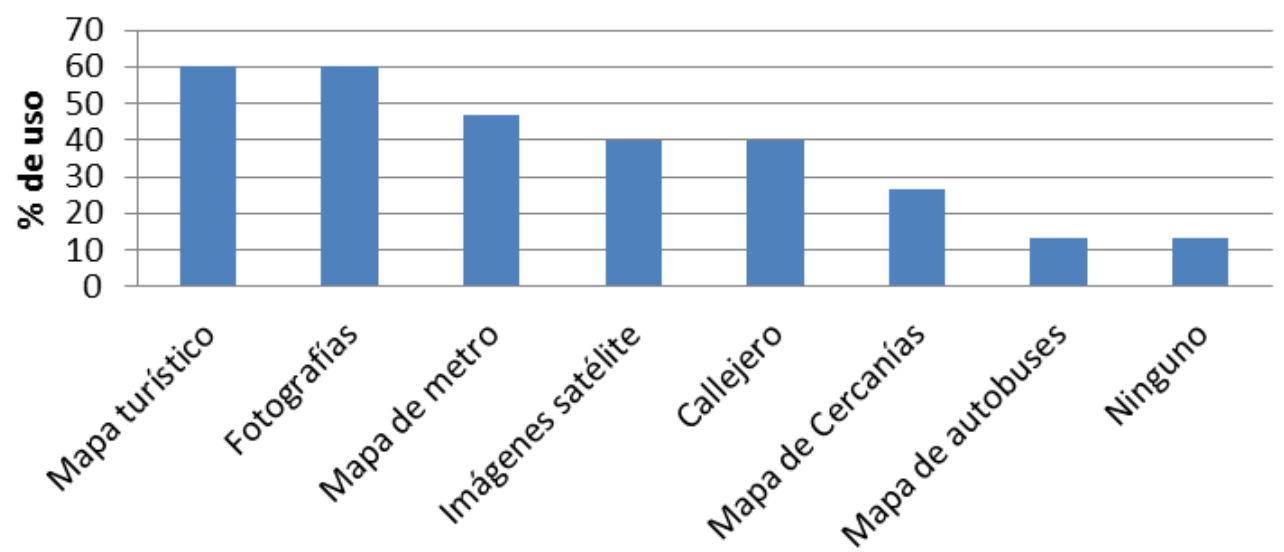

Figura A44: Productos turístico-cartográficos consultados durante el pre-viaje.

\section{Soporte/Fuente de información} turístico-cartográfica consultada durante el pre-viaje

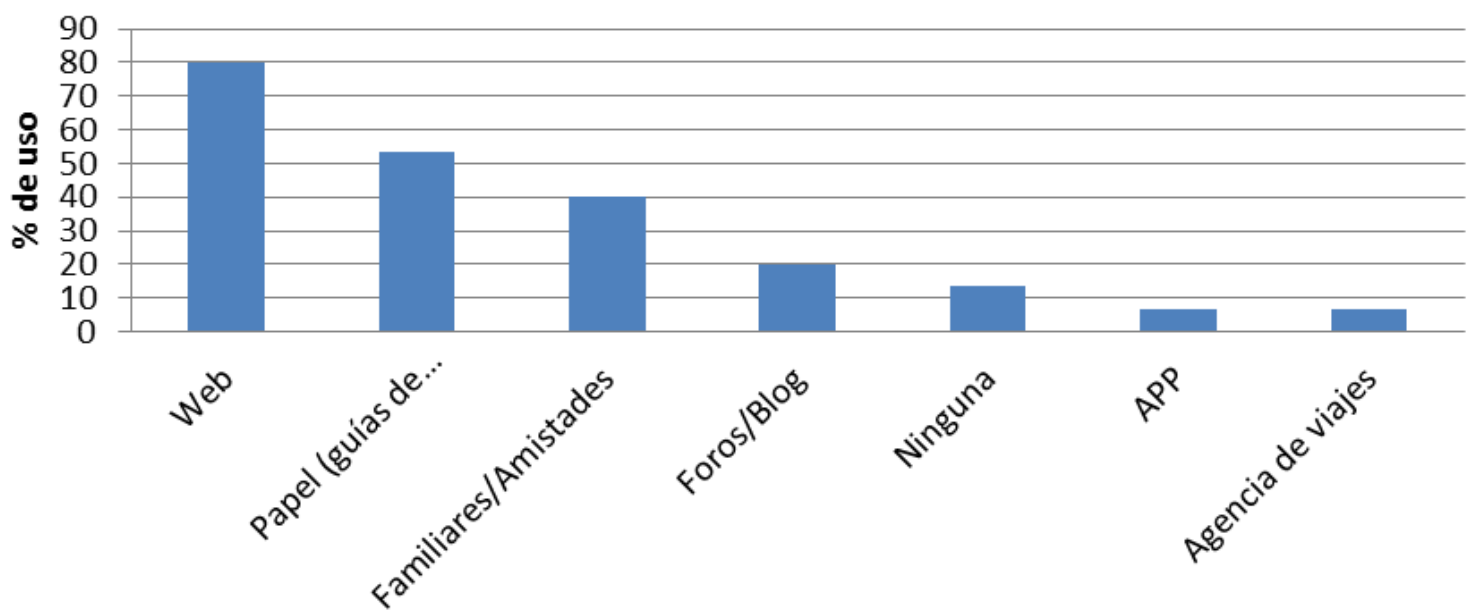

Figura A45: Soporte o fuente de información turística consultada durante el pre-viaje. 


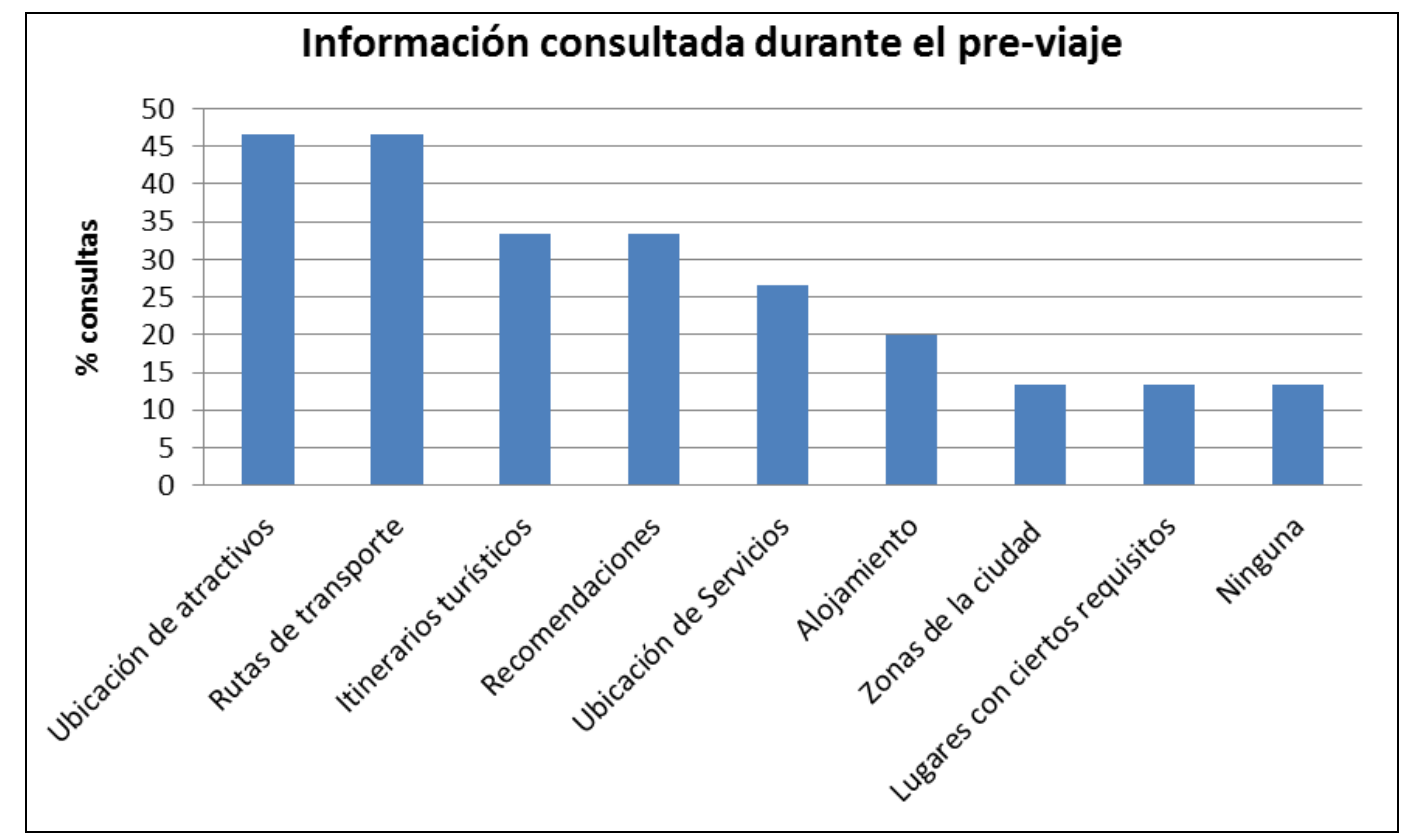

Figura A46: Información consultada durante el pre-viaje por los turistas encuestados.

- Durante de la visita

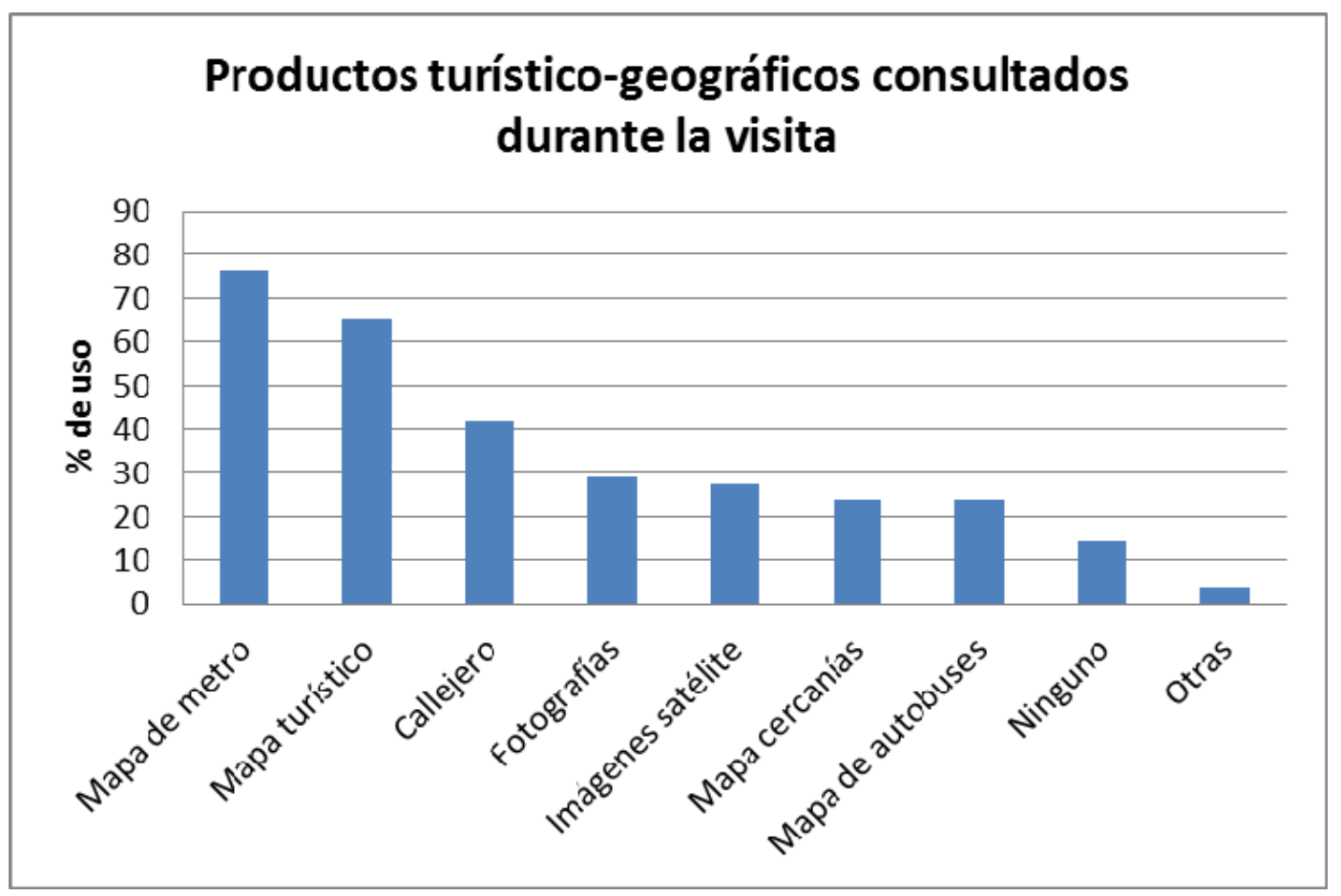

Figura A47: Productos turístico-cartográficos consultados durante el viaje. 


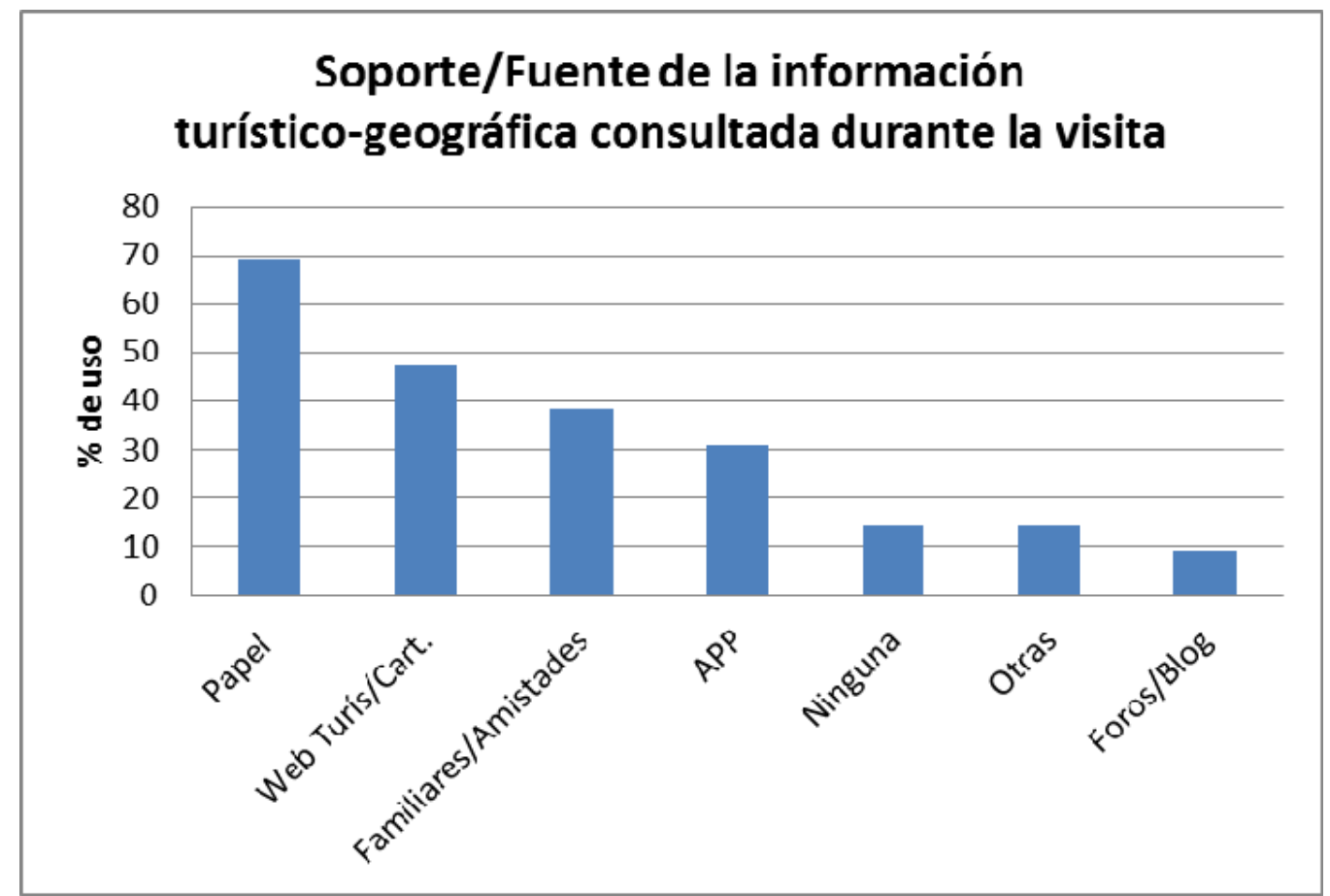

Figura A48: Soporte o fuente de información turística consultada durante el viaje.

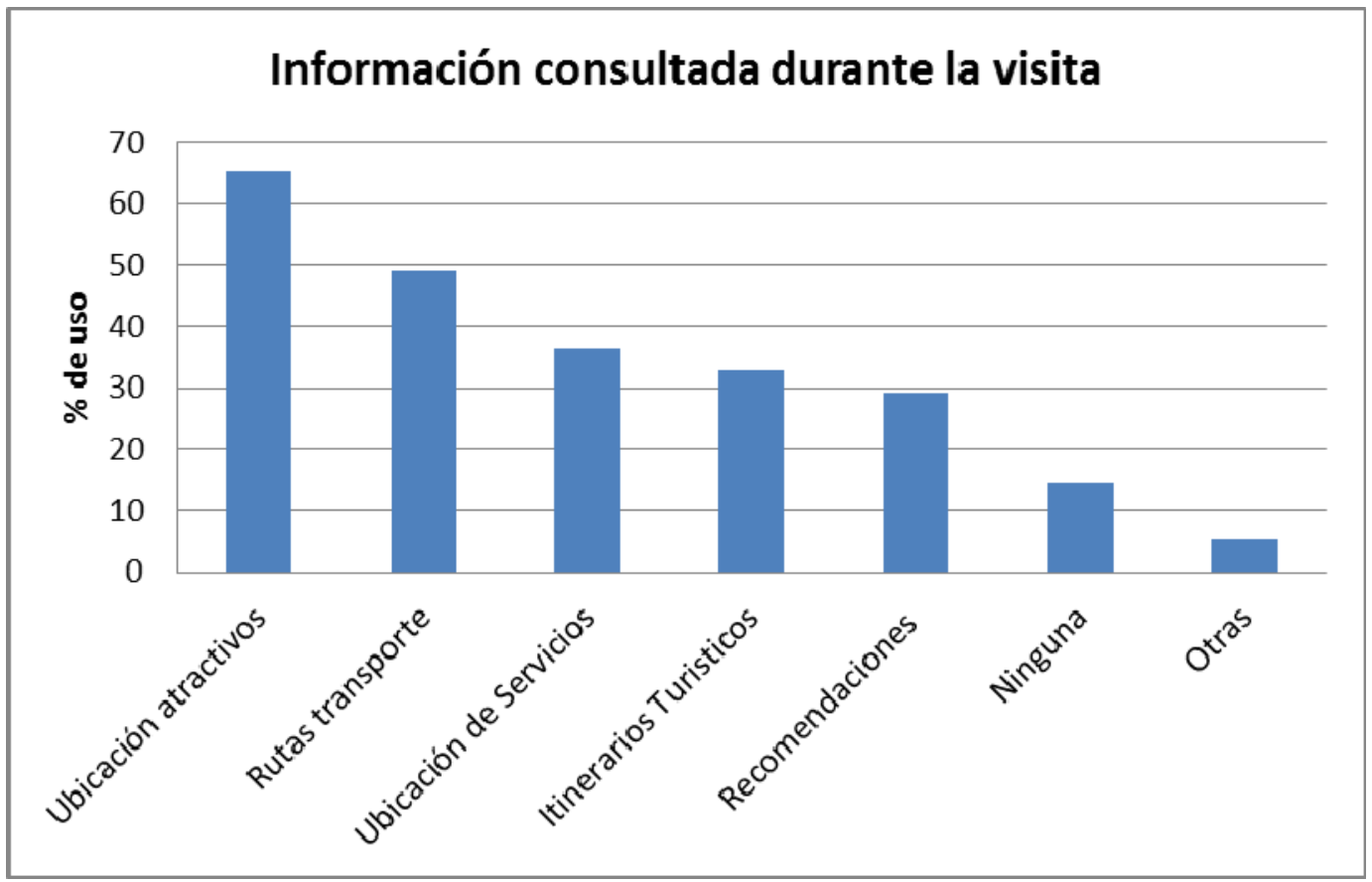

Figura A49: Información consultada durante el viaje por los turistas encuestados al finalizar su visita. 


\section{Anexo 20. Peculiaridades encontradas en los cuestionarios al realizar la síntesis de la interacción entre el turista y el ambiente en el que desarrolla su experiencia (Tarea 3.1).}

- Mapas mentales similares de turistas con distintos enfoques de experiencia.

A continuación se describe un caso inusual en el que dos turistas con mapas mentales muy similares, se asociaron a diferentes enfoques de experiencia, ya que el resto de factores considerados en el análisis los discriminaron. Las Figuras A50a y A50b, muestran mapas de apariencia muy similar, cuya conceptualización del espacio es fruto de experiencias turísticas diferenciadas por el grupo de viaje y sobre todo por la duración de la estancia, en relación al conocimiento adquirido. El turista del mapa correspondiente a la Figura A50a visitó Madrid en pareja, durante una estancia de 10 días, su mapa incluye 6 atractivos y se consideró condicionado, ya que su conocimiento de la ciudad es superior al alcanzado por los guiados e inferior al de los exploradores, en estancias largas. Por otro lado, la experiencia del turista correspondiente a la Figura A50b se consideró exploradora ya que viajó solo, su estancia fue de 5 días y su mapa incluyó 10 atractivos (prácticamente el doble de elementos que el turista anterior en la mitad de tiempo de estancia).

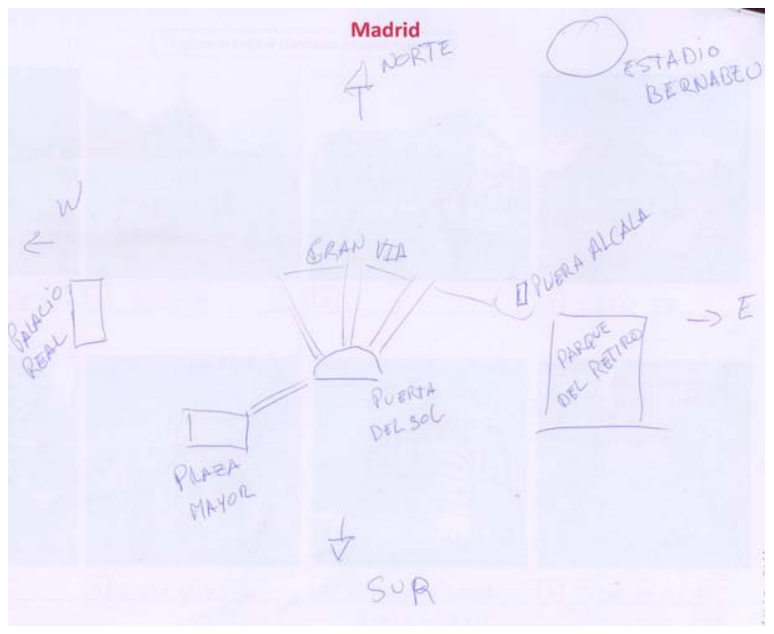

a

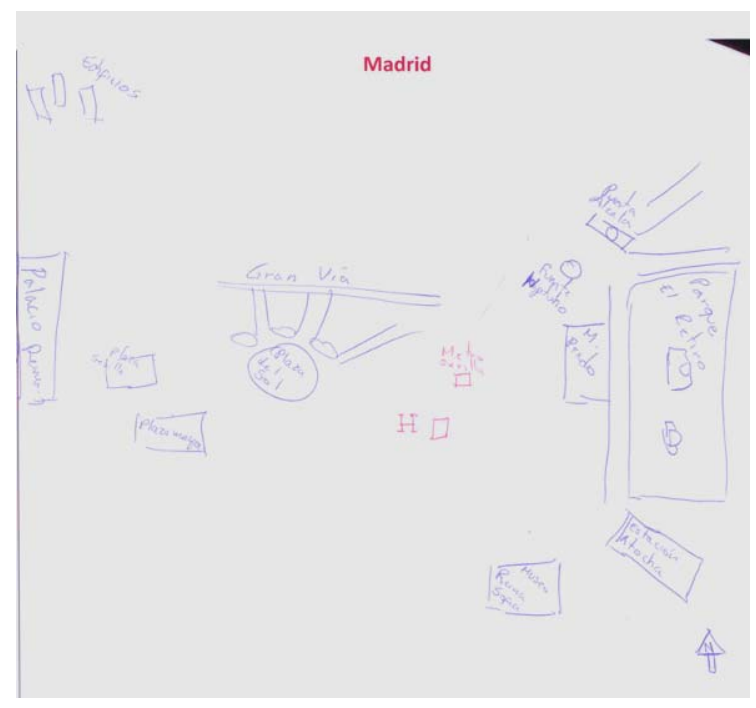

b

Figura A50: Mapas mentales de dos turistas al finalizar su visita, con un enfoque de experiencia a) condicionado y b) explorador.

- Casos peculiares relacionados con el conocimiento de Madrid por parte de los turistas.

Se da el caso de turistas que se alojan por ejemplo junto a Madrid Río (calle Virgen del Puerto) y que no mencionan este atractivo turístico. Lo que puede reflejar que aun conociendo un lugar éste no se incluye en el cuestionario, ni de forma gráfica, ni a través de texto.

En algunos casos los turistas manifiestan un interés que no se refleja en el conocimiento adquirido. Por ejemplo, un turista indica que solo le interesan los 
museos y no incluye ninguno en el mapa, ni entre los lugares visitados, ni identifica la foto del Museo del Prado.

-Falta de correlación entre el nivel de planificación y el conocimiento de la ciudad.

No se ha identificado una correlación entre el nivel de planificación de la visita y el conocimiento del espacio por parte de los turistas recién llegados. Este hecho, aunque chocante al principio, resulta lógico si se tiene en cuenta que una persona que viaja en un grupo organizado sabe exactamente lo que va a realizar cada día, aunque esta forma de planificar el viaje implica poca búsqueda de información y una mínima toma de decisiones por parte del turista, lo que supone un bajo conocimiento de los lugares que va a conocer, así como de su distribución geográfica. Mientras que otros turistas, que han consultado mucha información para decidir visitar Madrid pueden haber manifestado que no han planificado nada el viaje, ya que su forma de abordar la experiencia es flexible y espontánea según van surgiendo las situaciones en el destino; pero su nivel de conocimiento de la ciudad es alto y su conceptualización del espacio es abstracta y coordinada.

En coherencia con lo expuesto, en cuanto al nivel de planificación y el nivel de conocimiento al finalizar la visita, un turista identificado como explorador, con un nivel bajo de planificación, en solo 2 días conoce el Matadero, Lavapiés, el Km 0 y la cava baja, entre otros lugares. Mientras que otro turista de enfoque guiado que ha venido a visitar a familiares y que ha manifestado haber planificado completamente lo que va hacer en la ciudad, no llega a recordar prácticamente nada de ella.

Todo ello permite concluir que los niveles de planificación del viaje indicados por los encuestados obedecen a percepciones muy subjetivas, que no permiten establecer asociaciones con respecto al posible conocimiento adquirido de la ciudad. 


\section{Anexo 21. Detalles de la síntesis de la interacción entre el turista y los mapas que dan soporte a su experiencia de Madrid (Tarea 3.2)}

\section{- Explorador}

Conceptualización de Madrid antes de iniciar su visita, por parte de turistas que abordan la experiencia con enfoque explorador.

Los mapas de los turistas con enfoque explorador se caracterizan por un número relativamente elevado de elementos puntuales aislados ( 6 atractivos en las Figuras A.51a) y b)), por contener ejes de transporte ( 2 en la Figura A51c) y 1 en la Figuras A.51 d) y e)), por la escasa presencia de ejes en forma de calles (1 en las Figuras A51 a) y b) y ninguno en el resto); y por la presencia de zonas (4 en la Figura A51 d) y 1 en las Figuras A51 e y f)).

Estos mapas presentan sistemas de referencia:

-Diferenciado: con elementos puntales sueltos de los que parten algunos ejes (marco de referencia tipo (2), Figura A51a)),

- Multi-puntual cartográfico: sin o con ejes de transporte (marco de referencia tipo (3), Figuras A51b) y c), respectivamente)

- Coordinado: con elementos puntuales, zonas y referencias naturales (marco de referencia tipo (3), (4) y (5) respectivamente, en las Figuras A51d) y e)).

Estos mapas abarcan un área relativamente amplia de la ciudad, sin presencia de focos de referencia.

Conceptualización de Madrid una vez finalizada su visita, por parte de turistas que abordan la experiencia con enfoque explorador.

Los mapas se caracterizan por incluir un gran número de puntos de interés sueltos (12 atractivos turísticos y 6 estaciones de media), en relación a los mapas mentales del resto de los enfoques. Los mapas incluyen en menor medida ejes (calles o líneas de transporte) (3 de media) y zonas (1-2).

Los mapas finales de los turistas con enfoque explorador presentan tres sistemas de referencia característicos:

- Multi-puntual cartográfico: Con puntos de interés sueltos (marco de referencia tipo (3), Figura A52 a)).

- Diferenciado: Visiones parciales de zonas de la ciudad no coordinadas entre sí y representadas a través de puntos de interés sueltos (marco tipo 3, Figuras A52 b) y c)), conectados en algunos casos por calles (marco tipo 2, Figura A52 d))

- Coordinado: Al igual que los anteriores presentan puntos de interés sueltos (marco tipo 3 Figura A52 e)), que en algunos casos se conectan por calles (marco tipo 2, Figura A52 f)). Y que pueden incluir zonas de la ciudad y elementos naturales de referencia (marcos de referencia tipo 4, y 5 respectivamente, Figuras A52 g) y h)). 

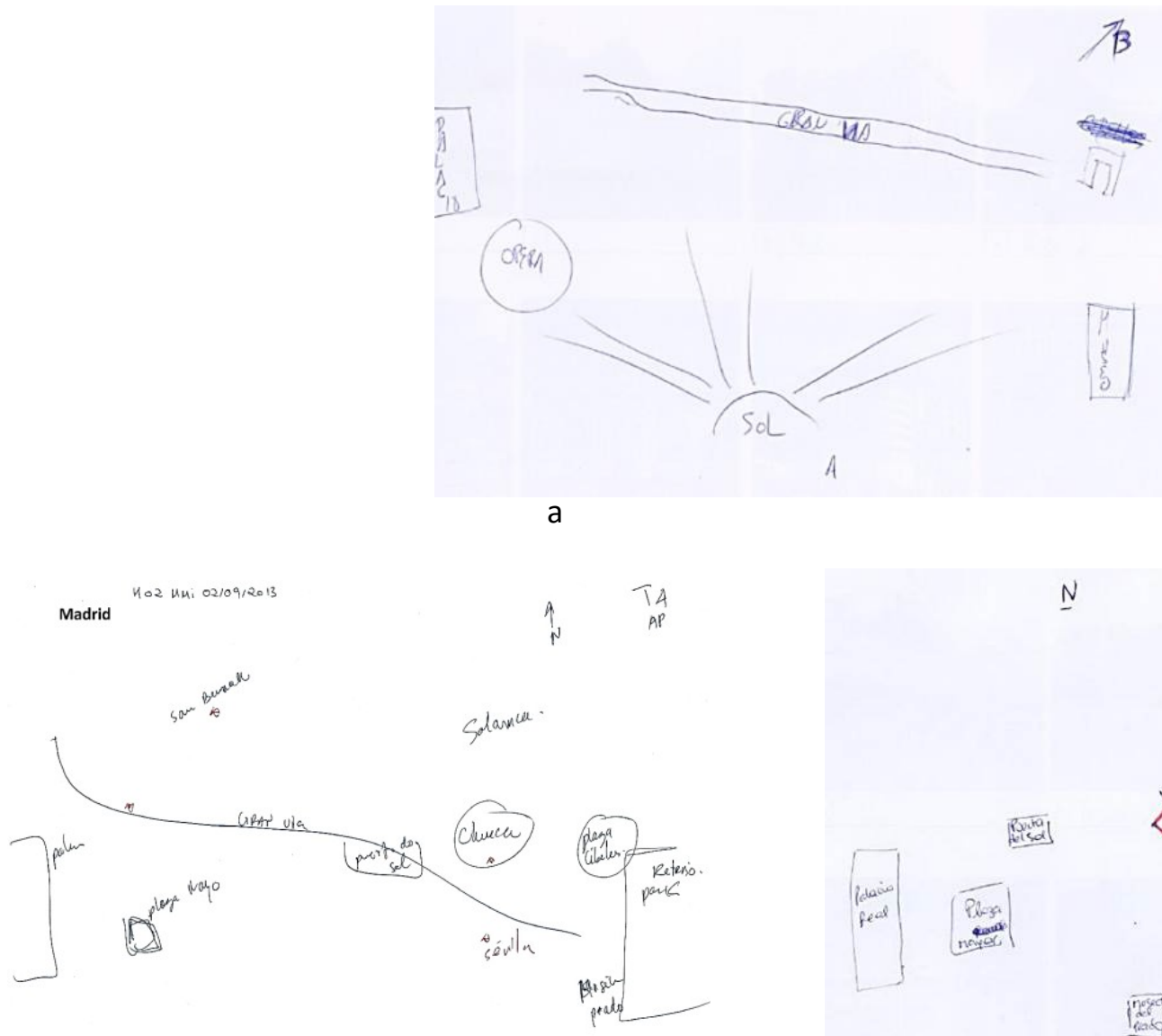

b
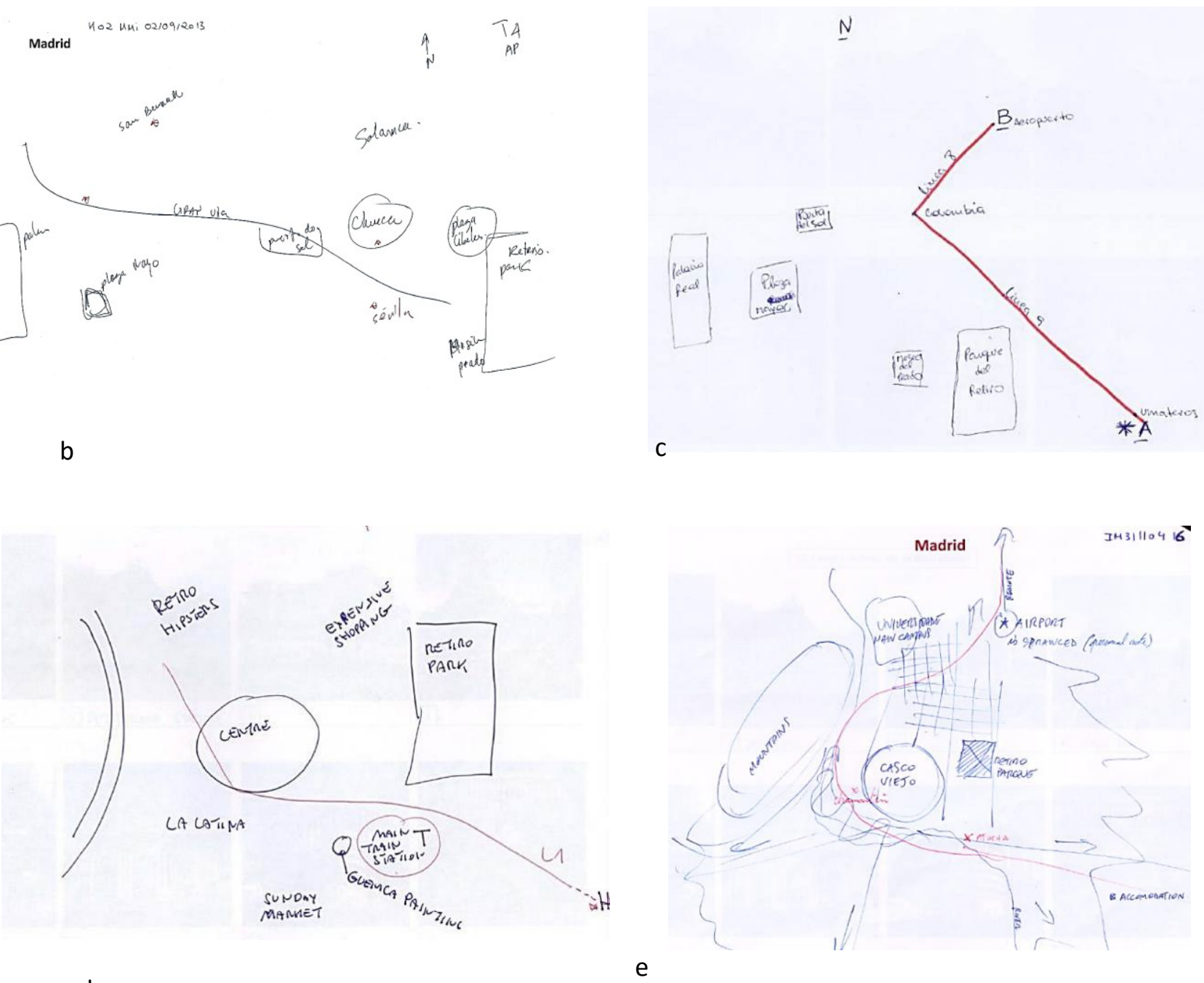

d

Figura A51: Mapas mentales iniciales de turistas que abordan su experiencia desde un enfoque explorador: a) Diferenciado; b) y c) Multi-puntual cartográfico; d) y e) Coordinado. 


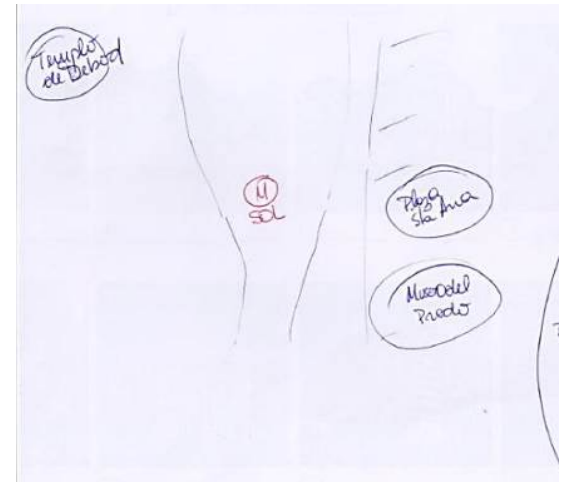

a
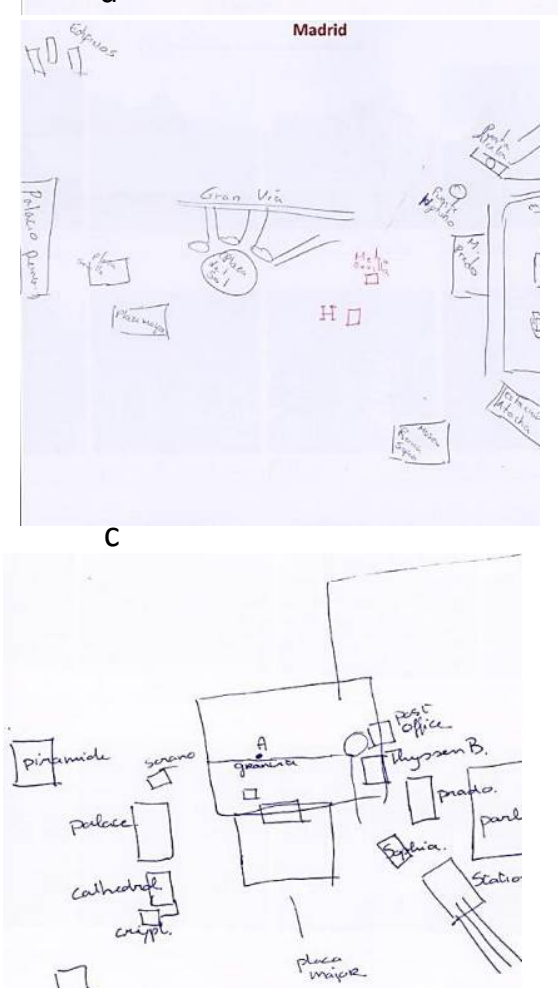

Fart. MFind

e

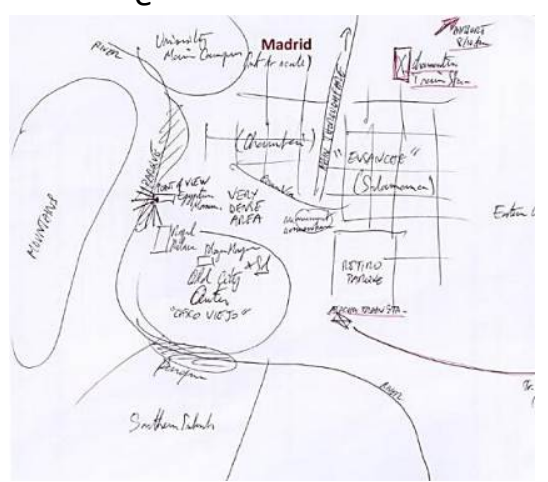

g
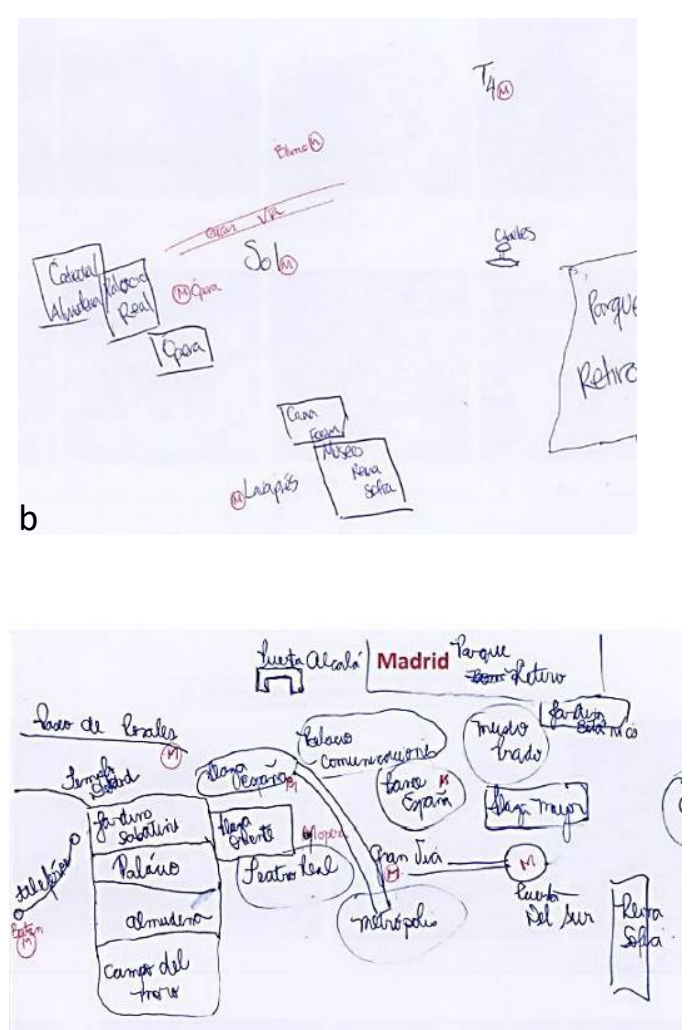

d

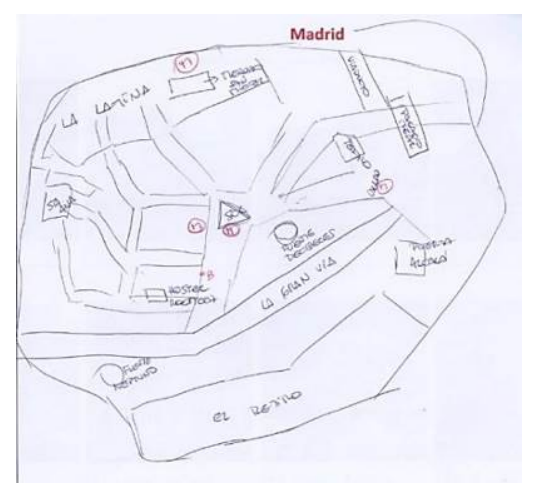

f

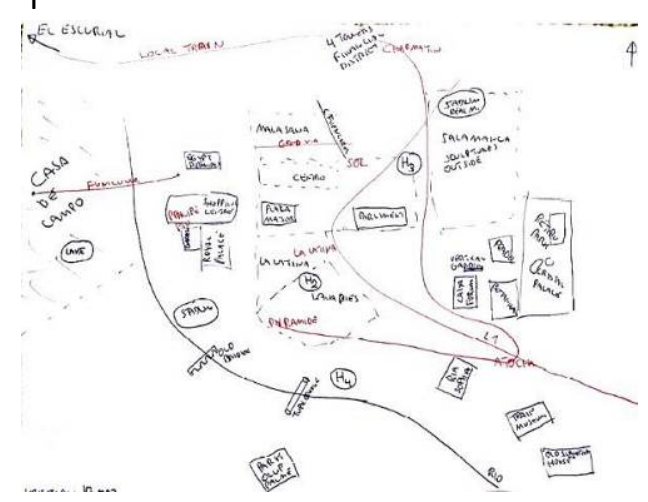

$\mathrm{h}$

Figura A52: Mapas mentales finales de turistas que abordan su experiencia desde un enfoque explorador: a) Multi-puntual cartográfico; b), c) y d) Diferenciado y d), e), f) g) y h) Coordinado. 
La mayoría de los mapas mentales de turistas con enfoque explorador presentan una cobertura espacial amplia de la ciudad de Madrid (global).

Como resultado del análisis de los mapas de los turistas con enfoque explorador se extrajeron las siguientes características:

- ¿Qué elementos incluyen? Predominantemente puntuales (media de 12 PIT y 6 infraestructuras de transporte) frente a ejes (3) y zonas (2).

- ¿Cómo los representan? Siguiendo un sistema de referencia diferenciado o coordinado. Las representaciones podrán incluir un foco vinculado a un punto de interés o ninguno. El contenido del mapa como interfaz se representará fundamentalmente a través de puntos sueltos que podrán unirse mediante ejes (calles o líneas de transporte) e integrar en zonas. También se contempla la posibilidad de incluir referencias naturales (Río Manzanares y Sierra de Guadarrama).

\section{- Guiado}

Conceptualización de Madrid al inicio de la visita, por parte de turistas que abordan la experiencia con enfoque guiado.

El $29 \%$ de los turistas con enfoque guiado no son capaces de dibujar ningún mapa mental o realizan una representación puntual de tipo imagen (Figura A53 a)) o cartográfica (Figura A53 b)). Algunos mapas reflejan la única experiencia que el turista ha tenido hasta el momento en la ciudad, asociada al recorrido desde el aeropuerto o la estación a la que llega a la ciudad (Figura A53 c)). Estos mapas tienen un sistema de referencia egocéntrico e incluyen como focos el aeropuerto y el alojamiento, que enlazan a través de las líneas de transporte (metro o tren). Su marco de referencia es de tipo (1) siendo estos ejes de transporte y no calles.

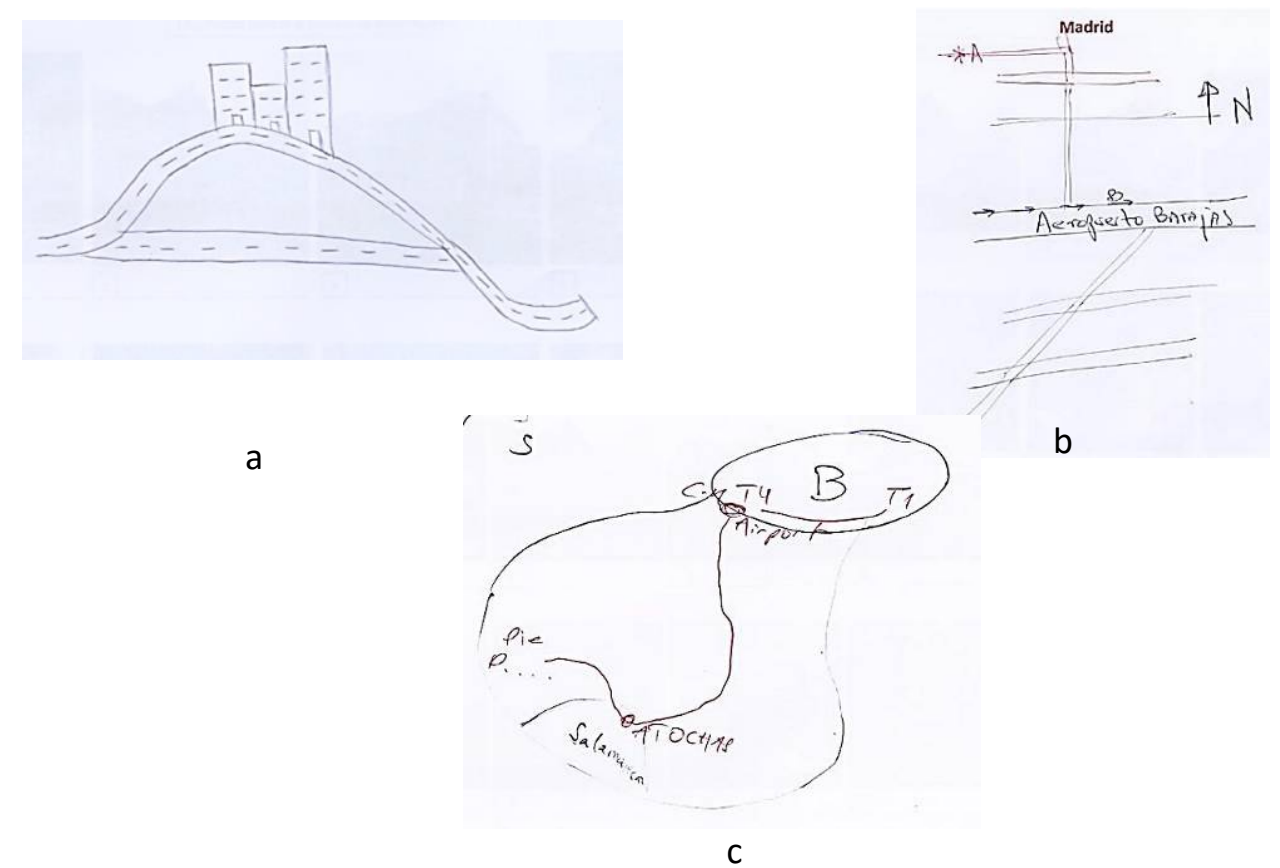

Figura A53: Mapas mentales iniciales de turistas que abordan su experiencia desde un enfoque guiado: a) Puntual tipo imagen, b) Puntual tipo cartográfico y c) Egocéntrico. 
Conceptualización de Madrid al finalizar la visita, por parte de turistas que abordan la experiencia con enfoque guiado.

El $24 \%$ de los turistas con enfoque guiado no dibujan ningún mapa mental al finalizar la visita y los mapas del resto presentan cuatro sistemas de referencia diferentes:

- Puntual: (Figura A54 a)

- Multi-puntual de tipo imagen o cartográfico (Figura A54 b) con marco de referencia tipo (3),

- Egocéntrico: caracterizado por el marco de referencia tipo (1) (Figura A54 c),

- Diferenciado: con marco de referencia tipo (2) combinado con 3 (puntos sueltos) (Figura A54 d).

Aproximadamente la mitad de estos mapas tienen un foco asociado al lugar de alojamiento o un atractivo turístico y el resto no tienen foco. El $58 \%$ de los mapas tienen una cobertura global, y el resto sectorial o puntual. Los mapas finales de los turistas con enfoque guiado se caracterizan por un escaso número de elementos entre los que predominan los puntuales (4 PIT y 1 estación de metro de media) frente a los ejes y zonas, que son prácticamente inexistentes.

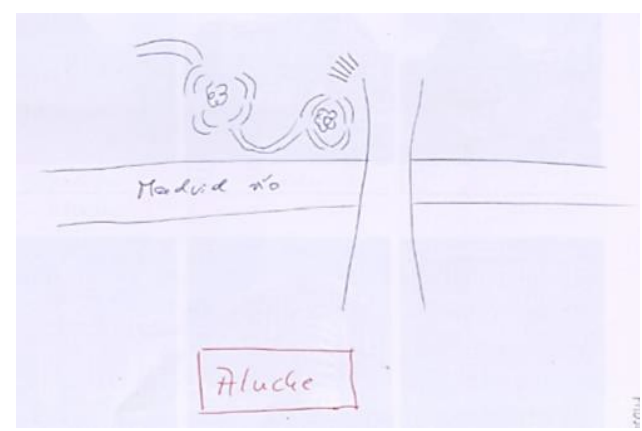

a

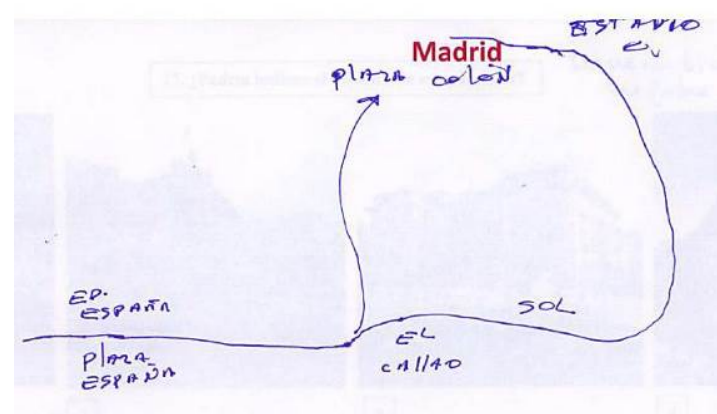

C

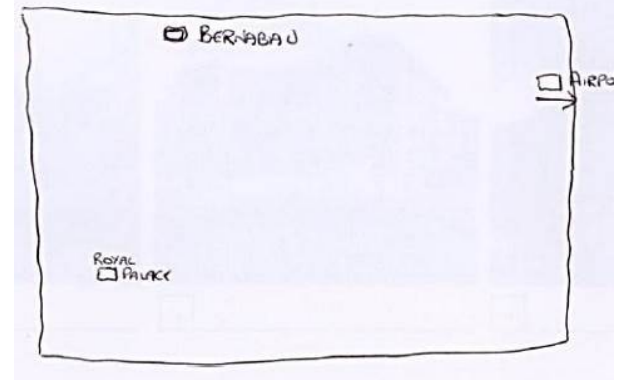

b

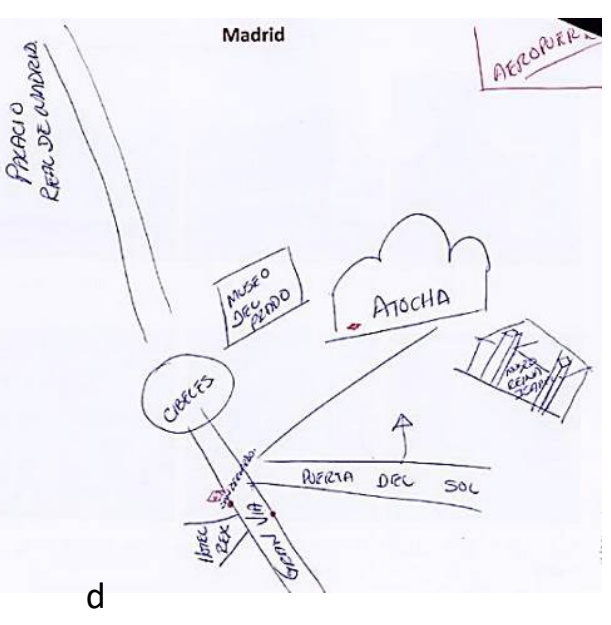

Figura A54: Mapas mentales de turistas que abordan su experiencia desde el enfoque guiado: a) Puntual, b) Multi-puntual de tipo cartográfico, c) Egocéntrico y d) Diferenciado. 
Como resultado del análisis de los mapas de los turistas con enfoque guiado se pueden extraer las siguientes características:

- ¿Qué elementos incluyen? Predominantemente puntuales (media de 4 PIT y 1 de infraestructura de transporte), frente a ejes (de media 0) y zonas (1).

- ¿Cómo los representan? Siguiendo un sistema de referencia egocéntrico: que podría aplicarse a representaciones asociadas a actividades que implican desplazamiento, como por ejemplo durante el recorrido por la ciudad en bus turístico; o diferenciado: que podría asociarse a actividades estáticas como la consulta de lugares de interés próximos a un atractivo concreto durante la visita de la ciudad. En los diseños se tratará de incluir un foco de referencia que podrá asociarse al lugar de alojamiento o a un atractivo turístico. En ambos casos también se contempla la posibilidad de incorporar PIT "sueltos" y el uso de fotografías en coherencia con las representaciones de tipo imagen de la ciudad. La cobertura geográfica será flexible.

\section{- Condicionado}

Conceptualización de Madrid al iniciar la visita, por parte de turistas que abordan la experiencia con enfoque condicionado.

El aspecto de estos mapas es en algunos casos similar al de los turistas con enfoque guiado (Figuras A55 a y b)) y otras a los del enfoque explorador (Figura A55 c)), al inicio de su visita. Los primeros presentan un sistema de referencia puntual cartográfico y egocéntrico (Figuras A55 a) y b) respectivamente) y los segundos un sistema de referencia coordinado (Figura A55 c)).

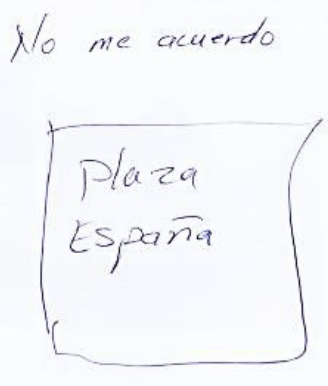

a

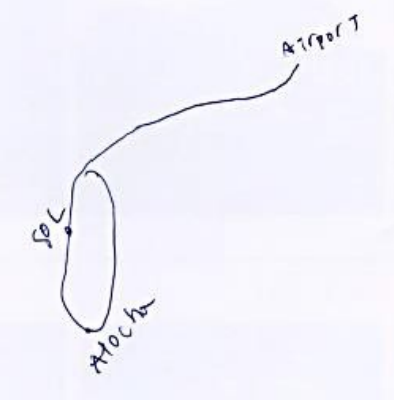

b

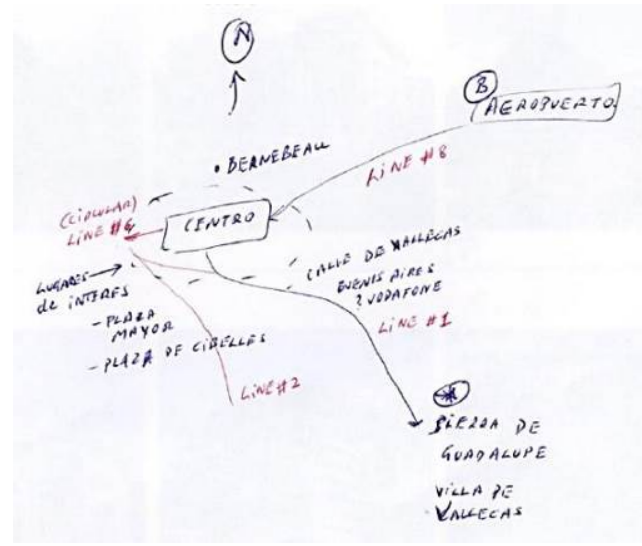

Figura A55: Mapas mentales iniciales de turistas que abordan su experiencia desde un enfoque condicionado: a) Puntual tipo cartográfico, b) Egocéntrico y c) Coordinado. 
Conceptualización de Madrid al finalizar la visita, por parte de turistas que abordan la experiencia con enfoque condicionado:

Los mapas de los turistas al finalizar su visita, presentan cuatro sistemas de referencia:

- Egocéntrico: Estos mapas se caracterizan por incluir uno o más recorridos que integran puntos de interés (marco de referencia tipo (1)) sin presencia de focos. Las Figuras A56 a) y b) muestran mapas con un recorrido basado en ejes de metro y en calles respectivamente y Figura A56 c) incluye un mapa con dos recorridos.

- Multi-puntual cartográfico: Presentan puntos de interés sueltos (marco de referencia tipo (3) sin presencia de focos (Figura A56 d)),

- Diferenciado: con puntos de interés que se conectan por calles (marco de referencia tipo (2)), presentando un foco asociado a un punto de interés próximo al alojamiento (Sol en la Figura A56 e)) o ningún foco.

- Coordinado: Puntos de interés que se conectan a través de ejes o que se integran en zonas (Figura A56 f)): marco de referencia tipo (3) y (4).

La cobertura de estos mapas es normalmente global (87\%) y en menor medida sectorial (13\%), pudiendo incluir o no focos. Los mapas se caracterizan por incluir una cantidad relativamente alta de puntos de interés (número entre los guiados y los exploradores, con 5 atractivos turísticos y 2 infraestructuras de transporte de media), en menor medida ejes (calles o líneas de transporte, 1 de media) y una o ninguna zona.

Como resultado del análisis de los mapas de los turistas con enfoque condicionado se pueden extraer las siguientes características:

- ¿Qué elementos incluyen? Predominantemente puntuales (media de 5 PIT y de 2 infraestructuras de transporte), frente a ejes (media de 1) y zonas (1).

- ¿Cómo los representan? A través de recorridos que integran puntos de interés sin focos (marco tipo1, con uno o varios recorridos) y mediante puntos sueltos (marco tipo 3) sin foco, que pueden estar conectados entre sí por ejes, con o sin foco (marco tipo 2), e integrados en zonas (marco tipo 4). 


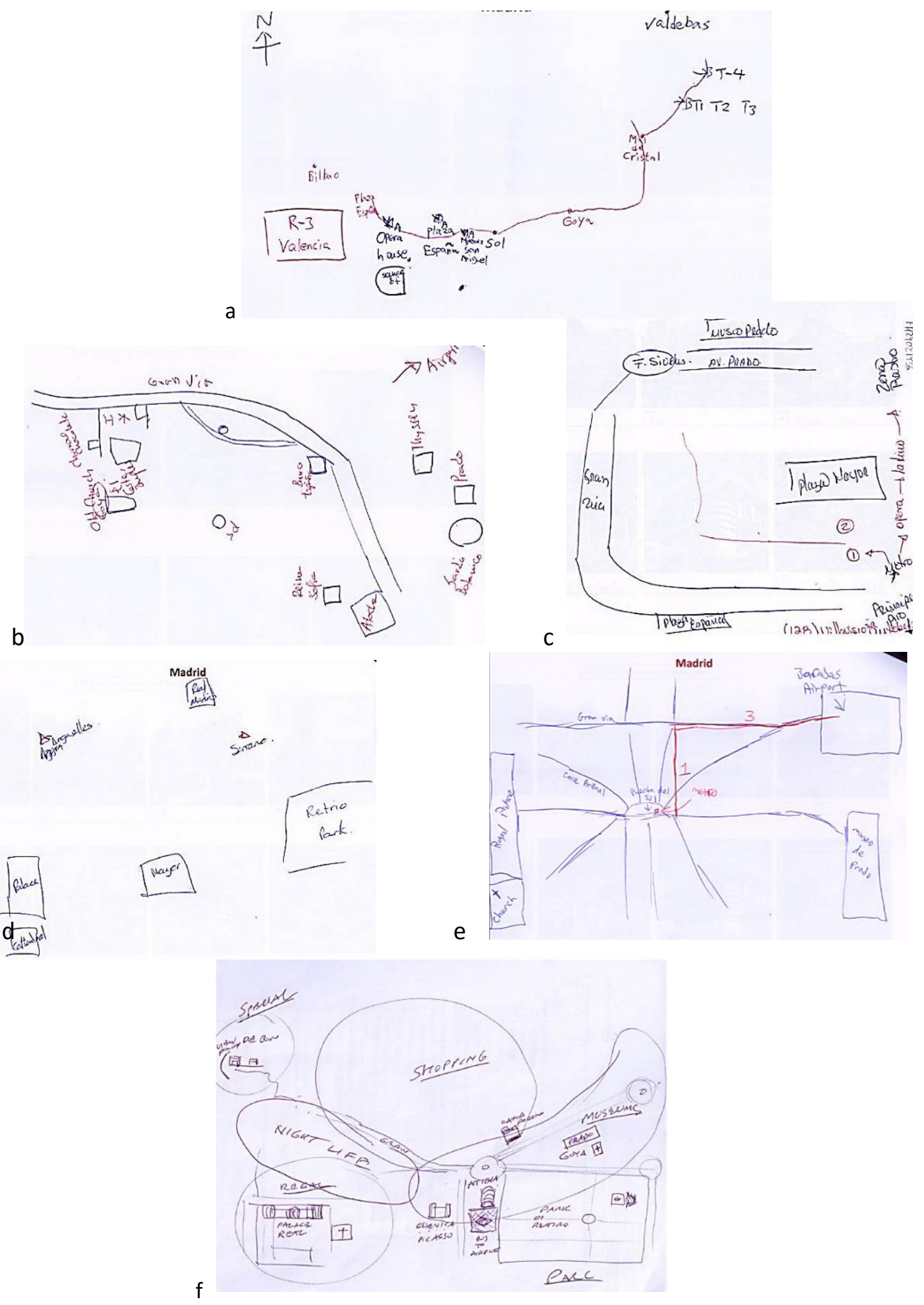

a

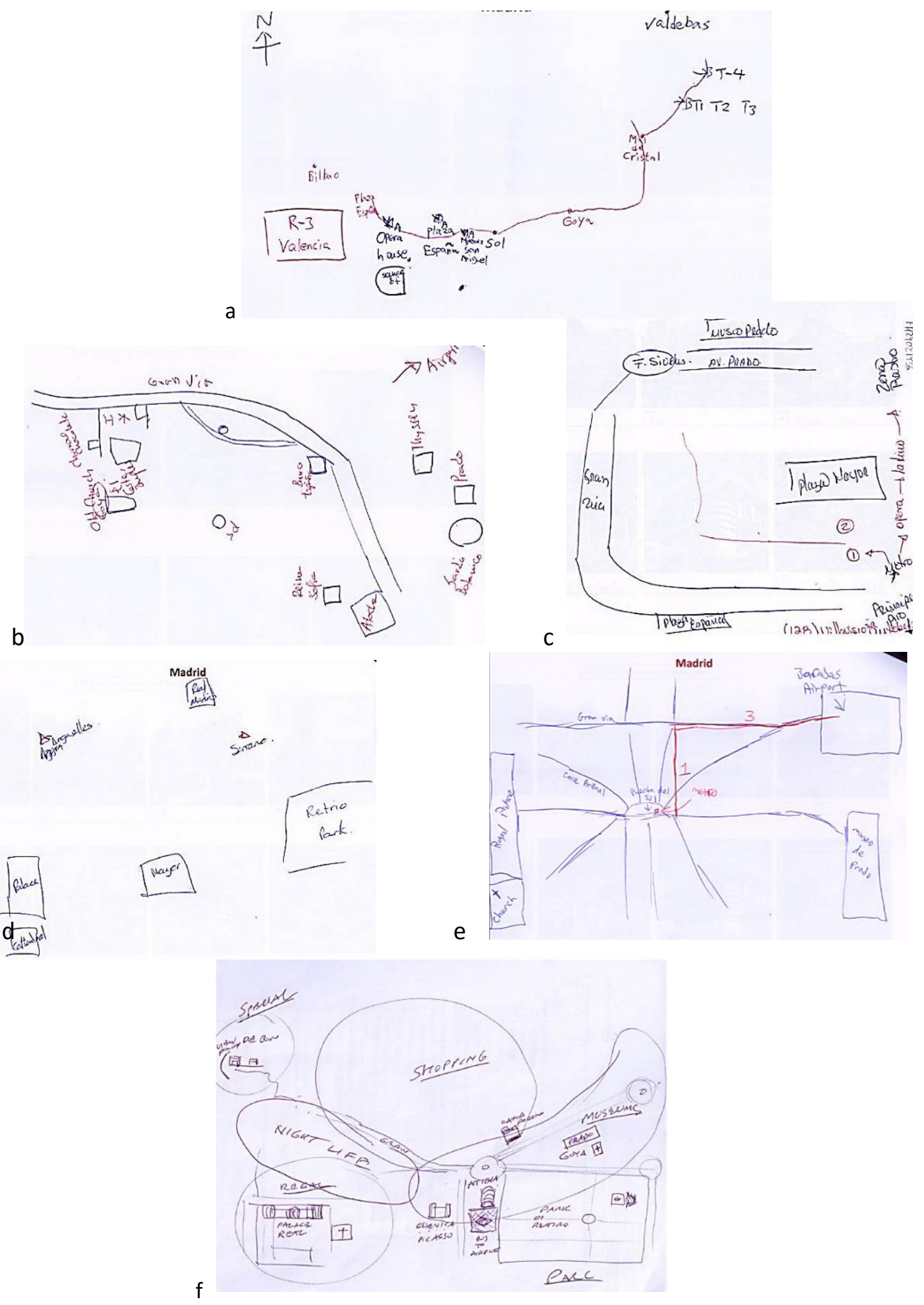

$\mathrm{b}$

Figura A56: Mapas mentales finales de turistas que abordan su experiencia desde un enfoque condicionado: a), b) y c) Egocéntrico; d) Multi-puntual cartográfico; e) Diferenciado y f) Coordinado. 


\section{Anexo 22. Inspiraciones para los diseños de los mapas}

a) Estructuras de navegación y contenidos cartográficos
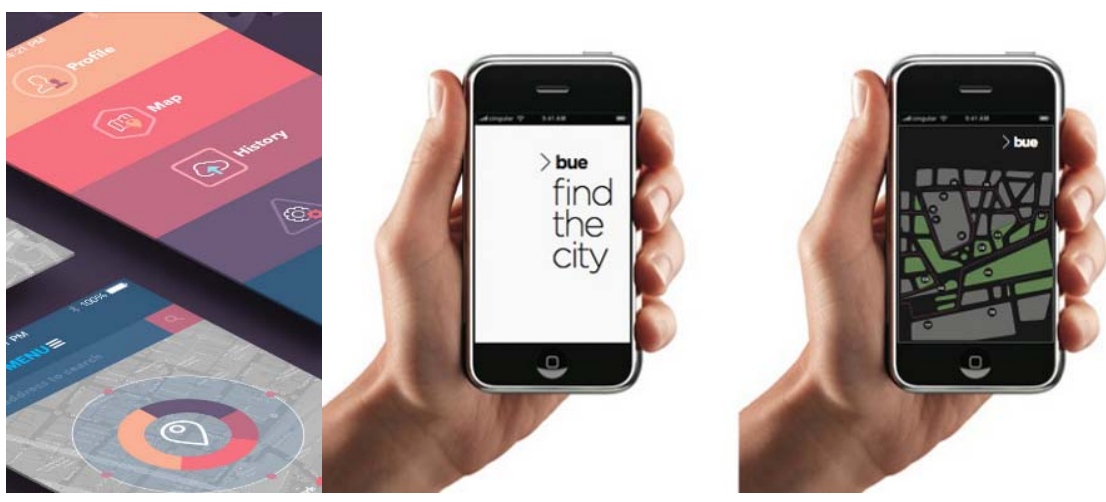

Fuente: https://www.behance.net/gallery/Buenos-Aires-Wayfinding-Sistem/3706058

b) Atractivos puntuales

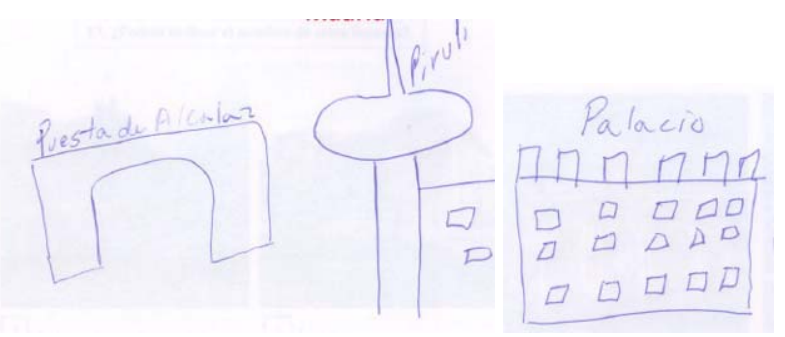

Fuente: Mapa mental de un turista encuestado

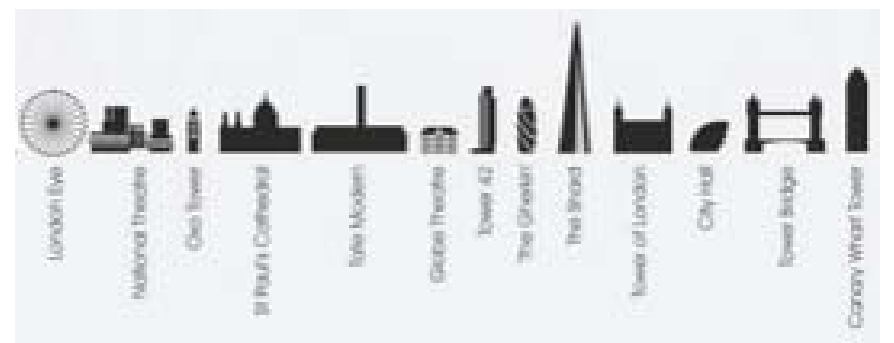

Fuente: http://www.quickmap.com/snip5.htm 


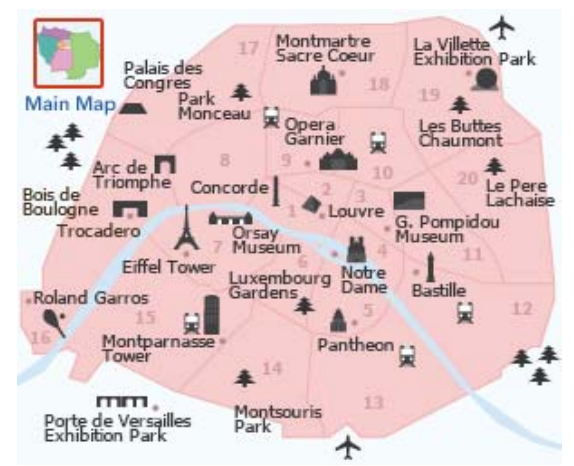

Fuente:http://www.tripadvisor.co.uk/VacationRentals-g187147-Reviews-Paris_lle_de_FranceVacation_Rentals.html

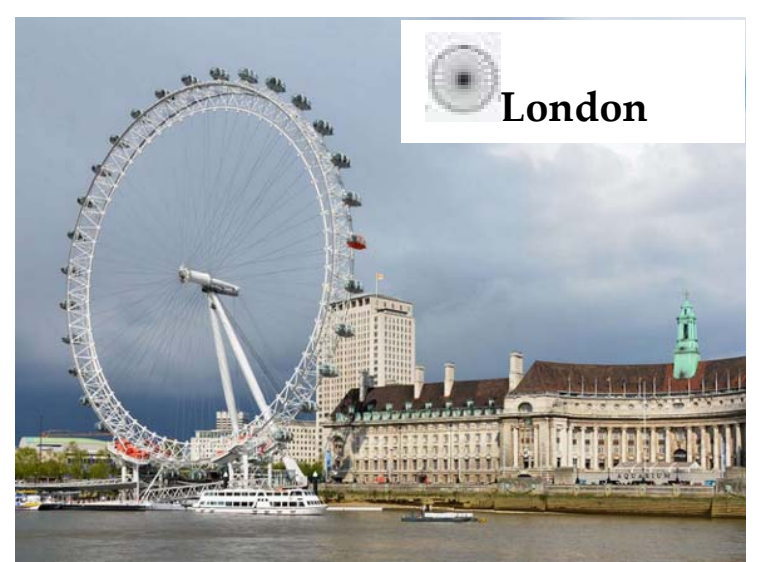

Fotografía e icono personalizado. Elaboración propia.

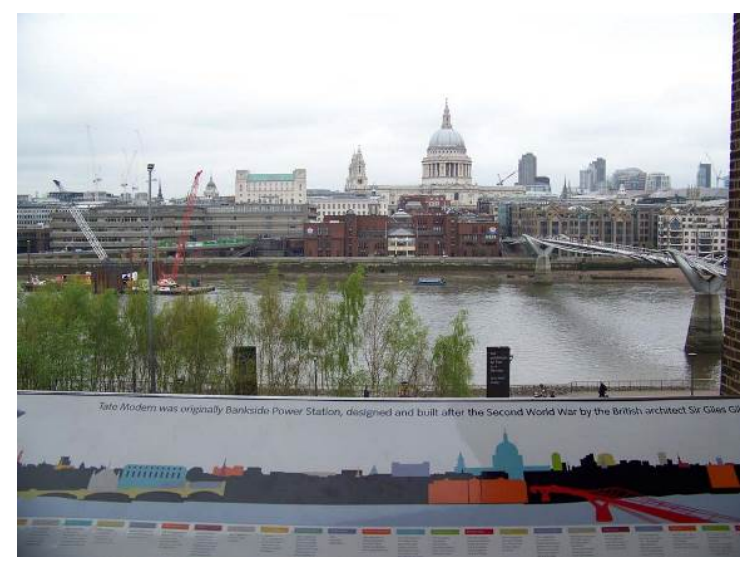

Fotografía tomada desde el Tate museo de Londres. Elaboración propia

\section{c) Atractivos entorno a una localización}

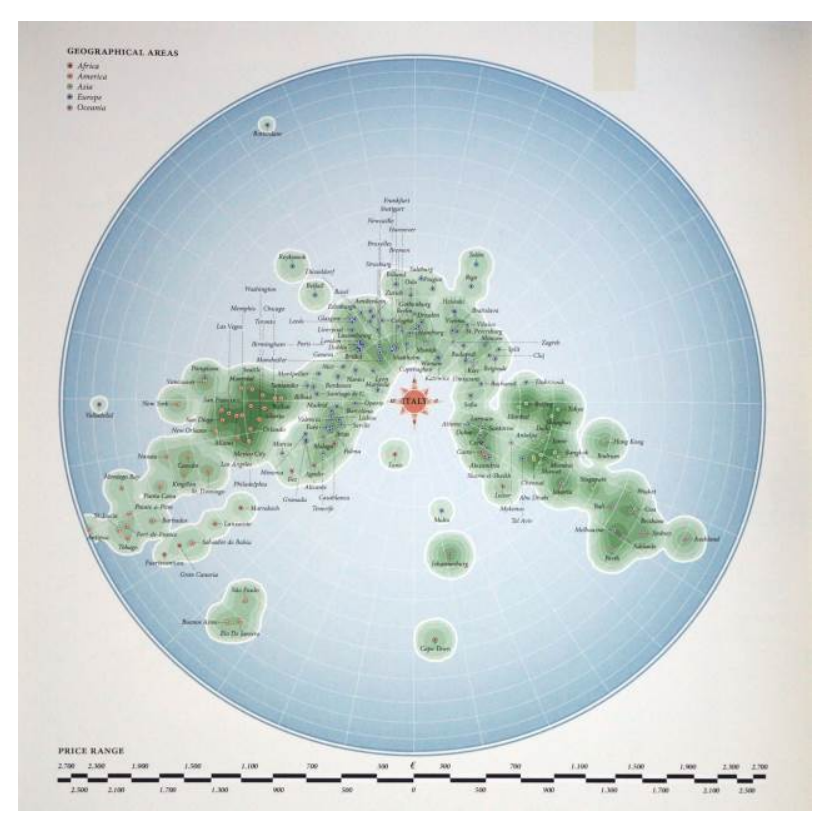



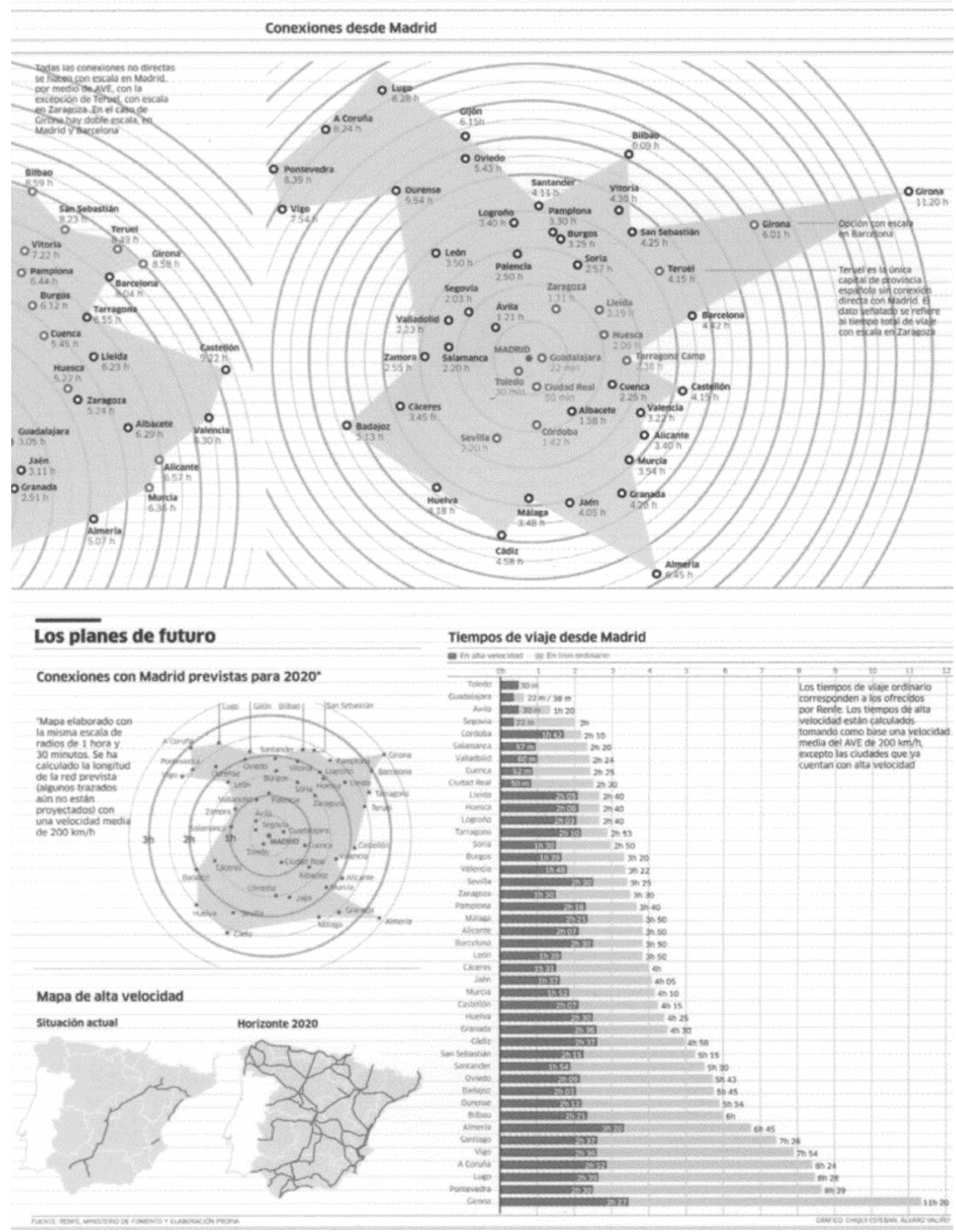

Animación que transforma el mapa geográfico de destinos en tren desde Madrid en un mapa esquemático en función de los tiempos de recorrido a estos destinos: http://chiquiesteban.com/graphics/timemap_spain train.html 


\section{ST BRIDE LIBRARY}

DATA VISUALISATION

Visualisation of the St Bride Library collection showing the library's classification hierarchy and volume of information per subject. Each spot represents a class, the size of the spot represents the volume of information within the class, the position of the spot shows it's place within the classification hierarchy and the colours show the type of information (historical, artistic etc).

The print is an example of a visualisation method that could be applied to any library with a similar system - which would enable comparison between libraries and reveal those with more/less information on particular subjects.
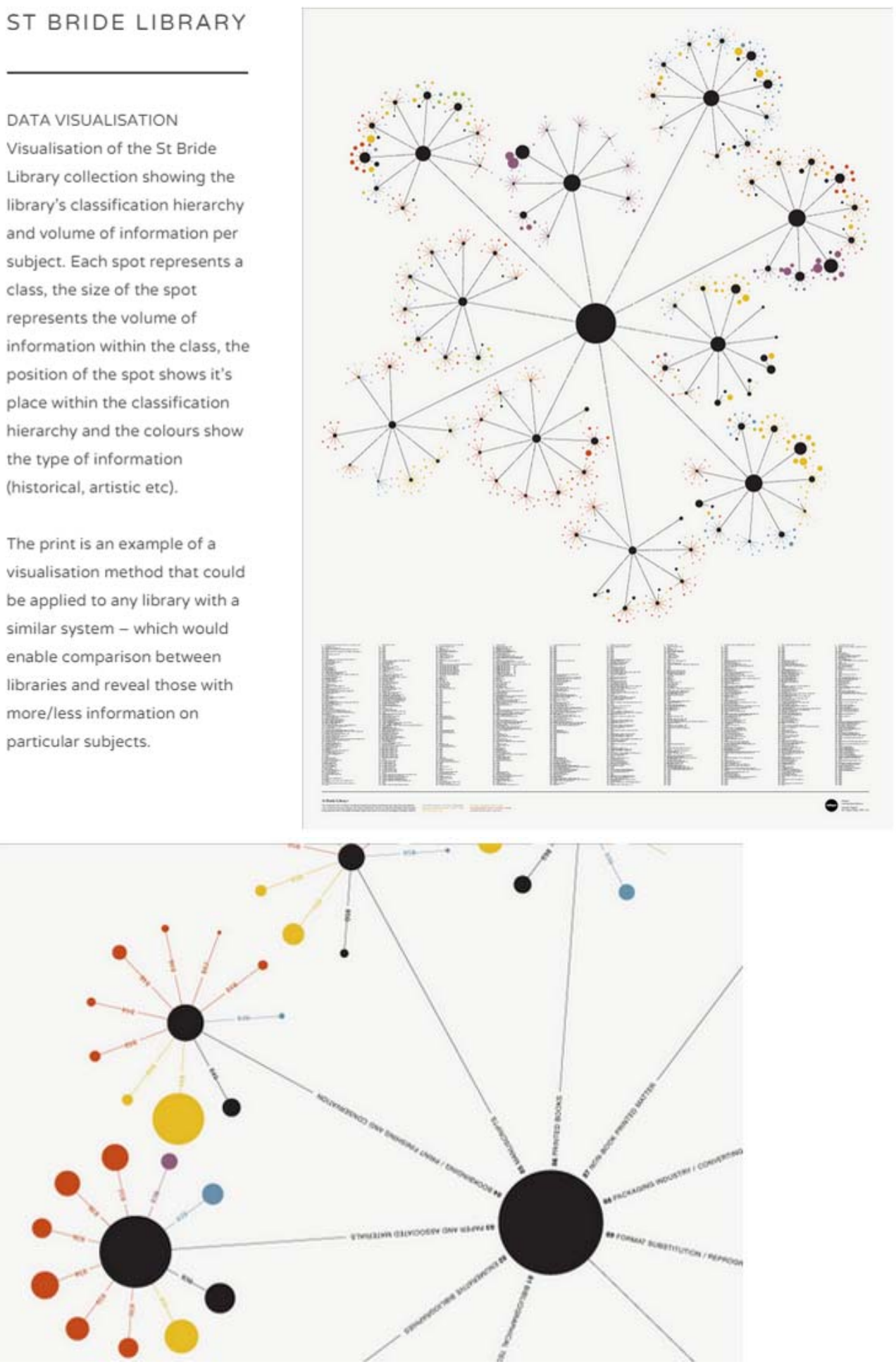

Fuente: http://iamalexandra.com/\#/bibliospot-data-visualisation/ 


\section{d) Caminando:}
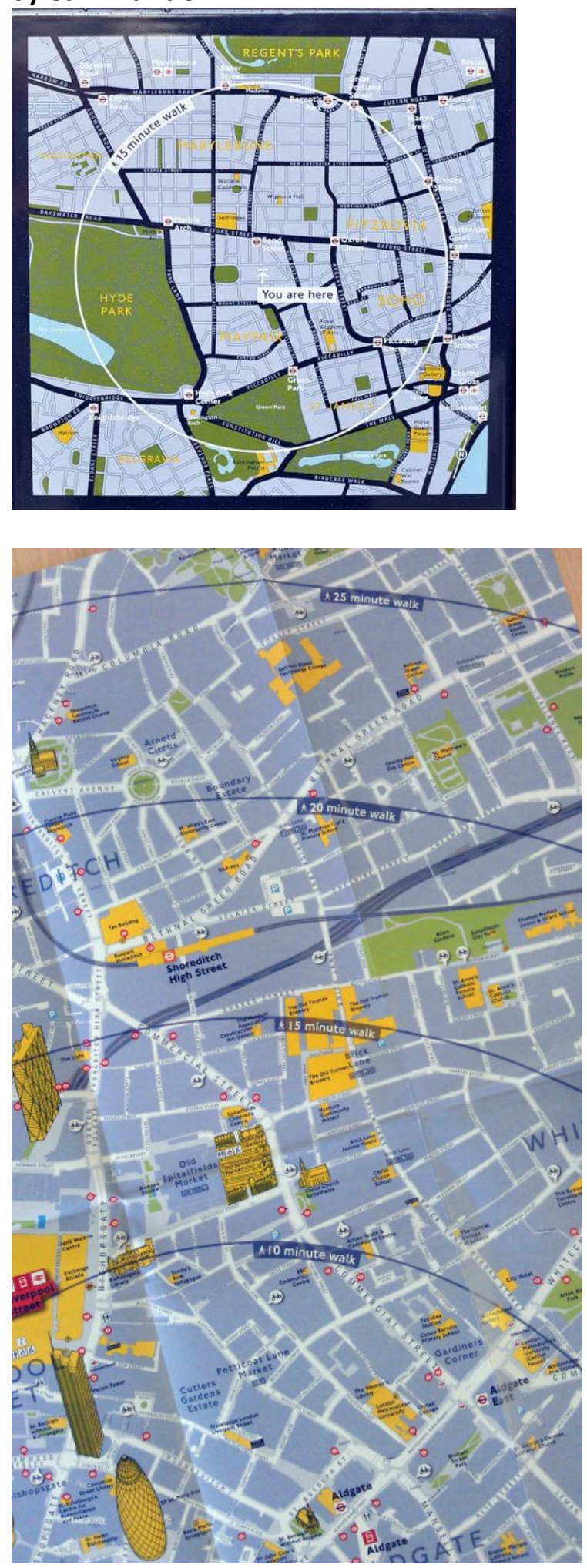

Fuente: http://mappinglondon.co.uk/2012/05/15/tfl-why-not-walk-it-maps/ 


\section{e) Visualización de recorridos}

Recorridos realizados cada día de la visita

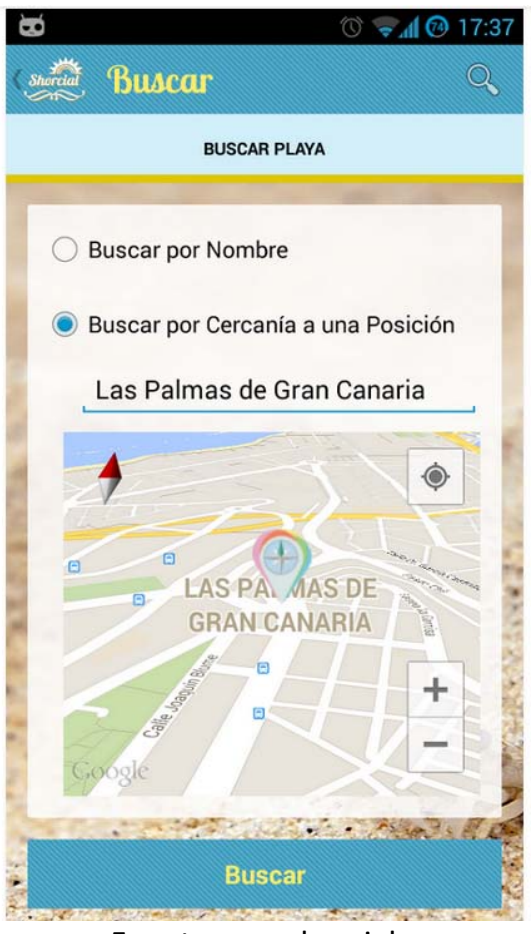

Fuente: app shorcial
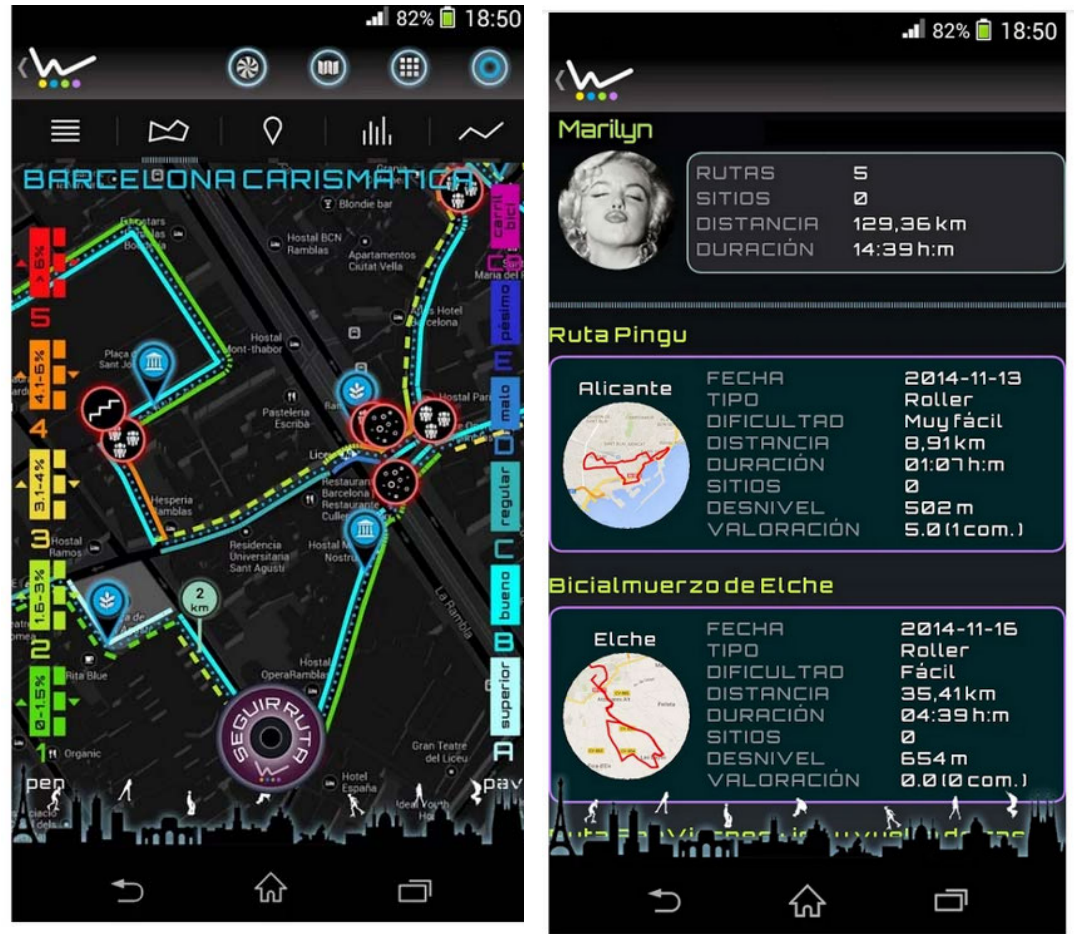

Fuente: app Aswings

Recorridos con iconos de atractivos

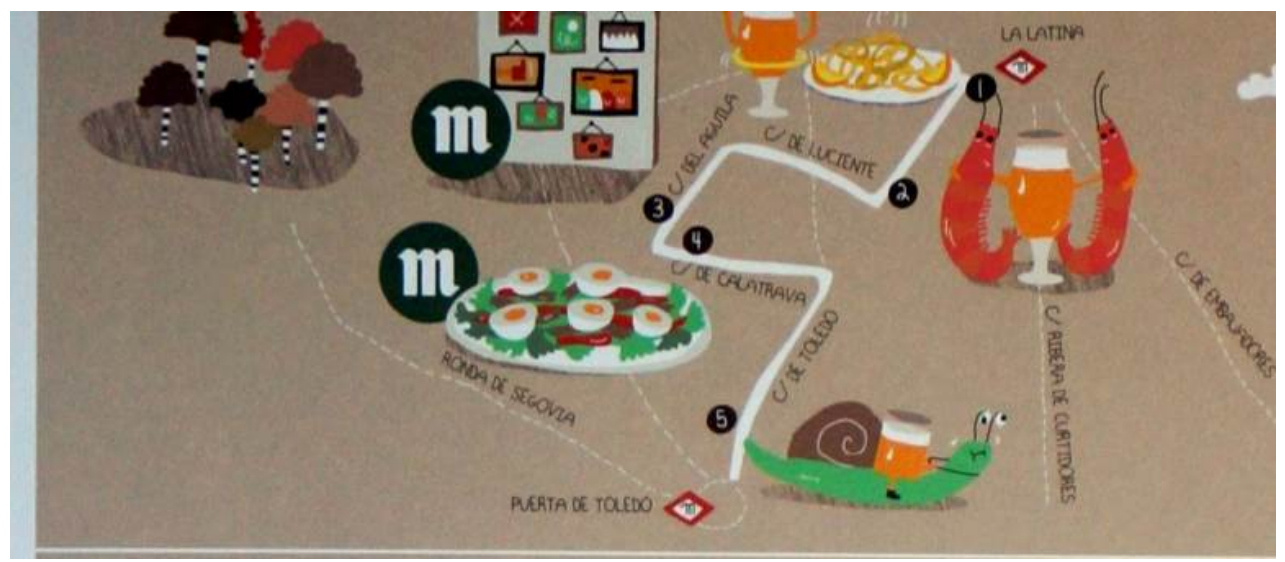




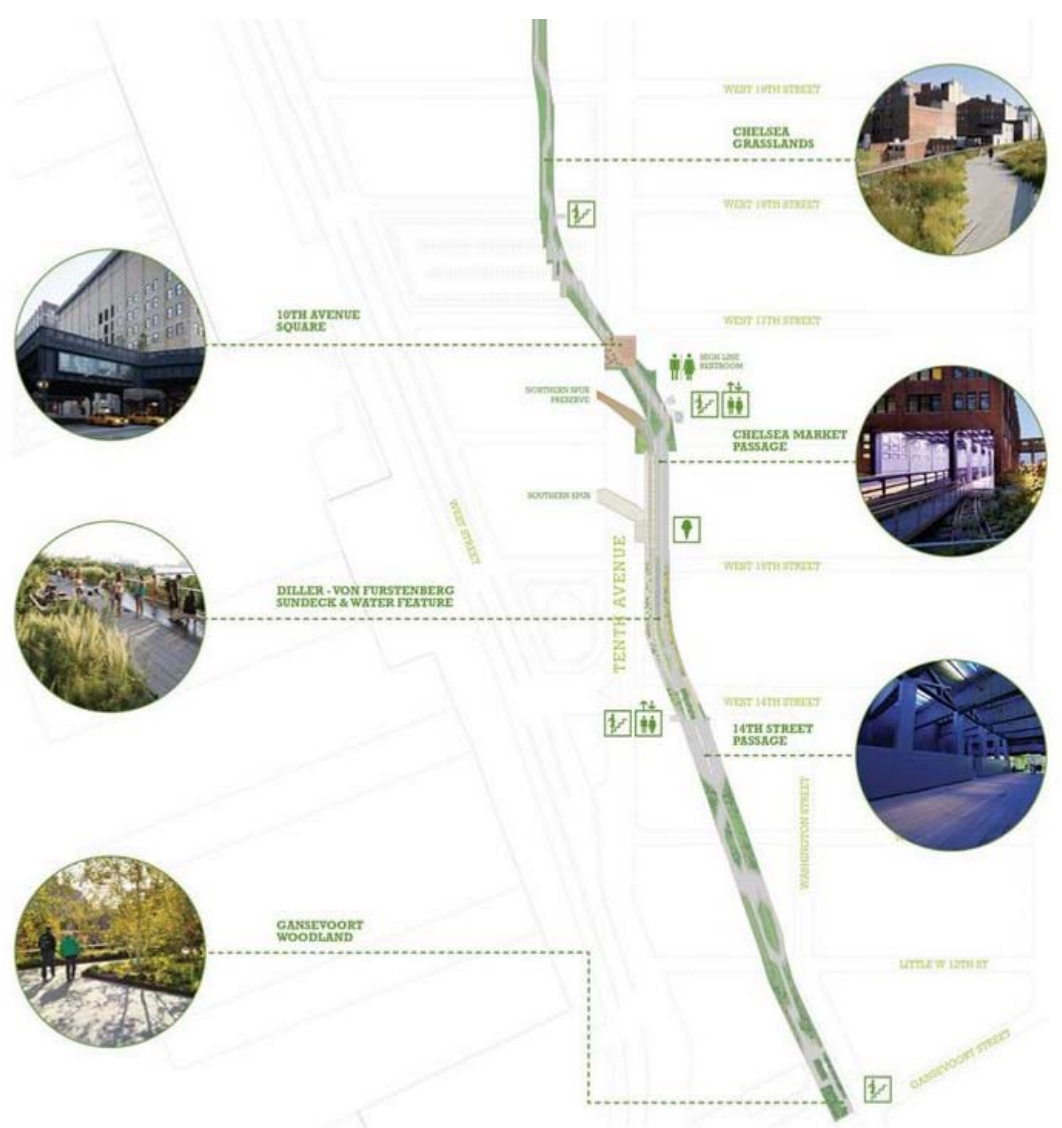

Animación de recorrido: https://www.behance.net/gallery/tram-gps-apphackaton/15341579

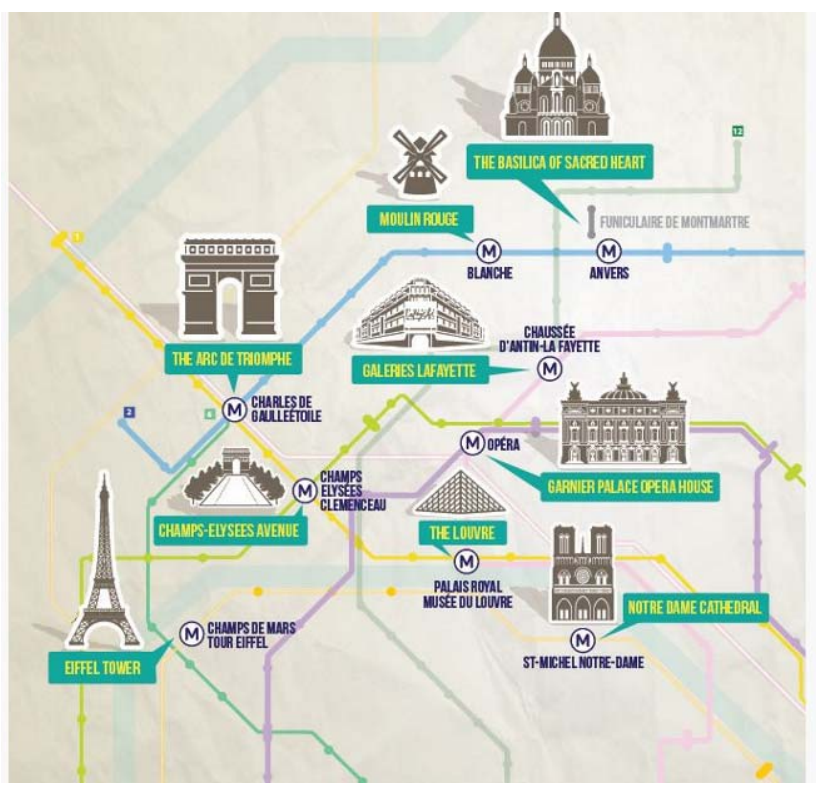




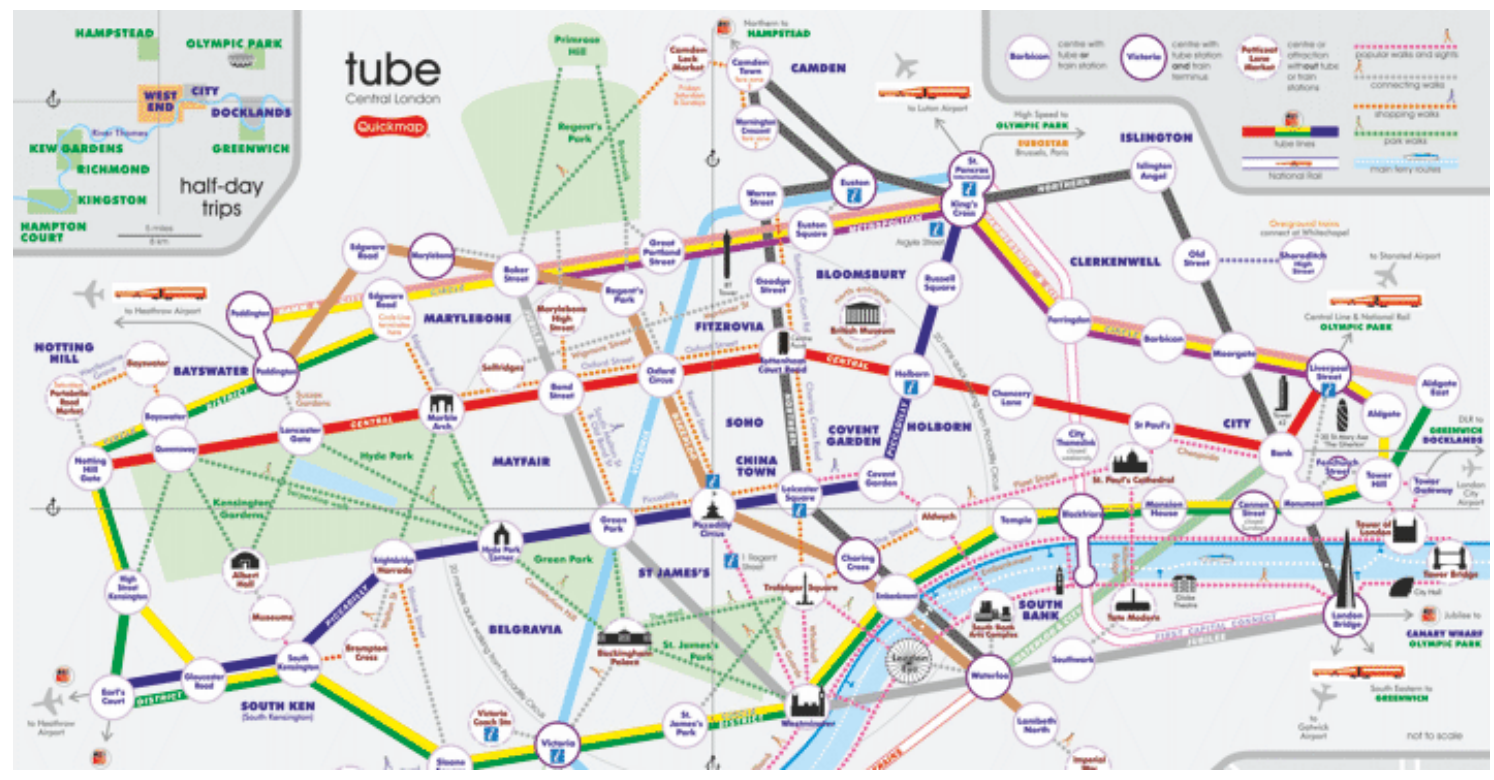

Fuente: http://www.quickmap.com/snip5.htm

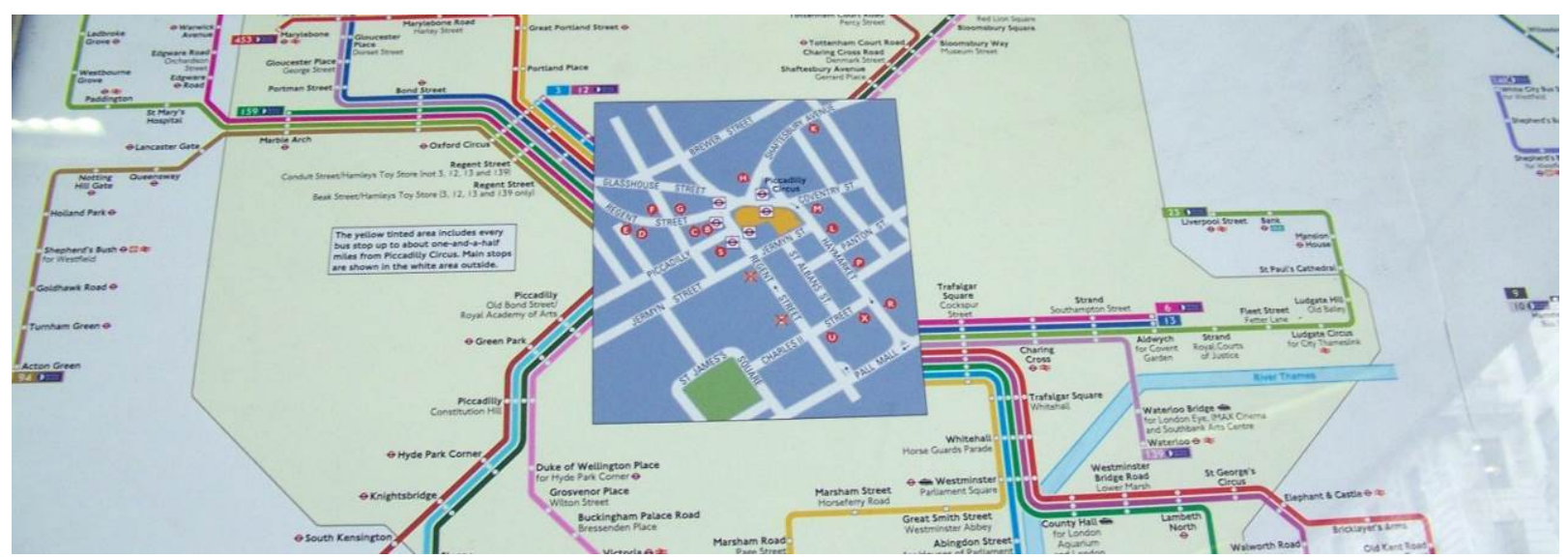

Fuente: Fotografía de un SpiderMap Bus-Tube London.

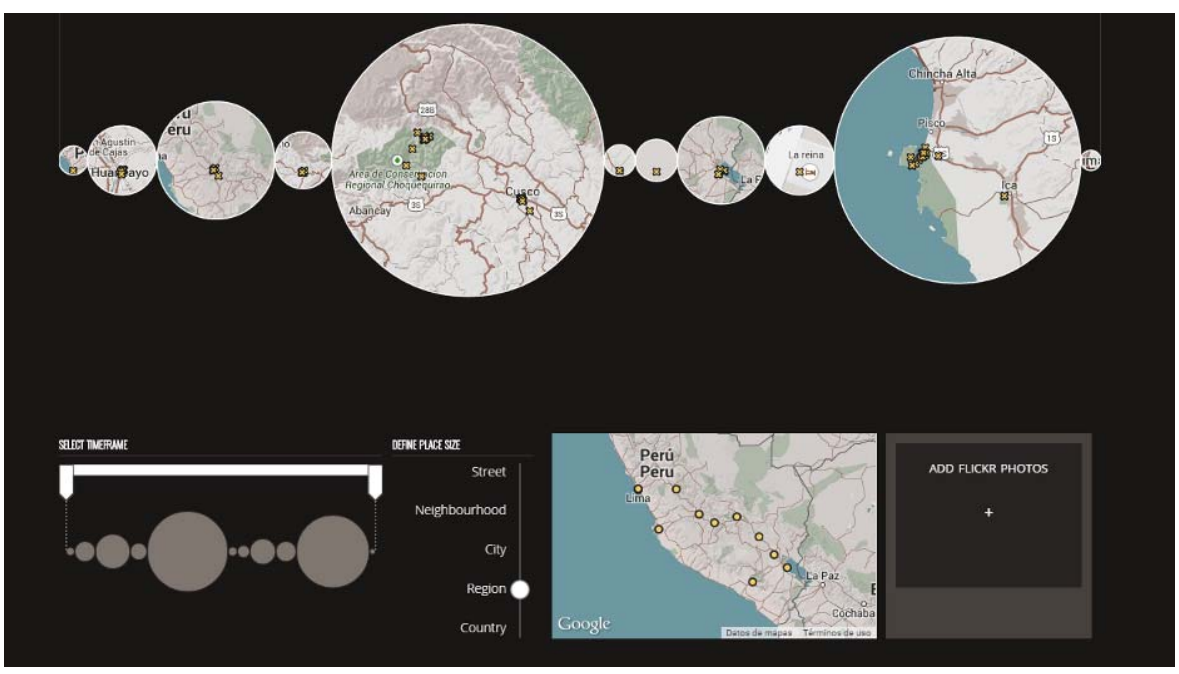

Fuente: $\underline{\text { http://v.isits.in/ }}$ 
f) Visualización de zonas
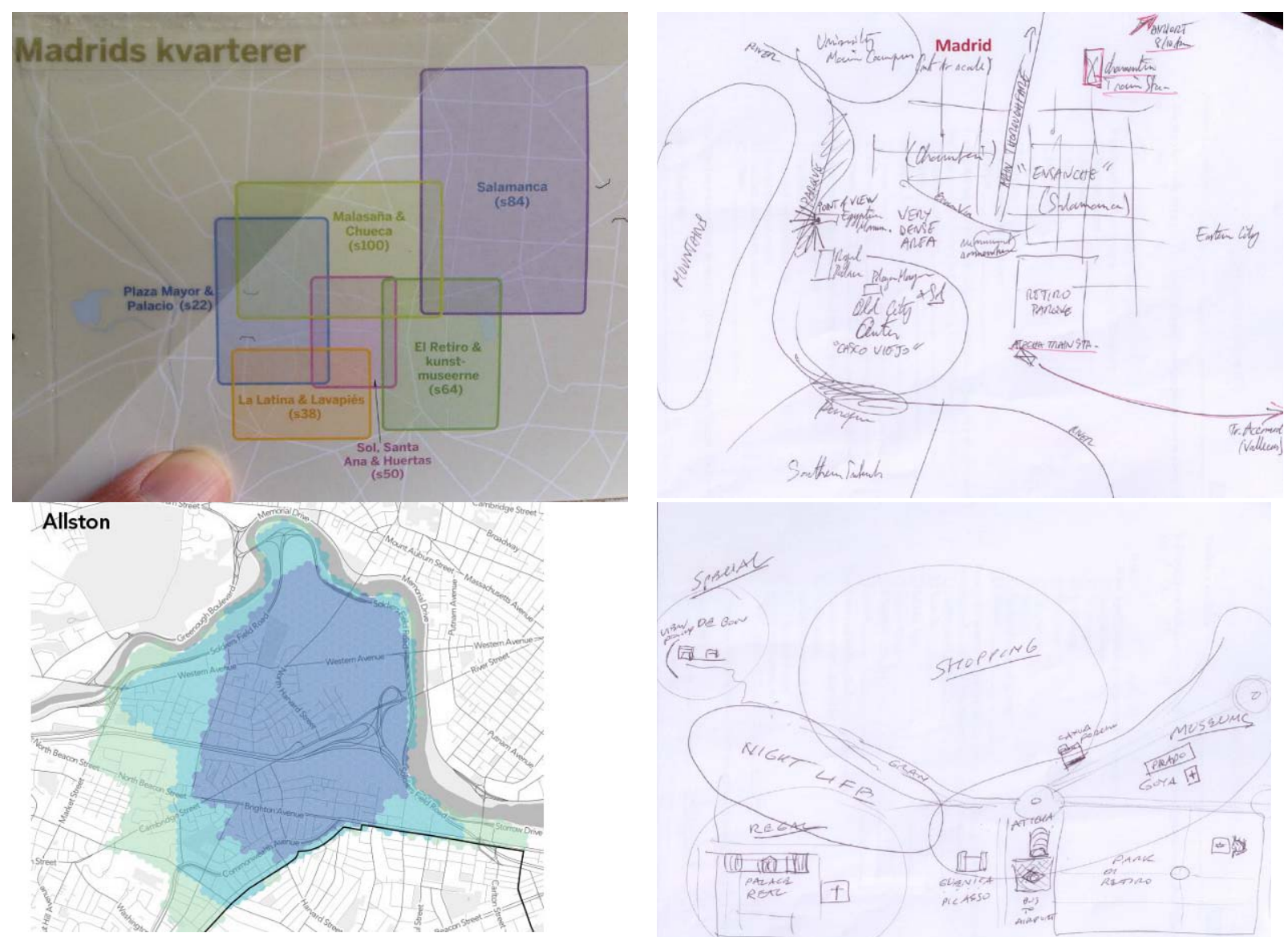

http://bostonography.com/2012/crowdsour

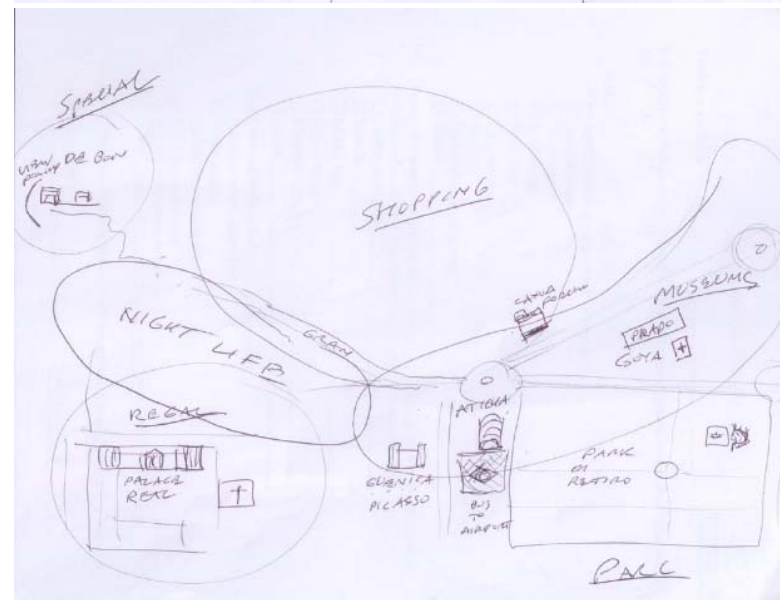

ced-neighborhood-boundaries-part-one-

\section{consensus/}

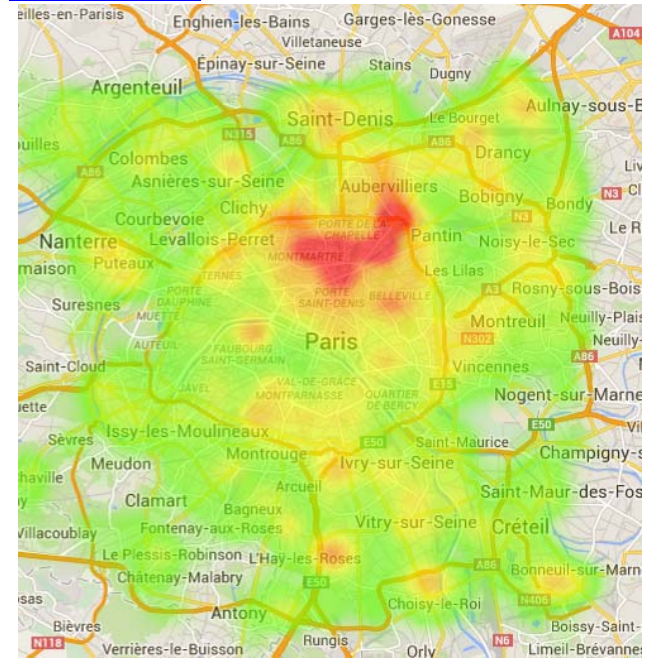

\section{http://www.twoo.com/getlucky/paris\#}

Figura A57: Inspiraciones para los diseños de los mapas: a) Estructuras de navegación y contenidos cartográficos, b) Atractivos puntuales, c) Atractivos entorno a una localización, d) Caminando, e) Visualización de recorridos y f) Visualización de zonas. 
Anexo 23. Prototipos de los mapas en papel 
Explorador-Escenario 1: Durante el viaje. Desplazamiento en metro

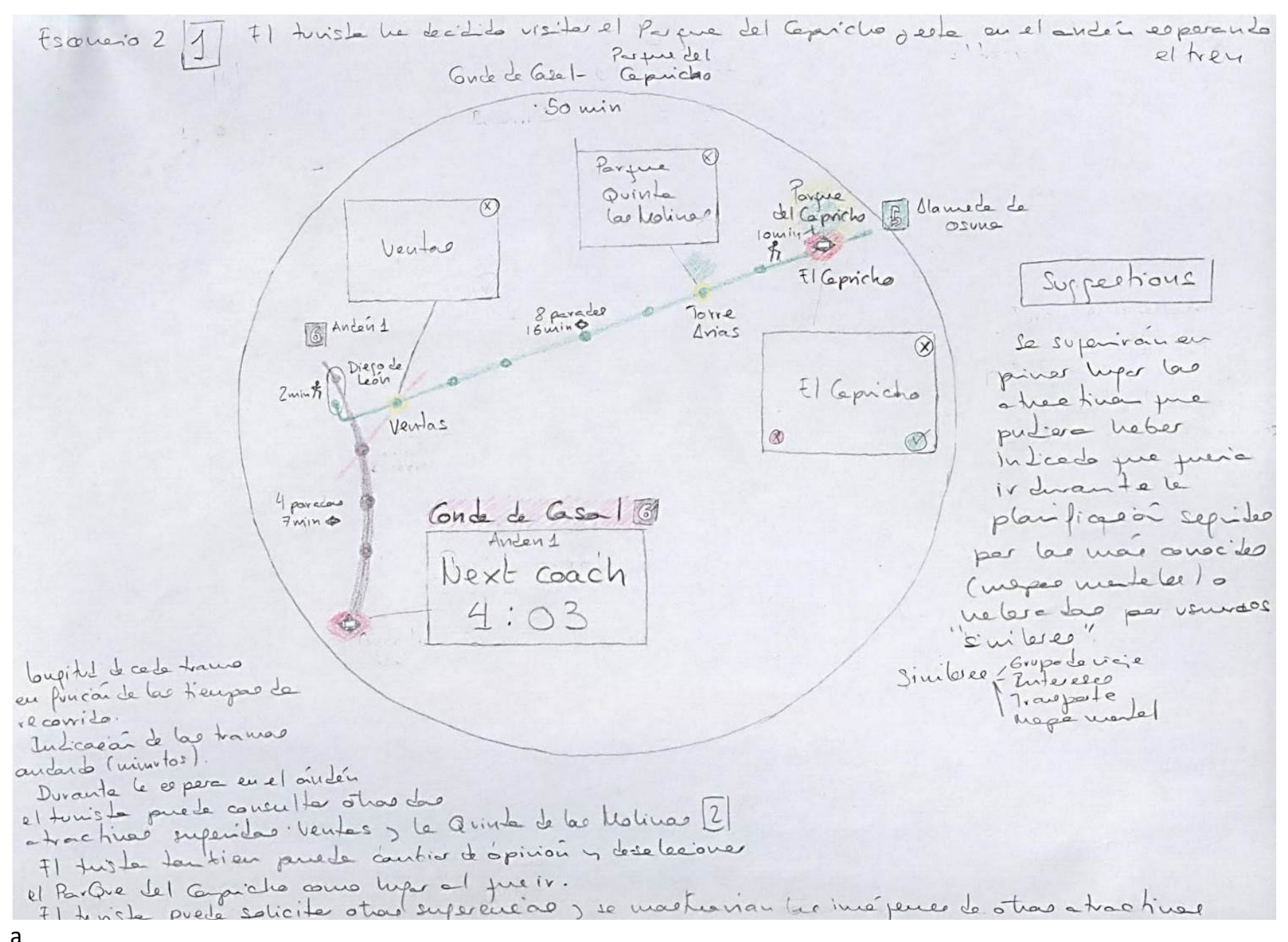




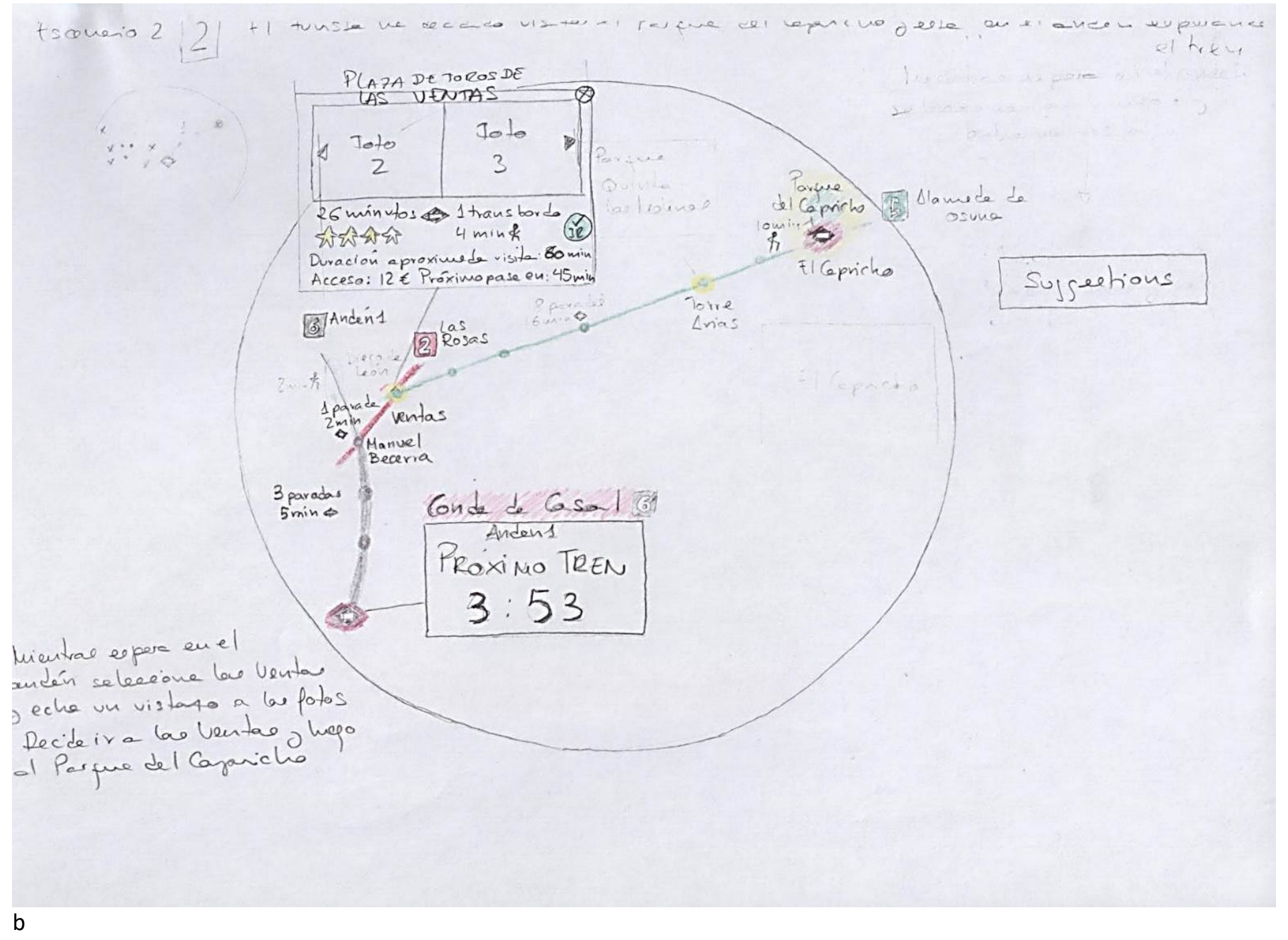

338 


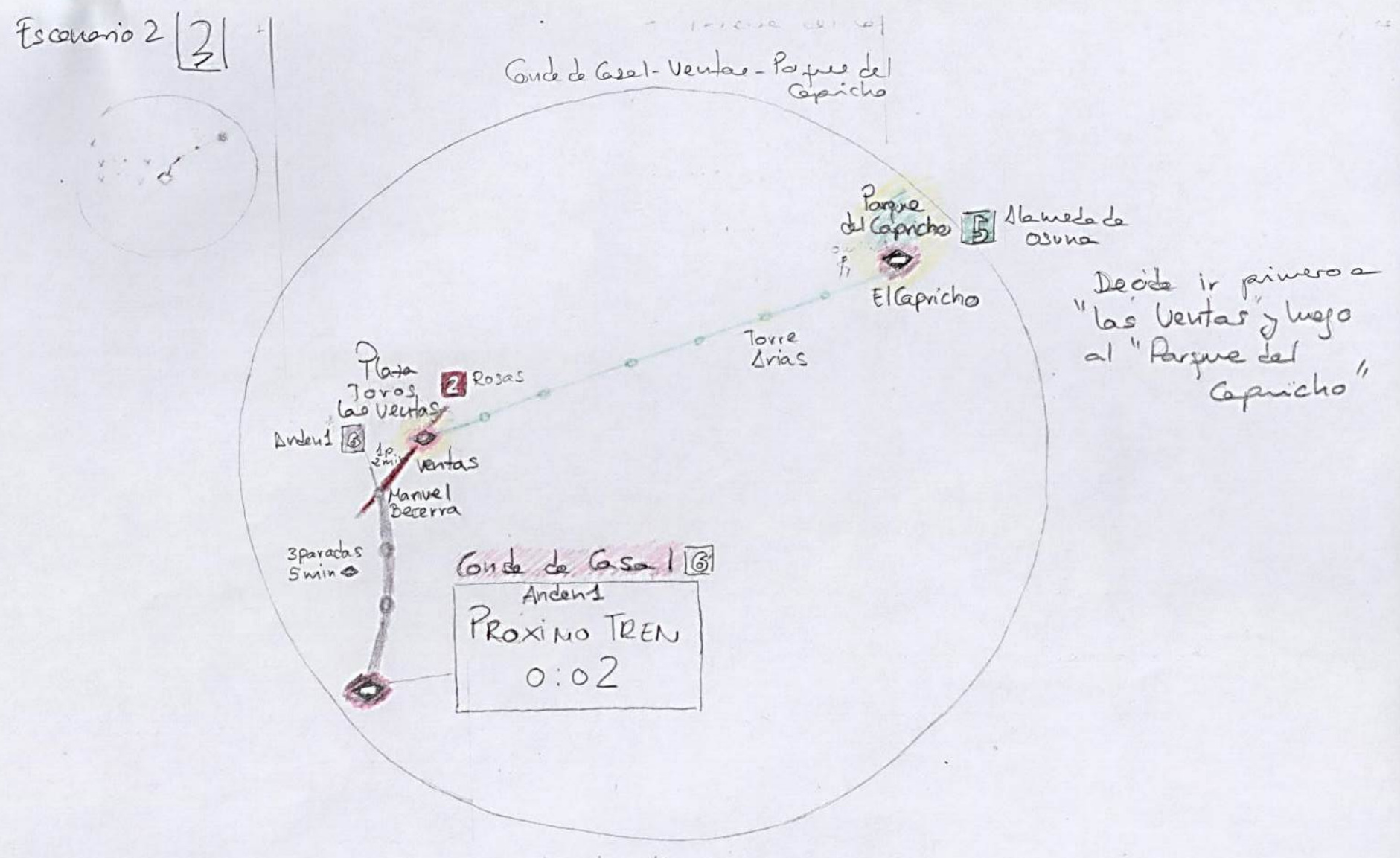

C

339 


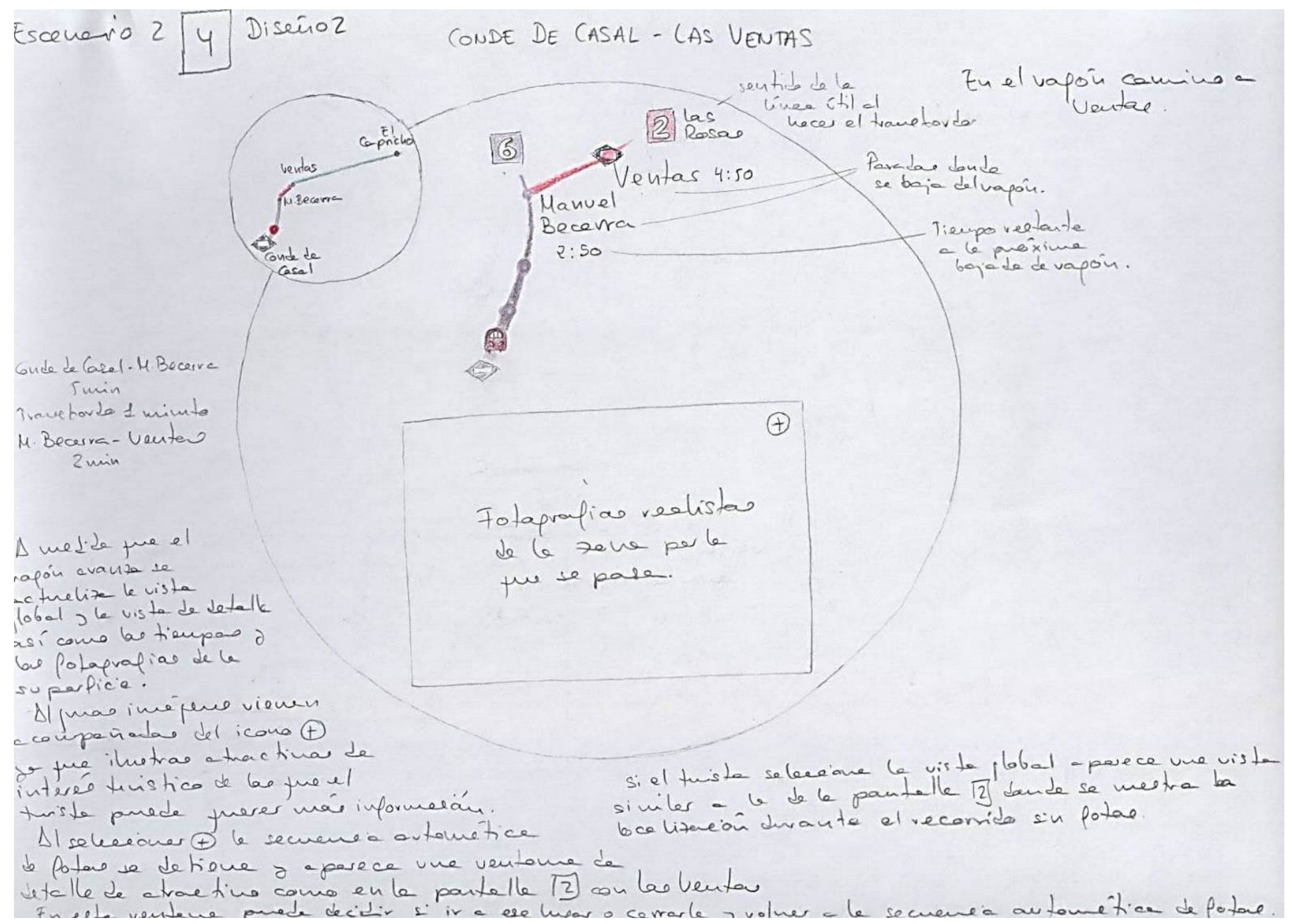




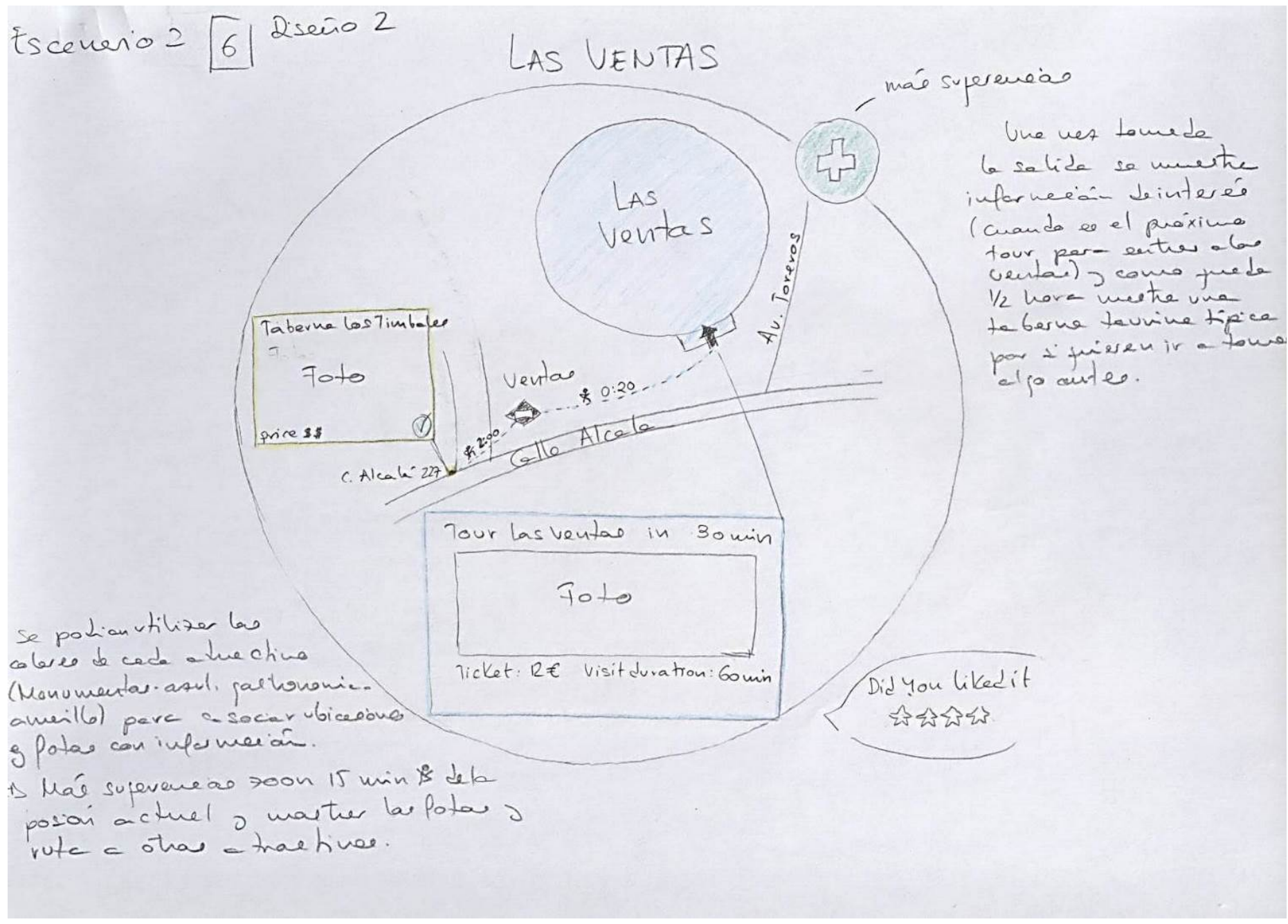

e

Figura A58: a-e) Prototipos de los mapas en papel del Explorador-Escenario 1: Durante el viaje. Desplazamiento en metro. 


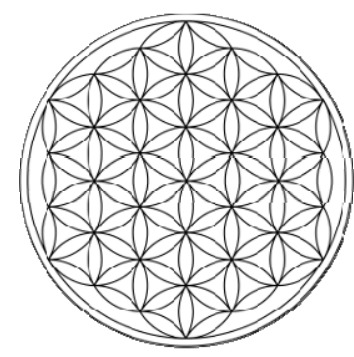

